\title{
Climatological Summary for the Hanford Area
}
W. A. Stone
J. M. Thorp
O. P. Gifford
D. J. Hoitink

June 1983

Prepared for the U.S. Department of Energy under Contract DE-AC06-76RLO 1830

Pacific Northwest Laboratory Operated for the U.S. Department of Energy by Battelle Memorial Institute 


\title{
DISCLAIMER
}

This report was prepared as an account of work sponsored by an agency of the United States Government. Neither the United States Government nor any agency thereof, nor any of their employees, makes any warranty, express or implied, or assumes any legal liability or responsibility for the accuracy, completeness, or usefulness of any information, apparatus, product, or process disclosed, or represents that its use would not infringe privately owned rights. Reference herein to any specific commercial product, process, or service by trade name, trademark, manufacturer, or otherwise, does not necessarily constitute or imply its endorsement, recommendation, or favoring by the United States Government or any agency thereof. The views and opinions of authors expressed herein do not necessarily state or reflect those of the United States Government or any agency thereof.

\author{
PACIFIC NORTHWEST LABORATORY \\ operated by \\ BATTELLE \\ for the \\ UNITED STATES DEPARTMENT OF ENERGY \\ under Contract DE-AC06-76RLO 1830
}

\begin{tabular}{|c|c|}
\hline \multicolumn{2}{|c|}{ Printed in the United States of America } \\
\hline \multicolumn{2}{|c|}{ Available from } \\
\hline \multicolumn{2}{|c|}{ National Technical Information Service } \\
\hline \multicolumn{2}{|c|}{ United States Department of Commerce } \\
\hline \multicolumn{2}{|c|}{5285 Port Royal Road } \\
\hline \multicolumn{2}{|c|}{ Springfield, Virginia 22161} \\
\hline \multirow{2}{*}{\multicolumn{2}{|c|}{$\begin{array}{l}\text { NTIS Price Codes } \\
\text { Microfiche A01 }\end{array}$}} \\
\hline & \\
\hline \multicolumn{2}{|c|}{ Printed Copy } \\
\hline & \\
\hline Pages & Codes \\
\hline 001-025 & $\mathrm{A} 02$ \\
\hline 026-050 & $\mathrm{A} 03$ \\
\hline 051.075 & $\mathrm{AOOA}$ \\
\hline $076-100$ & A05 \\
\hline $101-125$ & A06 \\
\hline $126-150$ & A07 \\
\hline $151-175$ & $\mathrm{~A} 0 \mathrm{~B}$ \\
\hline $176-200$ & A09 \\
\hline $201-225$ & A010 \\
\hline $226-250$ & A011 \\
\hline 251.275 & A012 \\
\hline $276-300$ & A013 \\
\hline
\end{tabular}




\section{6}

CLIMATOLOGICAL SUMMARY FOR THE HANFORD AREA
W. A. Stone
J. M. Thorp
0. P. Gifford
D. J. Hoitink

June 1983

Prepared for

the U.S. Department of Energy under Contract DE-AC06-76P.LO 1830

Pacific Northwest Laboratory

Richland, Washington 9935? 
SUMMARY 


\section{NARRATIVE CLIMATOLOGICAL SUMMARY OF THE HANFORD AREA*}

The Hanford Meteorology Station is situated on a plateau in south-central Washington. The plateau slopes downward toward the Columbia River about 10 miles north of the station and upward to the foothills of the Rattlesnake Mountains about 10 miles south. Elevation of the station is 733 feet, which is roughly 300 feet above the Columbia River to the north. Both the Rattlesnake Mountains south and southwest of the station and the Yakima Ridge to the west rise to more than 3500 feet, while the Saddle Mountains beyond the Columbia River to the north rise to more than 2500 feet.

Greatly affecting the climate of the Hanford Area, although not visible from the meteorology station, are the Cascade Mountains beyond Yakima to the west. Since Hanford is in the rain shadow of these mountains, precipitation averages only 6.25 inches annually. The 3 months November through January contribute 44 percent of this total, while the 3 months July through September contribute only 12 percent. On the average there are only 2 occurrences per year of 24-hour amounts of precipitation of 0.50 inch or more, while occurrences of 24-hour amounts of 1.00 inch or more number only 2 in the entire 35 years of record (1946-1980). One of these was the record storm of October 1-2, 1957, in which rainfall totalled 1.08 inches in 3 hours, 1.68 inches in 6 hours, and 1.88 inches in 12 hours. At the other extreme, there have been 81 consecutive days without measurable rain (June 22-September 10, 1967), 139 days with only 0.18 inch (June 22-November 7, 1967), and 172 days with only 0.32 inch (February 24-August 13, 1968). Only 0.15 inch of precipitation was recorded during the months of September through December 1976. Normal for that period of time is 2.50 inches and is 40 percent of the total annual precipitation.

About 38 percent of all precipitation during the months of December through February is in the form of snow. However, in only 1 winter in 4 is an accumulation of as much as 6 inches on the ground expected. The average seasonal number of days with 6 inches or more of snow on the ground is 4, although the 1964-65 winter had 35, 32 of which were consecutive. The record greatest depth of snow on the ground is 24.5 inches, which occurred in February 1916 . However, since that date, the greatest depth has been 12.1 inches, occurring in December 1964.

By serving as a source of cold air drainage, the Cascade Mountains also have considerable effect on the wind regime at Hanford. This drainage (gravity) wind, plus topographic channeling, causes a considerable diurnal range of speed during summer. In July, hourly average 50-foot speeds range from a low of $5.2 \mathrm{mph}$ from 9 to 10 a.m. to a high of $13.0 \mathrm{mph}$ from 9 to 10 p.m. In contrast, the corresponding speeds for January are 5.5 and $6.3 \mathrm{mph}$.

Although the gravity wind occurs with regularity in summer, it is seldom strong unless reinforced by frontal activity. In June, the month of highest average speed, there are fewer instances of hourly averages exceeding $31 \mathrm{mph}$ than in December, the month of lowest average speed. It is also notable that, although channeling results in a prevailing WNW or NW wind the year around, the strongest speeds are from the SSW, SW and WSW.

Atmospheric stagnation is an important factor in Hanford's wind regime. Decembers, for example, have an average of 10 days with peak gusts under $13 \mathrm{mph}$. By contrast, only once in 5 years does June have even one such day.

Temperatures at Hanford are colder in winter and warmer in summer than would be the case without the Cascades. However, other mountain ranges to the north and east shield the area from many of the arctic surges and half of all winters are free of temperatures as low as $0^{\circ} \mathrm{F}$. However, 6 winters in 63 of record have contributed a total of 16 days with temperatures $20^{\circ}$ or below and in January-February, 1950, there were 4 consecutive such days. There are 10 days of record when even the maximum temperature failed to get above zero. At the other extreme, in the winter of 1925-1926, the lowest temperature all season was $+22^{\circ}$

Although winter minima have varied from $-27^{\circ}$ to $+22^{\circ}$, summer maxima have varied only from $100^{\circ}$ to $115^{\circ}$. However, there is considerable variation in the frequency of such maxima. In 1954, for example, there was only 1 day with a maximum as high as $100^{\circ}$. On the other hand, there have been 3 summers (1938, 1962 and 1967) when the temperature went to $100^{\circ}$ or above for 11 consecutive days.

Although temperatures reach $90^{\circ}$ or above an average of 55 days a year, minimum temperatures $70^{\circ}$ or above occur only an average of 8 days a year. The usual cool nights are a result of the gravity wind mentioned earlier.

Thunderstorms have been observed at the station in every month except November and January and one occurred at Richland (about 25 miles SE) on January 18, 1953. Although severe ones are rare, lightning strikes have occasionally ignited grass fires which burned thousands of acres of the Hanford project land and resulted subsequently in considerable wind erosion. The most notable of these occurrences were in August 1961, July 1963, and July 1970.

On June 16, 1948, a tornado was observed near the east end of Rattlesnake Mountain about 10 miles south of the Hanford Meteorology Station. It was over barren country and no damage resulted. There have been two funnel clouds observed in 36 years $(1945-80)$ of observations. However, the nearest reported tornado damage has been at Yakima, about 45 miles west (April 30, 1957), and at Wallula Junction, about 50 miles southeast (June 26, 1958). Damage from these included moving a double garage off its foundation into a field 20 feet away, and lifting an 800 -pound boat across a road.

*Based on records kept at the Hanford Meteorology Station from 1945-1980 and supplemented with precipitation and temperature data taken by U.S. Weather Bureau cooperative observers at a site about 10 miles ENE of the present station location during the period 1912-1944 


\section{AVERAGES AND EXTREMES OF CLIMATIC ELEMENTS AT HANFORD}

(BASED ON ALL AVAILABLE RECORDS TO AND INCLUDING THE YEAR 1980)

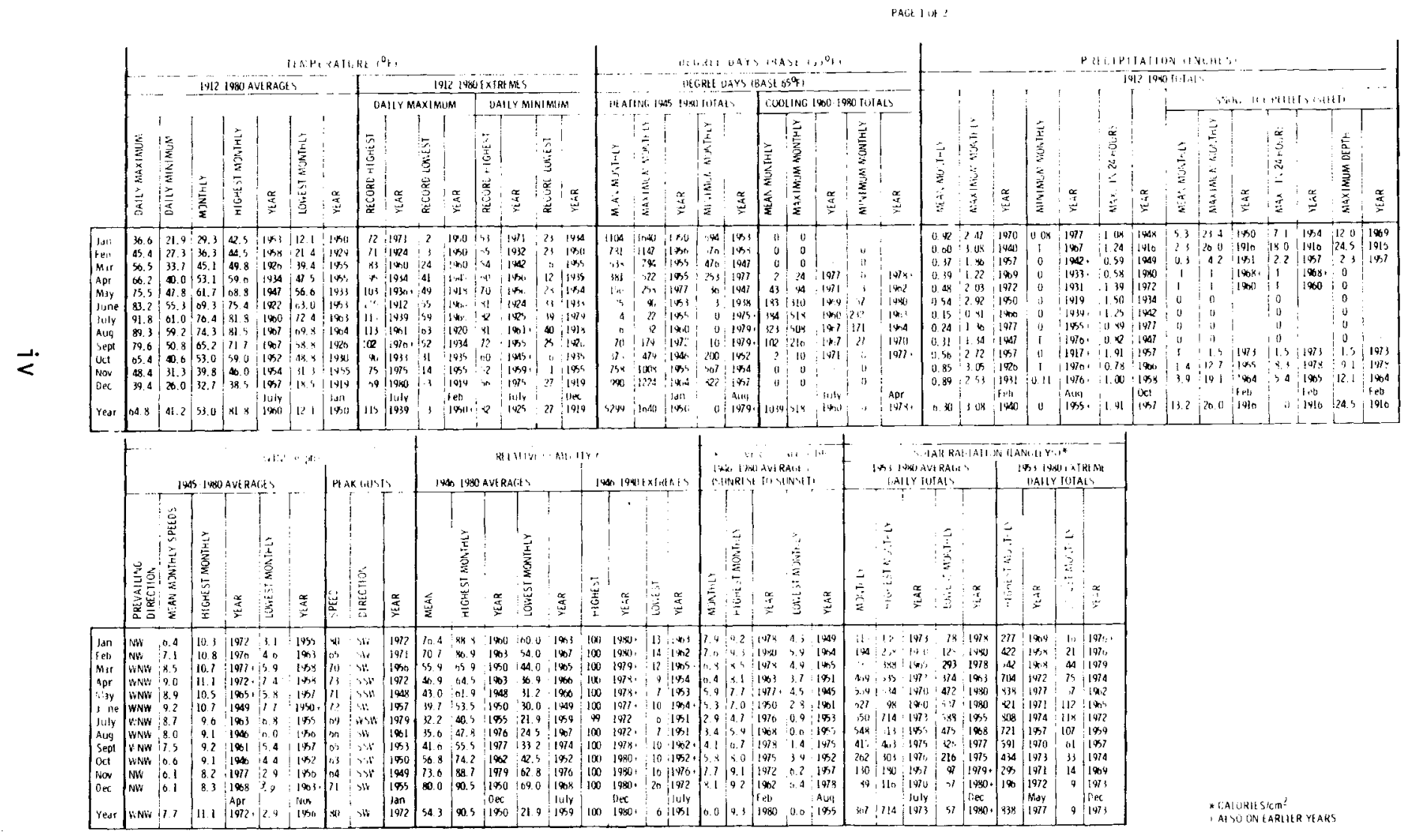

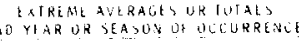

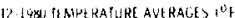

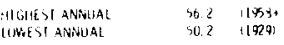

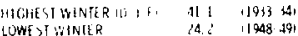

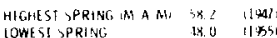

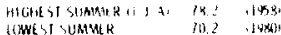

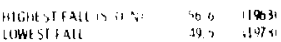

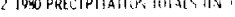

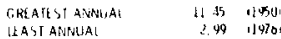

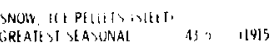

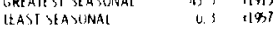

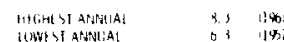

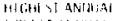

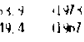

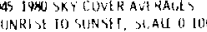

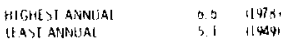
IOSB:

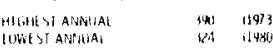




\section{AVERAGES AND EXTREMES OF CLIMATIC ELEMENTS AT HANFORD (cont'd)}

(BASED ON ALL AVAILABLE RECORDS TO AND INCLUDING THE YEAR 1980)
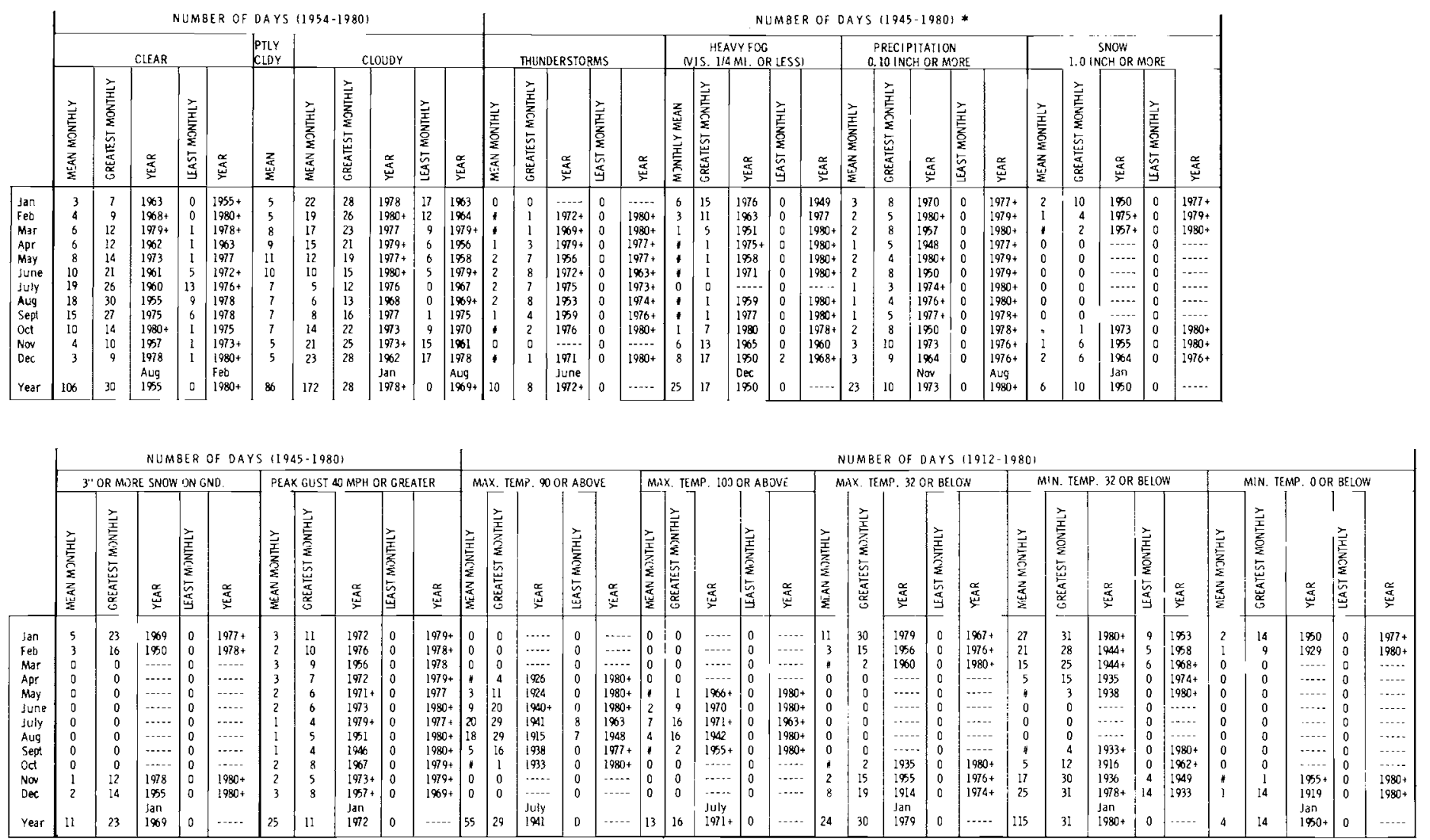

NUM JER OF DAYS

CLEAR 10-3 TENTHS SKY COVER, SR TO SSI $\begin{array}{lll}\text { GREATEST ANNUAL (1954-80) } & 121 & 1300 \\ \text { LEST ANNUAL (11954-80) } & { }_{80} & 197\end{array}$ CLOUDY Y9-10 TENTHS SKY COVER, SR TO SSY $\begin{array}{lll}\text { GREATEST ANNUAL (1954-80) } & 193 & 1978 \\ \text { LEAST ANNUAL 11954-80) } & { }_{85} & 1966\end{array}$ IHUNDERSTORMS

GREATEST ANNUAL (1945-80,
LAST ANNUAL (1195-80) MEAVY FOG NIS. 144 MILE OR LESS

GREATEST SEASONAL 11245-80) \& 150-5: PRECIPITATION 0.10 INCH OR MJRE

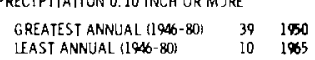
SNOW 1.0 INCH OR MORE

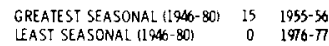
3 IN. OR MORE SNOW ON GROUNO

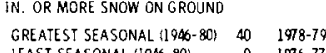
PEAK GUST $\triangle D$ MPH OR GREATER

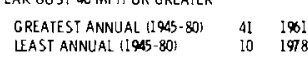
MAX. TEMPERATURE 90 OR ABOV

$\begin{array}{lll}\text { CREAEST ANNUAL } 1912-801 & 85 & 1900 \\ \text { LAST ANNUAL } 11912-80 ! & 29 & 1980\end{array}$ MAX. TEMPERATURE LOO OR ABO

GREATEST ANNUA1 11912-80! $32 \quad 194$

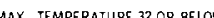

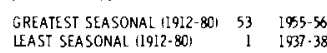

MIN. TEMPERATURE 32 OR BELOW

$\begin{array}{lll}\text { CREATEST SEASONAL (1912-801 } & 141 & 1916-17 \\ \text { LEAST SEASONAL L (1912-801 } & 75 & 1957-58\end{array}$

MIN. TEMPERATURE O OR BELOW

$\begin{array}{lrrr}\text { GREATEST SEASONAL (1912-80) } & 18 & 1949-50 \\ \text { LEAST SEASONAL (1912-80) } & 0 & 197-77\end{array}$

REFERENCE NOTES * PREC PITATION OB ERRVATIONS NOO - LESS THAN I/2

aLSO ON EARL IER YeARS
LOCATION AND HISTORY

PRESENT LOCATION ZS MILES WW JF RICHLAND, WA SHINGTON

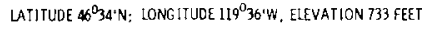

OBSERVATIONS FROM 1912 TO 1944 WERE BY UNITED STATES WEATHER
SUREAU COOPSRATIVE OBSERVERS AT A SIIE A8OUT 10 MILSS ENE OF

PRESENT LOCATION. SINCE 1944, OBSERVATIONS HAVE BEEN
MAINAA INED ONA 24 HOUR-A-DAY BASIS BY THREE DIFERENT 

CONTENTS

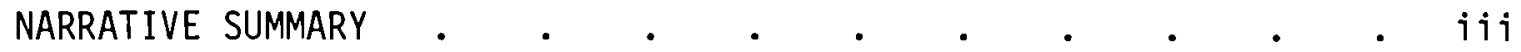

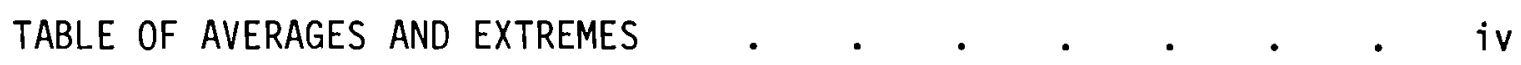

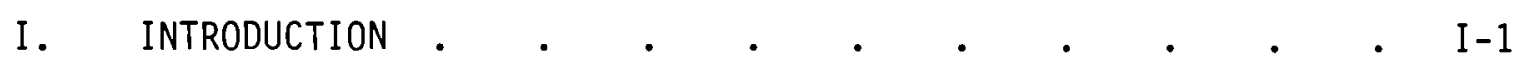

LOCATION AND DESCRIPTION OF THE HMS . . . . . . . I-1

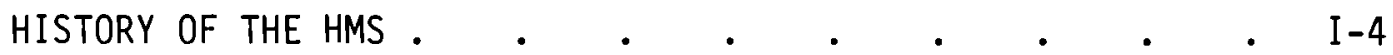

REPORT CONTENT $\quad . \quad . \quad . \quad . \quad . \quad . \quad . \quad . \quad . \quad . \quad . \quad$.

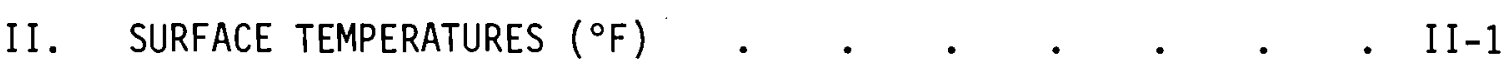

MONTHLY AND ANNUAL MEANS . . . . . . . . . II-2

FREQUENCY DISTRIBUTION OF DAILY MAXIMUM AND MINIMUM

TEMPERATURES: JANUARY VERSUS JULY

DAYS WITH MAXIMUM TEMPERATURES $100^{\circ} \mathrm{F}$ OR ABOVE, $90^{\circ} \mathrm{F}$ OR

ABOVE, AND $32^{\circ} \mathrm{F}$ OR BELOW

DAYS WITH MINIMUM TEMPERATURES $32^{\circ} \mathrm{F}$ OR BELOW AND $0^{\circ} \mathrm{F}$ OR

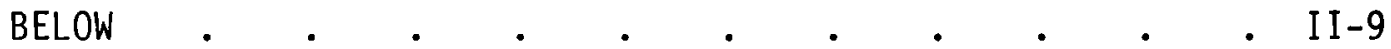

MONTHLY EXTREMES OF DAILY MAXIMUM AND MINIMUM TEMPERATURES - II-11

NORMALS AND EXTREMES OF DAILY TEMPERATURES . . . . . II-11

RECORD COLD TEMPERATURES .

UNSEASONABLE COLD PERIODS . . . • • • • . II-15

PROLONGED PERIODS WITH ABOVE NORMAL SUMMER TEMPERATURES - II-15

MEAN TEMPERATURE WITH 10 AND 15-YEAR MOVING AVERAGES • • II-16

FREEZE-THAW CYCLES . . . . . . . . . . . II-22

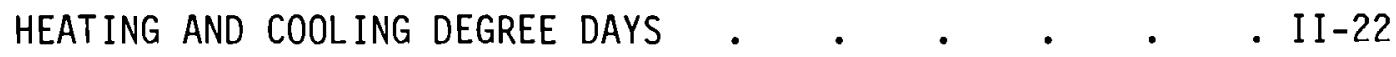

EXTREME TEMPERATURE PROBABILITY . . • • • • . . II-22

VERTICAL TEMPERATURE PROFILES . . . . • . . . II-22 


\section{CONTENTS (Continued)}

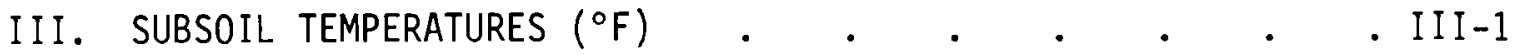
EXTREME SUBSOIL TEMPERATURE PROBABILITY • • • . III-1

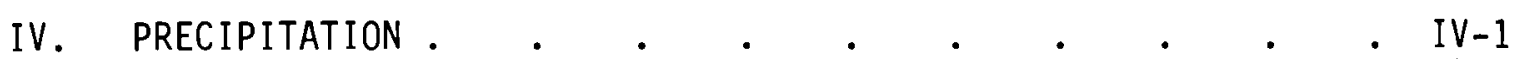
MONTHLY AND ANNUAL TOTALS AVERAGE NUMBER OF DAYS WITH SPECIFIED AMOUNTS . • • IV-1 TOTAL TIME WITH PRECIPITATION OBSERVED . . . . . . IV-1 PERCENT OF DAYS AND MONTHLY PRECIPITATION INTENSITY FACTORS • • • • • • • • • • • • IV 6 NOTABLE WET PERIODS $. \quad . \quad . \quad . \quad . \quad . \quad . \quad . \quad$ IV-6 NOTABLE DRY PERIODS . . . . . . . . IV-10 SNOWFALL • . . . . . . . . . . IV-10 MOVING AVERAGES . $. \quad . \quad . \quad . \quad . \quad . \quad$ IV-13 HMS VERSUS RICHLAND $. \quad . \quad . \quad . \quad . \quad$ • . . IV-13 EXTREME ANNUAL PRECIPITATION PROBABILITY . . . . . IV-17

V. 50-FOOT WIND . $. \quad . \quad . \quad . \quad . \quad . \quad . \quad . \quad . \quad \mathrm{V}-1$ MONTHLY AND ANNUAL PREVAILING WIND DIRECTIONS, AVERAGE SPEEDS, AND PEAK GUSTS • JUNE WIND SPEEDS VERSUS DECEMBER WIND SPEEDS . $\cdot$. $V-1$ SEASONAL AND DIURNAL VARIATION IN SPEED • SEASONAL AND DIURNAL VARIATION IN DIRECTION . . . . $\quad v-3$ WIND SPEED AND DIRECTION DURING PERIODS OF PRECIPITATION $\cdot V-11$ WIND DURING PERIODS OF FOG WIND PROFILES . . . . . . . . . . . V-13 EXTREME VALUE ANALYSIS OF PEAK GUSTS . . . . . . V-13 


\section{CONTENTS (Continued)}

VI. SKY COVER, VISIBILITY AND SOLAR RADIATION . . . . VI-1

SKY COVER

VISIBILITY . . . . . . . . . . . . VI-3

SOLAR RADIATION . . . . . . . . . . . VI-3

VII. PSYCHROMETRIC DATA . $. \quad . \quad . \quad . \quad$. $\quad$. . . . VII-1

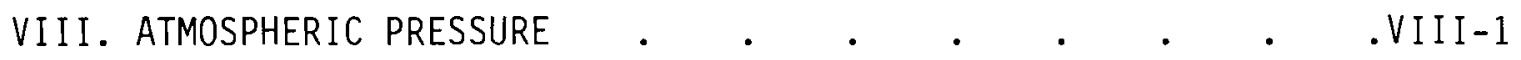

iX. MisCELLANEOUS PHENOMENA . . . . . . . . . . IX-1

THUNDERSTORMS . . . . . . . . . . . . . IX

HAIL . . . . . . . . . . . IX-1

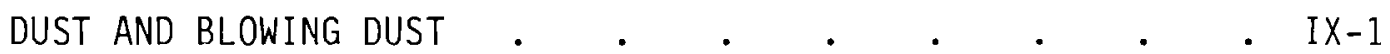

$\mathrm{ASH} \cdot . \quad . \quad . \quad . \quad . \quad . \quad . \quad . \quad$. $\mathrm{IX}-3$

FOG . . . . . . . . . . . . IX

GLAZE • . . . . . . . . . . . IX-5

WARM AND COLD FRONTS $. \quad . \quad . \quad . \quad . \quad . \quad . \quad . \quad$.

BLOWING AND DRIFTING SNOW . . . . • . . IX-5

DUST DEVILS

SMOKE . . . . . . . . . . . IX

TORNADOES $. \quad . \quad . \quad . \quad . \quad . \quad . \quad . \quad . \quad$ IX 6

RIME . . . . . . . . . . . IX-7

AURORAS . . . . . . . . . . IX-7

$X$. DIFFUSION CLIMATOLOGY . . . . . . . . .

VERTICAL TEMPERATURE PROFILES . . . . . . . $x-1$

PERSISTENCE OF INVERSIONS $. \quad . \quad . \quad . \quad . \quad . \quad \cdot \quad \times-5$

TYPES OF INVERSIONS

INVERSION TRAPPING . $. \quad . \quad . \quad . \quad . \quad . \quad \cdot \quad \times-8$ 
CONTENTS (Continued)

PERSISTENCE OF SUPERADIABATIC LAPSE RATES . . . . . $x-9$

WIND PROFILES . $\quad . \quad . \quad . \quad . \quad . \quad . \quad . \quad . \quad . \quad \times-9$

WIND SPEED AND DIRECTION VERSUS STABILITY . . . . $\quad x-76$

TOWER TEMPERATURES . . . . . . . . . . . . $\quad . \quad x-92$

XI. PERSistence AND EXTREME VAlUeS . . . . . . . . XI-1

PROBABILITY THAT A WINTER MINIMUM WILL FALL BELOW OR A

SUMMER MAXIMUM WILL EXCEED A GIVEN TEMPERATURE $. . . ~ X I-1$

PROBABILITY THAT A WINTER MINIMUM SUBSOIL TEMPERATURE

WILL FALL BELOW OR SUMMER MAXIMUM WILL. EXCEED A GIVEN

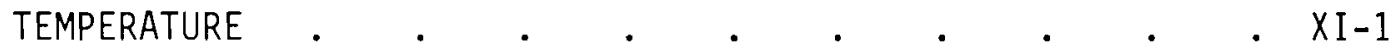

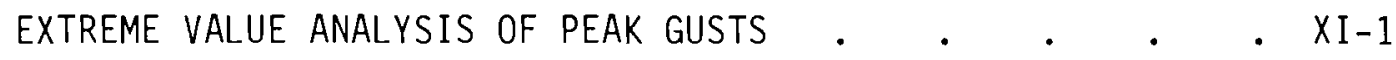

RAINFALL INTENSITY DURATION AND FREQUENCY . . . . X XI-1

PROBABILITY THAT THE GREATEST DEPTH OF SNOW ON THE GROUND

WILL EXCEED A GIVEN AMOUNT •

PROBABILITY THAT TOTAL ANNUAL PRECIPITATION WILL EXCEED

A GIVEN AMOUNT.$\quad \cdot \quad \cdot \quad \cdot \quad \cdot \quad \cdot \quad \cdot \quad \cdot \quad \cdot$ XI-9

XII. METEOROLOGICAL INSTRUMENTATION . . . . . . . . XII-1

TEMPERATURE $. \quad . \quad . \quad . \quad . \quad . \quad . \quad . \quad . \quad$ XII-1

SOLAR RADIATION

WIND $. \quad . \quad . \quad . \quad . \quad . \quad . \quad . \quad . \quad . \quad . X I I-1$

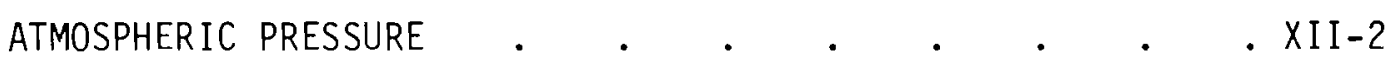

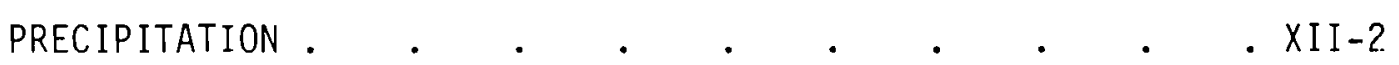

TEMPERATURE OF THE DEW POINT . . . . . . . . . XII-2

XIII. ACKNOWLEDGEMENTS .

XIV. REFERENCES . . . . . . . . . . . . . XIV-1

APPENDIX I: NOTABLE COLD PERIODS . . . . . . . . . A.I-1

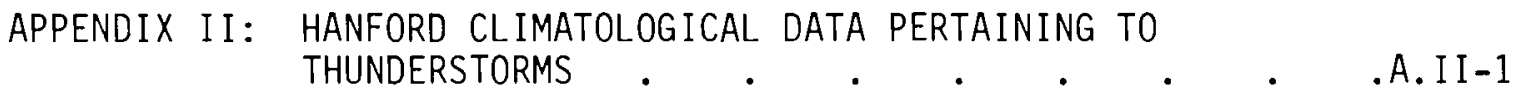




\section{CONTENTS (Continued)}

APPENDIX III: SUNRISE AND SUNSET AT THE HANFORD

METEOROLOGY STATION •

APPENDIX IV: HANFORD WIND TELEMETRY NETWORK . . . . . A.IV-1

APPENDIX V: PRECIPITATION CLIMATOLOGY OF THE ARID LANDS

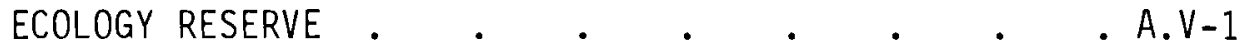




\section{FIGURES}

1a The Hanford Reservation in Relation to Surrounding

Terrain. . . . . . . . . . . I I-2

1b The Hanford Reservation and Vicinity . . . . . I-3

2 (a) The 410-Foot Meteorology Tower (Showing Instrument Booms); (b) Surface Installation 75 Feet Northwest of the Tower

3 Frequency Distribution of Monthly Mean Temperatures January and July, 1912 Through 1980 . . . . . II-3

4 Frequency Distribution of Daily Maximum and Minimum Temperatures January and July, 1951 Through 1980 . . II-5

5 Normal and Extreme Daily Temperatures at Hanford . . II-13

6 Annual Mean Temperature (1913 Through 1980) and 10 and 15-Year Moving Averages . . . . . . II-17

7 Summer Mean Temperatures and 15-Year Moving Averages for Period 1912 Through 1980 . $. \quad . \quad . \quad . \quad$. II-18

8 Winter Mean Temperatures and 15-Year Moving Averages for Period 1912 Through $1981 \quad$. $\quad . \quad$ • . . . . . II-19

9 March Mean Temperatures and 15-Year Moving Averages for Period 1912 Through 1980 . $\quad . \quad$. . . . . II-20

10 September Mean Temperatures and 15-Year Moving Averages for Period 1912 Through 1980 . $. . \quad . \quad . \quad$. II-21

11 Monthly and Diurnal Variation of Subsoil Temperature: 1955 Through $1980 . \quad . \quad . \quad . \quad . \quad . \quad$. III-3

12 Average Monthly Subsoil and Air Temperatures . . . III-6

13 Snow Cover Effect on Subsoil Temperatures . . . . III-7

14 Average Monthly Precipitation Amounts: 1912 Through 1980

15 (a) Precipitation - Percent of Days Statistics Based on the Period 1946 Through 1980; (b) Percent of Days in a Year With Precipitation as Indicated . . . . . IV-7 
FIGURES (Continued)

16 Monthly Average Precipitation Intensity Factors

Based on the Periods July 1946 Through June 1971

and July 1974 Through 1980 . . . . . . . IV-8

17 Total Annual Precipitation (1913 Through 1980) and 10-

and 15-Year Moving Averages . . . . . . . . IV-9

18 Greatest Depth of Snow on Ground During Winters of

Record at Hanford 1946-47 Through 1980-81 . . . . IV-14

19 Total Seasonal Snowfall and 15-Year Moving Averages

for Period 1913 Through 1981 . $\quad$ • . . . . IV-15

20 Hourly Average 50-Foot Wind Speeds: June Versus

December, 1955 Through 1980 . . . . . . . V-5

21 Percentage of 50-Foot Wind Direction From WNW and

NW by Hour: June Versus December, 1955 Through 1980 . . V-7

22 Monthly Wind Roses for HMS Based on 50-Foot Wind Data,

1955 Through 1980 ..$\quad$. . . . . . . . V-9

23 Average, Greatest and Least Daily Solar Radiation

Totals: 1953 Through 1980 . . . . . . . VI-6

24 Monthly and Annual Hourly Averages of Dry Bulb (D.B.)

and Wet Bulb (W.B.) Temperature, Relative Humidity (R.H.),

and Temperature of the Dew Point (D.P.) (1956 Through

1980)

25 Mean Relative Humidity (\%) at 1300 PST in July: Each

Year from 1946 to 1980 . . . . . . . . . . . . . . .

26 Monthly Average Temperature Profiles by Hour Based on

26 Years of Record: 1955 Through 1980. . . . . X-2

27 Monthly and Annual Average Temperature $\left({ }^{\circ} \mathrm{F}\right)$ Profiles:

1955 Through 1980 . $. \quad . \quad . \quad . \quad . \quad . \quad . \quad X-6$

28 Diurnal Course of Temperature for Three Levels, January, April, July and October: 1955 Through 1980 . . X-7

29 A Schematic Representation of an Inversion Trapping Situation

30 Monthly Hourly Average Wind Speeds for Five Levels, 1955 Through 1980 . 


\section{FIGURES (Continued)}

31 Lowest Temperature During Each of 68 Winters at Hanford: 1912-13 to 1979-80--Probability (\%) That Lowest

Temperature Will be Higher Than Given Temperature . . XI-2

32 Highest Temperature During Each of 66 Summers of Record at Hanford: 1912 Through 1980 . . . . . . XI-3

33 Annual Lowest Subsoil Temperatures, 1955 Through 1980 . XI-4

34 Annual Highest Subsoil Temperatures, 1955 Through 1979 . XI-5

35 Peak Wind Gust Return Period Probability Diagram, Based on Records 1945 Through 1980 . . . . . XI-6

36 Rainfall Intensity, Duration, and Frequency Based on the Period 1947 to 1969 at Hanford . . . . . XI-7

37 Hanford Meteorology Station Total Annual Precipitation 1913 Through 1980. . . . . . . . . XI-10

A.IV-1 Wind Roses for the Hanford Telemetry Network • . . A.IV-2

A.V-1 Location of the Arid Lands Ecology Reserve . . . . A.V-2

A.V-2 Locations of Temperature and Precipitation Measuring Stations in the Arid Lands Ecology Reserve. . . . A.V-3

A.V-3 Annual Average Distribution of Precipitation for the ALE Reserve (1969-1980) . . . . . . A.V-6 



\section{TABLES}

1 Composite Record of Monthly and Annual Mean Temperatures ( ${ }^{\circ} \mathrm{F}$ )

for Hanford Townsite (Near) and HMS: 1912 Through 1980 . II-2

2 Composite Record of Monthly and Seasonal Number of Days With Maximum Temperature ( ${ }^{\circ} \mathrm{F}$ ) in Relation to Certain Thresholds for Hanford Towns ite (Near) and HMS: 1912 Through 1980 . $. \quad . \quad$. . . . . . II-6

3 Composite Record of Annual First and Last Dates with Extreme Temperature $\left({ }^{\circ} \mathrm{F}\right)$ in Relation to Certain Thresholds for Hanford Townsite (Near) and HMS: 1912 Through 1980 . II-8

4 Composite Record of Monthly and Seasonal Number of Days With Minimum Temperature $\left({ }^{\circ} \mathrm{F}\right)$ in Relation to Certain Thresholds for Hanford Townsite (Near) and HMS: 1912 Through 1980 . $. \quad . \quad . \quad . \quad$. II-10

5 Monthly Extremes of Daily Maximum and Minimum Temperatures and Daily Temperature Ranges for Hanford Townsite (Near) and HMS Based on Period of Record 1912 Through 1980 . . II-12

6 Freeze-Thaw Cycles: Days on Which Maximum was Above $32^{\circ} \mathrm{F}$ and Minimum $32^{\circ} \mathrm{F}$ or Below: (1912 Through 1980) . II-23

7 Heating Degree Day Data for the Period 1945 Through $1980\left(\right.$ Base $\left.65^{\circ} \mathrm{F}\right)$. $. \quad . \quad . \quad . \quad . \quad . \quad . \quad$ II-24

8 Cooling Degree Day Data for Period 1960 Through 1980 (Base 65\% F). . . . . . . . . II-25

9 Subsoil Temperature Data (High and Low Extremes of Average Monthly Subsoi1) . . . . . . III-2

10 Composite Record of Monthly and Annual Precipitation (Inches) for Hanford Townsite (Near) and HMS: 1912 Through 1980

11 Average Number of Days with Precipitation of Specified Amount, 1946 Through 1980 . . . . . . . IV -4

12 Monthly and Annual Averages and Extremes in Total Time With Precipitation Observed: July 1946 Through June 1971, July 1974 Through December 1980 . . . . IV-5

13 Composite Record of Monthly and Seasonal Snowfall for Hanford Townsite (Near) and HMS: 1912. Through 1980 . . IV-1? 


\section{TABLES (Continued)}

14 Miscellaneous Snowfall Statistics, 1946 Through 1980 . IV-12

15 Monthly and Annual Averages and Extremes of Precipitation

for HMS Versus Richland, July 1946 Through December 1980 . IV-16

16 Monthly and Annual Prevailing Wind Directions, Average

Speeds and Peak Gusts at 50 Feet: 1945 Through 1980 . V-2

17 Percent Frequency of Monthly and Annual Wind Direction and Speed at 50-Foot Elevation, 1955 Through 1980 . . V-4

18 Monthly and Annual Diurnal Variation in the Percentage of Wind From WNW and NW at 50-Foot Level 1955 Through 1980

19 Monthly and Annual Hourly Average Wind Speed at 50-Foot Level: 1955 Through 1980 . . . . . . V-8

20 Monthly and Annual Diurnal Variation in the Percentage of Wind From SSW, SW and WSW at 50-Foot Level, 1955

Through 1980 . $. \quad . \quad . \quad . \quad . \quad . \quad . \quad$ V-10

21 Percentage of Wind From Various Directions During Observations of Precipitation: 1960 Through 1980 . . V-11

22 Percentage of Wind in Various Speed Classes During Hourly Observations of Precipitation: 1960 Through 1980 . V-12

23 Frequency Distribution (\%) of Wind Directions and Speeds During Hourly Observations of Fog With

Visibility $1 / 2$ Mile or Less: 1960 Through 1980 . . V-13

24 Average Sky Cover (Sunrise to Sunset) and Number of Days Clear, Partly Cloudy and Cloudy, 1946 Through 1980 . VI-2

25 Percent of Hourly Observations With Visibility Restricted to 6 Miles or Less by Various Phenomena (1960 Through 1980)

26 Hourly and Daily Average Solar Radiation Totals (Langleys) Period of Record 1955 Through 1980 . . . . . VI-5

27 Monthly Averages of Psychrometric Data, 1950 Through 1980 (Dry Bulb, wet Bulb and Dewpoint in ${ }^{\circ} \mathrm{F}$, Relative Humidity in \%) .

28 Percent Frequency Distribution of Dry Bulb Temperature Versus Wet Bulb Temperature (1955 Through 1980) . . VII-3

29 Percent Frequency Distribution of Dry Bulb Temperature, ${ }^{\circ} \mathrm{F}$, Versus Relative Humidity, 1955 Through 1980 . . VII-4 


\section{TABLES (Continued)}

30 Monthly Percent Frequency of Wet Bulb Temperature Category ( $\left.{ }^{\circ} \mathrm{F}\right) 1955$ Through 1980 . . . . . . VII-7

31 Average and Extreme Station and Sea Level Pressure Data, (1950 Through 1980) (Units = Inches of

Mercury

VI I I - 2

32 Monthly Hourly Average Sea Level Pressure 1955 Through 1980 (Units $=$ Millibars) . . . . . . . . VIII-3

33 Monthly Hourly Average Sea Level Pressure 1955 Through 1980 (Units $=$ Inches of Mercury) . $\quad . \quad . \quad . \quad$.VIII-4

34 Monthly Hourly Average Sea Level Pressure 1955 Through 1980 (Units $=$ Mi11imeters of Mercury) . . . . . . VIII-5

35 Monthly Hourly Average Station Pressure 1955 Through 1980 (Units $=$ Millibars) . . . . . . . . . . . . . . .

36 Monthly Hourly Average Station Pressure 1955 Through 1980 (Units $=$ Inches of Mercury) .... . . VIII-7

37 Monthly Hourly Average Station Pressure 1955 Through 1980 (Units $=$ Millimeters of Mercury) . . . . . VIII-8

38 Average Number of Days of Various Meteorological Phenomena at the HMS (1945 Through 1980) . . . . IX-2

39 Total Duration and Maximum Persistence of Fog Tabulated in Hours for the Period 1945 Through 1980 . . IX-4

40 Tornado 0ccurrences Within 100-Mile Radius of the Hanford Meteorology Station . . . . . . IX-8

41 Monthiy and Annual Percent Frequency Distribution of 50-Foot Wind Direction Versus Speed Class, 1955 Through 1980

42 Monthly and Annual Percent Frequency Distribution of 200-Foot Wind Direction Versus Speed Class, 1955 Through 1980

Monthly and Annual Percent Frequency Distribution of 400-Foot Wind Direction Versus Speed Class, 1955 Through 1980

44 Monthly and Annual Percent Frequency of Hourly Wind Direction at 50-Foot Level, 1955 Through 1980 . . . X-34 


\section{TABLES (Continued)}

45 Monthly and Annual Percent Frequency of Hourly Wind

Direction at 200-Foot Level, 1955 Through 1980 . . . X-41

46 Monthly and Annual Percent Frequency of Hourly Wind

Direction at 400-Foot Leve1, 1955 Through 1980 . . . X-48

47 Monthly and Annual Percent Frequency of Hourly Wind Speed Class and Average Speed, 50-Foot Level, 1955

Through 1980

48 Monthly and Annual Percent Frequency of Hourly Wind

Speed Class and Average Speed, 200-Foot Level, 1955

Through 1980

49 Monthly and Annual Percent Frequency of Hourly Wind Speed Class and Average Speed, 400-Foot Level, 1955

Through 1980

50 Seasonal and Annual Percent Frequency Distribution of Wind Speed and Direction Versus Stability (1955 Through 1980) at 200-Foot Leve1, Using $\Delta \mathrm{T}_{1} \cdot$. $_{1}$. $\quad$ • X-77

51 Seasonal and Annual Percent Frequency Distribution of Mind Speed and Direction Versus Stability (1955 Through 1980) at 200-Foot Level, Using $\Delta \mathrm{T}_{2}$. . . . . X-82

52 Seasonal and Annual Percent Frequency Distribution of Wind Speed and Direction Versus Stability (1955 Through 1980) at 400-Foot Level, Using $\Delta \mathrm{T}_{6} \cdot$. $_{6}$. . X-87

53 Monthly and Annual Hourly Average Tower Temperature at 3 Feet (1955 Through 1980).

54 Monthly and Annual Hourly Average Tower Temperature at 20 Feet (1955 Through 1980)

55 Monthly and Annual Hourly Average Tower Temperature at 50 Feet (1955 Through 1980) . . . . . . X-94

56 Monthly and Annual Hourly Average Tower Temperature at 100 Feet (1955 Through 1980) . . . . . . X-95

57 Monthly and Annual Hourly Average Tower Temperature at 200 Feet (1955 Through 1980) . . . . . . X-96

58 Monthly and Annual Hourlv Average Tower Temperature at 250 Feet (1955 Through 1980)

59 Monthly and Annual Hourly Average Tower Temperature at 300 Feet (1955 Through 1980) 


\section{TABLES (Continued)}

60 Monthly and Annual Hourly Average Tower Temperature at 400 Feet (1955 Through 1980) . . . . . . . X-99

61 Average Return Period (R) and Existing Record (ER) for Various Precipitation Amounts and Intensity During Specified Time Periods at Hanford (Based on Extreme Value Analysis of 1947 Through 1969 Records) . . . XI-8

A. I-1 Notable Cold Periods . . . . . . . . . A.I-1

A. III-1 Sunrise and Sunset at the Hanford Meteorology

Station . . . . . . . . . A.III-1

A. IV-1 Percent Frequency Distribution of Wind Direction and Average Wind Speeds (mph) for the Hanford Telemetry Network

A.V-1 Arid Lands Ecology Reserve--Average Monthly Precipitation (in.) for Years 1969 Through 1980 . . . . . A.V-4

A.V-2 Arid Lands Ecology Reserve--Average Monthly Precipitation (cm) for Years 1969 Through 1980 . . . . . A.V-5

A.V-3 Arid Lands Ecology Reserve--Calendar Year Precipitation (in.) for Years 1969 Through 1980 . . . . . A.V-7

A.V-4 Arid Lands Ecology Reserve--Calendar Year Precipitation (cm) for Years 1969 Through 1980 . . . . . A.V-9

A.V-5 Arid Lands Ecology Reserve--Bioyear Precipitation (in.) for Years 1969 Through 1980 . . . . . .A.V-10

A.V-6 Arid Lands Ecology Reserve--Bioyear Precipitation (cm) for Years 1969 Through 1980 . . . . . . .A.V-11 
I. INTRODUCTION 


\section{INTRODUCTION}

This document is a summarization of meteorological observations from the Hanford Meteorology Station (HMS), (a) located near Richland, Washington. The information in this document is based on records kept at the HMS from 1946 to 1980, supplemented with precipitation and temperature data taken by U.S. Weather Bureau cooperative observers at a site about 10 miles east-northeast of HMS during the period 1912 to 1943.

Hanford climatological data are applied in solutions of a wide variety of problems. Frequently, these applications include the following:

1. Safety analysis appraisals for planned operational facilities.

2. Design and construction of new or alteration of existing facilities.

3. Assessment of the diffusion climatology of an arid region.

One purpose of this document is to present climatological information applicable to each of the above. Another purpose is to update the information published in two earlier summary documents: A Climatological Study of the Hanford Area (Jenne and Kerns 1959) and Cl imatography of the Hanford Area (Stone, Jenne and Thorp 1972).

\section{LOCATION AND DESCRIPTION OF THE HMS}

The HMS is on a plateau in south-central Washington (Figures 1a and 1b). The plateau slopes downward toward the Columbia River, which is about 10 miles north of the station and about 300 feet lower in elevation. Elevation of the station is 733 feet MSL at latitude $46^{\circ} 34^{1} \mathrm{~N}$, longitude $119^{\circ} 36^{\prime} \mathrm{W}$. The nearest city is Richland, about 25 miles southeast.

(a) The HMS is operated for the U.S. Department of Energy by Battelle Memorial Institute. 


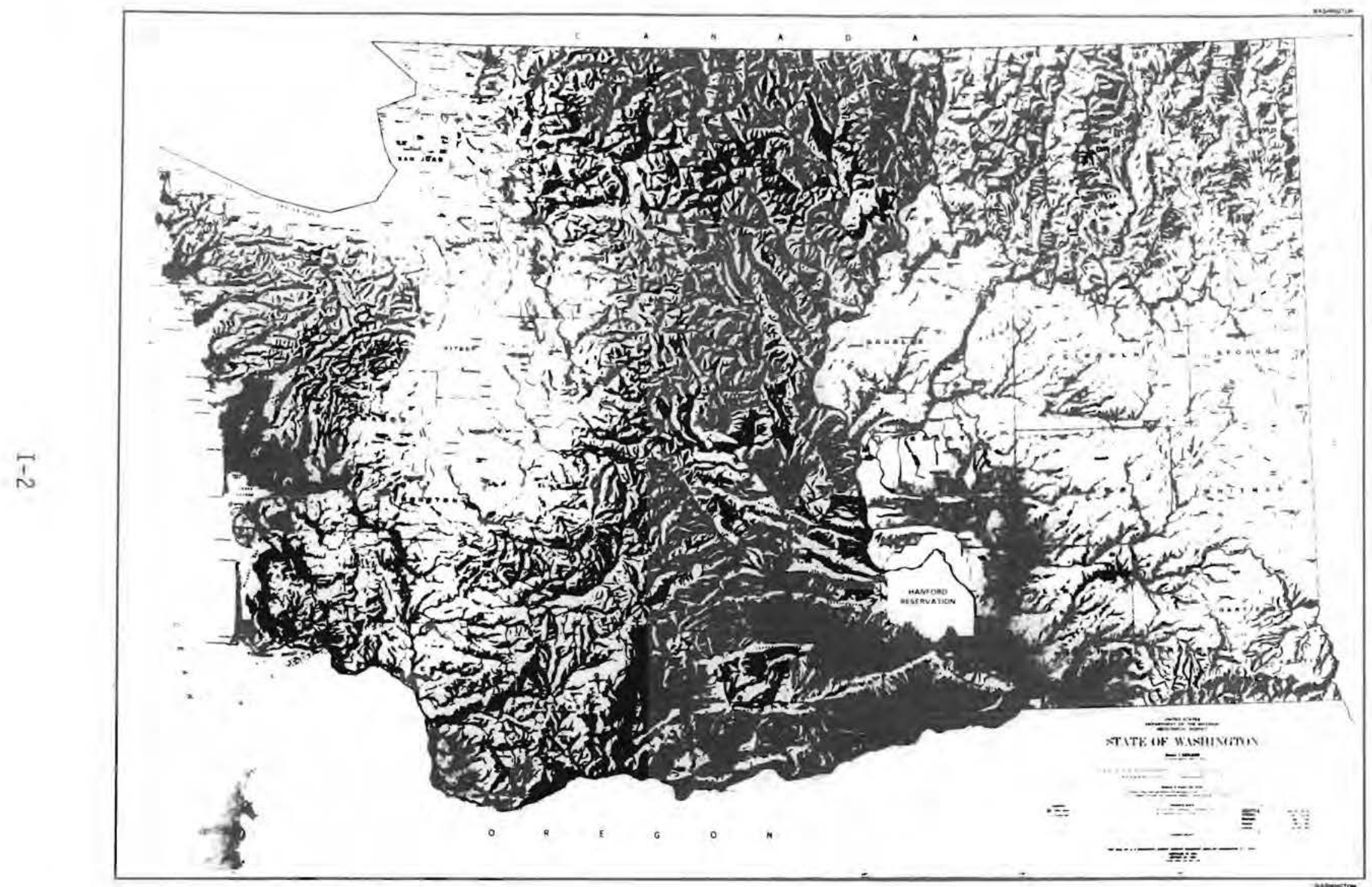

FIGURE 1a. The Hanford Reservation in Relation to Surrounding Terrain 
0

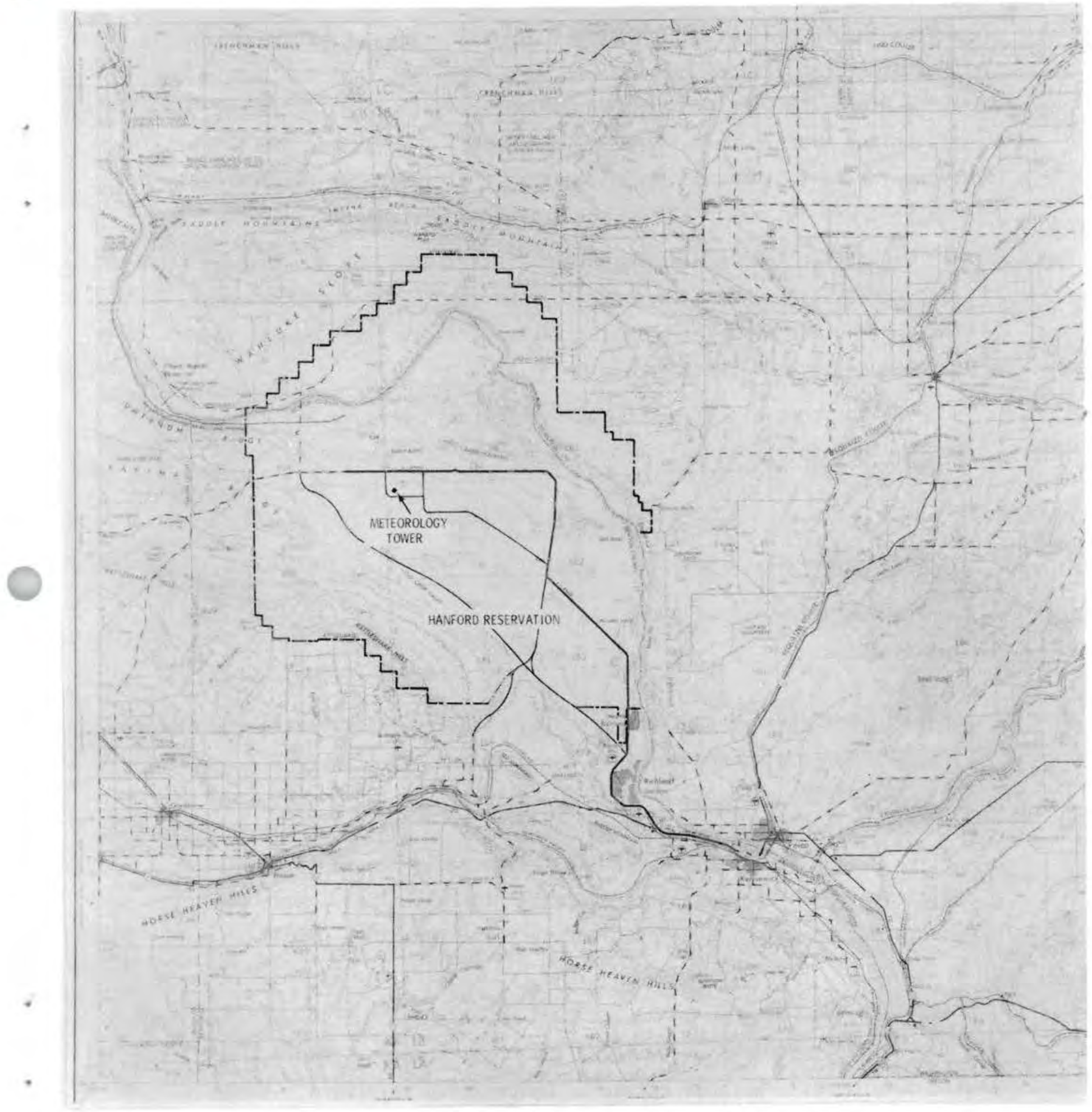

FIGURE 1b. The Hanford Reservation and Vicinity 
In the immediate vicinity of the meteorology station are the Rattlesnake Mountains south and southwest, the Yakima Ridge to the west, and the Saddle Mountains northwest and north. The latter are within 20 miles of the station and rise to more than 2500 feet MSL, while the Yakima Ridge and Rattlesnake Mountains are within 10 miles of the station and rise to more than 3500 feet MSL. The Cascade Mountains beyond Yakima to the west greatly affect the climate of the Hanford Area, but are not visible from the meteorology station.

Vegetation in the Hanford environs, including the mountainous areas, consists mainly of sagebrush, rabbitbrush, bunchgrass, cheat grass, and other semi-arid plants. There are few trees except in isolated cultivated locations.

The HMS consists of a 410-foot steel tower (Figure 2a) with booms spaced at 50-foot intervals and instrumented as shown below.

\section{Tower Levels (ft)}

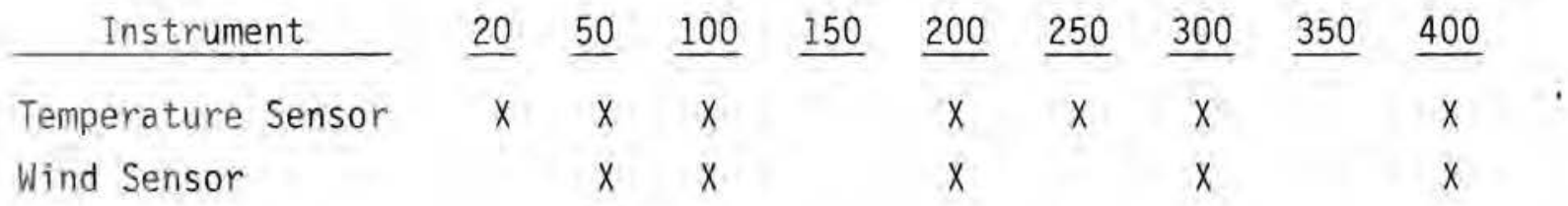

About 75 feet northwest of the tower is a surface installation consisting of temperature, wind and relative humidity sensors (Figure 2b). Near the meteorology building, about 1500 feet west of the tower, are a pyranometer, an acoustic sounder, precipitation gages, and an instrument shelter which houses the maximum and minimum thermometers. These facilities, plus the recorders and other installations inside the meteorology building, are described in detail by Stone (1964).

\section{HISTORY OF THE HMS}

The first official climatological observations in the Hanford Area were made by U.S. Weather Bureau (a) cooperative observers. These. 
(a)

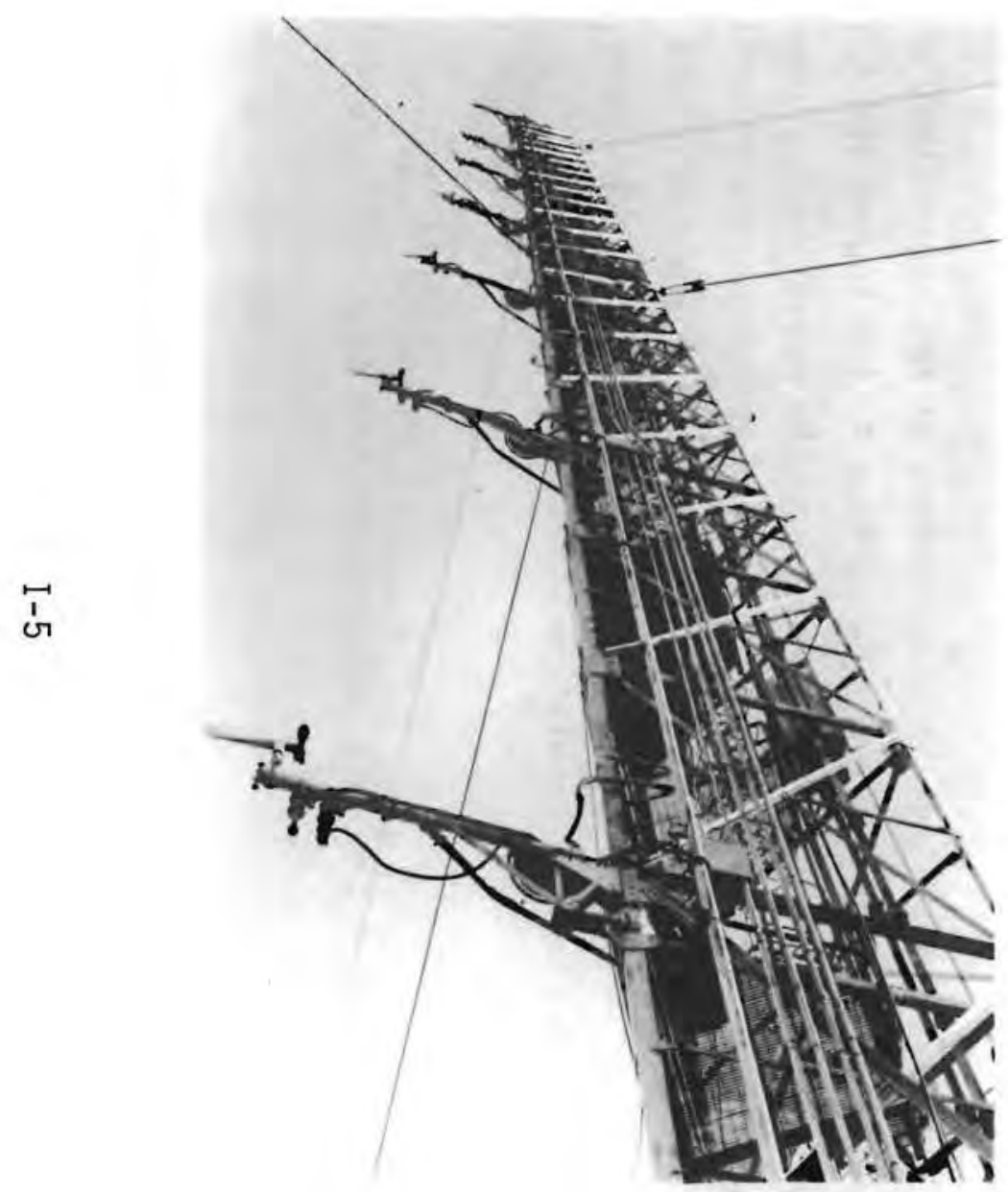

(b)

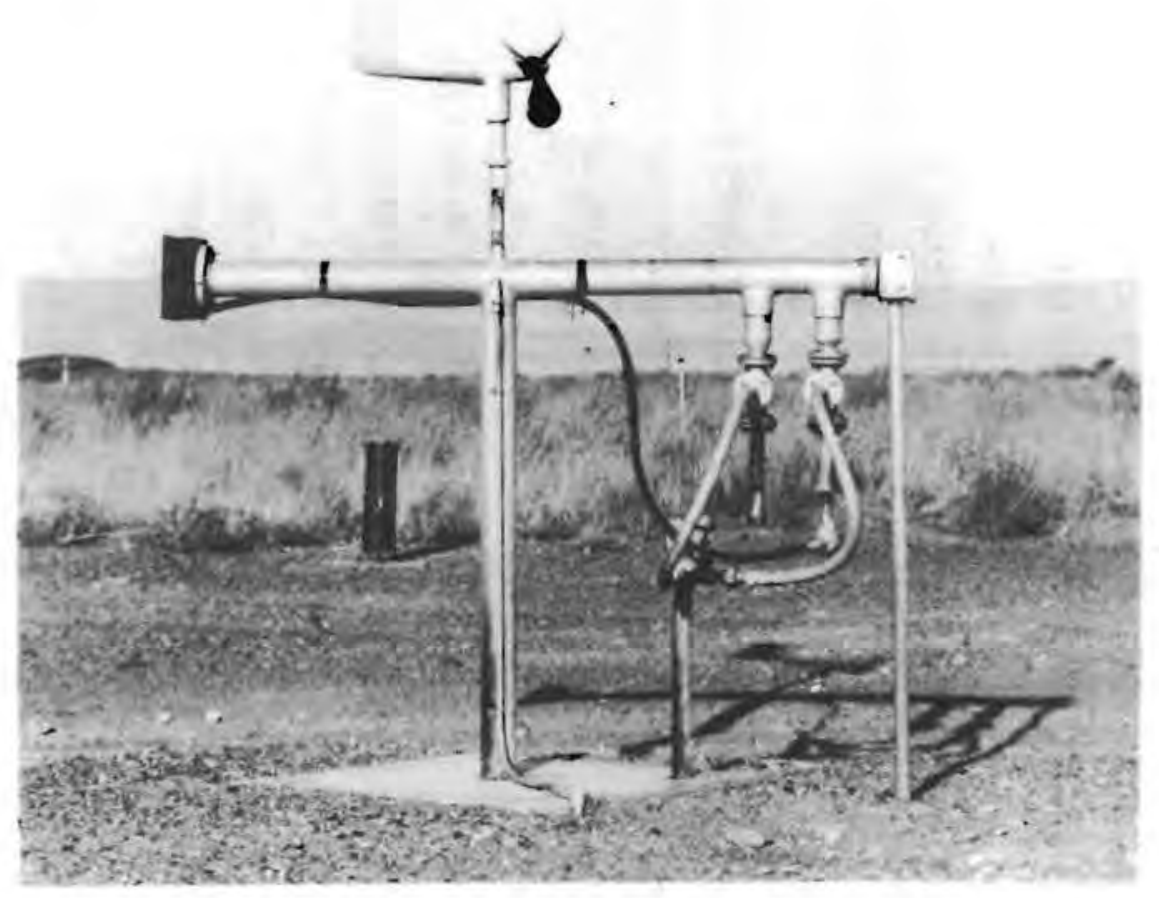

FIGURE 2. (a) The 410-Foot Meteorology Tower (Showing Instrument Booms);

(b) Surface Installation 75 Feet Northwest of the Tower 
observations began April 15, 1912, and continued almost without interruption until March 31, 1943. They consisted of daily maximum and minimum temperatures and total precipitation, including measurements of unnelted snow. Although there were minor changes in observer location, al1 were along the Columbia River about 10 miles east-northeast of the present HMS.

After March 1943, and until December 1944, the only official weather observations in the Hanford area were made by a U.S. Weather Bureau unit near Richland. These observations covered the period from December 1, 1943, to May 18, 1944.

The HMS was constructed as part of the Manhattan Project in 1944. Hourly observations on a continuous basis began on December 7, 1944, and continued through June 1971. From July 1971 through June 1974, the station was not manned for the hours from 1600 through 2300; however, most hourly data for that period of the day were recovered from recorder strip charts. These data include: ambient air temperature, temperature of the dew point, relative humidity, solar radiation, atmospheric pressure, precipitation and wind speed and direction. The HMS resumed 24-hour operation starting July 1974 and continues to operate on that basis.

Original meteorological measurements at HMS were mainly wind and temperature observations from the surface to the top of the 410 -foot tower. Before the end of 1946, however, the measurement program was expanded to include all of the standard "surface observations" specified by the Weather Bureau (Circular N). Since 1965, four of these hourly observations per day $(0400,1000,1600$ and 2200 PST) have been phoned to Seattle for national transmission over Teletype Service C.

\section{REPORT CONTENT}

This document presents summaries of HMS data in the following categories: 
- surface temperatures, degrees Fahrenheit

- subsoil temperatures, degrees Fahrenheit

- precipitation, inches

- tower wind speeds and directions, miles per hour

- tower temperatures, degrees Fahrenheit

- sky cover, visibility and solar radiation

- psychrometric data, degrees Fahrenheit

- atmospheric pressure

- miscellaneous meteorological phenomena (thunderstorm frequency, for example)

- diffusion climatology

- persistence and extreme values of temperatures, winds and precipitation

- meteorological instrumentation.

The data are summarized in graphic and tabular form. The narrative highlights significant features of the climatological information.

The HMS data are reported here in English units. For those interested in SI equivalents, a list of conversions is provided below:

1 centimeter $=0.393701$ inch

1 foot $=0.3048$ meter

1 inch $=2.54$ centimeters

1 kilometer $=0.621371$ statute mile

1 meter $=3.28084$ feet; 39.37 inches

1 mile (statute) $=1.609344$ kilometers

1 millibar $=10^{3}$ dynes $\mathrm{cm}^{-2} ; 0.0295$ inch $\mathrm{Hg}$

1 langley $=1$ gram calorie $\mathrm{cm}^{-2}$

Fahrenheit degrees $=1.8$ (Celsius degrees) $+32^{\circ}$

Celsius degrees $=\left(\right.$ Fahrenheit degrees $\left.-32^{\circ}\right) / 1.8$

1 mile per hour $=0.44704$ meters $\mathrm{s}^{-1} ; 0.868391$ knot

1 meter per second $=2.23694$ miles $^{-1} ; 1.94254$ knots 
. 


\section{SURFACE TEMPERATURES $\left({ }^{\circ} \mathrm{F}\right)$}




\section{SURFACE TEMPERATURES $\left({ }^{\circ} \mathrm{F}\right){ }^{(\mathrm{a})}$}

MONTHLY AND ANNUAL MEANS

Mean temperatures, computed from observed daily maximum and minimum 3-foot temperatures for the period 1912 through 1980, are presented in Table 1. The right side of the table shows annual averages and at the bottom of each column, both monthly averages and monthly normals are shown. The monthly averages are for the entire period of record while the normals are based on the 1951 through 1980 record (30 years).

As indicated in Table 1, there is a much greater range and variability in winter temperatures than in summer temperatures. Examples are shown below and in Figure 3 .

\begin{tabular}{cccc} 
& \multicolumn{1}{c}{ Monthly Means During Winter } \\
\cline { 2 - 4 } & $\underline{\text { Dec }}$ & $\underline{\text { Jan }}$ & $\underline{\text { Feb }}$ \\
Highest of Record $\left(M_{1}\right)$ & 42.0 & 42.5 & 44.5 \\
Lowest of Record $\left(M_{2}\right)$ & $\underline{18.5}$ & $\underline{12.1}$ & $\underline{21.4}$ \\
Range $\left(M_{1}-M_{2}\right)$ & 23.5 & 30.4 & 23.1 \\
& Monthly & Means During Summer \\
Highest of Record $\left(M_{3}\right)$ & $\underline{\text { June }}$ & $\underline{\text { July }}$ & $\underline{\text { Aug }}$ \\
Lowest of Record $\left(M_{4}\right)$ & 75.4 & 81.8 & 81.5 \\
Range $\left(M_{3}\right.$-M & $\underline{63.0}$ & $\underline{72.4}$ & $\underline{69.8}$ \\
& 12.4 & 9.4 & 11.7
\end{tabular}

(a) In addition to material presented in the numbered tables in this section, miscellaneous surface temperature statistics listed include:

Range of Monthly Temperature Means - Winter and Summer. Greatest Winter and Summer Temperature Departures From Average . . . . . . . . . . . II-4 Days With Maximum Temperature Less Than $0^{\circ} \mathrm{F}$. . . . . II-7 Record Cold Periods and Temperatures . . . . : II-14 Number of Observations With Temperatures $\leq$ Specified Low values.

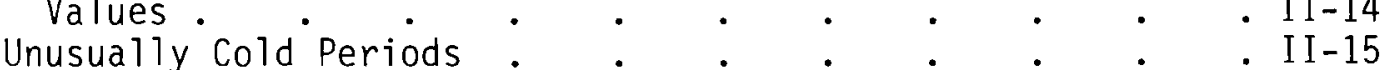
Prolonged Periods of Above-Normal Summer Temperatures . . II-16 
TABLE 1. Composite Record of Monthly and Annual Mean Temperatures ( ${ }^{\circ} \mathrm{F}$ ) for Hanford Townsite (Near) and HMS: 1912 Through 1980

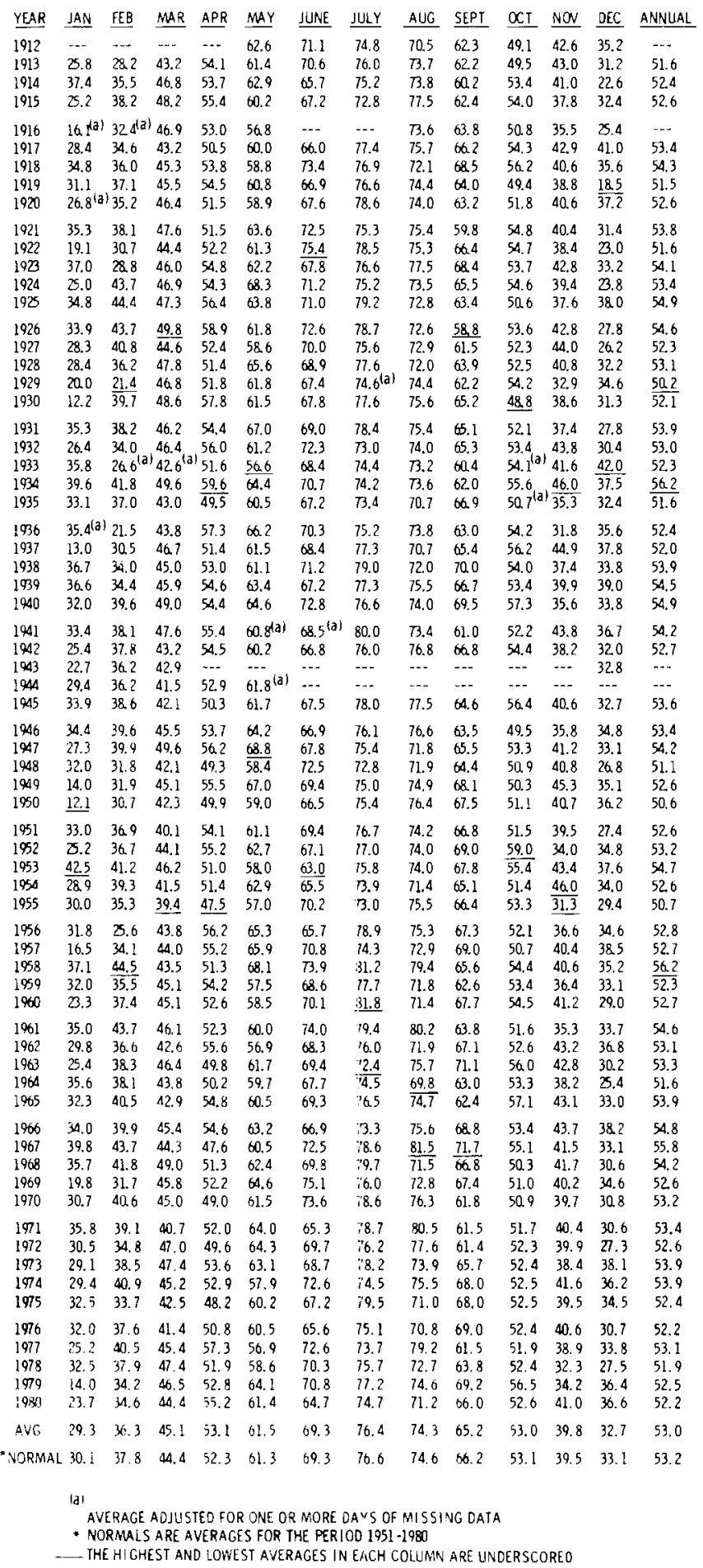




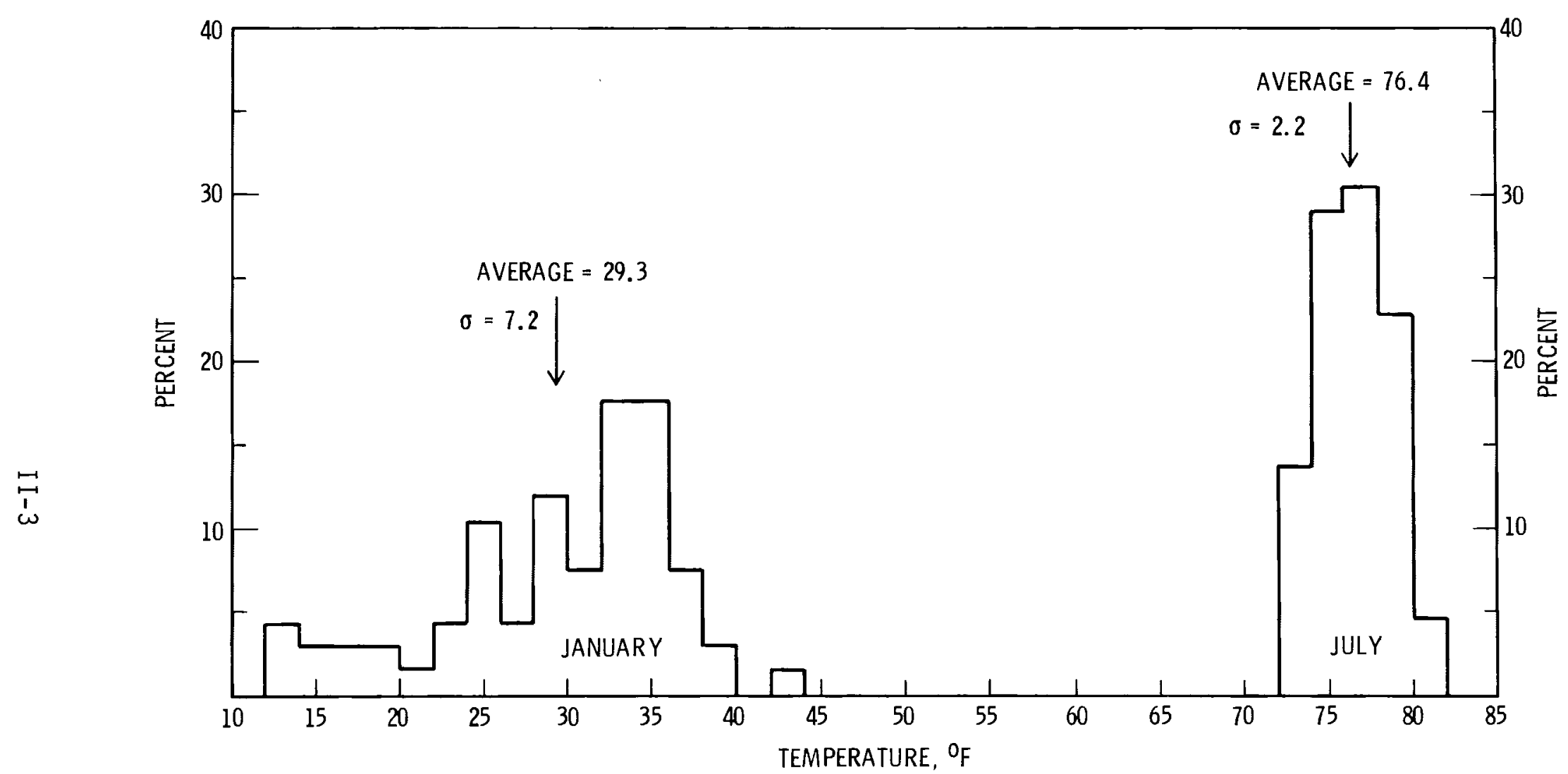

$10=$ STANDARD DEVIATION $)$

FIGURE 3. Frequency Distribution of Monthly Mean Temperatures January and July, 1912 Through 1980 
Table 1 also shows that negative departures from the average are greater than positive departures during winter months, but in the summer months the departures are more nearly equal. During July and August positive departures are higher than the negative departures as indicated below and in Figure 3.

\begin{tabular}{|c|c|c|c|}
\hline $\begin{array}{l}\text { Winter } \\
\text { Months } \\
\end{array}$ & $\begin{array}{l}\text { Average } \\
\text { (Table 1) }\end{array}$ & $\begin{array}{l}\text { Greatest Departure } \\
\text { Negative }\end{array}$ & $\begin{array}{l}\text { From Average } \\
\text { Positive } \\
\end{array}$ \\
\hline Dec & 32.7 & $14.2(1919)$ & $9.3(1933)$ \\
\hline Jan & 29.3 & $17.2(1950)$ & $13.2(1953)$ \\
\hline Feb & 36.3 & $14.9(1929)$ & $8.2(1958)$ \\
\hline $\begin{array}{l}\text { Summer } \\
\text { Months } \\
\end{array}$ & $\begin{array}{c}\text { Average } \\
\text { (Table 1) } \\
\end{array}$ & $\begin{array}{l}\text { Greatest Departure } \\
\text { Negative }\end{array}$ & $\begin{array}{c}\text { From Average } \\
\text { Positive } \\
\end{array}$ \\
\hline June & 69.3 & $6.3(1953)$ & $6.1(1922)$ \\
\hline July & 76.4 & $4.0(1963)$ & $5.4(1960)$ \\
\hline Aug & 74.3 & $4.5(1964)$ & $7.2(1967)$ \\
\hline
\end{tabular}

FREQUENCY DISTRIBUTION OF DAILY MAXIMUM AND MINIMUM TEMPERATURES: JANUARY AND JULY

The frequency distributions of daily maximum and minimum temperatures for the coldest and warmest months are shown in Figure 4, for the period 1951 through 1980 (30 years).

DAYS WITH MAXIMUM TEMPERATURES $100^{\circ} \mathrm{F}$ OR ABOVE, $90^{\circ} \mathrm{F}$ OR ABOVE, AND $32^{\circ} \mathrm{F}$ OR BELOW

The number of days with maximum temperatures in the above categories for the period 1912 through 1980 are summarized by month in Table 2.

Maximum temperatures $\geq 100^{\circ} \mathrm{F}$ have occurred as early as May 5 (1966) and as late as September 9 (1940). The annual number nf days with maximum temperatures $\geq 100^{\circ} \mathrm{F}$ has varied from 1 (1954) to 32 (1942). The greatest number of consecutive days with maximum temperatures $\geq 100^{\circ} \mathrm{F}$ is 11 and has occurred three times (July 13-23, 1938; July 22-August 1, 1962; and August 10-20, 1967). 


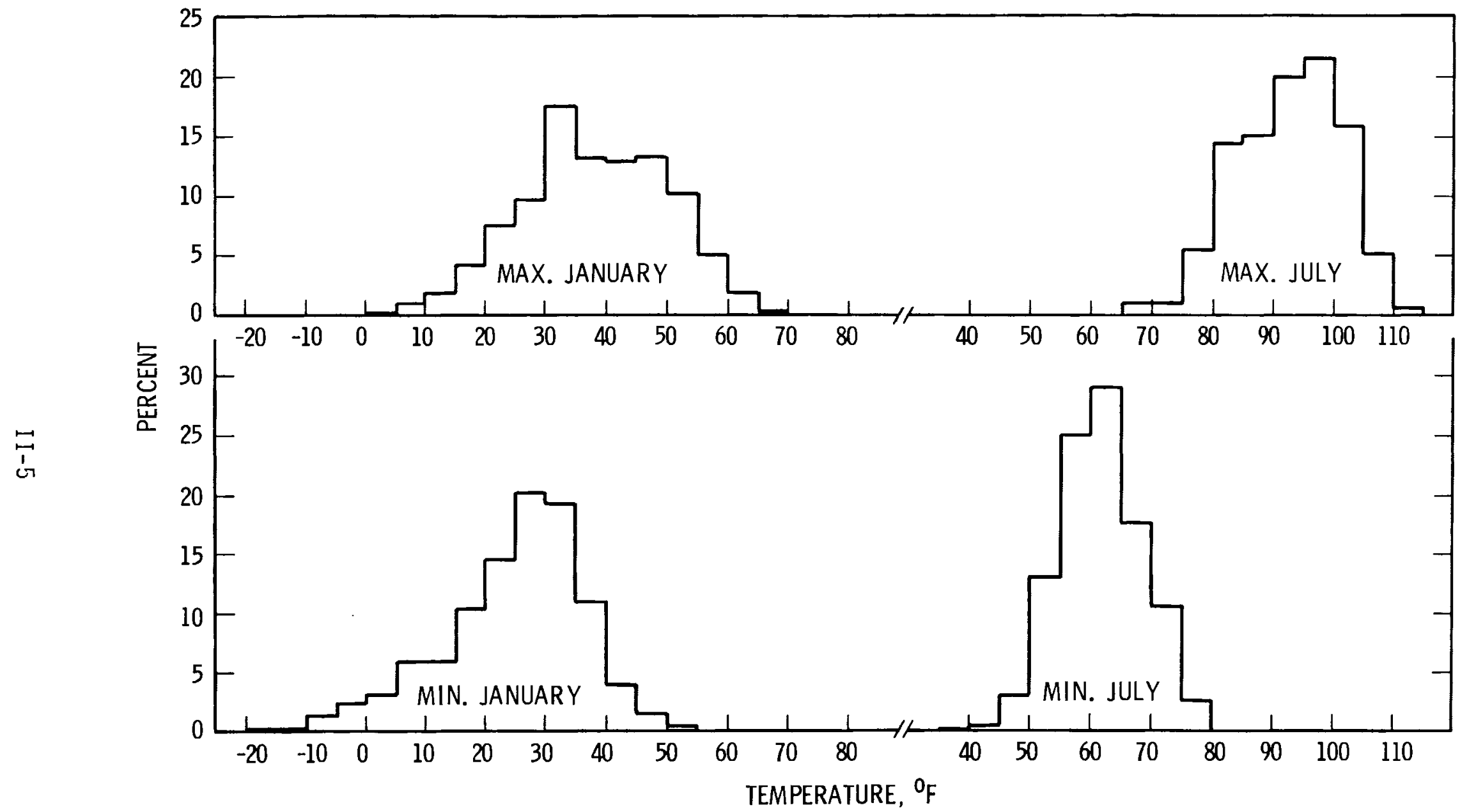

FIGURE 4. Frequency Distribution of Daily Maximum and Minimum Temperatures January and July, 1951 Through 1980 


\section{ABLE 2. Composite Record of Monthly and Seasonal Number of Days With Maximum Temperature $\left({ }^{\circ} \mathrm{F}\right)$ in Relation to Certain Thresholds for Hanford Townsite (Near) and HMS: 1912 Through 1980}

\begin{tabular}{|c|c|c|c|c|c|c|c|c|c|c|c|c|c|c|c|c|c|c|c|c|c|c|}
\hline \multicolumn{7}{|c|}{ I00 OR ABOVE } & \multicolumn{8}{|c|}{90 OR A BOVE } & & & & $320 R$ & SELON & & & \\
\hline SEASON & MAY & JUNE & $\underline{J U L Y}$ & $\underline{A \cup G}$ & SEPT & TOTAL & APR & MaY & JUNE & $\underline{J U L Y}$ & $\underline{A U G}$ & SEPT & $\underline{\mathrm{OCT}}$ & IOTAL & SEA SON & $\underline{O C I}$ & NOV & DEC & JAN & FEB & M.AR & IOTAL \\
\hline 1912 & 0 & 6 & 8 & 4 & 0 & 18 & 0 & 1 & 14 & $x$ & $\downarrow 4$ & 2 & 0 & 54 & $1912-13$ & 0 & 0 & 1 & 16 & 13 & 0 & 30 \\
\hline 1913 & 0 & 3 & 13 & 7 & 0 & 23 & 0 & 0 & 14 & 22 & 20 & 3 & 0 & 65 & $1913-14$ & 0 & 0 & 10 & 0 & 3 & 0 & 13 \\
\hline 1914 & 0 & 1 & 10 & 7 & 0 & 18 & 0 & 4 & 9 & 20 & 23 & 2 & 0 & ba & $1914-15$ & 0 & 0 & 19 & 15 & 0 & 0 & 34 \\
\hline 1915 & 0 & 0 & 0 & 9 & 0 & 15 & 0 & 1 & 3 & 15 & 29 & 4 & 0 & 57 & & & & & & & & \\
\hline 1916 & 0 & -. & -- & 7 & ${ }^{\mathrm{j}}$ & (7) & 0 & 0 & -. & $-\cdot$ & 17 & 1 & 0 & (:8) & $1915-16$ & 0 & 0 & 5 & 22 & 6 & 0 & 33 \\
\hline 1917 & 0 & 1 & 3 & 2 & 0 & 11 & 0 & 0 & ó & 24 & 26 & 5 & 0 & 61 & $1916-17$ & 0 & 5 & 14 & 10 & i & 0 & 30 \\
\hline 1918 & 0 & 2 & 6 & 0 & 0 & 8 & 0 & 2 & 19 & 18 & 13 & 7 & 0 & 59 & $1917-13$ & 0 & 0 & 1 & 3 & 2 & 0 & 6 \\
\hline 1919 & 0 & 0 & 0 & 1 & 0 & 7 & 0 & 1 & 0 & 23 & 0 & 3 & 0 & 53 & $1918+19$ & 0 & 0 & 7 & 11 & 0 & 0 & 18 \\
\hline 1920 & 0 & 1 & 11 & 5 & 0 & 17 & 0 & 0 & 5 & $2 s$ & 0 & 1 & 0 & 52 & $1919-20$ & 0 & 2 & 18 & 17 & 0 & 0 & 37 \\
\hline 1921 & 0 & 1 & 7 & 5 & 0 & 13 & 0 & 3 & 13 & 21 & 13 & 0 & 0 & 55 & $1920-21$ & 0 & 0 & I & 2 & 0 & 0 & 3 \\
\hline 1922 & 0 & 4 & 8 & 3 & 0 & 15 & 0 & 3 & 20 & 23 & 18 & 3 & 0 & 67 & $1921-22$ & 0 & 3 & 11 & 22 & 5 & 0 & 41 \\
\hline 1923 & 0 & 3 & 8 & 6 & 0 & 17 & 0 & 1 & 0 & 23 & 22 & 12 & 0 & $\infty$ & $1922-23$ & 0 & 1 & 17 & 2 & 8 & 0 & 28 \\
\hline .924 & 0 & 1 & 3 & 2 & 0 & 11 & 0 & 11 & 7 & 20 & 13 & 11 & 0 & 62 & $1023-24$ & 0 & 0 & 4 & 12 & 0 & 0 & 16 \\
\hline 1925 & 0 & 5 & 8 & 1 & 0 & 14 & 0 & 0 & 13 & 27 & .9 & 1 & 0 & 60 & $1924-25$ & 0 & 2 & 17 & 2 & 0 & 0 & 21 \\
\hline 1926 & 0 & 3 & 6 & 0 & 0 & 9 & 4 & 1 & 13 & 26 & .1 & 0 & 0 & 55 & $1925-26$ & 0 & 3 & 0 & 3 & 0 & 0 & 6 \\
\hline 1927 & 0 & 0 & 4 & 0 & 0 & 4 & 0 & 0 & 4 & 19 & 1.8 & 0 & 0 & 4] & $1926-27$ & 0 & 0 & 14 & 12 & 0 & 0 & 26 \\
\hline 1928 & 1 & 1 & 9 & 0 & 0 & 11 & 0 & 6 & 4 & 21 & 1.4 & 5 & 0 & 50 & $1927-28$ & 0 & 0 & 14 & 12 & 0 & 0 & 26 \\
\hline 1929 & 0 & 0 & 2 & 3 & 0 & 5 & 0 & 5 & 3 & 17 & 80 & 5 & 0 & 50 & $1928-29$ & 0 & 0 & 9 & 26 & 16 & 0 & 51 \\
\hline 1930 & 0 & 0 & 9 & 7 & 0 & 10 & 0 & 1 & 5 & 22 & $x$ & 3 & 0 & 51 & $1929-30$ & 0 & 0 & 5 & 26 & 0 & 0 & 31 \\
\hline 1931 & 1 & 3 & 10 & 6 & 0 & $x$ & 0 & 9 & 5 & 22 & 2 & 4 & 0 & 52 & $1930-31$ & 0 & 0 & 9 & 0 & 0 & 0 & 9 \\
\hline 1932 & 0 & 5 & 3 & 7 & 0 & 15 & 0 & 1 & 16 & 16 & 17 & 5 & 0 & 55 & $1931-32$ & 0 & 5 & 12 & 16. & 5 & 0 & 38 \\
\hline 1933 & 0 & 2 & 6 & 9 & 0 & 17 & 0 & $i$ & 8 & 2l & 18 & 1 & 1 & 50 & $1932-33$ & 0 & 0 & 12 & 4 & 12 & 0 & 28 \\
\hline 1934 & ] & 1 & 6 & 4 & 0 & 12 & 4 & 8 & 9 & 18 & 23 & 4 & 0 & 66 & $1933-34$ & 0 & 0 & 3 & 0 & 0 & 0 & 3 \\
\hline 1935 & 0 & 0 & 5 & 0 & 1 & 6 & 0 & 1 & 4 & 17 & 15 & 9 & 0 & 46 & $1934-35$ & 0 & 0 & 0 & 6 & 0 & 0 & 6 \\
\hline 1936 & 1 & 1 & 7 & 3 & 0 & 12 & 1 & 8 & 12 & 19 & 20 & 5 & 0 & 65 & $1935-36$ & 2 & 0 & 11 & 4 & 19 & 0 & 36 \\
\hline 1937 & 0 & 2 & 8 & 3 & 0 & 13 & 0 & 2 & 8 & 25 & 15 & 10 & 0 & 60 & $1936-37$ & 0 & 4 & 5 & 29 & 7 & 0 & 45 \\
\hline 1938 & 0 & 1 & 16 & 3 & 2 & 22 & 0 & 6 & 16 & 26 & 21 & 16 & 0 & 85 & $1937-38$ & 0 & 0 & 1 & 0 & 0 & 0 & 1 \\
\hline 1939 & 0 & 2 & 14 & 9 & 0 & 25 & 1 & 3 & 6 & 21 & 25 & 9 & 0 & $\overline{65}$ & $1938-39$ & 0 & 0 & 3 & 0 & 3 & 0 & 6 \\
\hline 1940 & 0 & 6 & 9 & $i$ & 1 & 23 & 0 & 9 & 20 & 25 & 24 & 7 & 0 & $\underline{85}$ & $1939-40^{-}$ & 0 & 0 & 0 & 4 & 1 & 0 & 5 \\
\hline 1941 & 0 & 1 & 12 & 6 & 0 & 19 & 0 & $\ldots$ & 8 & 29 & 18 & 0 & 0 & (55) & $1940-4]$ & 0 & 0 & 3 & 3 & 0 & 0 & 6 \\
\hline 1942 & 0 & 2 & 13 & 16 & 1 & 32 & 0 & 1 & 3 & 26 & 23 & 10 & 0 & 63 & $1941-42$ & 0 & 0 & 1 & 16 & 0 & 0 & 17 \\
\hline 1943 & -. & -. & -. & -- & .. & $\cdots$ & -. & .. & -. & .. & -. & -. & -. & .. & $1942-43$ & 0 & 0 & 5 & 20 & 1 & 0 & 26 \\
\hline 1944 & 0 & -. & $-\cdot$ & - & $\cdots$ & $\cdots$ & 0 & -. &.- & $\cdots$ & - & $\ldots$ & -. & -. & $1943-44$ & 0 & .. & 10 & 7 & 0 & 0 & (17) \\
\hline 1945 & 0 & 0 & 8 & 4 & 0 & 12 & 0 & 1 & 7 & 22 & 21 & 5 & 0 & 56 & $1944-45$ & -. & -. & $\cdots$ & 12 & 1 & 1 & (14) \\
\hline 1946 & 0 & 0 & 7 & 6 & 0 & 13 & 1 & 0 & 4 & 15 & 1.3 & 0 & 0 & 38 & $1945-46$ & 0 & 2 & 9 & 0 & 0 & 0 & 11 \\
\hline 1947 & 1 & 0 & 2 & 0 & 0 & 3 & 0 & 8 & 4 & 17 & II & 2 & 0 & 42 & $1946-47$ & 0 & 4 & 4 & 14 & 0 & 0 & 22 \\
\hline 1948 & 0 & 2 & 0 & 0 & 0 & 2 & 0 & 1 & 9 & 14 & 7 & 7 & 0 & 38 & $1947-48$ & 0 & 0 & 6 & 8 & 9 & 0 & 23 \\
\hline 1949 & 0 & 1 & 6 & 2 & 1 & 10 & 0 & 8 & 8 & 15 & 13 & 8 & 0 & 57 & $1948-49$ & 0 & 0 & 13 & 28 & 8 & 0 & 49 \\
\hline 1950 & 0 & 0 & 2 & 3 & 2 & 7 & 0 & 1 & 5 & 20 & $2 ?$ & 8 & 0 & 56 & $1949-50$ & 0 & 0 & 5 & 24 & 5 & 1 & 35 \\
\hline 1951 & 0 & 0 & 8 & 3 & 0 & 11 & 0 & 1 & 8 & 23 & 19 & 5 & 0 & 56 & $1950-51$ & 0 & 0 & 2 & 8 & 2 & 0 & 12 \\
\hline 1952 & 0 & 0 & 9 & 3 & 0 & 12 & 0 & 2 & 5 & 21 & $1 \%$ & 12 & 0 & 57 & $1951-52$ & 0 & 0 & 16 & 19 & 0 & 0 & 35 \\
\hline 1953 & 0 & 0 & 4 & 4 & 0 & 8 & 0 & 0 & 0 & 2l & 13 & 11 & 0 & 45 & $1952-53$ & 0 & 9 & 6 & 1 & 0 & 0 & 16 \\
\hline 1954 & 0 & 0 & 1 & 0 & 0 & 1 & 0 & 2 & 3 & 20 & 9 & 3 & 0 & 37 & $1953-54$ & 0 & 0 & 2 & 12 & 4 & 0 & 18 \\
\hline 1955 & 0 & 2 & 5 & 2 & 2 & $\overrightarrow{\text { II }}$ & 0 & 0 & 9 & 12 & 19 & 8 & 0 & 48 & $1954-55$ & 0 & 0 & 5 & 13 & 2 & 1 & 21 \\
\hline 1956 & 0 & 0 & 10 & 5 & 0 & 15 & 0 & 7 & 2 & 22 & lit & 7 & 0 & 54 & $1955-56$ & 0 & 15 & 16 & 7 & 15 & 0 & 53 \\
\hline 1957 & 0 & 1 & 1 & 0 & 0 & 2 & 0 & 3 & 8 & 14 & 8 & 6 & 0 & 39 & $1956-57$ & 0 & 7 & 10 & 22 & 7 & 0 & 46 \\
\hline 1958 & 0 & 6 & 10 & 11 & 0 & 28 & 0 & 8 & 11 & 28 & $2^{t_{i}}$ & 5 & 0 & 77 & $1957-58$ & 0 & 0 & 2 & 2 & 0 & 0 & 4 \\
\hline 1959 & 0 & 0 & 8 & 1 & 0 & 9 & 0 & 1 & 7 & 21 & $1 i$ & 3 & 0 & 44 & $1958-59$ & 0 & 3 & 4 & 8 & 2 & 0 & 18 \\
\hline 1960 & 0 & 0 & 16 & 5 & 0 & $2 \mathrm{l}$ & 0 & $i$ & 12 & 28 & $\ddot{10}$ & 5 & 0 & 58 & $1959-60$ & 0 & 5 & 7 & 23 & 1 & 2 & 38 \\
\hline 1961 & 0 & 7 & 8 & 10 & 0 & 25 & 0 & 1 & 15 & 20 & 24 & $!$ & 0 & 67 & $1960-61$ & 0 & 0 & 14 & 10 & 0 & 0 & 24 \\
\hline 1962 & 0 & 10 & 1 & 0 & 0 & 11 & 0 & 0 & 11 & 17 & ic & 8 & 0 & 46 & 1961.62 & 0 & 0 & 7 & 12 & 2 & 0 & 21 \\
\hline 1963 & 0 & 3 & 0 & 2 & 0 & 5 & 0 & 4 & 1 & 8 & $1 \varepsilon$ & 11 & 0 & 48 & 196263 & 0 & 0 & 3 & 14 & 3 & 0 & 20 \\
\hline 1964 & 0 & 0 & 6 & 0 & 0 & 6 & 0 & 0 & 5 & 14 & 10 & 2 & 0 & 41 & $1963-64$ & 0 & 1 & II & 3 & 0 & 0 & 15 \\
\hline 1965 & 0 & 0 & 6 & 5 & 0 & 11 & 0 & 0 & $i$ & 20 & lí & 1 & 0 & 40 & {$[964-65$} & 0 & 0 & 14 & 5 & 0 & 0 & 19 \\
\hline 1966 & 1 & 0 & 2 & 3 & 0 & 6 & 0 & 5 & 2 & 15 & 21 & 7 & 0 & 50 & $1965-66$ & 0 & 1 & 8 & 3 & 0 & 0 & 12 \\
\hline 1967 & 0 & 2 & 6 & 15 & 0 & 23 & 0 & 2 & 13 & 25 & 27 & 12 & 0 & 79 & 196667 & 0 & 0 & 2 & 0 & 0 & 0 & 2 \\
\hline 1968 & 0 & 0 & 10 & 3 & 0 & 13 & 1 & 1 & 5 & 22 & 12 & 4 & 0 & 45 & $1967-68$ & 0 & 0 & 10 & 4 & 0 & 0 & 14 \\
\hline 1969 & 0 & 3 & 3 & 2 & 0 & $y$ & 0 & 6 & 17 & 20 & 15 & 7 & 0 & 65 & $1968-69$ & 0 & 0 & 7 & $x$ & 4 & 0 & 31 \\
\hline 1970 & 0 & 7 & 11 & i & 0 & 25 & 0 & 2 & 15 & 22 & 19 & 0 & 0 & 58 & 19970 & 0 & 3 & 9 & 15 & 0 & 0 & 27 \\
\hline$\lfloor 971$ & 0 & 0 & 16 & $1:$ & 0 & 27 & 0 & 2 & 2 & $x$ & 20 & 2 & 0 & 52 & $1970-71$ & 0 & 2 & 11 & 9 & 1 & 0 & 23 \\
\hline 1972 & 0 & 0 & 5 & 10 & 0 & 15 & 0 & 5 & 8 & 21 & 19 & 5 & 0 & 58 & $1971-72$ & 1 & 0 & 10 & 9 & 7 & 0 & 27 \\
\hline 1973 & 0 & 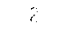 & 10 & 5 & (]) & 17 & 0 & i) & 7 & 21 & 18 & 4 & 0 & 50 & $1972-73$ & 0 & 0 & 14 & 10 & 0 & 0 & 24 \\
\hline 1974 & 0 & 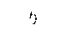 & 5 & 3 & 0 & 14 & 0 & 0 & 18 & 15 & 18 & 0 & 0 & 58 & $1973-74$ & 0 & 4 & 1 & 12 & 0 & 0 & .17 \\
\hline 975 & 0 & 0 & 0 & 0 & 0 & 9 & 0 & 2 & 4 & 22 & 12 & 8 & 0 & 48 & $1974-75$ & 0 & $c$ & 0 & 6 & 6 & 0 & 12 \\
\hline$: 975$ & 0 & $!$ & 2 & 0 & 0 & 3 & 0 & 1 & 4 & 17 & 9 & 4 & 0 & 35 & $1975-70$ & 0 & 3 & 5 & 7 & 0 & 0 & 15 \\
\hline 1977 & 0 & $i$ & 2 & 13 & 0 & 10 & 1 & 0 & 13 & is & 22 & i & 6 & 52 & $1976-77$ & 0 & 6 & 12 & $x$ & 3 & 0 & 35 \\
\hline 1972 & 0 & 1 & 6 & $?$ & 0 & 13 & 0 & 0 & 12 & 17 & 11 & 2 & 0 & 42 & $1977-78$ & 0 & 5 & 9 & 6 & 2 & C & 22 \\
\hline 1979 & 0 & 2 & 7 & $i$ & 0 & 10 & 0 & 1 & 13 & 23 & $x$ & $?$ & 0 & $x$ & $1978-79$ & 0 & 7 & 11 & 30 & 4 & 0 & 52 \\
\hline $19 \times 0$ & 0 & 0 & $?$ & 0 & 0 & 3 & u & 8 & 0 & 18 & 9 & 2 & 0 & $\underline{29}$ & $1979-80$ & 0 & 7 & 3 & 16 & $b$ & 0 & 32 \\
\hline AVG & 1 & 2 & 7 & 4 & , & 13 & $"$ & 3 & 9 & 20 & 19 & ; & 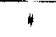 & 55 & AVD & $"$ & 2 & 8 & 11 & 3 & , & 24 \\
\hline
\end{tabular}


One notable period of above-normal temperatures occurred July 15August 13, 1971. During this 30-day period there were 27 days with maximum temperatures $\geq 100^{\circ} \mathrm{F}$ in three separate periods with 9 consecutive days $\geq 100^{\circ} \mathrm{F}$. The lowest maximum temperature for the 30 day period was $98^{\circ} \mathrm{F}$ and the highest was $112^{\circ} \mathrm{F}$. The average maximum temperature was $104.7^{\circ} \mathrm{F}$.

Maximum temperatures $\geq 90^{\circ} \mathrm{F}$ occur an average of 55 times a year but vary from a low of 29 (1980) to a high of 85 (1938 and 1940). The earliest occurrences have varied from April 17 (1936) to July 2 (1953), with an average annual date of May 23 (see Table 3). The latest annual occurrence of maximum temperatures $\geq 90^{\circ} \mathrm{F}$ has varied from August ?? (1977) to October 6 (1933). The median date for the period 1912 through 1980 is September 13. The greatest number of consecutive days with maximum temperatures $\geq 90^{\circ} \mathrm{F}$ is 37 (July 19 through August 24, 1942).

The average seasonal number of days with maximum temperature of $\leq 32^{\circ} \mathrm{F}$ is 24 , with 2 occurring in November and the other 22 during the months of December through February. The earliest seasonal occurrence of a day with a maximum temperature $\leq 32^{\circ} \mathrm{F}$ has been 0ctober 30 (1935) and the latest March 11 (1950). The number of winter days with maximum temperatures $\leq 32^{\circ} \mathrm{F}$ has ranged from 1 (winter of 1937-1938) to 53 (winter of 1955-1956). The greatest number of consecutive days with maximum temperatures $\leq 32^{\circ} \mathrm{F}$ is 29 (January 5 through February 2, 1937). During the period December 27, 1978, through February 4, 1979 ( 40 days), there was only 1 maximum temperature $\geq 32^{\circ} \mathrm{F}$. The average maximum temperature for that period was $21^{\circ} \mathrm{F}$.

There have been 10 days of record when the daily maximum temperature was $\leq 0^{\circ} \mathrm{F}$. These days are tabulated below.

\begin{tabular}{lcccc} 
Date & Max Temp & \multicolumn{2}{c}{ Date } & Max Temp \\
\cline { 2 - 3 } 1. Dec 12, 1919 & 0 & 6. Feb 1, 1950 & -3 \\
2. Dec 13, 1919 & -3 & 7. Feb 2, 1950 & 0 \\
3. Dec 14, 1919 & -3 & 8. Jan 27, 1957 & 0 \\
4. Feb 9, 1929 & -1 & 9. Dec 29, 1968 & -2 \\
5. Jan 31, 1950 & -2 & 10. Dec 30, 1968 & -2
\end{tabular}


TABLE 3. Composite Record of Annual First and Last Dates With Extreme Temperature $\left({ }^{\circ} \mathrm{F}\right)$ in Relation to Certain Thresholds for Hanford Townsite (Near) and HMS 1912 Through 1980

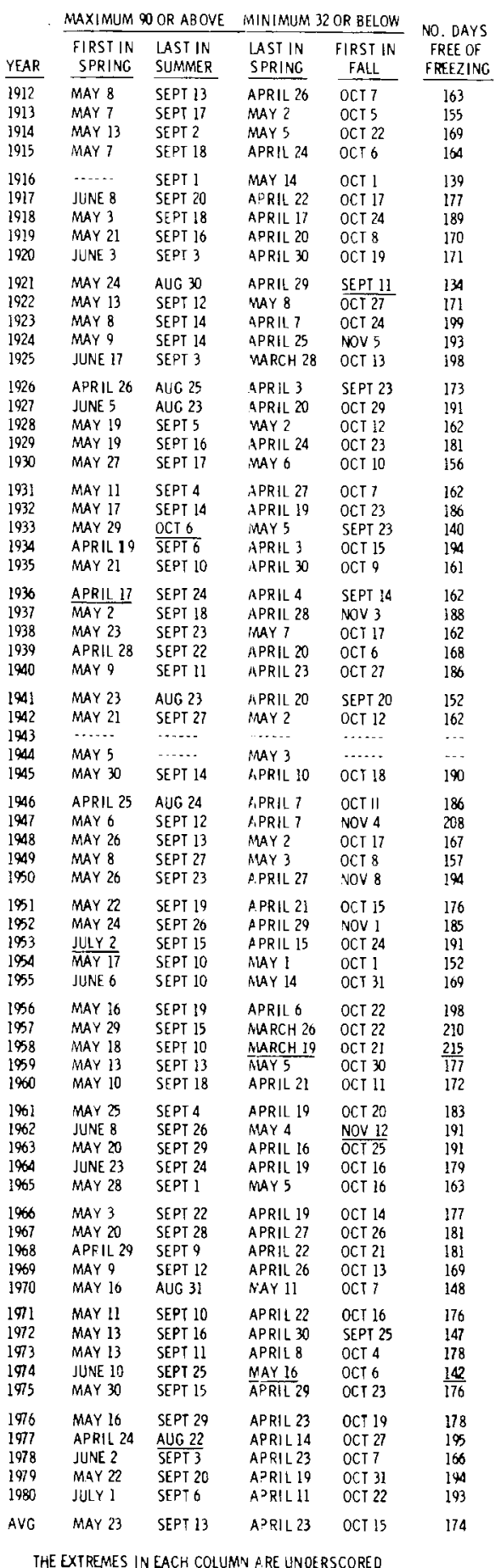


DAYS WITH MINIMUM TEMPERATURES $32^{\circ} \mathrm{F}$ OR BELOW AND $0^{\circ} \mathrm{F}$ OR BELOW

The number of days on which the minimum temperature was $\leq 32^{\circ} \mathrm{F}$ or was $\leq 0^{\circ} \mathrm{F}$ is tabulated by months for the entire period of record in Table 4.

The seasonal average number of days with minimum temperatures $\leq 32^{\circ} \mathrm{F}$ is 115. It has varied from 75 (winter of 1957-1958) to 141 (winter of $1916-1917)$.

The first autumn freezing temperature $\left(\leq 32^{\circ} \mathrm{F}\right)$ has occurred as early as September 11 (1921) and as late as November 12 (1962). The median date is October 15 (Table 3 ). The last date in spring for minimum temperatures $\leq 32^{\circ} \mathrm{F}$ has varied from March 19 (1958) to May 16 (1974), with an average date of April 23. The probability (p), based on Table 3, of one or more days with minimum temperatures $\leq 32^{\circ} \mathrm{F}$ after the specified spring dates, or before the specified fall dates, is shown in Table $4 a$.

TABLE 4a. Percent Probability of Minimum Temperature of $\leq 32^{\circ} \mathrm{F}$

\begin{tabular}{rlrl}
$\mathrm{p}(\%)$ & \multicolumn{1}{c}{ After } & Before \\
\cline { 2 - 3 } 95 & March 30 & 5 & Sept 24 \\
90 & Apri1 6 & 10 & Oct 2 \\
75 & Apri1 17 & 25 & Oct 7 \\
50 & Apri1 23 & 50 & Oct 17 \\
25 & May 1 & 75 & Oct 23 \\
10 & May 5 & 90 & Oct 30 \\
5 & May 12 & 95 & Nov 4
\end{tabular}

There is an average of 4 days per winter season when the daily minimum temperature is $\leq 0^{\circ} \mathrm{F}$ (Table 4). However, nearly half of all winters are free of such days. There were 18 days in January-February 1950 , and 13 days for the same months in 1957, with daily minimum temperatures $\leq 0^{\circ} \mathrm{F}$. During these periods there were 4 (1950) and 2 (1957) consecutive days with minimum temperatures $\leq-20^{\circ} \mathrm{F}$. 
TABLE 4. Composite Record of Monthly and Seasonal Number of Days With Minimum Temperature $\left({ }^{\circ} \mathrm{F}\right)$ in Relation to Certain Thresholds for Hanford Townsite (Near) and HMS: 1912 Through 1980

\begin{tabular}{|c|c|c|c|c|c|c|c|c|c|c|c|c|c|c|c|}
\hline \multirow[b]{2}{*}{ SEASON } & \multicolumn{10}{|c|}{32 OR BEL OW } & \multicolumn{5}{|c|}{0 OR BELOW } \\
\hline & $\underline{\text { SEPT }}$ & $\underline{\alpha T}$ & NOV & DEC & JAN & FEB & MAR & APR & MAY & TOTAL & NOV & DEC & JAN & FEB & TOTAL \\
\hline $1912-13$ & 0 & 9 & 15 & 27 & 30 & 26 & 2l & 8 & 2 & 138 & 0 & 0 & 2 & 4 & 6 \\
\hline $1913-14$ & 0 & 10 & 12 & 31 & 33 & 22 & 19 & 9 & $!$ & 127 & 0 & 0 & 0 & 0 & 0 \\
\hline $1914-15$ & 0 & 3 & 19 & 30 & 31 & 22 & 17 & 6 & 0 & 128 & 0 & 2 & 2 & 0 & 4 \\
\hline $1915-16$ & 0 & 7 & 24 & 26 & 28 & 22 & 11 & 6 & 3 & 127 & 0 & 0 & 11 & 0 & 11 \\
\hline $1916-17$ & 0 & 12 & $2 l$ & 30 & 29 & 24 & 22 & 3 & 0 & $14 \mathrm{i}$ & 0 & 1 & 0 & 0 & 1 \\
\hline $1917-18$ & 0 & 9 & 14 & 19 & 27 & 22 & 15 & 4 & 0 & 110 & 0 & 0 & 0 & 0 & 0 \\
\hline $1918-19$ & 0 & 3 & 19 & 3 & 25 & 22 & 11 & 7 & 0 & 110 & 0 & 0 & 0 & 0 & 0 \\
\hline $1919-20$ & 0 & 9 & 22 & 29 & 28 & 26 & 13 & 4 & 0 & $13 !$ & 0 & 14 & 0 & 0 & 14 \\
\hline $1920-21$ & 0 & 2 & 18 & 23 & 28 & 15 & 13 & 6 & 0 & 105 & 0 & 0 & 0 & 0 & 0 \\
\hline $1921-22$ & 3 & 4 & 20 & 23 & 31 & 26 & 17 & 3 & l & 228 & 0 & 0 & 6 & 0 & 6 \\
\hline $1922-23$ & 0 & 4 & 13 & 26 & 23 & 25 & 16 & 1 & 0 & 108 & 0 & 7 & 0 & 0 & 7 \\
\hline $1933-24$ & 0 & 6 & 19 & 28 & 29 & 15 & 16 & 6 & 0 & 119 & 0 & 1 & 3 & 0 & 4 \\
\hline $1924-25$ & 0 & 0 & 17 & 26 & 29 & 9 & 9 & 0 & 0 & 90 & 0 & 8 & 0 & 0 & 8 \\
\hline $1925-26$ & 0 & 5 & 3 & 18 & 27 & 16 & 12 & 1 & 0 & 102 & 0 & 0 & 0 & 0 & 0 \\
\hline $1926-27$ & 4 & 4 & 12 & 28 & 27 & 17 & 17 & 8 & 0 & 117 & 0 & 0 & 3 & 0 & 3 \\
\hline $1927-28$ & 0 & 1 & 11 & 29 & 29 & 28 & 9 & 6 & 2 & 115 & 0 & 0 & 0 & 0 & 0 \\
\hline $1928-29$ & 0 & 3 & 17 & 29 & 31 & 26 & 19 & 8 & 0 & 133 & 0 & 0 & 5 & 9 & 14 \\
\hline $1929-30$ & 0 & 7 & 27 & 21 & 31 & 18 & 10 & $i$ & 1 & 116 & 0 & 0 & 13 & $\overline{0}$ & 13 \\
\hline $1930-31$ & 0 & 11 & 22 & 27 & 23 & 21 & 12 & 4 & 0 & 120 & 0 & 0 & 0 & 0 & 0 \\
\hline $1931-32$ & 0 & 3 & 17 & 30 & 31 & 20 & 9 & 2 & 0 & 112 & 0 & 0 & 0 & 4 & 4 \\
\hline $1932-33$ & 0 & 3 & 8 & 24 & 24 & 24 & 22 & 8 & 1 & 114 & 0 & 5 & 0 & 4 & 9 \\
\hline $1933-34$ & 4 & 5 & 16 & 14 & 25 & 21 & 17 & 2 & 0 & 104 & 0 & 0 & 0 & 0 & 0 \\
\hline $1934-35$ & 0 & 2 & 8 & 19 & 23 & 22 & 21 & 15 & 0 & 110 & 0 & 0 & 1 & 0 & 1 \\
\hline $1935-36$ & 0 & 10 & 20 & 27 & 22 & 27 & 19 & 4 & 0 & 129 & 1 & 0 & 0 & 7 & 8 \\
\hline $1936-37$ & 2 & 9 & 30 & 26 & 31 & 22 & 13 & 5 & 0 & 138 & 0 & 0 & 10 & 3 & 13 \\
\hline $1937-38$ & 0 & 0 & 7 & 18 & 25 & 27 & 15 & 12 & 3 & 107 & 0 & 0 & 0 & 0 & 0 \\
\hline $1938-39$ & 0 & 9 & 26 & 27 & 26 & 26 & 17 & 8 & 0 & 139 & 0 & 0 & 0 & 0 & 0 \\
\hline $1939-40$ & 0 & 8 & 28 & 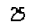 & 27 & 17 & 15 & 2 & 0 & 122 & 0 & 0 & 0 & 0 & 0 \\
\hline $1940-41$ & 0 & 2 & $\gamma$ & 23 & 28 & 25 & 23 & 5 & 0 & 131 & 0 & 0 & 0 & 0 & 0 \\
\hline $194 !-42$ & l & 1 & 18 & 23 & 27 & 19 & 25 & 8 & 2 & 124 & 0 & 0 & 4 & 0 & 4 \\
\hline $1942-43$ & 0 & 8 & 19 & 28 & 31 & 19 & 18 & -- & $-\cdot$ & (13) & 0 & 0 & 4 & 0 & 4 \\
\hline $1943-44$ & 0 & -. & $\therefore$ & 26 & $3 i$ & 28 & 25 & 7 & 1 & (11181 & 0 & 0 & 0 & 0 & 0 \\
\hline $1944-45$ & 0 &.- & -. & $\cdots$ & 27 & 18 & 12 & 6 & 0 & (63) & 0 & 0 & 0 & 0 & 0 \\
\hline $1945-46$ & 0 & 5 & 14 & 25 & 27 & 20 & 10 & 2 & 0 & 103 & 0 & 0 & 0 & 0 & 0 \\
\hline $1946-47$ & 0 & 8 & 23 & 24 & 27 & 19 & 6 & I & 0 & 108 & 0 & 0 & 1 & 0 & 1 \\
\hline $1947-48$ & 0 & 0 & 11 & 26 & 25 & 24 & 21 & 7 & 1 & 115 & 0 & 0 & 0 & 0 & 0 \\
\hline $1948-49$ & 0 & 8 & 15 & 30 & $3 !$ & 3 & II & 4 & 1 & 18 & 0 & 2 & 9 & 0 & 11 \\
\hline $1949-50$ & 0 & 10 & 4 & 25 & 30 & 22 & 18 & 4 & 0 & 113 & 0 & 0 & 14 & 4 & 18 \\
\hline $1950-51$ & 0 & 0 & 13 & 19 & 26 & 26 & 21 & 2 & 0 & 106 & 0 & 0 & 0 & 0 & 0 \\
\hline $1851-52$ & 0 & 0 & 19 & 26 & 31 & 24 & 20 & 6 & 0 & 132 & 0 & 0 & 0 & 0 & 0 \\
\hline $1982-53$ & 0 & 0 & 28 & 19 & 9 & 15 & 12 & 4 & 0 & 84 & 0 & 0 & 0 & 0 & 0 \\
\hline $1953-54$ & 0 & 1 & 14 & 22 & 23 & 16 & 19 & 4 & 1 & 100 & 0 & 0 & 2 & 0 & 2 \\
\hline $1934-55$ & 0 & 6 & 6 & 26 & 30 & 2 & 22 & 10 & 1 & 126 & 0 & 0 & 0 & 0 & 0 \\
\hline $1955-56$ & 0 & 1 & 22 & 28 & 8 & 26 & 14 & 2 & 0 & 118 & 1 & 0 & 2 & 3 & 6 \\
\hline $1960-57$ & 0 & 3 & 18 & $2 \mathrm{l}$ & 31 & 3 & 11 & 0 & 0 & 107 & $\overline{0}$ & 0 & 12 & l & 13 \\
\hline $1957-58$ & 0 & 2 & 17 & 16 & 19 & 5 & 16 & 0 & 0 & 75 & 0 & 0 & 0 & 0 & 0 \\
\hline $1958-59$ & 0 & 4 & 14 & 24 & 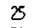 & 24 & 14 & 2 & 1 & $\overline{108}$ & 0 & 0 & 2 & 0 & 2 \\
\hline $1959-60$ & 0 & 2 & 24 & 26 & 31 & 21 & 10 & 4 & 0 & 118 & 0 & 0 & 1 & 0 & 1 \\
\hline $1960-61$ & 0 & 4 & 15 & 29 & 3 & 10 & 7 & 5 & 0 & 93 & 0 & 0 & 0 & 0 & 0 \\
\hline $1961-62$ & 0 & 7 & 28 & 26 & 27 & 17 & 19 & 0 & 1 & 186 & 0 & 0 & l & 0 & 1 \\
\hline $1962-63$ & 0 & 0 & 13 & 17 & 27 & 17 & II & 2 & 0 & 87 & 0 & 0 & 2 & 0 & 2 \\
\hline $1963-64$ & 0 & 5 & 8 & 31 & 26 & 26 & 16 & 4 & 0 & 116 & 0 & 0 & 0 & 0 & 0 \\
\hline $1964-65$ & 0 & 5 & 13 & 29 & 2 & 18 & 19 & 1 & l & 1111 & 0 & 2 & 0 & 0 & 2 \\
\hline $1965-66$ & 0 & 1 & 8 & 25 & 26 & 22 & 13 & 3 & 0 & 98 & 0 & 0 & 0 & 0 & 0 \\
\hline $1966-67$ & 0 & 3 & 11 & 18 & 20 & 17 & 18 & 9 & 0 & $\ddot{0}$ & 0 & 0 & 0 & 0 & 0 \\
\hline $1967-68$ & 0 & 1 & 17 & $z$ & 23 & 13 & 6 & 5 & 0 & 90 & 0 & 0 & 0 & 0 & 0 \\
\hline $1968-69$ & 0 & 3 & 8 & 24 & 30 & 35 & 15 & 1 & 0 & 106 & 0 & 4 & 5 & I & 10 \\
\hline $1969-70$ & 0 & 5 & 19 & 21 & 28 & I3 & 16 & 7 & 1 & 110 & 0 & 0 & 0 & 0 & 0 \\
\hline $1970-71$ & 0 & 8 & 14 & 28 & 24 & 19 & 20 & 1 & 0 & 120 & 0 & 0 & 0 & 0 & 0 \\
\hline $1971 \cdot 72$ & 0 & 9 & 18 & 27 & 25 & 23 & 13 & ij & 0 & 121 & 0 & 0 & 3 & l & 4 \\
\hline $1972-73$ & 3 & 6 & 13 & 23 & 30 & 23 & 10 & 1 & 0 & 112 & c & 7 & 1 & 0 & 8 \\
\hline $1973-74$ & 0 & 4 & 14 & 16 & 19 & 15 & 12 & i & 0 & 81 & 0 & 0 & 8 & 0 & 8 \\
\hline $1974-75$ & 0 & 4 & 12 & 26 & 29 & 24 & 17 & $?$ & 0 & 119 & 0 & 0 & 0 & 0 & 0 \\
\hline $1975-76$ & 0 & 2 & 23 & 28 & 30 & 22 & 19 & 0 & 0 & 130 & 0 & 0 & 0 & & 0 \\
\hline $1976-77$ & 0 & 8 & 17 & 30 & 30 & 19 & 14 & ? & 0 & 119 & 0 & 0 & 0 & 0 & 0 \\
\hline 1977.78 & 0 & 3 & 18 & 25 & 22 & 17 & 11 & 4 & 0 & 100 & 0 & l & 2 & 0 & 3 \\
\hline $1978 \cdot 79$ & 0 & 7 & 26 & 31 & 31 & 21 & 13 & ? & 0 & $13 i$ & 0 & 3 & 8 & 2 & 13 \\
\hline $1979-80$ & 0 & 1 & 23 & 22 & $3 !$ & 22 & 13 & 3 & 0 & 115 & 0 & 0 & i & 0 & I \\
\hline AVG & - & 5 & 17 & 25 & 27 & 21 & 15 & $s$ & . & 115 & 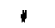 & 1 & 2 & 1 & 4 \\
\hline & NTH OR & & $O N$ & & & & & & & & & & & & \\
\hline i & INDIC & ATES & AN INC & COMPL & LETE $S$ & EASON & NAL TOI & DTAL & & & & & & & \\
\hline & $\mathbb{N}$ & & & if & LE & & & Al & & & & & & & \\
\hline
\end{tabular}


MONTHLY EXTREMES OF DAILY MAXIMUM AND MINIMUM TEMPERATURES

These data are presented in Table 5 and Figure 5 . Note that there is a greater temperature range during the winter months than in summer. December temperatures have ranged from $69^{\circ} \mathrm{F}$ to $-27^{\circ} \mathrm{F}$, a range of $96^{\circ}$, while July temperatures have ranged from $115^{\circ} \mathrm{F}$ to $39^{\circ} \mathrm{F}$, a range of $76^{\circ}$. The December minimum temperature has ranged from $56^{\circ} \mathrm{F}$ to $-27^{\circ} \mathrm{F}$, an $83^{\circ}$ range, while July minimum temperatures have varied only from $82^{\circ} \mathrm{F}$ to $39^{\circ} \mathrm{F}$, a $43^{\circ}$ range.

It is possible for high winter maxima to exceed low summer maxima. For example, on January 31,1972 , the maximum temperature reached $72^{\circ} \mathrm{F}$ while the high temperature for July 2, 1966, was $59^{\circ} \mathrm{F}$.

High winter minimum temperatures may also exceed low summer minima. The minimum temperature on December 2, 1975 , was $56^{\circ} \mathrm{F}$ compared to July 2, 1979 , which was $39^{\circ} \mathrm{F}$.

\section{NORMALS AND EXTREMES OF DAILY TEMPERATURES}

Figure 5 is a graph of daily extremes of maximum and minimum temperatures and the daily normals. Note that the large ranges between the extremes of maxima and minima temperatures occurred during the winter months. During winter also the minimum extremes depart more from norma 1 than do the maximum extremes.

RECORD COLD TEMPERATURES

The periods of December 1 through 17, 1919 (17 days duration), January 24 through February 5, 1950 (13 days duration), and January 12 through February 3, 1957 (23 days duration) were record-breaking cold periods. These three periods accounted for 7 of 10 days of record with a daily maximum temperature of $\leq 0^{\circ} \mathrm{F}$ and for 9 of 16 days of record with a minimum temperature of $\leq-20^{\circ} \mathrm{F}$. Some comparative statistics follow: 
TABLE 5. Monthly Extremes of Daily Maximum and Minimum Temperatures and Daily Temperature Ranges for Hanford Townsite (Near) and HMS Based on Period of Record 1912 Through 1980

DAILY MAXIMUM TEMPERATURE DAILY MINIMUM TEMPERATURE

\begin{tabular}{|c|c|c|c|c|c|c|c|c|c|c|c|c|}
\hline \multirow[b]{3}{*}{ MONTH } & \multirow{2}{*}{\multicolumn{2}{|c|}{$\begin{array}{r}\text { RECORD } \\
\text { HIGHEST } \\
\end{array}$}} & \multirow{2}{*}{\multicolumn{2}{|c|}{$\begin{array}{l}\text { RECÓRD } \\
\text { LOWEST }\end{array}$}} & \multirow{2}{*}{\multicolumn{2}{|c|}{$\begin{array}{c}\text { RECORD } \\
\text { HIGHEST } \\
\end{array}$}} & \multirow{2}{*}{\multicolumn{2}{|c|}{$\begin{array}{l}\text { RECORD } \\
\text { LOWEST }\end{array}$}} & \multicolumn{4}{|c|}{ DAILY TEMPERATURE RANGE* } \\
\hline & & & & & & & & & \multicolumn{2}{|c|}{ GREATEST } & \multicolumn{2}{|c|}{ LEAST } \\
\hline & ${ }^{0} \mathrm{~F}$ & DATE & ${ }^{0} \mathrm{~F}$ & DATE & ${ }^{0} \mathrm{~F}$ & DATE & ${ }^{0} \mathrm{~F}$ & DATE & ${ }^{0} \mathrm{~F}$ & DATE & ${ }^{0} \mathrm{~F}$ & DATE \\
\hline JAN & 72 & 31,1971 & -2 & 31,1950 & 53 & 30,1971 & -23 & $17,1916 \#$ & 43 & 13,1974 & 1 & 22, 1956" \\
\hline FEB & 71 & 12,1924 & -3 & 1,1950 & 55 & 26,1932 & -23 & $3,1950 \#$ & 42 & $-1,1947$ & 2 & $16,1959 \#$ \\
\hline MAR & 83 & 25,1960 & 24 & 3,1960 & 54 & 9,1942 & 6 & 5,1955 & 45 & 24,1979 & 2 & 6,1957 \\
\hline APR & 95 & $22,1934 \#$ & 41 & 7,1945 & 60 & 21,1956 & 12 & 1,1935 & 47 & $28,1968 \#$ & 7 & 20,1980 \\
\hline MAY & 103 & $26,1936 \#$ & 49 & 8,1918 & 70 & 19,1956 & 28 & 1,1954 & 48 & 11,1946 & 6 & $26,1980 \#$ \\
\hline JUNE & 110 & 25,1912 & 55 & 3,1966 & 81 & 30,1924 & 33 & 9,1933 & 46 & 28,1979 & 8 & $28,1946 \#$ \\
\hline JULY & 115 & 27,1939 & 59 & 2,1966 & 82 & 30,1925 & 39 & 2, 1979 & 44 & $16,1976 \#$ & 7 & 2,1966 \\
\hline AUG & 113 & 4,1961 & 63 & 25,1920 & 81 & 4,1961 & 40 & 18,1918 & 45 & 10,1979 & 10 & $7,1962 \#$ \\
\hline SEPT & 102 & $1,1976 \#$ & 52 & 23, 1934\# & 72 & 7,1955 & 25 & 23,1926 & 45 & $25,1974 \#$ & 5 & 13,1980 \\
\hline OCT & 90 & 6,1933 & 31 & 30,1935 & 60 & 26,1945 & 6 & 31,1935 & 45 & 4,1980 & 2 & 30,1971 \\
\hline NOV & 75 & 3,1975 & 14 & $13,1955 \#$ & 52 & $23,1959 \#$ & -1 & 14,1955 & 36 & 24,1970 & 1 & 26,1952 \\
\hline DEC & 69 & 26,1980 & -3 & $13,1919 \#$ & 56 & 2, 1975 & -27 & 12,1919 & 46 & 1,1975 & 1 & $24,1975 \#$ \\
\hline ANN & 115 & $\begin{array}{c}\text { JULY 27, } \\
1939\end{array}$ & -3 & $\begin{array}{l}\text { FEB. 1, } \\
\text { 1950\# }\end{array}$ & 82 & $\begin{array}{l}\text { JULY } 30 \\
1925\end{array}$ & -27 & $\begin{array}{l}\text { DEC. 12, } \\
1919\end{array}$ & 48 & $\begin{array}{l}\text { MAY ll, } \\
1946\end{array}$ & 1 & $\begin{array}{l}\text { NUMEROUS } \\
\text { DATES }\end{array}$ \\
\hline
\end{tabular}

* Statistics tabulated for the daIly temperature range are based ONLy ON the PERIOD OF RECORD 1945-1980

\# DENOTES ALSO ON EARLIER DATES 


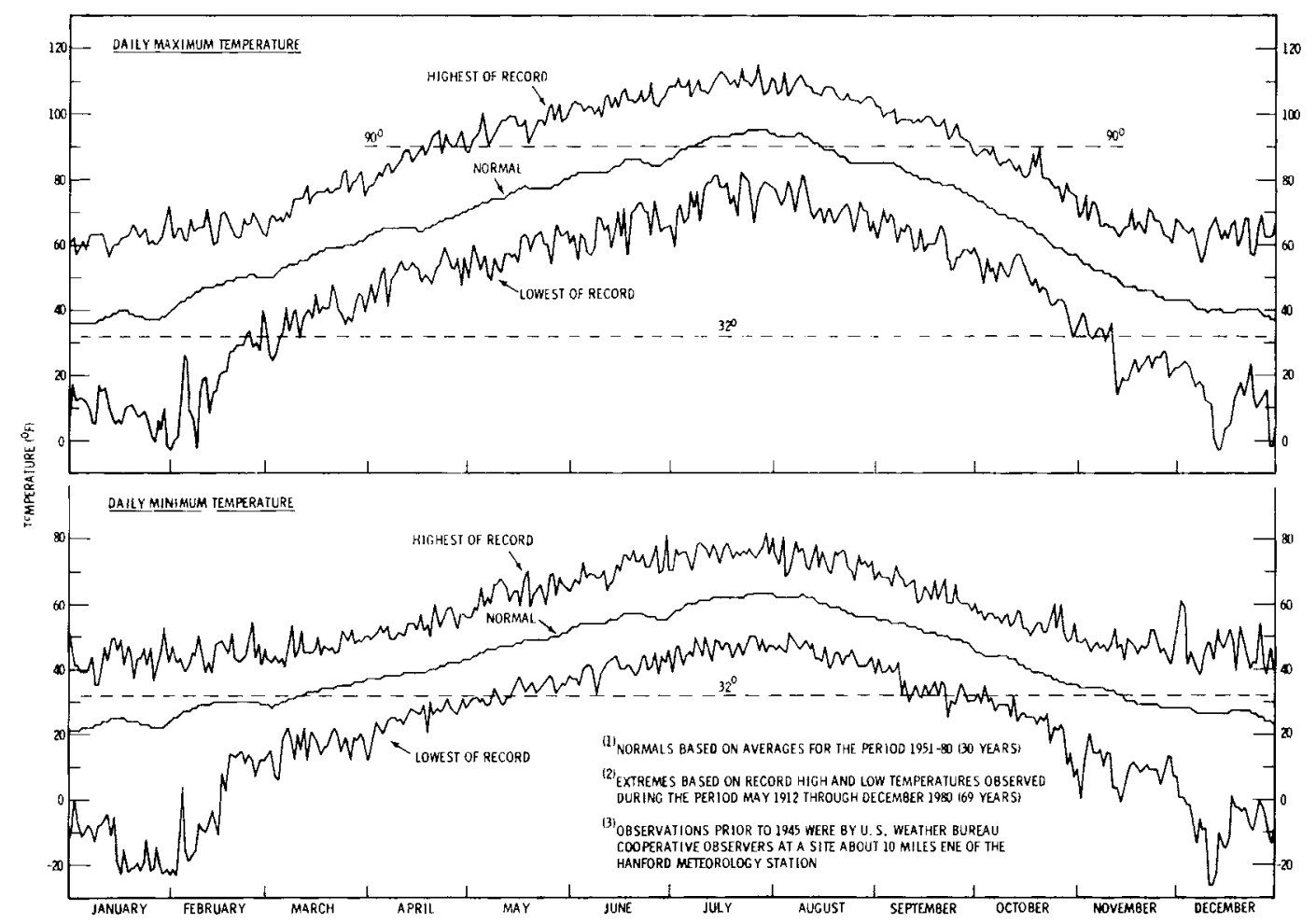

FIGURE 5. Normal (1) and Extreme ${ }^{(2)}$ Daily Temperatures at Hanford (3) 


\begin{tabular}{|c|c|c|c|}
\hline & $\frac{\text { Dec }}{1919}$ & $\frac{\text { Jan-Feb }}{1950}$ & $\frac{\text { Jan-Feb }}{1957}$ \\
\hline $32^{\circ} \mathrm{F}$ or below (consecutive in each case) & 17 & 13 & 23 \\
\hline $15^{\circ} \mathrm{F}$ or below & 7 & 10 & 7 \\
\hline $0^{\circ} \mathrm{F}$ or below & 3 & 3 & 1 \\
\hline \multicolumn{4}{|l|}{ Number of Days With Minimum Temperatures } \\
\hline $0^{\circ} \mathrm{F}$ or below (consecutive in each case) & 14 & 11 & 7 \\
\hline$-10^{\circ} \mathrm{F}$ or below & 6 & 6 & 5 \\
\hline$-20^{\circ} \mathrm{F}$ or below & 3 & 4 & 2 \\
\hline Extreme Lows & $-27^{\circ} \mathrm{F}$ & $-23^{\circ} \mathrm{F}$ & $-22^{\circ} \mathrm{F}$ \\
\hline
\end{tabular}

Statistics tabulated below are for the January-February, 1950 and 1957 periods of cold temperatures. Comparative statistics are not available for December 1919.

Number of Hourly Observations With Temperatures Equal to or Less Than values Indicated $\left({ }^{\circ} \mathrm{F}\right)$

\begin{tabular}{|c|c|c|c|c|}
\hline \multirow[b]{2}{*}{ Dates } & \multicolumn{4}{|c|}{ Temperature Classification } \\
\hline & $<+10$ & $<0$ & $<-10$ & $\leq-20$ \\
\hline $\begin{array}{l}\text { Jan } 28- \\
\text { Feb } 4,1950\end{array}$ & $163(117)$ & $135(93)$ & $55(16)$ & $6(3)$ \\
\hline $\begin{array}{l}\text { Jan } 15- \\
\text { Feb } 3,1957\end{array}$ & $272(136)$ & $120(44)$ & $40(16)$ & $7(2)$ \\
\hline
\end{tabular}

T) Indicates greatest number of consecutive hours

0ther periods of cold temperatures are tabulated below. These periods together with those of 1919, 1950 and 1957 account for al1 16 days of record with a minimum temperature of $\leq-20^{\circ} \mathrm{F}$. 
Number of Days

Maximum Minimum Minimum

$32^{\circ} \mathrm{F}$ or $0^{\circ} \mathrm{F}$ or $-20^{\circ} \mathrm{F}$ or Extreme

From To Total Below Below Below Low ( $\left.{ }^{\circ} \mathrm{F}\right)$

Dec 30,1915 Jan $20,1916 \quad 22 \quad 20 \quad 11 \quad 23$

Jan 6, $1930 \quad \operatorname{Jan} 31,1930 \quad 26 \quad 25 \quad 13 \quad 32$

Jan 5, 1937 Feb 2, $1937 \quad 29 \quad 29 \quad 12 \quad 23$

For additional information on extended periods of below normal temperatures see Appendix I, pages A.I-1 to A.I-4.

UNSEASONABLE COLD PERIODS

Two of the most unseasonably cold periods occurred during the year 1935. Lows of $12^{\circ} \mathrm{F}$ and $14^{\circ} \mathrm{F}$ were recorded, respectively, on April 1 and 2 of that year. A low of $10^{\circ} \mathrm{F}$ was recorded on October 29 , followed by a low of $0^{\circ} \mathrm{F}$ on November 2 .

The period of November 11 through 23, 1955, was the most prolonged period of cold temperatures for that month. During this period of time there were:

1. 12 consecutive days with maxima of $32^{\circ} \mathrm{F}$ or below

2. 5 consecutive days with maxima $20^{\circ} \mathrm{F}$ or below

3. 12 consecutive days with minima $20^{\circ} \mathrm{F}$ or below

4. 5 consecutive days with minima $10^{\circ} \mathrm{F}$ or below.

The extreme low during the period was $-1^{\circ} \mathrm{F}$ and occurred on November 14 .

PROLONGED PERIODS WITH ABOVE NORMAL SUMMER TEMPERATURES

There have been three summers $(1958,1971$ and 1977) when high temperatures have been most prolonged. Data for these periods follow: 
JuTy 5 to Juty 13 to Juty 20 to

Aug 26, 1958 Aug 21, 1971 Aug 22, 1977

Total days duration

53

40

34

Number of days with $\max \geq 90^{\circ} \mathrm{F}$

50

39

32

Number of days with $\max \geq 100^{\circ} \mathrm{F}$

21

27

Number of nights with min $\geq 70^{\circ} \mathrm{F}$

13

Number of nights with min $\leq 60^{\circ} \mathrm{F}$

7

16

15

Average daily maximum

97.9

5

9

5

Average daily minimum

65.8

103.2

98.4

Mean temperature

81.8

63.9

66.7

Extreme high

$107(7-28)$

86.2

82.7

Lowest minimum

$55(8-5) \quad 56(7-13,8-15)$

$107(8-18)$

$53(7-29)$

MEAN TEMPERATURE WITH 10 AND 15-YEAR MOVING AVERAGES

Depicted in Figures 6 through 10 are annual mean temperatures and mean temperatures for selected months and seasons for the period of record 1912 through 1980. Some data for the years 1912, 1916 and 1944 are missing. The record from 1912 through 1943 was kept by cooperative observers. Starting December 1944 the observations were recorded at the HMS.

The 10 and 15-year moving averages of mean annual temperatures started a rising trend in 1957, peaked in 1967 and began falling in 1974.

Winter and summer 15-year moving averages began to rise in 1957, peaked in 1972 and then began slowiy falling. The 1980 values remained well above the 1957 level.

The 15-year moving averages for March show a falling trend from 1934 through 1956, then a rising trend through 1972. The 1980 15-year moving average remained below that of 1934 .

September's 15-year moving average rose steadily from 1934 to a high in 1963 then fell slightly through 1980. However, the 1980,15 -year moving average remained well above that of 1934 . 


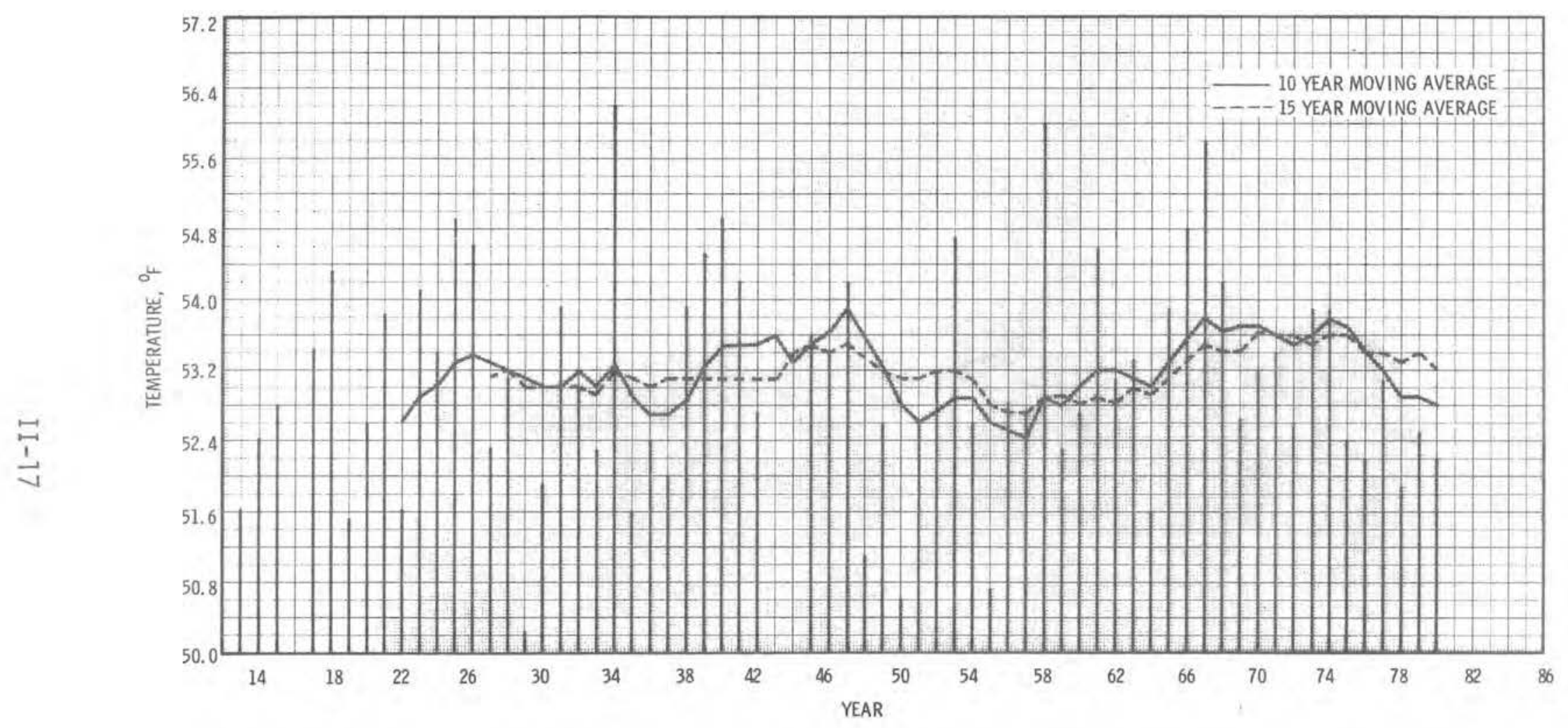

FIGURE 6. Annual Mean Temperatures (1913 Through 1980) and 10 and 15-Year Moving Averages 


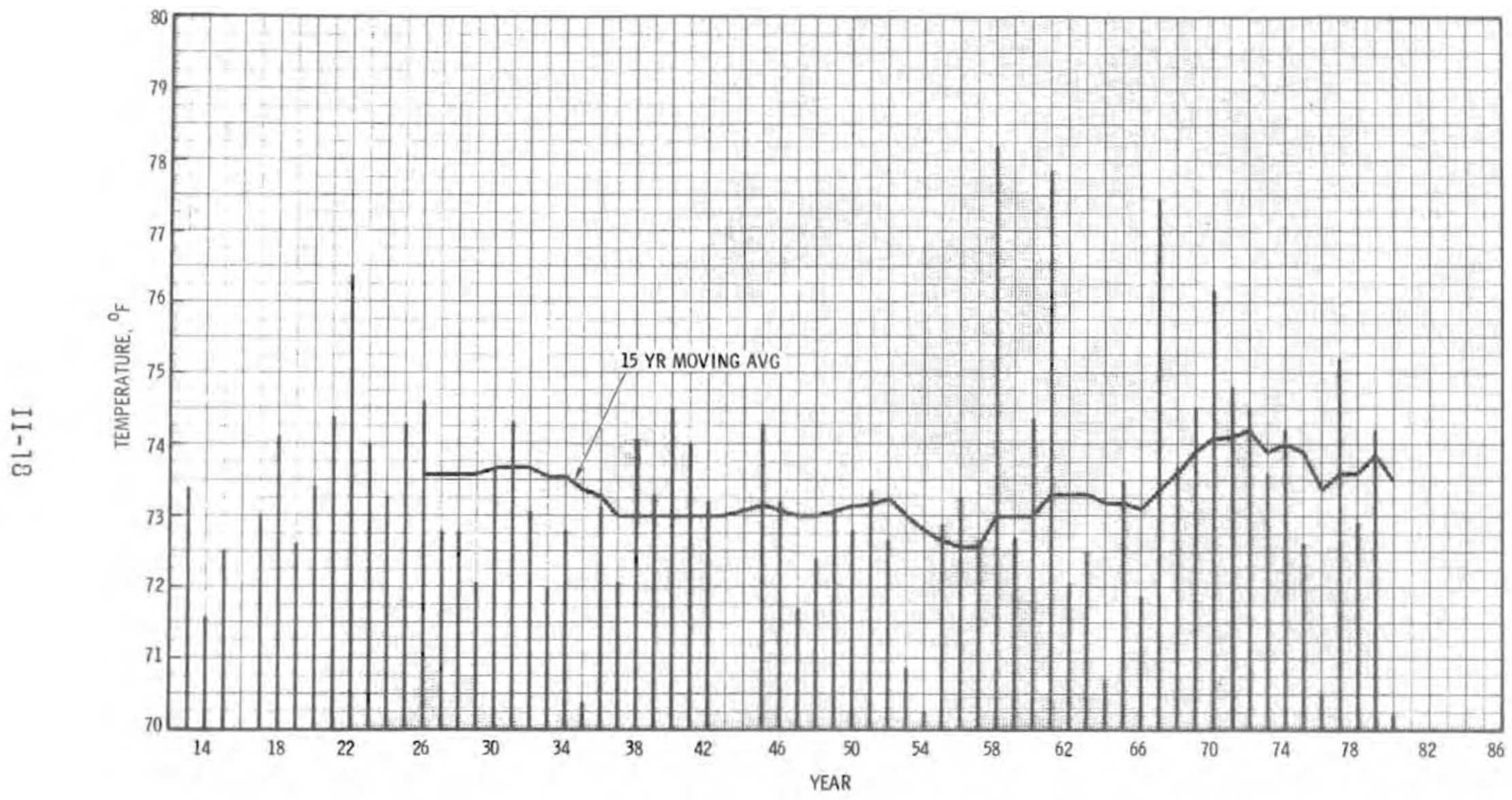

FIGURE 7. Summer Mean Temperatures and 15-Year Moving Averages for Period 1912 Through 1980 


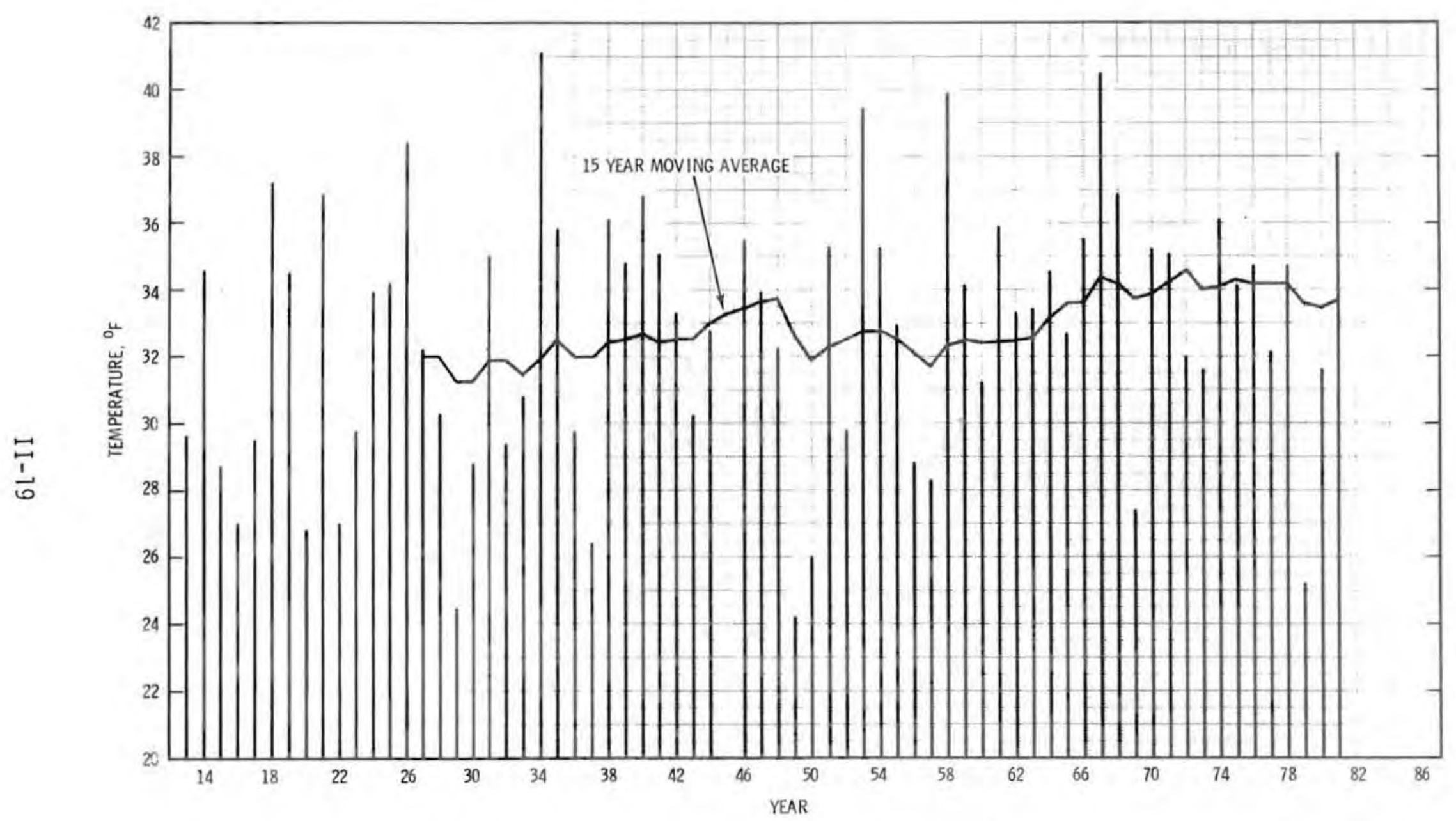

FIGURE 8. Winter Mean Temperatures and 15-Year Moving Averages for Period 1912 Through 1981 


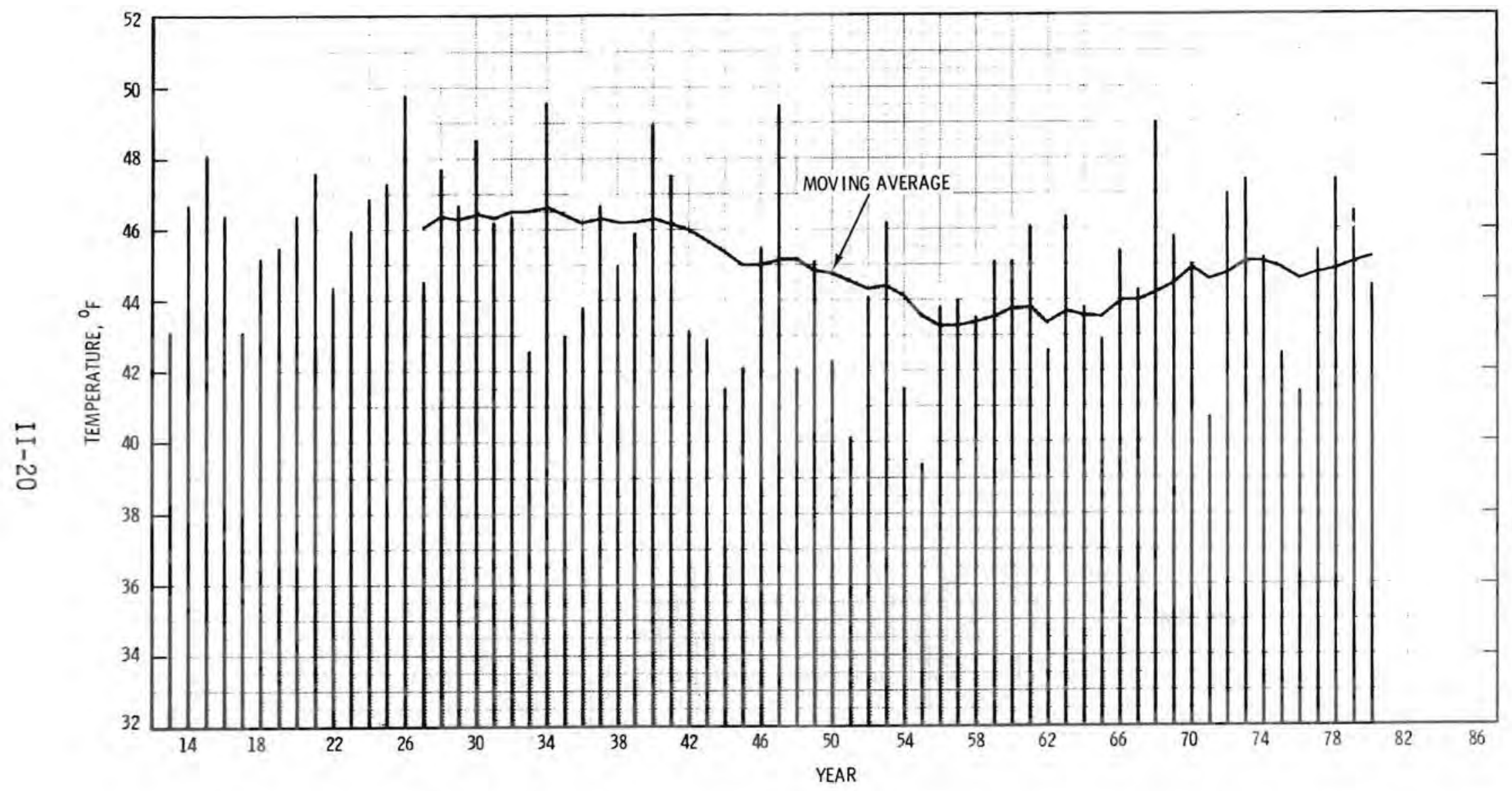

FIGURE 9. March Mean Temperatures and 15-Year Moving Averages for Period 1912 Through 1980 


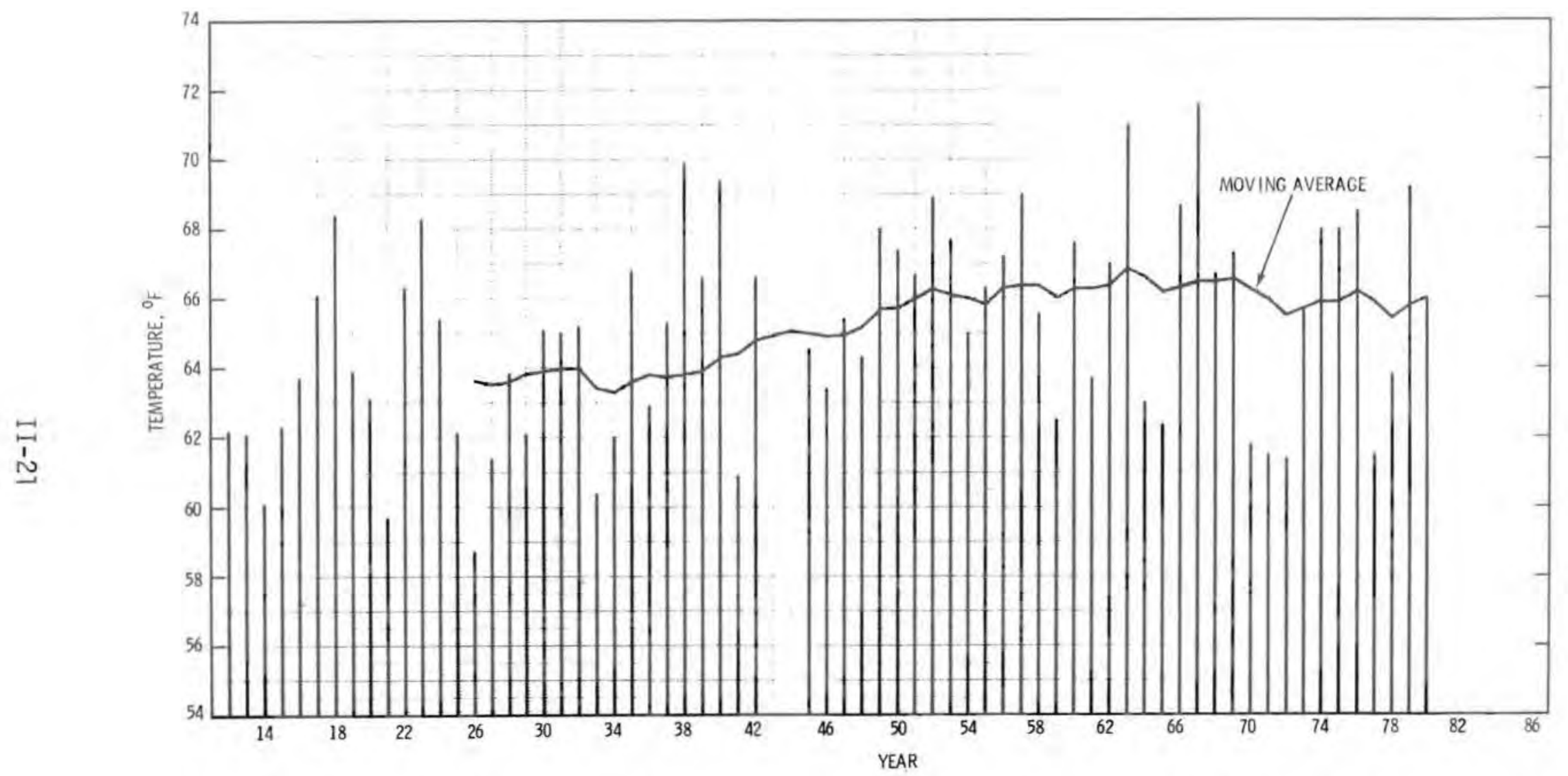

FIGURE 10. September Mean Temperatures and 15-Year Moving Averages for Period 1912 Through 1980 


\section{FREEZE-THAW LYCLES}

A freeze-thaw cycle occurs when the day's minimum temperature is below freezing and the maximum temperature is above the freezing level. A summary of freeze-thaw cycles for the period of record (1912 through 1980) is shown in Table 6.

\section{HEATING AND COOLING DEGREE DAYS}

The base for both heating and cooling degree days is $65^{\circ} \mathrm{F}$. If the daijy mean temperature is 1ess than $65^{\circ} \mathrm{F}$, the difference is heating degree days and if greater than $65^{\circ} \mathrm{F}$, the difference is cooling degree days. The degree day concept assumes that, if the mean daily outdoor temperature is $65^{\circ} \mathrm{F}$, no heating or cooling inside a building will be necessary, and that both the heating and cooling degree days will be zero. If the daily mean temperature is below or above $65^{\circ} \mathrm{F}$, the amount of energy required to maintain a comfortable temperature inside a butlding varies with the number of degree days.

Table 7 presents the heating degree data for the period 1945 through 1980 and Table 8 shows the cooling degree data for the period 1960 through 1980 . The heating season is assumed to run from July 1 through June 30 . The cooling season runs from January 1 through December 31.

\section{EXTREME TEMPERATURE PROBABILITY}

Refer to Section XI, pages 2 and 3 .

\section{VERTICAL TEMPERATURE PROFILES}

$$
\text { Refer to Section } X \text {, pages } 2-4 \text { and } 6 \text {. }
$$


IABLE 6. Hreeze-Inaw Cycles: Days on Which Maximum was Above $32^{\circ} \mathrm{F}$ and Minimum $32^{\circ} \mathrm{F}$ or Below (1912 Through 1980)

AVERAGE NUMBER MAXIMUM NUMBER MINIMUM NUMBER

\begin{tabular}{|c|c|c|c|c|c|}
\hline \multirow[b]{2}{*}{ JANUARY } & \multirow{2}{*}{$\frac{\text { OF CYCLES }}{16}$} & \multicolumn{2}{|c|}{ OF CYCLES } & \multicolumn{2}{|c|}{ OF CYCLES } \\
\hline & & 27 & $1946+$ & 1 & 1979 \\
\hline FEBRUARY & 18 & 28 & $1944+$ & 5 & 1924 \\
\hline MARCH & 16 & 25 & $1944+$ & 6 & $1968+$ \\
\hline APRIL & 5 & 15 & 1935 & 0 & $1974+$ \\
\hline MAY & $\#$ & 3 & $1938+$ & 0 & $1980+$ \\
\hline JUNE & 0 & 0 & --- & 0 & --- \\
\hline JULY & 0 & 0 & ---- & 0 & ---- \\
\hline AUGUST & 0 & 0 & ---- & 0 & --- \\
\hline SEPTEMBER & $\#$ & 4 & 1933 & 0 & $1980+$ \\
\hline OCTOBER & 5 & 12 & 1916 & 0 & $1962+$ \\
\hline NOVEMBER & 16 & 28 & $1961+$ & 4 & 1949 \\
\hline DECEMBER & 17 & 26 & $1974+$ & 9 & $1972+$ \\
\hline ANNUAL & 93 & 168 & & 25 & \\
\hline
\end{tabular}

\# DENOTES AN AVERAGE OF LESS THAN ONE-HALF DAY

+ ALSO IN EARLIER YEARS 
TABLE 7. Heating Degree Day Data for the Period 1945 Through 1980 (Base $65^{\circ} \mathrm{F}$ )

\begin{tabular}{|c|c|c|c|c|c|c|c|c|c|}
\hline MONTH & $\begin{array}{c}\text { MEAN } \\
\text { MONTHLY }\end{array}$ & $\begin{array}{l}\text { HIGHEST } \\
\text { MONTHLY }\end{array}$ & YEAR & $\begin{array}{l}\text { LOWEST } \\
\text { MONTHLY }\end{array}$ & YEAR & $\begin{array}{l}\text { HIGHEST } \\
\text { DAILY }\end{array}$ & DATE & $\begin{array}{l}\text { LOWEST } \\
\text { DAILY }\end{array}$ & DATE \\
\hline JAN & 1104 & 1640 & 1950 & 694 & 1953 & 77 & 31,1950 & 9 & 20,1968 \\
\hline FEB & 781 & 1147 & 1956 & 576 & 1958 & 78 & 1,1950 & 7 & 20,1961 \\
\hline MAR & 638 & 794 & 1955 & 476 & 1947 & 49 & 4,1955 & 3 & $25,1960+$ \\
\hline APR & 381 & 522 & 1955 & 253 & 1977 & 29 & 1,1976 & 0 & -....-- \\
\hline MAY & 156 & 258 & 1977 & 36 & 1947 & 22 & 1,1954 & 0 & ------ \\
\hline JUNE & 35 & 90 & 1953 & 3 & 1958 & 15 & $3,1966+$ & 0 & ------ \\
\hline JULY & 4 & 22 & 1955 & 0 & $1975+$ & 9 & $2,1966+$ & 0 & ----- \\
\hline AUG & 6 & 32 & 1960 & 0 & $1979+$ & 8 & 30,1964 & 0 & -...-- \\
\hline SEPT & 70 & 179 & 1972 & 10 & 1979 & 19 & $27,1972+$ & 0 & -......- \\
\hline ОСТ & 376 & 479 & 1946 & 200 & 1952 & 36 & 29,1971 & 0 & --.--- \\
\hline NOV & 758 & 1008 & 1955 & 567 & 1954 & 56 & 14,1955 & 3 & 3,1975 \\
\hline DEC & 990 & $\begin{array}{l}1224 \\
\text { (HS) }\end{array}$ & $\begin{array}{l}1964 \\
\text { (S) }\end{array}$ & $\begin{array}{r}822 \\
(\mathrm{LS})\end{array}$ & $\begin{array}{c}1957 \\
\text { (S) }\end{array}$ & 73 & $\begin{array}{c}30,1968 \\
\text { FEB. I }\end{array}$ & 4 & 26,1980 \\
\hline SEASON & 5299 & 6118 & $1978-79$ & 4599 & $1966-67$ & 78 & 1950 & 0 & ------ \\
\hline & \multicolumn{9}{|c|}{$\begin{array}{ll}+ & \text { ALSO ON EARLIER DATES } \\
\text { HS } & \text { HIGHEST SEASONAL TOTAL } \\
\text { LS } & \text { LOWEST SEASONAL TOTAL } \\
S & \text { SEASON OF OCCURRENCE }\end{array}$} \\
\hline
\end{tabular}


TABLE 8. Cooling Degree Day Data for Period 1960 Through 1980 (Base $65^{\circ} \mathrm{F}$ )

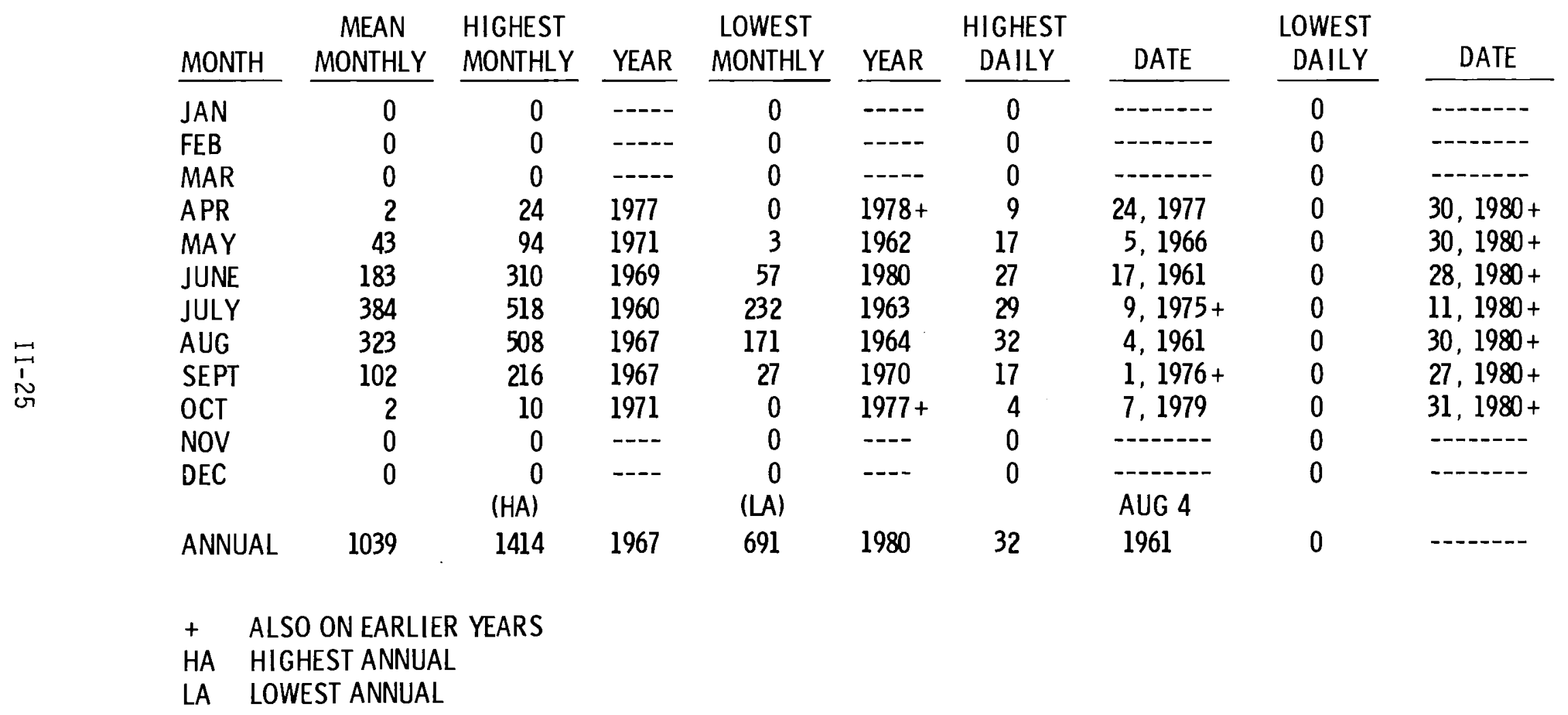


III. SUBSOIL TEMPERATURES $\left({ }^{\circ} \mathrm{F}\right)$ 


\section{SUBSOIL TEMPERATURES $\left({ }^{\circ} \mathrm{F}\right)$}

Hourly subsoil temperatures have been recorded at a depth of approximately 1/2-inch since 1944, and at the 15-inch and 36-inch depths since 1952. From 1944 to 1952 the $1 / 2$-inch sensor was a nickel thermohm. This was replaced with a copper thermohm in 1952. At the time that the 1/2-inch sensor was changed, copper thermohms were also installed at the 15- and 36-inch depths.

The subsoil sensors are installed in the natural soil of the area with the vegetation cover removed. The soil is sandy and is mixed with some large gravel.

Monthly averages and extremes of monthly averages are presented in Table 9. The absolute extremes are also shown in that table. Monthly and hourly subsoil temperatures are depicted in Figure 11 . The crossover months for the 15- and 36-inch subsoil temperatures are March and September. Figure 12 shows monthly averages compared with the 3-foot ambient air temperatures.

Even a slight snow cover has a noticeable effect on soil temperatures. Figure 13 shows the insulating effect on the 1/2- and 15-inch subsoil temperatures. On January 27 and 28, 1957 the ambient air temperature was cold but the soil temperature remained quite steady under a 4-inch snow cover. On January 8 and 9, 1979, the ambient air temperature was warmer, but the absolute 15-inch record low subsoil temperature occurred.

\section{EXTREME SUBSOIL TEMPERATURE PROBABILITY}

Refer to Section XI, pages 4 and 5 . 
TABLE 9. Subsoil Temperature Data (High and Low Extremes of Average Monthly Subsoil*)

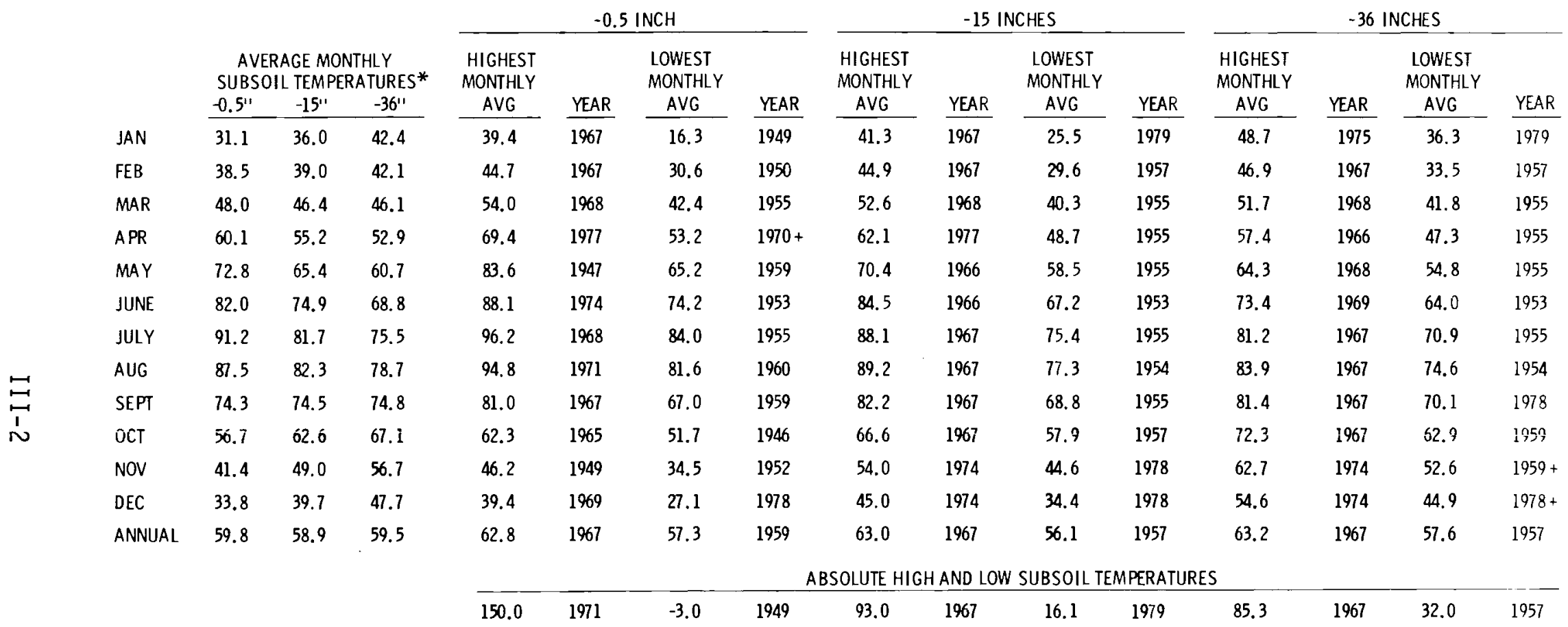

* - 0.5 INCH PER IOD OF RECORD1945-1980

15 INCH AND -36 INCH PER IOD OF RECORD 1952-1980

+ DENOTES ALSO IN EARLIER YEARS 

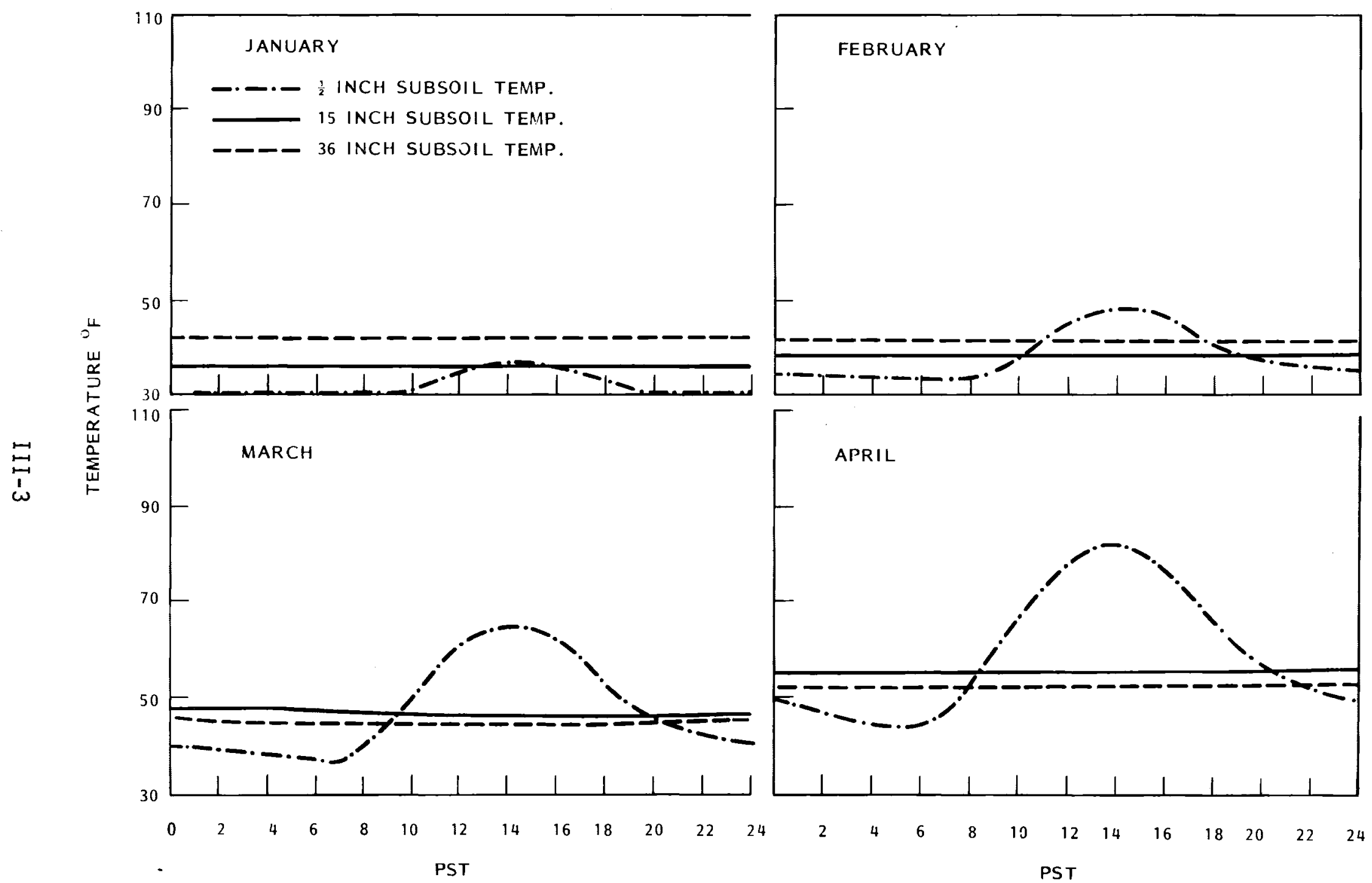

FIGURE 11. Monthly and Diurnal Variation of Subsoil Temperature: 1955 Through 1980 


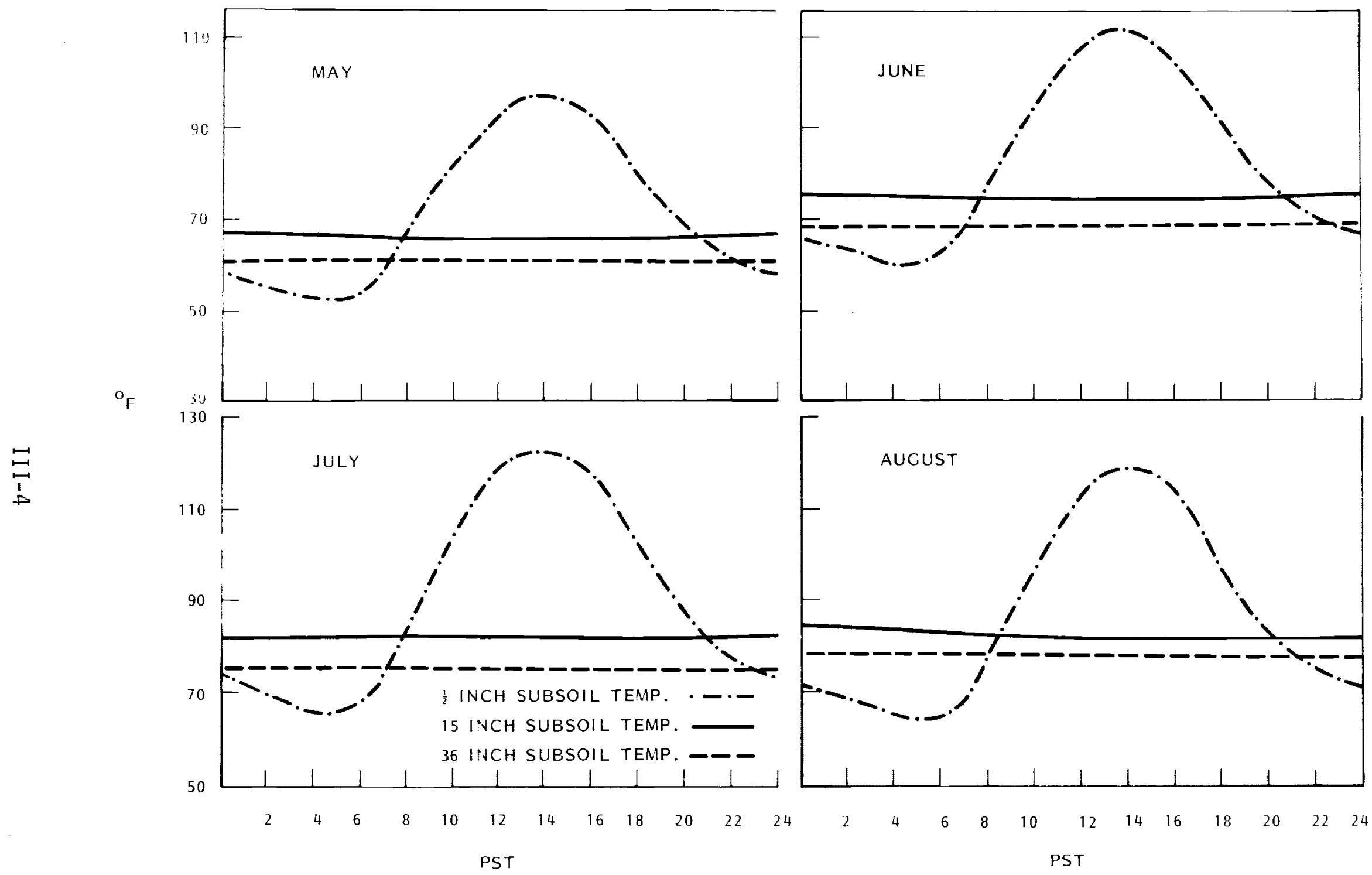

FIGURE 11. Continued 

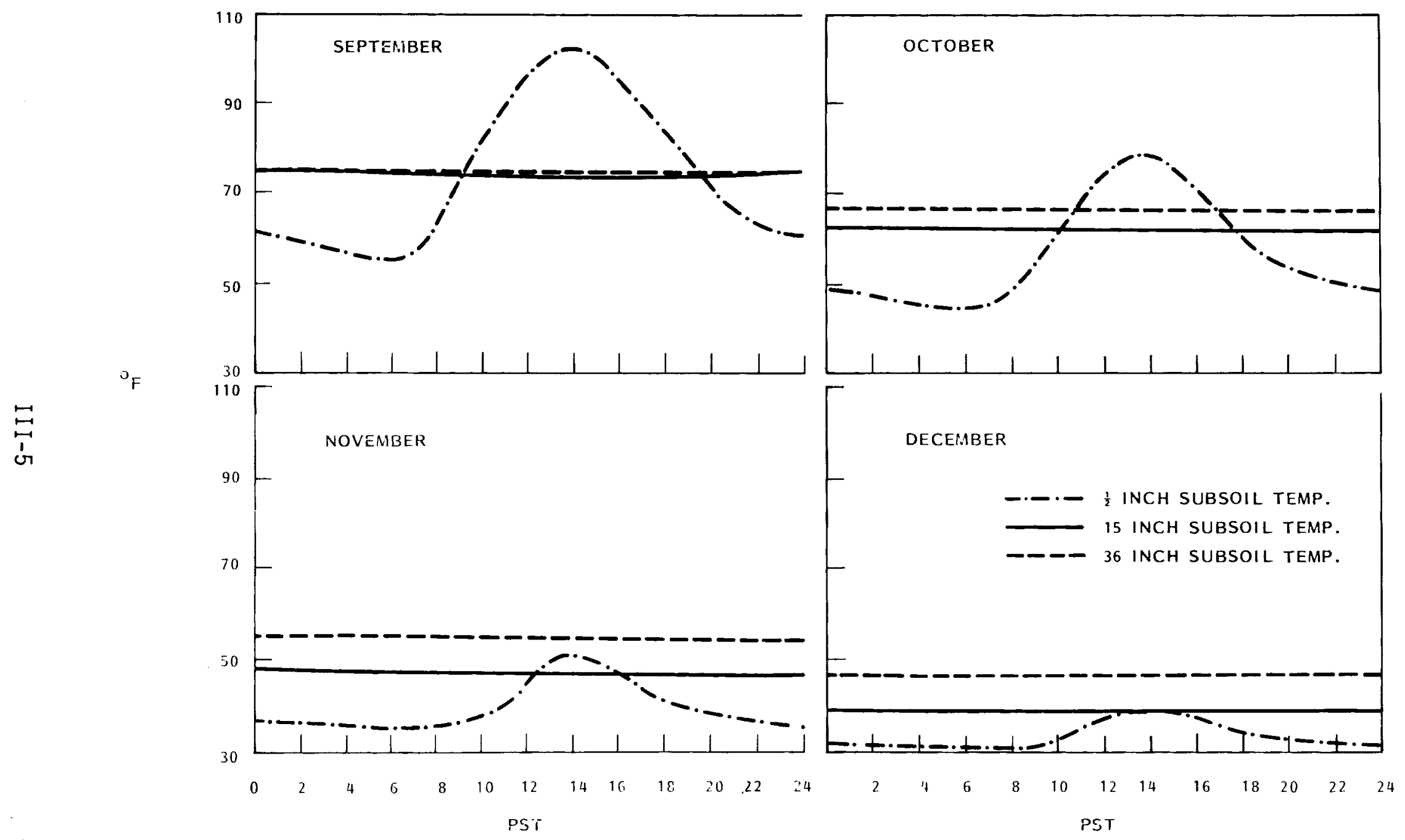

FIGURE 11. Continued 

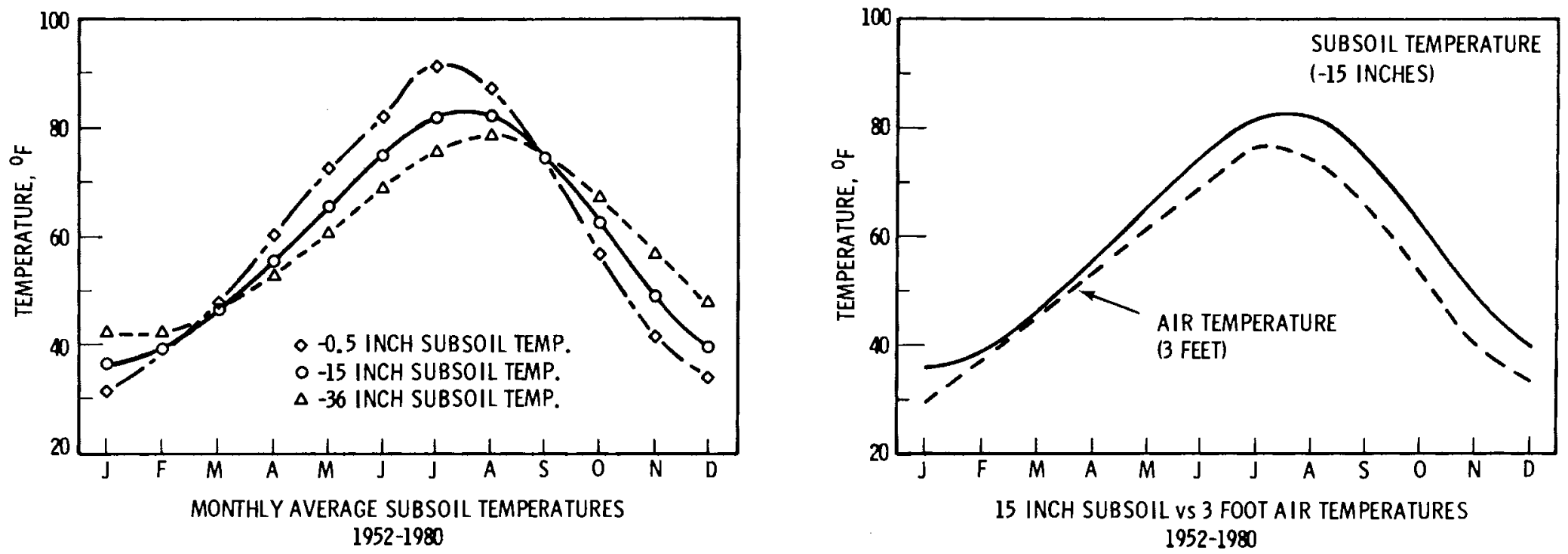

鸹
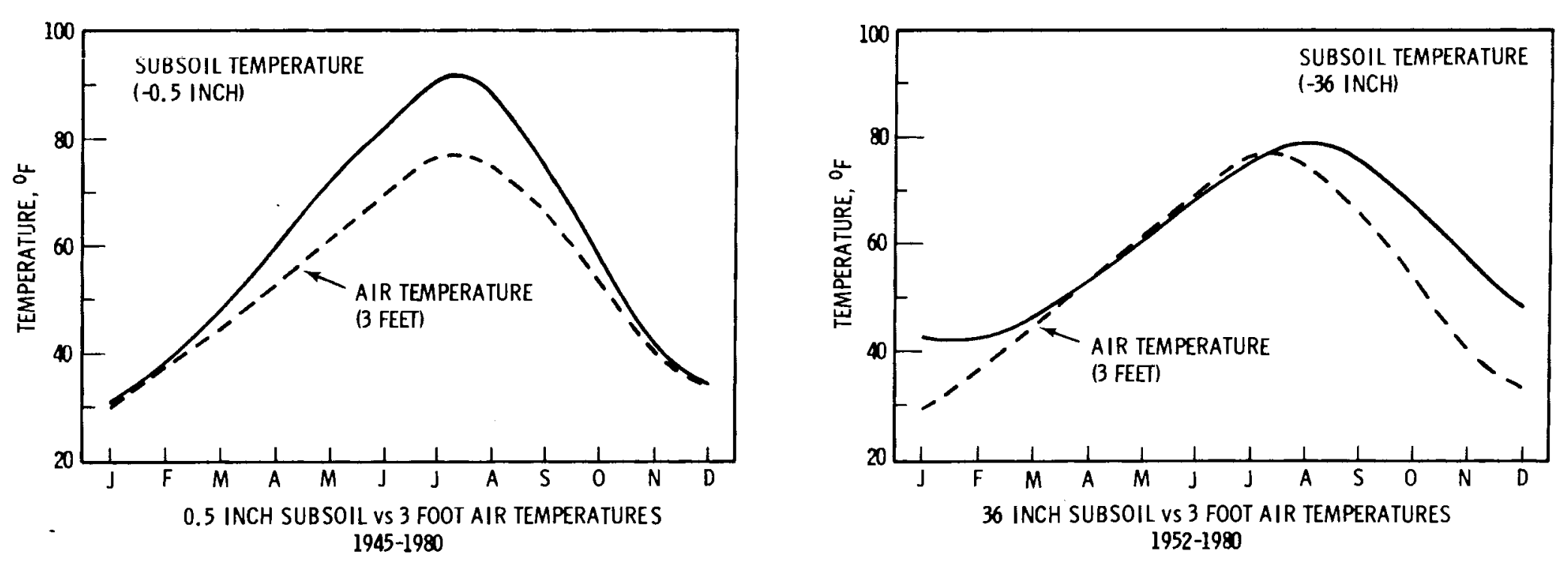

FIGURE 12. Average Monthly Subsoil and Air Temperatures 


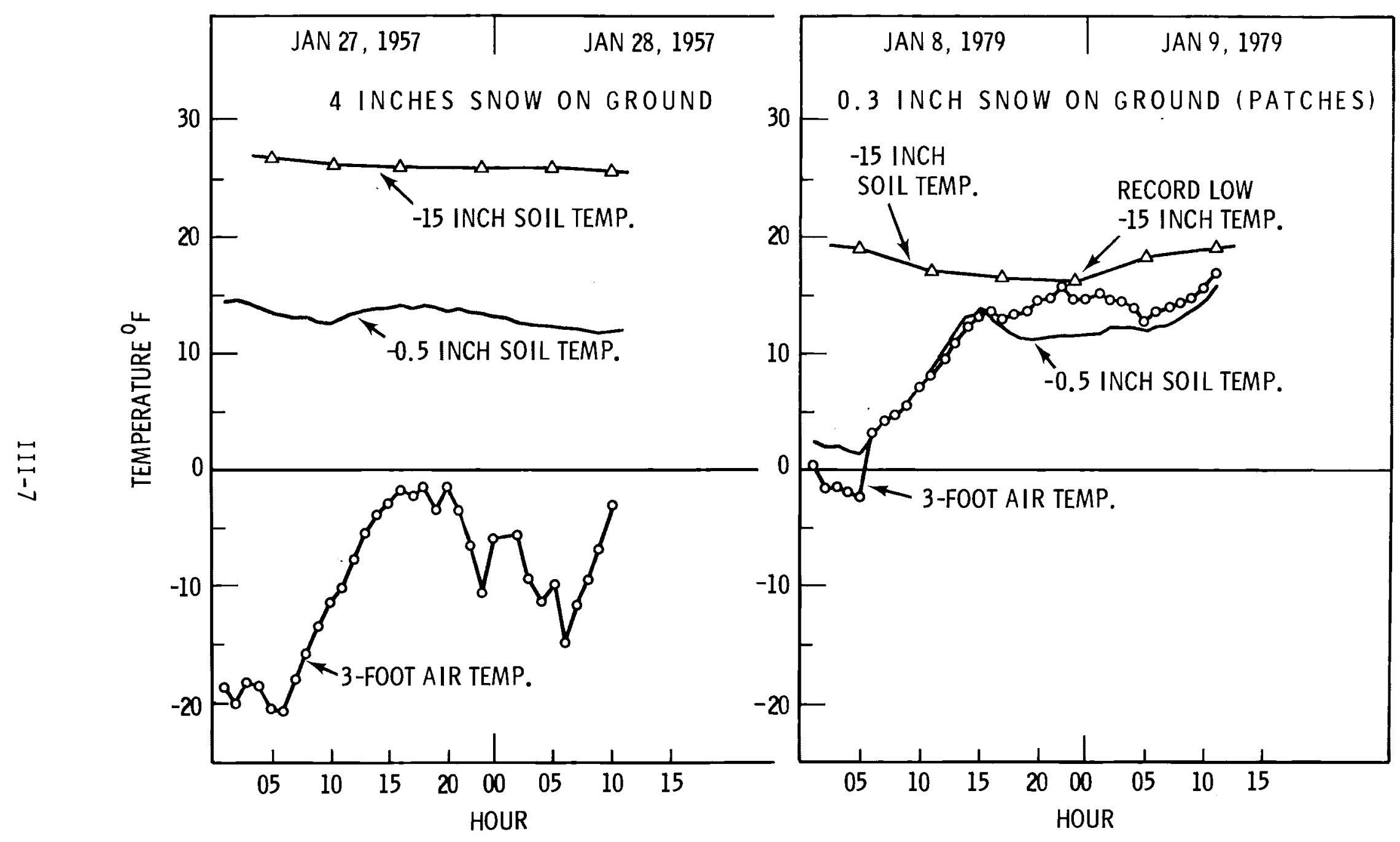

FIGURE 13. Snow Cover Effect on Subsoil Temperatures 


\section{PRECIPITATION}




\section{PRECIPITATION ${ }^{(a)}$}

MONTHLY AND ANNUAL TOTALS

Table 10 shows monthly and annual totals for the period of record 1912 through 1980. The average monthly values are presented in Figure 14. The months of November, December and January provide $42 \%$ of the total annual precipitation. July is the driest month and is followed by continual monthly increases through January. In Figure 14 it is interesting to note the steady increase from March through June and then the significant drop in July.

\section{AVERAGE NUMBER OF DAYS WITH SPECIFIED AMOUNTS}

These data are tabulated in Table 11 for the years 1946 through 1980. There are an average of 130 days per year when precipitation occurs; however, only 23 days per year have totals of 0.10 inch or more. During this 35-year record only twice has daily precipitation equalled or exceeded 1.00 inch.

TOTAL TIME WITH PRECIPITATION OBSERVED

The total time during which precipitation was observed at the HMS includes all types of precipitation. These data are presented in Table 12. No record was kept for the hours 1600 through 2400 from July 1971 through June 1974, so there is a 3-year gap in the record for those hours.

November's total monthly precipitation is close to that of December and January, but the percent of time that precipitation was observed is significantly less. There is a continual rise in the monthly average precipitation from March through June (see Figure 14) but no significant increase in the percent of time.

(a) In addition to material presented in the numbered tables in this section, miscellaneous precipitation statistics listed include:

Notable Wet Periods Notable Dry Periods 
TABLE 10. Composite Record of Monthly and Annual Precipitation (Inches)

for Hanford Townsite (Near) and HMS: 1912 Through 1980

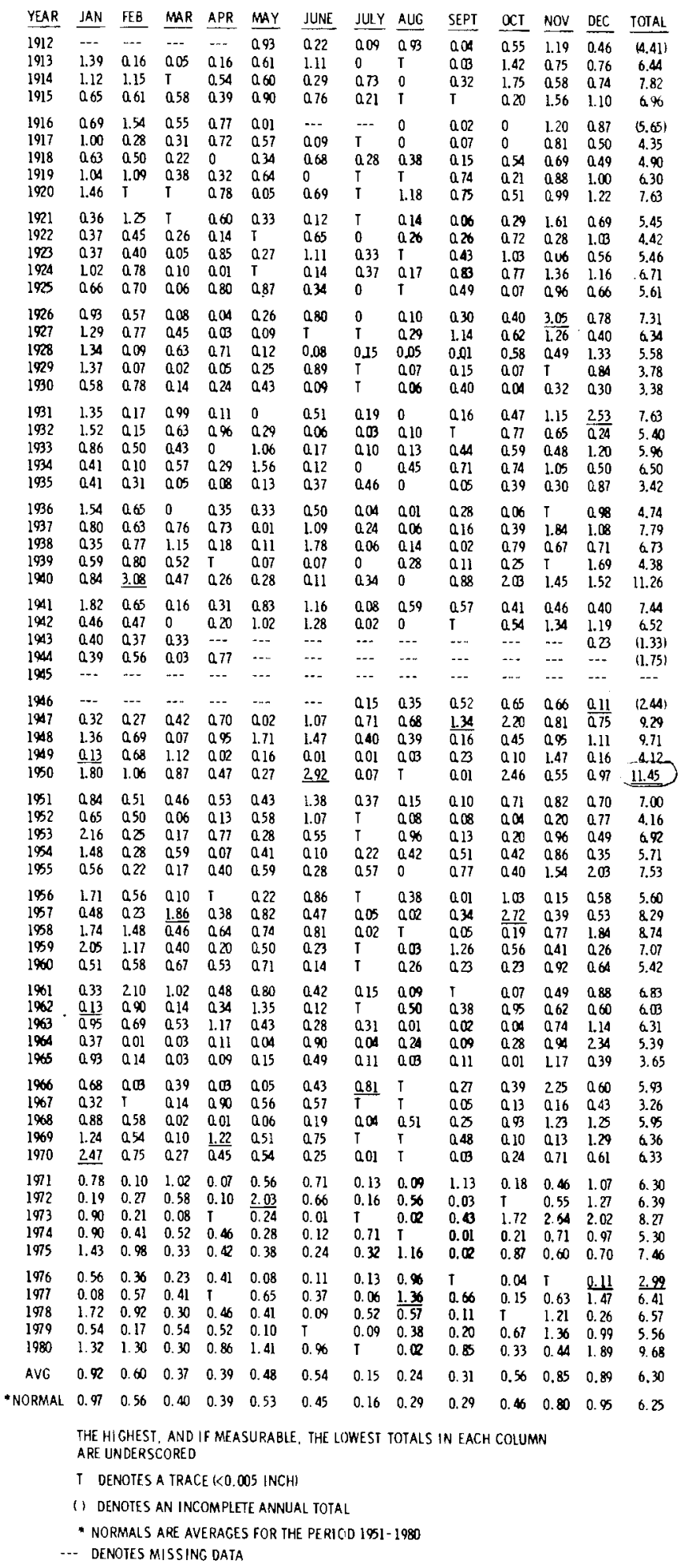




\begin{tabular}{|c|c|c|c|c|c|c|c|c|c|c|c|c|c|}
\hline YEAR & JAN & FEB & MAR & APR & MAY & JUN & JUL & AUG & SEP & OCT & NOV & DEC & ANNUAL \\
\hline 1945 & $\cdots$ & $\cdots$ & $\cdots$ & $\cdots$ & $\cdots$ & $\cdots$ & $\cdots$ & $\cdots$ & $\cdots$ & $\cdots$ & $\cdots$ & $\cdots$ & $\cdots$ \\
\hline $\begin{array}{l}1946 \\
1947 \\
1948 \\
1949 \\
1950\end{array}$ & $\begin{array}{l}0 . .- \\
0.32 \\
1.36 \\
0.13 \\
1.80\end{array}$ & $\begin{array}{l}0.27 \\
0.27 \\
0.69 \\
0.68 \\
1.06\end{array}$ & $\begin{array}{l}0.42 \\
0.42 \\
0.07 \\
1.12 \\
0.87\end{array}$ & $\begin{array}{l}0.70 \\
0.95 \\
0.02 \\
0.47\end{array}$ & $\begin{array}{l}0 . .2 \\
0.02 \\
1.71 \\
0.16 \\
0.27\end{array}$ & $\begin{array}{l}1 . . . \\
1.07 \\
1.47 \\
0.01 \\
2.92\end{array}$ & $\begin{array}{l}0.15 \\
0.71 \\
0.40 \\
0.01 \\
0.07\end{array}$ & $\begin{array}{l}0.35 \\
0.68 \\
0.39 \\
0.03 \\
T\end{array}$ & $\begin{array}{l}0.52 \\
1.34 \\
0.16 \\
0.23 \\
0.01\end{array}$ & $\begin{array}{l}0.65 \\
2.20 \\
0.45 \\
0.10 \\
2.46\end{array}$ & $\begin{array}{l}0.66 \\
0.81 \\
0.95 \\
1.47 \\
0.55\end{array}$ & $\begin{array}{l}0.11 \\
0.75 \\
1.11 \\
0.16 \\
0.97\end{array}$ & $\begin{array}{r}9.29 \\
9.71 \\
4.12 \\
11.45\end{array}$ \\
\hline $\begin{array}{l}1951 \\
1952 \\
1953 \\
1954 \\
1955\end{array}$ & $\begin{array}{l}0.84 \\
0.65 \\
2.16 \\
1.48 \\
0.56\end{array}$ & $\begin{array}{l}0.51 \\
0.50 \\
0.25 \\
0.28 \\
0.22\end{array}$ & $\begin{array}{l}0.46 \\
0.06 \\
0.17 \\
0.59 \\
0.17\end{array}$ & $\begin{array}{l}0.53 \\
0.13 \\
0.77 \\
0.07 \\
0.40\end{array}$ & $\begin{array}{l}0.43 \\
0.58 \\
0.28 \\
0.41 \\
0.59\end{array}$ & $\begin{array}{l}1.38 \\
1.07 \\
0.55 \\
0.10 \\
0.28\end{array}$ & $\begin{array}{l}0.37 \\
T \\
T \\
0.22 \\
0.57\end{array}$ & $\begin{array}{l}0.15 \\
0.08 \\
0.96 \\
0.42 \\
0\end{array}$ & $\begin{array}{l}0.10 \\
0.08 \\
0.13 \\
0.51 \\
0.77\end{array}$ & $\begin{array}{l}0.71 \\
0.04 \\
0.20 \\
0.42 \\
0.40\end{array}$ & $\begin{array}{l}0.82 \\
0.20 \\
0.96 \\
0.86 \\
1.54\end{array}$ & $\begin{array}{l}0.70 \\
0.77 \\
0.49 \\
0.35 \\
2.03\end{array}$ & $\begin{array}{l}7.00 \\
4.16 \\
6.92 \\
5.71 \\
7.53\end{array}$ \\
\hline $\begin{array}{l}1956 \\
1957 \\
1958 \\
1959 \\
1960\end{array}$ & $\begin{array}{l}1.71 \\
0.48 \\
1.74 \\
2.05 \\
0.51\end{array}$ & $\begin{array}{l}0.56 \\
0.23 \\
1.48 \\
1.17 \\
0.58\end{array}$ & $\begin{array}{l}0.10 \\
1.86 \\
0.46 \\
0.40 \\
0.67\end{array}$ & $\begin{array}{l}T \\
0.38 \\
0.64 \\
0.20 \\
0.53\end{array}$ & $\begin{array}{l}0.22 \\
0.82 \\
0.74 \\
0.50 \\
0.71\end{array}$ & $\begin{array}{l}0.86 \\
0.47 \\
0.81 \\
0.23 \\
0.14\end{array}$ & $\begin{array}{l}T \\
0.05 \\
0.02 \\
T \\
T\end{array}$ & $\begin{array}{l}0.38 \\
0.02 \\
T \\
0.03 \\
0.26\end{array}$ & $\begin{array}{l}0.01 \\
0.34 \\
0.05 \\
1.26 \\
0.23\end{array}$ & $\begin{array}{l}1.03 \\
2.72 \\
0.19 \\
0.56 \\
0.23\end{array}$ & $\begin{array}{l}0.15 \\
0.39 \\
0.77 \\
0.41 \\
0.92\end{array}$ & $\begin{array}{l}0.58 \\
0.53 \\
1.84 \\
0.26 \\
0.64\end{array}$ & $\begin{array}{l}5.60 \\
8.29 \\
8.74 \\
7.07 \\
5.42\end{array}$ \\
\hline $\begin{array}{l}1961 \\
1962 \\
1963 \\
1964 \\
1965\end{array}$ & $\begin{array}{l}0.33 \\
0.13 \\
0.95 \\
0.37 \\
0.93\end{array}$ & $\begin{array}{l}2.10 \\
0.90 \\
0.69 \\
0.01 \\
0.14\end{array}$ & $\begin{array}{l}1.02 \\
0.14 \\
0.53 \\
0.03 \\
0.03\end{array}$ & $\begin{array}{l}0.48 \\
0.34 \\
1.17 \\
0.11 \\
0.09\end{array}$ & $\begin{array}{l}0.80 \\
1.35 \\
0.43 \\
0.04 \\
0.15\end{array}$ & $\begin{array}{l}0.42 \\
0.12 \\
0.28 \\
0.90 \\
0.49\end{array}$ & $\begin{array}{l}0.15 \\
T \\
0.31 \\
0.04 \\
0.11\end{array}$ & $\begin{array}{l}0.09 \\
0.50 \\
0.01 \\
0.24 \\
0.03\end{array}$ & $\begin{array}{l}T \\
0.38 \\
0.02 \\
0.09 \\
0.11\end{array}$ & $\begin{array}{l}0.07 \\
0.95 \\
0.04 \\
0.28 \\
0.01\end{array}$ & $\begin{array}{l}0.49 \\
0.65 \\
0.74 \\
0.94 \\
1.17\end{array}$ & $\begin{array}{l}0.89 \\
0.60 \\
1.14 \\
2.34 \\
0.39\end{array}$ & $\begin{array}{l}6.84 \\
6.06 \\
6.31 \\
5.39 \\
3.65\end{array}$ \\
\hline $\begin{array}{l}1966 \\
1967 \\
1968 \\
1969 \\
1970\end{array}$ & $\begin{array}{l}0.68 \\
0.32 \\
0.88 \\
1.24 \\
2.47\end{array}$ & $\begin{array}{l}0.03 \\
T \\
0.58 \\
0.54 \\
0.75\end{array}$ & $\begin{array}{l}0.39 \\
0.14 \\
0.02 \\
0.10 \\
0.27\end{array}$ & $\begin{array}{l}0.03 \\
0.90 \\
0.01 \\
1.22 \\
0.45\end{array}$ & $\begin{array}{l}0.05 \\
0.56 \\
0.06 \\
0.51 \\
0.54\end{array}$ & $\begin{array}{l}0.43 \\
0.57 \\
0.19 \\
0.75 \\
0.25\end{array}$ & $\begin{array}{l}0.81 \\
T \\
0.04 \\
T \\
0.01\end{array}$ & $\begin{array}{l}T \\
T \\
0.51 \\
T \\
T\end{array}$ & $\begin{array}{l}0.27 \\
0.05 \\
0.25 \\
0.48 \\
0.03\end{array}$ & $\begin{array}{l}0.39 \\
0.13 \\
0.93 \\
0.10 \\
0.24\end{array}$ & $\begin{array}{l}2.25 \\
0.16 \\
1.23 \\
0.13 \\
0.71\end{array}$ & $\begin{array}{l}0.60 \\
0.43 \\
1.25 \\
1.29 \\
0.61\end{array}$ & $\begin{array}{l}5.93 \\
3.26 \\
5.95 \\
6.36 \\
6.33\end{array}$ \\
\hline $\begin{array}{l}1971 \\
1972 \\
1973 \\
1974 \\
1975\end{array}$ & $\begin{array}{l}0.78 \\
0.19 \\
0.90 \\
0.90 \\
1.70\end{array}$ & $\begin{array}{l}0.10 \\
0.27 \\
0.21 \\
0.41 \\
0.98\end{array}$ & $\begin{array}{l}1.02 \\
0.58 \\
0.08 \\
0.52 \\
0.33\end{array}$ & $\begin{array}{l}0.07 \\
0.10 \\
T \\
0.46 \\
0.42\end{array}$ & $\begin{array}{l}0.56 \\
2.03 \\
0.24 \\
0.28 \\
0.38\end{array}$ & $\begin{array}{l}0.71 \\
0.66 \\
0.01 \\
0.12 \\
0.24\end{array}$ & $\begin{array}{l}0.13 \\
0.16 \\
T \\
0.71 \\
0.32\end{array}$ & $\begin{array}{l}0.09 \\
0.56 \\
0.02 \\
T \\
1.16\end{array}$ & $\begin{array}{l}1.13 \\
0.02 \\
0.43 \\
0.01 \\
0.03\end{array}$ & $\begin{array}{l}0.18 \\
T \\
1.72 \\
0.21 \\
0.87\end{array}$ & $\begin{array}{l}0.46 \\
0.55 \\
2.64 \\
0.71 \\
0.60\end{array}$ & $\begin{array}{l}1.07 \\
1.27 \\
2.02 \\
0.97 \\
0.70\end{array}$ & $\begin{array}{l}6.30 \\
6.39 \\
8.27 \\
5.30 \\
7.73\end{array}$ \\
\hline $\begin{array}{l}1976 \\
1977 \\
1978 \\
1979 \\
1980\end{array}$ & $\begin{array}{l}0.56 \\
0.08 \\
1.52 \\
0.54 \\
1.32\end{array}$ & $\begin{array}{l}0.36 \\
0.57 \\
0.92 \\
0.17 \\
1.30\end{array}$ & $\begin{array}{l}0.23 \\
0.41 \\
0.30 \\
0.54 \\
0.30\end{array}$ & $\begin{array}{l}0.41 \\
T \\
0.46 \\
0.52 \\
0.86\end{array}$ & $\begin{array}{l}0.08 \\
0.65 \\
0.41 \\
0.10 \\
1.41\end{array}$ & $\begin{array}{l}0.11 \\
0.37 \\
0.09 \\
T \\
0.96\end{array}$ & $\begin{array}{l}0.13 \\
0.06 \\
0.52 \\
0.09 \\
T\end{array}$ & $\begin{array}{l}0.96 \\
1.36 \\
0.57 \\
0.38 \\
0.02\end{array}$ & $\begin{array}{l}T \\
0.66 \\
0.11 \\
0.20 \\
0.85\end{array}$ & $\begin{array}{l}0.04 \\
0.15 \\
T \\
0.67 \\
0.33\end{array}$ & $\begin{array}{l}T \\
0.63 \\
1.21 \\
1.36 \\
0.44\end{array}$ & $\begin{array}{l}0.11 \\
1.47 \\
0.26 \\
0.99 \\
1.89\end{array}$ & $\begin{array}{l}2.99 \\
6.41 \\
6.37 \\
5.56 \\
9.68\end{array}$ \\
\hline $\begin{array}{l}1981 \\
1982 \\
1983 \\
1984 \\
1985\end{array}$ & $\begin{array}{l}0.56 \\
0.33 \\
1.44 \\
0.23 \\
0.34\end{array}$ & $\begin{array}{l}0.60 \\
0.57 \\
1.36 \\
0.94 \\
0.82\end{array}$ & $\begin{array}{l}0.70 \\
0.30 \\
1.00 \\
1.01 \\
0.36\end{array}$ & $\begin{array}{l}0.02 \\
0.75 \\
0.42 \\
0.60 \\
0.01\end{array}$ & $\begin{array}{l}0.99 \\
0.28 \\
0.52 \\
0.55 \\
0.12\end{array}$ & $\begin{array}{l}0.43 \\
0.75 \\
0.68 \\
0.99 \\
0.15\end{array}$ & $\begin{array}{l}0.19 \\
0.22 \\
0.31 \\
0.06 \\
0.12\end{array}$ & $\begin{array}{l}0.03 \\
0.20 \\
0.12 \\
T \\
0.01\end{array}$ & $\begin{array}{l}0.60 \\
0.55 \\
0.46 \\
0.42 \\
0.63\end{array}$ & $\begin{array}{l}0.39 \\
1.33 \\
0.52 \\
0.07 \\
0.46\end{array}$ & $\begin{array}{l}1.08 \\
0.91 \\
2.12 \\
1.83 \\
1.24\end{array}$ & $\begin{array}{l}1.45 \\
1.79 \\
2.12 \\
0.57 \\
0.84\end{array}$ & $\begin{array}{r}7.04 \\
7.98 \\
11.07 \\
7.27 \\
5.10\end{array}$ \\
\hline $\begin{array}{l}1986 \\
1987 \\
1988 \\
1989 \\
1990\end{array}$ & $\begin{array}{l}1.76 \\
0.80 \\
0.48 \\
0.21 \\
0.77\end{array}$ & $\begin{array}{l}1.37 \\
0.19 \\
T \\
1.67 \\
0.09\end{array}$ & $\begin{array}{l}0.76 \\
1.05 \\
0.39 \\
1.56 \\
0.10\end{array}$ & $\begin{array}{l}T \\
0.14 \\
1.12 \\
0.84 \\
0.40\end{array}$ & $\begin{array}{l}0.30 \\
0.17 \\
0.33 \\
0.59 \\
0.86\end{array}$ & $\begin{array}{l}T \\
0.11 \\
0.11 \\
0.01 \\
0.36\end{array}$ & $\begin{array}{l}0.21 \\
0.50 \\
0.13 \\
0.01 \\
0.14\end{array}$ & $\begin{array}{l}0.02 \\
0.07 \\
0 \\
0.26 \\
0.83\end{array}$ & $\begin{array}{l}0.96 \\
0.01 \\
0.39 \\
0.02 \\
T\end{array}$ & $\begin{array}{l}0.29 \\
T \\
0.01 \\
0.42 \\
0.78\end{array}$ & $\begin{array}{l}0.65 \\
0.40 \\
0.82 \\
1.04 \\
0.02\end{array}$ & $\begin{array}{l}0.77 \\
1.63 \\
0.40 \\
0.29 \\
0.72\end{array}$ & $\begin{array}{l}7.09 \\
5.07 \\
4.18 \\
6.92 \\
5.07\end{array}$ \\
\hline $\begin{array}{l}1991 \\
1992 \\
1993\end{array}$ & $\begin{array}{l}0.33 \\
0.44 \\
1.30\end{array}$ & $\begin{array}{l}0.19 \\
0.94 \\
1.17\end{array}$ & $\begin{array}{l}1.12 \\
0.09 \\
0.67\end{array}$ & $\begin{array}{l}0.45 \\
0.94 \\
0.71\end{array}$ & $\begin{array}{l}0.49 \\
T \\
0.60\end{array}$ & $\begin{array}{l}1.44 \\
1.14 \\
0.12\end{array}$ & $\begin{array}{l}0.29 \\
0.38 \\
1.76\end{array}$ & $\begin{array}{l}0.07 \\
0.20 \\
0.24\end{array}$ & $\begin{array}{l}0 \\
0.27 \\
0.04\end{array}$ & $\begin{array}{l}0.53 \\
0.61 \\
0.09\end{array}$ & $\begin{array}{l}1.44 \\
1.07 \\
0.19\end{array}$ & $\begin{array}{l}0.40 \\
1.82 \\
0.94\end{array}$ & $\begin{array}{l}6.75 \\
7.90 \\
7.83\end{array}$ \\
\hline AVG & 0.87 & 0.61 & 0.49 & 0.42 & 0.50 & 0.53 & 0.21 & 0.25 & 0.31 & 0.51 & 0.84 & 0.92 & 6.49 \\
\hline NORMAL & 0.79 & 0.62 & 0.47 & 0.41 & 0.51 & 0.38 & 0.18 & 0.27 & 0.31 & 0.39 & 0.91 & 1.03 & 6.26 \\
\hline
\end{tabular}




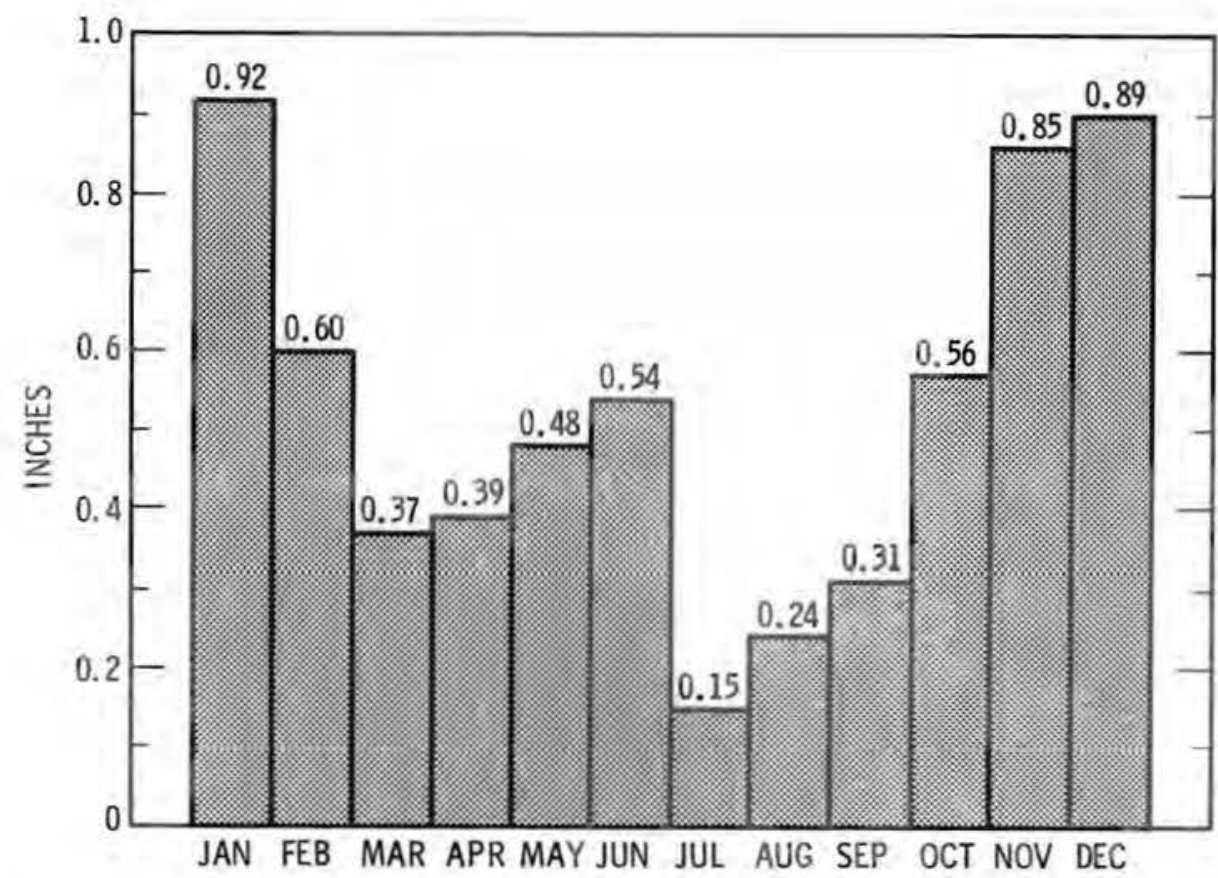

FIGURE 14. Monthly Average Precipitation Amounts: 1912 Through 1980 
TABLE 11. Average Number of Days With Precipitation of Specified Amount, 1946 Through 1980

$\underset{!}{\stackrel{5}{5}}$

\begin{tabular}{|c|c|c|c|c|c|c|}
\hline MONTH & $\begin{array}{c}\text { TRACE OR } \\
\text { MORE } \\
\end{array}$ & $\begin{array}{l}0.01 \text { INCH } \\
\text { OR MORE } \\
\end{array}$ & $\begin{array}{l}0.10 \text { INCH } \\
\text { OR MORE }\end{array}$ & $\begin{array}{l}0.25 \text { INCH } \\
\text { OR MORE } \\
\end{array}$ & $\begin{array}{l}0,50 \text { INCH } \\
\text { OR MORE } \\
\end{array}$ & $\begin{array}{r}1.00 \mathrm{INCH} \\
\text { OR MORE } \\
\end{array}$ \\
\hline JAN & 17 & 9 & 3 & 1 & \# & 0 \\
\hline FEB & 12 & 7 & 2 & I & \# & 0 \\
\hline MAR & 11 & 6 & 2 & \# & $\#$ & 0 \\
\hline APR & 11 & 5 & 1 & $\#$ & \# & 0 \\
\hline MAY & 10 & 5 & 2 & 1 & \# & 0 \\
\hline JUNE & 9 & 5 & 2 & 1 & $\#$ & $\#$ \\
\hline JULY & 5 & 2 & 1 & \# & 0 & 0 \\
\hline AUG & 6 & 3 & 1 & $\#$ & $\#$ & 0 \\
\hline SEPT & 7 & 3 & 1 & $\#$ & $\#$ & 0 \\
\hline OCT & 10 & 5 & 2 & 1 & $\#$ & $\#$ \\
\hline NOV & 15 & 8 & 3 & 1 & $\#$ & 0 \\
\hline DEC & 17 & 10 & 3 & 1 & $\#$ & 0 \\
\hline ANNUAL & 130 & 68 & 23 & 7 & $1^{*}$ & $\#$ \\
\hline
\end{tabular}

\# USED tO DENOTE AN AVERAGE OF LESS THAN 1/2 DAY 
TABLE 12. Monthiy and Annual Averages and Extremes in Total Time With Precipitation Observed: July 1946 Through June 1971, July 1974 Through December 1980

$\stackrel{\text { N }}{\text { i }}$

\begin{tabular}{llllll}
\multicolumn{2}{c}{ AVERAGES } & & \multicolumn{3}{c}{ GREATEST } \\
\cline { 5 - 6 } NO. OF & $\%$ OF & & NO. OF & $\%$ OF \\
$\frac{\text { HOURS }}{98.8}$ & $\frac{\text { TIME }}{13.3}$ & & $\frac{\text { HOURS }}{212.0}$ & $\frac{\text { TIME }}{28.5}$ & $\frac{\text { YEAR }}{1969}$
\end{tabular}

\begin{tabular}{lll}
\multicolumn{3}{c}{ LEAST } \\
\hline NO. OF & $\%$ OF \\
$\frac{\text { HOURS }}{29.2}$ & $\frac{\text { TIME }}{3.9}$ & $\frac{\text { YEAR }}{1949}$
\end{tabular}

60.39 .0

106.8

$15.9 \quad 1958$

$\begin{array}{lll}4.7 & 0.7 & 1967\end{array}$

MAR

38.7

5.2

135.2

18.21957

$\begin{array}{lll}7.3 & 1.0 & 1968\end{array}$

APR

31.3

4.3

69.2

$9.6 \quad 1953$

$\begin{array}{lll}1.8 & 0.2 \quad 1956\end{array}$

M. $4 Y$

35.24 .7

$89.9 \quad 12.1 \quad 1948$

$\begin{array}{lll}4.8 & 0.6 & 1947\end{array}$

JUNE

31.2

4.3

80.8

11.21950

$\begin{array}{lll}3.2 & 0.4 \quad 1949\end{array}$

$\begin{array}{lllll}10.7 & 1.4 & 38.2 & 5.1 & 1966\end{array}$

$\begin{array}{lll}1.2 & 0.2 & 1958\end{array}$

AUG

$15.8 \quad 2$.

61.7

$8.3 \quad 1968$

$\begin{array}{lll}0.0 & 0.0 & 1955\end{array}$

SEPT

$\begin{array}{ll}17.4 & 2.4\end{array}$

52.2

7.21959

1.0

$0.1 \quad 1975$

OCT

$36.2 \quad 4.9$

119.

$16.1 \quad 1947$

0.

NOV

65.79.

$132.2 \quad 18.4 \quad 1955$

$21.4 \quad 3.0 \quad 1957$

DEC

$89.7 \quad 12$.

179.6

$24.1 \quad 1963$

25.8

$2.1 \quad 1976$

AVG. ANNUAL $531.0 \quad 6.1$

AVG. ANNUAL EXTREMES

738.0

8.4 1950

294.6

$3.4 \quad 1976$ 
PERCENT OF DAYS AND MONTHLY PRECIPITATION INTENSITY FACTORS

Figures $15 \mathrm{a}, \mathrm{b}$ and 16 graphically depict the percent of days with precipitation within specified parameters and intensity factors. It is interesting to note that while November, December and January are the leading months for total precipitation, the months with the highest intensity factors are June, July, August and September. There is a steady increase in the intensity factor from March through June.

\section{NOTABLE WET PERIODS}

There are five periods listed below when precipitation was abnormally high. Four of the five occurred during the "wet" cycle shown by the moving averages in Figure 17.

\begin{tabular}{|c|c|c|c|c|c|}
\hline \multirow[b]{2}{*}{ Period } & \multicolumn{3}{|c|}{$\frac{\text { Number of Days Precip. } T^{(a)} \text { or More }}{\text { With }}$} & \multicolumn{2}{|c|}{$\begin{array}{l}\text { Total Amount } \\
\text { (Inches) }\end{array}$} \\
\hline & Altogether & $\begin{array}{c}\text { Greatest } \\
\text { Consec } \\
\end{array}$ & $\begin{array}{c}\text { With } \\
\text { Measurable } \\
\text { Precip } \\
\end{array}$ & $\begin{array}{l}\text { Water } \\
\text { Equiv }\end{array}$ & $\begin{array}{l}\text { Snow- } \\
\text { fall } \\
\end{array}$ \\
\hline Oct 7-Nov 4, 1947 & 23 out of 29 & 10 & 17 & 2.21 & 0 \\
\hline Jan 3-28, 1950 & 21 out of 26 & 10 & 15 & 1.80 & 23.4 \\
\hline Nov 11-Dec 19, 1950 & 33 out of 39 & 12 & 20 & 1.37 & 3.7 \\
\hline Nov 16-Dec 22, 1955 & 31 out of 37 & 15 & 24 & 3.19 & 22.7 \\
\hline Oct 31-Dec 7, 1973 & 32 out of 38 & 14 & 20 & 3.45 & 8,1 \\
\hline
\end{tabular}

An unusual year from a precipitation standpoint was 1973. Total precipitation for the year was 8.27 inches, which was $132 \%$ of normal (6.25 inches). The period March 30 through September 18, 1973 was dry (see table on page IV-10), while the period October 31 through December 7, 1973, was a notable wet period (see table above). During the months of October, November and December 1973, 6.38 inches were recorded, which was $289 \%$ of normal (2.21 inches) for those months. 
(a)

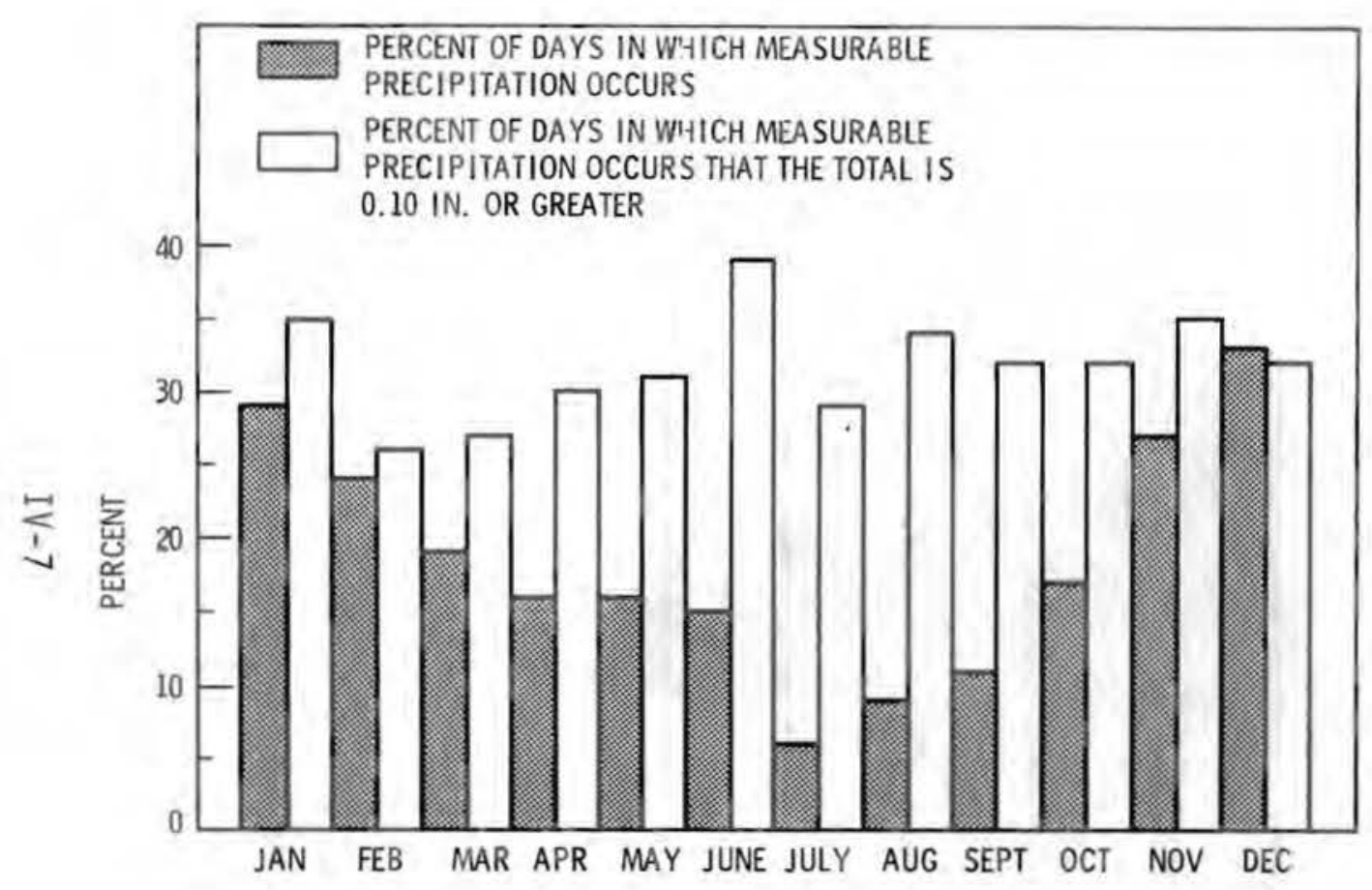

(b)

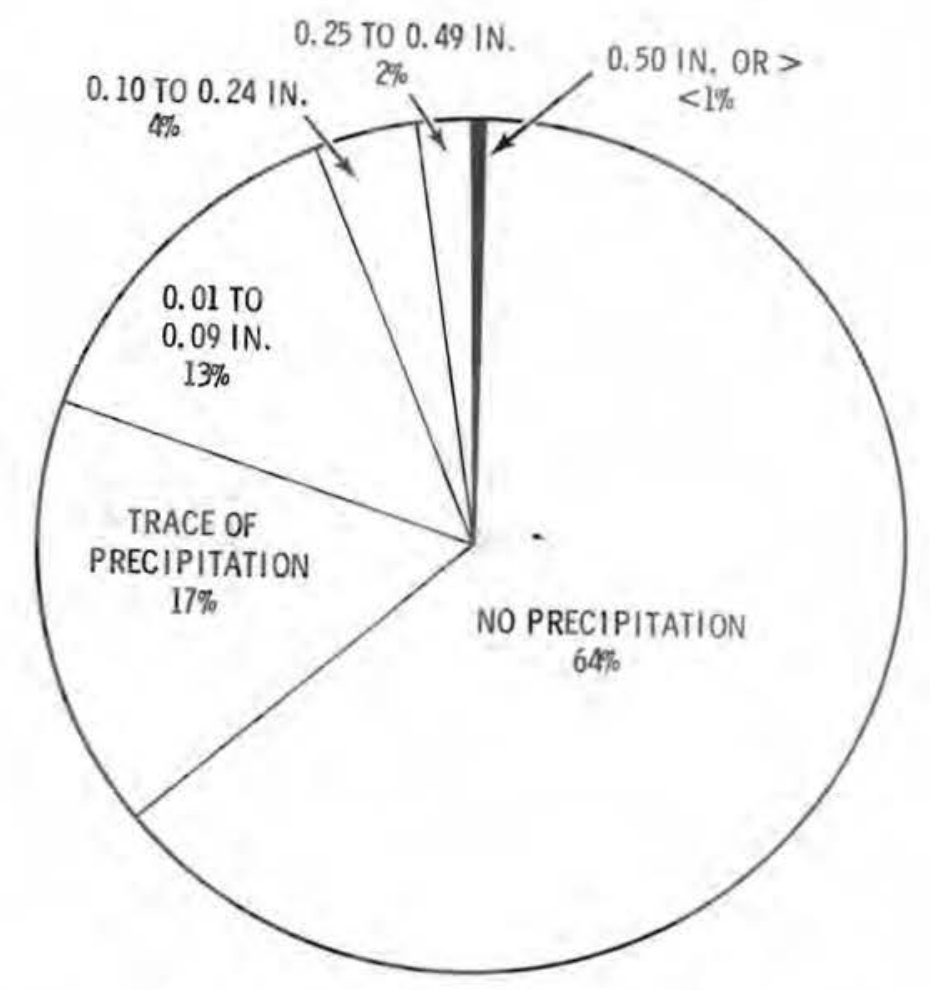

FIGURE 15. (a) Precipitation - Percent of Days Statistics Based on the Period 1946 Through 1980;

(b) Percent of Days in a Year With Precipitation as Indicated 


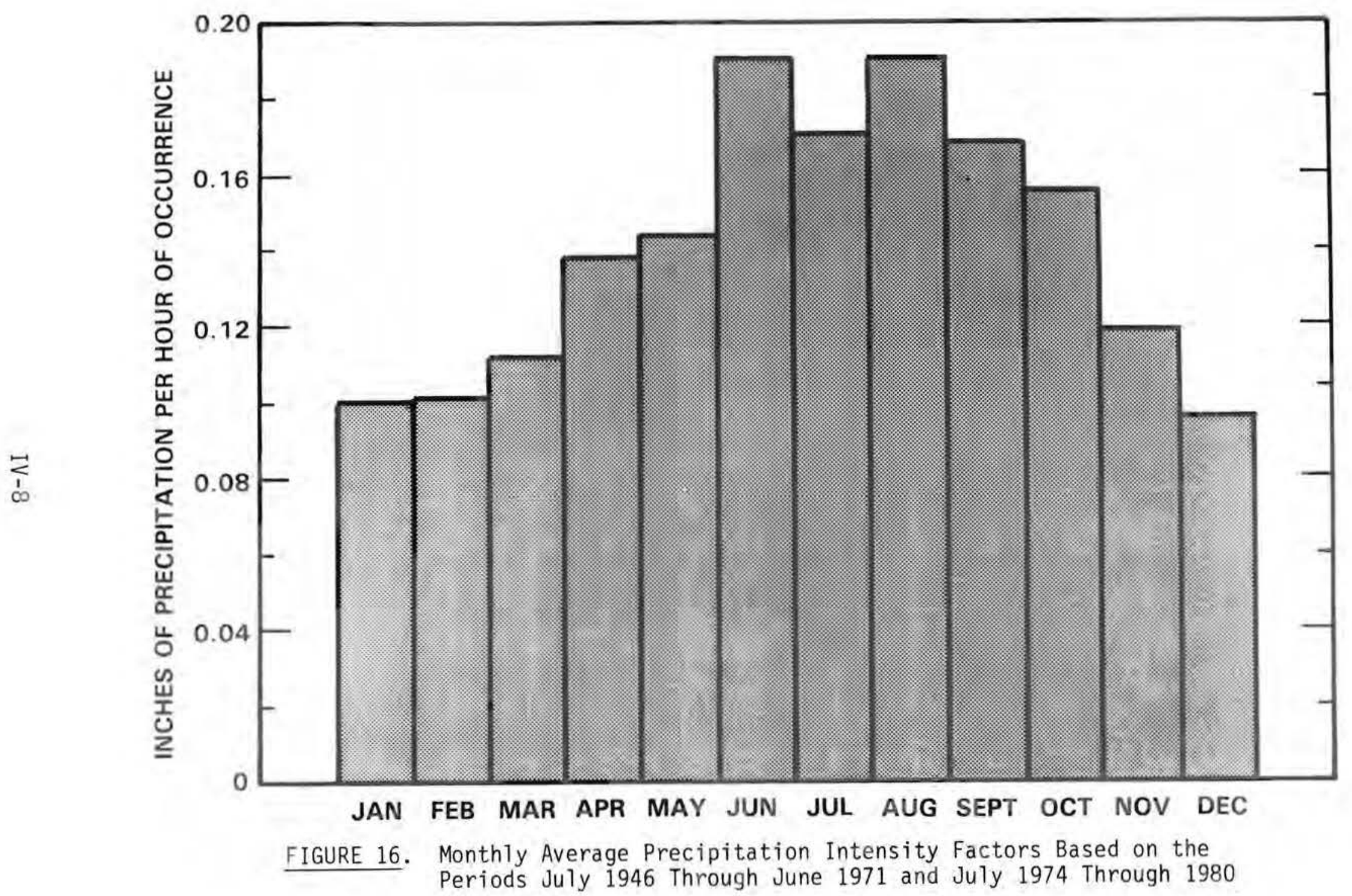




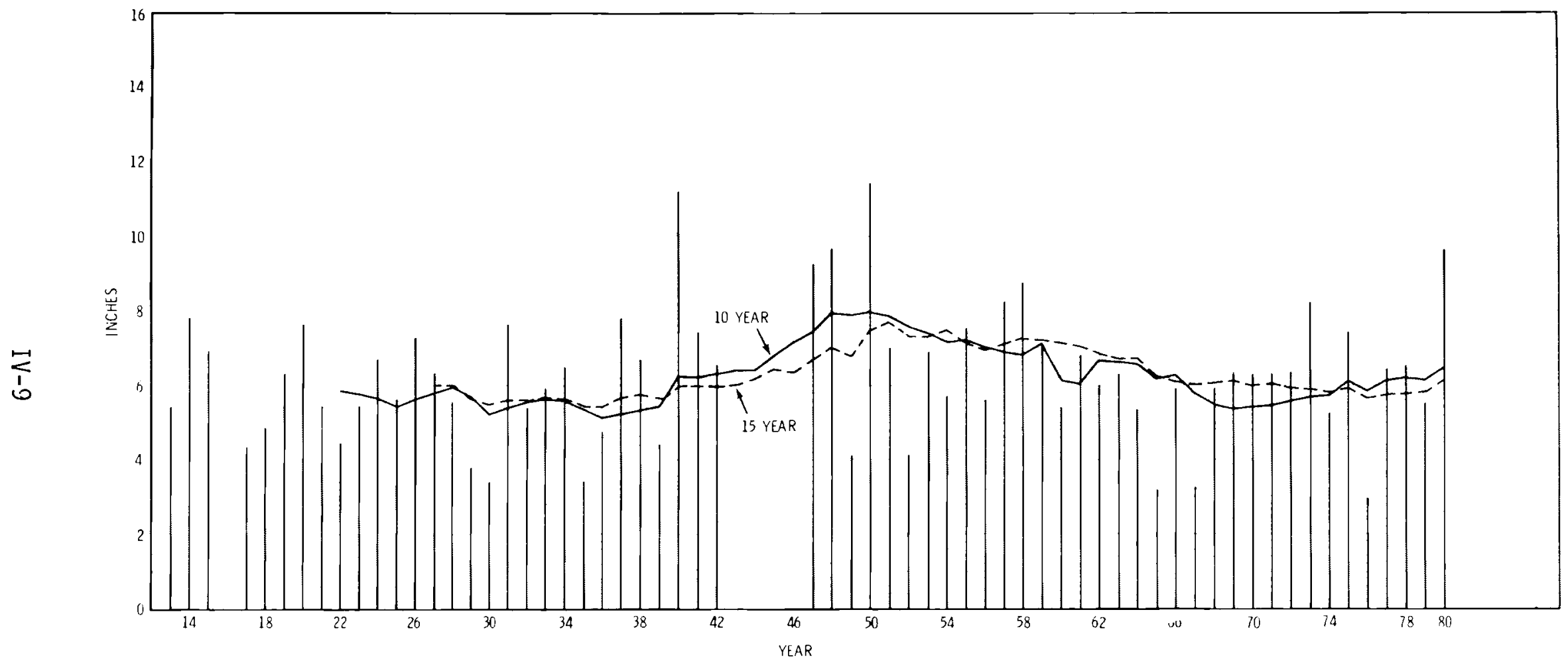

FIGURE 17. Total Annual Precipitation (1913 Through 1980) and 10- and 15-Year Moving Averages 
NOTABLE DRY PERIODS

The HMS is in a semi-arid region; therefore, there have been many dry periods. January and December are the only months that have always received measurable precipitation (1912 through 1980). There have been a total of 75 months in the period of record (1912. through 1980) without measurable precipitation. The months of July and August account for 43 of the 75 total (Table 10). The record number of consecutive days without measurable precipitation occurred in 1919. The period started May 23 and ran through September 1 (102 days). Listed below are some long periods with small amounts of precipitation.

\begin{tabular}{|c|c|c|c|c|}
\hline Year & From & To & $\begin{array}{l}\text { Number } \\
\text { Of Days }\end{array}$ & $\begin{array}{l}\text { Total Precip } \\
\text { (Inches) }\end{array}$ \\
\hline 1917 & May 29 & Nov 1 & 157 & 0.16 \\
\hline 1927 & April 1 & Aug 26 & 148 & 0.14 \\
\hline 1968 & Feb 24 & Aug 13 & 172 & 0.32 \\
\hline 1973 & Mar 30 & Sept 18 & 173 & 0.29 \\
\hline 1976 & Aug 26 & Dec 31 & 128 & 0.15 \\
\hline
\end{tabular}

The driest year of record (from 1912 through 1980) was 1976. Total precipitation for that year was 2.99 inches, which was only $48 \%$ of normal (6.25 inches). During the period September through December 1976 the total precipitation was 0.15 inch, which is $6 \%$ of normal (2.52 inches) for those months.

SNOWFALL

Snowfall, which includes all frozen precipitation, has varied from a seasonal total of 0.3 inch in 1957-1958 to 43.6 inches in 1915-1916 (Table 13). Snowfall accounts for $38 \%$ of all precipitation during the months December through February (Table 14). November and March snowfall accounts for about $16 \%$ of the total precipitation for those months. October and April both get a little snow but until April 6, 1982,, there had never been a measurable amount in April. On that date 1 inch was recorded (not included in any table in this document). 
TABLE 13. Composite Record of Monthly and Seasonal Snowfall for Hanford Townsite (Near) and HMS: 1912 Through 1980

\begin{tabular}{|c|c|c|c|c|c|c|c|c|c|c|c|c|}
\hline \multirow[b]{2}{*}{ SEASON } & \multirow[b]{2}{*}{$\underline{\propto T T}$} & \multirow[b]{2}{*}{ NOV } & \multirow[b]{2}{*}{$\underline{0 E C}$} & \multirow[b]{2}{*}{ JAN } & \multirow[b]{2}{*}{ FEB } & \multirow[b]{2}{*}{ MAR } & & & FIRST SE & EASONAL (1) & LAST SEA & SONAL II \\
\hline & & & & & & & APR & TOTAL & OATE & AMOUNT & OATE & AMOUNT \\
\hline 1912-13 & 0 & 0 & 0 & 120 & 25 & 0.4 & 0 & 14.9 & & & & \\
\hline $1913-14$ & 0 & 0 & 7.6 & $T$ & $\mathrm{I}$ & 0 & 0 & 7.6 & & & & \\
\hline $1914-15$ & 0 & $T$ & 1.5 & 4.0 & 0 & 0 & 0 & 5.5 & & & & \\
\hline $1915-16$ & 0 & 0 & 7.0 & 9.6 & 26.0 & 1.0 & 0 & 43.6 & & & & \\
\hline $1916-17$ & 0 & $T$ & 85 & 22 & 28 & 0 & 0 & $\overline{13.5}$ & & & & \\
\hline $1917-18$ & 0 & 0 & 1.0 & 22 & 0 & 0 & 0 & 3.2 & & & & \\
\hline $1918-19$ & 0 & $T$ & 1.2 & 5.0 & 3.0 & 0 & 0 & 9.2 & & & & \\
\hline $1919-20$ & 0 & 20 & 7.0 & 14.0 & $\mathrm{~T}$ & 0 & $\mathrm{~T}$ & 3.0 & & & & \\
\hline $1920-21$ & 0 & 0 & 4.0 & 20 & 4.0 & 0 & 0 & 10.0 & & & & \\
\hline $1921-22$ & 0 & 12.2 & 4.5 & 4,1 & 3.0 & 0 & 0 & 3.8 & & & & \\
\hline $1922-23$ & 0 & 0 & 8.5 & 0 & 4.0 & 0 & 0 & 12.5 & & & & \\
\hline $1923-24$ & 0 & 0 . & 20 & 4.0 & 0 & 0 & 0 & 60 & & & & \\
\hline $1924-25$ & 0 & 3.0 & 7.0 & 60 & 0 & 0 & 0 & 16.0 & & & & \\
\hline $198-26$ & 0 & 3.0 & 0.5 & 20 & 0 & 0 & 0 & 5.5 & & & & \\
\hline $1926-27$ & 0 & 5.5 & 60 & 9.8 & 0 & 0 & $T$ & 21.3 & & & & \\
\hline $1927-28$ & 0 & 0 & 7.0 & 29 & 0.2 & 0 & 0 & 10.1 & & & & \\
\hline $1928-29$ & 0 & 0 & 2.5 & 11.5 & 0.8 & 0 & 0 & 14.8 & & & & \\
\hline $1929-30$ & 0 & 23 & 3.5 & 6.6 & 3.0 & 0 & 0 & 15.4 & & & & \\
\hline $1930-31$ & 0 & 3.2 & 0.5 & $T$ & 0 & $T$ & 0 & 3.7 & & & & \\
\hline $1931-32$ & 0 & 0 & 7.7 & 13.9 & 1.5 & 0.2 & 0 & 3.3 & & & & \\
\hline $1932-33$ & 0 & 0 & 2.5 & 6.9 & 83 & 0 & 0 & 17.7 & & & & \\
\hline 1933-34 & 0 & 0 & 6.2 & $T$ & 0 & 0 & 0 & 62 & & & & \\
\hline $1934-35$ & 0 & 0 & $T$ & 28 & 0.8 & 0 & 0 & 3.6 & & & & \\
\hline $1935-36$ & $T$ & 0.2 & $T$ & 3.2 & 5.4 & 0 & 0 & 8.8 & & & & \\
\hline $1936-37$ & 0 & 0 & 0.3 & 125 & 4.2 & $T$ & 0 & 17.0 & & & & \\
\hline $1937-38$ & 0 & $T$ & 0.2 & $T$ & 6.2 & 0 & 0 & 0.4 & & & & \\
\hline $1938-39$ & 0 & 0 & 0.2 & 0.5 & 1.8 & 0 & 0 & 2.5 & & & & \\
\hline $1939-40$ & 0 & 0 & 0 & 7.1 & 2.0 & 0 & 0 & 9.1 & & & & \\
\hline $1940-41$ & 0 & 82 & 0 & 1.5 & $T$ & 0 & 0 & 9.7 & & & & \\
\hline $191-42$ & 0 & 1.0 & 0 & 3.0 & 1.0 & 0 & 0 & 5.0 & & & & \\
\hline $192-43$ & 0 & 4.0 & 8.5 & 6.0 & 0.5 & 0 & 0 & 19.0 & & & & \\
\hline $1943-44$ & 0 & 0 & 0.7 & 3.3 & 04 & 0 & 0 & 4.4 & & & & \\
\hline $1044-45$ & - & $\cdots$ & $\cdots$ & --- & $\cdots$ & - & - & --- & NOV 29 & & FEB 18 & \\
\hline $1945-46$ & - & $\cdots$ & $\cdots$ & $\ldots$ & $\cdots$ & - & - & $\ldots$ & NON 6 & & FEB 5 & \\
\hline $196-47$ & $T$ & 7.2 & 0.5 & 3.3 & $\mathrm{~T}$ & $T$ & 0 & 11.0 & NON 17 & 0.2 & JAN 31 & 22 \\
\hline $1997-48$ & 0 & $T$ & 3.0 & 26 & 5.5 & 0.1 & $T$ & 11.2 & DEC 3 & 0.1 & MAR 9 & 0.1 \\
\hline $1948-49$ & 0 & 1.7 & 8.1 & 1.8 & 6.9 & $T$ & 0 & 18.5 & NOV 18 & 1.7 & MAR 15 & I(2) \\
\hline $1999-50$ & $\mathrm{I}$ & 0 & 0.7 & 3.4 & 3.1 & 1.5 & $\mathrm{~T}$ & 28.7 & DEC 16 & 0.2 & MAR 13 & 0.3 \\
\hline $1950-5]$ & 0 & 0.8 & 2.9 & 5.3 & 5.3 & 4.2 & 0 & 18.5 & NOV 30 & 0.8 & MAR 12 & 1.7 \\
\hline $1951-52$ & 0 & 0.5 & 4.4 & 7.5 & 3.1 & $\bar{T}$ & 0 & 15.5 & NON 25 & 0.5 & FEB 19 & 3.0 \\
\hline $1952-53$ & 0 & $T$ & 3.1 & 27 & 0 & T & 0 & 5.8 & DEC I & 0.2 & JAN 2 & 27 \\
\hline $1953-54$ & 0 & 0 & 1.0 & 14.3 & 1.6 & $T$ & 0 & 16.9 & DEC 8 & 1.0 & & 1.6 \\
\hline $1954-55$ & 0 & 0 & 1.8 & 6.0 & 2.4 & 0.7 & $\mathrm{~T}$ & 10.9 & $\mathrm{DEC} 4$ & 1.8 & MAR 25 & 0.7 \\
\hline $1955-56$ & 0 & $\underline{127}$ & 13.4 & 10.2 & 2.2 & $T$ & 0 & 38.5 & NOV 2 & 0.2 & FEB $\boldsymbol{Z}$ & a. \\
\hline $1956-57$ & $T$ & $\overline{0.1}$ & 2.5 & 7.9 & 1.4 & 4.0 & $\mathrm{~T}$ & 15.9 & NOV 18 & & MAR & 1.7 \\
\hline $1957-58$ & 0.3 & 0 & $T$ & $T$ & 0 & $T$ & 0 & Q3 & ○ा 22 & $a_{3}$ & & $t$ \\
\hline $1958-59$ & 0 & $\mathrm{~T}$ & 0.9 & 4.5 & 127 & 0 & 0 & $\overline{181}$ & NON 14 & $T(2)$ & FEB 19 & 1.2 \\
\hline $1959-60$ & 0 & 0.3 & 1.0 & 5.9 & $\mathrm{~T}$ & 15 & 0 & 8.7 & NOV 14 & 0.1 & MAR 5 & 1.5 \\
\hline $1960-61$ & 0 & 0 & 3.3 & 1.9 & 0 & 16 & 0 & 6.8 & DEC 10 & a.l & MAR 5 & 1.6 \\
\hline $1961-62$ & 0 & 0.5 & a.] & 0.4 & 24 & a9 & 0 & 10.3 & NON 23 & a.1 & MAR 9 & al \\
\hline $1962-63$ & 0 & T & $T$ & 7.1 & 0.6 & 0 & 0 & 7.7 & JAN 30 & 0.1 & & 6.1 \\
\hline $1963-64$ & 0 & $T$ & 6.4 & 29 & $\mathrm{~T}$ & $\mathrm{~T}$ & $\mathrm{~T}$ & 9.3 & DEC 8 & 4.3 & & 1.5 \\
\hline $1964-65$ & 0 & $a_{1}$ & $\underline{19.1}$ & 6.6 & $T$ & $T$ & 0 & 25.8 & NON 22 & $T(2)$ & MAR 26 & $T(2)$ \\
\hline $1965-66$ & 0 & $T$ & 69 & 26 & $T$ & T & 0 & 9.5 & DEC 23 & 0.6 & MAR 21 & I(2) \\
\hline $1966-67$ & 0 & 0.4 & 2.8 & al & 0 & 0 & 0 & 3.3 & & $a$ & & Q.1 \\
\hline $1967-68$ & 0 & 0 & 5.7 & 4.5 & 0.3 & 0 & $\mathrm{~T}$ & 10.5 & & & & 0.3 \\
\hline $1968-69$ & 0 & $\mathrm{~T}$ & 9.7 & 15.9 & 2.1 & 0 & 0 & 27.7 & DEC I9 & al & FEB $\mathbf{Z}$ & T(2) \\
\hline $1969-70$ & 0 & $T$ & 2.7 & 0.6 & 1 & 0.2 & 0 & 9.5 & & $T(2)$ & MAR 1 & 0.2 \\
\hline $1970-71$ & 0 & 0.5 & 4.4 & 2.0 & $T$. & 0.6 & 0 & 7.5 & NOV 30 & 0.5 & MAR 22 & $T$ \\
\hline & 0.6 & 1 & 8.1 & 4.9 & 1.4 & 0.1 & T & 15.1 & & 0. & & $\mathrm{~T}$ \\
\hline $1972-73$ & 0 & $\mathrm{~T}$ & 7.2 & 4.3 & 1.7 & 0 & 0 & 13.2 & DEC 3 & 1. & FEB 10 & 1.7 \\
\hline $1973-74$ & 1.5 & 6.6 & 7.5 & 3.9 & 0 & $T$ & 0 & & & 1. & JAN 12 & 2.3 \\
\hline 1974.75 & 0 & 0 & 0.7 & 2.5 & 12.1 & $\mathrm{~T}$ & $\mathrm{~T}$ & 15.3 & $\mathrm{DEC} 12$ & 0.3 & FEB 9 & 1.7 \\
\hline $1975-76$ & 0 & & & & & $T$ & & 11.7 & & 0.6 & & 0.2 \\
\hline $1976-77$ & 0 & 0 & 0.2 & 2.9 & I & $\mathrm{T}$ & 0 & 3.1 & DEC 23 & 0.2 & JAN 31 & 0.2 \\
\hline $1977-78$ & 0 & 2.1 & 3.4 & 2.9 & 0.9 & $T$ & 0 & 9.3 & & 0.1 & FEB 26 & 0.1 \\
\hline $1978-79$ & 0 & 10.1 & 1.4 & 10.3 & 0.5 & 0.1 & 0 & 22.6 & NOV 18 & 9.1 & MAR 3 & 0.1 \\
\hline $1979-80$ & 0 & 5.6 & 7.3 & 8.7 & 4.5 & 0.3 & 0 & 26.2 & NOV 22 & 1.4 & M.R 4 & 0.3 \\
\hline AVG. & $\mathrm{T}$ & 1.4 & 3.9 & 5.3 & 2.3 & 0.3 & T & 13.2 & NOV 27 & & FEB 21 & \\
\hline & $\mathbf{T}$ & 1.4 & 4.6 & 5.4 & 1.8 & 0.5 & $\mathrm{~T}$ & 13.7 & & & & \\
\hline
\end{tabular}

THE HICHEST MONTHLY AND THE HIGHEST AND LOWEST SEASONAL TOTALS ARE UNDERS CORED (1) AMOUNTING TO O. OI INCH OR MORE IMELTEDI OR 0.1 INCH (UNMELTED (2) MELTED AS IT FELL

(I) DENOTES A TRACE $(<0.05$ INCHI

(*) THE FIRST SNOWFALL WAS THE ONLY SNOWFALL 
TABLE 14. Miscellaneous Snowfall Statistics, 1946 Through 1980

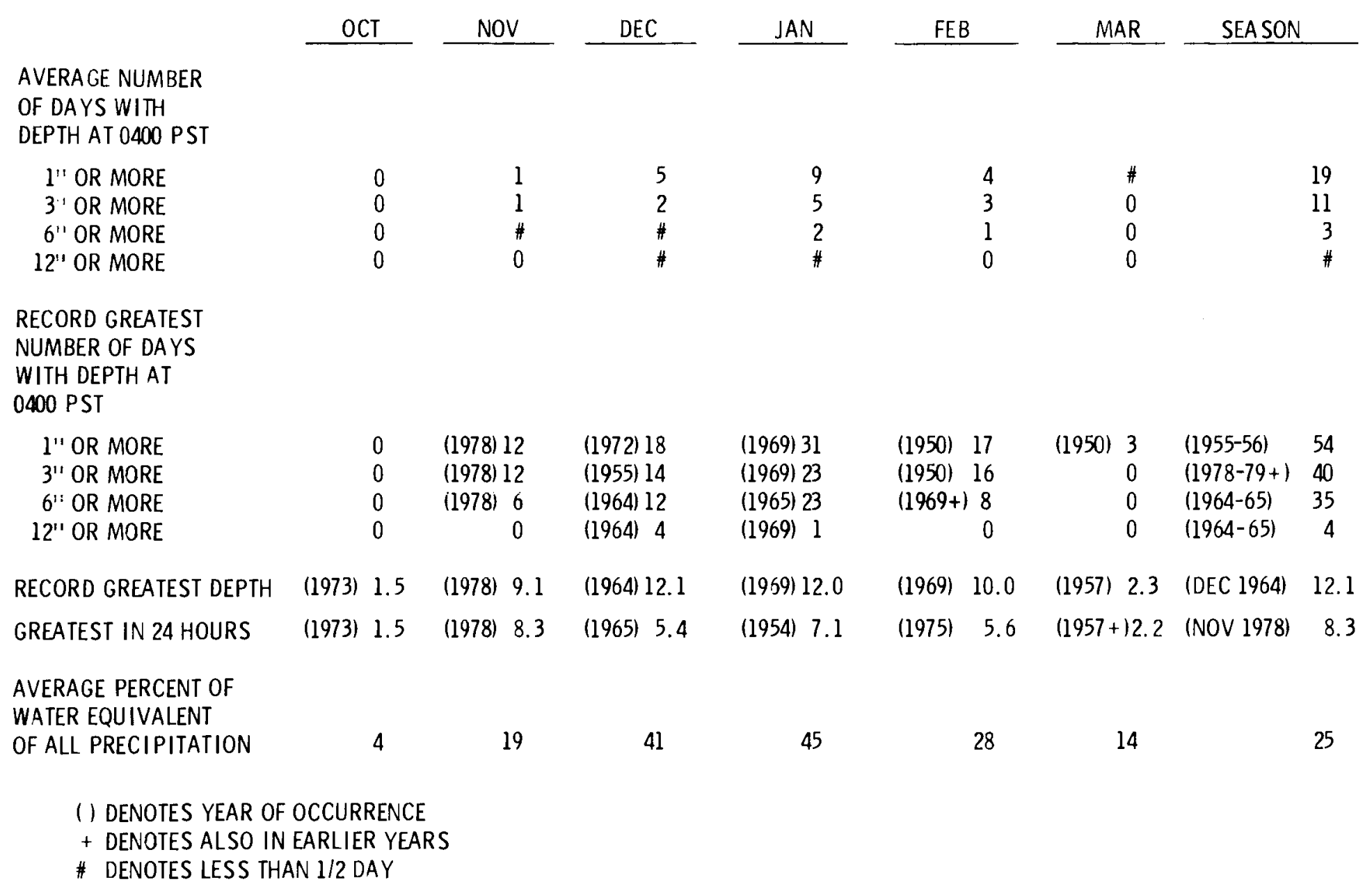


A record snow depth of 24.5 inches occurred in February 1916. Since that date, the greatest depth has been 12.1 inches, recorded in December 1964. Figure 18 shows that in 10 of 35 winters, the maximum snow depth on the ground has exceeded 6 inches. The number of days with 6 inches or more of snow on the ground has varied from 35 in the 19641965 season to none as recently as the 1977-1978 winter.

\section{MOVING AVERAGES}

Figure 17 shows the 10 - and 15 -year moving averages of total annual precipitation. There was an upward trend in the 10-year moving average from 1936 to 1951, then a slow fall through 1970. The last 10 years show a slow rise. However, the 15-year moving average continued a very slow fall through 1976.

The 15-year moving average of seasonal snowfall (Figure 19) fell steadily from the 1927-1928 season through 1947-1948, then rose to a new high in 1956-1957. From the 1956-1957 high there was a slow fall to a secondary low in 1971-1972 followed by a slow rising trend.

\section{HMS VERSUS RICHLAND}

Table 15 compares the precipitation records of Richland and the HMS. Richland is on the Columbia River about 25 miles southeast of the HMS and is about 375 feet lower than the HMS. During the period 1946 through 1980 the average annual precipitation was higher in Richland than at the HMS with December and February being significantly higher. Because of the elevation difference, the HMS received a higher annual snowfal1 (13.7 inches seasonal average compared to 11.2 inches for Richland); however, the snowfall extremes are greater in Richland. During the 1955-1956 season Richland received a seasonal record of 41.6 inches compared to 38.5 inches for the HMS. Also, the maximum depth of snow of the ground in Richland was 14.0 inches (January 10, 1980 ) compared to 12.1 inches (December 27, 1964) at the HMS. Richland's record 24-hour snowfall of 12.5 inches on January 8-9, 1980, exceeds the HMS record of 8.3 inches on November 18-19, 1978. During the 35 years of record, less than half of the extremes at the HMS and Richland have occurred in the same years. 
PROBABILITY (\%) THAT GREATEST DEPTH WILL EXCEED A GIVEN AMOUNT

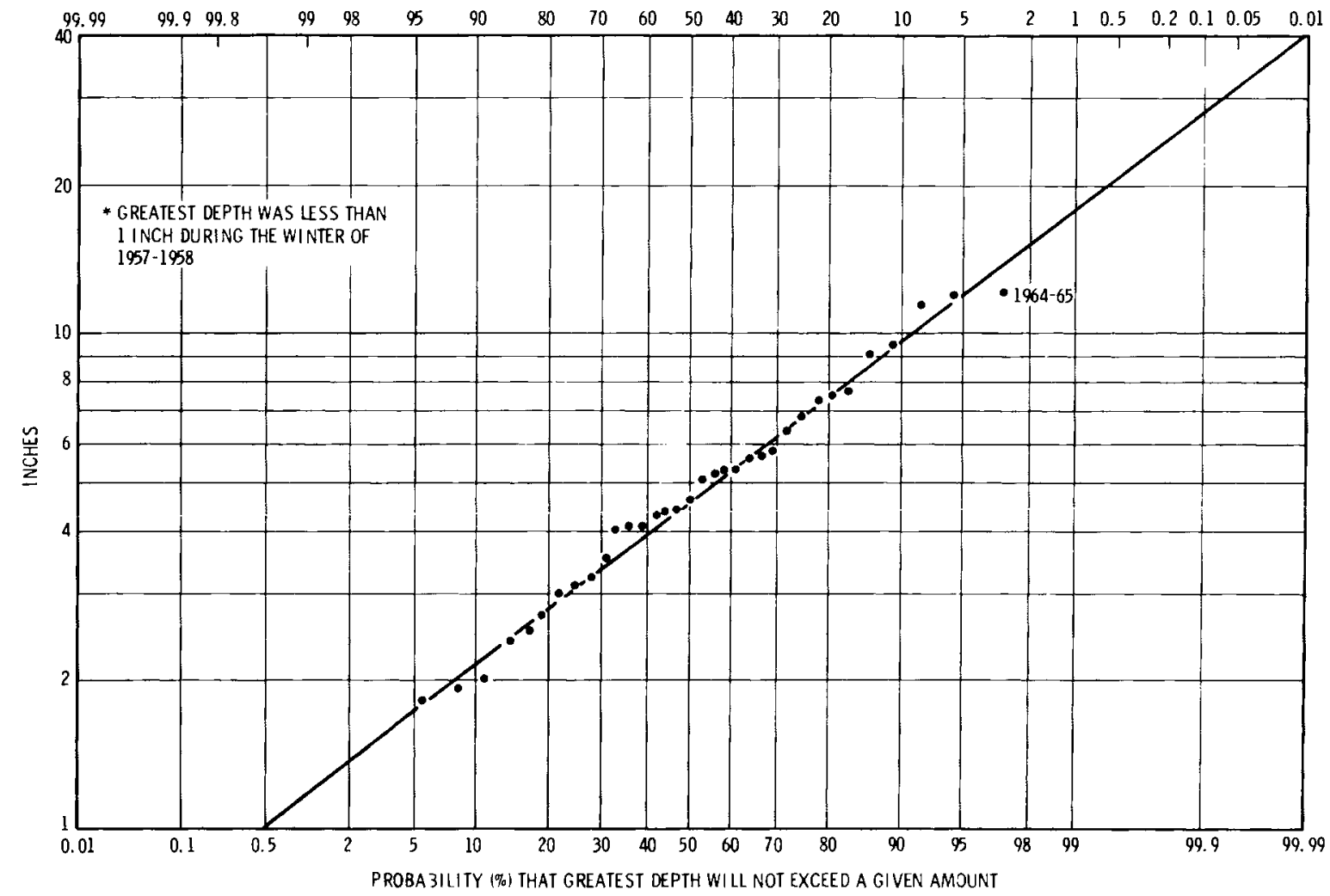

FIGURE 18. Greatest Depth of Snow on Ground During Winters of Record at Hanford 1946-47 Through 1980-81* 


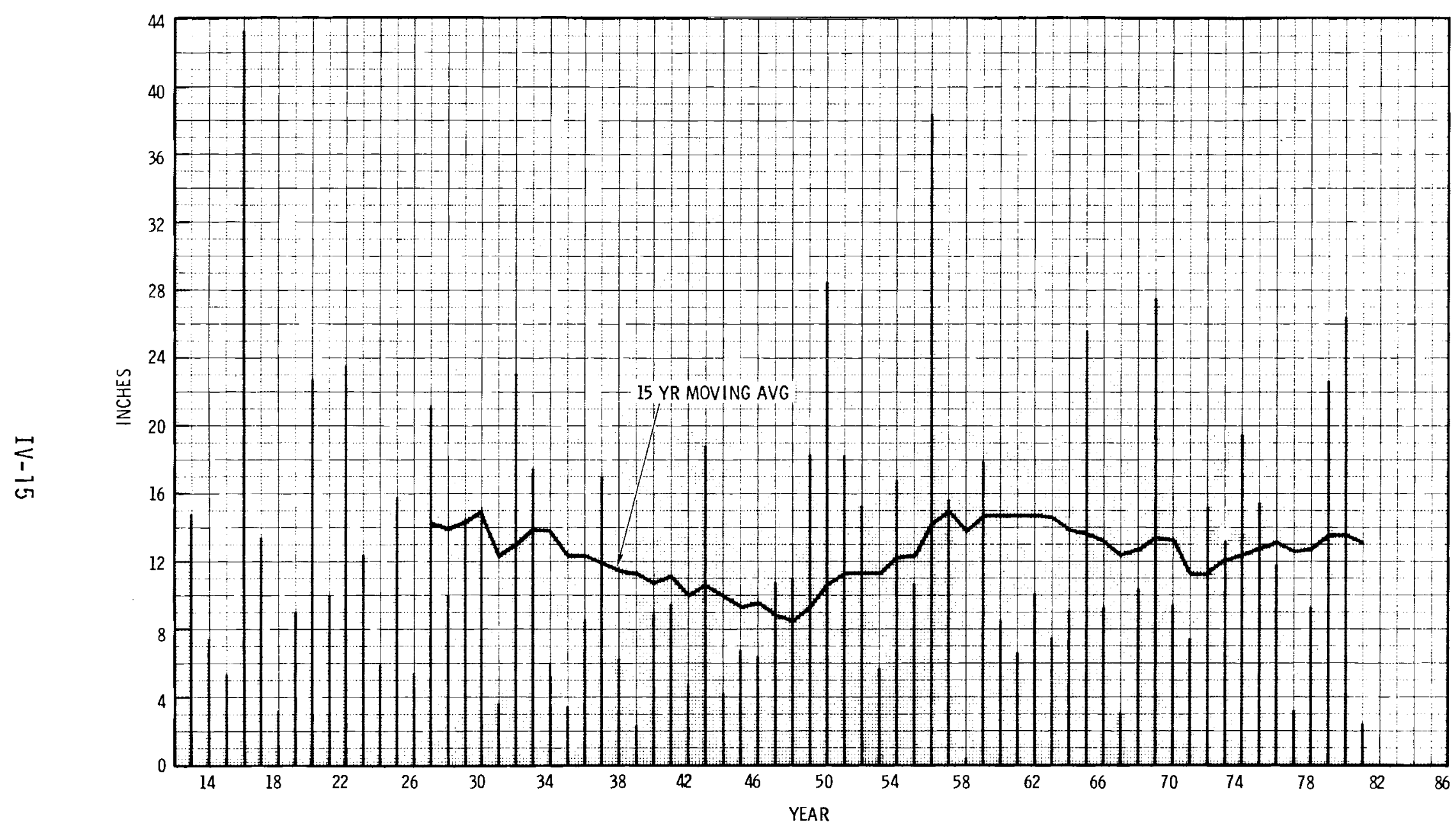

FIGURE 19. Total Seasonal Snowfall and 15-Year Moving Averages for Period 1913 Through 1981 
TABLE 15. Monthly and Annual Averages and Extremes of Precipitation for HMS Versus Richland, July 1946 Through December 1980

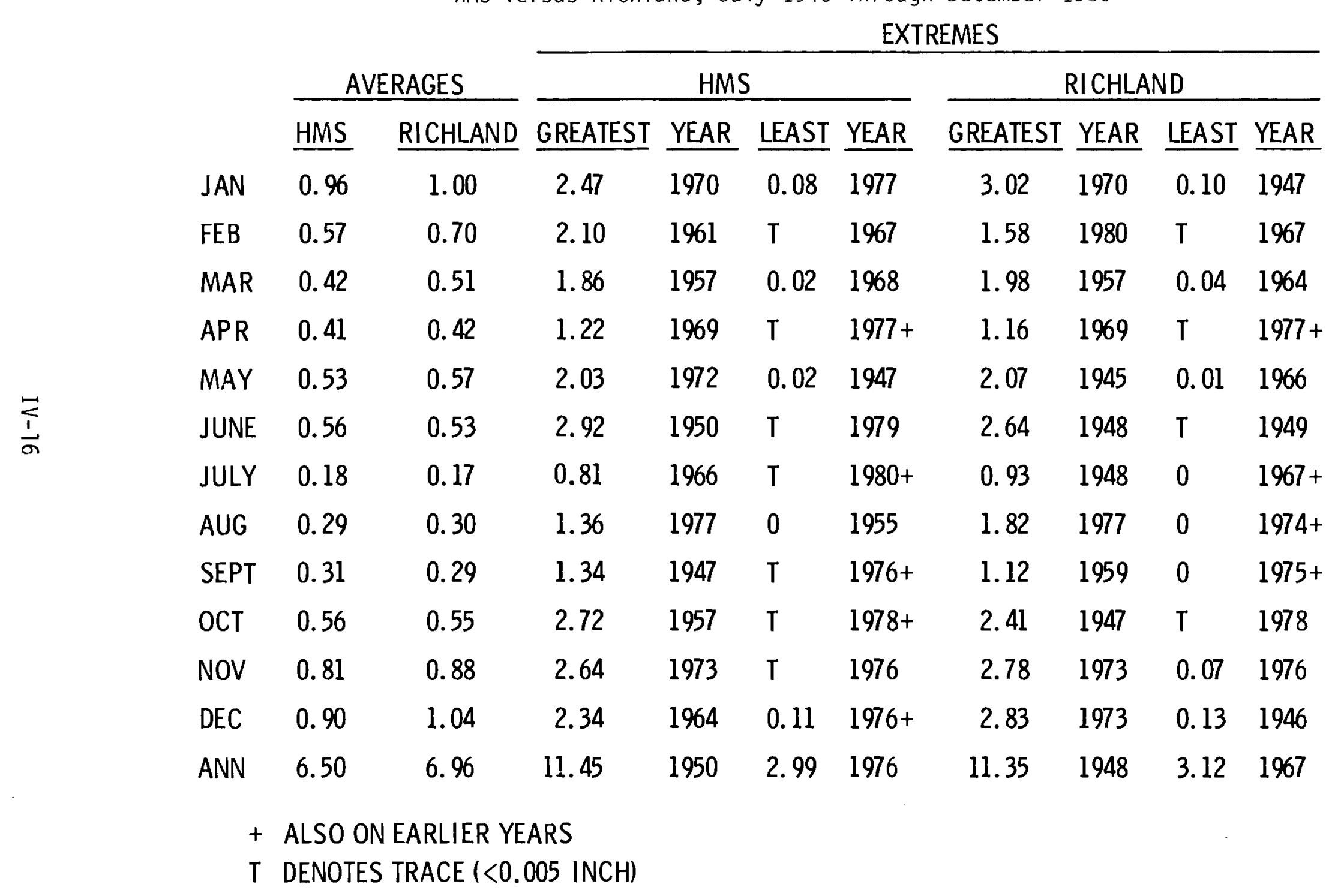


EXTREME ANNUAL PRECIPITATION PROBABILITY

Refer to Section XI, page 10.

$\dot{0}$ 

v. 50-FOOT WIND 


\section{50-FOOT WIND}

Wind speeds and directions are determined and recorded at the end of each hour. The speed is a visual average of speeds recorded on a strip chart for 1 hour. The direction is that which the observer considers to be the most persistent for the same time interval. When there is little or no movement of the direction pen for 1 hour and the speed is zero, the direction will be CM (calm) and the speed 0 . If the wind direction varies so that no direction can be considered to be representative, $V$ (variable) is recorded. In some of the wind tables, the wind directions, rounded to whole degrees, will be number-coded in direction classes as follows:

1. $\operatorname{NNE}\left(12^{\circ}-33^{\circ}\right)$

2. $N E\left(34^{\circ}-56^{\circ}\right)$

3. $\operatorname{ENE}\left(57^{\circ}-78^{\circ}\right)$

4. E $\left(79^{\circ}-101^{\circ}\right)$

5. $\operatorname{ESE}\left(102^{\circ}-123^{\circ}\right)$

6. $\operatorname{SE}\left(124^{\circ}-146^{\circ}\right)$
7. $\operatorname{SSE}\left(147^{\circ}-168^{\circ}\right)$

8. S $\left(169^{\circ}-191^{\circ}\right)$

9. $\operatorname{SSW}\left(192^{\circ}-213^{\circ}\right)$

10. SW $\left(214^{\circ}-236^{\circ}\right)$

11. WSW $\left(237^{\circ}-258^{\circ}\right)$

12. $W\left(259^{\circ}-281^{\circ}\right)$
13. WNW $\left(282^{\circ}-303^{\circ}\right)$

14. NW $\left(304^{\circ}-326^{\circ}\right)$

15. NNW $\left(327^{\circ}-348^{\circ}\right)$

16. $N\left(349^{\circ}-11^{\circ}\right)$

17. $V$ (variable)

18. CM (calm)

MONTHLY AND ANNUAL PREVAILING WIND DIRECTIONS, AVERAGE SPEEDS, AND PEAK GUSTS

The prevailing direction is either WNW or NW in every month of the year. The highest monthly average wind speeds occur in June, and the lowest in November and December (see Table 16). There is a greater variability in monthly average wind speeds during winter months than during the summer months. January's highest average is more than 3 times higher than the lowest average, while July's highest is only 1.4 times higher than the lowest. While the wind from $259^{\circ}$ to $326^{\circ}$ (W, WNW, NW) occurs $39 \%$ of the time compared to $18 \%$ from $192^{\circ}$ to $281^{\circ}$ (SSW, SW, WSW), the latter sector accounts for most hourly averages above $31 \mathrm{mph}$ ( $90 \%$ compared to $10 \%$ ).

\section{JUNE WIND SPEEDS VERSUS DECEMBER WIND SPEEDS}

The average wind speed for June is higher than that in December (Table 16); however, December has had 6 times as many hourly average 
TABLE 16. Monthly and Annual Prevailing Wind Directions, Average

Speeds and Peak Gusts at 50 Feet: 1945 Through 1980

PEAK GUSTS

\begin{tabular}{|c|c|c|c|c|c|c|c|c|c|}
\hline MONTH & $\begin{array}{l}\text { PREV. } \\
\text { DIR. }\end{array}$ & $\begin{array}{c}\text { AVG } \\
\text { SPEEED }\end{array}$ & $\begin{array}{c}\text { HIGHEST } \\
\text { AVG } \\
\end{array}$ & YEAR & $\begin{array}{l}\text { LOWEST } \\
\text { AVG }\end{array}$ & YEAR & SPEED & DIR. & YEAR \\
\hline JAN & NW & 6.4 & 10.3 & 1972 & 3.1 & 1955 & 80 & SW & 1972 \\
\hline FEB & NW & 7.1 & 10.8 & 1976 & 4.6 & 1963 & 65 & SW & 1971 \\
\hline M.AR & WNW & 8.5 & 10.7 & $1977+$ & 5.9 & 1958 & 70 & SW & 1956 \\
\hline APR & WNW & 9.0 & 11.1 & $1972+$ & 7.4 & 1958 & 73 & SSW & 1972 \\
\hline MAY & WNW & 8.9 & 10.5 & $1965+$ & 5.8 & 1957 & 71 & SSW & 1948 \\
\hline JUNE & WNW & 9.2 & 10.7 & 1949 & 7.7 & $1950+$ & 72 & SW & 1957 \\
\hline JULY & WNW & 8.7 & 9.6 & 1963 & 6.8 & 1955 & 69 & WSW & 1979 \\
\hline AUG & WNW & 8.0 & 9.1 & 1946 & 6.0 & 1956 & 66 & SW & 1961 \\
\hline SEPT & WNW & 7.5 & 9.2 & 1961 & 5.4 & 1957 & 65 & SSW & 1953 \\
\hline ОСТ & WNW & 6.6 & 9.1 & 1946 & 4.4 & 1952 & 63 & SSW & 1950 \\
\hline NOV & NW & 6.1 & 8.2 & 1977 & 2.9 & 1956 & 64 & SSW & 1949 \\
\hline DEC & NW & 6.1 & 8.3 & 1968 & 3.9 & $1963+$ & 71 & SW & 1955 \\
\hline YEAR & WNW & 7.7 & 8.3 & $1968+$ & 6.3 & 1957 & 80 & SW & 1972 \\
\hline
\end{tabular}


wind speeds in excess of $31 \mathrm{mph}$ (55 for December versus 9 for June during the 1955 through 1980 period of record). There have been 10 cases of wind speeds in the 39 through 46 mph class during December, and 1 in excess of $46 \mathrm{mph}$ ( $51 \mathrm{mph}$ ), but no such cases in June.

December has the highest frequency of low wind speeds (Table 17). Wind speeds in the 1 to $3 \mathrm{mph}$ class occur 33\% of the time in December compared to $11 \%$ in June. The frequency of calms (zero speed for 1 hour) during December is $7 \%$ versus $1 \%$ for June.

During the period 1949 through 1980, 323 December days had peak winds no greater than $12 \mathrm{mph}$ compared to only 6 June days.

The hourly average wind speeds for June and December are presented in Figure 20. Note that there is much less diurnal range in December than in June.

The prevailing direction in December is NW and in June WNW. There is a larger diurnal range in wind from the WNW and NW in June than there is in December (Table 18 and Figure 21).

SEASONAL AND DIURNAL VARIATION IN SPEED

July has the highest diurnal range of wind speeds (from 5.5 to $12.9 \mathrm{mph}$ ). December has the lowest diurnal range (from 5.6 to $6.7 \mathrm{mph}$ ). Table 19 shows the diurnal range in wind speeds for all months.

\section{SEASONAL AND DIURNAL VARIATION IN DIRECTION}

The wind at the HMS is from the WNW and NW $32 \%$ of the time. The months of June and July have the highest percentage of winds from the WNW and NW (38 and 37\%, respectively). October has the lowest percentage (25) from those directions (Table 18). Monthly wind roses for the HMS are presented in Figure 22.

Table 20 shows the monthly and annual diurnal variations in the percentage of wind directions from the SSW, SW, and WSW. Most hourly observations of wind speeds exceeding $31 \mathrm{mph}$ and the most cases of blowing dust occur with winds from these directions. 
TABLE 17. Percent Frequency of Monthly and Annual Wind Direction and Speed at 50-Foot Elevation, 1955 Through 1980

PERCENT FREGUENCY CF MCNTHLY AND ANNUAL HIAD DIRECTION AT 50-FCOT-1955-198C

\begin{tabular}{|c|c|c|c|c|c|c|c|c|c|c|c|c|c|}
\hline DIRECTION & JAN & $F E B$ & MAR & $A P R$ & MAY & JUN & JUL & $A \cup G$ & SEP & $O C \mathrm{~T}$ & NCV & LEC & ANNUAL \\
\hline 1 & 3.6 & 4.1 & 4.2 & 3.3 & 3.3 & 3.2 & 4.1 & 3.7 & 5.1 & 3.9 & 3.5 & 2.8 & 3.7 \\
\hline 2 & 2.7 & 3.3 & 3.2 & 3.2 & 3.3 & 3.3 & 3.6 & 3.0 & 4.2 & 3.3 & 2.7 & 2.2 & 3.2 \\
\hline 3 & $2 . \mathrm{C}$ & 1.9 & 1.8 & 2.1 & 2.2 & 2.0 & 2.2 & 2.2 & $2 \cdot 3$ & 2.4 & 2.4 & 2.1 & 2.1 \\
\hline 4 & $2 . t$ & 2.1 & $i \cdot c$ & 2.4 & 2.4 & 2.3 & 2.8 & 2.7 & 3.2 & 3.0 & 2.8 & 2.4 & 2.6 \\
\hline 5 & 2.5 & 2.2 & 2.4 & 2.0 & 2.2 & 2.3 & 2.5 & 2.7 & 2.9 & 3.3 & 3.2 & 2.7 & 2.6 \\
\hline 6 & 4.2 & 3.4 & 3.8 & 2.9 & 2.9 & 2.7 & 2.9 & 3.2 & 3.5 & 4.8 & 4.4 & 3.9 & 3.6 \\
\hline 7 & 3.1 & 2.7 & 3.0 & 2.6 & 2.4 & 2.2 & 2.0 & 2.5 & 2.7 & 3.4 & 3.4 & 3.3 & $2 . \varepsilon$ \\
\hline 8 & 3.4 & 3.3 & 3.9 & 3.0 & 2.8 & 2.7 & 2.6 & 2.8 & 2.9 & 3.8 & 4.2 & 3.7 & 3.2 \\
\hline 9 & 4.5 & 4.3 & 5.2 & 4.2 & 3.3 & 3.2 & 2.6 & 3.1 & 3.3 & 4.1 & 4.8 & 4.7 & 4.0 \\
\hline 10 & 6.8 & 7.5 & 9.4 & 8.6 & 6.3 & 6.2 & 5.6 & 6.1 & 5.6 & 6.4 & 6.6 & 6.9 & 0.8 \\
\hline 11 & 6.2 & 7.7 & 10.3 & 11.4 & 10.2 & 8.7 & 8.2 & 8.6 & 9.0 & 8.4 & 6.7 & 7.0 & 8.5 \\
\hline 12 & 6.5 & 9.2 & 10.3 & 12.6 & 12.3 & 11.5 & 10.7 & 11.7 & 11.9 & 11.2 & 8.4 & 7.8 & 10.3 \\
\hline 13 & 14.5 & 15.1 & 14.7 & $17 . \mathrm{C}$ & 18.3 & 19.3 & 18.9 & 17.8 & 14.5 & 12.9 & 12.9 & 13.6 & 15.8 \\
\hline 14 & 18.1 & 17.2 & 13.1 & 13.4 & 16.4 & 18.8 & 17.9 & 16.2 & 14.0 & 12.5 & 15.1 & 17.1 & 15.8 \\
\hline 15 & 6.8 & 6.0 & 5.1 & 3.8 & 3.9 & 4.0 & 4.3 & 4.2 & 5.2 & 5.9 & 6.9 & 6.5 & 5.2 \\
\hline 16 & 4.8 & 5.2 & 4.8 & 4.4 & 4.0 & 3.7 & 4.6 & 4.7 & 5.8 & 5.3 & 4.9 & 4.7 & 4.7 \\
\hline 17 & 5.4 & 3.2 & 1.0 & .7 & .7 & .0 & .4 & .7 & 1.4 & 3.1 & 5.5 & 6.9 & 2.5 \\
\hline 16 & 1.5 & 1.6 & 1.8 & 2.2 & 3.2 & 3.4 & 4.0 & 4.0 & 2.7 & 2.0 & 1.6 & 1.9 & 2.5 \\
\hline & $100 . c$ & 100.0 & 100.0 & 100.0 & 100.0 & 100.0 & 100.0 & 100.0 & 100.0 & 100.0 & 100.0 & 100.0 & 100.0 \\
\hline
\end{tabular}

PERCEAT frequency jf monthly and annual wind SPEEd at 50-F001 - 1955-1980

\begin{tabular}{|c|c|c|c|c|c|c|c|c|c|c|c|c|c|}
\hline $\begin{array}{l}\text { SPEEL } \\
\text { CLASS }\end{array}$ & JAN & $F \in B$ & MAK & $\triangle P R$ & MAY & JUN & JUL & AUG & SEP & $\mathrm{OCT}$ & $N \in \mathbb{V}$ & vec & $\triangle N N U A L$ \\
\hline 0 & 5.4 & 3.2 & 1.0 & .7 & .7 & .6 & .4 & .8 & 1.4 & 3.1 & 5.5 & 6.8 & 2.5 \\
\hline $1-3$ & 31.9 & 26.8 & 18.4 & 14.8 & 14.2 & 11.0 & 13.2 & 16.9 & 20.7 & 28.5 & 32.9 & 32.9 & 21.8 \\
\hline $4-7$ & 31.4 & 31.4 & 32.7 & 31.9 & 32.9 & 34.2 & 37.8 & 38.6 & 37.4 & 35.2 & 32.0 & $<9.9$ & 33.9 \\
\hline $8-12$ & 19.6 & 23.9 & 26.5 & 27.8 & 29.0 & 28.7 & 27.9 & 26.3 & 25.4 & 21.0 & 18.9 & 19.0 & 24.6 \\
\hline $13-16$ & 7.3 & 9.4 & 13.7 & 15.9 & 16.1 & 17.5 & 14.3 & 12.5 & 10.8 & 7.9 & 6.9 & 7.1 & 11.6 \\
\hline $19-24$ & 2.8 & 3.3 & 5.5 & 0.7 & 6.0 & 6.7 & 5.4 & 4.2 & 3.6 & 2.7 & 2.7 & 2.9 & 4.4 \\
\hline$<5-31$ & 1.1 & 1.5 & 1.9 & 2.0 & 1.1 & 1.3 & .9 & .7 & .7 & .7 & .9 & 1.1 & 1.2 \\
\hline $32-3 E$ & .3 & .4 & .4 & .2 & .1 & .0 & .0 & .0 & .0 & .1 & .2 &. $\bar{z}$ & .2 \\
\hline $39-46$ & .1 & .1 & .0 & .0 & .0 & .0 & .0 & .0 & .0 & .0 & .0 & .1 & .0 \\
\hline \multirow[t]{2}{*}{ GI.46 } &. $\mathrm{C}$ & .0 & .0 & .0 & .0 & .0 & .0 & .0 &.$c$ & .0 & .0 & .0 & .0 \\
\hline & $100 . c$ & 100.0 & 100.0 & 100.0 & 100.0 & 100.0 & 100.0 & 100.0 & 100.0 & 100.0 & 100.0 & 100.0 & 100.0 \\
\hline
\end{tabular}




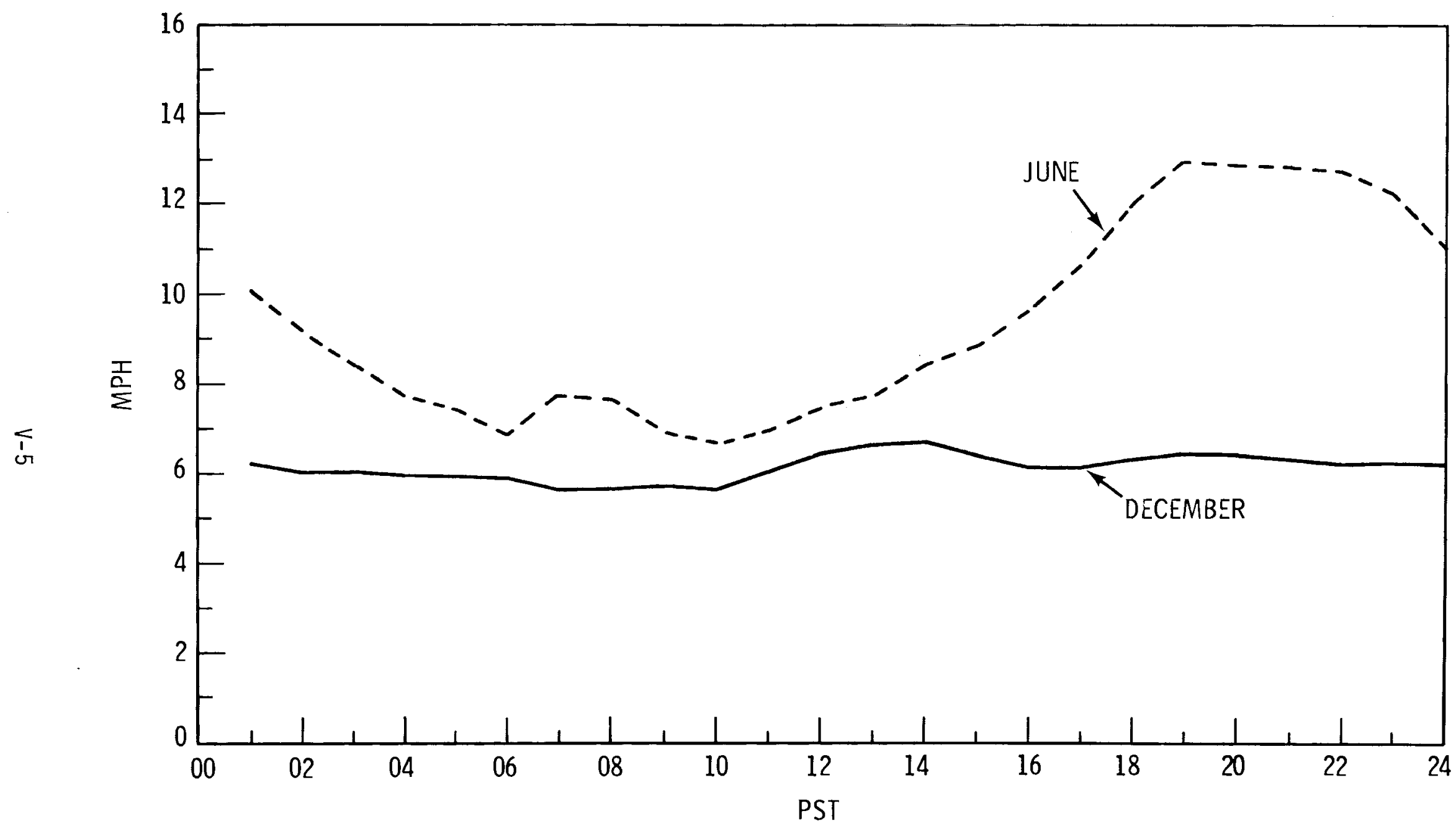

- FIGURE 20. Hourly Average 50-Foot Wind Speeds: June Versus December, 1955 Through 1980 
TABLE 18. Monthly and Annual Diurnal Variation in the Percentage of Wind From WNW and NW at 50-Foot Leve1 1955 Through 1980

\begin{tabular}{|c|c|c|c|c|c|c|c|c|c|c|}
\hline MAR & APR & MAY & JLN & JuL & AUC & SEP & $\mathrm{CGS}$ & NOV & $D E C$ & ANAUAL \\
\hline $\begin{array}{l}38 . \hat{3} \\
34 . \hat{z}\end{array}$ & $\begin{array}{l}39.4 \\
36.0\end{array}$ & $\begin{array}{l}47.8 \\
43.1\end{array}$ & $\begin{array}{l}57.6 \\
53.3\end{array}$ & $\begin{array}{l}02.2 \\
59.1\end{array}$ & $\begin{array}{l}55.0 \\
50.7\end{array}$ & $\begin{array}{l}45.0 \\
40.9\end{array}$ & $\begin{array}{l}34.1 \\
31.9\end{array}$ & $\begin{array}{r}32.1 \\
33.1\end{array}$ & $\begin{array}{l}33.3 \\
31.5\end{array}$ & $\begin{array}{l}42.9 \\
40.5\end{array}$ \\
\hline $35 . \overline{6}$ & 34.5 & $4 i .0$ & 48.1 & 50.9 & 44.7 & 37.2 & 31.1 & $3 c .4$ & 30.3 & 37.7 \\
\hline 35.1 & 33.1 & 37.5 & 40.9 & 44.2 & 39.5 & 35.0 & 29.0 & 30.4 & 33.3 & 35.7 \\
\hline 33.0 & 31.5 & 37.5 & 36.5 & 43.2 & 36.6 & 33.8 & ¿ 9.3 & 29.6 & 32.1 & 34.8 \\
\hline 32.6 & 32.2 & 35.7 & 40.6 & 45.5 & 35.2 & 33.3 & 29.2 & 28.6 & 31.0 & 34.5 \\
\hline 32.5 & 33.0 & 45.4 & $5 c .3$ & 54.1 & 47.6 & 31.4 & 29.3 & 29.7 & 31.3 & 38.0 \\
\hline 35.0 & 37.6 & 44.4 & 42.4 & $46 . \mathrm{C}$ & 46.3 & 37.1 & 29.3 & 28.6 & 30.9 & 37.3 \\
\hline $34 . \mathrm{C}$ & 34.6 & 33.0 & 29.2 & 25.8 & 30.0 & 27.6 & 29.9 & 28.4 & 31.0 & 31.3 \\
\hline 23.4 & 22.6 & 22.7 & 19.5 & 14.3 & 15.4 & 17.7 & 21.6 & 27.0 & 30.6 & 23.9 \\
\hline 19.3 & 19.1 & 14.1 & 16.0 & 9.4 & 12.4 & 13.6 & 10.4 & 24.7 & 30.6 & 26.1 \\
\hline 14.7 & 17.1 & 14.0 & 14.0 & $10 . \mathrm{C}$ & 10.4 & 10.9 & 13.8 & 21.0 & 26.9 & 17.2 \\
\hline 16.4 & 15.6 & 14.6 & 11.4 & 8.4 & 7.7 & 11.3 & 11.0 & 20.8 & 25.1 & 16.1 \\
\hline 15.7 & 15.1 & 16.0 & 15.8 & 9.3 & 8.7 & 11.5 & 11.5 & 19.0 & 25.4 & 10.0 \\
\hline 16.0 & 16.0 & 17.7 & 17.8 & $12 . \mathrm{C}$ & 12.4 & 13.1 & 14.0 & 19.9 & 26.2 & 17.6 \\
\hline 16.5 & 21.5 & 21.0 & 23.1 & 14.9 & 16.6 & 14.2 & 15.5 & 24.4 & 30.0 & 20.5 \\
\hline 21.3 & 26.4 & 27.8 & 27.8 & $<0.0$ & 21.6 & 17.8 & 22.5 & 28.2 & 31.2 & 25.3 \\
\hline 24.4 & 29.2 & 33.0 & 36.7 & 25.7 & 26.1 & 24.9 & 25.8 & 29.2 & 30.4 & 29.0 \\
\hline 27.5 & 33.8 & 40.6 & 42.7 & 35.7 & 34.2 & 29.6 & 27.7 & 29.9 & 31.8 & 33.4 \\
\hline 31.6 & 38.6 & 47.3 & 51.3 & 46.2 & 43.2 & 33.3 & 25.7 & 29.9 & 33.0 & 37.3 \\
\hline 30.0 & 41.2 & 49.5 & 57.6 & 50.5 & 51.1 & 37.7 & 27.4 & 32.4 & 34.3 & 40.5 \\
\hline 32.0 & 41.9 & 51.2 & $6 C .1$ & 61.8 & 56.0 & 40.8 & 31.6 & 30.9 & 31.6 & 42.3 \\
\hline 34.4 & 40.9 & 50.6 & 01.9 & 63.5 & 56.9 & 42.4 & 34.4 & 31.8 & 31.9 & 43.4 \\
\hline 35.4 & 38.8 & 48.0 & 60.5 & 63.4 & 56.2 & 45.7 & 35.7 & 32.7 & 32.2 & 43.3 \\
\hline 27.8 & 30.5 & 34.7 & 38.1 & 36.8 & 33.9 & 28.5 & 25.4 & 28.0 & 30.7 & 31.6 \\
\hline
\end{tabular}




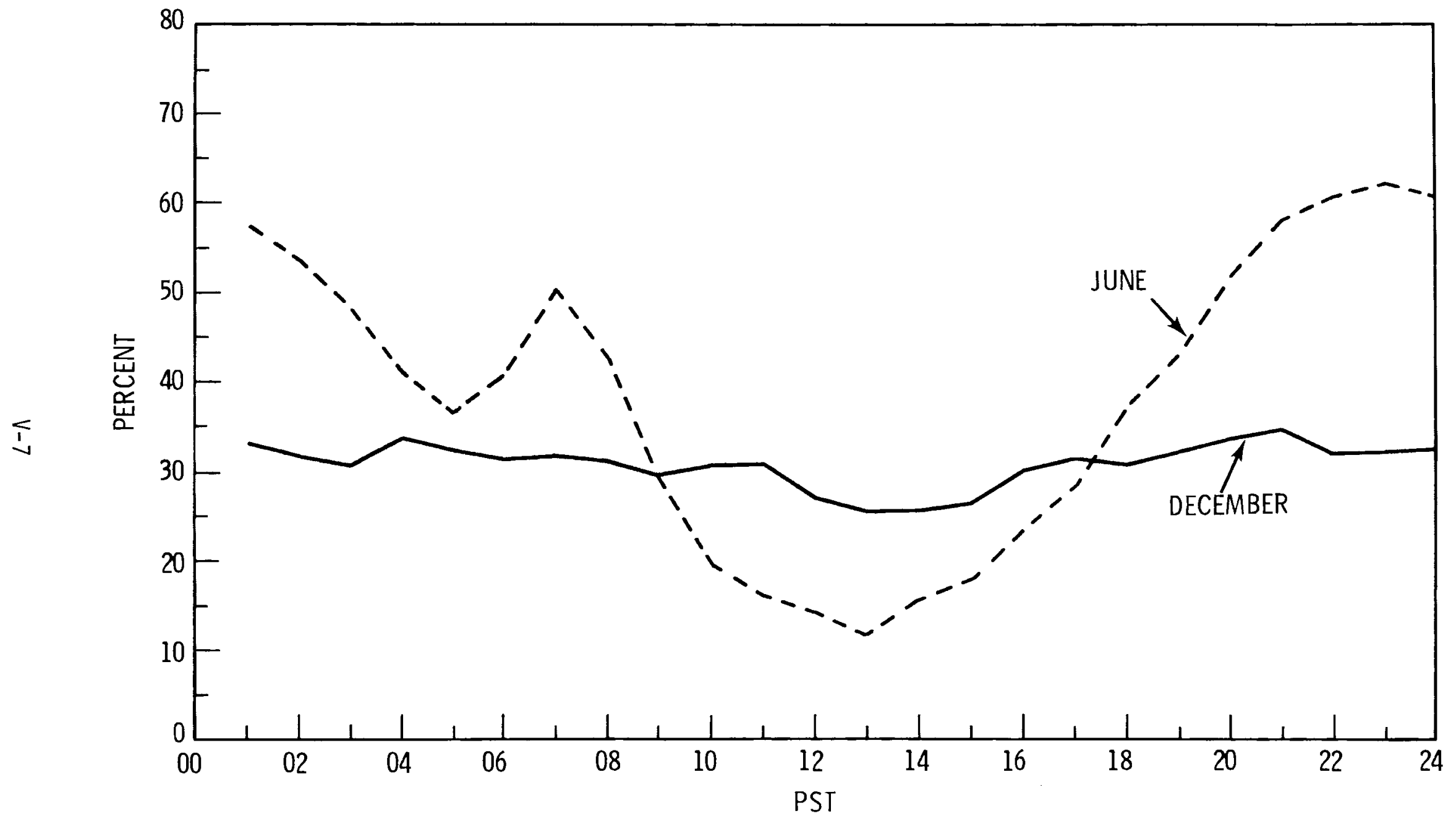

FIGURE 21. Percentage of 50-Foot Wind Direction From WNW and NW by Hour: June Versus December, 1955 Through 1980 
TABLE 19. Monthly and Annual Hourly Average Wind Speed at 50-Foot Level: 1955 Through 1980

$\begin{array}{ccc}\text { MAR } & \text { APR } & \text { MAY } \\ 8.1 & 8.9 & 9.1 \\ 8.0 & 8.6 & 8.6 \\ 7.8 & 8.2 & 8.1 \\ 7.4 & 7.7 & 7.7 \\ 7.3 & 7.3 & 7.4 \\ 7.1 & 7.0 & 6.8 \\ 6.5 & 6.7 & 7.2 \\ 6.8 & 7.7 & 7.5 \\ 7.6 & 8.4 & 7.1 \\ 8.1 & 8.2 & 6.9 \\ 8.5 & 8.4 & 7.1 \\ 8.9 & 8.7 & 7.6 \\ 9.3 & 9.2 & 8.0 \\ 9.8 & 9.6 & 8.5 \\ 10.1 & 10.1 & 9.0 \\ 10.2 & 10.4 & 9.6 \\ 10.2 & 11.0 & 10.3 \\ 9.6 & 11.2 & 10.9 \\ 9.5 & 12.9 & 11.2 \\ 9.6 & 11.0 & 11.4 \\ 9.5 & 11.1 & 11.6 \\ 9.1 & 10.6 & 11.6 \\ 8.6 & 10.1 & 10.8 \\ 8.4 & 9.4 & 1 C .0 \\ 8.6 & 9.6 & \\ 9.6 & 9.2 & 8.9\end{array}$

$\begin{array}{rr}J U N & J U L \\ & \\ 10.0 & 9.8 \\ 9.1 & 9.1 \\ 8.4 & 8.2 \\ 7.7 & 7.7 \\ 7.4 & 7.1 \\ 6.8 & 6.5 \\ 7.7 & 7.1 \\ 7.6 & 7.6 \\ 6.9 & 5.8 \\ 6.6 & 5.5 \\ 6.9 & 5.8 \\ 7.4 & 6.2 \\ 7.7 & 6.7 \\ 6.4 & 7.3 \\ 6.8 & 7.8 \\ 9.6 & 8.3 \\ 10.6 & 9.1 \\ 12.0 & 10.2 \\ 12.9 & 11.4 \\ 12.8 & 11.8 \\ 12.8 & 12.6 \\ 12.7 & 12.9 \\ 12.2 & 12.2 \\ 11.0 & 10.8 \\ 9.3 & 8.6 \\ 9.3 & 8\end{array}$

AUG
9.2
8.3
7.5
6.9
6.6
6.0
5.7
6.2
5.8
5.3
5.3
5.7
6.3
6.8
7.3
7.9
8.7
9.7
10.4
11.0
11.7
11.8
11.0
9.9
9.0

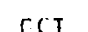

$\begin{array}{ll}7.9 & 0.6 \\ 7.3 & 6.3 \\ 7.0 & 6.0 \\ 6.8 & 5.9 \\ 6.4 & 5.8 \\ 6.2 & 5.6 \\ 5.6 & 5.5 \\ 6.0 & 5.2 \\ 0.4 & 5.4 \\ 6.3 & 6.0 \\ 6.3 & 6.2 \\ 6.5 & 0.2 \\ 6.9 & 6.5 \\ 7.1 & 6.7 \\ 7.5 & 7.0 \\ 8.1 & 7.0 \\ 8.5 & 7.0 \\ 8.8 & 7.1 \\ 9.0 & 7.7 \\ 9.6 & 7.8 \\ 9.6 & 7.6 \\ 9.2 & 7.4 \\ 8.6 & 7.0 \\ 8.2 & 6.8 \\ 7.5 & 6.5\end{array}$

6.0
6.0
5.8
5.8
5.9
5.6
5.4
5.2
5.2
5.7
6.2
6.5
6.6
$t .7$
6.4
6.2
6.1
6.5
$t .4$
6.3
6.3
6.2
6.1
6.1
$t$.

DE C

ANNUAL

$\begin{array}{ll}6.2 & \\ 6.1 & 7.0 \\ 6.0 & 6.8 \\ 5.9 & 6.8 \\ 5.9 & 6.7 \\ 6.0 & 6.6 \\ 5.8 & 6.4 \\ 5.8 & 6.2 \\ 5.8 & 6.1 \\ 5.9 & 6.4 \\ 6.4 & 6.9 \\ 6.7 & 7.2 \\ 7.0 & 7.4 \\ 6.9 & 7.6 \\ 6.8 & 8.1 \\ 6.4 & 8.2 \\ 6.3 & 8.2 \\ 6.5 & 7.9 \\ 6.8 & 7.6 \\ 6.9 & 7.8 \\ 6.7 & 7.7 \\ 6.5 & 7.5 \\ 6.2 & 7.3 \\ t .2 & 7.2 \\ & \\ t .3 & 7.2\end{array}$

8.6

9.9 


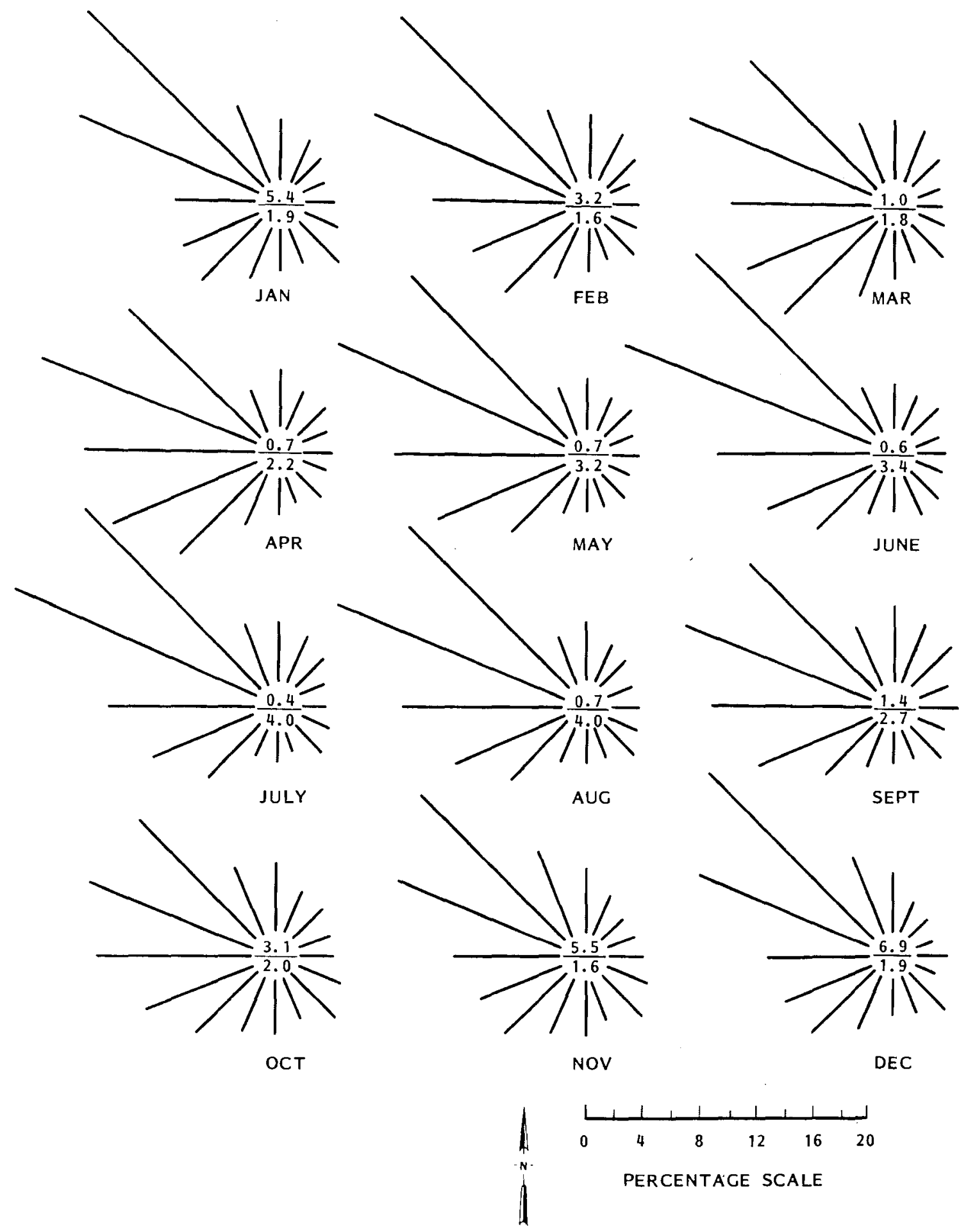

FIGURE 22. Monthly Wind Roses for HMS Based on 50-Foot Wind Data', 1955 Through 1980 . (The numbers in the centers are the percentages of caim [top numbers] and variable [bottom numbers] winds. The points of the rose represent the directions from which the winds blow.) 
TABLE 20. Monthly and Annual Diurnal Variation in the Percentage of Wind From SSW, SW and WSW at 50-Foot Leve1, 1955 Through 1980

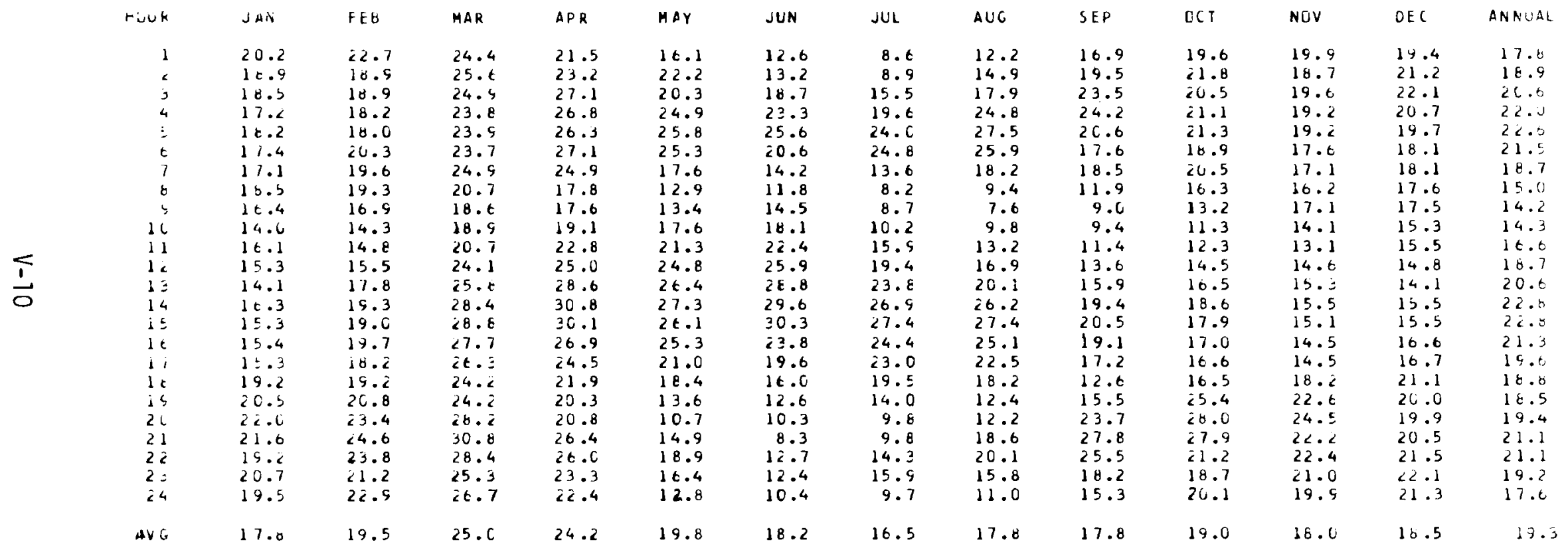


There is little seasonal or diurnal variation in the frequency of occurrence of wind directions of ENE, E, and ESE. These directions occur the least often ( $7 \%$ of the time), and have the lowest hourly average wind speeds $(4.2 \mathrm{mph})$. See Table 42 , in Section $X$, page 19 for additional information.

WIND SPEED AND DIRECTION DURING PERIODS OF PRECIPITATION

An analysis of the 50-foot wind direction and speed during observations of precipitation, by seasons, is presented in Tables 21 and 22 , respectively.

TABLE 21. Percentage of Wind From Various Directions During Observations of Precipitation: 1960 Through 1980

\begin{tabular}{|c|c|c|c|c|c|c|c|c|c|c|}
\hline \multirow[b]{2}{*}{ Season } & \multicolumn{10}{|c|}{ Direction } \\
\hline & $\underline{1-2}$ & $3-4$ & $\underline{5-6}$ & $7-8$ & $9-10$ & $11-12$ & $13-14$ & $15-16$ & 18 & TOTAL \\
\hline Winter $(D, J, F)$ & 3.4 & 3.5 & 5.8 & 6.3 & 3.9 & 6.7 & 43.2 & 9.6 & 17.6 & 100 \\
\hline Spring $(M, A, M)$ & 4.4 & 3.8 & 7.7 & 8.4 & 12.9 & 18.8 & 28.4 & 9.2 & 6.2 & 100 \\
\hline Summer $(J, J, A)$ & 2.5 & 3.4 & 5.3 & 7.2 & 16.3 & 27.2 & 26.7 & 5.5 & 6.0 & 100 \\
\hline$(S, 0, N)$ & 3.4 & 4.8 & 7.9 & 8.6 & 8.7 & 12.0 & 27.5 & 11.1 & 16.0 & 100 \\
\hline ANNUAL & 3.5 & 3.8 & 6.5 & 7.3 & 8.1 & 12.5 & 35.2 & 9.4 & 13.8 & 100 \\
\hline
\end{tabular}

West-southwest and west winds (direction classes 11 and 12) are more than four times as frequent during periods of summer precipitation as during periods of winter precipitation. During the winter months, WNW and NW winds (direction classes 13 and 14) account for nearly half of all wind directions during precipitation (Table 21). Precipitation during calm wind conditions (18) occurs less frequently during the spring and summer than during fall and winter.

Average wind speeds during precipitation are higher during the spring and summer (Table 22). 
TABLE 22. Percentage of Wind in Various Speed Classes During Hourly Observations of Precipitation: 1960-1980

\begin{tabular}{|c|c|c|c|c|c|c|c|c|c|c|c|}
\hline \multirow[b]{2}{*}{ Season } & \multicolumn{10}{|c|}{ Speed Class (mph) } & \multirow{2}{*}{$\begin{array}{l}\text { Avg. } \\
\text { Speed }\end{array}$} \\
\hline & Calm & $1-3$ & $4-7$ & $\underline{8-12}$ & $13-18$ & $19-24$ & $25-31$ & $32-38$ & $39-46$ & $>46$ & \\
\hline Winter $(D, J, F)$ & 16.3 & 21.9 & 30.3 & 23.8 & 6.3 & 0.9 & 0.2 & 0.2 & 0.1 & 0 & 5.7 \\
\hline Spring $(M, A, M)$ & 5.7 & 12.6 & $28: 2$ & 32.2 & 14.8 & 5.0 & 1.2 & 0.3 & 0 & 0 & 8.7 \\
\hline Summer $(J, J, A)$ & 5.5 & 8.6 & 28.2 & 33.1 & 18.9 & 4.3 & 1.1 & 0.3 & 0.1 & 0 & 9.2 \\
\hline Fall $(S, 0, N)$ & 14.2 & 19.6 & 30.4 & 24.5 & 8.3 & 2.2 & 0.6 & 0.2 & 0 & 0 & 6.3 \\
\hline ANNUAL & 12.5 & 18.1 & 29.7 & 26.6 & 9.8 & 2.4 & 0.6 & 0.3 & 0.1 & 0 & 6.8 \\
\hline
\end{tabular}


Most fog at the HMS is radiation fog, and occurs during periods of low wind speeds. Table 23 shows that $73 \%$ of all fog occurs when wind speeds are $3 \mathrm{mph}$ or less. Fog occurs most frequently with NNW and $\mathrm{N}$ winds (direction classes 15 and 16). The next most frequent directions during fog are WNW and NW (direction classes 13 and 14).

TABLE 23. Frequency Distribution (\%) of Wind Directions and Speeds During Hourly Observations of Fog With Visibility $1 / 2$ Mile or Less: 1960 Through 1980

\begin{tabular}{|c|c|c|c|c|c|c|c|c|c|}
\hline \multicolumn{10}{|c|}{ Direction Classes (see p. V-1) } \\
\hline $1-2$ & $3-4$ & $5-6$ & $7-8$ & $9-10$ & $11-12$ & $13-14$ & $15-16$ & 18 & TOTAL \\
\hline 7.8 & 6.2 & 4.9 & 7.6 & 5.3 & 6.0 & 13.9 & 16.0 & 32.3 & 100 \\
\hline
\end{tabular}

Speed Classes (mph)

\begin{tabular}{lllllll}
\hline Calm & $1-3$ & $4-7$ & $8-12$ & $\geq 12$ & $\frac{1}{\%}$ & $\begin{array}{c}\text { Average } \\
\text { Speed }\end{array}$ \\
30.1 & 42.9 & 24.0 & 2.7 & 0.4 & 100 & 2.3
\end{tabular}

WIND PROFILES

Refer to Section $X$, page 11 .

EXTREME VALUE ANALYSIS OF PEAK GUSTS

Refer to Section XI, page 6 . 
VI. SKY COVER, VISIBILITY AND SOLAR RADIATION 


\section{SKY COVER, VISIBILITY AND SOLAR RADIATION}

\section{SKY COVER}

The term sky cover is used to express the portion of the celestial dome that is described by one of the following conditions:

1. Amount of sky covered, but not necessarily hidden, by clouds or obscuring phenomena aloft.

2. Amount of sky hidden by an obscuring phenomenon on the ground (such as fog or smoke).

3. A combination of 1 and 2 .

The sky cover is determined hourly by scanning the sky and estimating the number of tenths that are covered ( 0 denotes clear sky and 10 denotes overcast). Average monthly sunrise to sunset sky cover values for 1946 through 1980 are shown in Table 24. The portion of Table 24 summarizing clear, partly cloudy and cloudy days covers the period 1954 through 1980 .

Sunrise to sunset sky cover observations for any particular month include only the hourly observations when the sun is near or above the horizon. These hours are the same for any given month, but do vary from month to month corresponding to changes in sunrise and sunset times.

The number of clear, partly cloudy and cloudy days in Table 24 is the result of assigning each day to one of the following categories:

\begin{tabular}{lc}
\multicolumn{1}{c}{ Category } & \multicolumn{2}{c}{$\begin{array}{c}\text { Average Sky Cover } \\
\text { Clear }\end{array}$} \\
\cline { 2 - 3 } Partiy Cloudy & $0-3$ \\
Cloudy & $4-7$ \\
\cline { 2 - 2 } & $8-10$
\end{tabular}

During the period of record (1954 through 1980), there has been an average of 192 sunny days per year at the HMS, (the sum of the clear and partly cloudy days from Table 24 ). 
TABLE 24. Average Sky Cover (Sunrise to Sunset) and Number of Days Clear, Partly Cloudy and Cloudy, 1946 Through 1980*

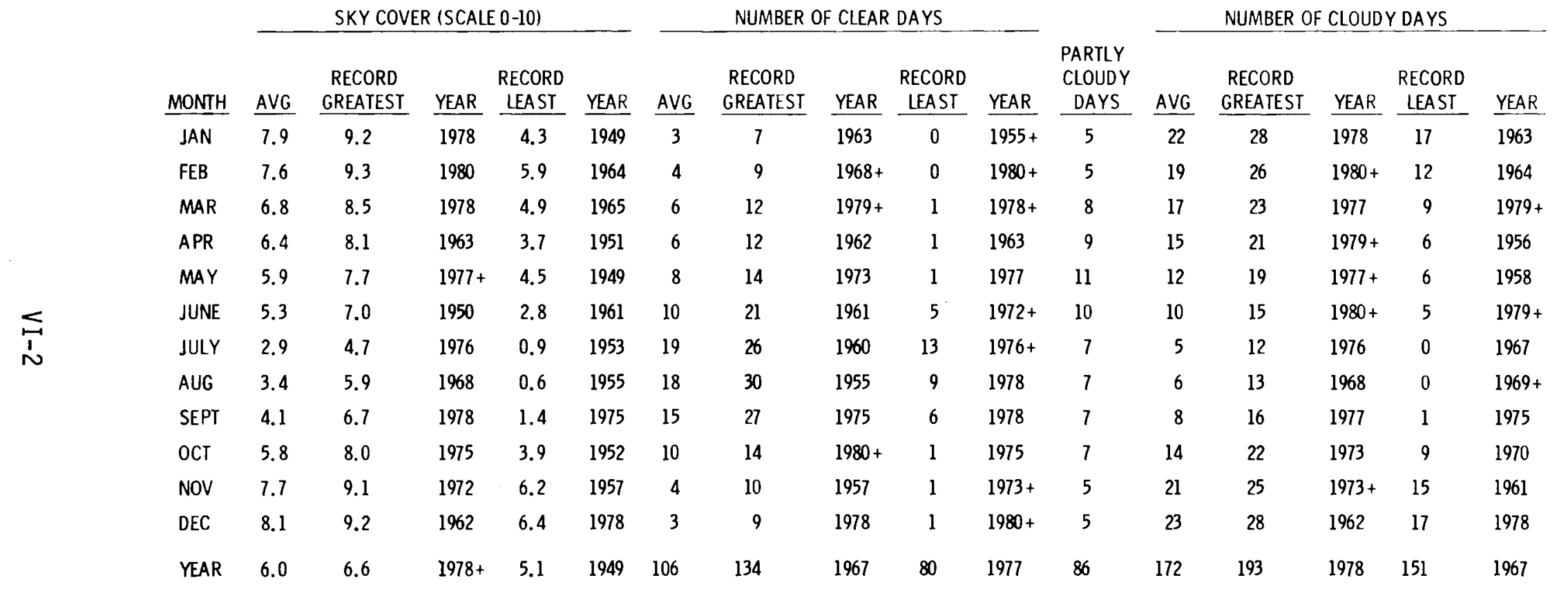

* NUmBer of Clear, PARTLY ClOUdy, AND CLOUDY DAYS 1954-1980

+ ALSO IN EARLIER YEARS 


\section{VISIBILITY}

Visibility is determined during each hourly observation. The values recorded are miles and fractions of a mile. If the visibility exceeds 15 miles, it is recorded as $15+$.

If the visibility is 6 miles or less, one or more phenomena must be recorded to explain the restriction. Fog and precipitation (usually snow) are the most common restrictions, but dust or blowing dust, volcanic ash, smoke, and blowing snow have also been observed. Table 25 gives the percent of all observations during the period 1955 to 1980 during which any of the above phenomena were recorded.

TABLE 25. Percent of Hourly Observations With Visibility Restricted to 6 Miles or Less by Various Phenomena (1960 Through 1980)

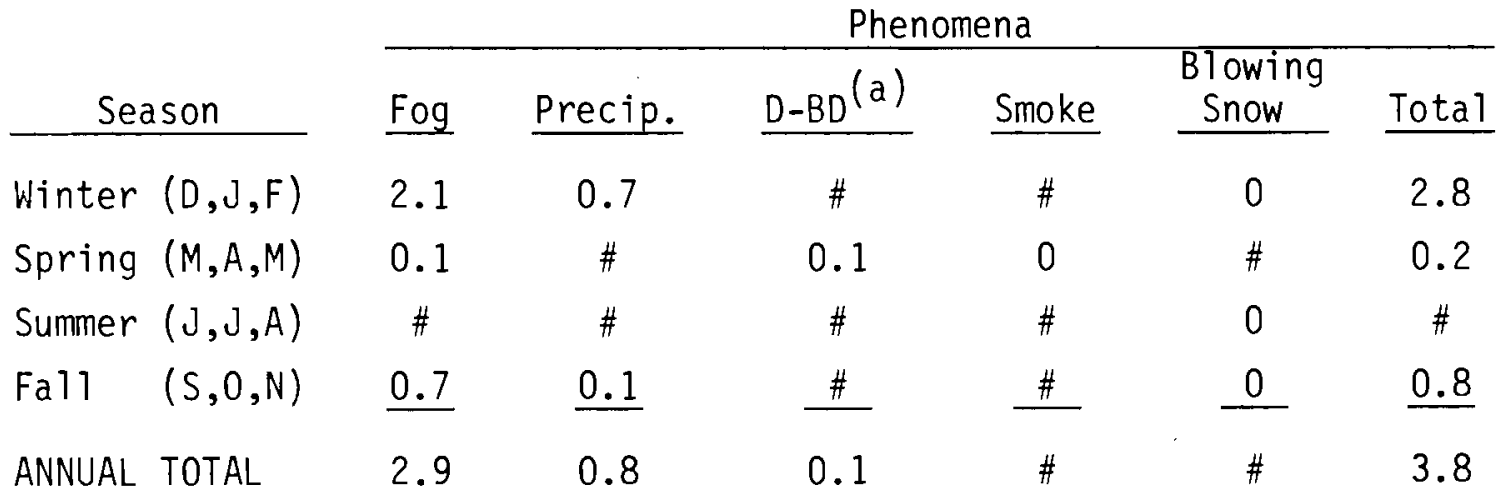

(a) Includes volcanic ash \# Denotes less than 0.05\%

SOLAR RADIATION

An Eppley(a) 10-junction pyranometer (Stone 1964) was used for the period 1957 through 1977 to measure both diffuse and direct solar radiation on a horizontal surface. The same measurements were made for the period 1978 through 1980 with an Eppley, Model PSP pyranometer. These data were recorded on a Leeds \& Northrup ${ }^{(b)}$ Speedomax recorder,

(a) Eppley Laboratories, Inc., Newport, Rhode Island

(b) Leeds \& Northrup Company, North Wales, Pennsylvania 
which was designed to record langleys ${ }^{(a)}$ per minute. Hourly averages were determined visually by the "equal area" method. These data are summarized in Table 26 and Figure 23.

The highest daily totals occur with a clear sky and clean air. The highest peaks, which are of short duration, occur when the sun's rays are in close proximity to highly reflective clouds. When this occurs the sensor receives both direct and reflected radiation. Instantaneous values may approach 2.00 langleys per minute.

The lowest daily totals commonly occur with low stratus overcasts, usually without precipitation. Instantaneous low readings occur in conjunction with cumulonimbus clouds. These low values sometimes approach zero on the chart, but are of short duration. The lowest mid-day values of hourly solar radiation occurred on May 18, 1980, as the dense ash cloud from the eruption of the Mount St. Helens volcano passed over eastern Washington. Hourly solar radiation dropped to 0 at 1100 and remained at 0 for the rest of the day.

Figure 23 graphically shows the least, average and greatest daily solar radiation totals for the period 1953 through 1980. It is interesting to note that the average daily solar radiation for the months of November through February (winter months) is about $45 \%$ of the greatest daily values, while for June through September (summer months) the percentages are between 70 and $80 \%$. This is due to the greater cloud cover during the winter (Table 24).

The highest average daily solar radiation totals do not occur in June as might be expected, but in July. The sun is above the horizon longer in June, but cloudiness in July is about one-half that in June. Also, clear days outnumber cloudy days 19 to 5 in July, compared to 10 to 10 in June (Table 24).

(a) A langley is defined as 1 gram calorie per square centimeter 
TABLE 26. Hourly and Daily Average Solar Radiation Totals

(Langleys) Period of Record 1955 Through 1980

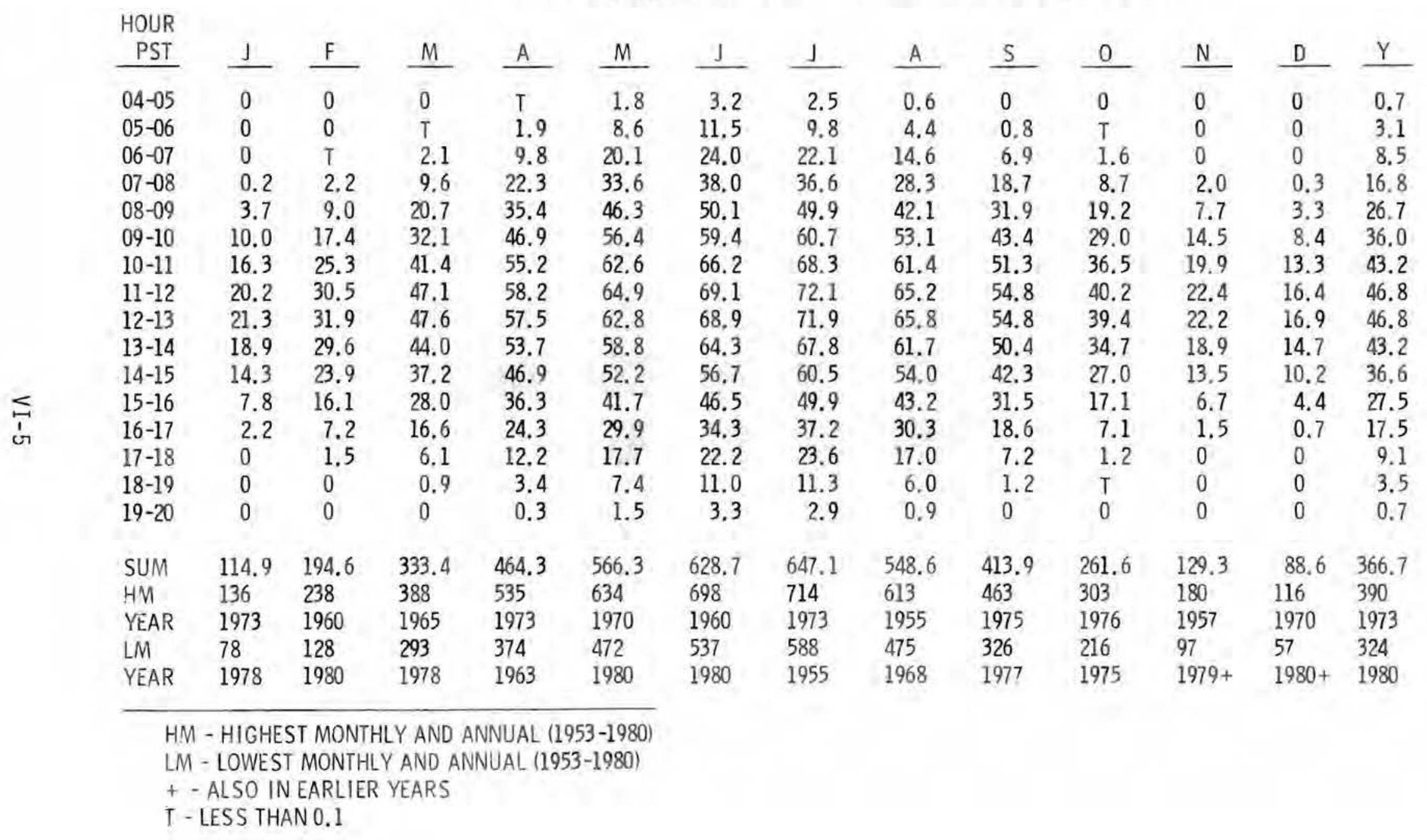




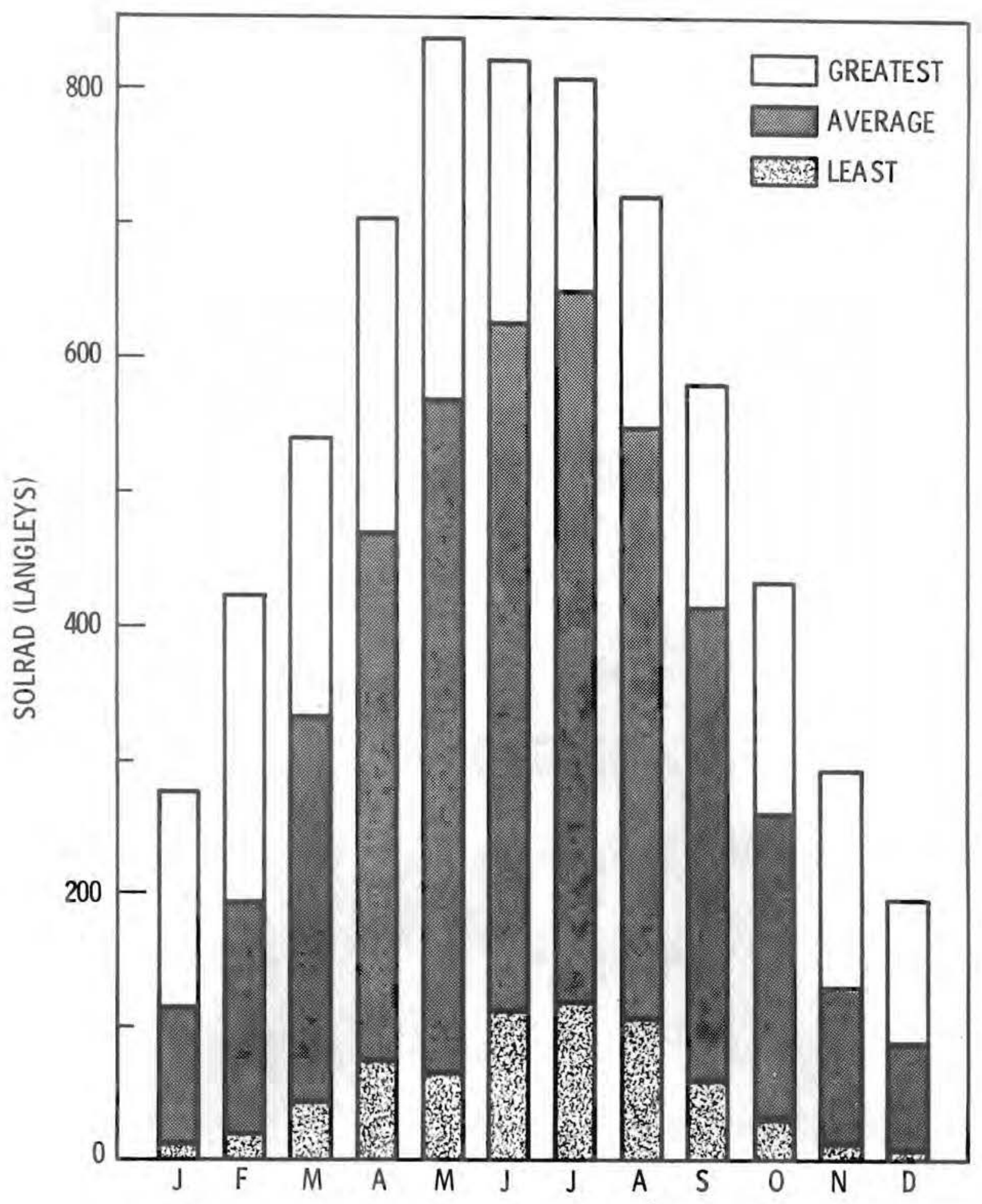

FIGURE 23. Average, Greatest and Least Daily Solar Radiation Totals: 1953 Through 1980 
VII. PSYCHROMETRIC DATA 


\section{PSYCHROMETRIC DATA}

Psychrometric data comprise observations of dry bulb, wet bulb, and dew point temperatures and relative humidity. The dry bulb temperature is the temperature of the ambient air and the wet bulb temperature is the lowest temperature to which a parcel of air, under constant pressure, can be cooled by evaporating water into it. The dew point temperature is the temperature to which a given parcel of air, under constant pressure and water-vapor content, must be cooled to attain saturation. Relative humidity is the ratio of the actual water-vapor content of the air to that at which saturation would occur if the pressure and temperature remained unchanged.

Psychrometric observations at HMS began in March 1946. Observations, taken at 3-hourly intervals, consisted of sling psychrometer readings of dry and wet bulb temperatures. Values for relative humidity and dew point temperatures were computed from the dry and wet bulb temperatures. Hourly psychrometric observations began in 1956.

In 1956 a Foxboro(a) Dew Point Measuring System was installed (Stone 1964). Starting August 1, dry bulb and dew point temperatures were recorded on Leeds \& Northrup ${ }^{(b)}$ Speedomax recorders and the values for relative humidity and wet bulb temperatures were computed. These data for the period 1957 through 1980 are depicted in Tables 27 through 30 and Figure 24.

Figure 25 is a bar diagram of average 1300 PST relative humidity for each July of record for the years 1946 through 1980. The 10-year moving average line on the diagram does not indicate a significant trend. The HMS is surrounded by irrigation projects but none are closer than 10 miles, so these data cannot be considered representative of conditions in irrigated areas.

Before 1975 , wet bulb temperatures $\geq 75^{\circ} \mathrm{F}$ had not been observed. On July 8,9 and 10,1975 , there were 7 hourly observations of wet bulb

(a) Foxboro Company, Foxboro, Massachusetts

(b) Leeds \& Northrup Company, North Wales, Pennsylvania 


\begin{tabular}{|c|c|c|c|c|c|c|c|c|c|c|c|c|c|c|}
\hline & & & & & & & AVE & RAGES & & & & & & \\
\hline & & JAN & FEB & MAR & APR & MAY & JUNE & JULY & $\underline{A \cup G}$ & SEPT & OCT 1 & NOV & $\underline{D E C}$ & YEAR \\
\hline & $\begin{array}{l}\text { DRY BULB } \\
\text { WET BULB } \\
\text { REL. HUM. } \\
\text { DEWPOINT }\end{array}$ & $\begin{array}{l}30 \\
27 \\
76 \\
23\end{array}$ & $\begin{array}{l}37 \\
34 \\
71 \\
28\end{array}$ & $\begin{array}{l}44 \\
37 \\
56 \\
28\end{array}$ & $\begin{array}{l}53 \\
43 \\
47 \\
31\end{array}$ & $\begin{array}{l}62 \\
49 \\
43 \\
36\end{array}$ & $\begin{array}{l}70 \\
54 \\
40 \\
41\end{array}$ & $\begin{array}{l}77 \\
58 \\
32 \\
43\end{array}$ & $\begin{array}{l}75 \\
57 \\
36 \\
43\end{array}$ & $\begin{array}{l}66 \\
52 \\
42 \\
40\end{array}$ & $\begin{array}{l}53 \\
45 \\
57 \\
36\end{array}$ & $\begin{array}{l}40 \\
36 \\
73 \\
31\end{array}$ & $\begin{array}{l}33 \\
31 \\
80 \\
27\end{array}$ & $\begin{array}{l}53 \\
44 \\
54 \\
34\end{array}$ \\
\hline & & & & & & MONT & HLY AV & ERAGE E & EXTREM & & & & & \\
\hline DRY BULB & $\begin{array}{l}\text { HIGHEST } \\
\text { YEAR } \\
\text { LOWEST } \\
\text { YEAR }\end{array}$ & $\begin{array}{l}43 \\
1953 \\
13 \\
1950\end{array}$ & $\begin{array}{l}44 \\
1958 \\
26 \\
1956\end{array}$ & $\begin{array}{l}49 \\
1968 \\
40 \\
1955\end{array}$ & $\begin{array}{l}58 \\
1977 \\
48 \\
1955\end{array}$ & $\begin{array}{l}69 \\
1958 \\
57 \\
1962\end{array}$ & $\begin{array}{l}76 \\
1969 \\
64 \\
1953\end{array}$ & $\begin{array}{l}83 \\
1960 \\
73 \\
1963\end{array}$ & $\begin{array}{l}82 \\
1967 \\
71 \\
1964\end{array}$ & $\begin{array}{l}72 \\
1967 \\
61 \\
1977\end{array}$ & $\begin{array}{l}59 \\
1952 \\
50 \\
1968\end{array}$ & $\begin{array}{l}46 \\
1954 \\
32 \\
1978+\end{array}$ & $\begin{array}{l}39 \\
1953 \\
26 \\
1964\end{array}$ & $\begin{array}{l}56 \\
1958 \\
51 \\
1955+\end{array}$ \\
\hline WET BULB & $\begin{array}{l}\text { HIGHEST } \\
\text { YEAR } \\
\text { LOWEST } \\
\text { YEAR }\end{array}$ & $\begin{array}{l}39 \\
1953 \\
12 \\
1950\end{array}$ & $\begin{array}{l}41 \\
1958 \\
23 \\
1956\end{array}$ & $\begin{array}{l}41 \\
1978+ \\
33 \\
1955\end{array}$ & $\begin{array}{l}46 \\
1980+ \\
39 \\
1955\end{array}$ & $\begin{array}{l}55 \\
1958 \\
45 \\
1959\end{array}$ & $\begin{array}{l}59 \\
1958 \\
51 \\
1954\end{array}$ & $\begin{array}{l}62 \\
1975 \\
56 \\
1977+\end{array}$ & $\begin{array}{l}61 \\
1961 \\
55 \\
+1980+\end{array}$ & $\begin{array}{l}56 \\
1963 \\
48 \\
1970\end{array}$ & $\begin{array}{l}48 \\
1962 \\
42 \\
1970\end{array}$ & $\begin{array}{l}42 \\
1954 \\
29 \\
1978\end{array}$ & $\begin{array}{l}36 \\
1966 \\
25 \\
1978\end{array}$ & $\begin{array}{l}46 \\
1958 \\
42 \\
1955\end{array}$ \\
\hline REL. HUM. & $\begin{array}{l}\text { HIGHEST } \\
\text { YEAR } \\
\text { LOWEST } \\
\text { YEAR }\end{array}$ & $\begin{array}{l}89 \\
1960 \\
60 \\
1963\end{array}$ & $\begin{array}{l}87 \\
1963 \\
54 \\
1967\end{array}$ & $\begin{array}{l}66 \\
1950 \\
44 \\
1965\end{array}$ & $\begin{array}{l}64 \\
1963 \\
37 \\
1966\end{array}$ & $\begin{array}{l}62 \\
1948 \\
31 \\
1966\end{array}$ & $\begin{array}{l}54 \\
1950 \\
30 \\
1949\end{array}$ & $\begin{array}{l}40 \\
1955 \\
22 \\
1959\end{array}$ & $\begin{array}{l}48 \\
1976 \\
24 \\
1967\end{array}$ & $\begin{array}{l}56 \\
1977 \\
33 \\
1974\end{array}$ & $\begin{array}{l}74 \\
1962 \\
42 \\
1952\end{array}$ & $\begin{array}{l}89 \\
1979 \\
63 \\
1976\end{array}$ & $\begin{array}{l}90 \\
1950 \\
69 \\
1968\end{array}$ & $\begin{array}{l}59 \\
1978 \\
49 \\
1967\end{array}$ \\
\hline DEWPOINT & $\begin{array}{l}\text { HIGHEST } \\
\text { YEAR } \\
\text { LOWEST } \\
\text { YEAR }\end{array}$ & $\begin{array}{l}34 \\
1953 \\
6 \\
1950\end{array}$ & $\begin{array}{l}37 \\
1958 \\
17 \\
1956\end{array}$ & $\begin{array}{l}34 \\
1961 \\
21 \\
1965+\end{array}$ & $\begin{array}{l}37 \\
1963 \\
26 \\
1955\end{array}$ & $\begin{array}{l}44 \\
1957 \\
30 \\
1964\end{array}$ & $\begin{array}{l}48 \\
1958 \\
38 \\
1954\end{array}$ & $\begin{array}{l}50 \\
1975 \\
35 \\
1959\end{array}$ & $\begin{array}{l}48 \\
1976 \\
38 \\
1955\end{array}$ & $\begin{array}{l}45 \\
1963 \\
34 \\
1970\end{array}$ & $\begin{array}{l}44 \\
1962 \\
31 \\
1974\end{array}$ & $\begin{array}{l}38 \\
1954 \\
23 \\
1978\end{array}$ & $\begin{array}{l}34 \\
1950 \\
20 \\
1978\end{array}$ & $\begin{array}{l}38 \\
1958 \\
32 \\
1955\end{array}$ \\
\hline
\end{tabular}


TABLE 28. Percent Frequency Distribution of Dry Bulb Temperature Versus Wet Bulb Temperature ${ }^{\circ} \mathrm{F}$ (1955 Through 1980)

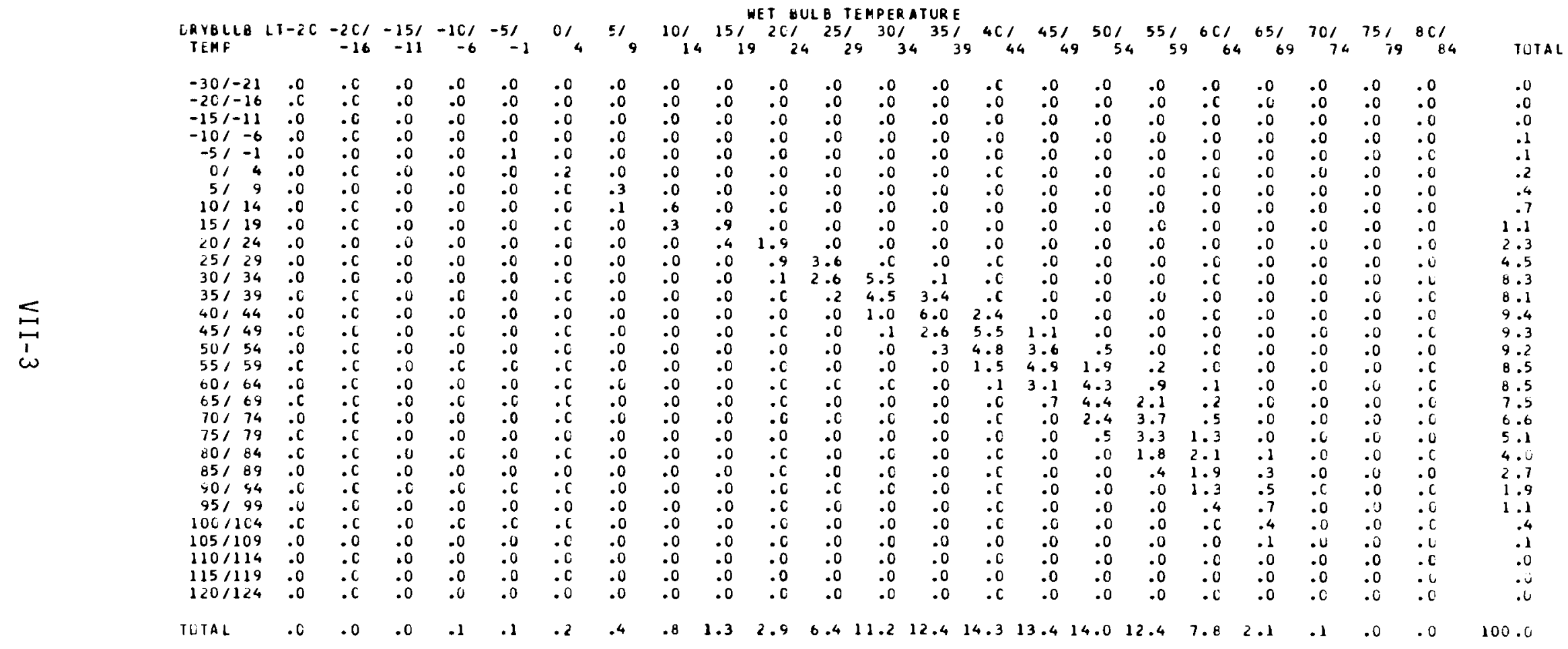


TABLE 29. Percent Frequency Distribution of Dry Bulb Temperature, ${ }^{\circ} \mathrm{F}$, Versus Relative Humidity, 1955 Through 1980

SEASON-1 CEC JAN FEB I

RELATIVE RUAIOITY

\begin{tabular}{|c|c|}
\hline DRY BULE & 12.30 \\
\hline$-\Sigma C /-z l$ & .00 \\
\hline$-2 C /-10$ & .00 \\
\hline$-15 /-11$ & .00 \\
\hline$-101-6$ & .00 \\
\hline$-3 /-1$ & .00 \\
\hline C/ 4 & .00 \\
\hline S/ 9 & .02 \\
\hline $101 \quad 14$ & .04 \\
\hline $15 / 19$ & .06 \\
\hline $201 \quad 24$ & .05 \\
\hline $651<9$ & .06 \\
\hline $30 / 34$ & .10 \\
\hline $35 / 39$ & .03 \\
\hline 40144 & .05 \\
\hline $45 / 49$ & .11 \\
\hline $50 / 54$ & .12 \\
\hline $55 / 59$ & .08 \\
\hline $60 / 64$ & .02 \\
\hline $65 / 69$ & .01 \\
\hline $70 / 74$ & .01 \\
\hline 75179 & .00 \\
\hline EG/ 84 & .00 \\
\hline$E 5 / 89$ & .00 \\
\hline $50 / 94$ & .00 \\
\hline $95 / 99$ & .00 \\
\hline $100 / 104$ & .00 \\
\hline $165 / 169$ & .00 \\
\hline $110 / 114$ & .00 \\
\hline $115 / 119$ & . 00 \\
\hline $120 / 124$ & .00 \\
\hline TCTAL & .77 \\
\hline
\end{tabular}

$30 / 44 \quad 45 / 59 \quad 60 / 74$

$75 / 89$

GT.8S

TOTAL

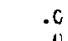

.06
.06
.00

.00

. $\mathrm{CO}$

.04
.05
.05

.05

. .14

.18
.16

.16
.24
.27

$\begin{array}{ll}.27 & 1.62 \\ .32 & 2.03\end{array}$

$.32 \quad 2.20$

$1.18 \quad 2.99$

$\begin{array}{ll}1.06 & 1.80 \\ .37 & \end{array}$

.37

.17

.93
.24

.04
.00
.00

.00

.24
.03
.00

.$C C$
$.0 C$

.00

.00

.00

. $\mathrm{CC}$
.00

.00
$.0 \mathrm{C}$

. $\mathrm{CC}$

.00
.00

$.0 \mathrm{C}$

.00
.02

.00

$.0 C$
.00
$.0 \mathrm{C}$

.00
$.0 \mathrm{C}$

.03
.12

.27

.32

$.4 C$
.46

.46

1.03

1.68

3.36
4.61

4.61
4.31

2.76

1.14

.02
.00

.00

.00
.00

.00

.00
.00

.00

.00

$3.03 \quad 14.67$

$21.4 t$

.00
.01
.01

.02

.11
.28

.28
.61
.02

.92

1.41

2.71
5.21

7.87
5.33

2.68
1.02

1.02
.10
.00

.01
.00
.60

.00
.00
.00

.00

.00
.00
.00

.00
.00

.00
.00
.00

.00
.00

.00
.00

28.35

.00
.06
.00
.00

.02

$.0 t$

.68
1.47

1.47
$3.2 \mathrm{C}$

6.07
10.47

$\begin{array}{rr}4.98 & 23.09 \\ 2.29 & 17.48\end{array}$

$2.29 \quad 13.30$

$\begin{array}{ll}.3 \mathrm{C} & 8.35 \\ .03 & 4.34\end{array}$

$\begin{array}{ll}.03 & 4.34\end{array}$

$.06 \quad 1.71$

$\begin{array}{ll}.06 & .46 \\ .00 & .07 \\ .06 & .01\end{array}$

$.0 \mathrm{C}$

$.0 \mathrm{C}$

$.0 \mathrm{C}$

$.00 \quad .00$

$.0 \mathrm{C} \quad .00$

.00

$.0 C$
.00

$29.7 \dot{z}$

100.00

SEASOR-1 MAR APR MAY ।

RELAIIVE PUAIOITY

\begin{tabular}{|c|c|c|c|c|c|c|c|}
\hline DRY BULB & LT.3C & $36 / 44$ & $45 / 59$ & $60 / 74$ & $75 / 89$ & GT.8G & TOTAL \\
\hline$-30 /-21$ & .00 & $.3 c$ & .00 & .00 & .00 & . LC & $.0 \mathrm{C}$ \\
\hline$-20 /-16$ & .00 & .00 & .00 & .00 & .00 & .00 & .00 \\
\hline$-15 /-11$ & .00 & $.0 \mathrm{C}$ &. $\mathrm{CO}$ & .60 & .00 & $.0 \mathrm{C}$ & .00 \\
\hline$-1 c /-t$ & $.0 \mathrm{C}$ &.$C C$ & .00 & .60 & .00 &.$c c$ & .00 \\
\hline$-5 /-1$ & .60 &.$C C$ & $.6 C$ & .00 & .00 & $.0 \mathrm{C}$ & .60 \\
\hline $0 / 4$ & .00 & .00 & .00 & .00 & .00 &. $\mathrm{CC}$ &. $\mathrm{CO}$ \\
\hline $5 / 4$ & .00 & .00 & .00 & .00 & .00 & .00 & .60 \\
\hline 10114 & .60 & $.0 \mathrm{C}$ & $.0 C$ & .06 & .01 & $.0 \mathrm{C}$ & .01 \\
\hline $15 / 14$ & .02 & .01 & .04 & .04 & .03 & .01 & $.1 t$ \\
\hline $60 / 24$ & .02 & .04 & .69 & .11 & .08 & $.0 \leq$ & .39 \\
\hline $251<9$ & .04 & .06 & .20 & $.3 d$ & .40 & .23 & 1.32 \\
\hline $30 / 34$ & .04 & .12 & .74 & 1.37 & 1.23 & .49 & 3.99 \\
\hline $35 / 35$ & .69 & .37 & 2.27 & 2.35 & 1.42 & .45 & 6.96 \\
\hline 40144 & .13 & 1.25 & 4.88 & 3.67 & 1.98 & .65 & $12.0 \mathrm{C}$ \\
\hline 45145 & .33 & 3.35 & 6.17 & 3.54 & 1.60 & .64 & 15.63 \\
\hline $30 / 54$ & 1.17 & 5.56 & $6 . C 8$ & 2.65 & $.9 t$ & .41 & 16.83 \\
\hline $55 / 59$ & 2.26 & 5.72 & 3.77 & 1.20 & .51 & .12 & 13.83 \\
\hline 60164 & 2.92 & 5.15 & (.3) & .51 & $.1 C$ & .01 & 11.00 \\
\hline 15169 & 2.82 & 3.45 & .90 & $.1 \mathrm{C}$ & .01 & $.0 \mathrm{C}$ & 7.24 \\
\hline $70 / 74$ & 2.57 & $1.8 \mathrm{t}$ & .27 & .01 & .00 & $.0 \mathrm{C}$ & 4.72 \\
\hline $15 / 74$ & 1.92 & .71 & .62 & .66 & .00 & $.0 \mathrm{C}$ & 2.60 \\
\hline 20184 & 1.38 & .18 & .01 & .00 & .00 & .00 & 1.57 \\
\hline $55 / 69$ & .69 & .34 & .00 & .00 & .00 &.$C C$ & .73 \\
\hline $301 \quad 44$ & .30 & $.6 C$ &.$C C$ & $.0 \mathrm{C}$ & .00 & $.0 C$ & .30 \\
\hline $55 / 49$ & .66 & .00 & .00 & .00 & .00 & $.0 \mathrm{C}$ & .06 \\
\hline $100 / 164$ & .00 & .00 & .40 & .00 & .00 & .00 & .00 \\
\hline $2(5 / 109$ & .00 & $.0 C$ & .60 & $.0 \mathrm{C}$ & .00 & $.0 \mathrm{C}$ & .00 \\
\hline $116 / 114$ & .ن & .00 & .0 & .00 & .00 & $.6 \mathrm{C}$ & .00 \\
\hline $115 / 119$ & .00 & $.0 \mathrm{C}$ &. $\mathrm{CO}$ & $.0 \mathrm{C}$ & .00 & $.0 \mathrm{C}$ & .00 \\
\hline $1<0 / 1<4$ & .60 & .00 & .00 & .00 & .00 & $.0 \mathrm{C}$ & .00 \\
\hline ILIAL & 16.77 & CE.08 & 27.76 & 16.00 & 8.33 & 3.07 & 100.00 \\
\hline
\end{tabular}


TABLE 29. Continued

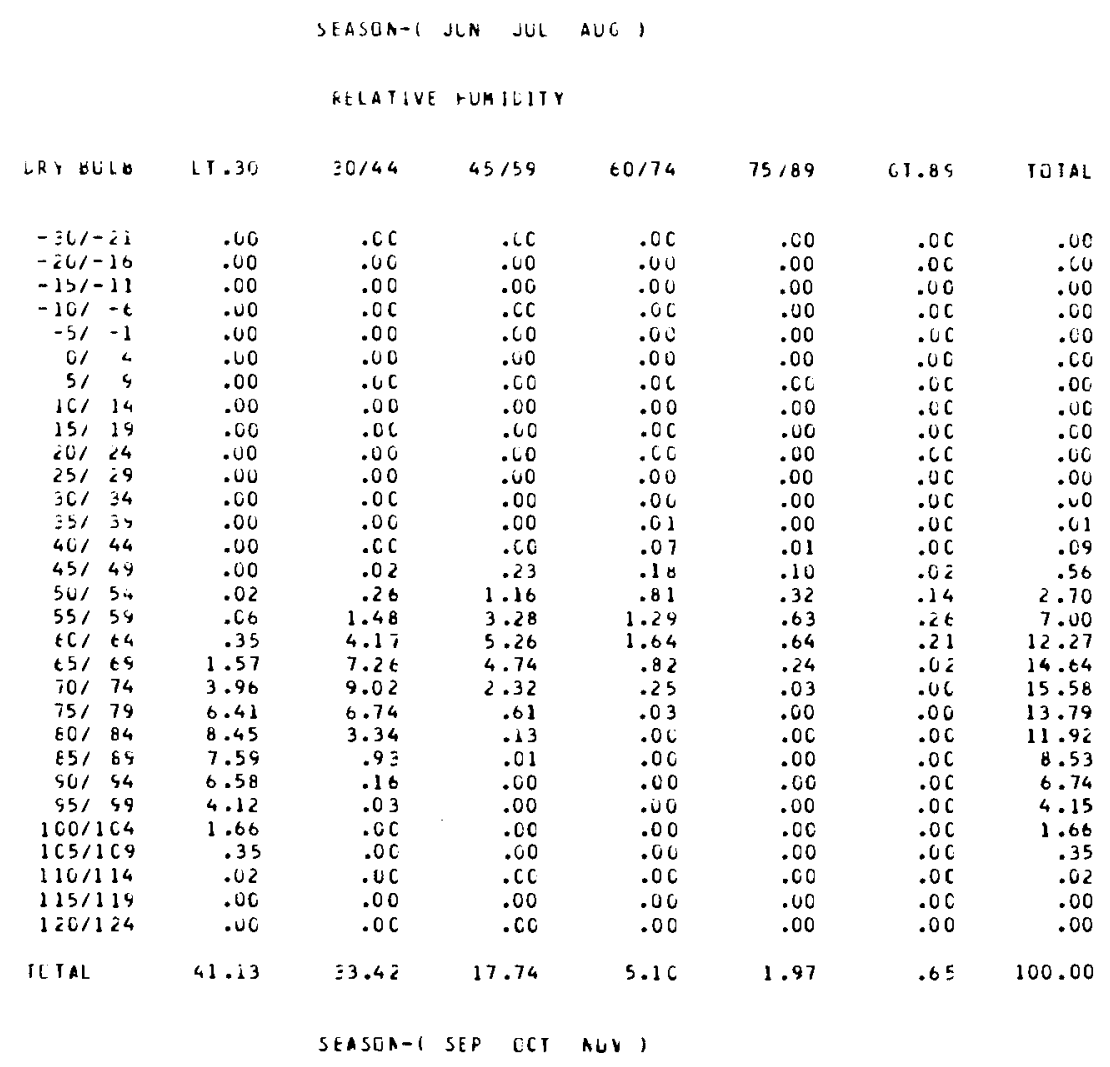

DEY BLLO LT.30

RELATIVE HUMIOIIY

\begin{tabular}{|c|c|c|c|c|c|c|c|}
\hline$-30 /-21$ & .00 & .00 & .00 & $.0 \mathrm{v}$ & .00 & .00 & .00 \\
\hline $\begin{array}{l}-20 /-1 t \\
-1 b /-11\end{array}$ & .60 & $\begin{array}{l}.0 C \\
.00\end{array}$ & $\begin{array}{l}.00 \\
.00\end{array}$ & .00 & $\begin{array}{l}.00 \\
.00\end{array}$ & $\begin{array}{l}.0 \mathrm{C} \\
.0 \mathrm{C}\end{array}$ & $\begin{array}{l}.00 \\
.00\end{array}$ \\
\hline$-16 /-6$ & .00 & $.0 \mathrm{C}$ & .00 & $.0 \mathrm{C}$ & .00 & $.0 \mathrm{C}$ & .00 \\
\hline $\begin{array}{ll}-5 / & -1\end{array}$ & .00 & .00 & .00 & .00 & .00 & $.6 C$ & .00 \\
\hline 014 & .00 & .00 & .00 & .00 & .60 & $.0 C$ & .00 \\
\hline $5 /$ & .00 & $.0 \mathrm{C}$ & .01 & .00 & .00 & $.6 c$ & .01 \\
\hline $10 / 14$ & .00 & .01 & .01 & .05 & .02 & .01 & .12 \\
\hline $15 / 14$ & .00 & . Ct & .04 & .09 & .06 & .68 & .34 \\
\hline iul 24 & .01 & .11 & .12 & .22 & .32 & .35 & 1.17 \\
\hline $25 / 29$ & .01 & .10 & .22 & .50 & .98 & 1.16 & 2.98 \\
\hline $50 / 34$ & .02 & .26 & .41 & 1.23 & 2.29 & 2.38 & 6.49 \\
\hline $35 / \quad 24$ & .62 & .25 & .95 & 2.07 & 2.86 & 1.82 & 7.98 \\
\hline $4 C / 44$ & .06 & $.4 t$ & 2.19 & 3.46 & 3.46 & 2.14 & 11.76 \\
\hline $45 / 49$ & .10 & 1.01 & 3.58 & 3.79 & 2.75 & 1.27 & 12.50 \\
\hline 50154 & .22 & 2.41 & 4.80 & 3.33 & 1.57 & .44 & 12.77 \\
\hline$E E / E G$ & .45 & 3.32 & 4.58 & 2.15 & .73 & .17 & 11.40 \\
\hline $60 / 64$ & 1.03 & 3.95 & 3.95 & 1.15 & .19 & .05 & 10.32 \\
\hline 65169 & 1.41 & 3.89 & 2.24 & .22 & .03 & $.0 \mathrm{C}$ & 7.78 \\
\hline T4 74 & 2.10 & 3.30 & .65 & .02 & .00 & $.0 \mathrm{C}$ & 6.08 \\
\hline $75 / 79$ & 2.01 & 1.76 & .08 & .00 & .00 & $.0 \mathrm{C}$ & 3.64 \\
\hline$\varepsilon C / E 4$ & 1.89 & .58 & .01 & .00 & .00 & $.0 \mathrm{C}$ & 2.47 \\
\hline $55 / 89$ & 1.29 &. $\mathrm{CB}$ &.$C C$ & $.0 u$ &. $\mathrm{CO}$ & $.0 \mathrm{C}$ & 1.36 \\
\hline sol s4 & .53 & .01 & .00 & $.0 \mathrm{C}$ & .00 & $.0 \mathrm{C}$ & .54 \\
\hline $53 / 59$ & .09 & .00 & .00 & . UC & .00 & $.0 \mathrm{C}$ & .09 \\
\hline $1 \mathrm{CC} / \mathrm{C}(4$ & .60 & .06 & .00 & .00 & .00 & $.0 \mathrm{C}$ & .00 \\
\hline $1 c s / 1 c y$ & .40 & $.0 \mathrm{C}$ & .00 & $.0 \mathrm{C}$ & .00 & $.0 \mathrm{C}$ & .00 \\
\hline $110 / 114$ & .00 & .00 & .00 & .00 & .00 &.$C C$ & .00 \\
\hline $115 / 119$ & .00 & .00 & .00 & .00 & .00 & .00 & .00 \\
\hline $120 / 124$ & .00 & $.0 \mathrm{C}$ & $.0 \mathrm{C}$ & .00 & .00 & $.6 C$ & .00 \\
\hline ICIAL & 11.24 & 61.42 & 23.83 & 18.30 & 15.27 & 5.94 & 100.00 \\
\hline
\end{tabular}




\section{TABLE 29. Continued}

SEASOA - 1 ANNUAL 1

RELATIVE FUMIDITY

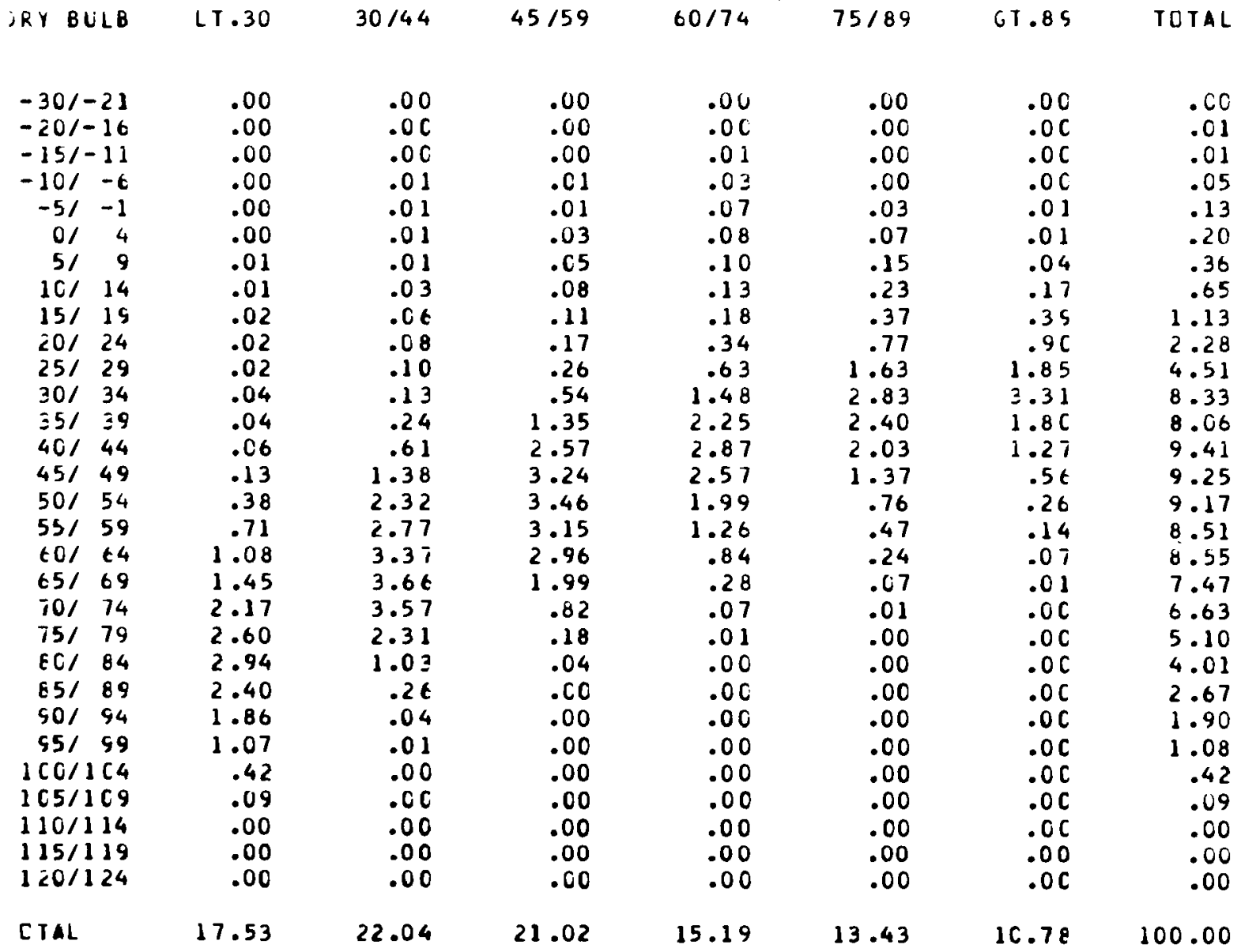


TABLE 30. Monthly Percent Frequency of Wet Bulb Temperature Category $\left({ }^{\circ} \mathrm{F}\right) 1955$ Through 1980

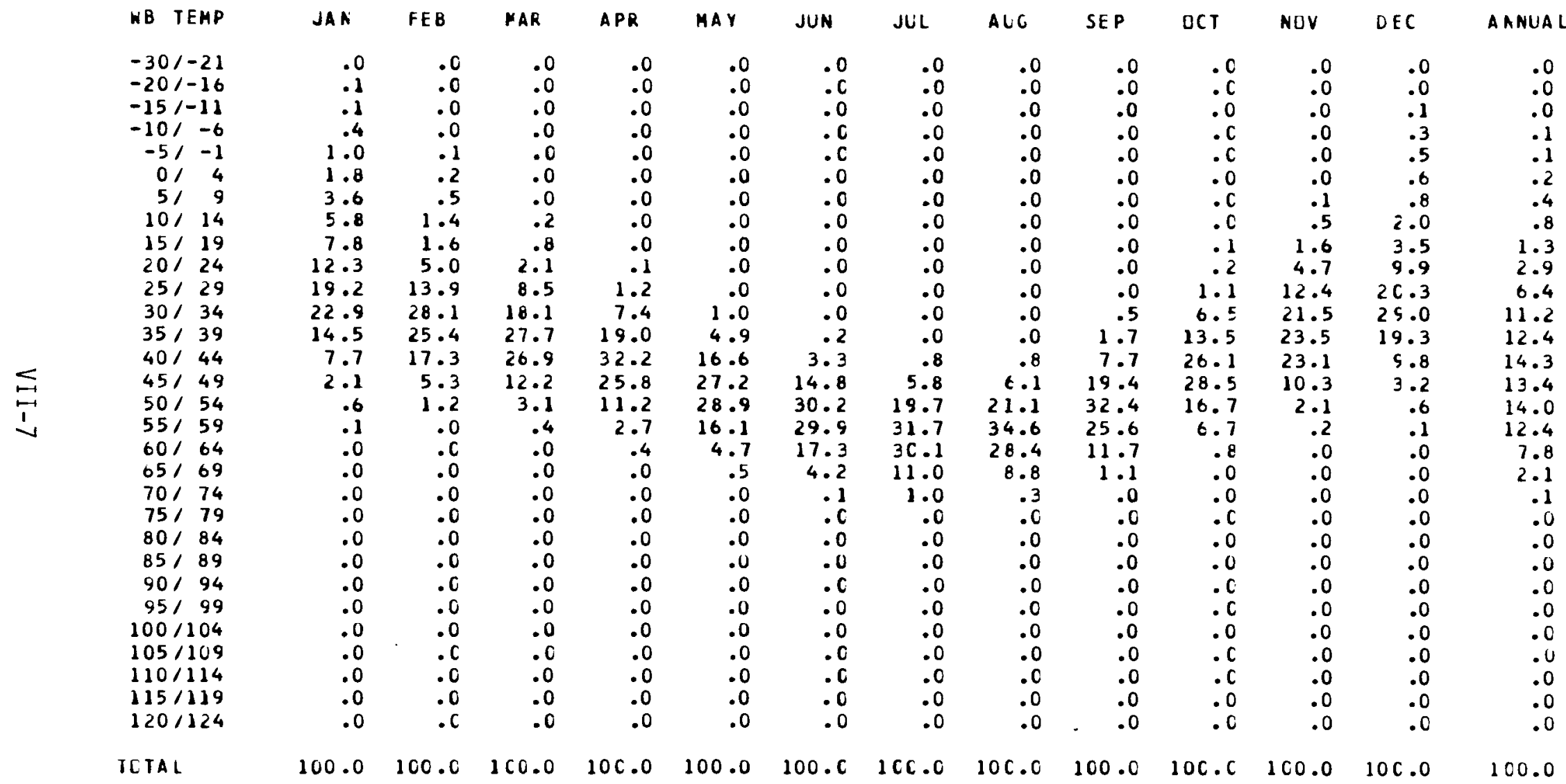



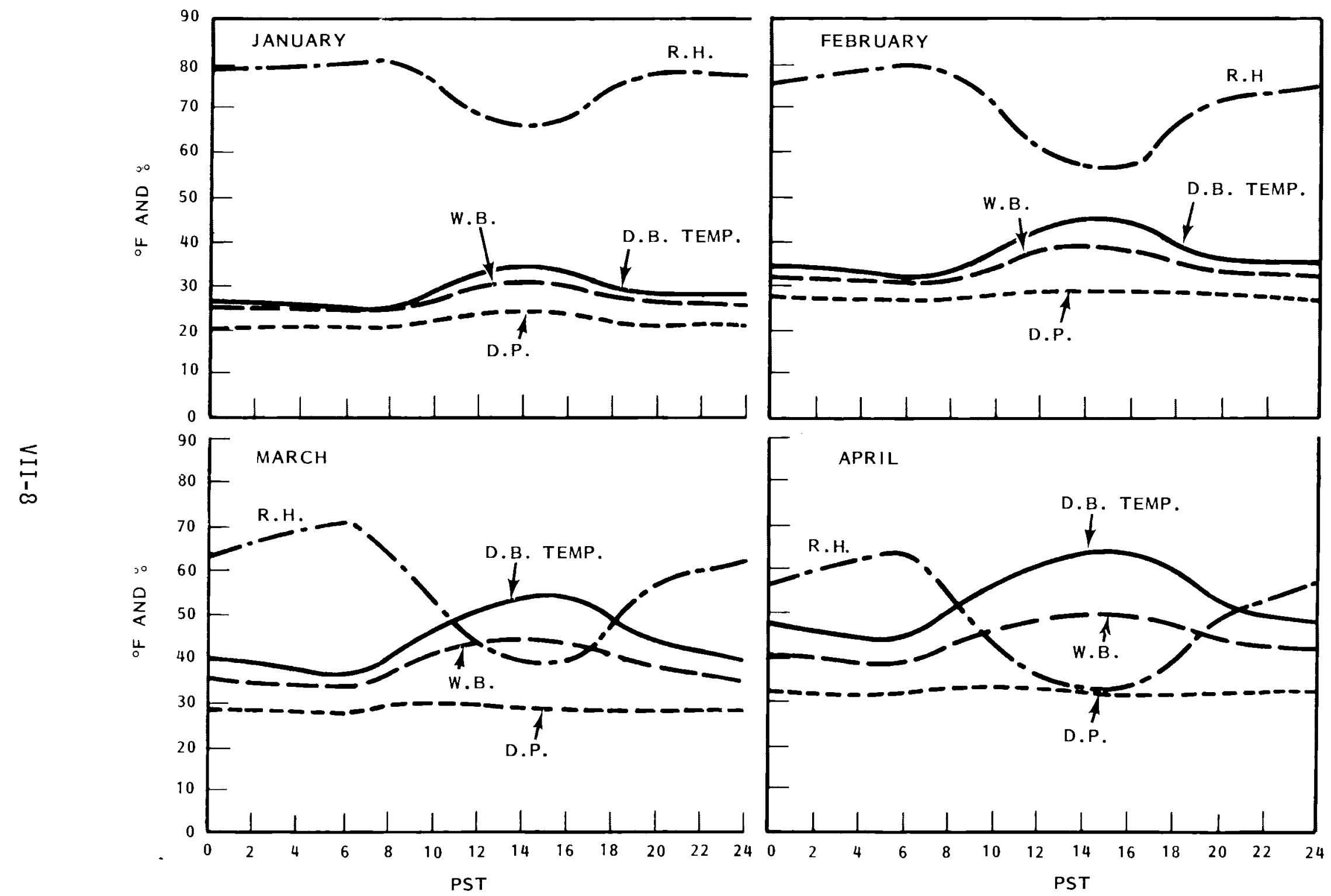

FIGURE 24. Monthiy and Annual Hourly Averages of Dry Bulb (D.B.) and Wet Bulb (W.B.) Temperature, Relative Humidity (R.H.), and Temperature of the Dew Point (D.P.) (1956 Through 1980) 

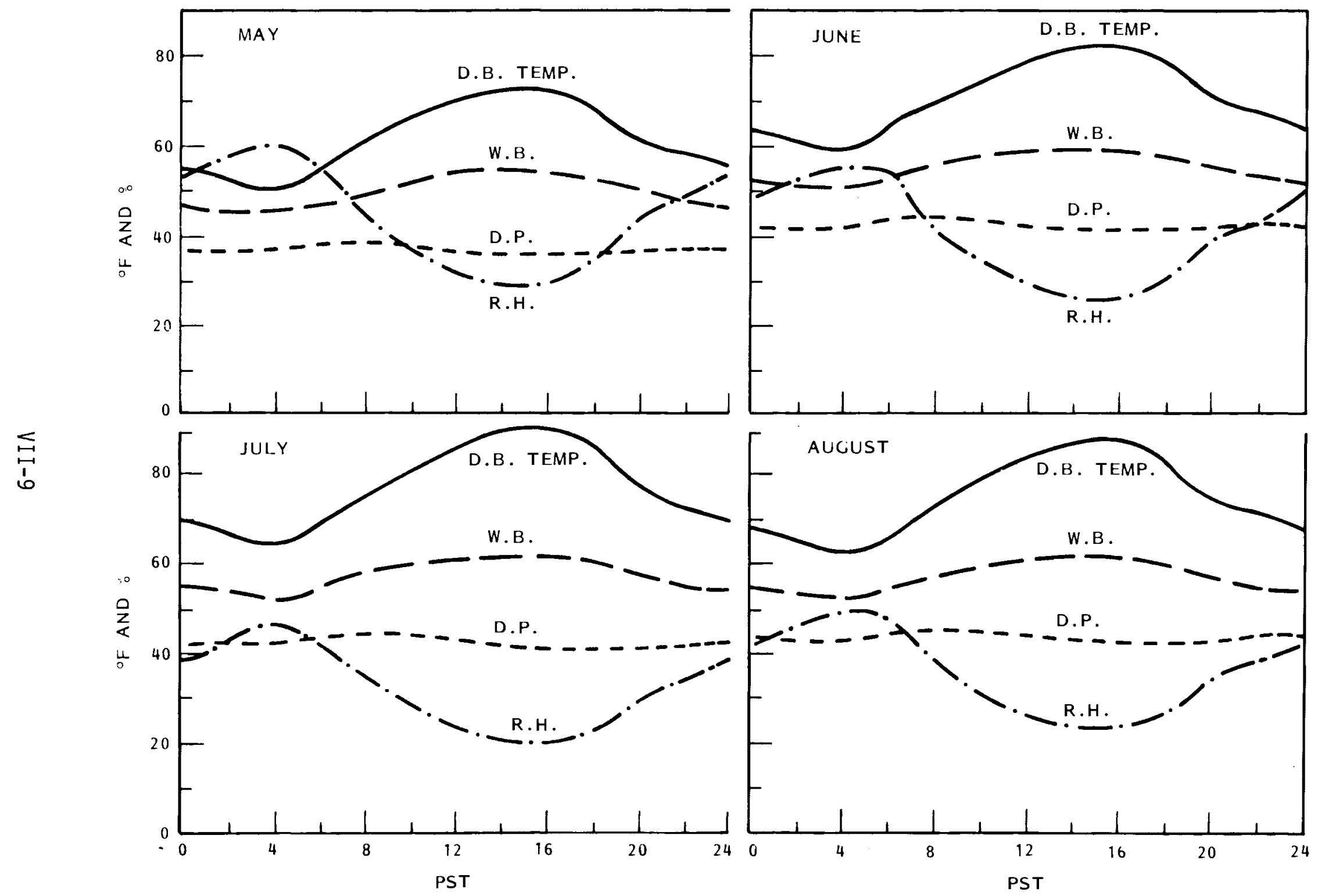

FIGURE 24. Continued 


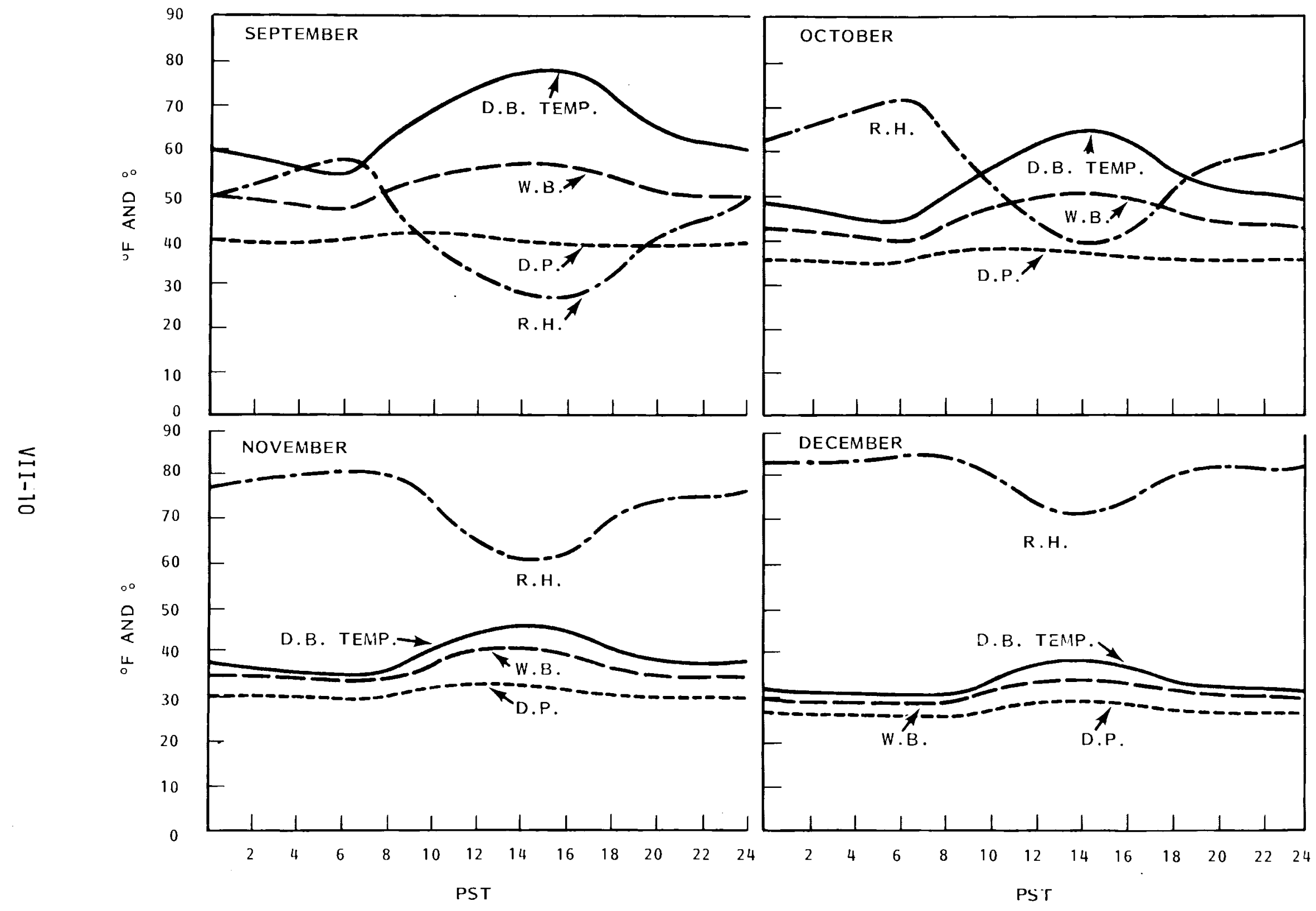

FIGURE 24. Continued 


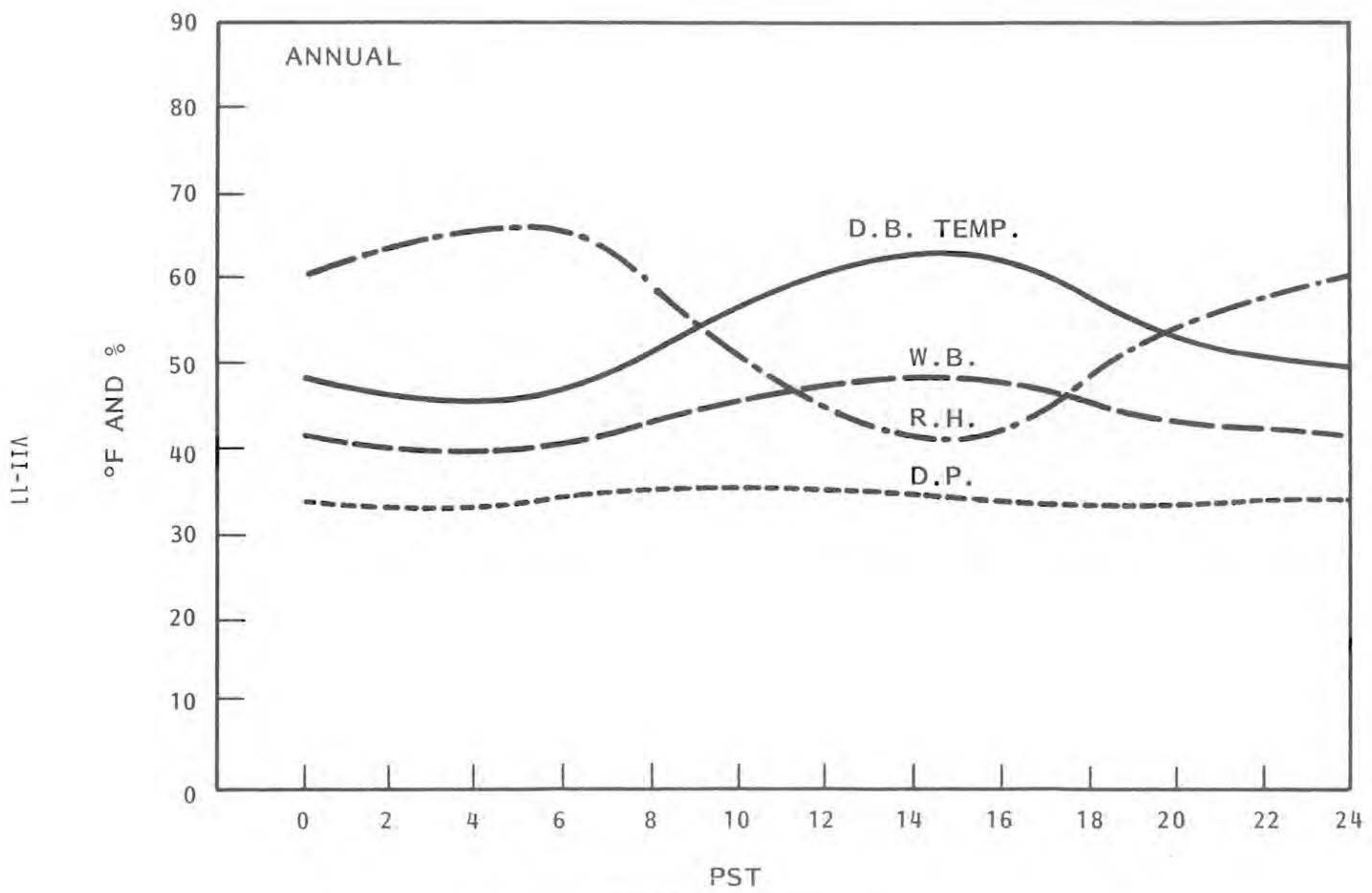

FIGURE 24. Continued 


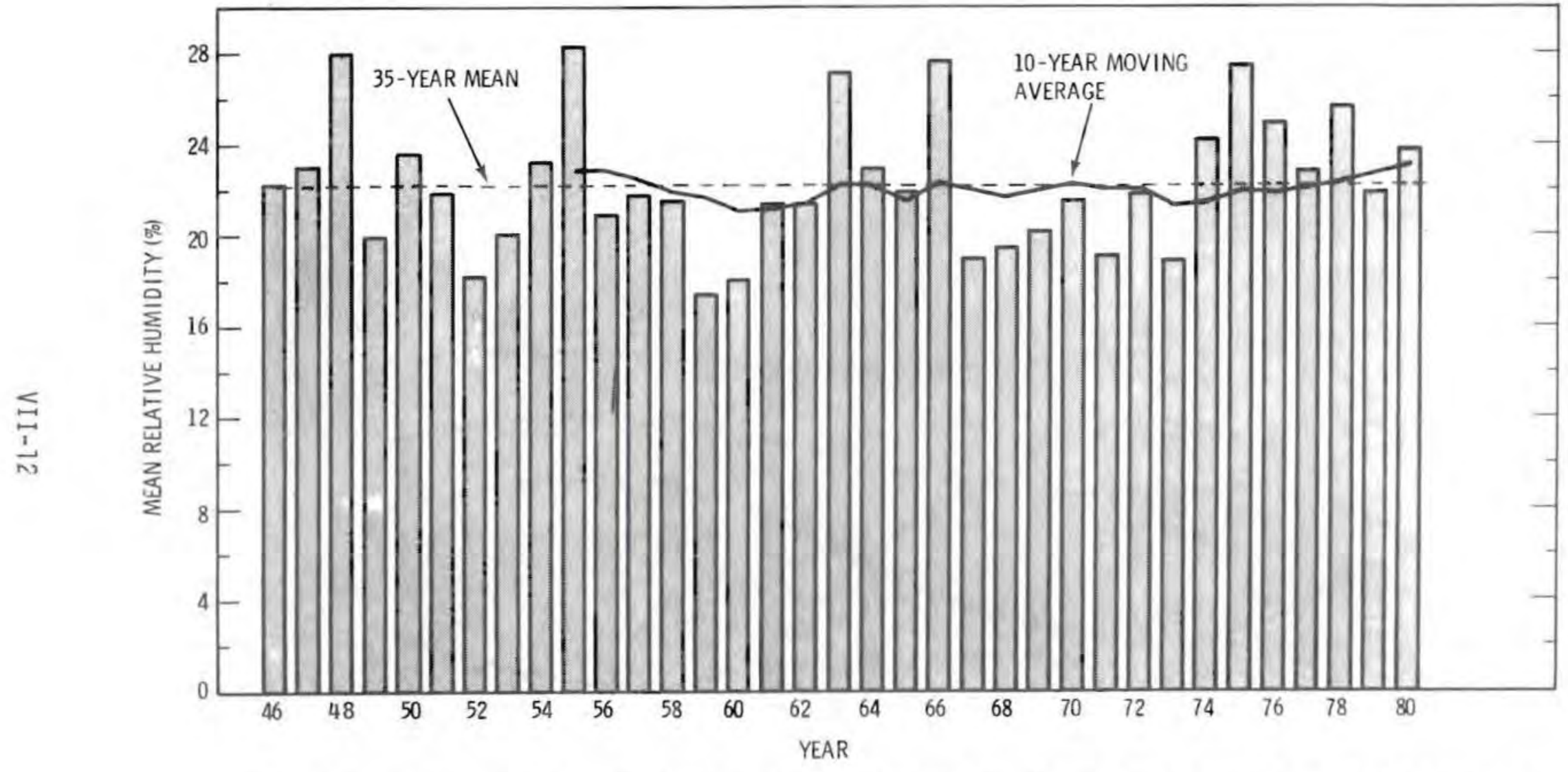

FIGURE 25. Mean Relative Humidity (\%) at 1300 PST in July: Each Year From 1946 to 1980 
temperature $\geq 75^{\circ} \mathrm{F}$ (not shown in Table 30 because the total was $<0.1 \%$ ). The average wet bulb temperature for the month was $62^{\circ} \mathrm{F}$ which is a record high for the period of record (1950-1980). 
.

.

.

. 
VIII. ATMOSPHERIC PRESSURE 


\section{ATMOSPHERIC PRESSURE}

Monthly averages of the hourly sea level and station pressures are summarized in millibars, inches of mercury $(\mathrm{Hg})$, and millimeters of mercury $(\mathrm{Hg})$ for the period of record 1955 through 1980. Station pressure is obtained from 6-hourly readings from a mercurial barometer and hourly observations from an aneroid barograph. Station pressure reduced to sea level is calculated hourly.

The atmospheric pressure averages are higher in the winter than in the summer. Both the absolute high and low records have occurred during the winter months. The extremes of sea level and station pressure are summarized in Table 31 (for the period 1950 through 1980). The diurnal ranges of sea level and station pressure are presented in Tables 32 through 37; sea level pressure is shown in Tables 32 through 34, and station pressure in Tables 35 through 37 .

Records have not been kept on the rate of pressure changes, but some information has been obtained from one memorable storm. As a frontal system approached the HMS on November 3, 1958, the pressure fall averaged 0.082 inch $\mathrm{Hg} /$ hour over a 6 -hour period. The maximum hourly fall was 0.160 inch $\mathrm{Hg}$. The rise for the same time period following the frontal passage averaged 0.090 inch of $\mathrm{Hg} /$ hour, and the maximum hourly rise was 0.145 inch $\mathrm{Hg}$. 
TABLE 31. Average and Extreme Station and Sea Level Pressure Data, 1950 Through 1980 (Units = Inches of Mercury)

STATION PRESSURE

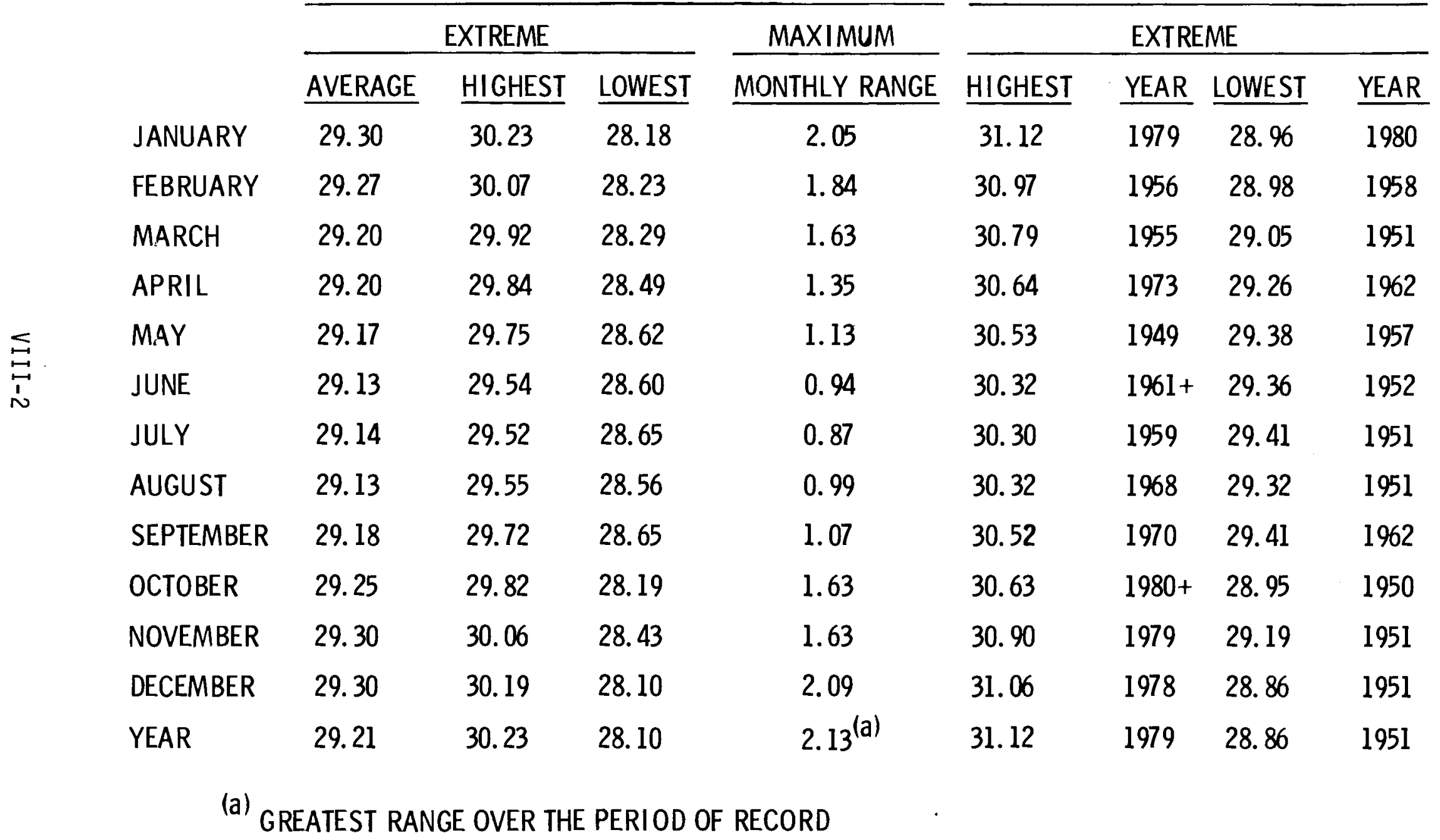


TABLE 32. Monthly Hourly Average Sea Level Pressure 1955 Through 1980 (Units = Mi11ibars)

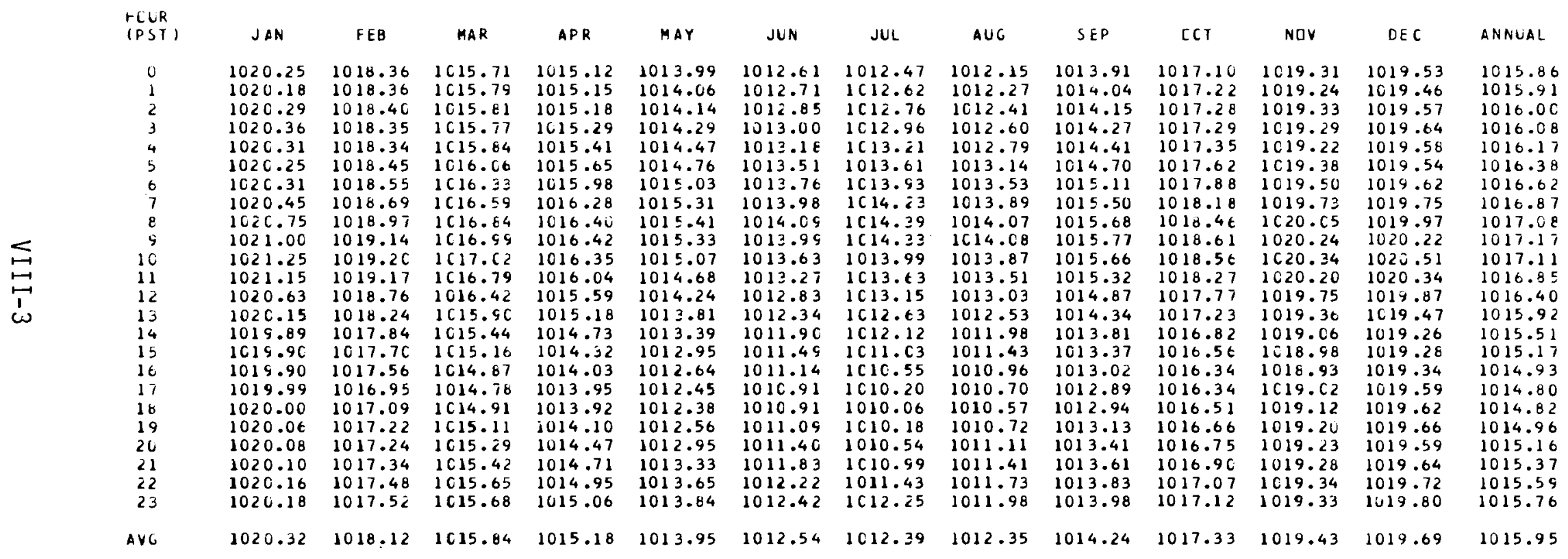


TABLE 33. Monthly Hourly Average Sea Level Pressure 1955 Through 1980 (Units = Inches of Mercury)

\begin{tabular}{|c|c|c|c|c|c|c|c|c|c|c|c|c|c|}
\hline $\begin{array}{l}\text { hLUR } \\
\text { (FST) }\end{array}$ & $J A A$ & FEB & MAR & APR & MAY & JLN & JUL & $\triangle U G$ & SEP & CCT & NOV & DEC & ANNCAL \\
\hline 0 & $3 c .13$ & $\equiv 0 . \mathrm{CT}$ & 29.59 & 29.98 & 29.94 & $29.9 \mathrm{C}$ & 29.90 & 29.89 & 29.94 & 30.03 & 30.10 & 30.11 & 30.00 \\
\hline 1 & 30.13 & 30.07 & $30 . \mathrm{CO}$ & 29.98 & 29.95 & 29.91 & 29.90 & 29.89 & 29.94 & 30.04 & 30.10 & 30.10 & 30.00 \\
\hline 2 & 30.13 & 30.07 & 30.60 & 29.98 & 29.95 & $29.9 i$ & 29.91 & 29.90 & 29.95 & 30.04 & 30.10 & 30.11 & 30.00 \\
\hline 3 & 20.13 & 30.07 & $30 . \mathrm{CC}$ & 29.98 & 29.95 & 29.91 & 29.91 & $29.9 \mathrm{C}$ & 29.95 & 20.04 & 30.10 & 30.11 & 30.00 \\
\hline 4 & 30.13 & 30.07 & 30.00 & 29.99 & 29.96 & 29.92 & 29.92 & 29.91 & 29.96 & $\Xi 0.04$ & 30.10 & 30.11 & 30.01 \\
\hline s & 30.13 & 30.07 & 30.00 & 29.99 & 29.97 & 25.93 & 29.93 & 29.92 & 29.96 & 20.05 & 30.10 & 30.11 & 30.01 \\
\hline 6 & 30.13 & 30.08 & 30.01 & 30.00 & 25.97 & 29.94 & 29.94 & 29.93 & 29.98 & 30.06 & 30.11 & 30.11 & 30.02 \\
\hline 7 & $3 c .13$ & 30.08 & 30.02 & 30.01 & 25.98 & 29.94 & 29.95 & 29.94 & 29.99 & 36.07 & 30.11 & 30.11 & 30.03 \\
\hline 8 & 30.14 & 30.09 & 30.03 & 30.01 & 29.99 & 25.95 & 29.95 & 29.95 & 29.99 & $\equiv 0.08$ & 30.12 & 30.12 & 30.03 \\
\hline 5 & 30.15 & $20.1 \mathrm{C}$ & $30 \cdot[3$ & 30.01 & 29.98 & 29.94 & 29.95 & 29.95 & 30.00 & 20.08 & 30.13 & 30.13 & 30.04 \\
\hline 10 & 30.16 & 30.10 & 30.03 & 30.01 & 29.97 & $29.9 \equiv$ & 29.54 & 29.94 & 25.59 & $\equiv 0.08$ & 30.13 & 30.14 & 30.04 \\
\hline 11 & $3 c .15$ & $3 \mathrm{C} .1 \mathrm{C}$ & 30.6 & 30.00 & 29.96 & 25.92 & 29.93 & 29.93 & 29.98 & 30.07 & 30.13 & 30.13 & 30.03 \\
\hline 12 & $3 C .14$ & $\approx 0.66$ & $30 . C_{1}$ & 29.99 & 25.95 & 25.91 & $25.5 z$ & 29.91 & 29.97 & $\Xi 0.05$ & 30.11 & 30.12 & 30.01 \\
\hline 13 & $=c .13$ & 20.07 & $30 . C C$ & 29.98 & 29.94 & 25.89 & 29.90 & 29.90 & 29.95 & $\equiv 0.04$ & 30.10 & 30.10 & $20.0 \mathrm{C}$ \\
\hline 14 & $3 C .12$ & $20.0 t$ & 29.59 & 29.96 & 29.93 & 25.88 & ¿S.ES & 29.88 & 29.94 & $\Xi 0.03$ & 30.69 & 30.10 & 29.95 \\
\hline 12 & 30.12 & 30.05 & 29.98 & 29.95 & 29.91 & 29.87 & 29.86 & 29.87 & 29.92 & 36.02 & 30.05 & 30.10 & 29.98 \\
\hline 16 & 30.12 & 30.05 & 29.57 & 29.94 & 29.90 & $29.8 t$ & 29.84 & 29.85 & 29.91 & $\equiv 0.01$ & 30.09 & 30.10 & 29.97 \\
\hline 17 & 30.12 & 30.03 & 29.57 & 29.94 & 29.90 & 29.85 & 29.83 & 29.85 & 29.91 & 30.01 & 30.09 & 30.11 & 29.97 \\
\hline 18 & 30.12 & $30 . C \equiv$ & 29.57 & 29.54 & 25.90 & 25.85 & 29.83 & 29.84 & 29.91 & 30.02 & $30 . c 9$ & 30.11 & 29.97 \\
\hline 19 & 32.12 & 30.04 & 29.58 & 29.95 & 29.90 & 25.86 & 29.83 & 29.85 & 29.92 & $\Xi 0.02$ & 30.10 & 30.11 & 29.97 \\
\hline 20 & $3 c .12$ & $\equiv C_{0} \mathrm{C}_{4}$ & 29.98 & 29.96 & 29.91 & 29.87 & 29.84 & 29.86 & 29.93 & 30.02 & 30.10 & 30.11 & $<9.98$ \\
\hline 21 & 36.12 & 30.04 & 29.99 & 29.96 & 29.92 & 29.88 & 29.85 & 29.87 & 29.93 & 30.03 & 30.10 & 30.11 & 29.98 \\
\hline$<2$ & 30.13 & 30.05 & 29.59 & 29.97 & 29.93 & 29.85 & 29.87 & 29.88 & 29.94 & 30.03 & 30.10 & 30.11 & 29.99 \\
\hline 23 & 30.13 & 30.05 & 29.99 & 29.97 & 29.94 & $29.9 C$ & 29.89 & 29.88 & 29.94 & 30.04 & 30.10 & 30.11 & 30.00 \\
\hline AVG & 30.13 & 30.07 & $30 . \mathrm{CO}$ & 29.98 & 29.94 & $29.9 \mathrm{C}$ & 29.90 & 29.89 & 29.95 & 20.04 & 30.10 & 30.11 & 30.00 \\
\hline
\end{tabular}


TABLE 34. Monthly Hourly Average Sea Leve1 Pressure 1955 Through 1980 (Units $=$ Millimeters of Mercury)

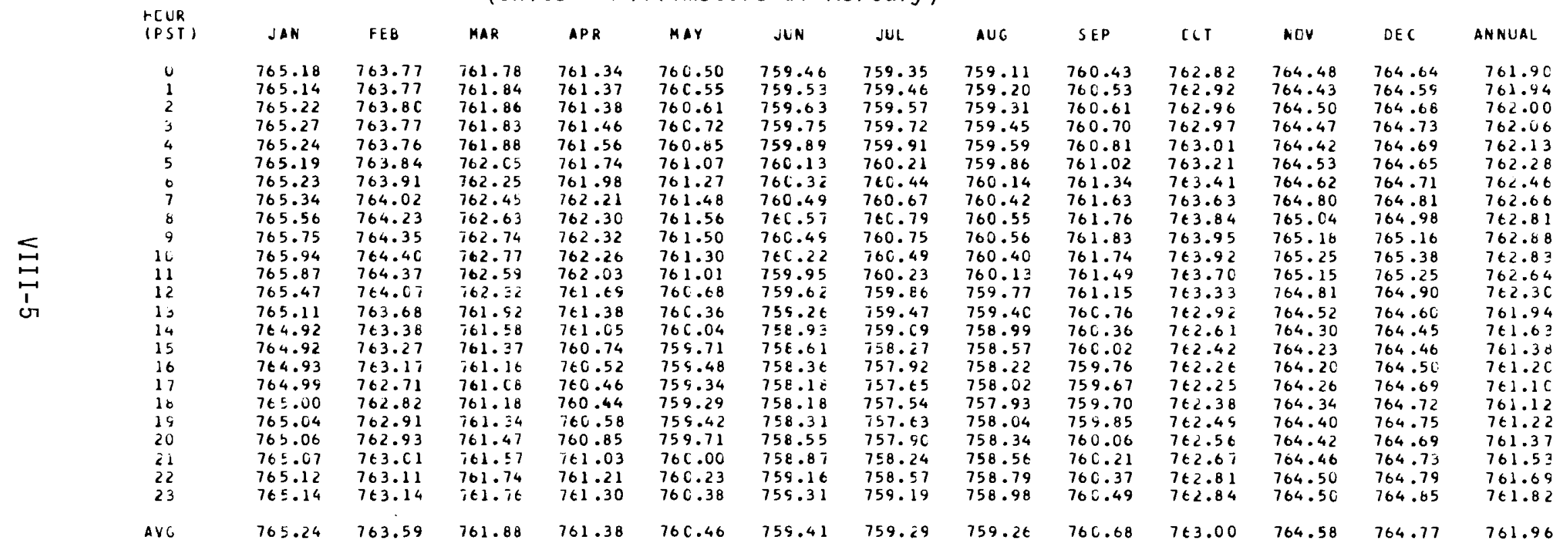


TABLE 35. Monthly Hourly Average Station Pressure 1955 Through 1980 (Units = Millibars)

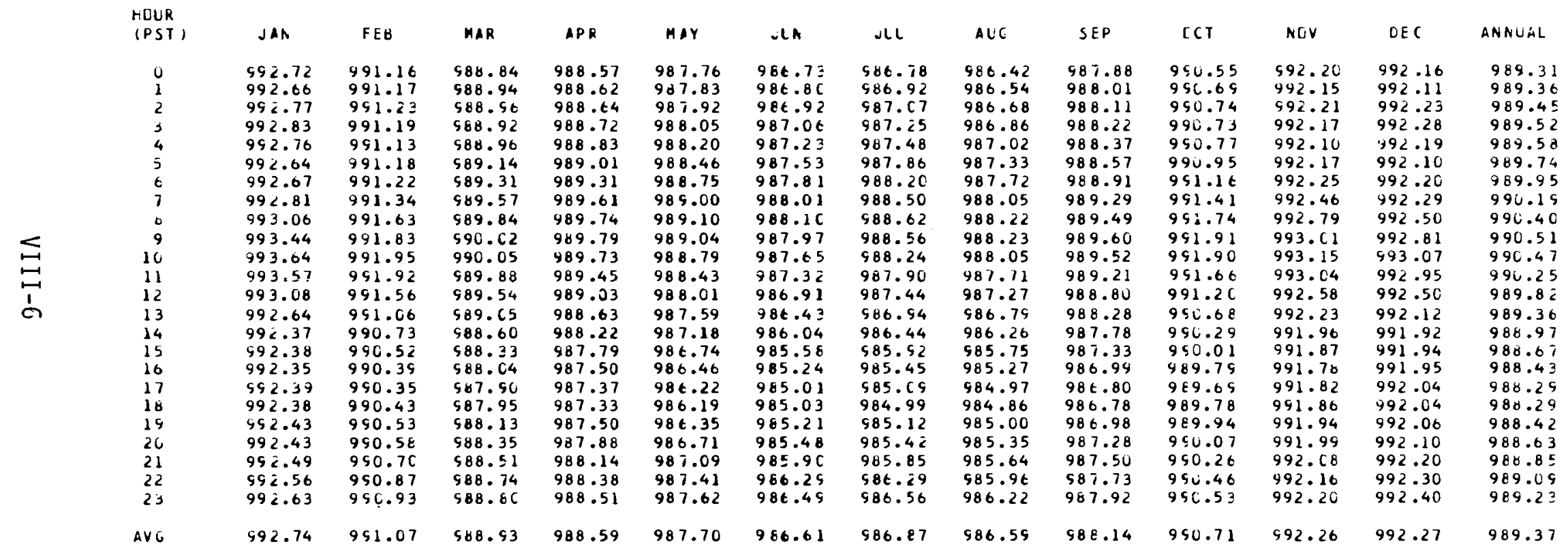


TABLE 36. Monthly Hourly Average Station Pressure 1955 Through 1980

JAN
29.32
29.31
29.32
29.32
29.32
29.31
29.31
25.32
29.33
25.34
29.34
29.34
29.33
29.31
29.30
29.31
25.30
29.31
25.31
29.31
29.31
29.31
29.31
29.31
29.32

FEB
29.27
29.27
29.27
29.27
29.27
29.27
29.27
29.27
29.28
29.29
29.29
29.29
29.28
29.27
29.26
29.25
29.25
29.25
29.25
29.25
29.25
29.26
29.26
29.21
29.27

MAR

\subsection{0}

$29.2 \mathrm{C}$

$29.2 \mathrm{C}$

29.20

29.21

29.21

29.22
29.23

29.24

29.24

29.23
29.22

29.21

29.19

29.18

29.17

29.17

29.18

29.19

29.20
29.20

$29.2 \mathrm{C}$ (Units = Inches of Mercury)

\subsection{9} 29.19

$$
29.19
$$$$
29.20
$$$$
29.20
$$$$
29.21
$$$$
29.21
$$$$
\begin{aligned}
& 29.22 \\
& 29.23
\end{aligned}
$$$$
\begin{array}{r}
29.23 \\
29.23
\end{array}
$$

29.23
29.23

29.23
29.22

29.21
29.19

29.19
29.18

29.18
29.17

29.16

29.16

29.16
29.16

29.16
29.17
29.18

29.19

25.17

$\begin{array}{ll}\text { JUN } & \text { JUL } \\ 29.14 & 29.14 \\ 29.14 & 29.14 \\ 29.14 & 29.15 \\ 25.15 & 29.15 \\ 29.15 & 29.16 \\ 29.14 & 29.17 \\ 29.17 & 29.18 \\ 29.18 & 29.19 \\ 29.18 & 29.19 \\ 29.17 & 29.19 \\ 29.17 & 29.18 \\ 29.14 & 29.17 \\ 29.14 & 29.16 \\ 29.13 & 29.14 \\ 29.12 & 29.13 \\ 29.10 & 29.11 \\ 29.09 & 29.16 \\ 29.09 & 29.09 \\ 29.05 & 29.19 \\ 29.09 & 29.19 \\ 29.16 & 29.10 \\ 25.11 & 29.11 \\ 25.13 & 29.13 \\ 29.13 & 29.13 \\ 2911 & \\ 29.19 & 29.14\end{array}$

25.13

\begin{abstract}
AUG
\end{abstract}
29.13
29.13 29.13
29.14 29.14 29.14
29.15 29.16 29.17 29.18 29.18
29.18 29.18 29.17 29.17 29.14 29.12 29.11 $29.1 \mathrm{C}$ 29.09 29.08 29.09 29.10 29.11 29.12
29.12

29.13

ICT

29.25
29.26
29.26
29.26
29.26
29.26
29.27
29.28
29.29
29.29
29.29
29.28
29.27
29.25
29.24
29.24
29.23
29.23
29.22
29.23
29.24
29.24
29.25
29.25
29.26

NOV
29.30
29.30
29.30
29.30
29.30
29.30
29.30
29.21
29.31
29.32
29.33
29.32
29.31
29.30
29.29
29.29
29.29
29.29
29.29
29.29
29.29
29.30
29.30
29.30
29.30

$29.2 t$
DEC

29.30 29.30

29.30

29.30

29.30

29.30

29.30

29.30

29.3

29.32
29.33

29.3

29.32
29.31

29.30

29.29

29.29

29.29

29.29

29.30

29.30

29.30

29.30

29.30

29.31

29.30
ANNUAL

29.21 29.22 29.22 29.2 29.22 29.23 29.24

29.25

29.25

29.24

29.23

29.22

29.20

29.20

29.19

29.18

29.19

29.19

29.20

29.21

29.22 
TABLE 37. Monthly Hourly Average Station Pressure 1955 Through 1980 (Units = Millimeters of Mercury)

\begin{tabular}{|c|c|c|c|c|c|c|c|c|c|c|c|c|c|c|}
\hline & $\begin{array}{l}r[U R \\
\text { (FST) }\end{array}$ & $\therefore A$ & FEU & MAR & $A P R$ & MAY & JUN & JUL & $A \cup C$ & SEP & $\mathrm{CCT}$ & NOV & DEC & ANNUAL \\
\hline & c & 744.54 & 743.37 & 741.63 & 741.43 & 74 し.82 & 740.05 & 740.09 & 739.81 & 740.91 & 742.92 & 744.15 & 744.12 & 741.98 \\
\hline & $\mathrm{i}$ & 744.50 & 743.38 & 741.71 & 741.46 & 740.87 & 740.10 & 740.19 & 739.90 & 741.01 & 743.02 & 744.11 & 744.09 & 742.02 \\
\hline & 2 & 744.58 & $743.4 \mathrm{z}$ & 741.72 & 741.48 & 740.94 & 740.15 & 740.30 & 740.01 & 741.08 & 743.05 & 744.16 & 744.16 & 742.09 \\
\hline & 3 & 744.62 & 743.39 & 741.69 & 741.54 & 741.04 & $74 c .25$ & 740.44 & 740.15 & 741.16 & 743.05 & 744.13 & 744.21 & 742.14 \\
\hline & 4 & 744.57 & 743.35 & 741.72 & 741.62 & 741.15 & 746.42 & 740.61 & 740.26 & 741.28 & 743.08 & 744.67 & 744.14 & $742.1 \varepsilon$ \\
\hline & b & 744.48 & 743.38 & 741.85 & 741.76 & 741.34 & 740.65 & 740.89 & 740.50 & 741.43 & 743.22 & 744.13 & 744.08 & 742.30 \\
\hline & $c$ & $744.5 \mathrm{C}$ & $743.4 \pi$ & 741.58 & 741.98 & 741.56 & $740.8 t$ & 741.15 & 740.79 & 741.68 & 743.37 & 744.15 & 744.15 & 742.47 \\
\hline & 7 & 744.60 & 743.51 & 742.18 & 742.20 & 741.75 & 741.01 & 741.38 & 741.04 & 741.96 & 743.56 & 744.35 & 744.22 & 742.64 \\
\hline & 0 & 744.80 & 743.72 & 742.38 & 742.31 & 741.83 & 741.07 & 741.47 & 741.16 & 742.11 & 743.81 & 744.59 & 744.37 & $742.8 \mathrm{C}$ \\
\hline & $\xi$ & 745.08 & 743.87 & 742.51 & 742.34 & 741.78 & 740.98 & 741.42 & 741.18 & 742.20 & 743.93 & 744.76 & 744.61 & 742.88 \\
\hline & 10 & 745.23 & 743.97 & 742.54 & 742.30 & 741.59 & $74 C .74$ & 741.18 & 741.04 & 742.14 & 743.93 & 744.87 & 744.80 & 742.85 \\
\hline & 11 & 745.18 & 743.94 & 742.41 & 742.09 & 741.32 & 740.49 & 740.92 & 740.79 & 741.91 & 743.75 & 744.78 & 744.71 & 742.69 \\
\hline & 12 & 744.81 & 743.67 & 742.15 & 741.77 & 741.01 & $74 i .16$ & 740.58 & 740.45 & 741.60 & 743.40 & 744.44 & 744.38 & 742.30 \\
\hline & 1) & 744.48 & 743.30 & 741.79 & 741.47 & 740.69 & 139.83 & 740.20 & 740.09 & 741.21 & 743.01 & 744.17 & 744.09 & 742.02 \\
\hline & 14 & 744.28 & 743.04 & 741.45 & 741.16 & 740.38 & 739.53 & 739.83 & 739.69 & 740.84 & 742.72 & 743.97 & 743.94 & 741.73 \\
\hline & 15 & 744.29 & 742.89 & 741.25 & 740.84 & 740.06 & 739.19 & 739.44 & 739.31 & 740.50 & 742.51 & 743.50 & $743.9 b$ & 741.51 \\
\hline & 16 & 744.26 & 742.79 & 741.03 & 740.62 & 739.85 & 738.93 & 739.08 & 738.95 & 740.24 & 742.34 & 743.84 & 743.96 & 741.32 \\
\hline & 17 & 744.29 & 742.76 & 740.92 & 740.53 & 739.66 & $738.7 t$ & $738.8 \hat{c}$ & 738.73 & 740.10 & 742.27 & 743.86 & 744.03 & 741.22 \\
\hline & 18 & 744.29 & 742.82 & 740.56 & 140.49 & 739.64 & 738.77 & 738.74 & 738.64 & 740.08 & 742.34 & 743.90 & 744.03 & 741.22 \\
\hline & 14 & 744.32 & 742.96 & 741.10 & 740.66 & 735.76 & 738.91 & 738.64 & 738.75 & $74 C .24$ & 742.46 & 743.56 & 744.04 & 741.32 \\
\hline & 20 & 744.33 & 742.93 & 741.26 & 740.91 & 740.03 & 739.11 & 739.67 & 739.01 & 740.46 & 742.56 & 743.99 & 744.07 & 741.47 \\
\hline & 21 & 744.37 & 743.63 & 741.38 & 741.11 & $74 C .32$ & 735.43 & 739.39 & 739.23 & 740.63 & 742.69 & 744.16 & 744.15 & 741.64 \\
\hline & 22 & 744.42 & 743.15 & 741.56 & 741.28 & $74 c .56$ & 739.72 & 739.72 & 739.47 & $74 \mathrm{C} .80$ & 742.84 & 744.12 & 744.23 & 741.82 \\
\hline & $2=$ & 744.48 & $743.2 \mathrm{C}$ & $741 . t C$ & 741.38 & $74 C .71$ & 735.87 & 739.92 & $739.6 t$ & 740.94 & $742.9 \mathrm{C}$ & 744.15 & 744.30 & 741.92 \\
\hline & Arc & 744.55 & 743.30 & 741.70 & 741.45 & $74 C .78$ & $7 \approx 5.9 t$ & $74 C .15$ & 739.94 & 741.10 & $743.0 \pm$ & 744.19 & 744.20 & 742.03 \\
\hline
\end{tabular}


IX. MISCELLANEOUS PHENOMENA 


\section{MISCELLANEOUS PHENOMENA}

The different meteorological phenomena and the number of days per month and year that each occurs at the HMS are presented in Table 38 .

\section{THUNDERSTORMS}

A thunderstorm day is one in which thunder is heard at the observing station one or more times in a calendar day. If a thunderstorm begins just before midnight, it is possible to have two thunderstorm days from a single storm.

Table 38 shows that thunderstorms have occurred in every month except January and November; however, on January 18, 1953, one occurred in Richland which is about 25 miles southeast of the HMS. The thunderstorm season essentially is April through September. The average number of thunderstorm days per year is 10 , but the total has varied from 3 in 1949 to 23 in 1948. The record monthly total is 8 and has occurred 3 times: in June 1948, August 1953 and June 1972.

See Appendix II for additional information about thunderstorms.

HAIL

Hail is seldom observed at the HMS. Two days with hail in any year is the maximum recorded. Hail is associated with thunderstorms in most cases.

The most unseasonable hailstorms occurred on January 25,1953 , February 22, 1962 (with thunder), and December 22, 1971 (with thunder) when hail occurred in Richland but not at the HMS.

\section{DUST AND BLOWING DUST}

The criterion for both of these phenomena is that horizontal visibility be reduced to 6 miles or less. Dust is carried into the area from a distant source and may occur with little wind. Blowing dust occurs when dust is being picked up locally and occurs with stronger winds. Both dust and blowing dust occur at the HMS but in most cases it is blowing dust. 
TABLE 38. Average Number of Days of Various Meteorological Phenomena at the HMS (1945 Through 1980)

\begin{tabular}{|c|c|c|c|c|c|c|c|c|c|c|c|c|c|}
\hline PHENOMENON & $\mathrm{J}$ & $F$ & $M$ & A & M & $J$ & $\mathrm{~J}$ & A & $\mathrm{S}$ & 0 & $\mathrm{~N}$ & D & $Y$ \\
\hline HUNDERSTORM & 0 & \# & \# & 1 & 2 & 2 & 2 & 2 & 1 & \# & 0 & \# & 10 \\
\hline HAIL & \# & \# & \# & \# & \# & \# & \# & \# & \# & 0 & 0 & 0 & $1 *$ \\
\hline$O R B^{(1)}$ & $\#$ & \# & 1 & 1 & 1 & \# & 1 & \# & 1 & $\#$ & \# & $\#$ & 5 \\
\hline OG (2) & 10 & 6 & 2 & \# & \# & \# & $\#$ & \# & \# & 2 & 9 & 13 & 42 \\
\hline OOG, DENSE (3) & 6 & 3 & 1 & \# & \# & \# & 0 & \# & \# & 1 & 6 & 8 & 25 \\
\hline LAZE & 2 & 1 & \# & 0 & 0 & 0 & 0 & 0 & 0 & 0 & 1 & 2 & 6 \\
\hline NARM FRONT & 2 & 2 & 1 & \# & $\#$ & 0 & 0 & 0 & \# & 1 & 2 & 2 & 10 \\
\hline COLD FRONT & 4 & 4 & 5 & 5 & 5 & 4 & 4 & 4 & 4 & 5 & 4 & 4 & 52 \\
\hline
\end{tabular}

1. DUST OR BLOWING DUST

2. ALL FOG WITH VISIBILITY $₹ 6$ MILES

3. VISIBILITY $=1 / 4$ MILE

\# LESS THAN 1/2 DAY

* ALTHOUGH THE AVERAGE IS LESS THAN 1/2 DAY FOR ANY SINGLE MONTH, THERE HAVE BEEN 29 DAYS WITH HAIL IN 34 YEARS OF RECORD FOR AN AVERAGE ANNUAL NUMBER OF 1. 
Blowing dust has occurred with wind speeds ranging from 19 to $80 \mathrm{mph}$, while the speed range has been from 4 to $30 \mathrm{mph}$ when dust has been observed. An unusual case of dust occurred on September 13, 1950, when dust obscured the sky, and restricted visibility to a range of $5 / 16$ to 3 miles, during 5 consecutive hours. The hourly wind speeds ranged from 4 to $9 \mathrm{mph}$ during the period.

Observations of dust or blowing dust may occur with any wind direction, however, the strongest winds at the HMS are from the southwest and therefore there are more cases of blowing dust from that direction. Dust most often is associated with winds from the north and northeast.

$\underline{\text { ASH }}$

On May 18, 1980, Mount St. Helens, a volcano 135 miles west of the Hanford area, erupted. The upper 2500 feet of the 9,677-foot mountain were blown off in the initial explosion. Pulverized rock and ash were carried eastward, covering the area with an ash cloud and falling ash. The falling ash reduced visibility to less than 6 miles from 1100 on May 18 until 0100 on May 19. From then until 2100 on May 21 (except for the hours 1300 and 1400 on May 20) visibility continued less than 6 miles due to dust and ash. Ceilings as low as 600 feet and visibilities down to $3 / 16$ mile were recorded during that time. Surface winds were generally light during the entire period; however, there were a few gusts in the 20 to $30 \mathrm{mph}$ range on the 19 th and $21 \mathrm{st}$.

FOG

Fog has occurred in every month of the year; however, $95 \%$ of the occurrences are during the months of November, December, January and February. Less than 1\% occurs during the months April through September. Table 39 summarizes the statistics on fog at the HMS.

Most fog at the HMS is of the radiation type and occurs during periods of low wind speeds. See Table 23, Section V, page 13 . 
TABLE 39. Total Duration* and Maximum Persistence of Fog

Tabulated in Hours for the Period 1945 Through 1980 (1)

\begin{tabular}{|c|c|c|c|c|c|c|c|c|}
\hline $\begin{array}{c}\text { ALL FOG } \\
\text { (VIS } 0-6 \text { MILES) }\end{array}$ & $\begin{array}{l}\text { AVG TOTAL } \\
\text { DURATION } \\
\end{array}$ & $\begin{array}{l}\text { MAX TOTAL } \\
\text { DURATION } \\
\end{array}$ & YEAR & $\begin{array}{l}\text { MIN TOTAL } \\
\text { DURATION } \\
\end{array}$ & YEAR & $\begin{array}{l}\text { AVG DURATION PER } \\
\text { DAY OF OCCURRENCE }\end{array}$ & MAX. PERSISTENCE (4) & YEAR \\
\hline JAN & 88.4 & 317.5 & 1979 & 0 & 1949 & 7.8 & 89.4 & 1977 \\
\hline FEB & 39.1 & 206.2 & 1963 & 0 & 1967 & 5.7 & 58.0 & 1963 \\
\hline MAR & 6.4 & 35.1 & 1978 & 0 & $1968+$ & 3.3 & 14.8 & 1978 \\
\hline APR & 0.4 & 4.2 & 1975 & 0 & $1980+$ & 1.5 & 3.2 & 1975 \\
\hline MAY & 0.3 & 2.7 & 1958 & 0 & $1980+$ & 1.3 & 2.7 & 1958 \\
\hline JUNE & 0.2 & 4.8 & 1971 & 0 & $1979+$ & 1.9 & 2.2 & 1980 \\
\hline JULY & $\because$ & 0.7 & 1966 & 0 & $1980+$ & 0.7 & 0.7 & 1966 \\
\hline AUG & 0.2 & 3.3 & 1978 & 0 & $1980+$ & 1.8 & 3.0 & 1978 \\
\hline SEPT & 0.4 & 5.5 & 1957 & 0 & $1979+$ & 2.1 & 2.9 & 1977 \\
\hline OCT & 9.6 & 82.4 & 1980 & 0 & $1978+$ & 4.5 & 39.0 & 1962 \\
\hline NOV & 64.1 & 168.5 & 1979 & 1.0 & 1960 & 6.4 & 65.4 & 1963 \\
\hline $\mathrm{DEC}$ & 118.2 & 248.2 & 1976 & 6.5 & 1968 & 8.6 & 83.2 & 1980 \\
\hline YEAR & 327.3 & $746.3^{(2)}$ & $1979-80$ & $147.7^{(3)}$ & $1948-49$ & 7.0 & 89.4 & $1976-77$ \\
\hline
\end{tabular}

DENSE FOG

(VIS I/4 MI OR LESS)

\begin{tabular}{|c|c|c|c|c|c|c|c|c|}
\hline JAN & 22.7 & 92.5 & 1976 & 0 & 1949 & 3.5 & 16.4 & 1976 \\
\hline FEB & 11.9 & 86.7 & 1963 & 0 & $1977+$ & 3.6 & 24.8 & 1980 \\
\hline MAR & 1.4 & 7.8 & 1949 & 0 & $1980+$ & 2.0 & 5.0 & $1 \% 61$ \\
\hline APR & 0.1 & 1.9 & 1975 & 0 & $1980+$ & 1.8 & 0 & $\ldots$ \\
\hline MAY & $\#$ & 1.6 & 1958 & 0 & $1980+$ & 1.6 & 1.6 & 1958 \\
\hline JUNE & $\#$ & 0.5 & 1971 & 0 & $1980+$ & 0.5 & 0.5 & 1971 \\
\hline JULY & 0 & 0 & -... & 0 &...- & 0 & 0 & - \\
\hline AUG & $\#$ & 1.0 & 1959 & 0 & $1980+$ & 1.0 & 0.7 & 1959 \\
\hline SEPT & 0.1 & 3.2 & 1957 & 0 & $1980+$ & 2.1 & 1.4 & 1957 \\
\hline OCT & 3.9 & 36.5 & 1980 & 0 & $1978+$ & 3.5 & 15.8 & 1962 \\
\hline NOV & 21.4 & 71.4 & 1952 & 0 & 1960 & 3.5 & 20.6 & 1963 \\
\hline DEC & 43.2 & 119.8 & 1947 & 1.3 & 1968 & 5.3 & 47.0 & 1957 \\
\hline YEAR & 104.7 & $201.5^{(2)}$ & $1962-63$ & $36.7^{(3)}$ & $1977-78$ & 4.0 & 47.0 & $1957-58$ \\
\hline
\end{tabular}

* total duRation denOtes total number of hours and teNTHS IN WHICH fog IS OBSERVEd

DENOTES LESS THAN 0.05 HOUR

(1) DATA FOR JULY 1,1971 THROUGH JUNE 30,1974 MISSING

(2) DENOTES THE GREATEST NUMBER OF HOURS IN A SEASON

(3) DENOTES THE LEAST NUMBER OF HOURS IN A SEASON

(4) MAXIMUM PERSISTENCE OF DENSE FOG BASED ON THE PERIOD 1953-80 
Glaze (sometimes called silver thaw) is a coating of ice formed when rain or drizzle freezes on contact with any surface which has a temperature that is below freezing. During the HMS period of record 1947 to 1980, there have been an average of $6 \mathrm{glaze}$ days per year (Table 38). While many of these days cause little or no problem, some create major traffic hazards.

WARM AND COLD FRONTS

A warm front is a line of discontinuity formed when an advancing current of relatively warm air is replacing a retreating colder air mass. A cold front is a line of discontinuity along which a wedge of cold air is underrunning and displacing a warmer air mass.

During the period of record 1945 to 1980, an average of 10 warm fronts and 52 cold fronts passed the HMS each year. These averages have not changed significantly from those reported in an earlier work (Jenne and Kerns 1959).

Temperature changes have been quite large with frontal passages. Some of the data from frontal passages was presented by Stone, Jenne and Thorp (1972). It is not unusual for temperatures to rise or fall more than $10^{\circ} \mathrm{F}$ in a 15 -minute period following frontal passages.

\section{BLOWING AND DRIFTING SNOW}

Both of these are phenomena of wind-driven snow. They are distinguished by the fact that blowing snow restricts visibility to a height of at least 6 feet above the surface, while drifting snow does not. Falling snow is not a requisite condition for either phenomenon; however, both are dependent upon a quantity of dry, powdery snow on the ground, subfreezing temperatures, and sufficient wind to blow the snow about. This combination of meteorological events is rarely experienced at HMS and so blowing and drifting snow do not often occur.

In the period of record 1945 through 1980, the most memorable storm with blowing snow was that of February 4 and 5, 1948. There were 
5 inches of freshly fallen snow on the ground the evening of the 4 th when the wind began to increase from the north. During the 14-hour period of blowing snow the temperature ranged from $22^{\circ} \mathrm{F}$ to $30^{\circ} \mathrm{F}$ and the peak wind was from the NNE at $47 \mathrm{mph}$. No new snow was recorded, but dust was mixed with the blowing snow and visibility was reduced to 2 miles.

\section{DUST DEVILS}

A dust devil is a small column of whirling wind which may carry dust and debris several hundred feet into the air. The diameter may vary from a few feet to more than 100 feet.

Dust devils usually occur on sunny days with light winds. Sometimes the peak gust for a day occurs in conjunction with a dust devil. A characteristic of those which have hit the meteorology tower is that the peak gust is strongest near the surface and decreases with height.

\section{SMOKE}

Smoke sufficiently thick to restrict visibility to 6 miles or less occurs, on the average, only about 2 days per year at the HMS. The most common sources in this area are forest fires, orchard smudging and agricultural field burning. None of these sources are near the HMS, and therefore the station is seldom affected.

Another situation which occasionally causes smoke at the HMS is the slow buildup from many small sources due to adverse meteorological conditions. These conditions are typified by an inversion aloft and by light surface winds.

\section{TORNADOES}

On June 16, 1948, a tornado was observed near the east end of Rattlesnake Mountain about 10 miles south of the HMS. It was in barren country and no damage resulted. Funnel clouds (not reaching the ground) were observed on March 24, 1961, and on July 15, 1970. The former was estimated 10 to 15 miles south-southeast of HMS and the latter about 9 miles south-southwest on the north slope of Rattlesnake Mountain. 
Daubek (1970) has published a study on these and similar observations occurring within an approximate 100 -mile radius of the HMS. The probability for an occurrence in any year at any one point within the 100 -mile radius is 0.000006824 or one tornado each 146,000 years. It also indicates that the best estimates of the maximum tangential wind speed expected from a tornado similar to those which have occurred within the 100-mile radius over the past quarter of a century is $145 \mathrm{mph}$.

Data on the tornadoes that have been observed within an approximate 100-mile radius of the HMS are presented in Table 40.

RIME

Rime occurs during periods of supercooled fog. It resembles frost and is sometimes called hoarfrost. Rime, however, occurs from rapid freezing of supercooled water droplets, whereas frost is deposited by direct condensation of aqueous vapor in the same manner as dew, except that the temperature is below freezing.

Rime deposits are not uncommon on the Hanford Reservation, particularly at the higher elevations. Hills around the HMS are shrouded in fog for extended periods of time in winter and the rime deposits are heavy.

Rime amounts at the HMS are generally less than those on the surrounding hills, but during the period November 21 to 23, 1952, deposits were sufficiently heavy to break some local electrical distribution lines (Jenne and Kerns 1959).

\section{AURORAS}

An aurora, although not strictly a meteorological phenomenon, is nevertheless customarily observed by meteorologists. It is closely connected with the appearance of magnetic disturbances. The particles originate on the sun and become luminous when attracted by the earth's magnetic field and pass through the atmosphere.

Auroras are observed an average of 9 nights per year at the HMS. The months of July, September and October account for $39 \%$ of the auroras 
TABLE 40. Tornado Occurrences Within 100-Mile Radius of the Hanford Meteorology Station

\begin{tabular}{|c|c|c|}
\hline No. & DATE & LOCATION \\
\hline 1 & JUNE 26, 1916 & WALLA WALLA (SOUTHEAST), WASHINGTON \\
\hline 2 & APRIL 15, 1925 & CONDON, OREGON \\
\hline 3 & SEPTEMBER 2,.1936 & WALLA WALLA, WASHINGTON \\
\hline 4 & MAY 20, 1948 & YAKIMA, WASHINGTON \\
\hline 5 & MAY 29, 1948 & YAKIMA, WASHINGTON \\
\hline 6 & JUNE 11, 1948 & EPHRATA, WASHINGTON \\
\hline 7 & JUNE 16, 1948 & $\begin{array}{l}\text { HANFORD METEOROLOGY STATION } \\
\text { (10 MILES SOUTH SOUTHEAST), WASHINGTON }\end{array}$ \\
\hline 8 & MAY 9, 1956 & KENNEWICK (10 MILES SOUTHEAST), WASHINGTON \\
\hline 9 & APRIL 12, 1957 & IONE, OREGON \\
\hline 10 & APRIL 30, 1957 & YAKIMA, WASHINGTON \\
\hline 11 & MAY 6, 1957 & HARRINGTON, WASHINGTON \\
\hline 12 & APRIL 24, 1958 & WALLA WALLA (2O MILES NORTHWEST), WASHINGTON \\
\hline 13 & JUNE 26, 1958 & WALLULA JUNCTION, WASHINGTON \\
\hline 14 & MARCH 14, 1966 & LITTLE GOOSE DAM, WASHINGTON \\
\hline 15 & AUGUST 30, 1971 & COLFAX, WASHINGTON (NEAR) \\
\hline 16 & APRIL 5, 1972 & SPOKANE, WASHINGTON (40-80 MILES WEST OF GEIGER FIELD) \\
\hline 17 & JULY 1, 1978 & HATTON, WASHINGTON (SOUTHEAST) \\
\hline 18 & AUGUST 15, 1978 & ALMIRA, WASHINGTON \\
\hline 19 & MAY 1,1979 & DAVENPORT, WASHINGTON (NEAR) \\
\hline 20 & JULY 1, 1979 & MOSES LAKE, WASHINGTON (10 MILES SOUTH) \\
\hline 21 & MAY 12,1980 & RITZVILLE, WASHINGTON (2 MILES EAST) \\
\hline
\end{tabular}

TORNADOES ACCEPTED AS AUTHENTIC WHEN RECORDED OR REFERENCED IN OFFICIAL NWS DOCUMENTS AND NOT AUTHENTIC WHEN USED INTERCHANGEABLY WITH WORD FUNNEL CLOUD. 
observed at the HMS. Some of the displays are barely visible while others are quite spectacular. The dates when the more spectacular auroral displays occurred are listed below:

September 12-13, 1957

February 10, 1958

May 25-26, 1967

July 6, 1974

October 12, 1974. 
8 
X. DIFFUSION CLIMATOLOGY 
X. DIFFUSION CLIMATOLOGY

The transport of airborne particles, gases, water vapor, kinetic energy, etc. is primarily a result of the horizontal and vertical distribution of temperature, moisture and wind velocity in the atmosphere. Previous sections have dealt only with observations made at a single level near the ground surface. The study of diffusion requires, in addition, a knowledge of the vertical distribution of these parameters, particularly temperature and wind. The decrease of temperature with height is called the temperature lapse rate. In the free atmosphere the temperature decreases at about $6^{\circ} \mathrm{C} \mathrm{km}^{-1}$ to heights of about $10 \mathrm{~km}$ at temperate latitudes. This, of course, is an average; the actual lapse rate of any particular place or time may be quite different. For example, during nights with clear skies and light wind, sufficient heat from the earth's surface is radiated to space to cool the lowest layers of the atmosphere. This cooling produces a temperature profile in which temperature increases with height through the cooled layer. This condition is called a temperature inversion and is very common.

of great importance in the process of diffusion is the stability of the atmospheric layer in which diffusion is taking place. If a parcel of air near the surface rises within its surroundings, but there is no exchange of heat between the parcel and its environment, the process is said to be adiabatic. The rate of decrease of temperature with height of adiabatically ascending dry air is known as the dry adiabatic lapse rate, and it is equal to $9.8^{\circ} \mathrm{C} \mathrm{km}^{-1}$ (5.4 $4^{\circ} \mathrm{F}$ per 1000 feet). In any specific atmospheric layer then, if the decrease of temperature with height is greater than $9.8^{\circ} \mathrm{C} \mathrm{km}^{-1}$, the dry adiabatic lapse rate, the layer is defined as being unstable; if the decrease of temperature is equal to $9.8^{\circ} \mathrm{C} \mathrm{km}^{-1}$ the layer has neutral stability; and if the decrease of temperature with height is less than $9.8^{\circ} \mathrm{C} \mathrm{km}^{-1}$ the layer is stable.

\section{VERTICAL TEMPERATURE PROFILES}

Figure 26 depicts profiles of the hourly average temperature for each month (see Tables 53-60). The profiles show a breakup of the 


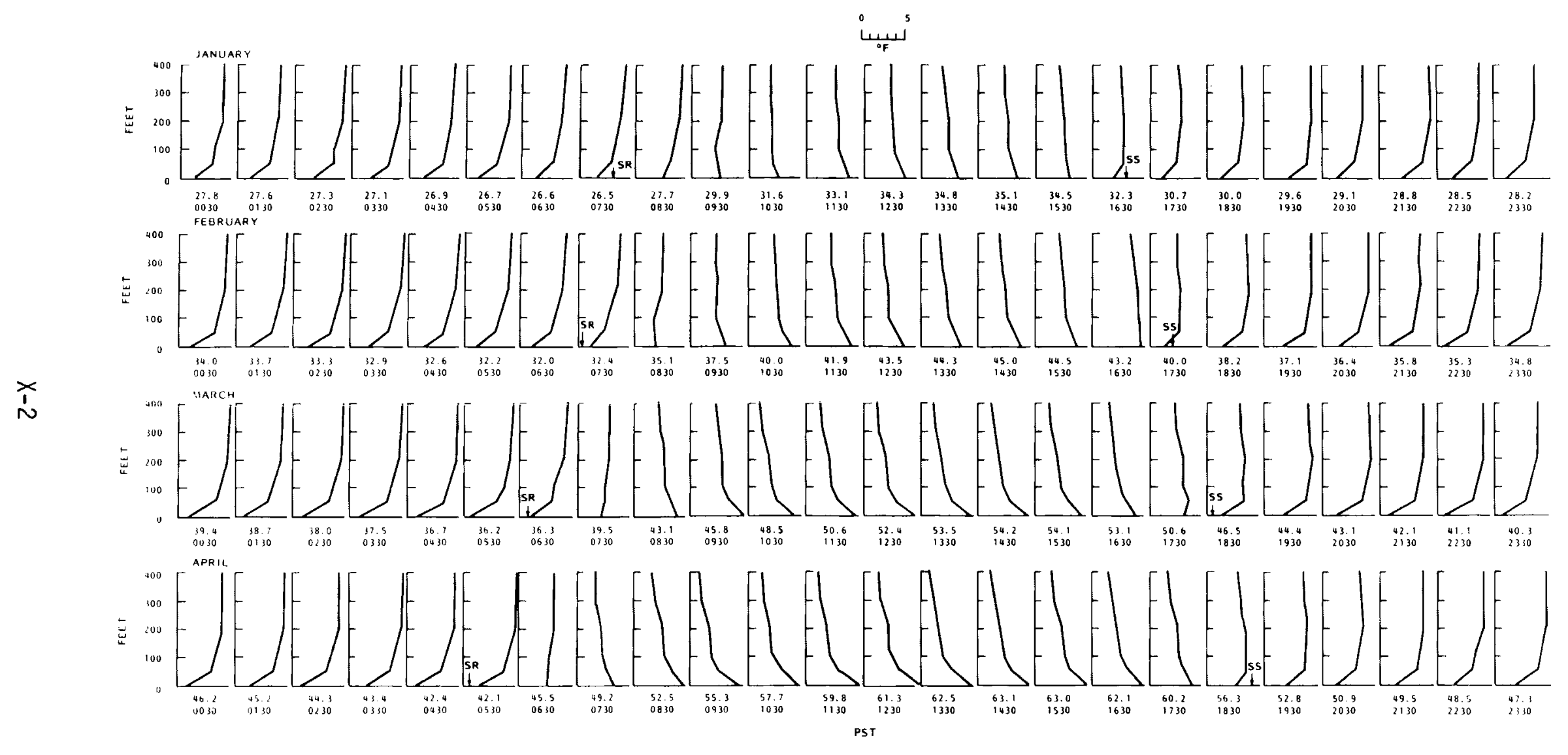

FIGURE 26. Monthly Average Temperature Profiles by Hour Based on 26 Years of Record: 1955 Through 1980 (see Tables 53 Through 60) 


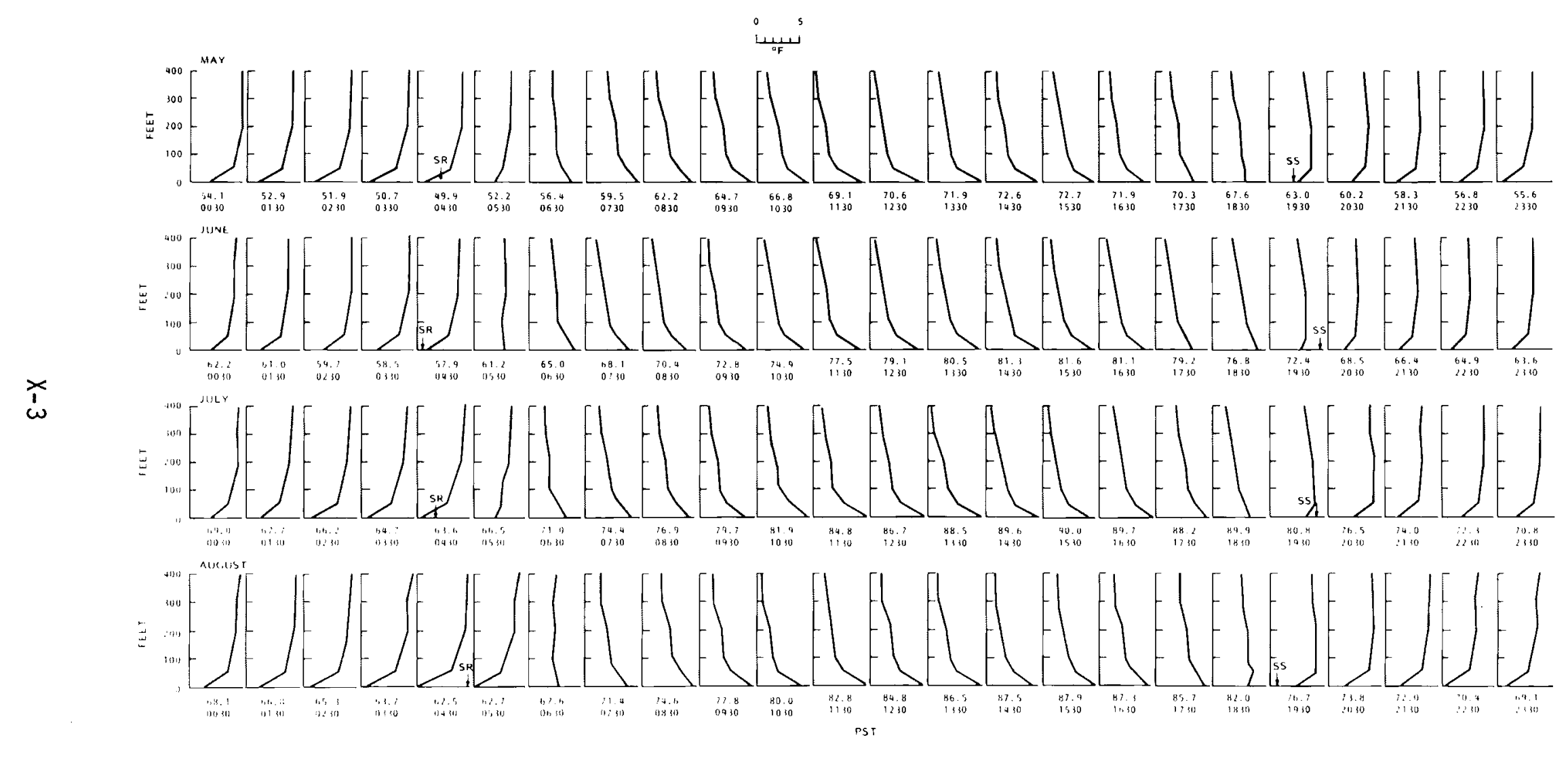

FIGURE 26. Continued 


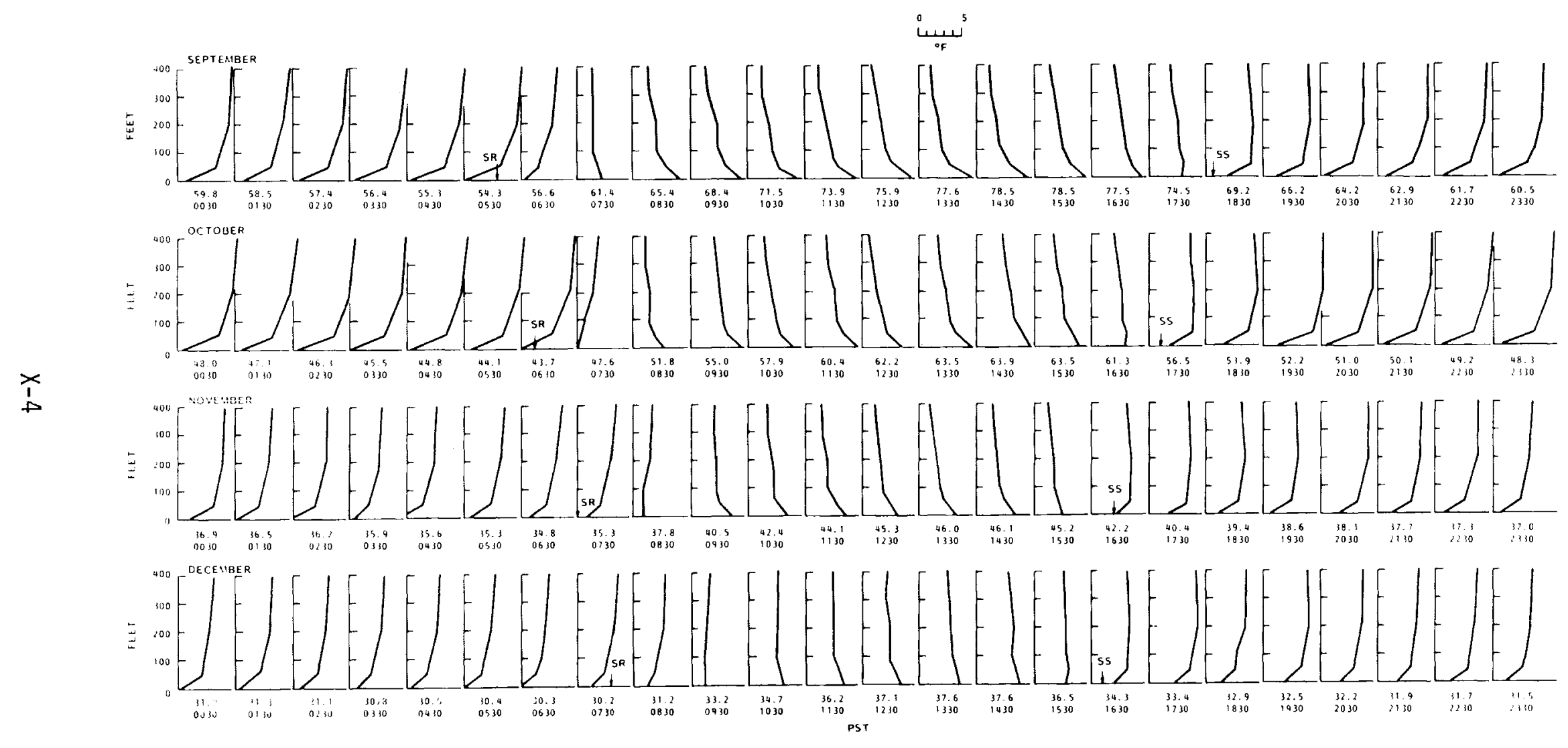

FIGURE 26. Continued 
average nocturnal inversion by the second or third hourly observation after sunrise and formation again by the first hourly observation after sunset. The profiles also show that the intensity of both lapses and inversions is greatest in the first 50 feet above ground surface. Even above 50 feet, however, lapse rates average adiabatic or superadiabatic $\left(>9.8^{\circ} \mathrm{C} \mathrm{km}^{-1}\right)$ during part of the day for a good portion of the year. Overa11, June is the most unstable month and October the most stable (Figure 27).

Figure 28 shows the diurnal course of temperature at 3 levels during 4 months of the year. During most of the inversion period for al1 months, there is a greater difference in temperature between the surface and 50-foot levels than in the remainder of the height to 400 feet.

\section{PERSISTENCE OF INVERSIONS}

Because of the long winter nights, and lower average wind speeds from December through February, an inversion formed during this period is likely to persist longer than inversions observed during the other seasons.

The nocturnal inversion forms about $1 / 2$ hour before sunset and lasts until about 1-1/2 hours after sunrise. The length of the inversion period averages 13.7 hours, but varies seasonally from 10.0 hours in June to 17.7 hours in December.

\section{TYPES OF INVERSIONS}

The radiation inversion is by far the most commonly observed inversion type at the HMS. It accounts for nearly a 11 summertime inversions and a good percentage of those in winter. It forms from radiational cooling near the ground and builds upward. It is a diurnal phenomenon and may be less important from an air pollution standpoint than other types with greater persistence. Temperature differences between the surface and 200 feet may exceed $10^{\circ} \mathrm{F}$ at times, but rarely, if ever, exceed $15^{\circ} \mathrm{F}$. Wind speeds are usually below $13 \mathrm{mph}$. However, wind speed is not as closely related to the temperature profile as its 


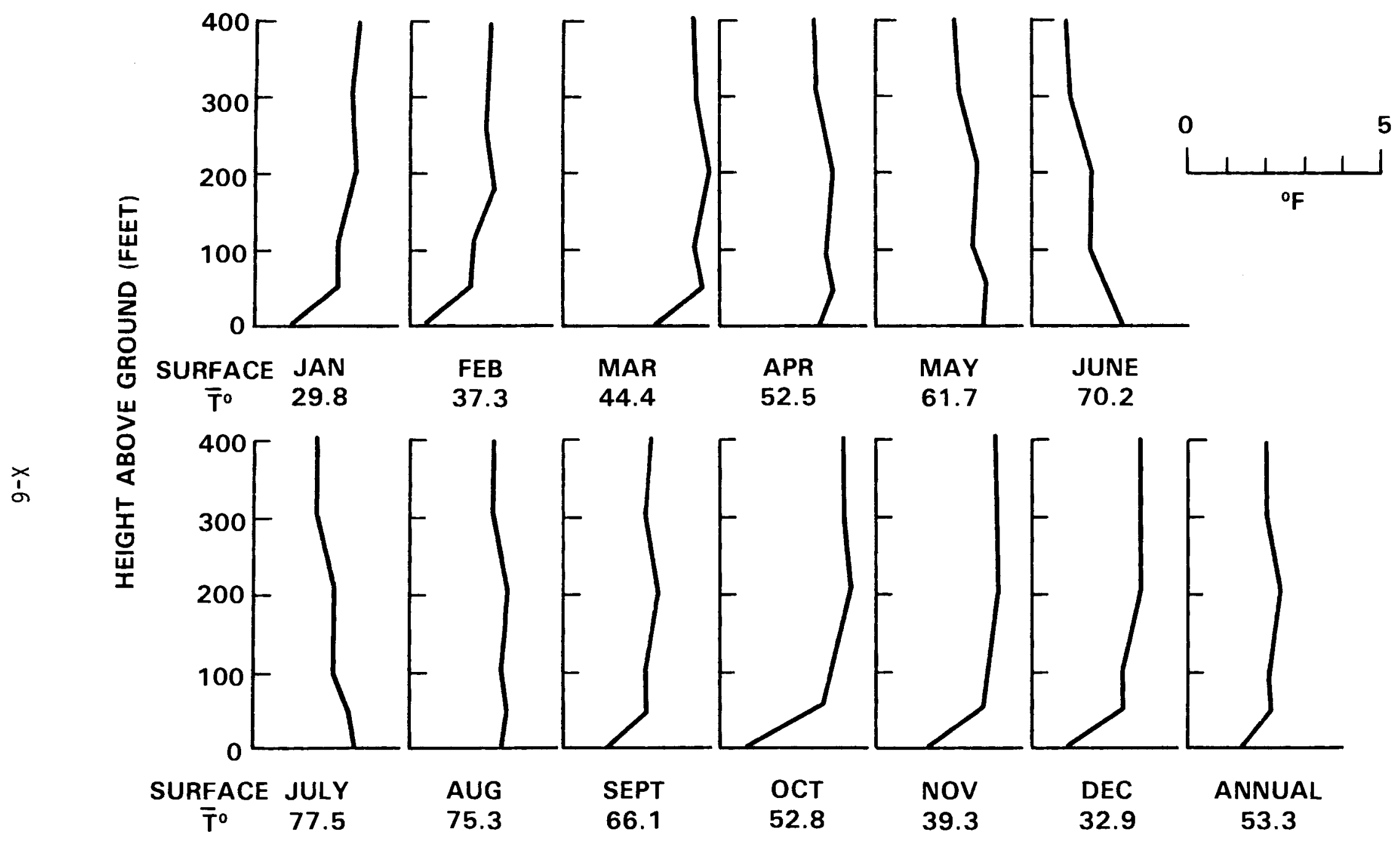

FIGURE 27. Monthly and Annual Average Temperature ( ${ }^{\circ} \mathrm{F}$ ) Profiles: 1955 Through 1980 (see Tables 53 Through 60 for Temperature Values) 

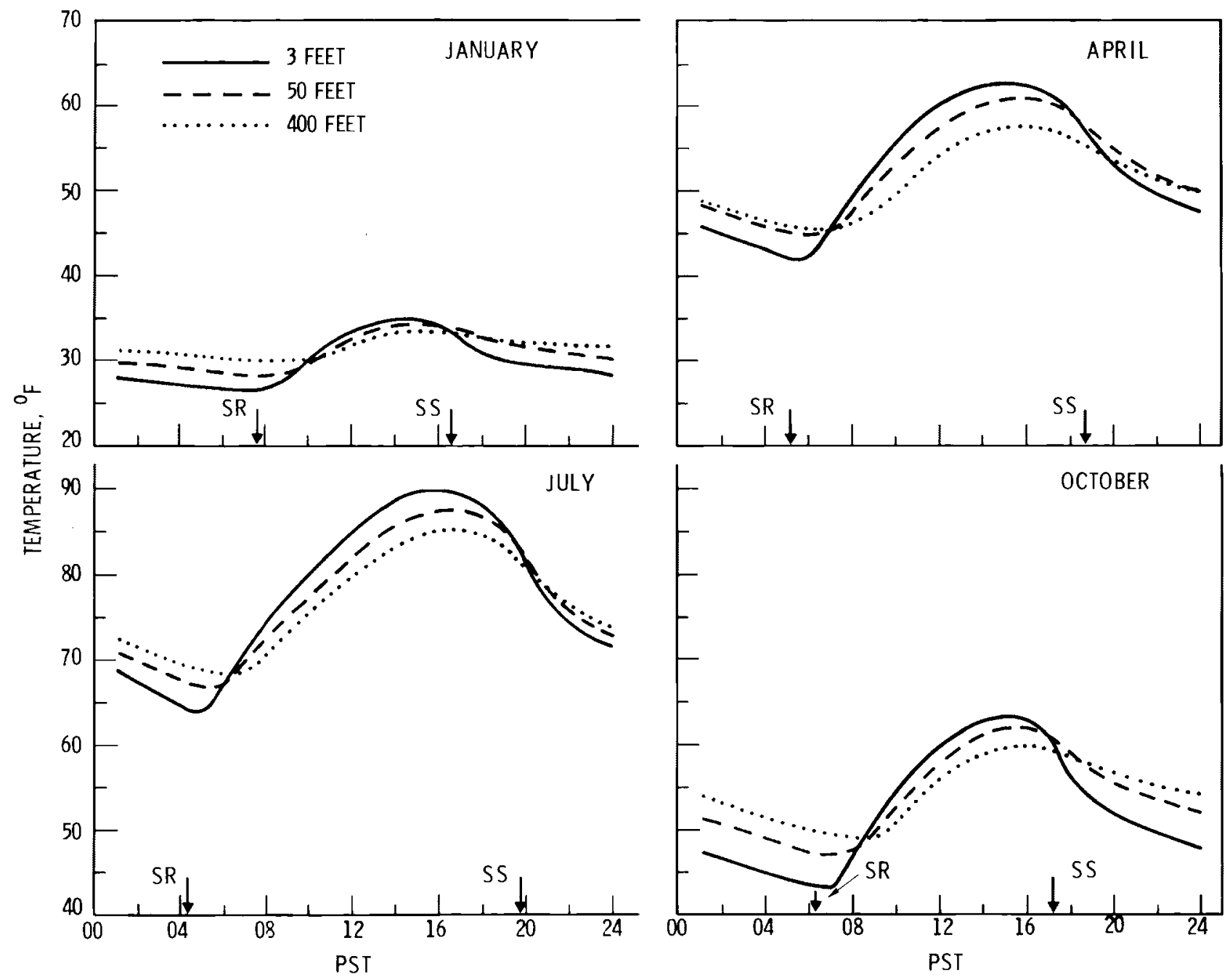

FIGURE 28. Diurnal Course of Temperature for Three Leve1s, January, Apri1, July and 0ctober: 1955 Through 1980 
gustiness (Singer and Smith 1963). Large inversions are sometimes observed in connection with wind speeds exceeding $20 \mathrm{mph}$ if the winds are not gusty in character.

A chinook inversion, although never observed except during the cold season, is the second most common inversion type at the HMS. It forms when advecting warm air overrides and erodes the cold and more dense surface air. As the cold surface layer is eroded away to less than 400 feet in thickness the temperature will rise atop the 410 -foot HMS meteorological tower; sometimes the increase will be temporary if the overriding warm wind is of insufficient strength or duration.

Chinook inversions are characterized by stability and strong wind shear. Temperature differences between the surface and 200-foot levels may exceed $20^{\circ} \mathrm{F}$ and the wind may be blowing northeast at the surface and southeast at 400 feet. Surface speeds are usually under 10 mph until the warm air reaches the surface.

Chinook inversions may form at any time of the day or night. Although most last from 4 to 8 hours, some last less than 1 hour and others for days. A 99-hour chinook inversion occurred in February 1963. At 1330 PST on February 3 the 200-foot temperature exceeded that at the surface by $17.8^{\circ} \mathrm{F}$, and the 250 -foot temperature exceeded the 50 -foot temperature by $15.2^{\circ} \mathrm{F}$.

The decay of a chinook inversion may bring rather dramatic warming at the surface, as in the case below for February 10, 1971.

$\begin{array}{lcc}\begin{array}{l}\text { Time } \\ \text { (PST) }\end{array} & \begin{array}{c}\text { Temperature } \\ \left({ }^{\circ} \mathrm{Fat} 3-\mathrm{ft} \text { Leve }\right)\end{array} & \text { Temperature Rise }\left({ }^{\circ} \mathrm{F}\right) \\ 1022 & 40.1 & \\ 1026 & 47.3 & 7.2^{\circ} \text { in } 4 \mathrm{~min} \\ 1030 & 53.1 & 13.0^{\circ} \text { in } 8 \mathrm{~min} \\ 1034 & 56.3 & 16.2^{\circ} \text { in } 12 \mathrm{~min}\end{array}$

\section{INVERSION TRAPPING}

Occasionally, atmospheric contaminants are trapped below the mountain tops surrounding the Hanford Area. This is a wintertime 
situation and occurs when an unstable or neutral layer of air at the surface is capped by an inversion layer aloft (Figure 29). Low clouds or fog, Tow surface wind speeds, and a high barometric pressure are usually associated with this trapping. The inversion is formed by adiabatic warming of subsiding air or by a frontal surface aloft over the area. The average recurrence interval for 10 consecutive days of this situation at the HMS is 2 years (Jenne 1963).

\section{PERSISTENCE OF SUPERADIABATIC LAPSE RATES}

When the decrease in temperature with height exceeds the dry adiabatic lapse rate, the condition is known as superadiabatic. Recall

that the dry adjabatic lapse rate is $9.8^{\circ} \mathrm{C} \mathrm{km}^{-1}$ (or $5.4^{\circ} \mathrm{F}$ per 1000 feet). Superadiabatic lapse rates in the 3 to 200 foot atmospheric layer at the HMS occur $\sim 50 \%$ of the time during the summer months compared to less than 15\% of the time in December and January (Stone, Jenne and Thorp 1972).

\section{WIND PROFILES}

Wind profiles on the Hanford Meteorology Tower (HMT) are characterized by large seasonal and diurnal variations in speed (Figure 30 ).

Speed variation with height, on the average, is least at mid-day and greatest during the night. The magnitude of the diurnal variation has a seasonal dependency, reaching a maximum in June and July and becoming very slight in December and January. An interesting feature in Figure 30 is the 1 to 2 hour temporary increase in speed at elevations up to 2100 feet shortly after sunrise in the summer months.

Tables 41 through 43 show the monthly and annual joint percent frequency distribution between wind speed and direction for the 50-, 200- and 400-foot levels on the HMT. Tables 44 through 49 show monthly and annual percent frequency of hourly wind direction and speed for these same ievels. 


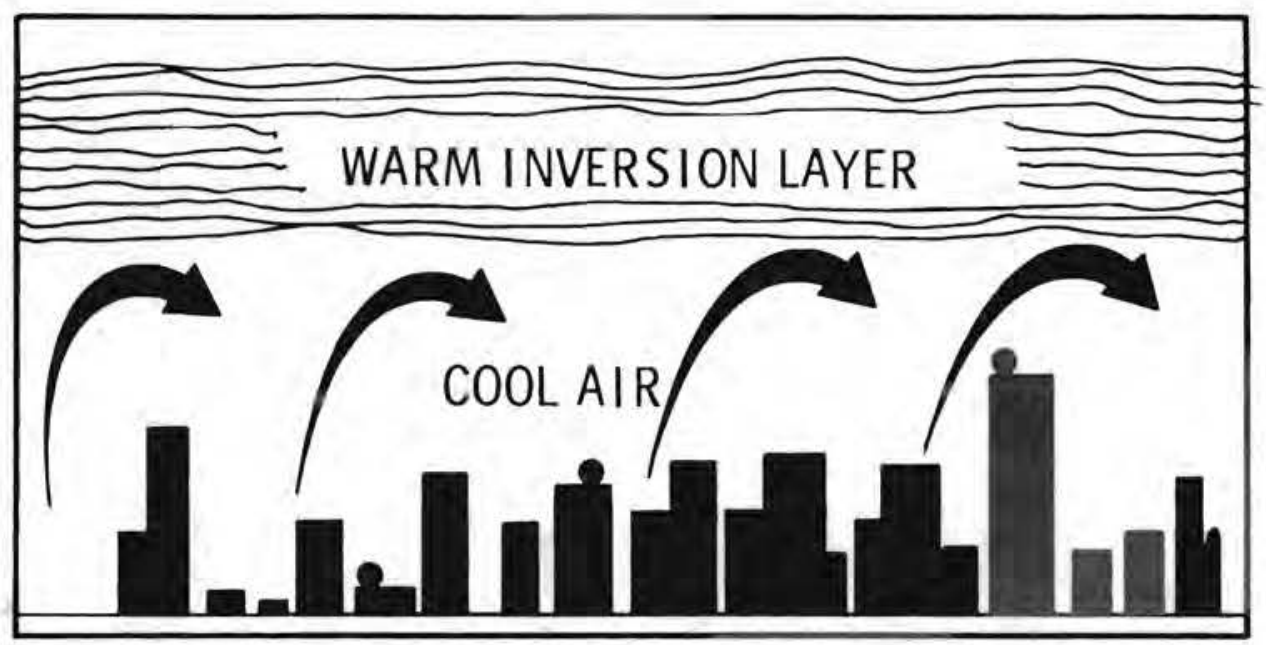

FIGURE 29. A Schematic Representation of an Inversion Trapping Situation 


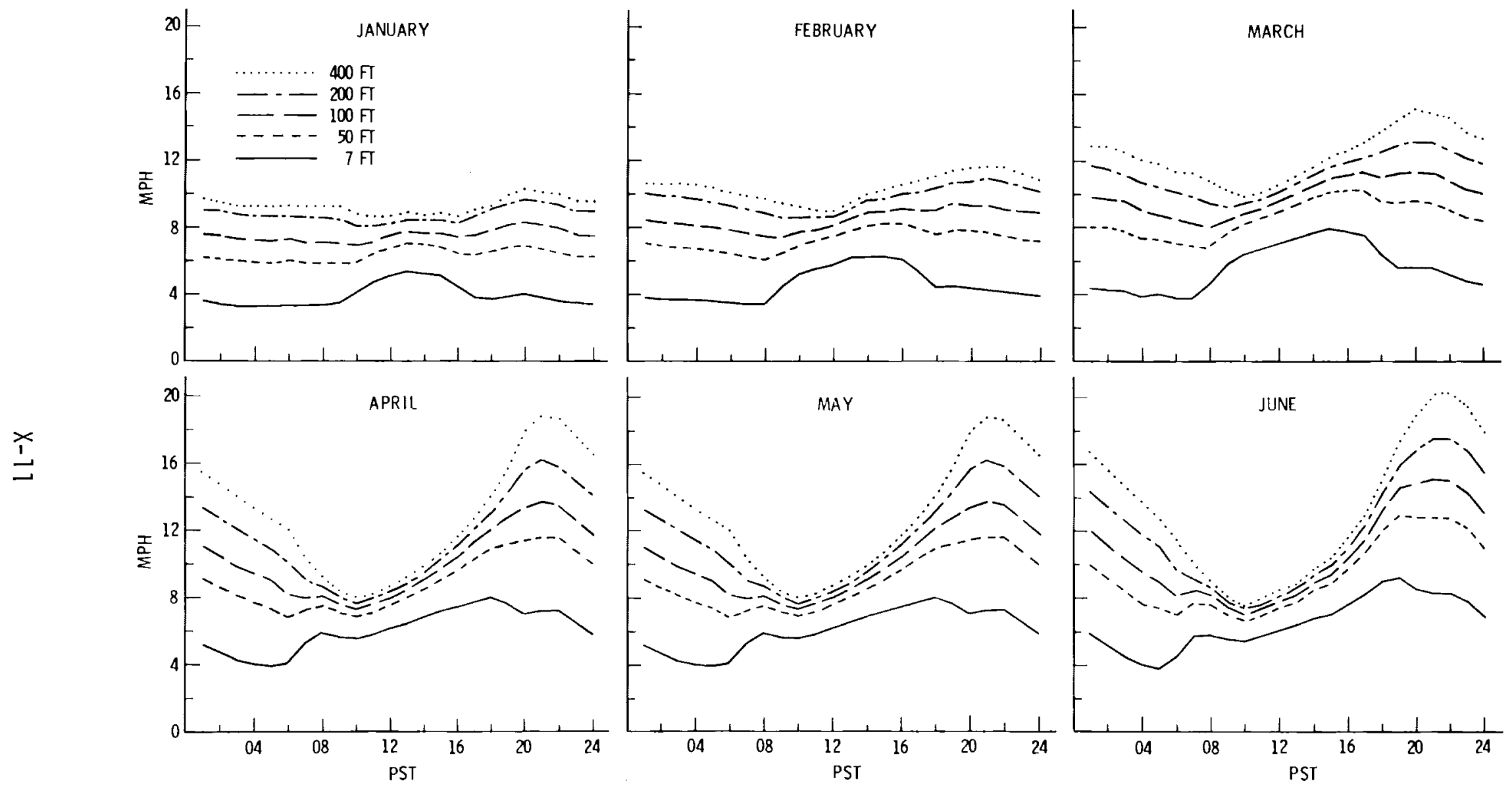

FIGURE 30. Monthly Hourly Average Wind Speeds for Five Levels, 1955 Through 1980 


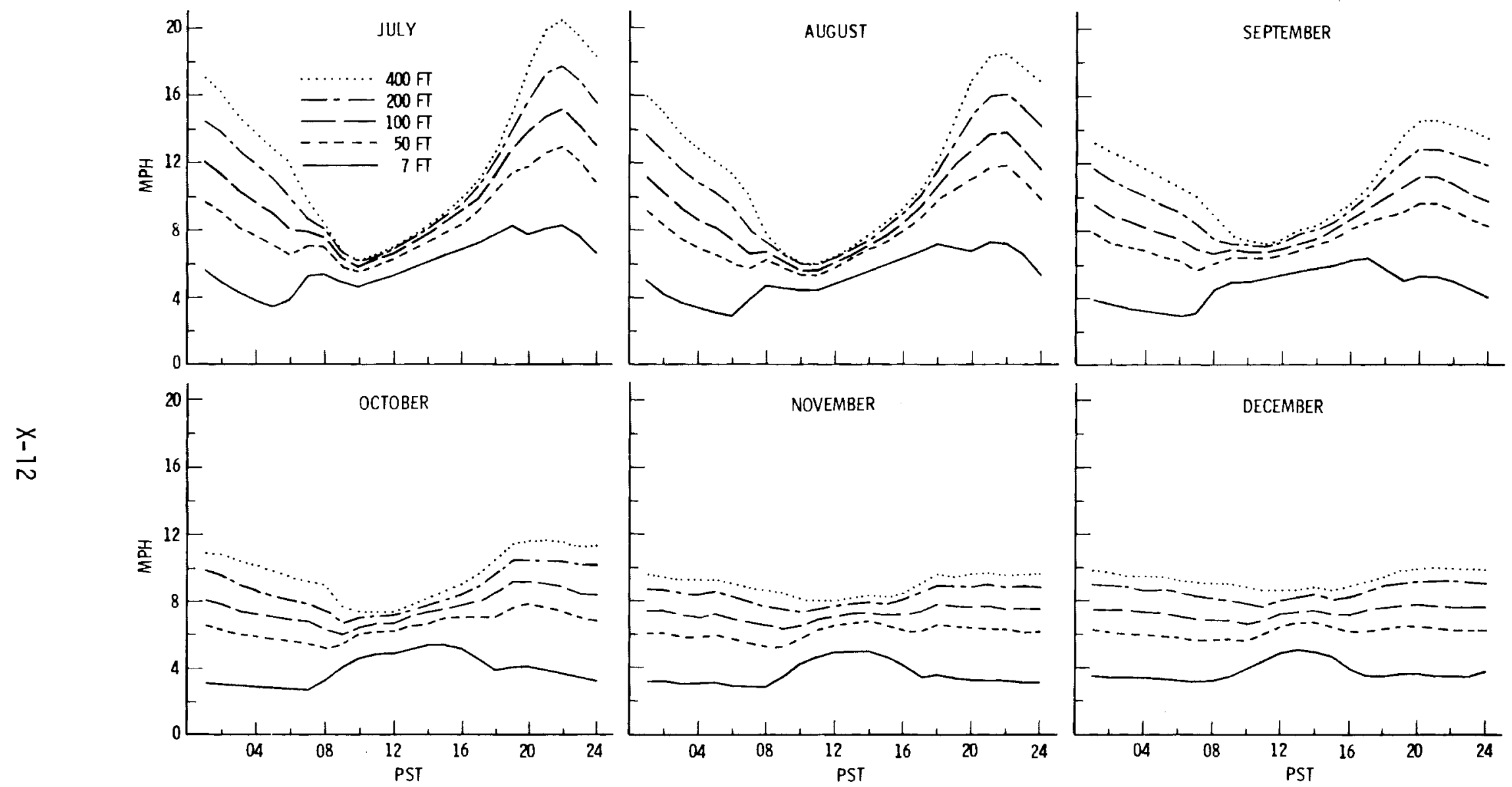

FIGURE 30. Continued 
TABLE 41. Monthly and Annual Percent Frequency Distribution of 50-Foot Wind Direction Versus Speed Class, 1955 Through 1980

JAK

\begin{tabular}{|c|c|c|c|c|c|c|c|c|c|c|c|c|}
\hline LIKELTICK & 0 & $1-3$ & $4-7$ & $8-12$ & $13-18$ & $19-24$ & $25-31$ & $32-38$ & $39-46$ & 67.46 & IOTAL & AV.SPEED \\
\hline 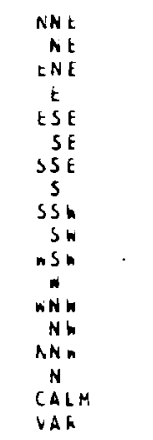 & $\begin{array}{l}.0 \\
.0 \\
.0 \\
.0 \\
.0 \\
.0 \\
.0 \\
.0 \\
.0 \\
.0 \\
.0 \\
.0 \\
.0 \\
.0 \\
.0 \\
.0 \\
5.4 \\
.0\end{array}$ & $\begin{array}{l}1.9 \\
1.6 \\
1.4 \\
1.7 \\
1.6 \\
2.4 \\
1.6 \\
1.4 \\
1.2 \\
1.2 \\
1.3 \\
1.8 \\
2.3 \\
3.1 \\
2.8 \\
2.6 \\
.0 \\
1.8\end{array}$ & $\begin{array}{r}1.0 \\
.8 \\
.5 \\
.8 \\
.7 \\
1.4 \\
1.0 \\
1.1 \\
1.0 \\
1.2 \\
1.6 \\
2.7 \\
5.6 \\
7.5 \\
3.0 \\
1.4 \\
.0 \\
.1\end{array}$ & $\begin{array}{l}.3 \\
.1 \\
.0 \\
.1 \\
.1 \\
.3 \\
.3 \\
.3 \\
.6 \\
1.3 \\
1.6 \\
1.4 \\
5.5 \\
6.3 \\
.8 \\
.4 \\
.0 \\
.0\end{array}$ & $\begin{array}{r}.2 \\
.1 \\
.0 \\
.0 \\
.0 \\
.1 \\
.2 \\
.4 \\
.9 \\
1.5 \\
.9 \\
.5 \\
1.0 \\
1.1 \\
.1 \\
.2 \\
.0 \\
.0\end{array}$ & $\begin{array}{l}.1 \\
.1 \\
.0 \\
.0 \\
.0 \\
.0 \\
.1 \\
.2 \\
.6 \\
.8 \\
.5 \\
.1 \\
.1 \\
.1 \\
.0 \\
.1 \\
.0 \\
.0\end{array}$ & $\begin{array}{l}.0 \\
: 0 \\
.0 \\
0 \\
00 \\
: 0 \\
.0 \\
.1 \\
: 4 \\
.4 \\
.2 \\
.0 \\
.0 \\
.0 \\
.0 \\
.0 \\
.0 \\
.0\end{array}$ & $\begin{array}{l}.0 \\
.0 \\
.0 \\
.0 \\
.0 \\
.0 \\
.0 \\
.0 \\
.1 \\
.1 \\
.0 \\
.0 \\
.0 \\
.0 \\
.0 \\
.0 \\
.0\end{array}$ & $\begin{array}{l}.0 \\
.0 \\
.0 \\
.0 \\
.0 \\
.0 \\
.0 \\
.0 \\
.0 \\
.0 \\
.0 \\
.0 \\
.0 \\
.0 \\
.0 \\
.0 \\
.0 \\
.0\end{array}$ & $\begin{array}{l}.0 \\
.0 \\
.0 \\
.0 \\
.0 \\
.0 \\
.0 \\
.0 \\
.0 \\
.0 \\
.0 \\
.0 \\
.0 \\
.0 \\
.0 \\
.0 \\
.0 \\
.0\end{array}$ & $\begin{array}{r}3.5 \\
2.5 \\
2.6 \\
2.6 \\
2.5 \\
4.8 \\
3.1 \\
3.5 \\
4.5 \\
6.8 \\
6.2 \\
6.5 \\
14.5 \\
18.1 \\
6.8 \\
4.8 \\
5.4 \\
1.9\end{array}$ & $\begin{array}{r}5.1 \\
4.5 \\
2.9 \\
3.1 \\
3.3 \\
3.8 \\
5.2 \\
7.0 \\
11.4 \\
12.1 \\
9.5 \\
6.2 \\
7.3 \\
7.0 \\
4.6 \\
4.5 \\
.0 \\
1.7\end{array}$ \\
\hline
\end{tabular}

SPEEO CLASS (HPH)

\begin{tabular}{|c|c|c|c|c|c|c|c|c|c|c|c|c|}
\hline LIRECTIOA & 0 & $1-3$ & $4-7$ & $8-12$ & $13-18$ & $19-24$ & $25-31$ & $32-38$ & $39-46$ & СТ.46 & TOTAL & AV.SPEED \\
\hline 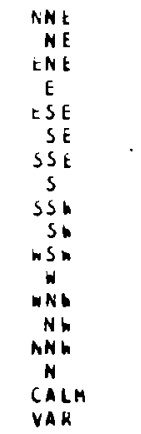 & $\begin{array}{l}.0 \\
.0 \\
.0 \\
.0 \\
.0 \\
.0 \\
.0 \\
.0 \\
.0 \\
.0 \\
.0 \\
.0 \\
.0 \\
.0 \\
.0 \\
.0 \\
3.2 \\
.0\end{array}$ & $\begin{array}{l}1.9 \\
2.0 \\
1.2 \\
1.3 \\
1.2 \\
1.8 \\
1.2 \\
1.3 \\
1.0 \\
.9 \\
1.1 \\
1.5 \\
1.8 \\
2.6 \\
2.1 \\
2.5 \\
1.0 \\
1.4\end{array}$ & $\begin{array}{r}1.8 \\
.5 \\
.6 \\
.8 \\
.8 \\
1.8 \\
.8 \\
.9 \\
.5 \\
1.4 \\
2.0 \\
3.6 \\
4.8 \\
6.8 \\
2.9 \\
1.8 \\
.0 \\
.2\end{array}$ & $\begin{array}{l}.6 \\
.1 \\
.1 \\
.0 \\
.2 \\
.4 \\
.4 \\
.5 \\
.9 \\
1.3 \\
2.2 \\
2.9 \\
6.6 \\
6.3 \\
.9 \\
.6 \\
.0 \\
.0\end{array}$ & $\begin{array}{l}.3 \\
.1 \\
.0 \\
.0 \\
.0 \\
.0 \\
.2 \\
.4 \\
.0 \\
1.0 \\
1.4 \\
1.0 \\
1.6 \\
1.3 \\
.1 \\
.3 \\
.0 \\
.0\end{array}$ & $\begin{array}{l}.1 \\
.1 \\
.0 \\
.0 \\
.0 \\
.0 \\
.1 \\
.2 \\
.5 \\
1.2 \\
.5 \\
.2 \\
.3 \\
.1 \\
.0 \\
.0 \\
.0 \\
.0\end{array}$ & $\begin{array}{l}: 0 \\
: 1 \\
: c \\
0 \\
00 \\
0 \\
0 \\
0 \\
: 1 \\
: 6 \\
: 4 \\
: 1 \\
: 1 \\
: 1 \\
0 \\
0 \\
0 \\
0\end{array}$ & $\begin{array}{l}.0 \\
.0 \\
.0 \\
.0 \\
.0 \\
.0 \\
.0 \\
.0 \\
.1 \\
.2 \\
.1 \\
.0 \\
.0 \\
.0 \\
.0 \\
.0 \\
.0 \\
.0\end{array}$ & $\begin{array}{l}.0 \\
.0 \\
.0 \\
.0 \\
.0 \\
.0 \\
.0 \\
.0 \\
.0 \\
.1 \\
.0 \\
.0 \\
.0 \\
.0 \\
.0 \\
.0 \\
.0 \\
.0\end{array}$ & $\begin{array}{l}.0 \\
.0 \\
.0 \\
.0 \\
.0 \\
.0 \\
.0 \\
.0 \\
.0 \\
.0 \\
.0 \\
.0 \\
.0 \\
.0 \\
.0 \\
.0 \\
.0 \\
.0\end{array}$ & $\begin{array}{r}4.1 \\
3.2 \\
1.9 \\
2.1 \\
2.2 \\
3.4 \\
2.7 \\
3.3 \\
4.2 \\
7.5 \\
7.7 \\
9.8 \\
15.1 \\
17.2 \\
6.0 \\
9.2 \\
3.2 \\
1.6\end{array}$ & $\begin{array}{r}5.8 \\
4.5 \\
3.3 \\
3.3 \\
3.7 \\
4.1 \\
5.4 \\
7.1 \\
10.9 \\
13.5 \\
10.6 \\
7.7 \\
8.3 \\
7.4 \\
5.0 \\
4.8 \\
.0 \\
1.9\end{array}$ \\
\hline TUTAL & 3.2 & 26.8 & 31.4 & 23.9 & 9.4 & 3.3 & 1.5 & .4 & .1 & .0 & $100 . c$ & 7.2 \\
\hline
\end{tabular}


TABLE 41. Continued

SPEED CLASS (MPH)

\begin{tabular}{|c|c|c|c|c|c|c|c|c|c|c|c|c|}
\hline UIRECTIOAN & $u$ & $1-3$ & $4-7$ & $8-12$ & $13-18$ & $19-24$ & $25-31$ & $32-3 \theta$ & $39-46$ & 67.40 & IOTAL & AV.SPEED \\
\hline ANE & .0 & 1.4 & 1.5 & .8 & .5 & .0 & .0 & .0 & .0 & .0 & 4.2 & 6.4 \\
\hline NE & .0 & 1.5 & 1.1 & .3 & .2 & .0 & .0 & .0 & .0 & .0 & 3.2 & 4.8 \\
\hline $\mathrm{LAE}$ & .0 & .0 & .8 & .1 & .0 & .0 &. $\mathrm{C}$ & .0 & .0 & .0 & $1 . \overline{6}$ & 4.5 \\
\hline $\bar{E}$ & .0 & 1.0 & .9 & .2 & .0 & .0 & .0 & .0 & .0 & .0 & 2.6 & 4.0 \\
\hline ESt & .0 & 1.0 & 1.2 & .2 & .0 & .0 & .0 & .0 & .0 & .0 & 2.4 & 4.5 \\
\hline So & .4 & 1.3 & 1.8 & .6 & .1 & .0 & . C & .0 & .0 & .0 & 3.8 & 5.1 \\
\hline $35 \mathrm{c}$ & .0 & .7 & 1.2 & .8 & .2 & .0 & .0 & .0 & .0 & .0 & $3 . \mathrm{C}$ & 6.8 \\
\hline$s$ & .0 & .9 & 1.5 & .8 & .5 & .3 & .0 & .0 & .0 & .0 & 3.9 & 7.9 \\
\hline sS. &.$c$ & .6 & 1.5 & 1.1 & 1.1 & .6 & .3 & .0 & .0 & .0 & 5.2 & 11.5 \\
\hline Sh & .0 & .8 & $2 . c$ & 1.8 & 2.4 & 1.5 & .8 & .2 & .0 & .0 & 9.4 & 13.4 \\
\hline ins n & .0 & .7 & 2.5 & 3.2 & 2.4 & 1.0 & .4 & .1 & .0 & .0 & 10.3 & 11.6 \\
\hline$n$ & .0 & $1 . c$ & 3.8 & 3.7 & 1.3 & .3 & .1 & .0 & .0 & .0 & 10. & 8.5 \\
\hline minh &.$c$ & .9 & 4.1 & 6.0 & 2.6 & .9 &.$i$ & .0 & .0 & .0 & 14.7 & 10.0 \\
\hline Nh & .c & 1.4 & 4.1 & 5.1 & 1.8 & .6 & .1 & .0 & .0 & .0 & $13 . i$ & 9.1 \\
\hline $\mathrm{Akin}$ &.$c$ & 1.3 & 2.5 & 1.0 & .2 & .0 & .0 & .0 & .0 & .0 & 5.1 & 5.8 \\
\hline$\kappa$ & .0 & 1.7 & 1.5 & .9 & .2 & .1 &. $\mathrm{c}$ & .0 & .0 & .0 & 4.8 & 5.7 \\
\hline$C A L M$ & 1.0 &.$J$ & $\cdot c$ & .0 & .0 & .0 & .0 & .0 & .0 & .0 & $1 . \mathrm{c}$ & .c \\
\hline VAK & . C & 1.5 & .3 & .0 & .0 & .0 & .0 & .0 & .0 & .0 & $1 . \varepsilon$ & 2.3 \\
\hline TLTAL & 1.6 & 18.4 & 32.7 & 26.6 & 13.6 & 5.5. & 1.9 & .4 & .0 & .0 & $100 . c$ & 8.6 \\
\hline
\end{tabular}

\begin{tabular}{|c|c|c|c|c|c|c|c|c|c|c|c|c|}
\hline & & & & & Ar & & & & & & & \\
\hline & & & & & SPEED & $S S$ INPH & & & & & & \\
\hline LIRECTIEA & $\iota$ & $1-3$ & $4-7$ & $8-12$ & $13-18$ & $19-24$ & $25-31$ & $32-38$ & $39-46$ & 6.1 .46 & IUTAL & AV.SPEED \\
\hline ivet & .0 & 1.0 & 1.4 & .6 & .3 & .1 & .0 & .0 & .0 & .0 & 3.3 & 6.5 \\
\hline $\mathrm{NE}$ & .0 & $1 . \bar{z}$ & $1 \cdot \hat{a}$ & .3 & .3 & .1 & .0 & .0 & .0 & .0 & 3.2 & 6.3 \\
\hline ENt & .0 & .7 & 1.0 & .3 & .1 & .0 &.$c$ & .0 & .0 & .0 & 2.1 & 5.6 \\
\hline $\mathrm{E}$ & .0 & .8 & 1.2 & .4 & .0 & .0 & .0 & .0 & .0 & .0 & 2.4 & 5.1 \\
\hline ts $E$ & .0 & .7 & 1.2 & .2 & .0 & .0 &.$c$ & .0 & .0 & .0 & 2.6 & 4.6 \\
\hline$S E$ & .0 & .9 & 1.5 & .5 & .1 & .0 & .0 & .0 & .0 & .0 & 2.5 & 5.2 \\
\hline SSE & .0 & .5 & 1.1 & .9 & .2 & .0 & .0 & .0 & .0 & .0 & $2 . t$ & 6.9 \\
\hline$s$ & .0 & .7 & 1.3 & .7 & .3 & .1 & .0 & .0 & .0 & .0 & 3.0 & 6.8 \\
\hline $35 n$ & .0 & .6 & 1.4 & .9 & .8 & .4 & .1 & .0 & .0 & .0 & 4.2 & 9.6 \\
\hline sin & .0 & .6 & 2.2 & 1.9 & 1.8 & 1.5 & .5 & .1 & .0 & .0 & $8 . t$ & 12.5 \\
\hline as h & .0 & .8 & 2.8 & 4.0 & 2.4 & 1.0 & .4 & .1 & .0 & .0 & 11.4 & 11.2 \\
\hline 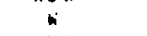 & .0 & 1.0 & 4.2 & 5.1 & 1.9 & .4 & .1 & .0 & .0 & .0 & 12.6 & 9.0 \\
\hline nNh & .0 & .7 & 3.6 & 6.3 & 4.4 & 1.7 & .4 & .0 & .0 & .0 & $17 . \mathrm{c}$ & 11.5 \\
\hline $\mathrm{Nn}$ & .0 & 1.0 & 3.4 & 4.3 & 3.0 & 1.4 & .4 & .0 & .0 & .0 & 13.4 & 11.1 \\
\hline $\mathrm{inN}$ & .0 & .8 & $2 . c$ & .8 & .2 & .0 & $\because 0$ & .0 & .0 & .0 & 3.8 & 0.1 \\
\hline$N$ & .0 & 1.5 & 1.8 & .8 & .3 & .1 & .0 & .0 & .0 & .0 & 4.0 & 5.8 \\
\hline$C A L M$ & .7 & .0 &.$c$ & .0 & .0 & .0 & .0 & .0 & .0 & .0 & .7 & .0 \\
\hline VAf & .0 & 1.6 &.$t$ & .0 & .0 & .0 & .0 & .0 & .0 & .0 & 2.2 & 2.7 \\
\hline TWTAL & .7 & 14.8 & 31.5 & 27.8 & 15.9 & 6.7 & 2.0 & .2 & .0 & .0 & $100 . c$ & 9.2 \\
\hline
\end{tabular}


TABLE 41. Continued

Mar

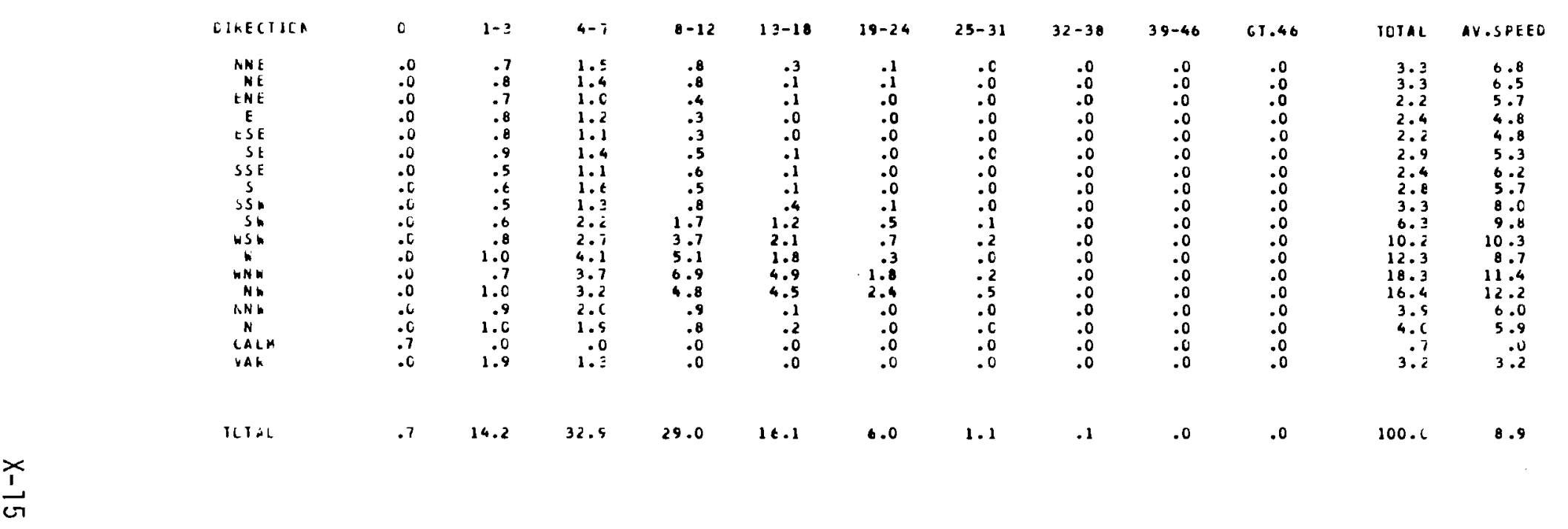

SPEED CLASS (MPH)

\begin{tabular}{|c|c|c|c|c|c|c|c|c|c|c|c|c|}
\hline LIKECIICA & c & $1-3$ & $4-i$ & $8-12$ & $13-18$ & $19-24$ & $25-31$ & $32-38$ & $39-46$ & $C 1.46$ & IOTAL & AV.SPEED \\
\hline NNE & .0 & .6 & $1 . t$ & .7 & .3 & .0 &.$c$ & .0 & .0 & .0 & 3.2 & 6.8 \\
\hline $\mathrm{NE}$ & .0 & .7 & 1.4 & .7 & .3 & .1 & .0 & .0 & .0 & .0 & 3.3 & 7.0 \\
\hline EN E &. $\mathrm{c}$ & .4 & 1.0 & .5 & .1 & .0 & .0 & .0 & .0 & .0 & $2 . \mathrm{c}$ & 6.3 \\
\hline $\bar{c}$ &.$c$ & .4 & 1.4 & .4 & .1 & .0 & .0 & .0 & .0 & .0 & 2.3 & 5.8 \\
\hline$E S t$ & .0 & .5 & 1.4 & .4 & .0 & .0 & . C & .0 & .0 & .0 & 2.3 & 5.3 \\
\hline SE & .0 & .6 & $1 . t$ & .4 & .0 & .0 & .0 & .0 & .0 & .0 & 2.7 & 5.3 \\
\hline SSE & .0 & .5 & 1.2 & .4 & .0 & .0 & .0 & .0 & .0 & .0 & 2.2 & 5.7 \\
\hline 5 &.$c$ & .5 & 1.7 & .4 & .1 & .0 & .0 & .0 & .0 & .0 & 2.7 & 5.7 \\
\hline ssh & .0 & .5 & 1.6 & .8 & .2 & .1 & .0 & .0 & .0 & .0 & 3.2 & 7.1 \\
\hline 5 & .0 & .6 & 2.3 & 1.9 & 1.0 & .4 & .0 & .0 & .0 & .0 & 6.2 & 9.1 \\
\hline ins. & .0 & .6 & 2.5 & 3.2 & 1.7 & .5 & .1 & .0 & .0 & 0 & 8.9 & 10.0 \\
\hline$\because$ & .0 & .7 & $4 . \bar{c}$ & 4.7 & 1.8 & .3 & .0 & .0 & .0 & .0 & 13.5 & 8.9 \\
\hline WN & .0 & .6 & 3.2 & 7.1 & 5.9 & 2.0 & $: 4$ & .0 & .0 & .0 & 19.3 & $12: 1$ \\
\hline Nh &.$c$ & .7 & 3.4 & 5.2 & 5.6 & $\begin{array}{l}2.0 \\
3.2\end{array}$ & .7 & .0 & .0 & .0 & $\begin{array}{l}18.3 \\
18.8\end{array}$ & 13.1 \\
\hline NA & .0 & .5 & 2.1 & 1.0 & .2 & .0 & 0 & .0 & .0 & .0 & $4 . \mathrm{C}$ & 6.9 \\
\hline h & .0 & .8 & 1.9 & .8 & .1 & .0 & .0 & .0 & .0 & .0 & 3.7 & 6.0 \\
\hline CALM & .6 & .0 & .0 & .0 & .0 & .0 & .0 & .0 & .0 & .0 &.$t$ & .0 \\
\hline VAK & .0 & 1.7 & 1.7 & .0 & .0 & .0 & .0 & .0 & .0 & .0 & 3.4 & 3.4 \\
\hline ILTAL & .6 & 11.0 & 34.2 & 28.7 & 17.5 & 6.7 & 1.3 & .0 & .0 & .0 & $100 . \mathrm{C}$ & 9.3 \\
\hline
\end{tabular}


TABLE 41. Continued

SPEEO CLASS (MFH)

\begin{tabular}{|c|c|c|c|c|c|c|c|c|c|c|c|c|}
\hline WIRECIICA & 6 & $1-3$ & $4-7$ & $8-12$ & $1 \geq-18$ & $19-24$ & $25-31$ & $32-38$ & $39-46$ & $C 1.46$ & IOTAL & AV.SPEED \\
\hline WNE & .0 & .8 & 2.2 & .9 & .3 & .0 & .0 & .0 & .0 & .0 & 4.1 & 0.2 \\
\hline$N \mathrm{E}$ & .0 & .7 & $2 \cdot c$ & .5 & .2 & .0 & .0 & .0 & .0 & .0 & $3 . t$ & 0.1 \\
\hline$C \Lambda E$ & .0 & .5 & 1.3 & .4 & .1 & .0 & .0 & .0 & .0 & .0 & 2.2 & 5.0 \\
\hline$\varepsilon$ & .0 & .6 & 1.6 & .6 & .0 & .0 &.$c$ & .0 & .0 & .0 & $2 \cdot \varepsilon$ & 5.6 \\
\hline CSE & .0 & .7 & 1.5 & .4 & .0 & .0 &. $\mathrm{C}$ &.$c$ & .0 & .0 & 2.5 & 5.2 \\
\hline st & .0 & .8 & 1.8 & .4 & .0 & .0 & .0 & .0 & .0 & .0 & 2.9 & 5.1 \\
\hline SSE &. $\mathrm{c}$ & .5 & 1.1 & .4 &.$c$ & .0 &. $\mathrm{c}$ & .0 & .0 & .0 & $2 . c$ & 5.7 \\
\hline 3 & .0 & .7 & 1.5 & .3 & .1 & .0 &. $\mathrm{C}$ & .0 & .0 & .0 & $2 . t$ & 5.4 \\
\hline ssh & $\because 0$ & .5 & 1.4 & .6 & .2 & .0 & .0 & .0 & .0 & .0 & $2 . t$ & 0.0 \\
\hline sh &.$i$ &.$t$ & c. 1 & 1.7 & .9 & .3 & .1 & .0 & .0 & .0 & $5 . t$ & $9 . \mathrm{C}$ \\
\hline ns &.$c$ & .6 & 2.5 & 2.8 & 1.4 & .3 & .2 & .0 & .0 & .0 & 8.6 & 9.5 \\
\hline 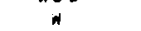 &.$c$ & .9 & 4.5 & 4.0 & 1.1 & .1 & . C & .0 & .0 & .0 & 10.7 & 8.0 \\
\hline minn & .0 & .6 & 3.8 & 7.9 & 4.7 & 1.6 & .2 & .0 & .0 & .0 & 18.9 & 11.2 \\
\hline$n$ & .0 & .7 & $\bar{j} .5$ & 5.5 & 5.0 & 2.8 & .5 & .0 & .0 & .0 & 17.9 & 12.5 \\
\hline NN & .0 & .7 & 2,3 & 1.0 & .2 & .0 & .0 & .0 & .0 & .0 & 4.3 & 6.4 \\
\hline $\mathrm{N}$ & .0 & 1.0 & 2.7 & .8 & .1 & .0 & .0 & .0 & .0 & .0 & $4 . t$ & 5.6 \\
\hline$C A L F$ & .4 &.$c$ & .6 & .0 & .0 & .0 & .0 & .0 & .0 & .0 & .4 & .0 \\
\hline VAF & .0 & 2.3 & 1.7 & .0 & .0 & .0 & .0 & .0 & .0 & .0 & $4 . C$ & 3.3 \\
\hline TUTAL & .4 & 13.2 & 37.8 & 27.9 & 14.3 & 5.4 & .9 & .0 & .0 & .0 & 100.6 & 8.6 \\
\hline
\end{tabular}

$\frac{x}{\sigma}$

Ale

SPEED CLASS (MPH)

\begin{tabular}{|c|c|c|c|c|c|c|c|c|c|c|c|c|}
\hline LIKECTILE & $u$ & $1-3$ & $4-7$ & $8-12$ & $13-18$ & $19-24$ & $25-31$ & $32-38$ & $39-46$ & C.T.46 & TOTAL & AV.SPEED \\
\hline NNE & .0 & 1.0 & 2.1 & .6 & .1 & .0 & .0 & .0 & .0 & .0 & 3.7 & 5.3 \\
\hline NE & .6 & 1.1 & $1 . t$ & .2 & .1 & .0 & .0 & .0 & .0 & .0 & $3 . c$ & 4.6 \\
\hline ENE & .0 & .7 & 1.3 & .1 & .0 & .0 & .0 & .0 & .0 & .0 & 2.2 & 4.7 \\
\hline$E$ & .0 & .9 & 1.5 & .3 & .0 & .0 & .0 & .0 & .0 & .0 & 2.7 & 4.7 \\
\hline ESt & .0 & .8 & $1 . t$ & .3 & .0 & .0 & .0 & .0 & .0 & .0 & 2.7 & 4.9 \\
\hline Sk & .0 & .9 & 1.6 & .4 & .0 & .0 &.$c$ & .0 & .0 & .0 & 3.2 & 4.9 \\
\hline SSE & .6 & .6 & 1.2 & .6 & .0 & .0 &. $\mathrm{C}$ & .0 & .0 & .0 & 2.5 & 5.6 \\
\hline 5 & .0 & .8 & 1.4 & .5 & .1 & .0 & .0 & .0 & .0 & .0 & 2.8 & 5.2 \\
\hline ssh & .6 & .5 & 1.5 & .7 & .3 & .1 & .0 & .0 & .0 & .0 & 3.1 & 7.6 \\
\hline sn & .0 & .9 & 2.4 & 1.6 & .8 & .3 & .1 & .0 & .0 & .0 & 6.1 & 8.4 \\
\hline nsh & .0 & .8 & 3.1 & 3.1 & 1.4 & .2 & .0 & .0 & .0 & .0 & $8 . t$ & 8.6 \\
\hline 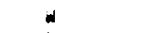 & .0 & 1.1 & 5.0 & 4.5 & .9 & .1 & .0 & .0 & .0 & .0 & 11.7 & 7.7 \\
\hline in $N$ & .0 & .8 & 4.6 & 7.2 & 4.2 & 1.4 & .1 & .0 & .0 & .0 & 17.8 & 10.8 \\
\hline $\mathrm{Nh}$ & .0 & 1.0 & 3.5 & 4.8 & 4.3 & 2.2 & .4 & .0 & .0 & .0 & 16.2 & 11.8 \\
\hline NN & .0 & 1.0 & 2.4 & .7 & .1 & .0 & .0 & .0 & .0 & .0 & 4.2 & 5.8 \\
\hline $\mathrm{N}$ & .0 & 1.2 & 2.8 & .6 & .1 & .0 & .0 & .0 & .0 & .0 & 4.7 & 5.2 \\
\hline$C A L M$ & .7 & .0 & .0 & .0 & .0 & .0 & .0 & .0 & .0 & .0 & .7 & .4 \\
\hline VAR & .0 & 2.7 & 1.3 & .0 & .0 & .0 & .0 & .0 & .0 & .0 & $4 . C$ & 3.0 \\
\hline LATITL & .8 & 16.9 & 38.6 & 26.3 & 12.5 & 4.2 & .7 & .0 & .0 & .0 & $100 \cdot c$ & 8.0 \\
\hline
\end{tabular}


TABLE 41. Continued

SEP
SPEED CLASS (MPH)

\begin{tabular}{|c|c|c|c|c|c|c|c|c|c|c|c|c|}
\hline LIKEGTICA & 0 & $1-3$ & $4-7$ & $8-12$ & $13-18$ & $19-24$ & $25-31$ & $32-38$ & $39-46$ & CT.46 & IOTAL & AV.SHEED \\
\hline 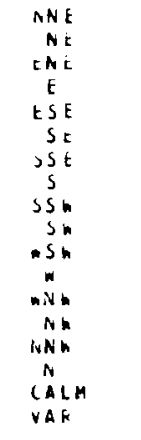 & $\begin{array}{l}. c \\
.0 \\
. c \\
.0 \\
. c \\
.0 \\
.6 \\
. c \\
.0 \\
.0 \\
.0 \\
.0 \\
.0 \\
.0 \\
.0 \\
.0 \\
1.4 \\
.0\end{array}$ & $\begin{array}{l}1.5 \\
1.6 \\
1.1 \\
1.5 \\
1.1 \\
1.2 \\
.7 \\
.9 \\
.7 \\
.7 \\
1.0 \\
1.2 \\
1.1 \\
1.2 \\
1.2 \\
1.7 \\
. .4 \\
2.1\end{array}$ & $\begin{array}{l}2.6 \\
1.7 \\
.9 \\
1.4 \\
1.6 \\
1.5 \\
1.2 \\
1.4 \\
1.6 \\
2.0 \\
3.1 \\
5.3 \\
4.0 \\
3.5 \\
2.7 \\
2.8 \\
.6 \\
.6\end{array}$ & $\begin{array}{r}1.1 \\
.5 \\
.1 \\
.2 \\
.1 \\
.4 \\
.7 \\
.5 \\
.6 \\
1.3 \\
3.1 \\
4.3 \\
5.6 \\
4.8 \\
1.1 \\
1.0 \\
.0 \\
.0\end{array}$ & $\begin{array}{l}.4 \\
.3 \\
.1 \\
.0 \\
.0 \\
.0 \\
.1 \\
.1 \\
.3 \\
1.0 \\
1.2 \\
.9 \\
2.8 \\
3.1 \\
.2 \\
.2 \\
.0 \\
.0\end{array}$ & $\begin{array}{l}.1 \\
.1 \\
.0 \\
.0 \\
.0 \\
.0 \\
.0 \\
.0 \\
.1 \\
.4 \\
.5 \\
.2 \\
.9 \\
1.3 \\
.0 \\
.0 \\
.0 \\
.0\end{array}$ & $\begin{array}{l}.0 \\
.0 \\
.0 \\
.0 \\
.0 \\
.0 \\
.0 \\
.0 \\
.1 \\
.2 \\
.1 \\
.0 \\
.1 \\
.1 \\
.0 \\
.0 \\
.0 \\
. c\end{array}$ & $\begin{array}{l}.0 \\
.0 \\
.0 \\
.0 \\
.0 \\
.0 \\
.0 \\
.0 \\
.0 \\
.0 \\
.0 \\
.0 \\
.0 \\
.0 \\
.0 \\
.0 \\
.0 \\
.0\end{array}$ & $\begin{array}{l}.0 \\
.0 \\
.0 \\
.0 \\
.0 \\
.0 \\
.0 \\
.0 \\
.0 \\
.0 \\
.0 \\
.0 \\
.0 \\
.0 \\
.0 \\
.0 \\
.0 \\
.0\end{array}$ & $\begin{array}{l}.0 \\
.0 \\
.0 \\
.0 \\
.0 \\
.0 \\
.0 \\
.0 \\
.0 \\
.0 \\
.0 \\
.0 \\
.0 \\
.0 \\
.0 \\
.0 \\
.0 \\
.0\end{array}$ & $\begin{array}{r}5.1 \\
4.2 \\
2.3 \\
3.2 \\
2.5 \\
3.5 \\
2.7 \\
2.5 \\
3.2 \\
5.6 \\
9.1 \\
11.9 \\
14.5 \\
14.0 \\
5.2 \\
5.8 \\
1.4 \\
2.7\end{array}$ & $\begin{array}{r}6.3 \\
5.8 \\
4.8 \\
4.0 \\
4.1 \\
4.6 \\
5.8 \\
5.6 \\
7.1 \\
9.5 \\
9.1 \\
7.7 \\
9.9 \\
10.6 \\
6.0 \\
5.6 \\
.0 \\
2.5\end{array}$ \\
\hline TUTAL & 1.4 & 20.6 & 37.4 & 25.4 & 10.8 & 3.6 & .7 & .0 & .0 & .0 & $100 . \mathrm{C}$ & 7.5 \\
\hline
\end{tabular}

$\stackrel{x}{\stackrel{y}{y}}$

OCT

SPEEO CLASS (MFH)

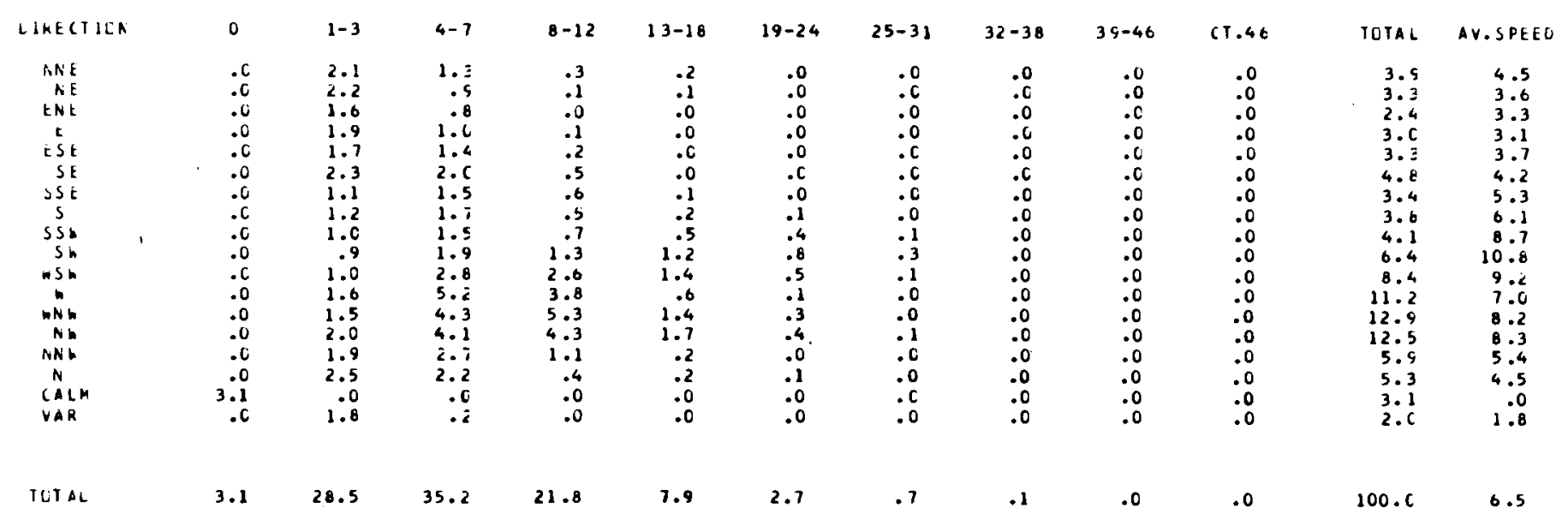


TABLE 41. Continued

NCV

SPEEC CLASS (MFF)

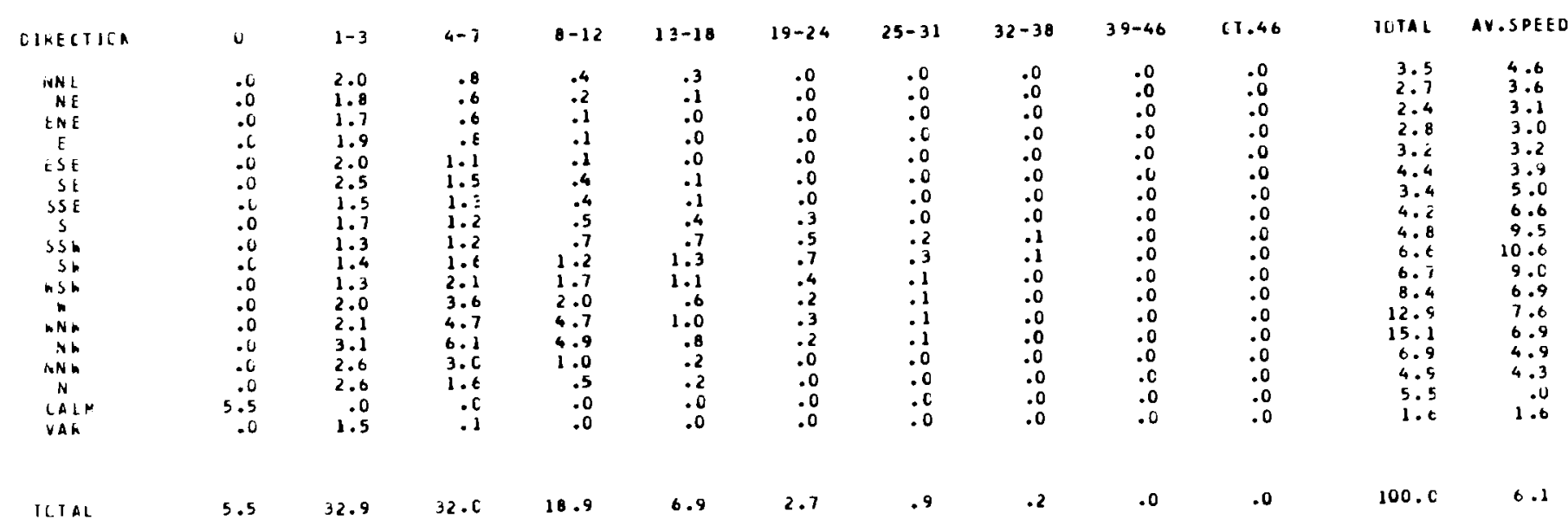

$\frac{x}{00}$

DEC

SPEED (LASS (MPH)

\begin{tabular}{|c|c|c|c|c|c|c|c|c|c|c|c|c|}
\hline LIktCTIEA & c & $1-3$ & $4-7$ & $8-12$ & $13-18$ & $19-24$ & $25-31$ & $32-38$ & $39-46$ & 61.46 & TOTAL & AV.SPEED \\
\hline $\begin{array}{l}\mathrm{WN} \\
\mathrm{NE}\end{array}$ & $\begin{array}{l}.0 \\
.0\end{array}$ & $\begin{array}{l}1.7 \\
1.6\end{array}$ & .7 & .2 & .2 & .0 & .0 & .0 & .0 & .0 & 2.8 & 4.2 \\
\hline$E N E$ & .0 & $\begin{array}{l}1.6 \\
1.5\end{array}$ & .5 & .1 & .0 & .0 & .0 & .0 & .0 & .0 & 2.2 & 2.8 \\
\hline$E$ & .0 & & $\cdot t$ & .0 & .0 & & $\begin{array}{l}-6 \\
0\end{array}$ & .0 & & .0 & $\begin{array}{l}2.1 \\
2.4\end{array}$ & $\begin{array}{l}2.8 \\
2.9\end{array}$ \\
\hline tst & .0 & 1.6 & .7 & .1 & .0 & $\because 0$ & .0 & .0 & .0 & .0 & $\begin{array}{l}2.4 \\
2.7\end{array}$ & \\
\hline$S E$ & .0 & 2.3 & $\begin{array}{r}.8 \\
1.8\end{array}$ & .2 & .1 & $\begin{array}{l}.0 \\
.0\end{array}$ & .0 & .0 & .0 & .0 & 3.9 & $\begin{array}{l}3.6 \\
3.7\end{array}$ \\
\hline $55 \mathrm{E}$ &.$C$ & 1.6 & $\begin{array}{l}1.8 \\
1.8\end{array}$ & .3 & .12 & .0 & .0 & .0 & .0 & .0 & 3.3 & 4.7 \\
\hline$s$ & .0 & 1.7 & i. $\mathrm{c}$ & .3 & .3 & .2 & .0 & .0 & $\because 0$ & .0 & 3.7 & 6.2 \\
\hline sSh & .6 & 1.4 & .5 & .6 & .8 & .6 & .4 & .1 & .0 & .0 & 4.7 & 11.1 \\
\hline$s$ & .0 & 1.4 & 1.4 & 1.1 & 1.3 & 1.1 & .5 & .1 & .0 & .0 & 0.8 & 11.9 \\
\hline ns b & .0 & 1.5 & 1.8 & 1.8 & 1.3 & .5 & .2 & .0 & .0 & .0 & 7.6 & $9 \cdot 3$ \\
\hline$n$ & .0 & $2 . c$ & 2.5 & 1.8 & .8 & .2 & .1 & .0 & .0 & .0 & 7.8 & 7.0 \\
\hline man & .0 & 2.5 & 5.2 & 4.9 & .7 & .1 & . $C$ & .0 & .0 & .0 & 13.6 & 7.0 \\
\hline$v_{h}$ & .0 & 3.2 & 6.5 & 5.8 & 1.0 & .1 & .0 & .0 & .0 & .0 & 17.1 & 6.9 \\
\hline WNE & .6 & 2.7 & 2.7 & 1.0 & .1 & .0 & .0 & .0 & .0 & .0 & 6.5 & 4.6 \\
\hline $\mathrm{A}$ & .0 & 2.8 & 1.2 & .4 & .2 & .0 & .0 & .0 & .0 & .0 & 4.7 & $\begin{array}{l}4.0 \\
.0\end{array}$ \\
\hline$\because A L M$ & 6.9 & .00 & $\begin{array}{l}.0 \\
.1\end{array}$ & .0 & $\begin{array}{l}.0 \\
.0\end{array}$ & .0 & $\because 0$ & .0 & $\begin{array}{l}.0 \\
.0\end{array}$ & $\begin{array}{l}.0 \\
.0\end{array}$ & $\begin{array}{l}6.9 \\
1.5\end{array}$ & 1.0 \\
\hline VAR & .0 & 1.8 & $\cdots$ & & & & & & & & & \\
\hline & 6.9 & 32.9 & 29.5 & 19.0 & 7.1 & 2.9 & 1.1 & .2 & .1 & .0 & $100 . C$ & 6.1 \\
\hline
\end{tabular}


TABLE 41. Continued

ANNUAL

SPEED CLASS (MFH)

\begin{tabular}{|c|c|c|c|c|c|c|c|c|c|c|c|c|}
\hline LIKECIILA & 0 & $1-3$ & $4-7$ & $8-12$ & $13-18$ & $19-24$ & $25-31$ & $32-38$ & $39-46$ & GT.46 & TDTAL & AV.SPEED \\
\hline IVNE & ن & 1.4 & 1.4 & .6 & .3 & .1 & .0 & .0 & .0 & .0 & 3.7 & 5.7 \\
\hline $\mathrm{NE}$ &.$c$ & 1.4 & $1 . \bar{c}$ & .3 & .2 & .1 & .0 & .0 & .0 & .0 & 3.2 & 5.1 \\
\hline$E A^{\prime} E$ & .0 & 1.0 & .5 & .2 & .0 & .0 & .0 & .0 & .0 & .0 & 2.1 & 4.3 \\
\hline$t$ & .0 & 1.2 & 1.1 & .2 & .0 & .0 & .0 & .0 & .0 & .0 & $2 . t$ & 4.1 \\
\hline CSE & .0 & 1.1 & 1.2 & .2 & .0 & .0 & .0 & .0 & .0 & .0 & 2.6 & 4.2 \\
\hline SE &.$c$ & 1.5 & $1 . t$ & .4 & .1 & .0 & . C & .0 & .0 & .0 & 3.6 & 4.5 \\
\hline SSt & .0 & .9 & 1.2 & .5 & .1 & .0 & .0 & .0 & .0 & .0 & 2.8 & 5.6 \\
\hline 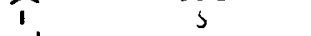 & .0 & 1.0 & 1.3 & .5 & .2 & .1 & .0 & .0 & .0 & .0 & 3.3 & 6.4 \\
\hline ssn &.$c$ & .8 & 1.3 & .7 & .6 & .3 & .1 & .0 & .0 & .0 & 4.0 & 9.4 \\
\hline sh &.$C$ & .9 & 1.5 & 1.5 & 1.4 & .8 & .3 & .1 & .0 & .0 & 6.8 & 11.1 \\
\hline$n .5 \mathrm{~h}$ & .0 & .9 & 2.5 & 2.8 & 1.6 & .6 & .2 & .0 & .0 & .0 & 8.5 & 9.9 \\
\hline$w$ & .0 & 1.3 & 4.1 & 3.6 & 1.1 & .2 & .0 & .0 & .0 & .0 & 10.3 & 7.9 \\
\hline W.Y W & .0 & 1.3 & 4.3 & 6.2 & 2.9 & 1.0 & .1 & .0 & .0 & .0 & 15.8 & 9.8 \\
\hline$N$ in & .0 & 1.7 & 4.7 & 5.2 & 2.8 & 1.2 & .2 & .0 & .0 & .0 & 15.8 & 9.8 \\
\hline NN n & .0 & 1.5 & 2.5 & .9 & .2 & .0 & .0 & .0 & .0 & .0 & 5.2 & 5.5 \\
\hline iv & .0 & 1.8 & 2.0 & .7 & .2 & .0 & . C & .0 & .0 & .0 & 4.7 & 5.1 \\
\hline CALM & 2.5 & .0 & .0 & .0 & .0 & .0 & .0 & .0 & .0 & .0 & 2.5 & .0 \\
\hline VAK & .4 & 1.9 & .7 & .0 & .0 & .0 & .0 & .0 & .0 & .0 & 2.5 & 2.6 \\
\hline TLTAL & 2.5 & 21.8 & 33.8 & 24.0 & 11.6 & 4.4 & 1.2 & .2 & .0 & .0 & 100.0 & $B .0$ \\
\hline
\end{tabular}


TABLE 42. Monthly and Annual Percent Frequency Distribution of 200-Foot Wind Direction Versus Speed Class, 1955 Through 1980

Jak

SPEED CLASS (MPH)

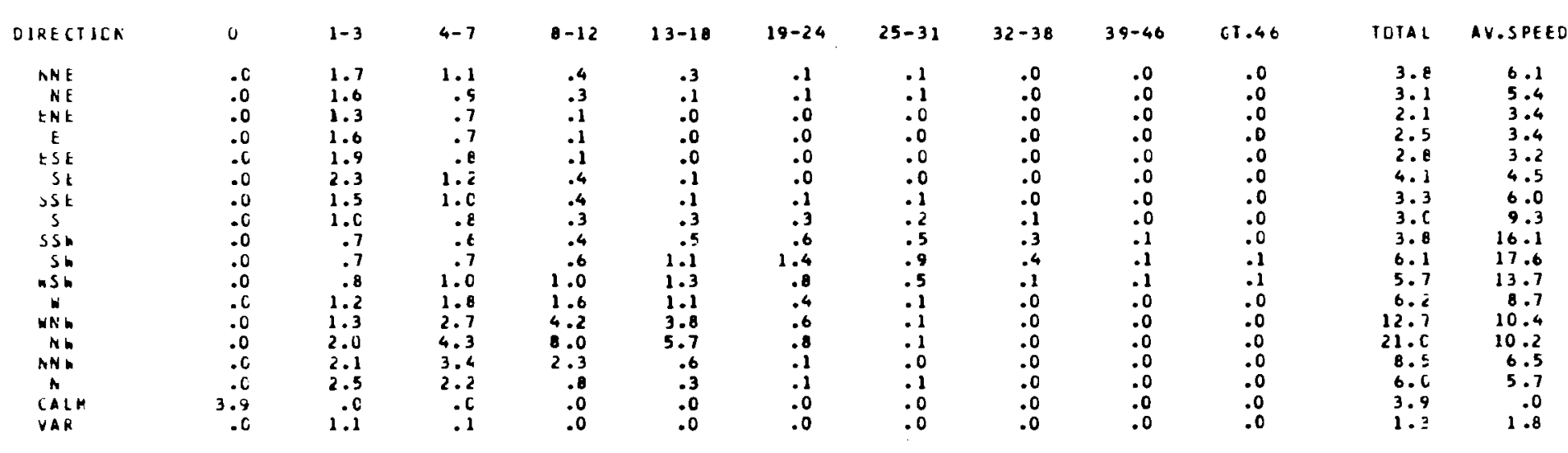

$x$
1
0

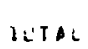

3.9

$25.4 \quad 24.1$

21.2

15.6

$5.5 \quad 2.8 \quad 1.0$

FEB

SPEED CLASS (MPH)

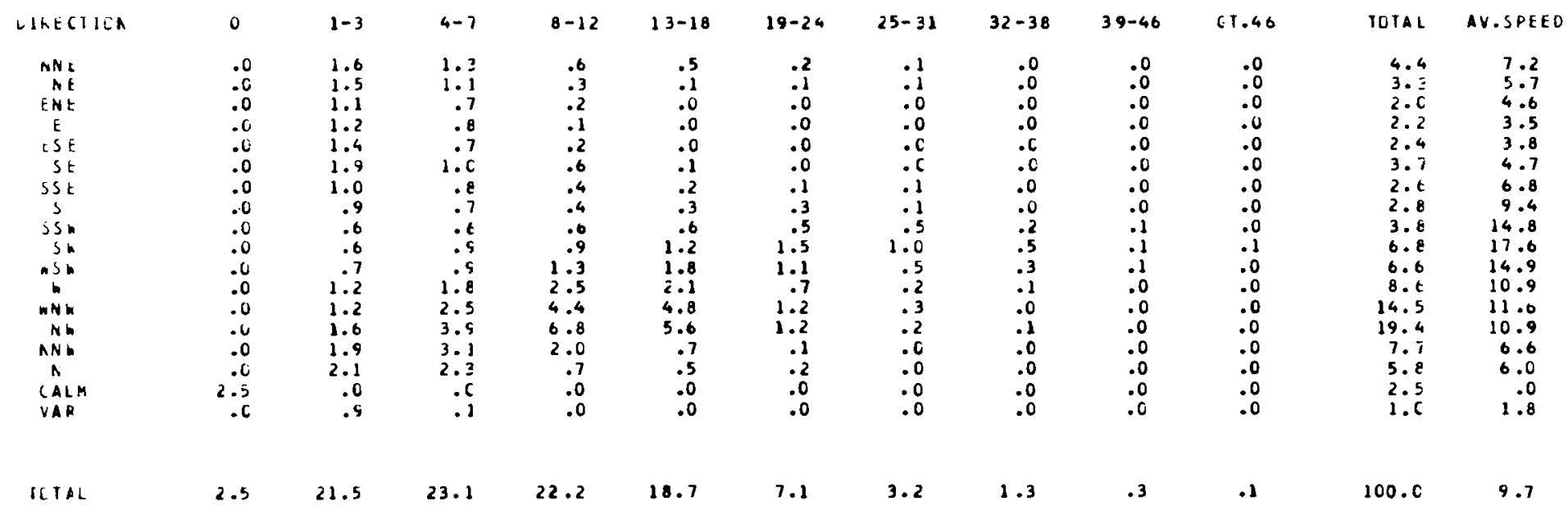


TABLE 42. Continued

\section{MAR}

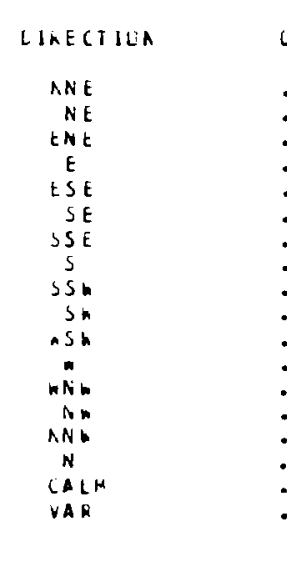

$x$
1
1

$\begin{array}{rrr}1-3 & 4-7 & 8-12 \\ 1.1 & 1.4 & .9 \\ 1.3 & 1.3 & .5 \\ .7 & .8 & .2 \\ .9 & 1.0 & .2 \\ 1.0 & 1.0 & .2 \\ 1.0 & 1.8 & .8 \\ .6 & 1.0 & .8 \\ .6 & 1.1 & .7 \\ .5 & .5 & 1.1 \\ .6 & .9 & 1.4 \\ .5 & 1.8 & 1.7 \\ .7 & 1.9 & 3.0 \\ .6 & 2.1 & 4.2 \\ 1.9 & 2.7 & 5.0 \\ 1.4 & 2.4 & 1.8 \\ .0 & 2.2 & 1.1 \\ .8 & .0 & .0 \\ & .1 & .0 \\ & & \end{array}$

13-18

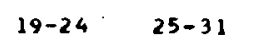

$32-38 \quad 39-46$

$\begin{array}{crc}(T .46 & \text { TOTAL } & \text { AV.SPEED } \\ .0 & 4.4 & 7.9 \\ .0 & 3.4 & 5.8 \\ .0 & 1.5 & 5.2 \\ .0 & 2.2 & 4.7 \\ .0 & 2.4 & 4.6 \\ .0 & 3.5 & 6.1 \\ .0 & 3.6 & 8.4 \\ .0 & 3.3 & 10.3 \\ .0 & 5.4 & 14.2 \\ .0 & 8.4 & 17.4 \\ .0 & 9.1 & 15.7 \\ .0 & 9.6 & 11.7 \\ .0 & 14.7 & 13.7 \\ .0 & 15.6 & 12.3 \\ .0 & 6.8 & 7.3 \\ .0 & 5.3 & 6.8 \\ .0 & .7 & .0 \\ .0 & 1.7 & 2.6\end{array}$

ILTAL

$14.4 \quad 24.1$

23.4

21.1
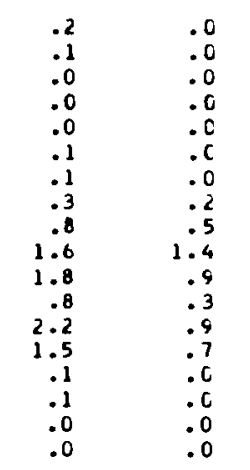

.0
.0
.0
.0
.0
.0
.0
.0
.2
.5
.2
.1
.1
.1
.0
.0
.0

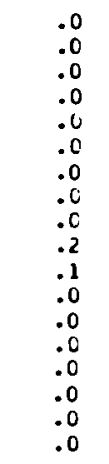

$100 . c$

11.2

\section{AFR}

SPEEO CLASS (MFT.)

LIKECTIEA 6 1.3 $4-7 \quad 8-12$

$13-18 \quad 19-24$
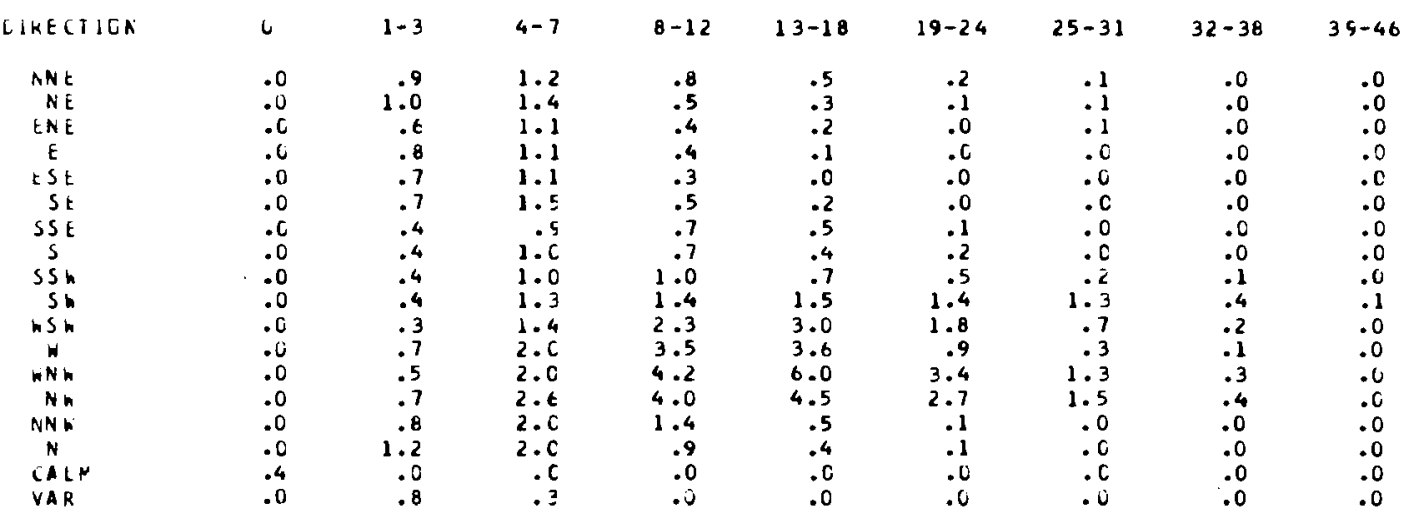

$6 T .46$
.0
.0
.0
.0
.0
.0
.0
.0
.0
.0
.0
.0
.0
.0
.0
.0
.0
.0

TLTAL AV.SFEED

ICIAL

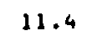

23.7

23.0

22.5

11.8

5.7

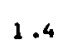

.0

$100 \cdot 0$

11.9 
TABLE 42. Continued

SPEED CLASS (MPH)

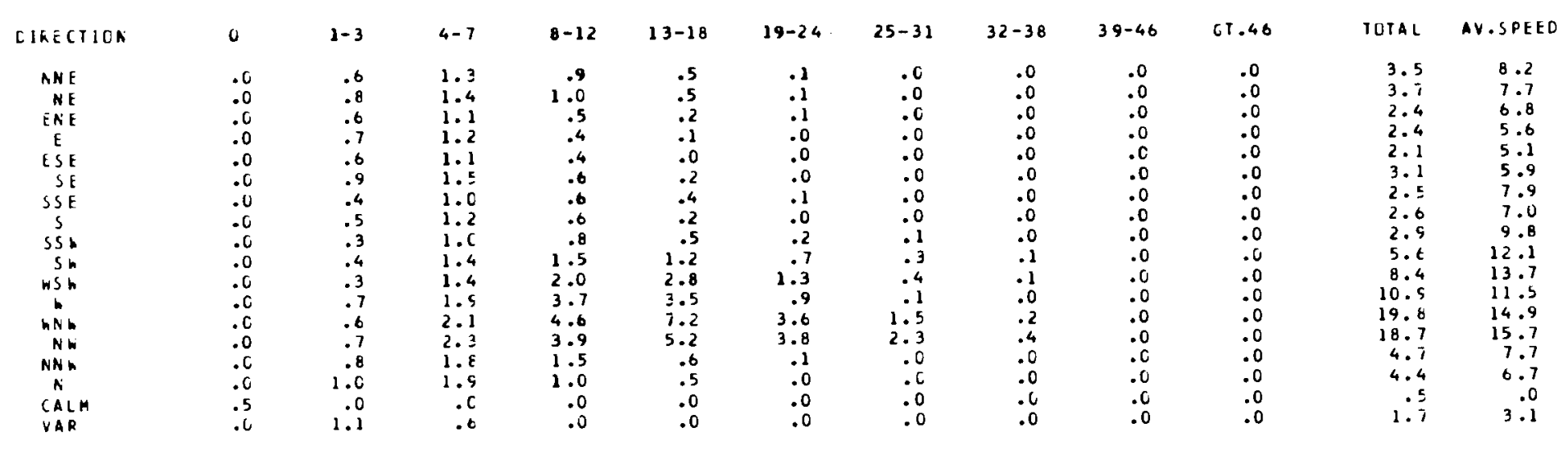

$x$
$N$

$\begin{array}{lllllllllllllllll}\text { HAL } & .5 & 11.0 & 24.1 & 24.1 & 23.4 & 11.0 & 5.0 & .8 & .1 & .0 & 100 . \mathrm{C} & 11.5\end{array}$

\section{Jルa}

SPEED (LASS IMPH)

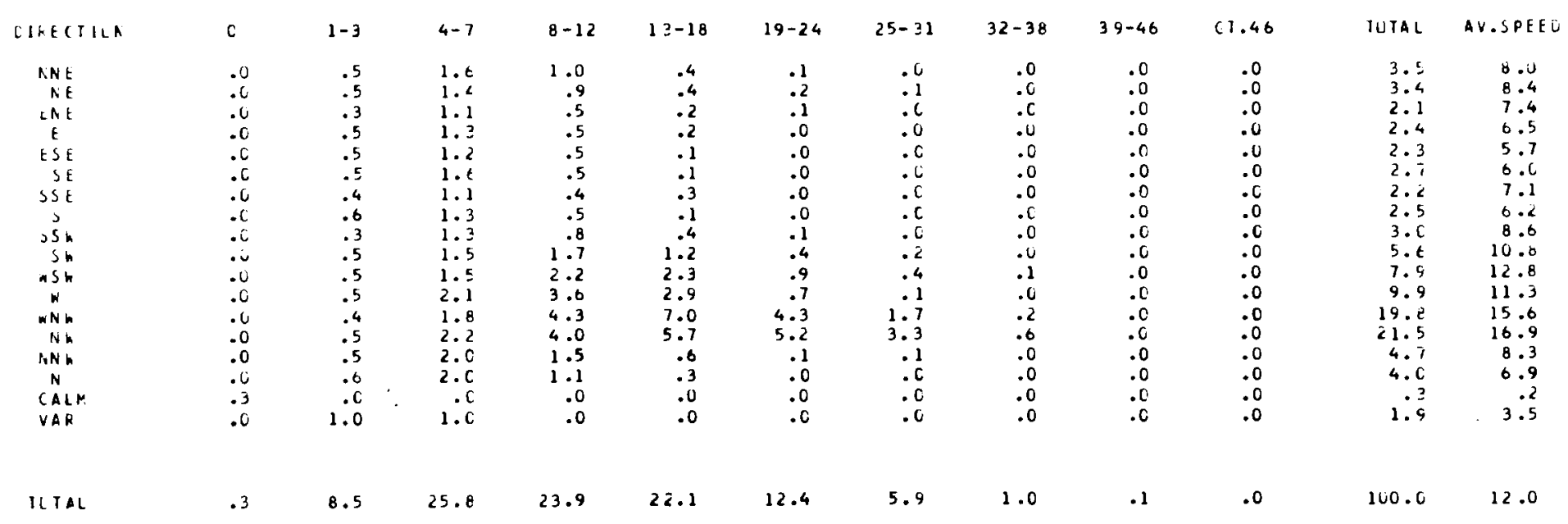


TABLE 42. Continued

\section{JUL}

SPEED CLASS (MPH)

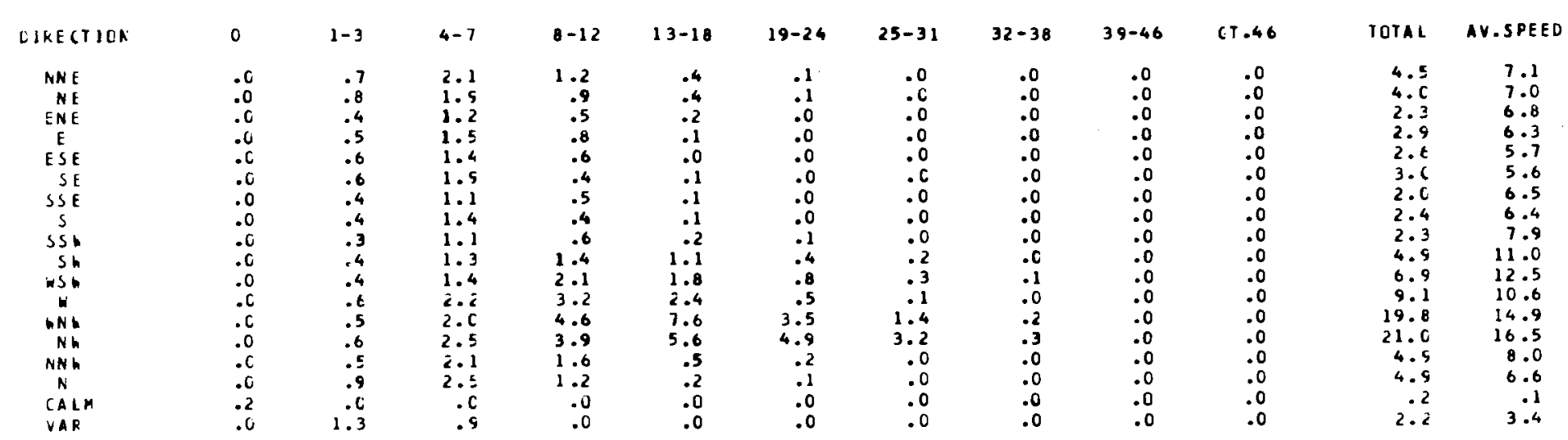

杀

EED CLASS (MPH)

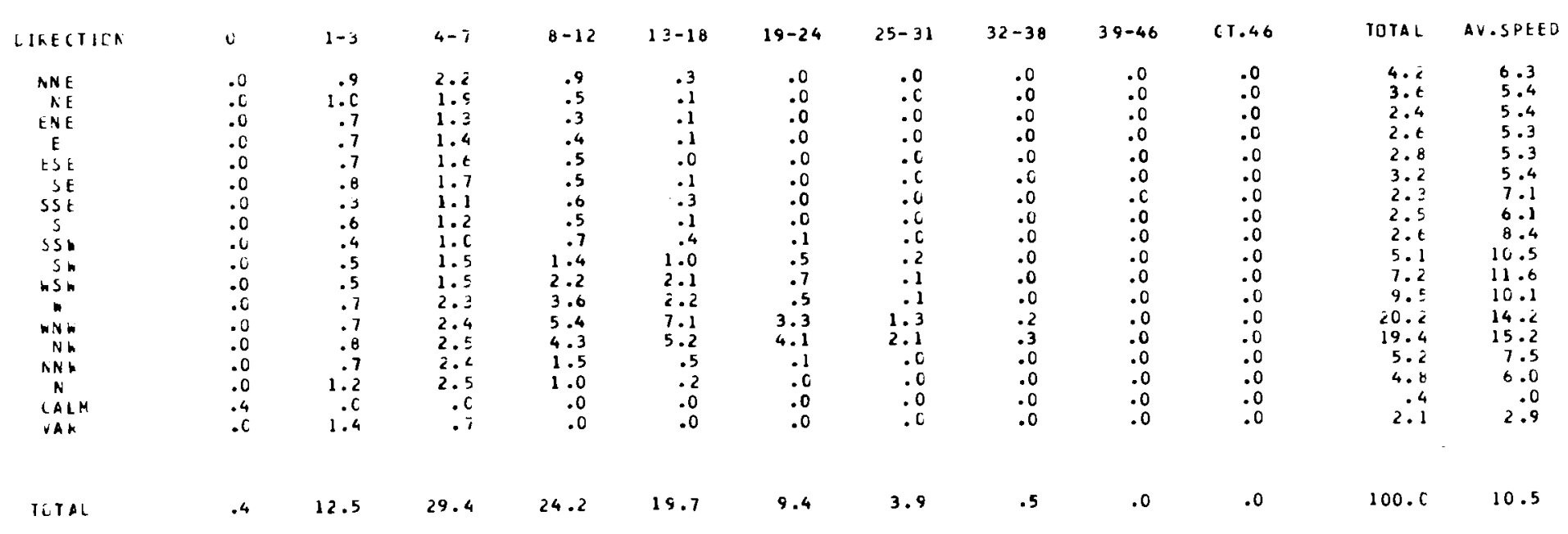


TABLE 42. Continued

\section{SEP}

SPEED CLASS (MPH)

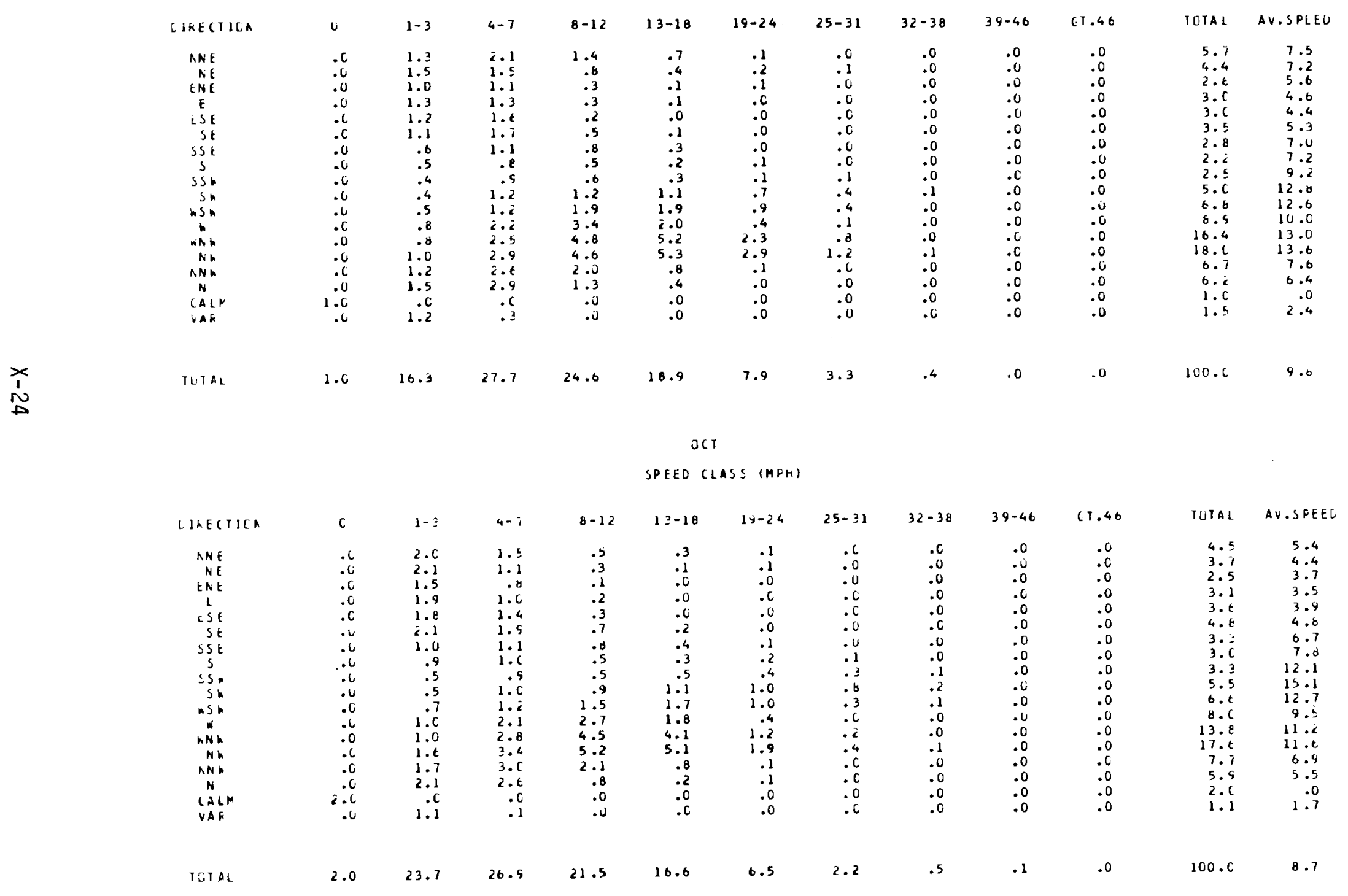


TABLE 42. Continued

NOV

SPEED CLASS - (HPH)

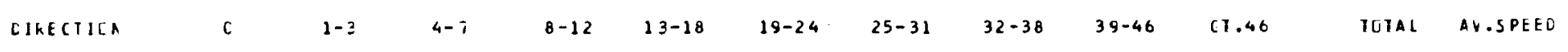
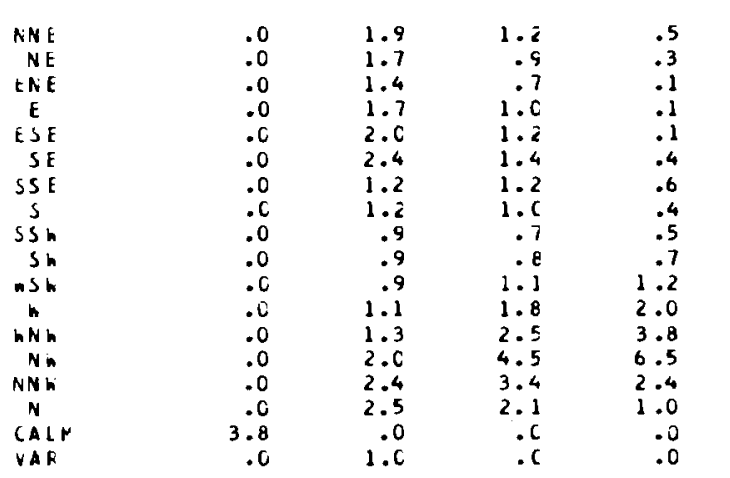

.5
.1
.0
.0
.0
.2
.3
.4
.7
1.1
1.3
1.3
3.3
4.3
.7
.4
.0
.0

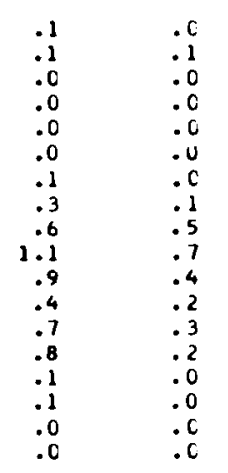

.0
.0
.0
.0
.0
.0
.0
.0
.1
.3
.1
.1
.0
.1
.0
.0
.0
.0
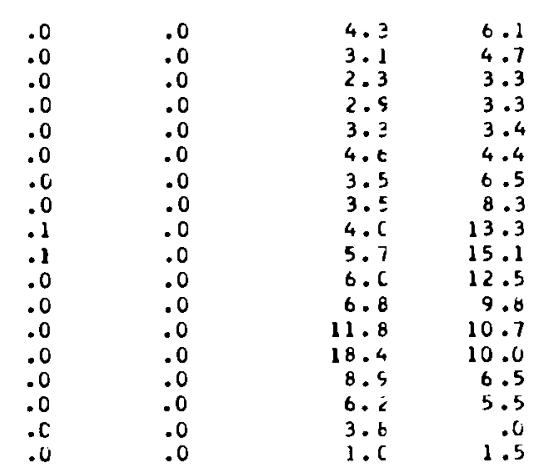

$\underset{\substack{n \\ \mathfrak{n}}}{\stackrel{x}{1}}$

TUTAL

26.5

$25 . t \quad 20.7$

$14.7 \quad 5.2$

2.5

.7

.2

$100 . i$

DEC

SPEED CLASS (MPH)

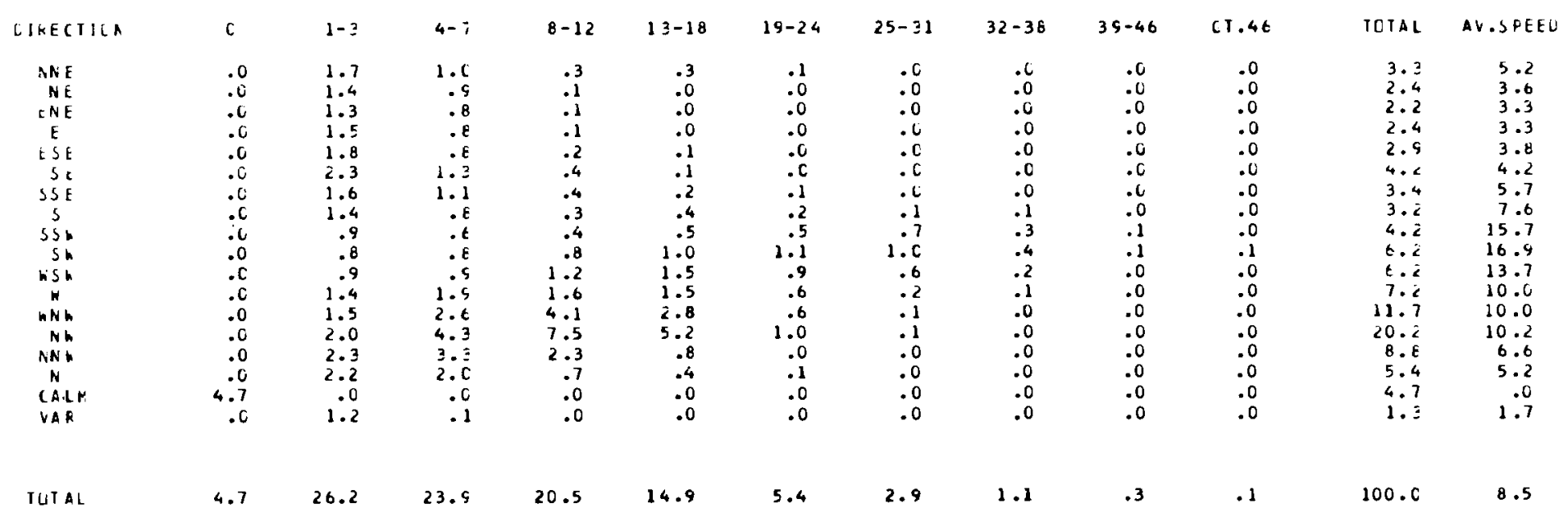




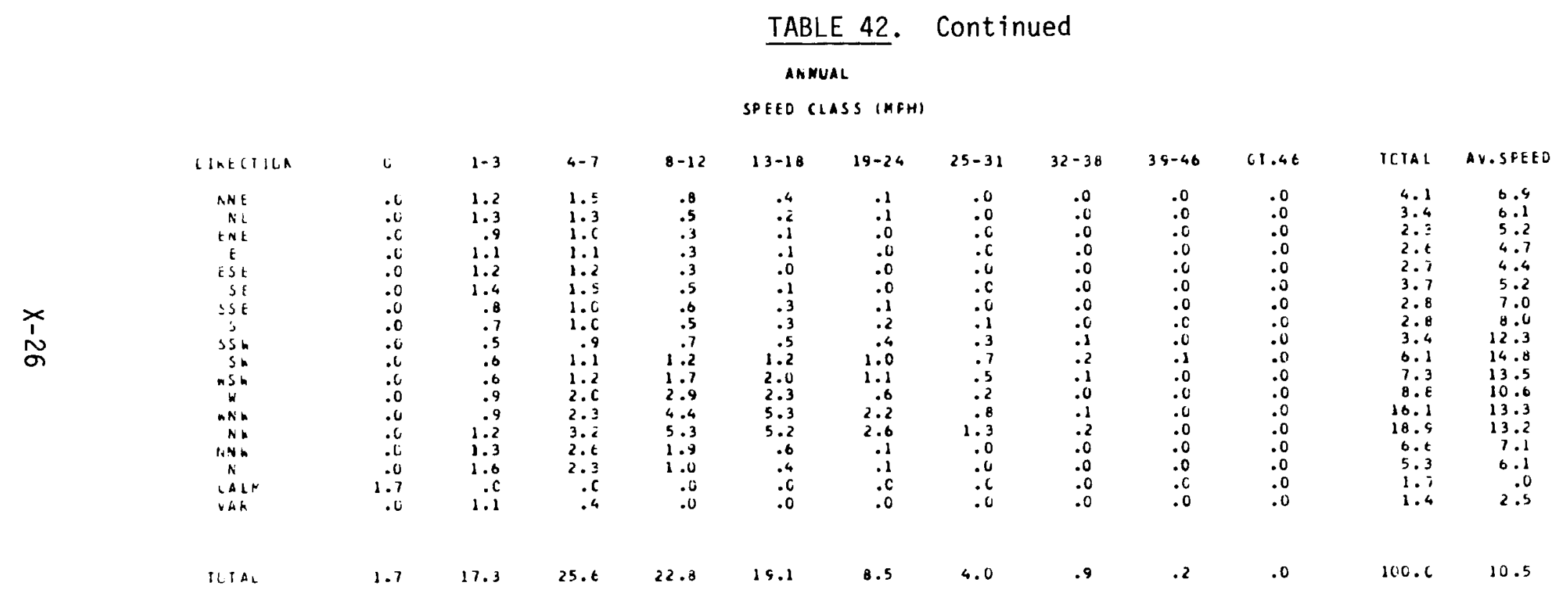


TABLE 43. Monthly and Annual Percent Frequency Distribution of 400-Foot Wind Direction Versus Speed Class, 1955 Through 1980

JAN

SPEED CLASS (

\begin{tabular}{|c|c|c|c|c|c|c|c|c|c|c|c|c|}
\hline CIFECTICA & 0 & $1-3$ & $4-7$ & $8-12$ & $13-18$ & $19-24$ & $25-31$ & $32-38$ & $39-46$ & CT.46 & TOTAL L & AV.SPEED \\
\hline NNE & .0 & 1.6 & 1.0 & .5 & .4 & .2 & .1 & .0 & .0 & .0 & 3.8 & 7.0 \\
\hline $\begin{array}{r}N E \\
\text { NNE }\end{array}$ & $\cdot \mathrm{C}$ & 1.2 & $\cdot 6$ & .2 & .1 & -1 & .1 & .0 & .0 & .0 & 2.4 & 6.2 \\
\hline ENE & -6 & 1.1 & .7 & .1 & .0 & .0 & .0 & .0 & .0 & .0 & 1.5 & 3.7 \\
\hline E & .0 & 1.9 & .6 & .1 & .0 & .0 & .0 & .0 & .0 & .0 & 2.6 & 2.8 \\
\hline ESE & .0 & 1.6 & .7 & .1 & .0 & .0 & .0 & .0 & .0 & .0 & 2.4 & 3.1 \\
\hline SE & . C & 2.2 & 1.1 & .3 & .1 & .0 & .0 & .0 & .0 & .0 & 3.8 & 4.4 \\
\hline SSE &. $\mathrm{c}$ & 1.2 & .7 & .3 & .2 & .1 & .1 & .1 & .0 & .0 & 2.8 & 7.6 \\
\hline 5 & .0 & .9 &.$t$ & .3 & .3 & .3 & 1 & $\because 1$ & .0 & .0 & 2.7 & 10.0 \\
\hline ssm &. $\mathrm{C}$ &.$e$ & .4 & .4 & .5 & .6 & .5 & .4 & .2 & .1 & 3.7 & 18.6 \\
\hline 5 & .0 & .7 & .7 & .7 & 1.0 & $1: 2$ & $1: 2$ & .0 & .4 & .1 & 6.5 & 19.9 \\
\hline WS h & .0 & .7 & .9 & .9 & 1.2 & 1.0 & .7 & .4 & .1 & .1 & $6 . \mathrm{C}$ & 15.9 \\
\hline W & .0 & 1.0 & 1.5 & 1.6 & 1.1 & .5 & .2 & .0 & .0 & .0 & 5.5 & 10.1 \\
\hline WN & .0 & 1.5 & 2.4 & 2.9 & 2.6 & .8 & .2 & .0 & .0 & .0 & 10.3 & 10.3 \\
\hline $\mathrm{Nh}$ & .0 & 2.0 & 4.4 & 7.8 & 6.4 & 1.2 & .1 & .1 & .0 & .0 & 22.6 & 10.6 \\
\hline ANh & .0 & 2.2 & 3.7 & 2.8 & 1.0 & .1 &.$c$ & .0 & .0 & .0 & 9.8 & 7.0 \\
\hline N & .0 & 2.4 & 2.3 & 1.0 & .4 & .2 & .1 & .0 & .0 & .0 & 6.3 & 6.3 \\
\hline$C A L M$ & $t .0$ & .0 & .6 & .0 & .0 & .0 & .0 & .0 & .0 & .0 & $0 . \bar{c}$ & .0 \\
\hline$V A F$ & .0 & 1.0 & .1 & .0 & .0 & .0 & .0 & .0 & .0 & .0 & $1 . i$ & 1.5 \\
\hline TETAL & $t .0$ & 23.8 & 22.4 & 19.7 & 15.4 & 6.3 & $3 . t$ & 1.7 & .8 & .3 & $100 \cdot C$ & 9.3 \\
\hline
\end{tabular}

SPEE (LASS (HFH)

\begin{tabular}{|c|c|c|c|c|c|c|c|c|c|c|c|c|}
\hline CIRECTICA & $c$ & $1-3$ & $4-7$ & $8-12$ & $13-18$ & $19-24$ & $25-31$ & $32-38$ & $35=46$ & 61.46 & IUTAL & AV.SPEED \\
\hline NNE & i & 1.4 & 1. $C$ & .6 & .6 & .3 & .1 & .1 & .0 & .0 & 4.1 & 8.8 \\
\hline $\mathrm{NE}$ & .0 & 1.3 & .8 & .3 & .1 & .2 & .0 & .1 & .0 & .0 & $2 . \varepsilon$ & 6.8 \\
\hline $\operatorname{ENE}$ & .0 & 1.0 &.$t$ & .1 & .0 & .0 & . c & .0 & .0 & .0 & 1.8 & 3.8 \\
\hline E & .6 & 1.4 & .7 & .1 & .0 & .0 & .0 & .0 & .0 & .0 & 2.1 & 3.3 \\
\hline $\operatorname{cs} E$ &.$c$ & 1.3 & .7 & .2 & .0 &. $\mathrm{c}$ &. $\mathrm{c}$ & .0 & .0 & .0 & 2.3 & 3.8 \\
\hline $\mathrm{SE}$ & .0 & 1.7 & 1. $c$ & .5 & .2 & .0 & .0 & .0 & .0 & .0 & 3.4 & 5.1 \\
\hline \&5 &.$c$ & 1.0 & .6 & .4 & .3 & .2 & .1 & .0 & .0 & .0 & $2 . t$ & 7.5 \\
\hline 5 & .0 & .7 & .7 & .3 & .3 & .3 &. $\bar{z}$ & .0 & .0 & .0 & 2.5 & 10.1 \\
\hline ssh & .0 & .5 & .5 & .5 & .7 & .5 & .5 & .3 & .1 & .0 & $3 . t$ & 16.7 \\
\hline sh &.$c$ & .6 & .7 & .7 & 1.1 & 1.3 & 1.3 & .8 & .4 & .1 & $7 . \mathrm{C}$ & 20.7 \\
\hline ns &.$c$ & .6 & . E & 1.1 & 1.6 & 1.4 & .7 & .4 & .2 & .0 & $6 . \varepsilon$ & 16.9 \\
\hline 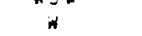 &.$c$ & 1.1 & 1.7 & 2.0 & 2.1 & 1.0 & .3 & .1 & .0 & .0 & 8.4 & 12.0 \\
\hline$n N n$ &.$c$ & $\begin{array}{l}1.1 \\
1.2\end{array}$ & 2.2 & 2.9 & 3.3 & 1.2 & .6 & .2 & .0 & .0 & 11.5 & 12.2 \\
\hline$N_{n h}$ &.$c$ & 1.8 & 3.5 & 6.8 & 5.9 & 1.6 & .8 & .2 & .0 & .0 & 20.5 & 11.4 \\
\hline$A N$ & .0 & 1.6 & 3.5 & 2.9 & 1.1 & .2 &.$c$ & .0 & .0 & .0 & 9.3 & 7.7 \\
\hline N & .0 & 2.2 & 2.3 & 1.1 & .6 & .1 & .0 & .0 & .0 & .0 & 6.4 & 6.2 \\
\hline$C A L M$ & 4.1 &.$c$ & .6 & .0 & .0 & .0 & .0 & .0 & .0 &.$C$ & 4.1 & .0 \\
\hline$V A F$ &.$c$ & .9 & .6 & .0 & .0 & .0 & . $c$ & .0 & .0 & .0 & .5 & 1.5 \\
\hline TUTAL & 4.1 & 20.2 & 21.5 & 20.4 & 18.0 & 8.3 & 4.2 & 2.2 & .8 & .2 & $100 . c$ & 10.4 \\
\hline
\end{tabular}


TABLE 43. Continued

SPEEC CLASS (MFH)

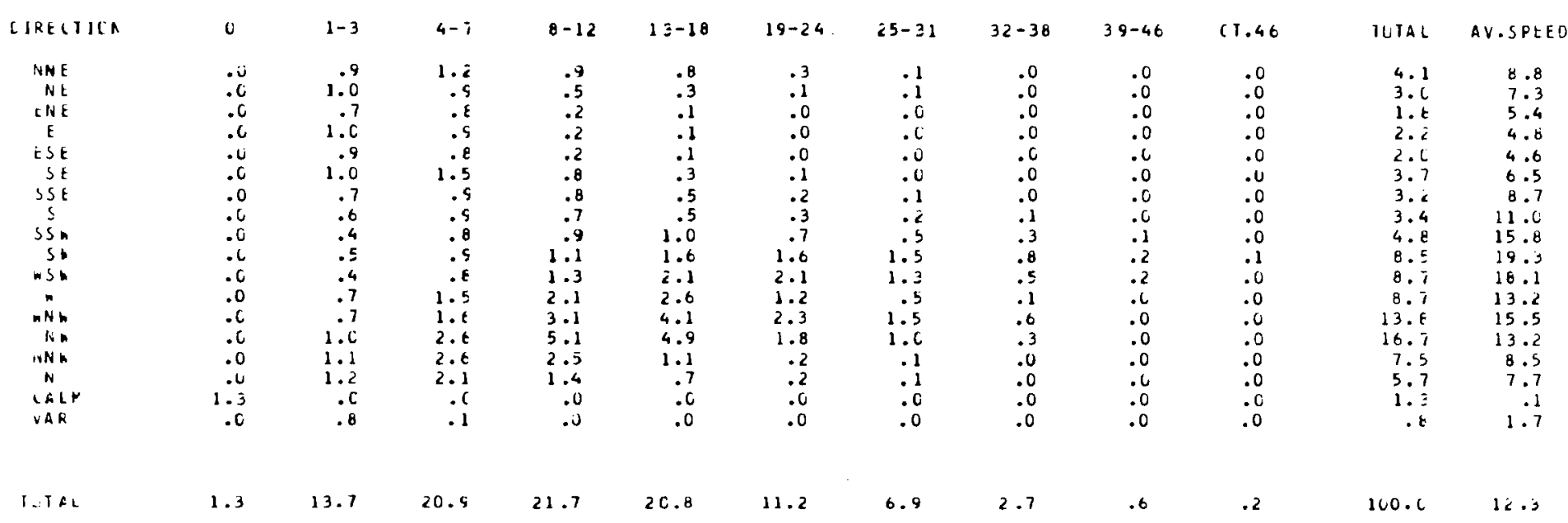

SPEEO (LASS (MFH)

\begin{tabular}{|c|c|c|c|c|c|c|c|c|c|c|c|}
\hline LIAECTILA & u & $1-3$ & $4-7$ & $8-12$ & $13-18$ & $25-31$ & $32-38$ & $39-46$ & 67.46 & TUJAL & AV.SFEE \\
\hline $\operatorname{liNE}$ & .0 & .9 & 1.1 & .8 & .6 & .1 & .0 & .0 & .0 & 3.7 & 8.0 \\
\hline $\mathrm{Ni}$ & .0 & .9 & 1.1 & .4 & .3 & .1 & .0 & .6 & .0 & $3 . \mathrm{C}$ & 7.8 \\
\hline ES E & $\cdot c$ & .7 & .5 & .5 & .2 & .1 & .0 & .0 & .0 & $2 . t$ & 7.6 \\
\hline$i$ & .0 & .8 & 1.1 & .4 & .2 &.$c$ & .0 & .0 & .0 & 2.6 & 6.0 \\
\hline $25 t$ & .6 & .6 & d.C & .2 & .0 & . u & .0 & .0 & .0 & $1 . \varepsilon$ & 5.1 \\
\hline $5 E$ & .0 & .7 & 1.5 & .6 & .2 & . $c$ & .0 & .0 & .0 & $3 . \mathrm{c}$ & 6.7 \\
\hline $25 \mathrm{E}$ & .0 & .4 &.$\varepsilon$ & .6 & .5 & . $c$ &.$C$ &.$c$ & .0 & 2.5 & $8 . y$ \\
\hline$s$ & .6 & .4 & $1 . C$ & .6 & $\cdot 3$ & . $c$ & .0 & . $c$ & .0 & $2 . t$ & 8.4 \\
\hline SSh & .6 & .3 & .9 & .9 & .6 & .2 & .0 & .0 & .0 & 3.7 & 12.4 \\
\hline sh & -6 & .4 & $1 . \mathrm{C}$ & 1.2 & 1.4 & 1.4 & .6 & .1 & .0 & 7.7 & 18.2 \\
\hline ast & .0 & .4 & 1.6 & 1.7 & 2.2 & 1.1 & .4 & .1 & .0 & 8.5 & 16.6 \\
\hline$h$ & .0 & .6 & $1 . t$ & 2.3 & 3.6 & .6 & .1 & .0 & .0 & 10.5 & 13.7 \\
\hline an k & .0 & .6 & $1 . \varepsilon$ & 3.3 & 5.3 & 2.7 & .9 & .1 & .0 & 18.8 & 17.3 \\
\hline in & .0 & .7 & 2.3 & 3.9 & 4.3 & 1.5 & .8 & .2 & .0 & $16 . t$ & 15.8 \\
\hline NNh & .0 & .9 & $2 . c$ & 1.6 & 1.0 & .0 & .0 & .0 & .0 & $5 . t$ & 8.3 \\
\hline$\therefore$ & $-c$ & 1.1 & $1 . E$ & 1.0 & .6 & .1 & .0 & .0 & .0 & 4.7 & 7.6 \\
\hline CALP & .8 & $\cdot c$ &.$c$ & .0 & .0 & $\cdot c$ & .0 & .0 & .0 & .6 &.$c$ \\
\hline vak & .0 & .8 & .1 & .0 & .0 & .0 & .0 & .0 & .0 & .5 & 2.1 \\
\hline MLTEL & .8 & 11.1 & 20.5 & 20.3 & 21.4 & 8.3 & 3.0 & .6 & .1 & 100.6 & 13.2 \\
\hline
\end{tabular}


TABLE 43. Continued

SPEED CLASS (MPH)

\begin{tabular}{|c|c|c|c|c|c|c|c|c|c|c|c|c|}
\hline CIKECTICA & 0 & $1-3$ & $4-7$ & $8-12$ & $13-18$ & $19-24$ & $25-31$ & $32-38$ & $39-46$ & $(\pi .46$ & TOTAL & AV.SPEEU \\
\hline TUTHL & $\cdot t$ & $1 C .5$ & 21.5 & 21.2 & 22.3 & 13.8 & 7.3 & 2.5 & .3 & .0 & 100.6 & 12.4 \\
\hline
\end{tabular}

No

JUA

SPEED CLASS (MPM)

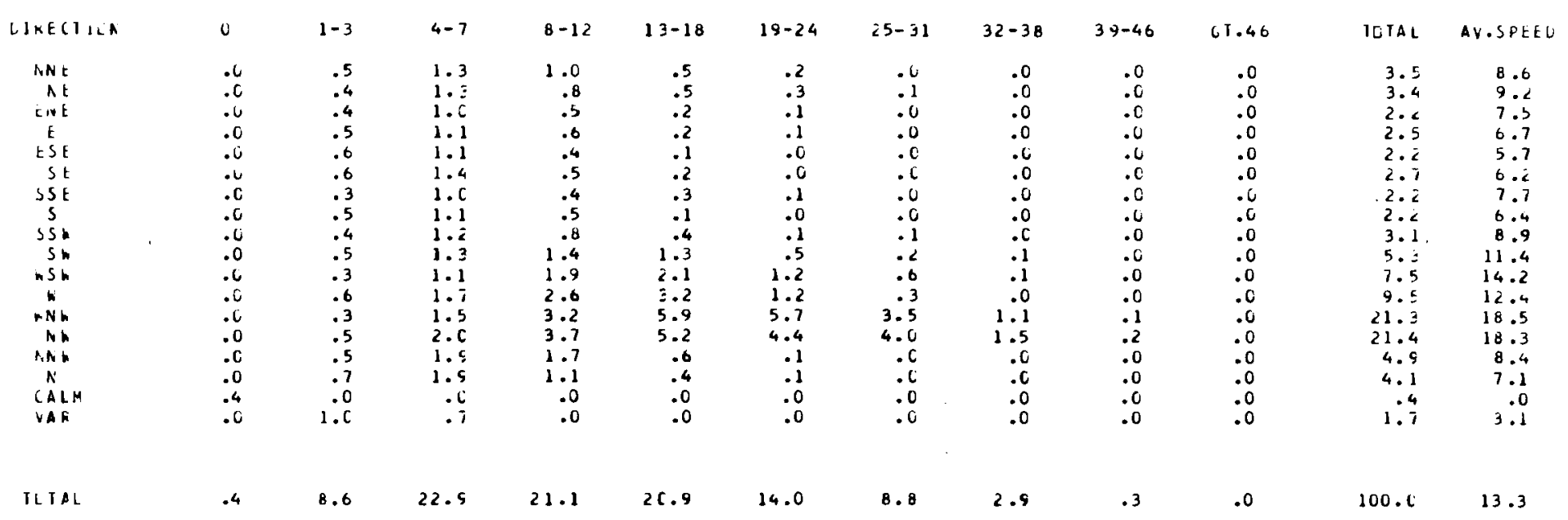


TABLE 43. Continued

JUL

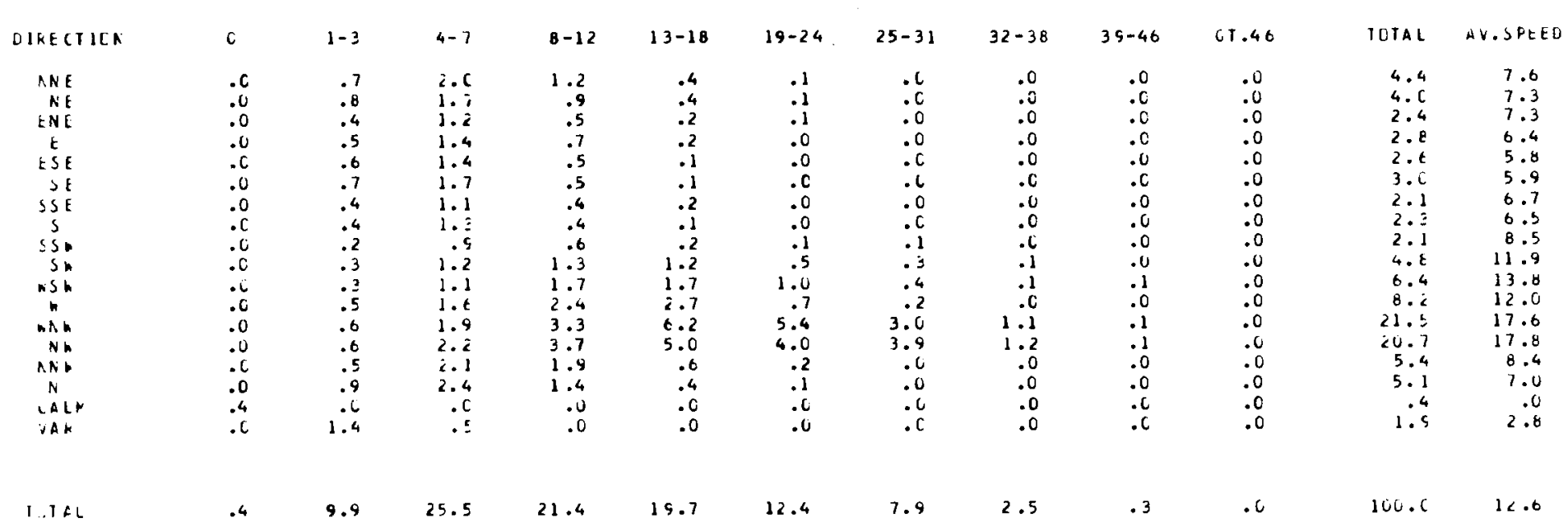

ALC

SPEEC CIASS IMfH)

\begin{tabular}{|c|c|c|c|c|c|c|c|c|c|c|c|c|}
\hline$L \cdot A \in E(T) L A$ & $u$ & $1-3$ & $4-7$ & $8-12$ & $13-18$ & $19-24$ & $25-31$ & $32-38$ & $35-46$ & $(T .4 t$ & ILTAL & AV.SFEED \\
\hline$r . \mathrm{N} \mathrm{t}$ & .6 &.$d$ & 1.5 & .9 & .3 & .0 & .0 & .0 &.$c$ & .0 & 3.5 & 6.0 \\
\hline$A l$ &.$u$ & 1.0 & 1.7 & .5 & .1 &.$c$ &.$\iota$ & .0 &.$c$ & .0 & 3.4 & 5.5 \\
\hline test & .0 & .7 & 1.2 & .1 & .1 & .0 & .6 & .0 & .0 & .0 & $2 . \Xi$ & 5.4 \\
\hline $\mathrm{c}$ & .0 &.$e$ & 1.2 & .4 & .1 & .0 &.$c$ & .0 & .0 & .0 & 2.7 & 5.4 \\
\hline SE & .0 & .0 & $1 . t$ & .6 & .1 & .0 &. $\mathrm{~L}$ & .0 & .0 & .4 & 3.2 & 5.0 \\
\hline $25 t$ & .6 & .4 & .5 & .6 & .4 & .0 &. $\mathrm{C}$ &. $\mathrm{c}$ & .0 & .0 & 2.3 & 7.6 \\
\hline 3 &.$c$ &. .5 & 1.1 & .5 & .1 & .0 & . U & .0 & .0 & .0 & 2.3 & 0.3 \\
\hline ssh & .0 & .3 & .5 & .7 & .4 & .1 & .0 & .0 & .0 & .0 & $2 . t$ & 8.9 \\
\hline sh & .0 & .5 & $1 . \hat{c}$ & 1.3 & 1.0 & .6 & .3 & .0 &.$c$ & .0 & 4.9 & 11.7 \\
\hline I., & .0 & .8 & 2.4 & 4.1 & 5.2 & 3.8 & 2.7 & .9 & .1 & .0 & 20.1 & 16.3 \\
\hline 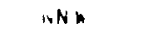 & .0 & .7 & 2.2 & 1.7 & .6 & .1 &.$\iota$ & .0 & .0 & .0 & 5.4 & 7.8 \\
\hline is &.$c$ & 1.1 & 2.4 & 1.3 & .2 & .0 & .0 & .0 & .0 & .0 & 5.1 & 6.3 \\
\hline$C A L$ & .5 &. $\mathrm{c}$ &.$c$ & .0 & .0 & .0 &. $\mathrm{C}$ & .0 & .0 & .0 &. & .1 \\
\hline$V A R$ &.$v$ & 1.4 & .5 & .0 & .0 & .0 & $\cdot u$ & .0 & .0 & .0 & . 1.8 & 2.7 \\
\hline I C.IAL & .5 & 12.1 & 25.9 & 21.9 & 19.5 & 11.8 & 6.0 & 2.1 & .1 & .0 & $100 . c$ & 11.7 \\
\hline
\end{tabular}


TABLE 43. Continued

SPEED CLASS (MPH)

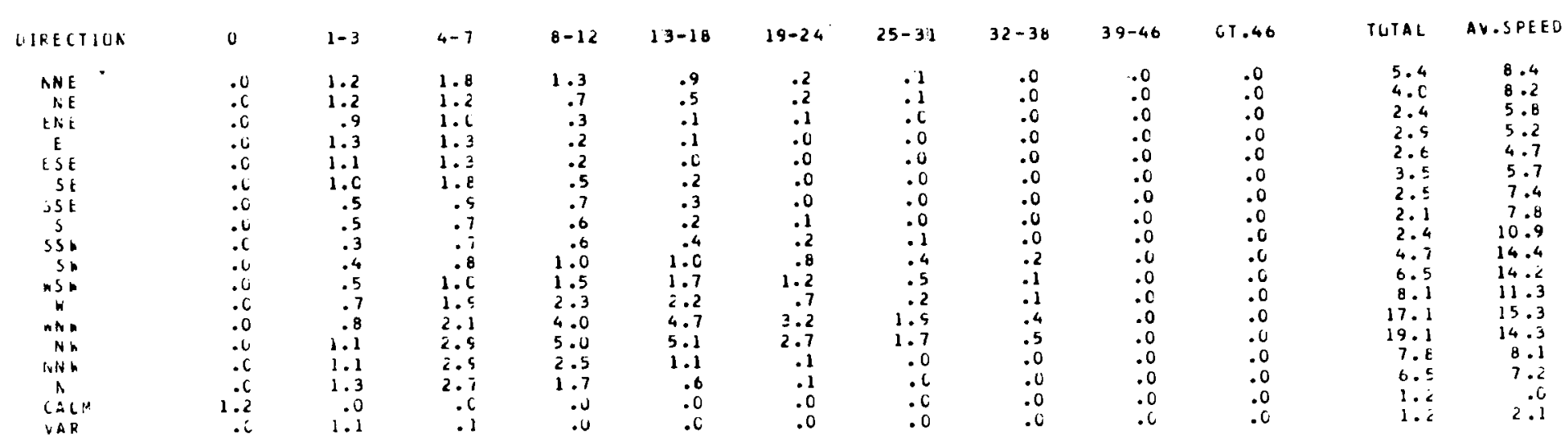

$\stackrel{x}{\omega}$

I. I I S

1.2

$14.8 \quad 25 .$.

23.1

19.1

9.8

5.

$J C T$

SPEED CLASS (MEH)

\begin{tabular}{|c|c|c|}
\hline LIKECIILA & u & $1-3$ \\
\hline L, N $\mathbf{E}$ &.$c$ & $1 . t$ \\
\hline $\mathrm{AE}$ & .0 & 1.7 \\
\hline LNE & .6 & 1.5 \\
\hline$t$ & .0 & 1.9 \\
\hline$b 3 t$ &.$c$ & $1 . t$ \\
\hline$S E$ & .0 & 1.5 \\
\hline 550 & .0 & .7 \\
\hline 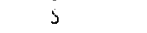 &.$c$ &.$t$ \\
\hline ss. &.$c$ & .5 \\
\hline$s_{n}$ & .0 & .5 \\
\hline is $n$ & .6 & .6 \\
\hline & .c & $1 . \mathrm{C}$ \\
\hline$n N h$ & .6 & 1.1 \\
\hline in $h$ & .0 & 1.6 \\
\hline UNh & .0 & $1 . t$ \\
\hline N &.$u$ & 2.1 \\
\hline$C A L F$ & 3.2 &. $\mathrm{c}$ \\
\hline$\forall \dot{R}$ & .0 & .9 \\
\hline
\end{tabular}
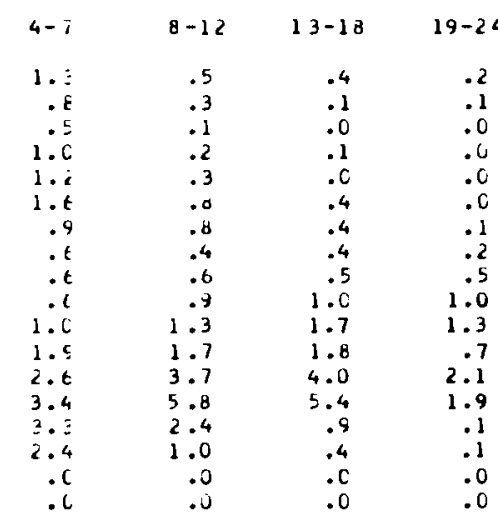

$25-31$
.6
.1
.6
.6
.6
.6
.6
.1
.3
.6
.5
.2
.7
.8
.0
.6
.0
.0

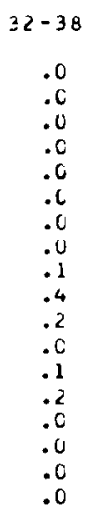

$39-46$
.0
.0
.0
.0
.0
.0
.0
.0
.0
.1
.1
.0
.0
.0
.0
.0
.0
.0

.7 .46
.0
.0
.0
.0
.0
.0
.0
.0
.0
.0
.0
.0
.0
.0
.0
.0
.0
.0

$\begin{array}{rc}\text { IUTAL } & \text { AV.SFEti } \\ 4 . C & 0.2 \\ 3.1 & 5.1 \\ 2.2 & 3.7 \\ 3.1 & 3.5 \\ 3.1 & 3.9 \\ 4.8 & 5.5 \\ 3.6 & 7.7 \\ 2.4 & 9.4 \\ 3.1 & 13.9 \\ 5.4 & 17.4 \\ 6 . t & 14.5 \\ 7.5 & 16.4 \\ 14.3 & 12.6 \\ 19.2 & 12.1 \\ 8.4 & 7.3 \\ 6.1 & 6.1 \\ 3.2 & . .4 \\ .9 & 1.5\end{array}$

TUtal

21.4

23.8

20.7

17.5

8.5

3.7

1.1

.0

$100 \cdot 6 \quad 9.7$ 
TABLE 43. Continued

\section{NCV}

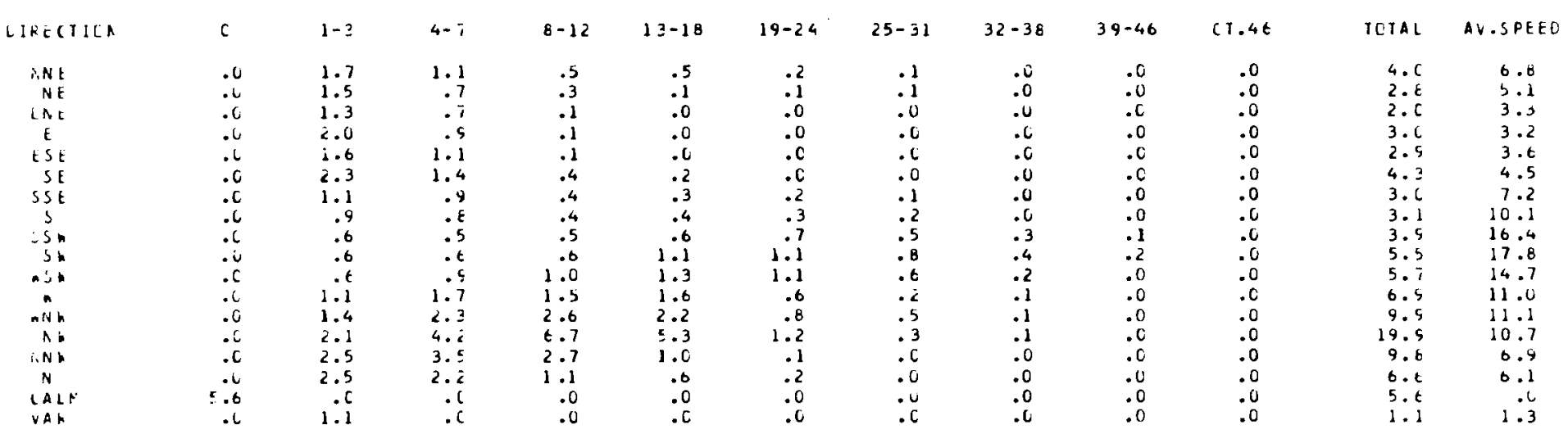

DEC

SPEED CLASS (MPH)

\begin{tabular}{|c|c|c|c|c|c|c|c|c|c|c|c|c|}
\hline L IHECOILA & $c$ & $1-3$ & $4=7$ & $8-12$ & $13-18$ & $19-24$ & $25-31$ & $32-38$ & $39-46$ & $C 1.4 t$ & TUTAL & AV.SFEED \\
\hline $\begin{array}{c}M A E \\
M E\end{array}$ &.$c$ & $\begin{array}{l}1.4 \\
1.4\end{array}$ & .5 & $\begin{array}{l}.3 \\
.1\end{array}$ & $\begin{array}{r}.3 \\
.1\end{array}$ & .2 & $\begin{array}{l}. c \\
.0\end{array}$ & $\begin{array}{l}. c \\
.0\end{array}$ &.$c$ & .0 & $3 \cdot c$ & 6.0 \\
\hline (iit & .6 & 1.2 &.$t$ & .1 & .0 & .0 & $: 0$ & .0 & .0 & $\begin{array}{l}.0 \\
.0\end{array}$ & 2.5 & 3.5 \\
\hline $\mathrm{t}$ &.$c$ & 1.7 & .7 & .1 & .0 &.$c$ & .0 & 0 & .0 & .0 & 1.5 & 3.1 \\
\hline $\mathrm{t} S \mathrm{E}$ & .0 & $1 . t$ & .7 & .1 &.$c$ & .c & . c & .0 & .0 & $\cdot 0$ & 2.5 & 3.1 \\
\hline Si &.$c$ & $\mathrm{z} . \mathrm{C}$ & $1:=$ & .4 & .2 & .1 & .0 & $\because 0$ & .0 & .0 & 2.5 & 3.0 \\
\hline sst & .0 & 1.2 & .8 & .3 & .3 & .1 & 1 & .0 & .0 & .0 & 4.6 & 4.9 \\
\hline 3 & .0 & 1.0 & $\because \bar{i}$ & .3 & .03 & .2 & $: \frac{1}{6}$ & .0 & .0 & .0 & 2.7 & 6.4 \\
\hline $55 n$ & .6 & .6 & .5 & .4 & .5 & .6 & .6 & .1 & .0 & .0 & 2.5 & 9.5 \\
\hline$s k$ &.$i$ & .6 & .7 & .8 & .9 & 1.1 & 1.0 & .4 & .2 & .1 & 3.5 & 18.0 \\
\hline ns n &.$c$ & .7 & . & .7 & 1.5 & 1.2 & 10 & .8 & .3 & .1 & 6.4 & $\angle 0.0$ \\
\hline$w$ & .6 & 1.3 & 1.5 & 1.5 & 1.5 & & $\because$ & .4 & .1 & .0 & 6.3 & 16.5 \\
\hline$n N n$ & .0 & 1.6 & 2.4 & 3.3 & 2.5 & $\begin{array}{l}.1 \\
.7\end{array}$ & .4 & .1 & .0 & .0 & 7.1 & 11.4 \\
\hline$\wedge$ &.$c$ & 2.2 & 2.5 & 7.4 & $\begin{array}{l}2.3 \\
6.4\end{array}$ & 1.2 & $\cdot 3$ & .0 & .0 & .0 & 10.5 & 10.3 \\
\hline$i N n$ & .6 & 2.2 & 3.3 & 2.9 & $i_{1}^{4}$ & 1.2 & $\cdot 3$ & .0 & .0 & .0 & 20.5 & 10.6 \\
\hline$a^{n}$ & .c & 2.3 & 1.9 & .8 & 1.5 & .1 & $: 0$ & .0 & .0 & .0 & 9.5 & 7.1 \\
\hline$A L L^{\circ}$ & 6.9 &. &. $\mathrm{C}$ & .0 & .0 & .0 & .0 & .0 & .0 & .0 & 5.6 & 5.7 \\
\hline$V A k$ &.$c$ & 1.2 & .1 & .0 & .0 & .0 & .0 & $\begin{array}{l}.0 \\
.0\end{array}$ & $\begin{array}{l}.0 \\
.0\end{array}$ & $\begin{array}{l}.0 \\
.0\end{array}$ & $\begin{array}{l}6.5 \\
1.2\end{array}$ & .6 \\
\hline$T L T A L$ & 6.9 & 24.2 & 21.2 & 19.7 & 15.2 & 6.3 & 3.5 & 2.0 & .8 & .3 & 100.6 & 9.9 \\
\hline
\end{tabular}


TABLE 43. Continued

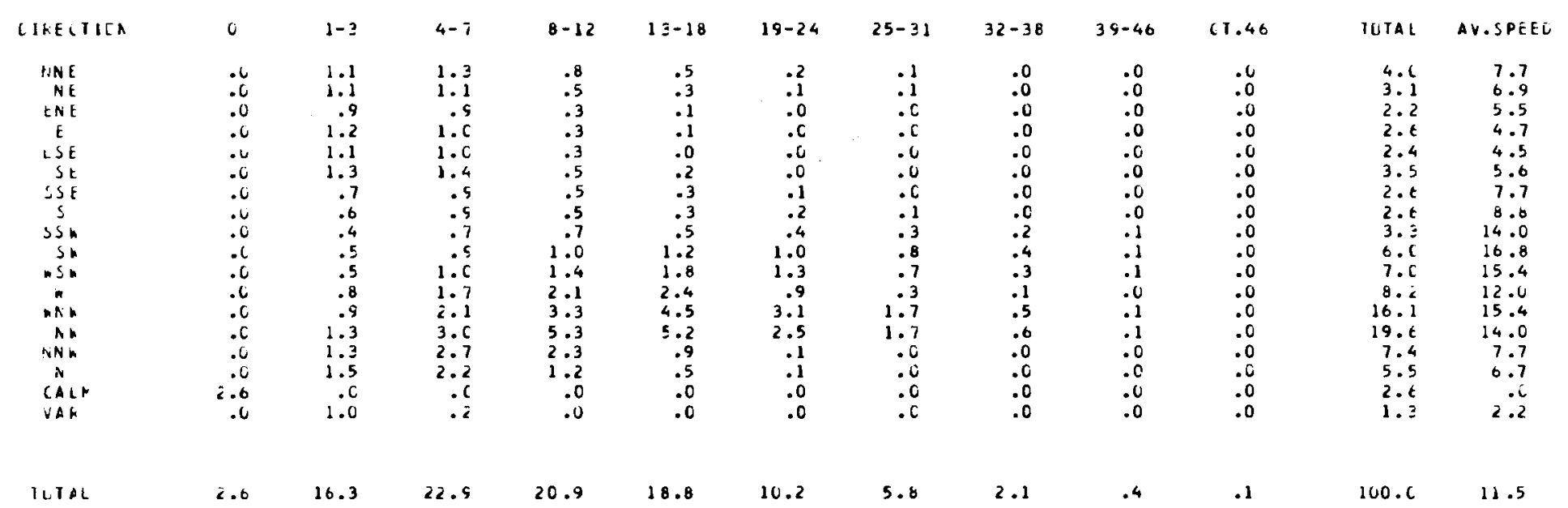


TABLE 44. Monthly and Annual Percent Frequency of Hourly Wind

Direction at 50-Foot Level, 1955 Through 1980

PERCENT FREGUENCY UF HOURLY WIND DIRECTION AT 50-FODI LEVEL-1955-1980 FOR JAN

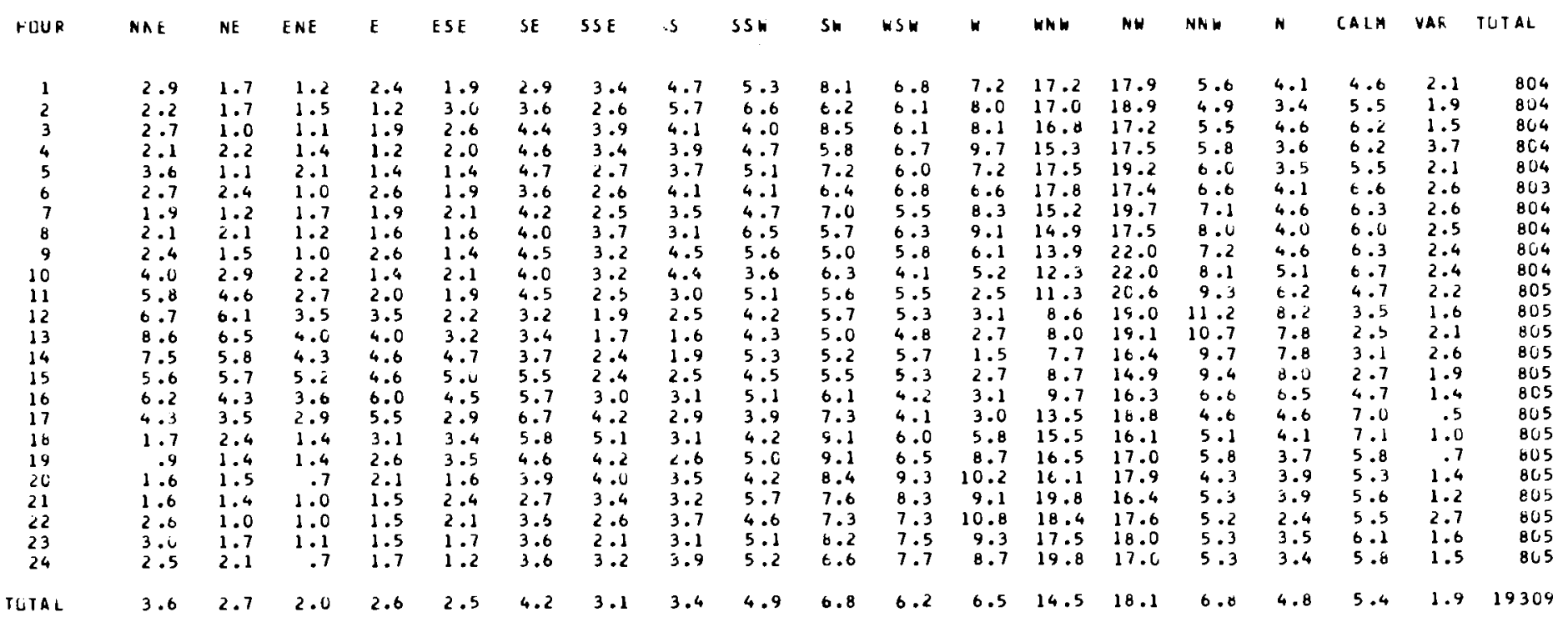

PERCEAT FRECUENCY OF FOURLY WINO CIRECTIOA AT 50-FGOT LEVEL-1955-1980 FUR FEB

HUUk

ESE

5 SSI SH
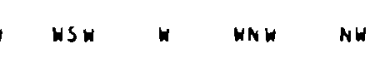

NH NNW.

\section{CALM VAR TCTAL}

1
2
3
4
5
6
7
8
9
10
11
12
13
14
15
16
17
18
19
20
21
22
23
24

\begin{tabular}{|c|c|c|c|c|c|c|c|c|c|c|c|c|c|c|c|c|c|c|}
\hline 1.4 & 1.5 & .8 & .7 & 1.8 & 2.4 & 3.4 & 3.1 & 4.4 & 8.7 & 9.7 & 14.4 & 18.6 & 16.2 & 5.2 & 2.2 & 3.8 & 1.8 & 735 \\
\hline & 1.5 & .5 & 1.4 & 1.8 & 3.7 & 4.5 & 2.9 & 2.9 & 6.8 & 9.3 & 14.1 & 19.5 & 16.3 & 3.9 & 2.7 & 4.8 & 1.6 & 735 \\
\hline 2.2 & 1.8 & 1.4 & 2.0 & 1.1 & 3.1 & 3.1 & 3.9 & 3.7 & 5.7 & 9.5 & 13.1 & 18.8 & 16.6 & 4.8 & 3.1 & 4.6 & 1.5 & 735 \\
\hline 2.7 & 2.3 & 1.2 & 1.8 & 1.8 & 2.9 & 3.3 & 3.8 & 3.9 & 0.0 & 8.3 & 10.9 & 20.0 & 18.1 & 3.8 & 3.4 & 3.9 & 1.9 & 735 \\
\hline 2.4 & 1.9 & .3 & 1.5 & 2.2 & 3.0 & 2.6 & 3.9 & 4.4 & 6.8 & 6.8 & 11.4 & 18.2 & 19.9 & 5.6 & 2.7 & 4.6 & 1.8 & 735 \\
\hline 2.3 & 1.5 & .8 & 1.2 & 2.2 & 3.1 & 3.4 & 4.5 & 5.3 & 6.5 & 8.4 & 10.1 & 17.4 & 18.0 & 5.9 & 3.5 & 3.9 & 1.9 & 735 \\
\hline 2.9 & 1.8 & 1.1 & 2.0 & 1.4 & 3.0 & 2.3 & 4.4 & 4.9 & 6.1 & 8.6 & 11.0 & 17.1 & 18.1 & 5.7 & 2.7 & 4.5 & 2.4 & 735 \\
\hline 2.4 & 2.0 & 1.4 & 1.1 & 2.0 & 3.4 & 2.2 & 5.2 & 5.4 & 6.4 & 7.5 & 7.8 & 16.7 & 20.7 & 5.7 & 3.5 & 4.2 & 2.3 & 735 \\
\hline 3.3 & 2.9 & 2.0 & 1.6 & 1.1 & 2.4 & 3.4 & 4.1 & 4.2 & 5.6 & 7.1 & 6.5 & 15.4 & 21.4 & 7.1 & 4. & 4.6 & 2.9 & 735 \\
\hline 3.8 & 5.0 & 3.4 & 1.9 & 1.1 & 2.9 & 2.7 & 2.9 & 4.2 & 5.7 & 4.4 & 5.0 & 13.7 & 24.5 & 8.3 & 6.8 & 2.4 & 1.2 & 735 \\
\hline 7.9 & 5.6 & 3.3 & 1.6 & 2.9 & 2.7 & 2.2 & 1.6 & 3.3 & 6.4 & 5.2 & 3.0 & 10.9 & 21.0 & 10.2 & 8.3 & 1.9 & 2.2 & 735 \\
\hline 9.3 & 7.5 & 2.9 & 3.1 & 2.7 & 2.7 & 1.8 & 2.3 & 3.0 & 7.5 & 5.0 & 3.5 & 7.1 & 19.5 & 9.8 & 9.7 & 1.0 & 1.8 & 735 \\
\hline 7.6 & 8.6 & 3.0 & 3.1 & 2.6 & 3.8 & 1.1 & 2.0 & 5.4 & 7.5 & 4.9 & 3.7 & 7.9 & 17.0 & 8.2 & 10.7 & .7 & 2.2 & 735 \\
\hline 9.0 & 6.4 & 3.0 & 3.7 & 2.7 & 3.4 & 1.4 & 3.0 & 4.5 & 8.7 & 6.1 & 3.8 & 6.7 & 13.9 & & 12. & .8 & 1.8 & 735 \\
\hline 10.2 & 6.7 & 3.5 & 4.2 & 3.8 & 3.8 & 1.8 & 2.3 & 3.7 & 9.3 & 6.1 & 2.4 & 9.1 & 12. & 7.0 & 9. & 1.9 & 1.8 & 735 \\
\hline 7.5 & 7.3 & 3.7 & 4.4 & 3.4 & 4.9 & 1.8 & 2.6 & 5.2 & 8.6 & 6.0 & 3.1 & 8.8 & 13. & 7.3 & 8 & 1.2 & 1.6 & 735 \\
\hline 6.0 & 4.5 & 3.8 & 3.8 & 4.4 & 4.2 & 1.6 & 3.7 & 5.4 & 7.6 & 5.2 & 4.8 & 10.5 & 15. & 6.8 & & 4.1 & 1.1 & 735 \\
\hline 5.2 & 2.9 & 2.7 & 2.9 & 3.9 & 6.0 & 3.5 & 2.6 & 4.6 & 7.5 & 7.1 & 4.5 & 14.1 & 17.1 & 5.2 & 5. & 3.8 & .8 & 735 \\
\hline 2.2 & 2.7 & 2.0 & 2.7 & 2.3 & 5.6 & 4.1 & 3.0 & 4.5 & 9.4 & 6.9 & 8.8 & 17.6 & 16.9 & 4.1 & 4.1 & 2.3 & .8 & 735 \\
\hline 1.5 & 1.1 & 1.8 & 1.6 & 2.0 & 4.4 & 4.5 & 3.8 & 3.7 & 8.3 & 11.4 & 12.5 & 17.7 & & 4.5 & & 2.3 & 1.1 & 735 \\
\hline 1.0 & .8 & .3 & 1.1 & 1.8 & 3.4 & 3.0 & 3.3 & 4.8 & 9.3 & 10.6 & 17.1 & 18.5 & 13.7 & 4.2 & 3.1 & 3.3 & .8 & 735 \\
\hline 1.2 & 1.2 & .4 & 1.5 & 1.4 & 2.3 & 2.7 & 2.3 & 4.8 & 8.6 & 10.5 & 18.2 & 18.8 & 14.7 & 3.5 & 2.7 & 4.4 & .8 & 735 \\
\hline 1.9 & 1.4 & .7 & 1.5 & 2.0 & 2.0 & 2.2 & 3.4 & 3.4 & 8.2 & 9.7 & 16.3 & 21.1 & 15.4 & 3.4 & 3.3 & 3.3 & 1.0 & 735 \\
\hline 1.9 & 1.1 & .6 & 1.1 & 1.2 & 1.8 & 3.0 & 4.4 & 3.8 & 8.3 & 10.7 & 14.6 & 19.2 & 16.3 & 4.8 & 2.2 & 3.3 & 1.6 & 735 \\
\hline 4.1 & 3.3 & 1.9 & 2.1 & 2.2 & 3.4 & 2.7 & 3.3 & 4.3 & 7.5 & 7.7 & 9.2 & 15.1 & 17.2 & 6.0 & 5.2 & 3.2 & 1.6 & 17640 \\
\hline
\end{tabular}

ICTA 
TABLE 44. Continued

PERCENT FREQUENCY OF HOURLY WIND OIRECTION AT 50-FOOT LEVEL-1955-1980 FOR MAR
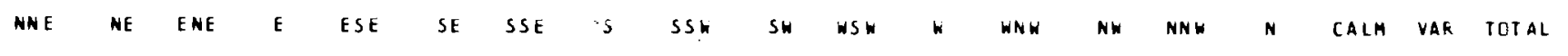

\begin{tabular}{|c|c|c|c|c|c|c|c|c|c|c|c|c|c|c|c|c|c|c|}
\hline 1.1 & .7 & .9 & 1.1 & 1.4 & 2.4 & 2.4 & 2.7 & 4.5 & 7.7 & 12.3 & 18.0 & 24.8 & 13.5 & 3.0 & 2.0 & & 1.0 & \\
\hline 1.0 & 1.0 & .5 & 1.0 & 1.5 & 2.9 & 2.5 & 3.0 & 4.3 & 8.1 & 13.2 & 18.6 & 21.1 & 13.2 & 3.7 & 2.0 & 1.5 & 1.0 & 806 \\
\hline 1.4 & 1.2 & .4 & 1.2 & 2.0 & 3.2 & 2.5 & 3.6 & 3.7 & 10.0 & 11.2 & 15.3 & 21.2 & 14.0 & 5.1 & 2.0 & .9 & 1.1 & 806 \\
\hline 1.9 & 1.1 & .4 & 1.1 & 2.1 & 3.0 & 3.5 & 4.1 & 5.0 & 7.1 & 11.8 & 14.0 & 20.5 & 14.6 & 4.7 & 2.5 & 1.2 & 1.5 & 806 \\
\hline 2.2 & 1.4 & 1.5 & .5 & 1.6 & 3.2 & 2.5 & 4.6 & 4.6 & 9.2 & 10.2 & 14.5 & 18.9 & 14.1 & 4.3 & 3.1 & 1.9 & 1.7 & 806 \\
\hline 1.6 & 1.2 &.$t$ & 1.5 & 1.7 & 3.5 & 2.5 & 5.0 & 5.1 & 7.7 & 10.9 & 14.5 & 17.1 & 14.9 & 4.8 & 2.7 & 2.5 & 2.1 & 806 \\
\hline 2.0 & 1.0 & 1.1 & 1.7 & 1.5 & 2.9 & 3.0 & 6.2 & 5.7 & B. 3 & 10.9 & 10.9 & 18.6 & 14.5 & 4.5 & 3.5 & 2.2 & 2.1 & 806 \\
\hline 3.3 & 2.4 & 1.9 & 1.2 & 1.2 & 2.4 & 2.9 & 4.1 & 5.3 & 6.6 & 8.8 & 10.9 & 18.7 & 16.3 & 6.6 & 3 & & & 806 \\
\hline 5.5 & 4.3 & 1.9 & 1.6 & 1.7 & 2.0 & 2.5 & 2.9 & 4.7 & 6.2 & 7.7 & 5.1 & 13.3 & 20.7 & 10.3 & $b$ & 1.5 & & 806 \\
\hline 7.1 & 7.4 & 2.2 & 1.7 & 2.9 & 2.2 & 2.0 & 2. & 4.3 & 6.1 & 8.4 & 3. & 9.6 & 13.9 & 13.2 & 9. & .9 & & 806 \\
\hline 8.6 & 7.1 & 4.8 & 3.4 & 2.5 & 2.9 & 2. & 3. & 4.3 & 8.7 & 7.7 & 2.4 & 6.6 & 12.7 & 8.8 & 10.2 & .6 & 3.7 & 805 \\
\hline 9.7 & 7.7 & 3.7 & 4.0 & 2.1 & 3.0 & 2.5 & 4.3 & 6.8 & 10.8 & 6.5 & 3.2 & 5.0 & 9.7 & 7.1 & 10.2 & .2 & 3.5 & 805 \\
\hline 9.6 & 6.1 & 1.6 & 3.7 & 3.2 & 4.6 & 2.9 & 4.2 & 8.0 & 11.4 & 6.5 & 3.7 & 6.7 & 9.7 & 5.7 & 8.8 & .0 & & 805 \\
\hline 9.7 & 5.6 & 3.4 & 2.2 & 4.0 & 4.0 & 2.5 & 4.8 & 7.0 & 12.9 & 8.6 & 4.0 & 7.6 & 8.1 & 5.2 & & .1 & & 805 \\
\hline 8.0 & 6.1 & 4.1 & 1.6 & 4.0 & 4.7 & 1.9 & 4.5 & 7.0 & 13.2 & 0.7 & 4.0 & 6.1 & 9.9 & 5.5 & &.$c$ & & 805 \\
\hline 8.7 & 5.1 & 2.6 & 3.1 & 3.6 & 6.2 & 3.4 & 5. & 4.6 & 12.3 & 10.8 & 3.2 & 5.8 & 10.7 & 3.7 & & .2 & 3.0 & 805 \\
\hline$t .2$ & 6.0 & 2.7 & 3.3 & 4.0 & 6.7 & 4.8 & 3. & 6.9 & 10.8 & 8.6 & 3.8 & 8.3 & 13.0 & 3.5 & & .5 & .7 & 806 \\
\hline 4.3 & 3.6 & 3.3 & 4.8 & 3.1 & 7.8 & 3.7 & 5. & 6.5 & 8.3 & 9.4 & 4.7 & 11.3 & 13 & 3.6 & 4. & & .5 & 806 \\
\hline 2.9 & 2.5 & 2.6 & 3.0 & 4.5 & 6.9 & 5.7 & 5. & 5.3 & 10.2 & 8.7 & 5.8 & 14.3 & 13 & 3. & & 1.7 & .5 & 806 \\
\hline 1.6 & 1.7 & .5 & 2.2 & 2.9 & 5.3 & 5.3 & 5.0 & 5.2 & $1<.5$ & 10.4 & 9.9 & 17.6 & 14.0 & 2.4 & 2. & .6 & .5 & 806 \\
\hline 1.7 & .7 & .6 & 1.6 & 1.7 & 3.7 & 5.0 & 3. & 4.3 & 11.8 & 14.6 & 15.9 & 17.0 & 13.0 & 2.5 & 1. & .1 & .9 & 806 \\
\hline 1.4 & .5 & 1.0 & 1.1 & 1.4 & 3.1 & 2.2 & 2. & 3.8 & 9.9 & 14.6 & 20 & 18.4 & 13.6 & 2. & & .9 & .9 & 6 \\
\hline 1.6 & .7 & .5 & .7 & 1.4 & 2.6 & 1.6 & 2.9 & 3.3 & 7.8 & 14.1 & 19.9 & 22.3 & 12.0 & 3.3 & 3.1 & .7 & 1.2 & 806 \\
\hline 1.c & .5 & .1 & 1.4 & 1.7 & 2.2 & 1.9 & 1.6 & 4.6 & 8.7 & 13.4 & 20.3 & 22.6 & 12.8 & 3.8 & 2.1 & .7 & .5 & 806 \\
\hline 4.2 & 3.2 & 1.8 & 2.0 & 2.4 & 3.8 & 3.0 & 3.9 & 5.2 & 9.4 & 10.3 & 10.3 & 14.7 & 13.1 & 5.1 & 4.8 & 1.0 & 1.0 & 19338 \\
\hline
\end{tabular}

PERCEAT FREGUENCY DF FOURLY WIMO OIRECTIOA AT 50-FOOT LEVEL-1955-198U FUR APK

HOUR

NWE NE ENE E ESE SE SSE S SSW SW WSW W WNW NH HNW N CALM VAR TETAL

1
2
3
4
5
6
7
8
9
10
11
12
13
14
15
16
17
18
19
20
21
22
23
24
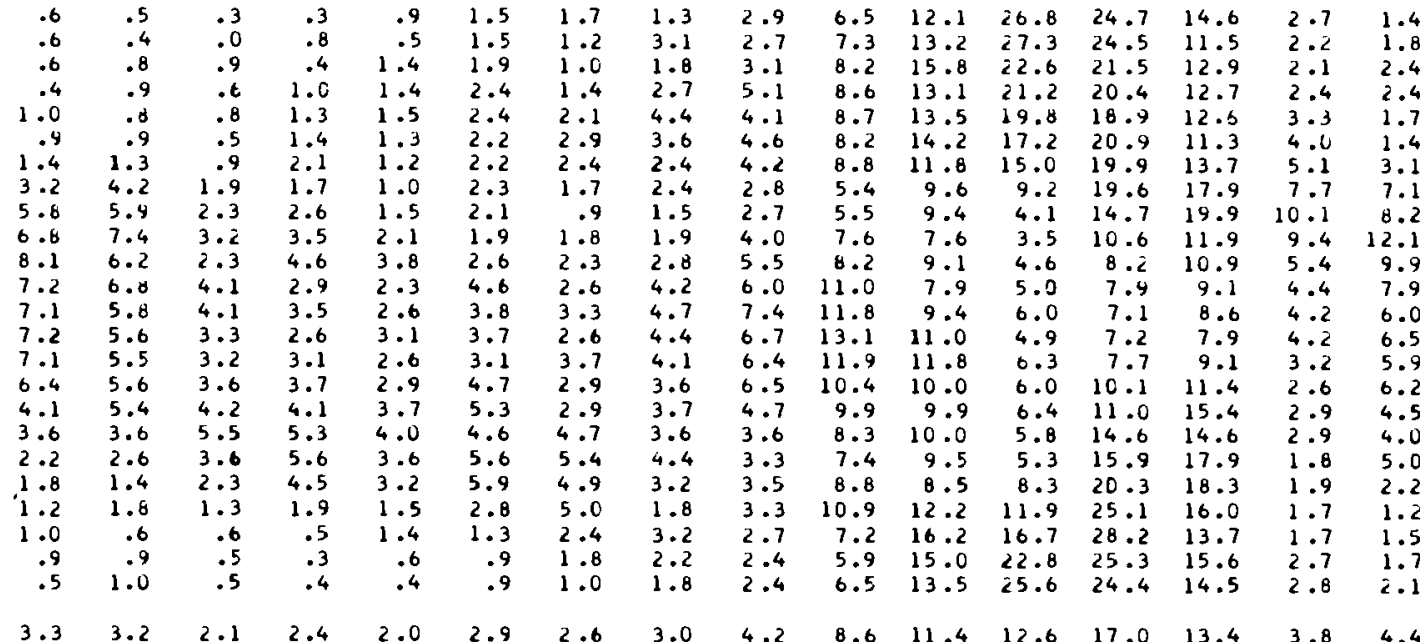

$\begin{array}{rrrr}1.4 & .5 & .6 & 780 \\ 1.8 & .0 & .6 & 780 \\ 2.4 & 1 . .6 & 1.4 & 780 \\ 2.4 & 1.8 & 1.4 & 780 \\ 1.7 & 1.3 & 1.9 & 779 \\ 1.4 & 2.6 & 1.9 & 730 \\ 3.1 & 2.6 & 1.9 & 780 \\ 7.1 & 1.0 & 1.2 & 780 \\ 8.2 & .0 & 2.2 & 780 \\ 12.1 & .1 & 4.7 & 780 \\ 9.9 & .0 & 5.5 & 780 \\ 7.9 & .1 & 5.8 & 780 \\ 6.0 & .0 & 4.6 & 780 \\ 6.5 & .1 & 5.9 & 780 \\ 5.9 & .0 & 5.4 & 780 \\ 6.2 & .1 & 3.1 & 780 \\ 4.5 & .0 & 1.8 & 780 \\ 4.0 & .4 & .9 & 780 \\ 5.0 & .8 & .1 & 780 \\ 2.2 & .9 & .1 & 780 \\ 1.2 & .3 & .1 & 780 \\ 1.5 & .4 & .6 & 780 \\ 1.7 & .3 & .3 & 780 \\ 2.1 & .9 & .8 & 780 \\ 4.4 & .7 & 2.2 & 18719\end{array}$


TABLE 44. Continued

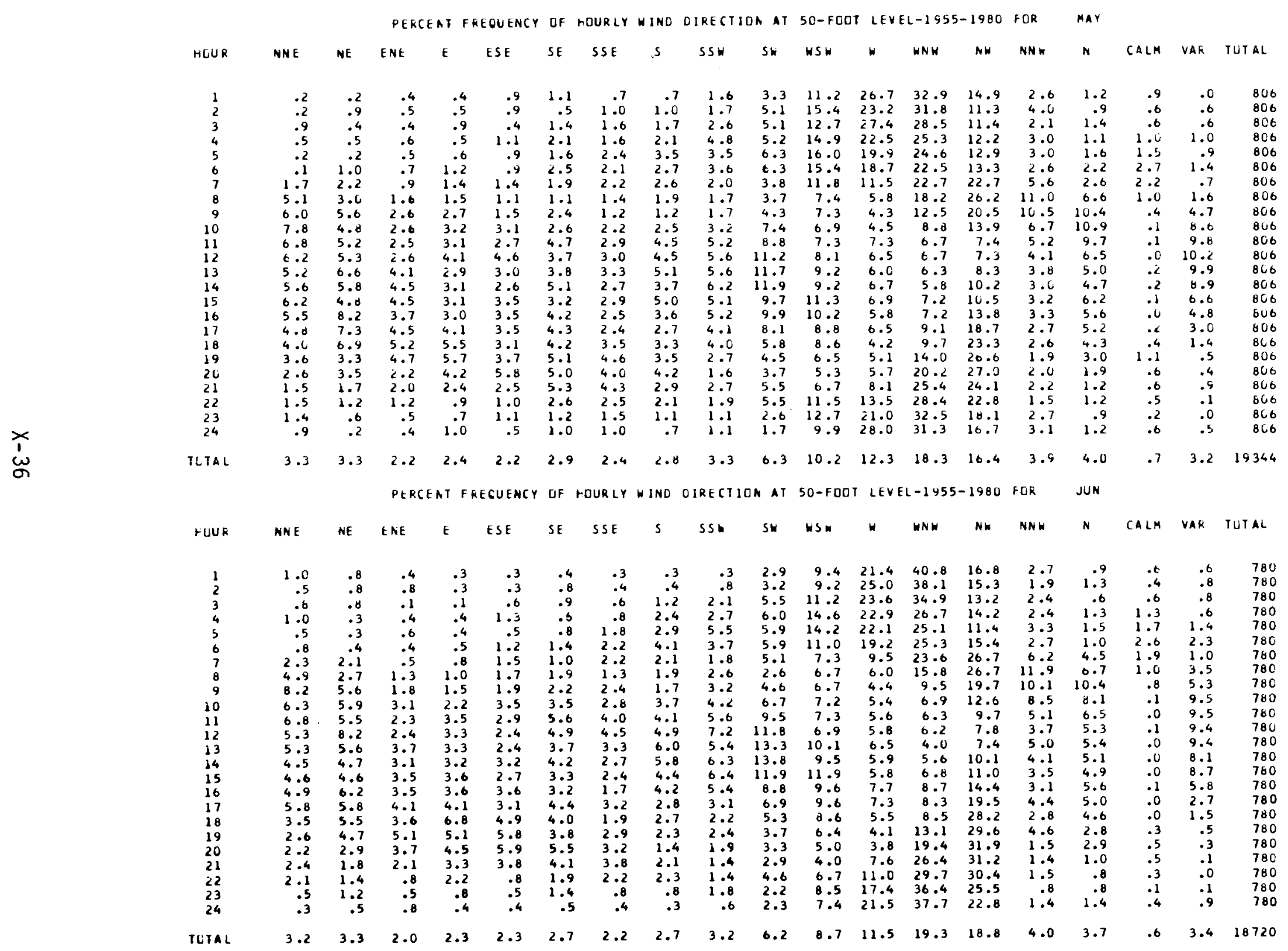


TABLE 44. Continued

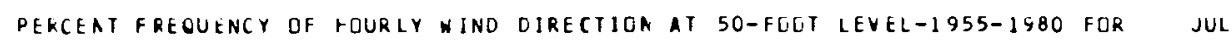

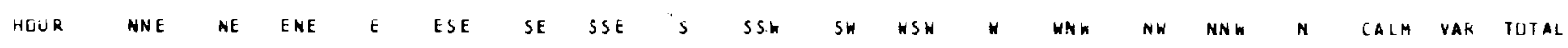

\begin{tabular}{|c|c|c|c|c|c|c|c|c|c|c|c|c|c|c|c|c|c|c|}
\hline .2 & .4 & .4 & .0 & .2 & .2 & .0 & 1.1 & .2 & 1.6 & 6.7 & 22.3 & 41.7 & 20.6 & 2.6 & 1.4 & .0 & .2 & 806 \\
\hline .4 & .2 & .1 & .4 & .2 & .5 & .2 & 1.1 & .4 & 2.0 & 6.6 & 85.2 & 41.6 & 17.5 & 2.5 & .4 & .1 & .6 & 806 \\
\hline .2 & .1 & .4 & .9 & .6 & 1.0 & 1.2 & 1.2 & 1.1 & 4.2 & 10.2 & 23.7 & 38.2 & 12.7 & 2.4 & .6 & .5 & .7 & 806 \\
\hline .1 & .2 & .4 & .5 & .7 & .6 & 1.5 & 2.0 & 3.2 & 4.5 & 11.9 & 64.9 & 32.1 & 12.0 & 2.1 & 1.2 & 1.2 & .6 & 806 \\
\hline .7 & .2 & .0 & .5 & .6 & $1 \cdot 1$ & 1.0 & 2.7 & 3.5 & 8.1 & 12.4 & 20.9 & 31.4 & 11.8 & 1.7 & .9 & 1.6 & .7 & 805 \\
\hline .0 & .4 & .2 & .5 & .7 & 1.2 & 1.4 & 3.1 & 5.0 & 8.4 & 11.4 & 15.7 & 28.6 & 16.9 & 2.9 & .6 & 1.1 & 1.2 & 805 \\
\hline 1.2 & .7 & 1.1 & .9 & 1.2 & 1.0 & .9 & 3.1 & 2.1 & 4.5 & 7.1 & 9.8 & 24.6 & 29.5 & 6.6 & 3.6 & 1.2 & .9 & 816 \\
\hline 4.8 & 2.7 & 1.1 & .7 & 1.5 & 1.1 & 1.4 & 2.2 & 1.7 & 2.9 & 3.6 & 4.7 & 14.1 & 31.9 & 15.0 & 8.6 & .5 & 1.4 & 806 \\
\hline 10.4 & 6.1 & 2.6 & 1.2 & 2.0 & 2.9 & 2.0 & 1.4 & 1.5 & 2.9 & 4.3 & 2.9 & 7.4 & 16.4 & 14.5 & 13.6 & .2 & 5.7 & 806 \\
\hline 12.7 & 7.6 & 3.5 & 3.6 & 3.1 & 3.6 & 3.7 & 3.8 & 2.2 & 4.6 & 3.3 & 3.8 & 5.0 & 5.3 & 7.8 & 12.8 & .2 & 9.3 & 806 \\
\hline 8.3 & 6.3 & 4.3 & 4.8 & 4.8 & 5.6 & 4.3 & 5.5 & 4.2 & 6.2 & 5. & 4. & 3. & 6. & 4. & 10. & .) & 11.5 & 806 \\
\hline 7.9 & 8.3 & 2.0 & 3.7 & 5.3 & 6.3 & 4.3 & 5.5 & 4.8 & 8.1 & 6.5 & 3. & 4.2 & 5.8 & 3.3 & 6.7 & .0 & 13.4 & 806 \\
\hline 7.1 & 7.2 & 4.2 & 3.5 & 4.6 & 5.7 & 4.2 & 4.2 & 4.5 & 11.8 & 7.6 & 5.0 & 3.0 & 5.5 & 4.1 & 5.0 & .0 & 13.0 & 806 \\
\hline 6.3 & 7.1 & 2.5 & 3.5 & 3.7 & 4.6 & 3.6 & 4.5 & 6.3 & 11.2 & 9.4 & 6.1 & 3.6 & 5.7 & 4.3 & 7.3 & .0 & 10.3 & 806 \\
\hline 5.5 & 6.1 & 4.5 & 4.0 & 3.5 & 3.8 & 2.7 & 3.7 & 4.1 & 12.2 & 11.2 & 6.1 & 4.6 & 7.4 & 2.9 & 8.7 & ن & 9.2 & 806 \\
\hline 6.2 & 7.2 & 4.0 & 4.7 & 3.2 & 4.8 & 1.4 & 4.0 & 4.3 & 9.8 & 10.3 & 7. & 5.7 & 9. & 3. & 6. & .1 & 7.1 & 806 \\
\hline 6.9 & 5.3 & 5.2 & 6.3 & 4.2 & 3.2 & 2.1 & 2.1 & 3.3 & 7.9 & 11.7 & 0.8 & 6.6 & 14. & 3. & $\circ$. & & 5.2 & 806 \\
\hline 0.5 & 5.8 & 5.1 & 8.3 & 4.0 & 4.5 & 1.1 & 3.0 & 2.0 & 6.0 & 11.5 & 6.2 & 6.3 & 19. & 3. & 5. & . & 2.4 & 806 \\
\hline 5.2 & 5.2 & 4.6 & 7.3 & 5.0 & 5.7 & 1.6 & 1.7 & 1.7 & 3.7 & 8.6 & 5.2 & 8.6 & 27 & 3. & 4. & .1 & .04 & 806 \\
\hline 4.2 & 3.1 & 2.6 & 0.2 & 0.2 & 6.6 & 1.9 & 1.6 & 1.1 & 3. & 5. & 4.2 & 14.4 & 31 & 3. & 3. & & .2 & 806 \\
\hline 1.6 & 2.5 & 1.9 & 3.6 & 3.1 & 3.7 & 3.6 & 2.1 & 1.9 & 3. & 4.3 & 5.5 & 22.8 & 33 & 3 & 2.1 &. & .6 & 806 \\
\hline .5 & 1.4 & 1.4 & 1.2 & .6 & 1.5 & 2.7 & 2.5 & 1.5 & 4. & 8.4 & 9.2 & 26.4 & 35 & 1.4 & .9 & . & .2 & 806 \\
\hline .4 & .5 & 1.1 & .4 & .0 & .9 & .7 & .4 & .9 & 2.4 & 12.7 & 12.3 & 37.2 & $2 t .3$ & 3. & .6 & .2 & .1 & 806 \\
\hline .4 & .7 & .4 & .2 & .2 & .2 & .5 & .6 & 1.0 & 1.4 & 7.3 & 19.5 & 41.2 & 22.2 & 2.4 & 1.0 & .5 & .2 & 806 \\
\hline 4.1 & 3.6 & 2.2 & 2.8 & 2.5 & 2.9 & 2.0 & 2.6 & 2.6 & 5.6 & 8.2 & 10.7 & 18.9 & 17.9 & 4.3 & 4.6 & .4 & 4.0 & 19342 \\
\hline
\end{tabular}

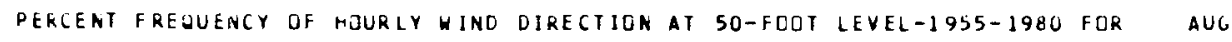

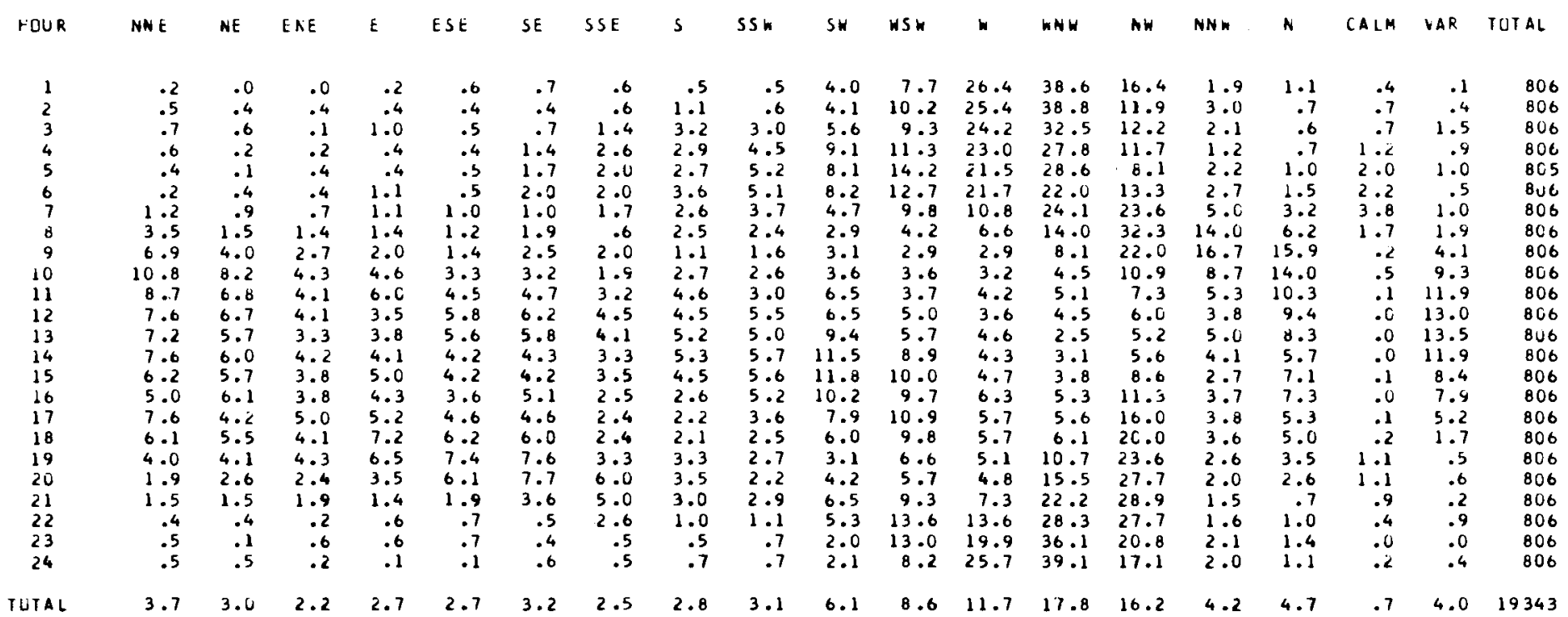


TABLE 44. Continued

PERCENT FREQUENCY UF HOURLY WINO OIRECTION AT 50-FOOT LEVEL-1955-1980 FOR SEP

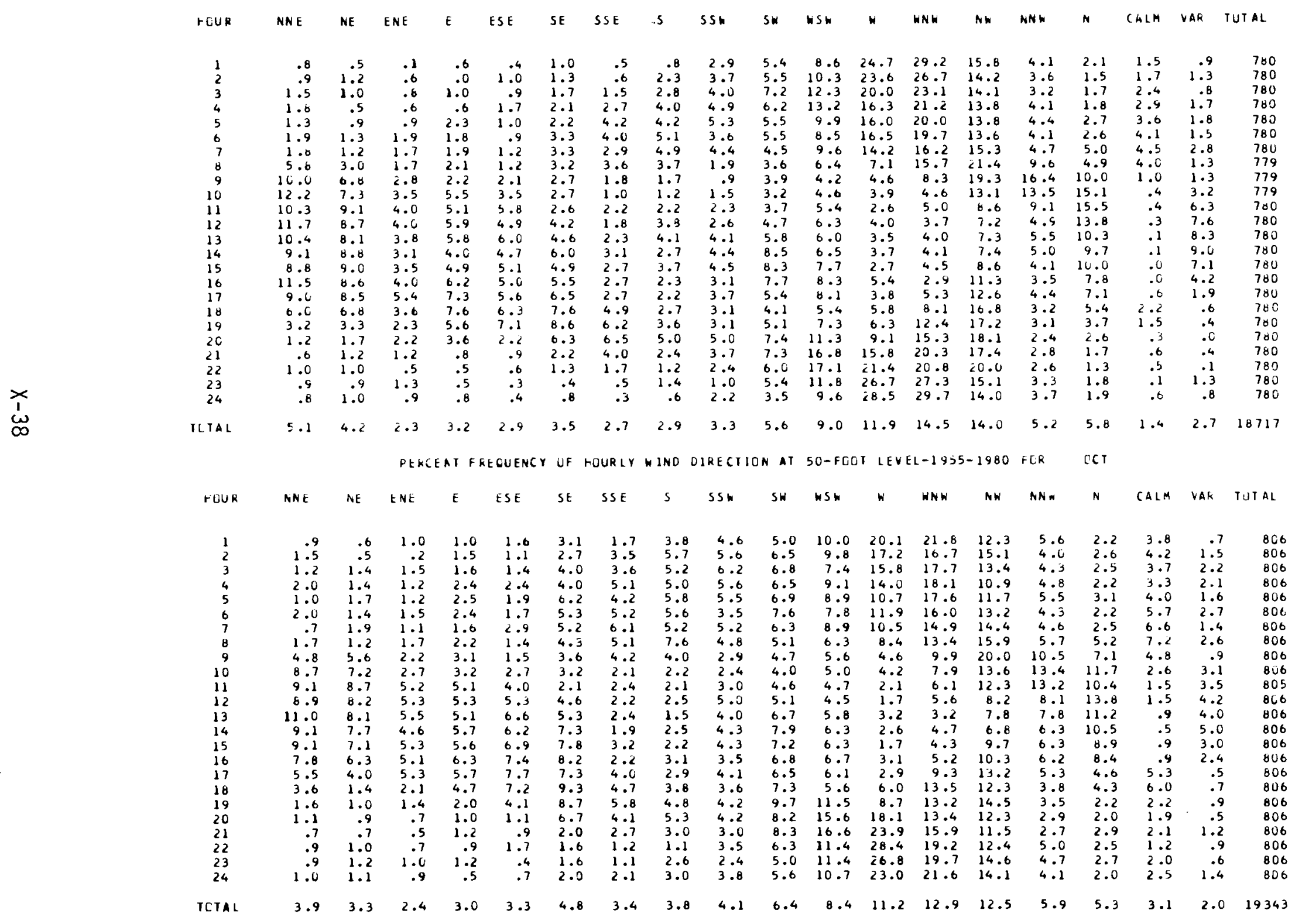


TABLE 44. Continued

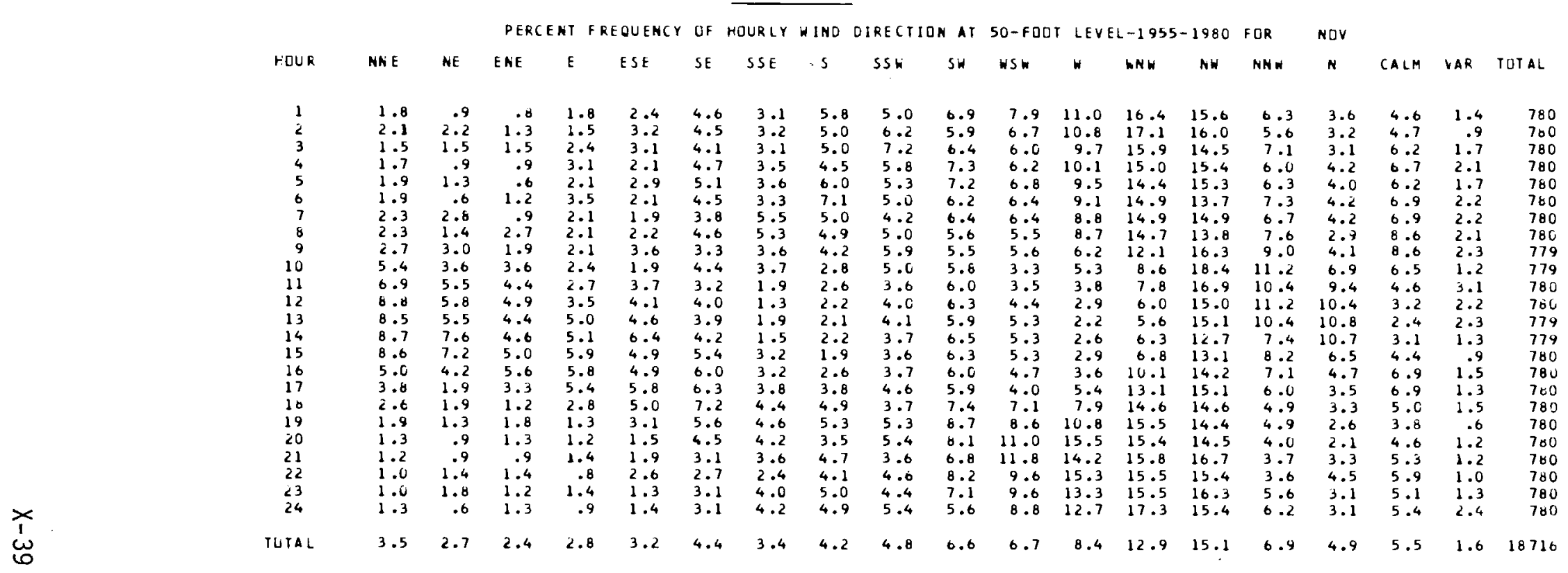

PERCEAT FREQUENCY OF RUURLY WIND DIRECTION AT 50-FOOT LEVEL-1955-1980 FOR DEC

\begin{tabular}{|c|c|c|c|c|c|c|c|c|c|c|c|c|c|c|c|c|c|c|c|}
\hline FUUK & NNE & NE & EAk & $\mathrm{E}$ & ESE & SE & SSE & $s$ & sst & SH & WSW & $*$ & WNK & NW & NN h & N & CALM & VAR & TUTAL \\
\hline
\end{tabular}


TABLE 44. Continued

PERCEAT FREQUENCY OF RQURLY WIND CIRECTIOA AT 50-FODT LEVEL-1955-1980 FOR ANNUAL

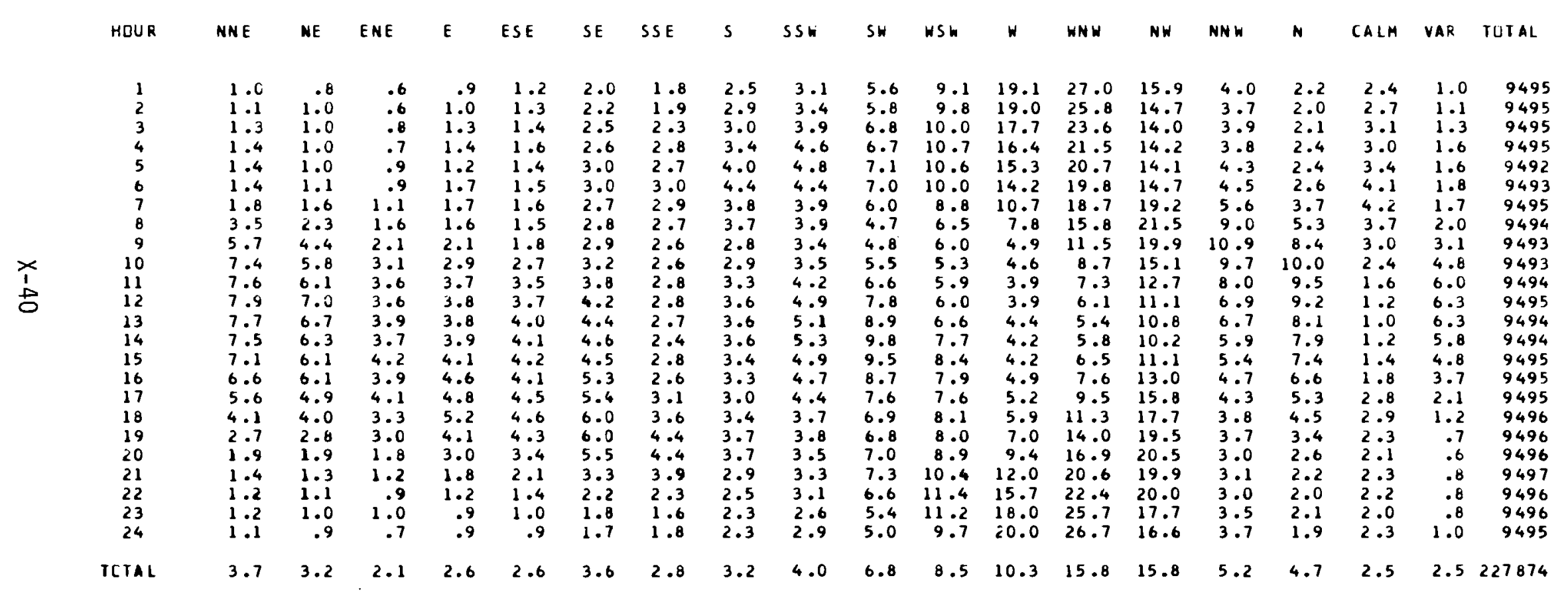


TABLE 45. Monthly and Annual Percent Frequency of Hourly Wind Direction at 200-Foot Level, 1955 Through 1980

PERCENT FREQUENCY UF RDURLY HIND DIRECTIOA AT 200FOOT LEVEL-1955-1980 FUR JAN

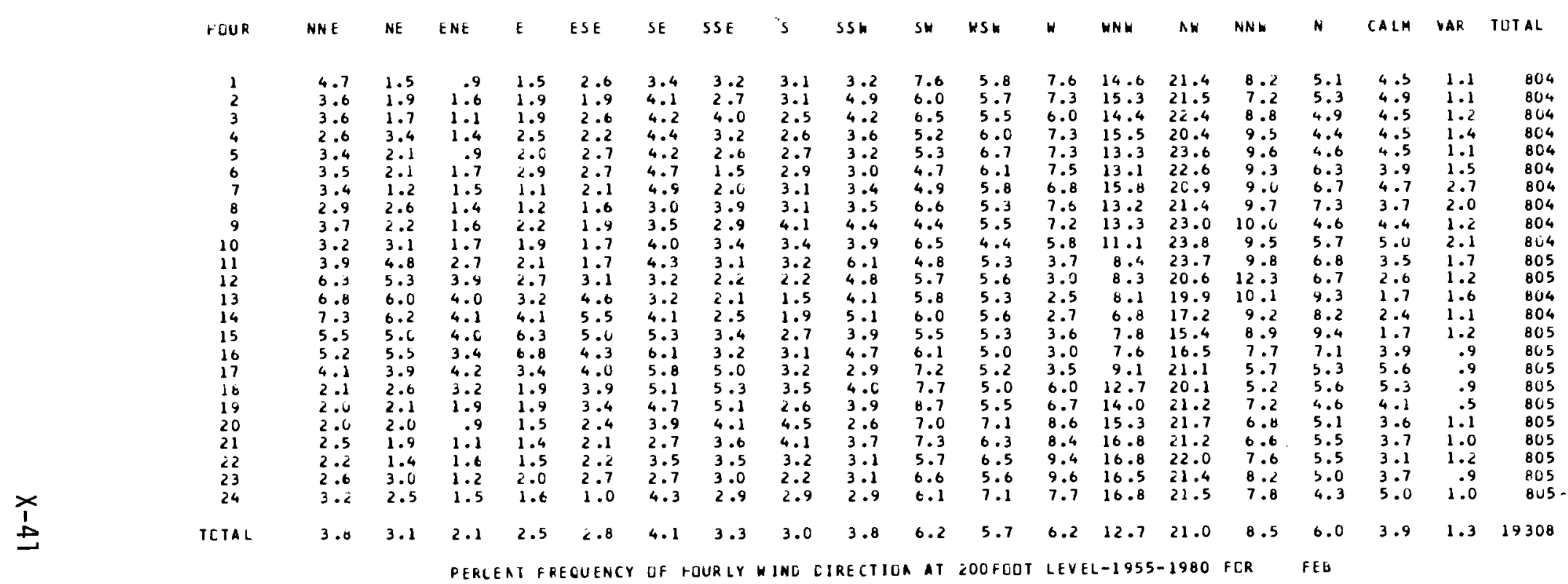

hUUR NNE NE ENE E ESE SE SSE S SSW SH WSW " WNW NW NNW N CALM VAR TCTAL

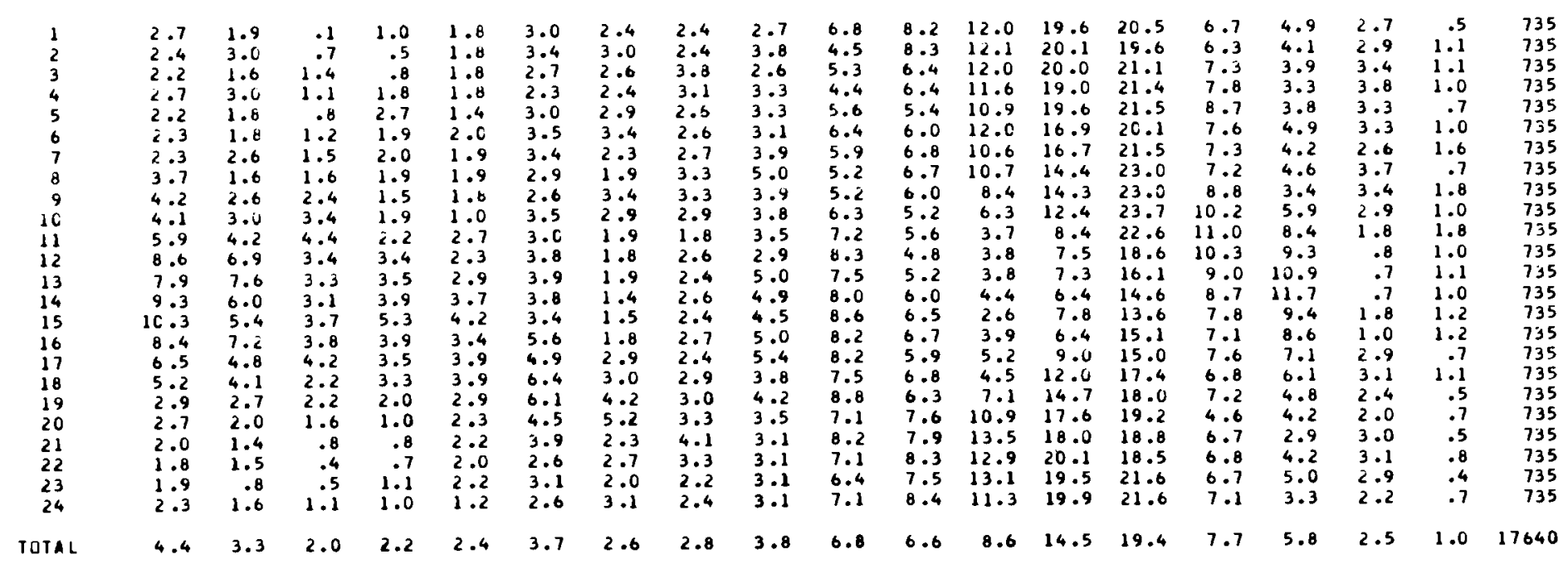


TABLE 45. Continued

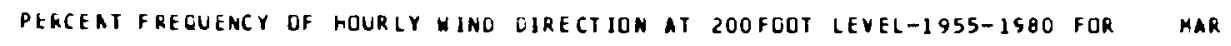

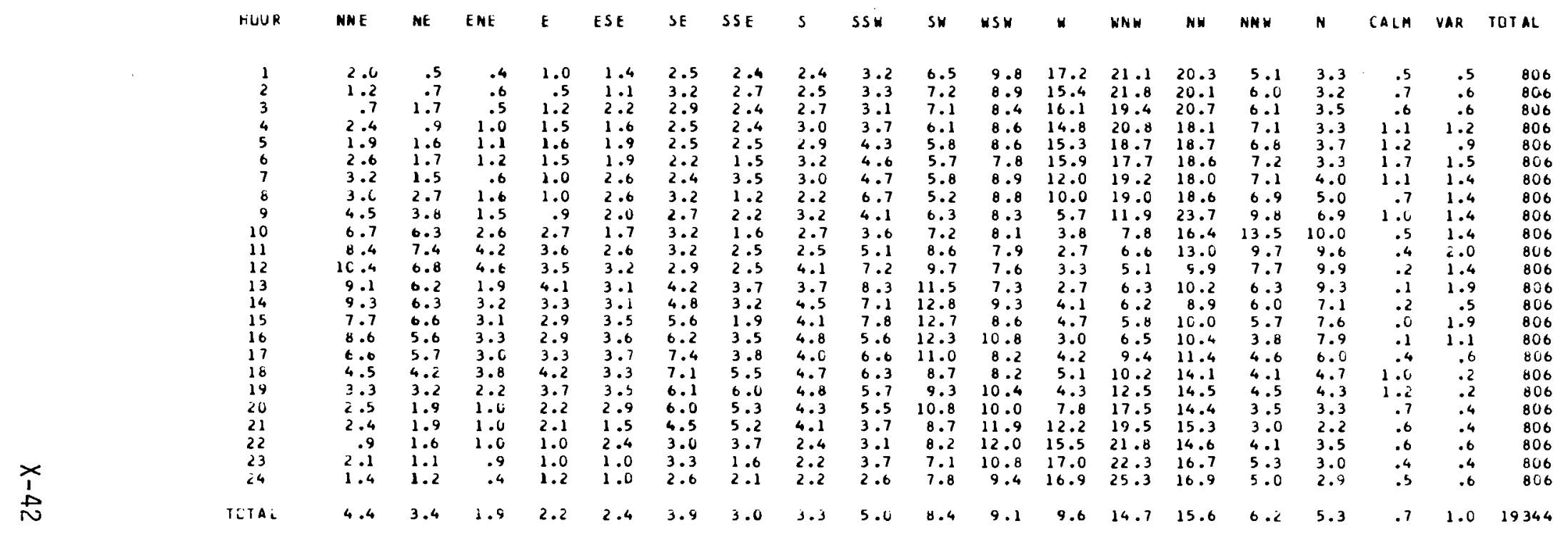

PERCEAT FREQUEACY GF mDURLY WIND DIRECTION AT 200 FDOT LEVEL-1955-1980 FOR APR

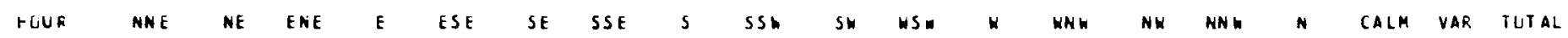

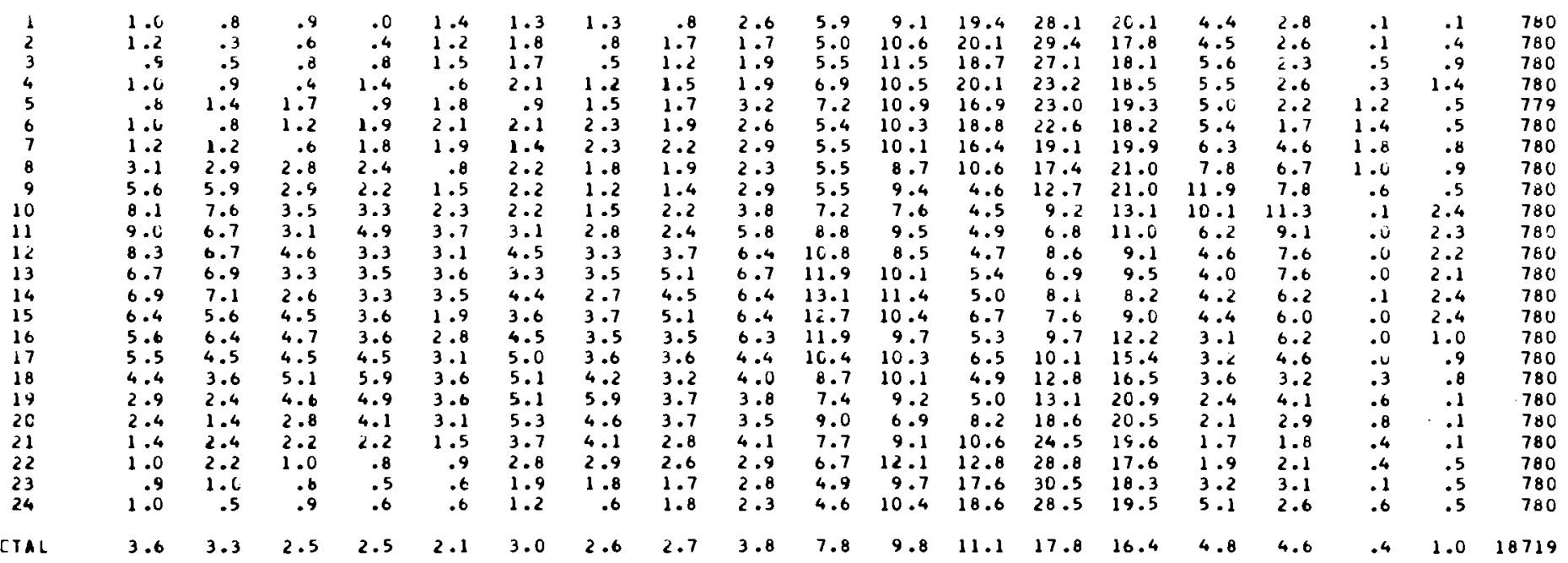


TABLE 45. Continued

PERCEAT FREQUENCY UF HOURLY WIND OIRECTION AT 200 FOOT LEVEL-1955-1980 FOR MAY

\begin{tabular}{|c|c|c|c|c|c|c|c|c|c|c|c|c|c|c|c|c|c|c|}
\hline .6 & .4 & .4 & .4 & .6 & 1.9 & .6 & .9 & .7 & 2.6 & 7.1 & 20.5 & 38.2 & 18.7 & 4.6 & 1.9 & .0 & .0 & 806 \\
\hline .6 & .5 & .5 & .4 & .5 & 1.2 & .9 & .6 & .7 & 2.7 & 10.3 & 18.0 & 37.1 & 18.6 & 4.6 & 2.0 & .6 & .1 & 806 \\
\hline .5 & .7 & 1.1 & .5 & .7 & 1.4 & 1.2 & .9 & 1.9 & 2.5 & 9.4 & 18.6 & 35.2 & 18.6 & 3.3 & 2.7 & .5 & .1 & 806 \\
\hline .5 & .9 & .6 & .2 & .9 & 2.1 & 1.6 & .9 & 1.9 & 4.0 & 8.6 & 20.3 & 31.9 & 17.9 & 3.6 & 3.2 & .7 & .2 & 800 \\
\hline .7 & .7 & .4 & 1.4 & .5 & 1.6 & 2.1 & 1.1 & 1.6 & 2.1 & 10.5 & 18.6 & 31.0 & 18.9 & 4.2 & 2.4 & 1.2 & .9 & 806 \\
\hline .9 & .7 & .5 & 1.4 & .9 & 2.0 & 1.7 & 1.4 & 1.6 & 2.6 & 9.7 & 22.2 & 26.2 & 19.5 & 4.7 & 2.0 & 1.5 & .6 & 806 \\
\hline 1.0 & 1.5 & 1.4 & 1.2 & 1.5 & 2.1 & 1.9 & 1.9 & 1.0 & 3.5 & 9.3 & 12.7 & 23.9 & 23.3 & 7.6 & 3.7 & 1.9 & .7 & 806 \\
\hline 4.2 & 2.9 & 1.9 & $1: 4$ & 1.0 & 1.1 & 1.2 & 1.4 & 1.9 & 4.6 & 6.8 & 7.2 & 16.1 & 28.3 & 10.4 & 7. & 1.2 & .9 & 806 \\
\hline 6.3 & 5.1 & 3.0 & 3.2 & 1.7 & 2.2 & .9 & 1.7 & 1.4 & 4.1 & 8.4 & 4.8 & 11.7 & 19.5 & 12.7 & 10.3 & .2 & 2.5 & 806 \\
\hline 7.6 & 5.8 & 3.3 & 3.0 & 3.3 & 2.6 & 2.4 & 2.4 & 3.7 & 8.6 & 7.2 & 3.8 & 8.7 & 12.5 & 8.4 & 11.3 & .2 & 5.1 & 806 \\
\hline 6.6 & 6.6 & 2.2 & 3.1 & 3.0 & 5.7 & 3.3 & 4.7 & 5.6 & 9.1 & 8.1 & 6.5 & 6.6 & 8.4 & 5.7 & 10.0 & .1 & 4.7 & 806 \\
\hline 6.9 & 6.5 & 2.7 & 3.5 & 4.1 & 4.3 & 3.6 & 5.8 & 5.8 & 10.8 & 9.4 & 6.5 & 5.7 & 8.2 & 4.3 & 0.1 & .0 & 5.7 & 806 \\
\hline 6.7 & 6.3 & 4.3 & 3.7 & 2.9 & 4.2 & 3.8 & 5.6 & 5.5 & 12.0 & 8.4 & 0.6 & 6.6 & 7.8 & 4.3 & 5.1 & .2 & 5.8 & 806 \\
\hline 6.0 & 6.7 & 5.0 & 3.6 & 2.2 & 5.0 & 3.3 & 4.2 & 6.6 & 11.5 & 9.7 & 6.7 & 6.6 & 9. & & & .4 & & 806 \\
\hline 6.5 & 5.5 & 4.1 & 3.2 & 2.5 & 4.1 & 3.3 & 4.2 & 5.6 & 10.8 & 11.8 & 0.6 & 6.5 & 11. & & & .2 & & 806 \\
\hline 5.8 & 8.6 & 3.8 & 3.5 & 2.7 & 5.5 & 2.1 & 3.8 & 4.6 & 10.7 & 10.9 & 5.1 & 6.5 & 15.0 & 3.2 & 5. & .0 & 2.5 & 806 \\
\hline 5.2 & 7.9 & 4.6 & 4.2 & 3.5 & 4.7 & 2.2 & 2.6 & 4.7 & 6.7 & 9.8 & 5.6 & 8.8 & 19.0 & 3.5 & 5.1 & .1 & 1.5 & 806 \\
\hline 4.3 & 7.2 & 4.8 & 5.2 & 3.7 & 4.1 & 3.6 & 2.6 & 4.2 & 6.1 & 7.9 & 4.8 & 9.4 & 23.2 & 3.1 & 4.2 & .4 & 1.0 & 806 \\
\hline 4.2 & 3.1 & 4.7 & 6.1 & 3.7 & 5.3 & 4.5 & 3.1 & 2.7 & 4.2 & 6.8 & 5.1 & 13.2 & 26.4 & 2. & 3. & .7 & .2 & 806 \\
\hline 2.5 & 4.5 & 2.4 & 4.6 & 5.5 & 4.3 & 4.3 & 3.2 & 2.5 & 2.9 & 5.8 & 5.5 & 18.2 & 28.5 & 3.0 & 1. & .2 & .2 & 806 \\
\hline 2.0 & 3.0 & 2.9 & 2.7 & 2.7 & 5.0 & 4.6 & 2.7 & 2.2 & 4.3 & 5.3 & 6.9 & 24.8 & 26.2 & 3.2 & 1. & .0 & .2 & 806 \\
\hline 1.4 & 2.4 & 2.0 & .7 & 1.4 & 2.7 & 3.5 & 3.2 & 2.0 & 4.5 & 0.3 & 11.9 & 30.0 & 24.8 & 2.0 & 1.0 & .2 & .0 & 806 \\
\hline 1.6 & 1.2 & .9 & .5 & 1.5 & 1.4 & 1.7 & 2.1 & 1.5 & 2.4 & 7.2 & 17.5 & 33.7 & 23.3 & 2.0 & 1.1 & .4 & .0 & 806 \\
\hline 1.1 & .5 & .6 & .9 & .2 & 1.0 & 1.6 & 1.0 & .6 & 1.7 & 7.0 & 18.6 & 37.6 & 20.9 & 3.5 & 2.9 & .1 & .1 & 805 \\
\hline 3.5 & 3.7 & 2.4 & 2.4 & 2.1 & 3.1 & 2.5 & 2.6 & 2.9 & 5.6 & 8.4 & 10.9 & 19.8 & 18.7 & 4.7 & 4.4 & .5 & 1.7 & 19343 \\
\hline
\end{tabular}

PERCEAT FREQUENCY OF ROURLY WIND DIRECIION AT 200FOOT LEVEL-1955-1980 FOR JUN

rouk

NNE
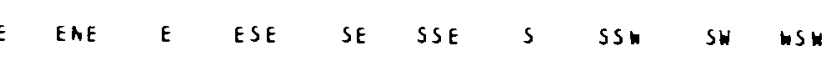

WN NW NNE N

CALM VAR tCTAL

1
2
3
4
5
6
7
8
9
10
11
12
13
14
15
16
17
18
19
20
21
22
23
24
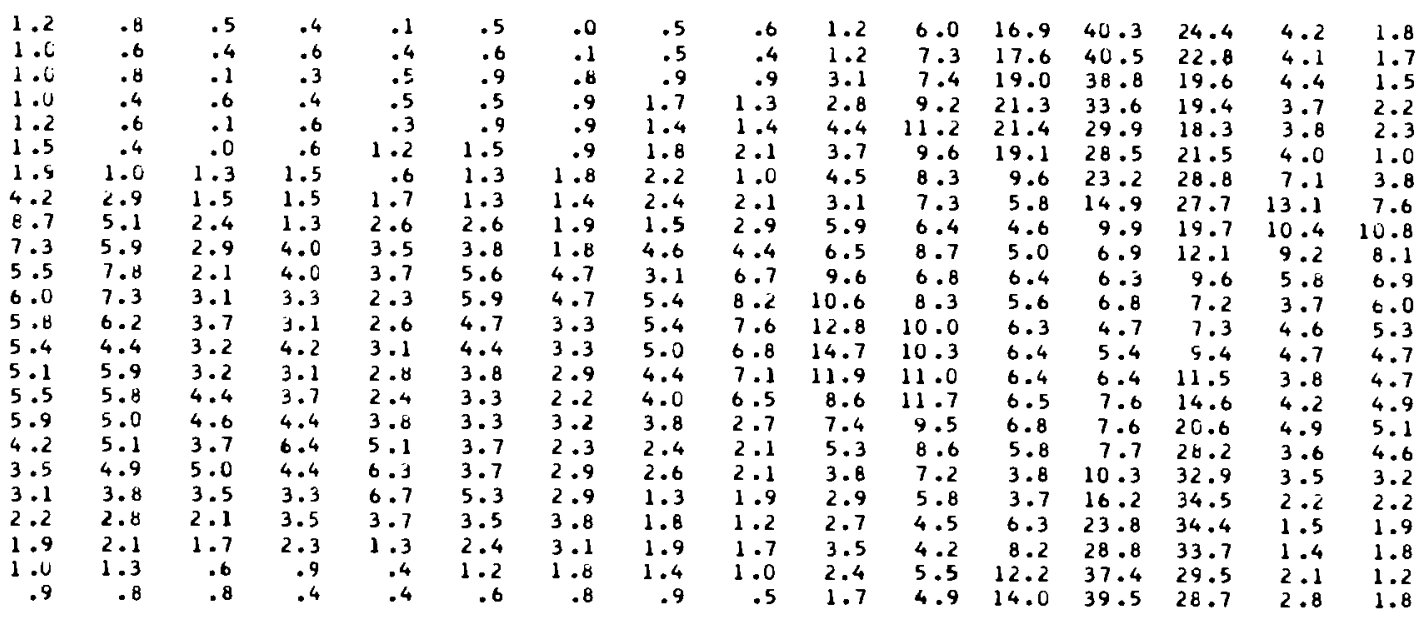

$\begin{array}{rrr}.1 & .5 & 780 \\ .0 & .1 & 780 \\ .0 & .0 & 780 \\ .4 & .1 & 780 \\ .9 & .4 & 780 \\ 1.4 & 1.2 & 780 \\ 1.2 & .8 & 780 \\ .4 & 1.2 & 780 \\ .6 & 2.6 & 780 \\ .1 & 5.1 & 780 \\ .0 & 5.4 & 780 \\ .1 & 5.3 & 780 \\ .1 & 6.5 & 730 \\ .0 & 4.6 & 780 \\ .1 & 5.6 & 780 \\ .0 & 4.1 & 780 \\ .0 & 1.3 & 780 \\ .1 & 1.0 & 780 \\ .0 & .0 & 780 \\ .5 & .3 & 780 \\ .3 & .1 & 780 \\ .0 & .0 & 780 \\ .1 & .0 & 780 \\ .4 & .3 & 780 \\ .3 & 1.9 & 18720\end{array}$ 
TABLE 45. Continued

PEACEAT FREGUENCY OF FOURLY WIND CIREGTIOA AT 200FOOT LEVEL-1955-1980 FOR JUL

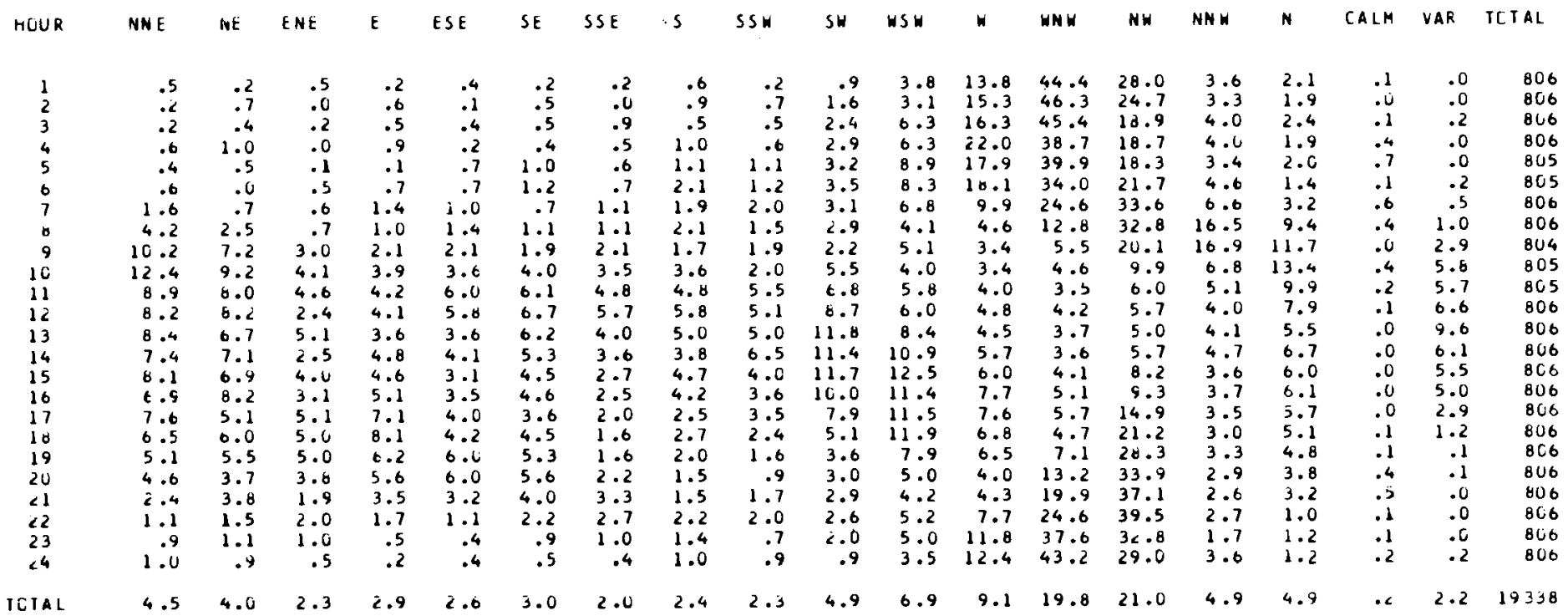

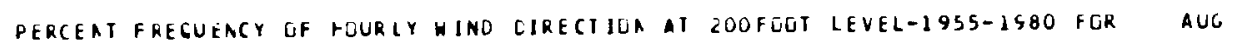

HOUR

NNE INE ENE

ESE SE SSE S SSW

SH WSH

CALM VAR TUIAL

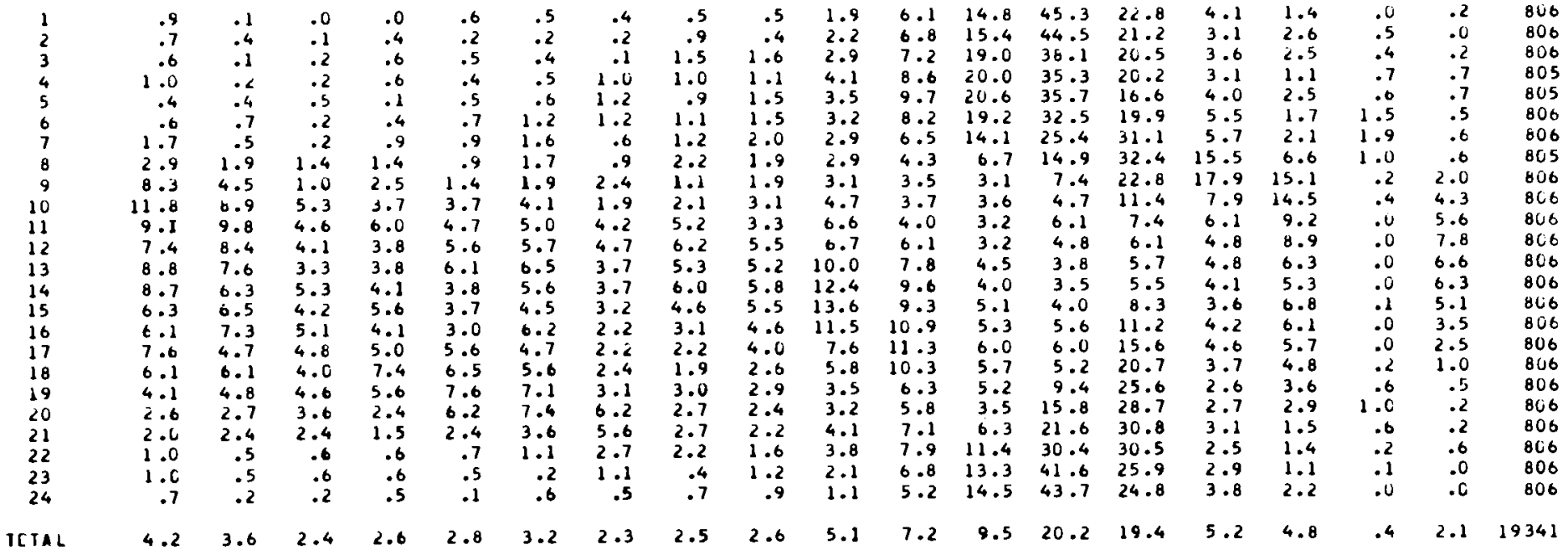


TABLE 45. Continued

PERCEAT FRECUENCY OF FOURLY WINO DIRECTICA AT 200FOOT LEVEL-1955-1980 FOR SEP

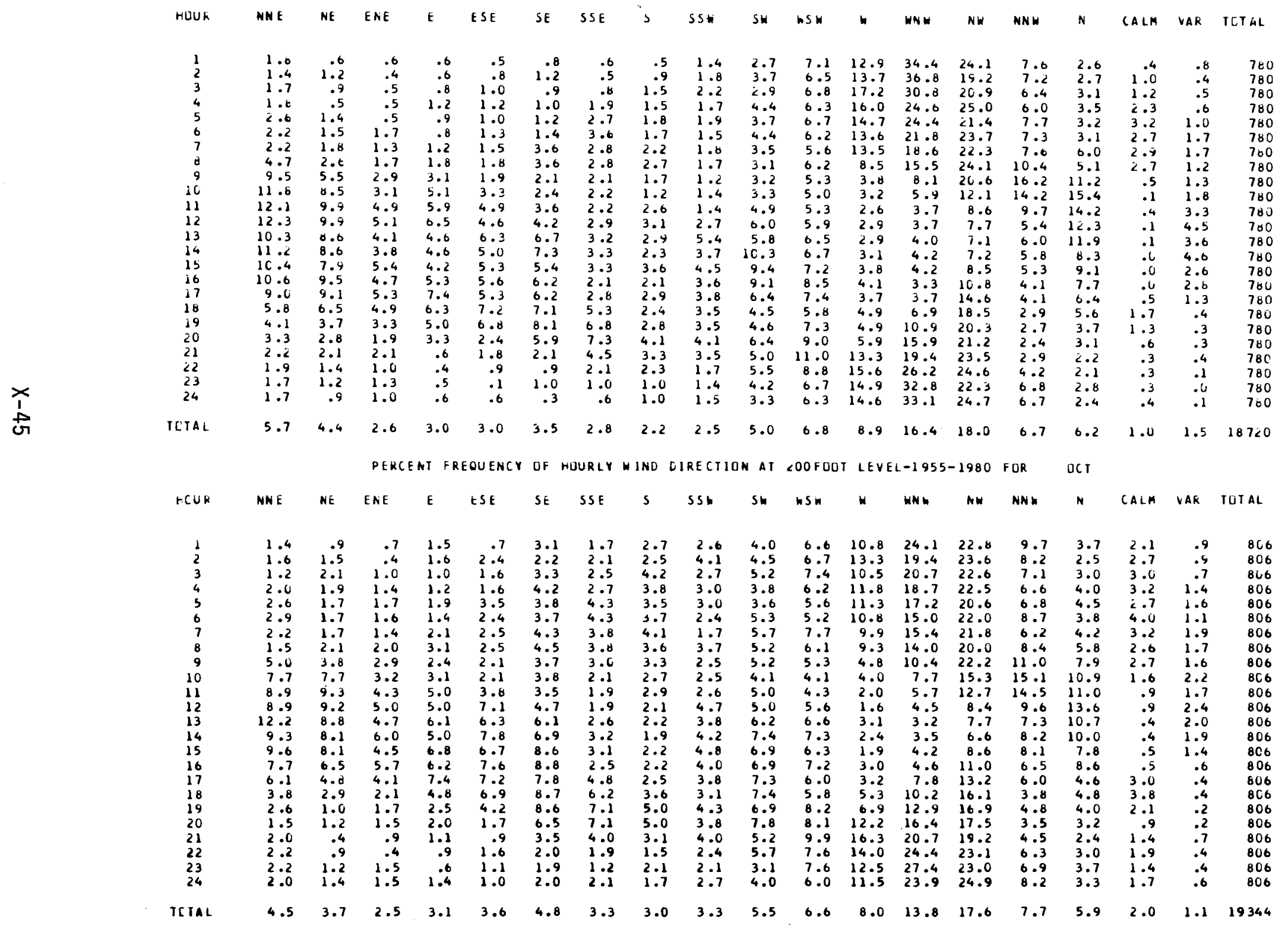


TABLE 45. Continued

PERCEAT FREQUENCY DF HOURLY WIND DIRECTION AI 200FOOT LEVEL-1955-1980 FOR NCV

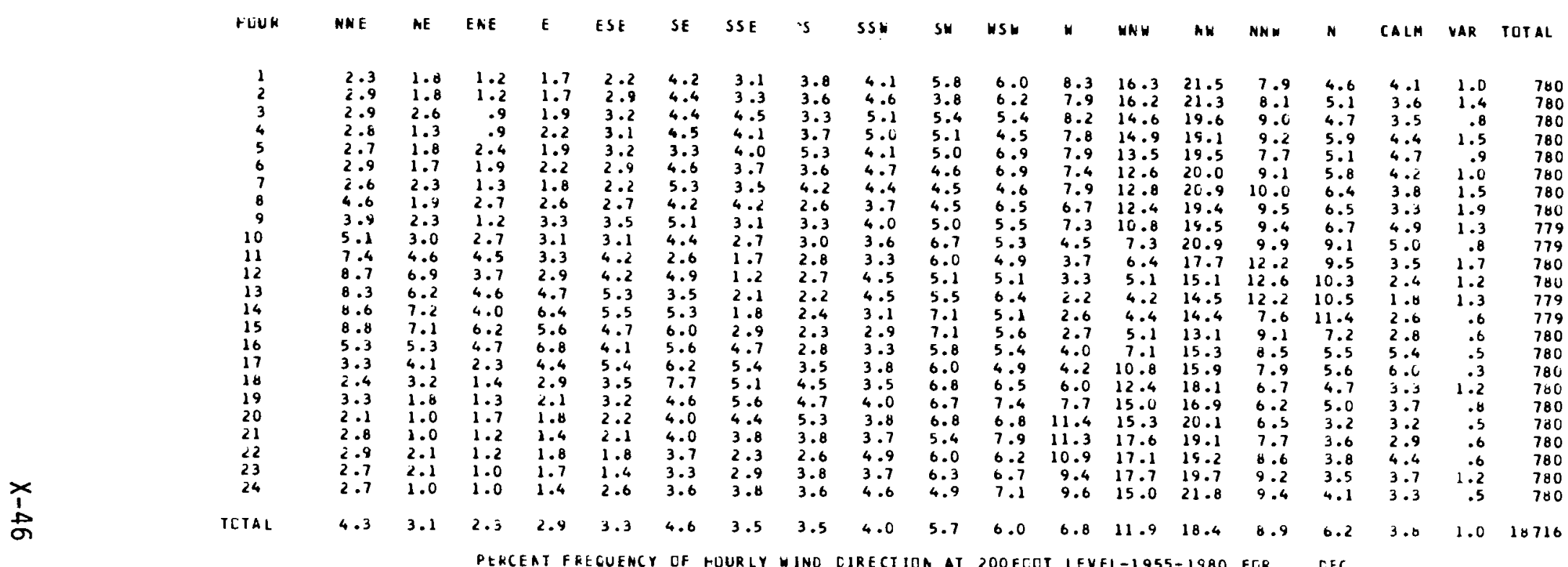

rCUR

ANE

NE TNE

ESE

\footnotetext{
SSE
}

Ssk shis

SW WS

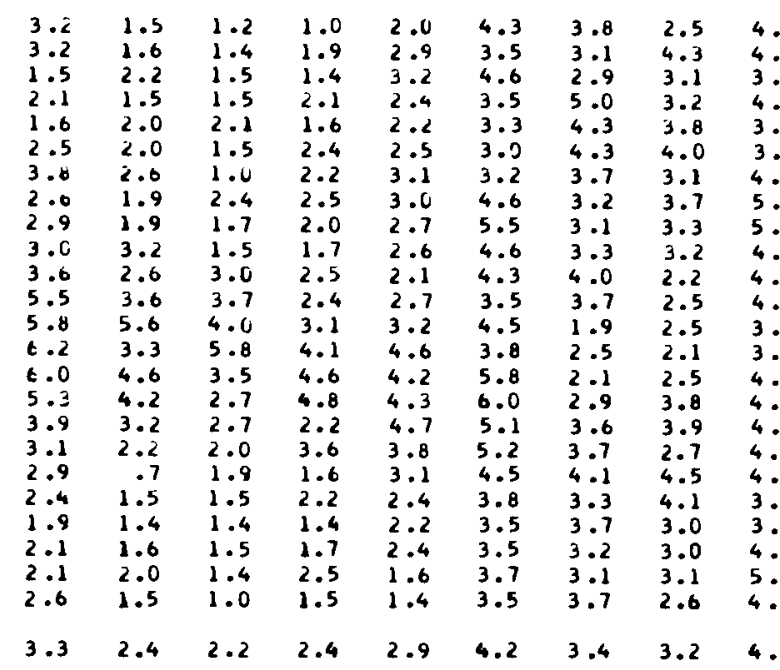

$\begin{array}{lll}.7 & 7.3 & 7.4 \\ .7 & 6.8 & 6.9 \\ .7 & 7.4 & 7 \\ .3 & 6.1 & 6.5 \\ .3 & 6.8 & 6.1 \\ 3.5 & 5.6 & 6.3 \\ .0 & 5.1 & 5 \\ .0 & 5.0 & 4.8 \\ .1 & 5.0 & 5.0 \\ .6 & 5.1 & 5.7 \\ .2 & 4.6 & 7 \\ .8 & 5.0 & 5 \\ .6 & 6.5 & 4.8 \\ .6 & 6.7 & 5 \\ .3 & 6.9 & 5 \\ .2 & 7.3 & 5.1 \\ .3 & 7.6 & 5.0 \\ .0 & 7.7 & 6 \\ .1 & 6.8 & 6.7 \\ .5 & 7.4 & 5.7 \\ .2 & 5.6 & 7.4 \\ .0 & 5.0 & 7.3 \\ .2 & 5.8 & 7.0 \\ .3 & 7.2 & 7.7 \\ .2 & 6.3 & 6.2\end{array}$

$\begin{array}{llll}7.4 & 8.1 & 14.5 & 21.3 \\ 6.9 & 8.9 & 14.0 & 19.2 \\ 7.1 & 8.7 & 11.2 & 21.3\end{array}$

$\begin{array}{llll}6.5 & 7.2 & 13.4 & 20.7 \\ 0.1 & 8.9 & 12.3 & 22.3\end{array}$

$\begin{array}{llll}6.3 & 8.6 & 12.3 & 22.3 \\ 5.2 & 8.2 & 13.9 & 20.2 \\ 4.8 & 8.6 & 11.9 & 19.4\end{array}$

$\begin{array}{llll}4.8 & 8.6 & 11.9 & 20.6 \\ 5.0 & 8.2 & 10.8 & 20.6\end{array}$

$\begin{array}{lllll}5.0 & 8.2 & 10.8 & 20.6 & 10.4\end{array}$

$\begin{array}{lllll}5.7 & 7.1 & 12.8 & 20.6 & 10.5 \\ 7.7 & 6.0 & 9.1 & 21.2 & 10.5\end{array}$

5.84 .1

$\begin{array}{lllll}4.8 & 4.0 & 6.0 & 11.3 & 11.7\end{array}$

$\begin{array}{llll}5.2 & 4.0 & 7.2 & 18.0\end{array}$

$\begin{array}{llll}5.0 & 4.1 & 8.1 & 19.4 \\ 6 & 4.6 & 9.6 & 19.4\end{array}$

$\begin{array}{llll}6.1 & 6.2 & 11.5 & 19.6 \\ 6.7 & 9.6 & 13.8 & 18.7\end{array}$

$\begin{array}{llll}6.7 & 9.6 & 13.8 & 18.7 \\ 5.7 & 8.7 & 15.5 & 20.3\end{array}$

$\begin{array}{llll}7.4 & 8.9 & 15.5 & 20.3 \\ 7.3 & 8.9 & 14.7 & 23.3 \\ 7.3 & 9.9 & 15.1 & 19.7\end{array}$

$\begin{array}{llll}7.8 & 9.2 & 15.3 & 20.2 \\ 7.7 & 8.8 & 15.8 & 20.4\end{array}$

TCTAL

\begin{abstract}
$\begin{array}{llll}7.2 & 11.7 \quad 20.2\end{array}$
\end{abstract}

$\begin{array}{rrrrr}8.8 & 3.5 & 4.3 & .4 & 806 \\ 7.4 & 4.6 & 4.8 & .6 & 806 \\ 8.3 & 4.6 & 6.0 & 1.4 & 806 \\ 9.1 & 5.0 & 5.1 & 1.5 & 806 \\ 8.6 & 5.2 & 3.0 & 1.5 & 806 \\ 9.9 & 5.6 & 4.6 & 1.4 & 806 \\ 8.2 & 5.8 & 5.7 & 1.7 & 806 \\ 8.2 & 6.0 & 4.8 & 1.4 & 806 \\ 10.4 & 5.6 & 4.8 & 1.5 & 806 \\ 10.5 & 4.8 & 4.6 & 1.6 & 806 \\ 10.5 & 6.9 & 3.6 & 1.9 & 806 \\ 11.7 & 8.6 & 3.5 & 1.2 & 806 \\ 11.8 & 8.6 & 3.6 & 1.9 & 806 \\ 9.4 & 8.1 & 4.6 & 1.4 & 806 \\ 8.9 & 6.3 & 4.3 & 1.5 & 806 \\ 8.1 & 4.6 & 4.2 & .9 & 806 \\ 7.3 & 6.3 & 5.6 & 1.0 & 805 \\ 6.8 & 4.3 & 6.1 & 1.2 & 806 \\ 7.4 & 4.0 & 4.8 & .9 & 806 \\ 9.1 & 3.6 & 4.6 & .4 & 806 \\ 7.6 & 4.1 & 5.6 & 1.2 & 807 \\ 8.7 & 5.1 & 5.1 & 1.1 & 806 \\ 6.6 & 4.3 & 4.2 & 1.9 & 806 \\ 7.2 & 4.5 & 4.5 & 1.9 & 805 \\ 8.8 & 5.4 & 4.7 & 1.3 & 19343\end{array}$


TABLE 45. Continued

PERCENT FREQUENCY OF HOURLY WIND DIRECTION AT 200 FOOT LEVEL-1955-1980 FOR ANNUAL

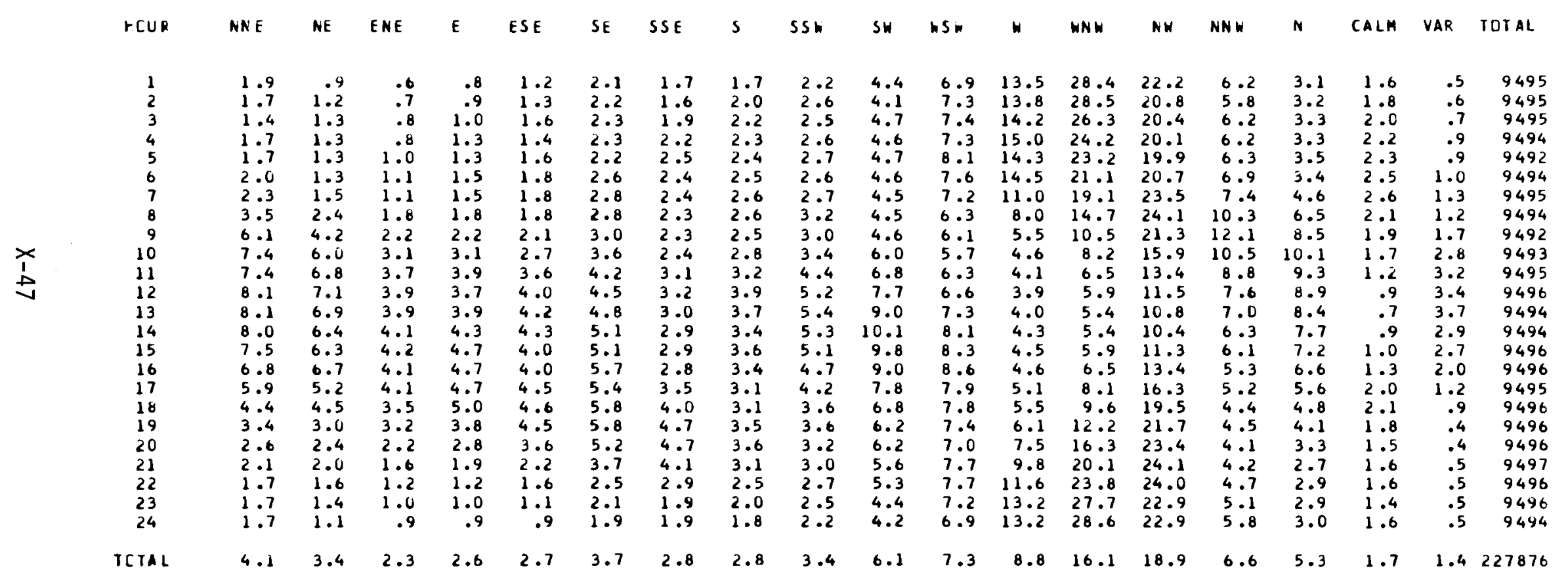


TABLE 46. Monthly and Annual Percent Frequency of Hourly Wind

Direction at 400-Foot Leve1, 1955 Through 1980

PLKCEAT FREGUENCY OF FQURLY WINO DIREGIION AT 400 FOOT LEVEL-1955-1S80 FOR

JAN

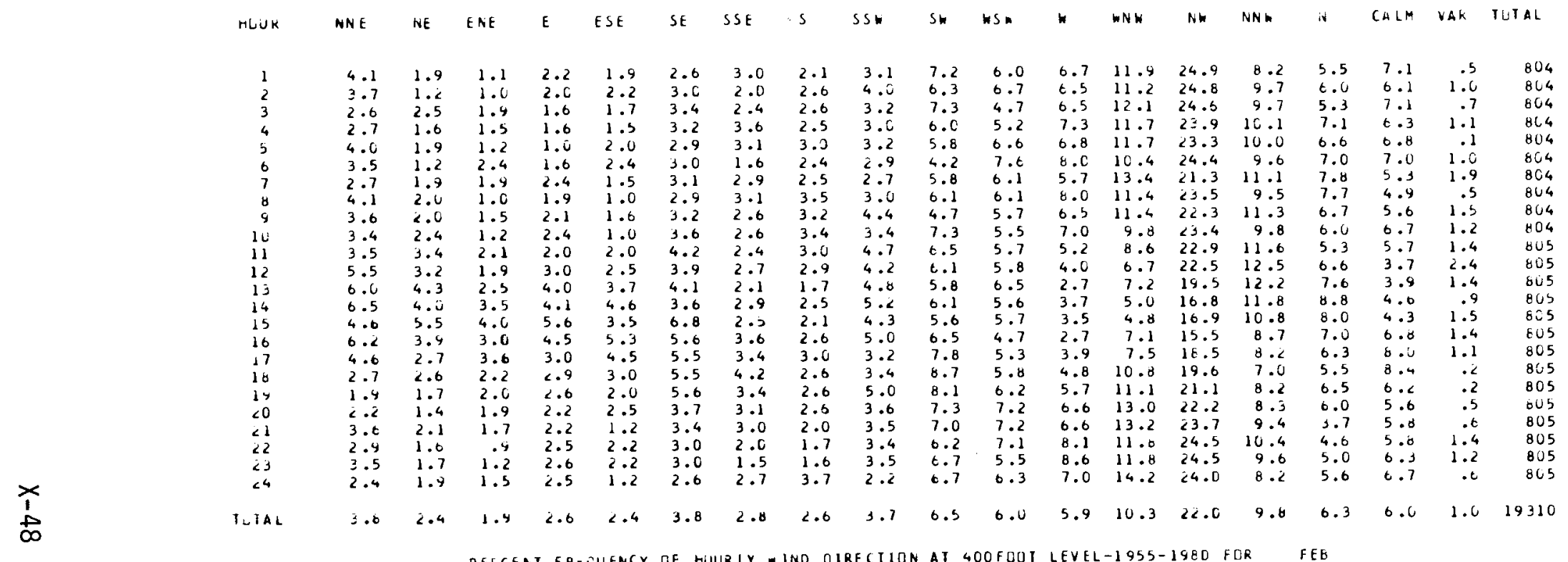

PERCEMI FRTUUENCY OF HUURLY WIND OIRECTION AT 400 FOUT LEVEL-1955-1980 FDR FEB

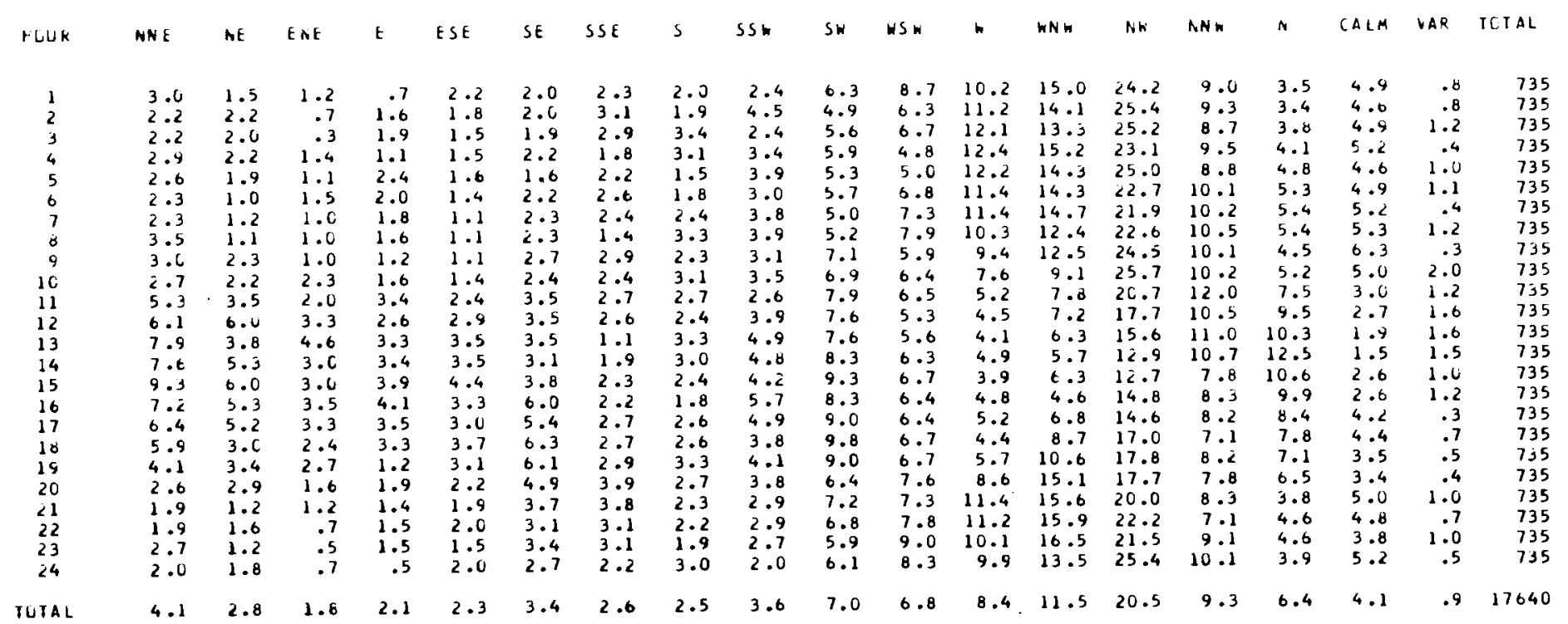


TABLE 46. Continued

PERGENT FREQUENGY OF HCURLY WIND LIRECTION AT 400 FOOT LEVEL-1955-1950 FOR MAR

\begin{tabular}{|c|c|c|c|c|c|c|c|c|c|c|c|c|c|c|c|c|c|c|c|}
\hline ruok & NNE & NE & ENE & $t$ & ESE & SE & SSE & $\mathrm{s}$ & SSW & $5 n$ & W 5 & $w$ & WNW & $A k$ & NN K & $N$ & CALM & VAR & TUTAL \\
\hline 1 & 1.6 & 1.1 & .7 & .5 & 1.0 & 2.2 & 2.4 & 2.0 & 2.7 & 0.3 & 9.1 & 15.5 & 19.6 & 21.2 & 9.1 & 3.0 & 1.6 & .4 & \\
\hline 2 & 1.5 & .9 & .t & .5 & .5 & 2.4 & 3.0 & 1.9 & 4.2 & 7.1 & 8.6 & $\begin{array}{l}13.3 \\
12.9\end{array}$ & 18.4 & 23.1 & 9.3 & 3.6 & 1.5 & .2 & $\begin{array}{l}806 \\
8 C E\end{array}$ \\
\hline 3 & 1.4 & 1.1 & .7 & .7 & 1.4 & 3.1 & 1.7 & 2.5 & 3.6 & 0.1 & 6.8 & 13.5 & 20.1 & 20.7 & 10.9 & 3.0 & 1.0 & .7 & 800 \\
\hline 4 & 1.9 & 1.4 & .6 & 1.2 & 1.1 & 1.9 & 2.4 & 3.0 & 3.7 & 4.6 & 7.7 & 13.8 & 21.1 & 21.6 & 9.1 & 4.1 & 1.2 & .4 & $8 \mathrm{Ct}$ \\
\hline 5 & 1.4 & 1.6 & .9 & .9 & 1.4 & 3.0 & 2.4 & 2.2 & 3.7 & 5.1 & 8.2 & 12.3 & 20.5 & 20.0 & 9.7 & 3.6 & 2.7 & .6 & But \\
\hline 6 & 1.7 & 1.2 & .7 & 1.1 & 1.4 & 2.5 & 1.9 & 2.0 & 3.8 & 0.5 & 7.3 & 13.4 & 16.0 & 22.5 & 8 & 4.7 & 3.1 & .0 & \\
\hline 7 & 2.9 & 1.0 & .7 & .7 & 1.4 & 1.6 & 2.4 & 3.0 & 5.3 & 5.5 & 7.4 & 12.4 & 17.7 & 20.2 & 9 & & & .9 & \\
\hline 8 & 2.6 & 1.4 & .6 & .9 & .7 & 2.7 & 2.0 & 2.1 & 4.2 & 7.1 & 7.6 & 10.5 & 17 & 21 & 10 & & & 1.1 & \\
\hline 9 & 4.6 & 2.2 & 1.2 & 1.1 & .7 & 2.5 & 2.7 & 2.2 & 4.3 & 6.9 & 7. & 7.8 & 13 & 22 & & & 1.7 & $\begin{array}{l}1.1 \\
1.5\end{array}$ & Buf \\
\hline 10 & 5.6 & 4.1 & 2.9 & 2.2 & 3.2 & 2. & 1. & 2.5 & 4 & 7. & 8 & 5 & & 10.4 & 14.0 & 9.7 & 1.6 & 1.5 & 806 \\
\hline 11 & 7.8 & 5.0 & 4.6 & 3.6 & 2.7 & 3. & 2 & 3.0 & 4.8 & 9.3 & & 3.3 & 6.9 & 12.2 & $10 . \mathrm{s}$ & 9.9 & .9 & 1.1 & $8 \mathrm{C}$ \\
\hline 12 & 9.8 & 0.5 & 4.1 & 4.1 & 3.2 & 2.9 & 2 & 4.6 & 6.9 & 10.3 & 7. & 3.7 & 5.6 & 9.7 & 7 & 8.8 & .4 & 1.6 & $B C 0$ \\
\hline 13 & 7.9 & 5.6 & 2.1 & 3.5 & 3.7 & 4.5 & 3. & 4.1 & B. 3 & 11.4 & 7. & 2.6 & 6.3 & 10.5 & 6 & 10. & .1 & 1.7 & BCE \\
\hline 14 & 8.3 & 5.6 & 3.2 & 3.3 & 2 & 4.5 & 3. & 4.6 & 7. & 12.8 & $\theta$. & 4.2 & 6.6 & 8 & & & ל & & \\
\hline 15 & 7.7 & 5.3 & 3.1 & 3.1 & 3 & 5.6 & 1 & 6.1 & 7 & 12.3 & 8 & 5.5 & 6.3 & & & & .1 & 1.5 & 80 \\
\hline 16 & 7. & 0.1 & 2.9 & 3.5 & & & & 4.8 & 5 & 12.2 & 10 & 4.1 & 5.6 & & & & .4 & $1 . t$ & 806 \\
\hline 17 & $t$ & 4.3 & 3 & 4.5 & & & & 4.3 & 5 & 11.0 & & 4.2 & 7 & & & & .7 & .9 & to \\
\hline 10 & 4.5 & 4.3 & 2. & 5.2 & 2.4 & 6. & 6 & 4. & 6. & 5.8 & 8 & 5.0 & 8 & & & $\varepsilon$. & 1.2 & .1 & 606 \\
\hline 19 & 3.7 & 3.8 & 1.7 & 3.0 & 3 & 5.8 & 6. & 4.2 & & 9. & 10 & 4.8 & 10 & & & 4. & & & QCO \\
\hline 20 & 2.6 & 2.2 & 2.0 & 2.5 & 2.5 & 5.5 & 6. & 4.0 & 5.0 & 9.9 & 9 & 7.1 & 17.0 & 13 & 4 & 3. & & .1 & \&ut \\
\hline$<1$ & 2.7 & 2.0 & 1.4 & 3.5 & 1.9 & 5. & 4. & 3.6 & 4.6 & 8.4 & 12 & 8.2 & & & & 2.0 & 1.2 & .2 & $\theta 06$ \\
\hline 22 & 1.7 & i. $\mathrm{z}$ & 1.4 & 2.2 & 2.7 & 3 & 3 & 4 & & 8. & & 12.5 & & & & 3. & 1.2 & .1 & Euo \\
\hline$<3$ & 1. & 1.5 & 1.2 & 1.0 & .9 & 3. & 2.1 & 2.7 & 3 & 7. & 10.3 & 13.2 & 19.9 & 19. & 6. & 3.3 & 1.1 & .5 & 806 \\
\hline 24 & 1.5 & 1.5 & .4 & 1.0 & 1.0 & 2.0 & 1.9 & 2.2 & 2.6 & 8.3 & 9.1 & 19.8 & 21.0 & 21.5 & 6.1 & 9.6 & 1.6 & .7 & 806 \\
\hline 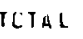 & 4.1 & 3.0 & 1.8 & 2.2 & 2.0 & 3.7 & 3.2 & 3.4 & 4.8 & 8.5 & 8.7 & 8.7 & 13.8 & 16.7 & 7.5 & 5.7 & 1.3 & .8 & 19344 \\
\hline
\end{tabular}

FERCEAT FRECUENCY UF FOURLY WINO CIRECTIOA AI 400 FCET LEVEL-1955-1980 HOK APR

HuUk

NNE NE

ENE E ESE SE SSE

S SSW SW WSW WNW Nh NNW N CALM VAF ICTAL

1
2
3
4
5
6
7
8
9
10
11
12
13
14
15
16
17
18
19
20
21
22
23
24

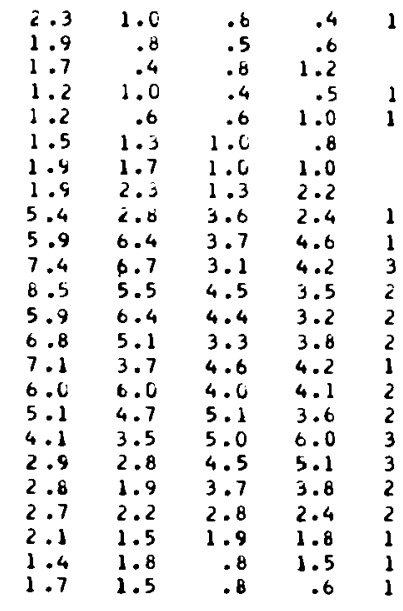

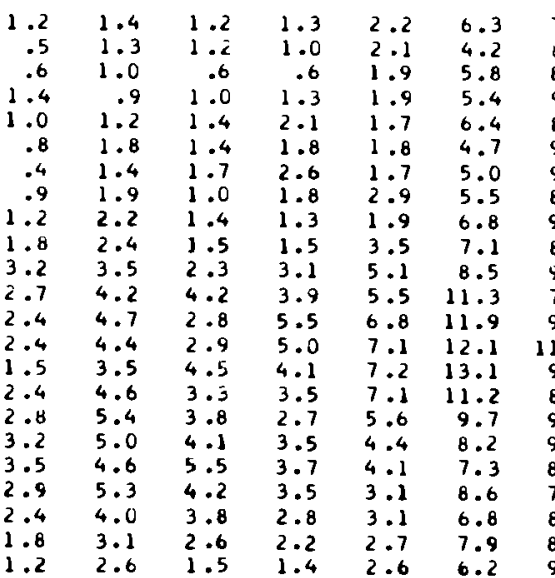

$\begin{array}{llll}7.6 & 15.9 & 28.6 & 21.3 \\ 8.5 & 18.2 & 28.5 & 19.0\end{array}$

$\begin{array}{llll}8.5 & 18.2 & 28.5 & 19.0 \\ 8.2 & 19.0 & 26.3 & 20.0 \\ 9.0 & 18.5 & 24.4 & 20.9\end{array}$

$\begin{array}{lllllllll}9.0 & 18.5 & 24.4 & 20.9 & 7.8 & 3.2 & .4 & .9 & 780 \\ 8.5 & 17.5 & 24.0 & 21.1 & 7.7 & 1.9 & 1.5 & .6 & 779 \\ 9.0 & 19.4 & 22.1 & 20.9 & 5.4 & 2.6 & 2.7 & .6 & 780\end{array}$

6.2
7.7
7.8
7.8
7.7
5.4
7.1

$\begin{array}{llll}2.2 & .4 & .0 & 780 \\ 2.8 & 1.0 & .3 & 780 \\ 2.9 & 1.0 & .1 & 780\end{array}$

\begin{tabular}{rrrrrrr}
.7 & 8.3 & 21.9 & 21.5 & 8.1 & 2.7 & 2.6 \\
\hline & 5.6 & 13.9 & 20.5 & 13.5 & 6.9 & 2.4
\end{tabular}

$\begin{array}{rrrrrr}8.5 & 5.3 & 9.8 & 13.1 & 13.5 & 6.9 \\ 9.1 & 0.3 & 7.8 & 11.4\end{array}$

$\begin{array}{rrrrrr}7.8 & 6.3 & 7.6 & 11.2 & 6.4 & 9.6 \\ 9.4 & 9.5 & 9.0 & 4.2 & 8.3\end{array}$

$\begin{array}{llll}9.5 & 5.8 & 7.5 & 9.0 \\ 9.4 & 9.6 & 9.4 & 9.0\end{array}$

$\begin{array}{rrrr}9.2 & 7.7 & 9.4 & 7.2 \\ 8.8 & 6.3 & 10.6 & 9.2 \\ 9.9 & 6.8 & 11.3\end{array}$

$\begin{array}{ll}5.4 & 6.3 \\ 4.6 & 7.2\end{array}$

4.6
3.2
3.3

$\begin{array}{llll}.9 & 6.8 & 11.0 & 14.7 \\ 9 & 5.6 & 13.6 & 15.9\end{array}$

$\begin{array}{llll}.5 & 5.6 & 13.6 & 15.9 \\ .5 & 6.2 & 14.7 & 16.8 \\ 8.4 & 6.4 & 20.0 & 19.9\end{array}$

ICIAL

\begin{abstract}
$3.7 \quad 3.0$
\end{abstract}
$1.8 \quad 3.0$

$\begin{array}{llllllll}5 & 1.4 & 2.6 & 6.2 & 9.2 & 11.5 & 29.0 & 18.1 \\ 4 & 1.3 & 2.2 & 4.5 & 3.5 & 13.1 & 30.3 & 19.5 \\ 4 & & & & & 29.1 & 20.1\end{array}$

$\begin{array}{ll}3.7 \\ .3 & 3.7 \\ .1 & 4.6\end{array}$

$\begin{array}{lll}.8 & 2.6 & 1.9\end{array}$

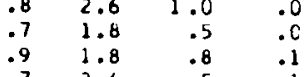

.5 
TABLE 46. Continued

PERCEAT FREGUENCY UF rUURLY HIND DIRECTION AT 400 FUOT LEVEL-1955-1980 For RAY

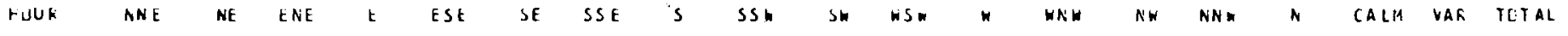

\begin{tabular}{|c|c|c|c|c|c|c|c|c|c|c|c|c|c|c|c|c|c|c|}
\hline .4 & .5 & .7 & .7 & .1 & .9 & 1.7 & .9 & .9 & 2.0 & 5.5 & 18.5 & 38.0 & 21.6 & 4.5 & 2.6 & .5 & $\cdot 1$ & 806 \\
\hline 1.2 & .7 & .5 & .4 & .4 & 2.0 & .9 & .7 & .5 & 2.6 & 6.7 & 17.0 & 37.1 & 21.3 & 5.5 & 1.9 & .5 & .1 & 806 \\
\hline 1.2 & 1.2 & .2 & .6 & .5 & 1.2 & .7 & 1.4 & 1.4 & 2.5 & 7.9 & 17.6 & 33.7 & 21.8 & 5.7 & 1.7 & .4 & .0 & 806 \\
\hline .6 & 1.6 & .5 & .4 & .4 & 1.0 & 1.2 & .7 & 1.2 & 2.9 & 7.4 & 17.2 & 34.5 & 20.8 & 6.0 & 2.1 & 1.0 & .4 & 806 \\
\hline .9 & .6 & .5 & 1.0 & .y & .6 & .9 & .6 & 1.9 & 2.2 & 8.2 & 15.4 & 33.9 & 21.5 & 7.3 & 2.1 & 1.0 & .6 & 806 \\
\hline .6 & $\therefore 4$ & 1.0 & .9 & . & 1.1 & 1.5 & 1.5 & .7 & 2.1 & 8.2 & 17.2 & 32.5 & 20.0 & 7.4 & 2.9 & 1.2 & $\hat{\imath}$ & 806 \\
\hline 1.2 & 1.2 & .6 & 1.2 & .6 & 1.9 & 1.2 & 1.1 & .9 & 2.7 & $8 \cdot 3$ & 12.3 & 28.3 & 23.9 & 8.2 & & 2.2 & . $t$ & 806 \\
\hline 3.5 & 2.4 & 1.1 & 1.6 & .5 & 1.2 & .9 & 1.1 & 1.7 & 3.7 & 7.4 & 8.3 & 17.6 & 27.2 & 11.3 & 8 & 1.5 & .7 & 806 \\
\hline 5.2 & 4.8 & 2.6 & 3.1 & 1.7 & 1.9 & 1.2 & 1.5 & 1.6 & 4.1 & 8.1 & 5.3 & 12.3 & 18.9 & 14.0 & 10. & .2 & 2.7 & $8 \cup 6$ \\
\hline 7.3 & 5.2 & 3.8 & 2.7 & 3.1 & 3.2 & 2.4 & 3.0 & 2.9 & 8.9 & 6.2 & 5.6 & 9.2 & ij.9 & 7.8 & 11 . & .2 & 4.8 & 806 \\
\hline 6.7 & 6.1 & 2.2 & 4.0 & 3.1 & 5.5 & 3.6 & 4.8 & 3.3 & 9.2 & 8.7 & t. 0 & 7.4 & 7.9 & 6.0. & 8.8 & .1 & $4 . t$ & $8<6$ \\
\hline 8.6 & 5.7 & 2.7 & 2.9 & 4.2 & 5.3 & 3.5 & 5.6 & 5.6 & 12.3 & 8.8 & 6.1 & 6.6 & 8.0 & 4.2 & 3.8 & .0 & 4.7 & 805 \\
\hline 6.7 & 7.3 & 3.5 & 3.2 & 2.1 & 5.1 & 3.7 & 5.2 & 6.6 & 11.5 & 9.2 & 6.2 & 7.2 & 0.2 & 4.1 & 5.1 & .1 & 4.3 & 806 \\
\hline 6.8 & 6.5 & 4.6 & 3.0 & 2.4 & 5.8 & 2.5 & 3.4 & 7.1 & 12.6 & 10.8 & 5.7 & 7.5 & 8.6 & 4.1 & 4. & .2 & 4.2 & BCS \\
\hline 6.9 & 5.5 & 4.1 & 3.1 & 2.7 & 4.0 & 3.2 & 4.7 & 5.5 & 16.2 & 13.2 & 5.7 & 7.3 & 10.0 & 4.3 & 6. & .2 & 3.1 & 806 \\
\hline 6.7 & 0.4 & 4.2 & 3.2 & 2.5 & 5.6 & 1.9 & 4.3 & 4.2 & 10.5 & 10.9 & 6.2 & 0.3 & 15.3 & 3.0 & 5 & .2 & 2.1 & 806 \\
\hline t. .0 & 6.6 & 5.1 & 4.0 & 3.2 & 4.1 & 2.5 & 2.5 & 4.6 & 7.6 & 9. & 6.1 & 9.6 & 17 & & 5. & .5 & $1 . t$ & 806 \\
\hline 4.7 & 5.8 & 6.3 & 4.2 & 3.5 & 4.2 & 3.6 & 3.1 & 3.6 & 6.0 & 8.7 & 4.2 & 10.3 & 23 & 2.6 & 4. & .0 & .7 & ๒し \\
\hline 3.6 & 4.6 & 4.0 & 5.3 & 3.8 & 5.0 & 4.3 & 2.5 & 3.5 & 4.6 & 6.3 & 5.5 & 13.8 & 25 & 2.9 & 3.1 & 1.0 & .2 & 806 \\
\hline 6.7 & 5.0 & 2.0 & 3.8 & 5.1 & 4.1 & 4.3 & 3.7 & 2.0 & 3. & 5.5 & 4.6 & 19.6 & 26 & 2.2 & 2. & .2 & .2 & 806 \\
\hline$i .2$ & $3 . \mathrm{C}$ & 3.3 & 2.6 & 2.9 & 6.0 & 3.8 & 3.1 & 2.1 & 3. & 5.7 & 6.2 & 26.3 & 24 & 2.0 & 2 & .4 & .4 & 806 \\
\hline 1.6 & 2.4 & 3.6 & 1.1 & 2.5 & 2.9 & 3.7 & 3.2 & $1 . y$ & 3.8 & 5.2 & 9.3 & 33.9 & $2 C .7$ & 2.4 & 2.2 & .1 & .1 & $8 \subset 6$ \\
\hline 1.5 & 2.1 & .9 & 1.0 & 1.6 & 2.0 & 2.6 & 1.5 & 1.4 & 2.0 & 6.1 & 13.6 & 37.8 & $2 G .6$ & 3.0 & 1.5 & .6 &.$<$ & 8ub \\
\hline 1.1 & .4 & .7 & .9 & .7 & 1.2 & 2.1 & 1.2 & 1.1 & 2.1 & 6.2 & 15.9 & 39.5 & 19.6 & 3.5 & 2.7 & . & .1 & 805 \\
\hline 3.7 & 3.6 & 2.5 & $<.3$ & 2.1 & 3.2 & 2.4 & 2.6 & 2.8 & 5.5 & 7.9 & 9.8 & 21.3 & 18.6 & 5.2 & 4.5 & .6 & $1 . t$ & 19341 \\
\hline
\end{tabular}

FEKLEAT FFEGUENCY LF RUURLY WIND CIRECTION AT 40 OCGET LEVEL-1955-148C FOR JUN

\begin{tabular}{|c|c|c|c|c|c|c|c|c|c|c|c|c|c|c|c|c|c|c|c|}
\hline rugk & NAE & NAt & ENE & $t$ & ESE & St & SSE & $s$ & sst & SW & KS h & $n$ & WhW & $\mathrm{AH}$ & NN h & $\mathrm{N}$ & CALM & VAR & TOTAL \\
\hline 1 & 1.2 & 1.4 & .3 & .4 & .3 & .9 & .6 & .3 & .4 & 1.4 & 5.5 & 14.2 & 40.8 & $2 t .4$ & 2.6 & 2.3 & .0 & .5 & 780 \\
\hline 2 & 1.4 & .8 & .1 & .8 & .1 & .9 & .0 & .9 & .4 & .9 & 6.3 & 16.4 & 40.8 & 22.8 & 4.9 & 2.3 & .3 & .0 & 700 \\
\hline 3 & 1.3 & .9 & .0 & .3 & .4 & .3 & .9 & .5 & .8 & 2.3 & 4.9 & 18.3 & 39.1 & 21.3 & 6.5 & 1.9 & .3 & .1 & 760 \\
\hline 4 & 1.2 & .5 & .6 & .0 & .3 & .5 & .6 & .5 & .8 & 2. & 6.5 & 19.5 & 36.5 & 22.6 & 4.4 & 2.6 & .3 & .4 & 780 \\
\hline 5 & 1.4 & .4 & .3 & .1 & .3 & .8 & .6 & .4 & 1.2 & 2.2 & 9.1 & 20.3 & 32.2 & 21.4 & 4.9 & 3.7 &.$t$ & .3 & 700 \\
\hline 0 & 1.2 & .1 & .4 & .6 & .6 & 1.2 & .3 & .5 & 1.8 & 2.8 & 7.4 & 16.9 & 34.6 & 21.0 & 5.4 & 3.1 & 1.4 & .6 & 780 \\
\hline 7 & & .9 & .9 & 1.0 & .5 & 1.2 & .8 & 1.7 & 1.5 & 2.7 & B. 1 & 10.8 & 26.9 & $\angle 8.3$ & 7.4 & 2.9 & .9 & 1.0 & 80 \\
\hline$\theta$ & 3 & 2.1 & .5 & 1.5 & 1.3 & 1.2 & 1.3 & 2.7 & 1.8 & 3. & 6.8 & 7.4 & 16.2 & 26.3 & 12.3 & 7.6 & .6 & 1.5 & 760 \\
\hline 9 & 8.7 & 3.7 & 2.6 & 1.3 & 2.2 & 2.2 & 2.1 & 1.5 & 3.0 & 5 & 6 & 5.5 & 10 & 19 & 10.8 & 10.4 & .9 & 2.8 & 779 \\
\hline 10 & 7.1 & 3.0 & 3.0 & 3.7 & 3.3 & 3.7 & 2.2 & 4.0 & 4.7 & 6.2 & 8. & 5.8 & & 12 & 8.9 & 9.4 & .1 & 4.6 & 779 \\
\hline $1 / 1$ & 5.5 & 6.9 & 2.2 & 4.0 & 3.6 & 6.3 & 5.0 & 3.6 & 6.2 & 10.0 & 7.8 & 5.1 & 7.6 & 9 & 5.6 & 7. & .0 & 4.2 & 779 \\
\hline 12 & 5.3 & 6.9 & 3.7 & 3.3 & 3.5 & 5.5 & 4.9 & 5.5 & 8.0 & 10.4 & 9.4 & 5.6 & 7.1 & 6.9 & 3. & 5.6 & .0 & 4.4 & 779 \\
\hline 13 & 5.4 & 5.1 & 4.1 & 2.9 & 4.1 & 4.5 & 2.8 & 6.0 & 7.2 & 14.0 & 9.5 & 6.4 & 5.3 & 6. & 5 & 5.3 & .1 & 5.0 & 780 \\
\hline 14 & & 4.7 & 3.6 & 4.1 & 2.8 & 4.1 & 3.1 & 4.5 & 8.3 & 14.7 & 11.0 & 7.1 & 5.1 & 8 & & 5. & .0 & 3.6 & 780 \\
\hline 15 & 5.4 & 5. & 3. & 3.2 & 2. & 4.0 & 3.1 & 4.1 & 7.2 & 12.3 & 10 & 6.7 & 7.4 & 11 & & 4.2 & .1 & 5.0 & 780 \\
\hline 16 & & 6.3 & 4. & 3.2 & 3. & 2.7 & 2.8 & 3.3 & 6. & 9.2 & 12 & 7.1 & $\theta$ & & & 4.2 & .0 & $3 . \bar{c}$ & 780 \\
\hline 17 & 4.7 & 6.3 & 4.1 & 4.5 & 3.1 & 3.5 & 2.7 & 4.0 & 2. & 7. & 9. & 7.6 & 6.7 & 21 & 4 & 4.7 & .1 & 1.8 & 760 \\
\hline 18 & 4.4 & 4.9 & 4.2 & 5.9 & 4.5 & 4.2 & 2.4 & 2.7 & 2.2 & 5.1 & 9.2 & 5.3 & 9.0 & 27 & 3 & 4. & .1 & .8 & 78 \\
\hline 19 & 3.6 & 5.1 & 4.4 & 5.4 & 4.5 & 4.4 & 2.8 & 1.5 & 2.6 & & & 4.0 & 12.4 & & & 3. & .0 & .3 & \\
\hline 20 & 3.3 & 4.5 & 3.2 & 3.8 & 6.0 & 4.2 & 3 & 1.5 & 1.8 & & 6 & 3.8 & 18 & & & 2. & .5 & .3 & $7 t$ \\
\hline 21 & 2.4 & 3.1 & 2.3 & 3.8 & 3.5 & 3.3 & 3.8 & 1.2 & 1.7 & 2. & 4. & 5.8 & 26.4 & & & 1. & .3 & .0 & 78 \\
\hline 22 & 2.6 & 2.6 & 1.9 & 2.9 & 1.5 & 2.6 & 2.8 & .9 & 1.7 & 2.6 & 4.2 & 7.2 & 34.4 & 29. & 1. & 1.2 & .3 & .0 & \\
\hline 23 & 1.4 & 1.8 & 1.3 & 1.4 & 1.2 & 1.5 & 1.7 & .9 & .8 & 1.7 & 5.1 & 9.1 & 38.3 & 29.4 & 2 & 1.3 & .8 & .3 & 78 \\
\hline 24 & 1.9 & .6 & .9 & .6 & .5 & 1.0 & 1.0 & .5 & .6 & 2.2 & 3.8 & 11.5 & 39.6 & 29.6 & 2.7 & 1.8 & .5 & .4 & 78 \\
\hline ia & 3.5 & 3.4 & 2.2 & 2.5 & 2.2 & 2.7 & 2.2 & 2.2 & 3.1 & 5.3 & 7.5 & 9.5 & 21.3 & 21.4 & 4.9 & 4.1 & .4 & 1.7 & 1871 \\
\hline
\end{tabular}




\section{TABLE 46. Continued}

PERCEAT FREGUENCY OF FUURLY WIND CIRECIICA AT 400FGOT LEVEL-1955-1580 FOR JUL

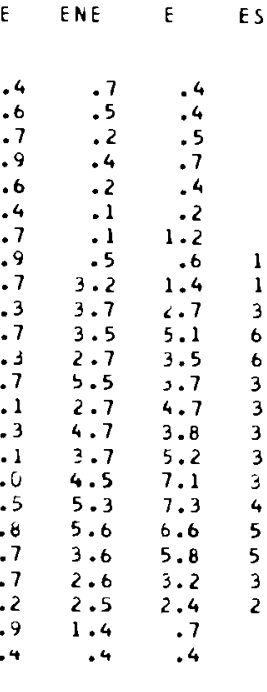

SE SE SSE S

SSh SH

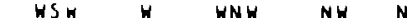

n CALM VAF TUTAL

PEKLEAT FREQUEACY OF FOURLY WIAD CIRECTIOA AT 400 FGOT LEVEL-1955-1980 FGR AUG

HLUR

NNE NE
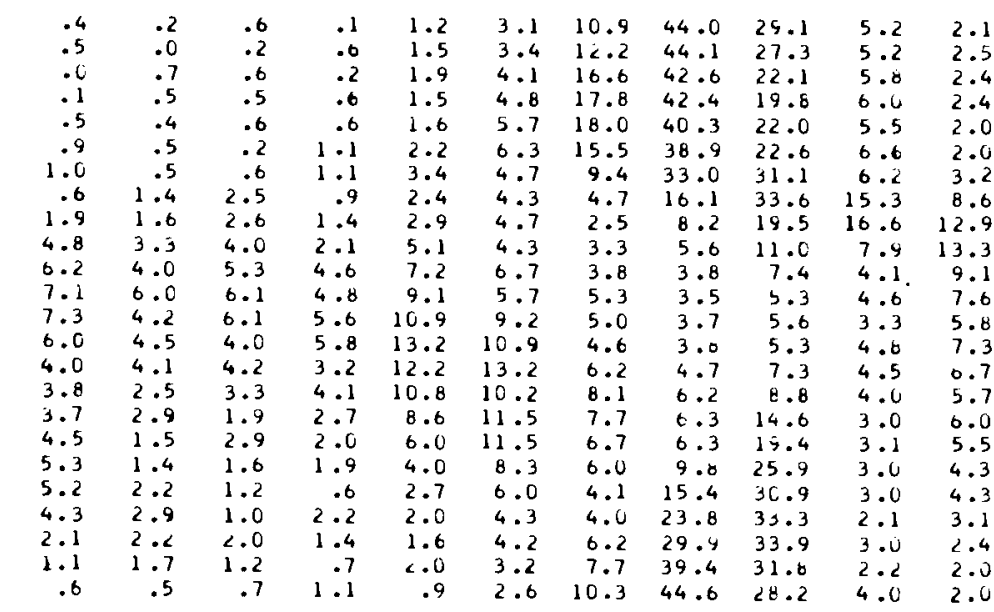

\begin{tabular}{|c|c|c|}
\hline .2 & .1 & ecs \\
\hline. $\bar{c}$ & . c & 805 \\
\hline .1 & .0 & 805 \\
\hline .0 & .6 & ous \\
\hline .7 & .0 & 804 \\
\hline .6 & .6 & 804 \\
\hline 1.5 & .4 & 805 \\
\hline .2 & 3.5 & $\begin{array}{l}806 \\
806\end{array}$ \\
\hline .1 & 4.6 & 806 \\
\hline .1 & 6.0 & eut \\
\hline .0 & 6.2 & 806 \\
\hline .0 & 6.1 & 860 \\
\hline .0 & 4.2 & $80 t$ \\
\hline.$u$ & 4.5 & 806 \\
\hline .1 & 4.6 & 806 \\
\hline 0 & 2.6 & $8 \mathrm{C}_{6}$ \\
\hline .u & 1.4 & eve \\
\hline .1 & .0 & 806 \\
\hline .2 & .0 & 806 \\
\hline .4 & .0 & $\varepsilon 00$ \\
\hline .7 & .1 & 866 \\
\hline .4 & .1 & 805 \\
\hline .5 & .1 & $0<5$ \\
\hline .4 & 1.9 & 9333 \\
\hline
\end{tabular}

1
2
3
4
5
6
7
8
4
10
11
12
13
14
15
16
17
16
19
20
21
22
23
24
19
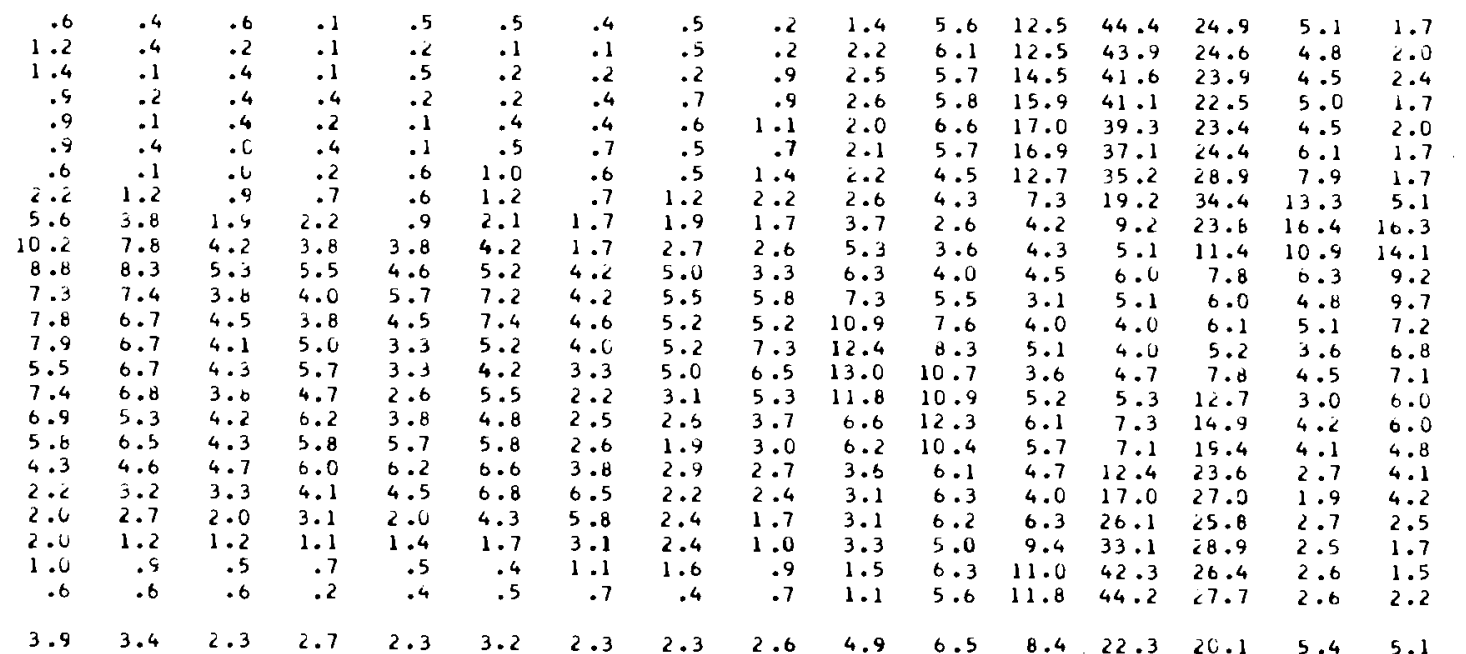

CALM VAK TUTAL

TITAL

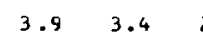

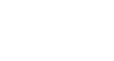


TABLE 46. Continued

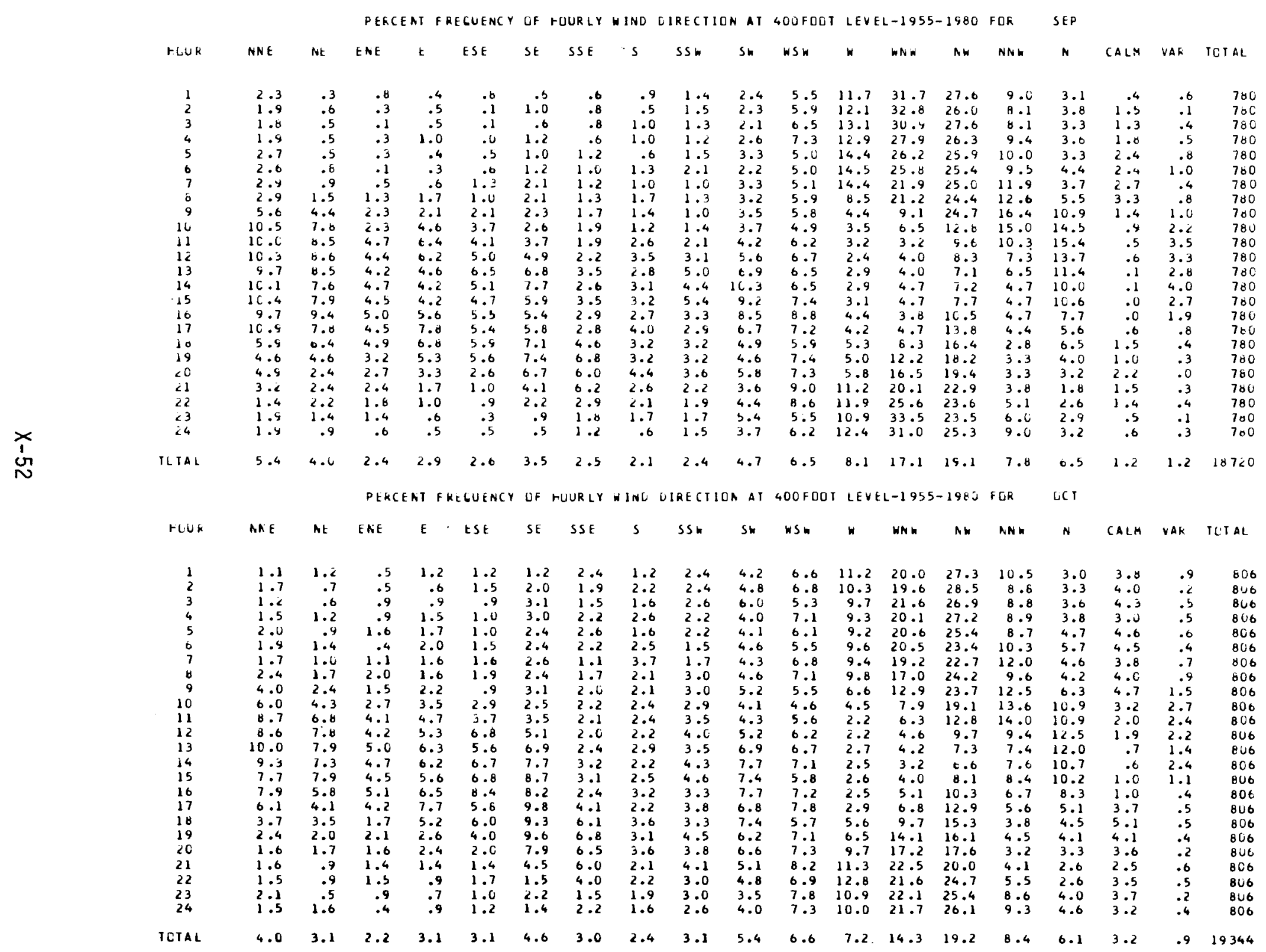




\section{TABLE 46. Continued}

PERCEAT FREGUENCY LF FUURLY INO DIRECTIUN AT 400 FOOT LEVEL-1955-19BO FOK NEV

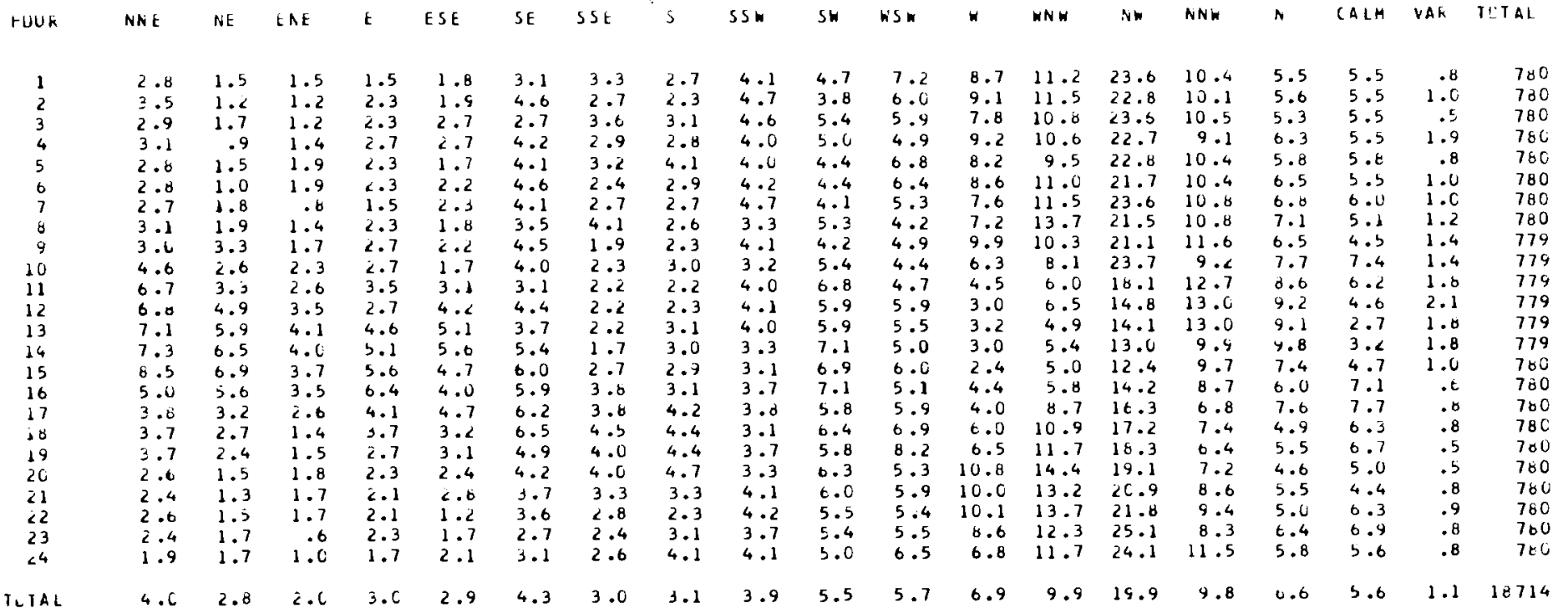

PEKGEAT FREGUENCY OF HOURLY WIND LIRECTIOA AT 400 FOLT LEVEL-1955-1980 FOR CEL

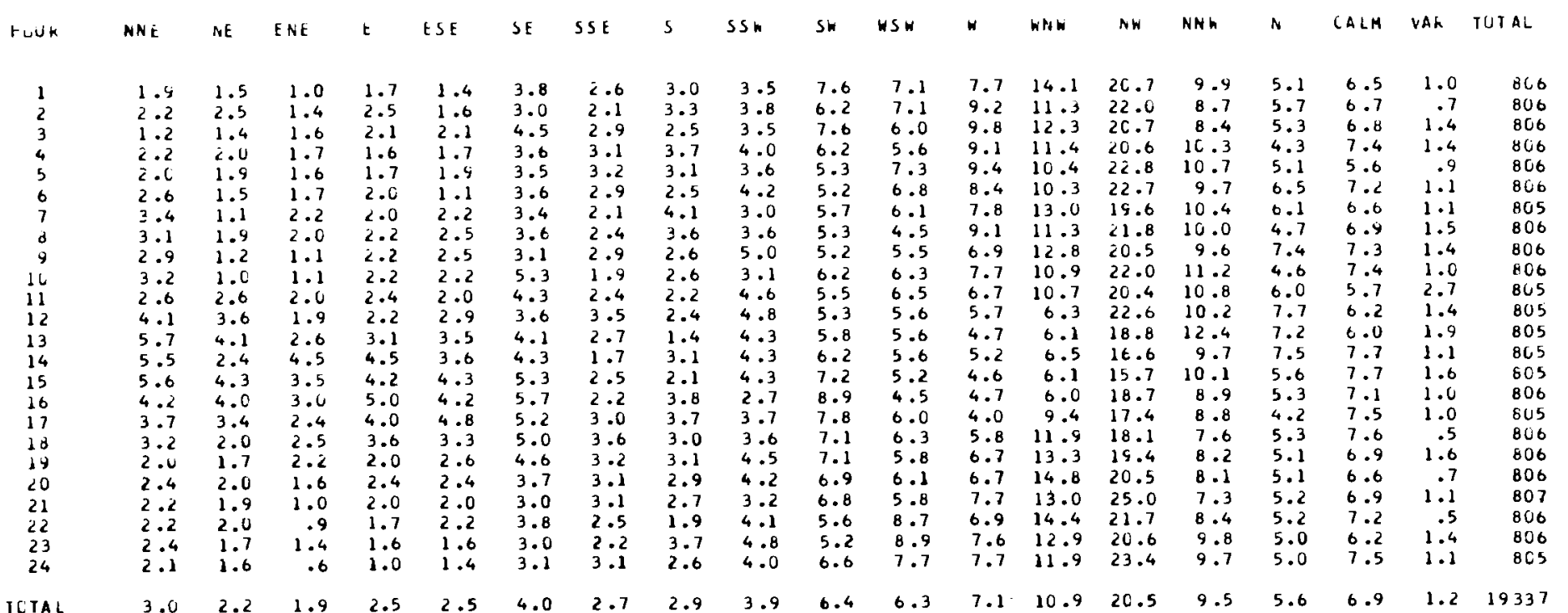


TABLE 46. Continued

PEKCEAT FREGUENCY OF FOURLY WINO OIRECTION AT 4 OOFOOT LEVEL-1955-198U FOR ANNLAL

\begin{tabular}{|c|c|c|c|c|c|c|c|c|c|c|c|c|c|c|c|c|c|c|c|}
\hline rCUK & NA E & $\mathrm{NE}$ & ENE & $\mathrm{E}$ & ESE & SE & SSE & 5 & 55 & $s k$ & hish & $w$ & Whan & $\mathrm{AW}$ & NN " & $\mathrm{N}$ & CALM & VAR & TUTAL \\
\hline$\frac{1}{2}$ & 1.8 & 1.1 & $\cdot y$ & .9 & 1.6 & 1.6 & 1.7 & 1.5 & 1.9 & 4.2 & 6.4 & 12.0 & 26.7 & 24.4 & 7.5 & 3.3 & 2.6 & .5 & 949 \\
\hline 2 & 1.9 & 1.0 & .6 & 1.0 & .9 & 1.9 & 1.5 & 1.5 & 2.4 & 3.9 & 6.5 & 12.3 & 26.2 & 24.0 & 7.7 & 3.6 & & .4 & $94 \times 6$ \\
\hline & $\begin{array}{l}1.6 \\
1.7\end{array}$ & $\begin{array}{l}1.1 \\
1.2\end{array}$ & .7 & $\begin{array}{l}1.1 \\
1.1\end{array}$ & $\begin{array}{l}1.1 \\
1.0\end{array}$ & $\begin{array}{l}1.8 \\
1.8\end{array}$ & $\begin{array}{l}1.6 \\
1.7\end{array}$ & $\begin{array}{l}1.7 \\
1.9\end{array}$ & $\frac{2.2}{2.2}$ & $\begin{array}{r}4.6 \\
4.1\end{array}$ & $\begin{array}{l}6.1 \\
6.4\end{array}$ & $\begin{array}{l}13.2 \\
13.6\end{array}$ & $\begin{array}{l}25.4 \\
25.4\end{array}$ & $\begin{array}{r}3.2 \\
32.6\end{array}$ & 8.0 & $\begin{array}{l}3.5 \\
3.8\end{array}$ & 2.8 & $\begin{array}{r}.5 \\
.7\end{array}$ & 9496 \\
\hline 5 & 1.6 & 1.0 & .9 & 1.1 & 1.0 & $\begin{array}{l}1.8 \\
1.8\end{array}$ & 1.8 & 1.7 & 2.4 & 4.0 & $\begin{array}{l}0.4 \\
6.9\end{array}$ & 13.4 & $\begin{array}{r}24.8 \\
23.6\end{array}$ & 22.9 & 8.2 & 3.8 & 3 & . & $\begin{array}{l}9446 \\
9442\end{array}$ \\
\hline 6 & & .9 & .4 & 1.2 & 1.1 & 2.1 & 1.6 & 1.7 & 2.3 & 3.9 & 6.8 & 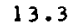 & 22.8 & 22.7 & & 4.4 & 3.5 & 7 & 9493 \\
\hline & 2.1 & 1.1 & .9 & 1.3 & 1.2 & 2.1 & 1.6 & 2.2 & 2.4 & 4.2 & 6.6 & 10.7 & 21.5 & 24.0 & 9.4 & 4.4 & 3.4 & .6 & 9443 \\
\hline 8 & 3.0 & 1.8 & 1.1 & 1.6 & 1.2 & 2.1 & 1.8 & 2.3 & 2.7 & 4.5 & 6.2 & 8.3 & 16.3 & 25.4 & 11.2 & 0.3 & 3.2 & 1.1 & 9495 \\
\hline 1 & 6.0 & 4.06 & $=0$ & 30 & 1.00 & 3.0 & 2.3 & 2.1 & 4 & 300 & 0.0 & 5.5 & 11.4 & 1.0 & 10.8 & 0.0 & 200 & 13 & 9493 \\
\hline & $t .9$ & 5.0 & 3.2 & 4.1 & 3.4 & 4.4 & 2.9 & 3.3 & 4.2 & 7.1 & 0.6 & & & 13 & & & & 3 & \\
\hline & 7.4 & & 3.4 & 3.6 & 4.2 & 4.8 & 3.4 & 3.9 & 5.1 & 8.0 & 6.7 & 4.3 & .0 & 11.7 & & . 8 & & 3.3 & 94 \\
\hline & 7.2 & 0.2 & 3.9 & 3.9 & 4.1 & 5.2 & 2.9 & 3.9 & 5.5 & 9.2 & 7.4 & 4.2 & 5.5 & 10.7 & 7.7 & 8.2 & 1.3 & 3.0 & 9496 \\
\hline & 7.3 & 5 & 3.8 & 4.3 & 3.9 & 5.2 & 2.9 & 3.6 & 5 & 14.2 & 8. & 4.5 & & 9.7 & & 8.3 & 1.5 & 2.8 & 9493 \\
\hline & 1.1 & 6 & 4.0 & & 3.8 & 5.2 & 3.1 & 3.6 & 5 & 9.9 & 8 & & 8 & 10.7 & & & & 2.5 & 9495 \\
\hline & $\because: 0$ & 5,4 & 3.9 & 0 & 3.4 & 5.5 & 8.0 & 3.3 & 4. & 79 & 8.4 & 5.0 & 0.4 & 15.8 & 5 & 30 & 8. & 12 & 9496 \\
\hline & & & 3.6 & & & & & & & & & 5.4 & & 18.7 & & & & & \\
\hline & 3.5 & 3.5 & 3.3 & 4.0 & 4.0 & 5.8 & 4.3 & 3.0 & 3.6 & 6.1 & 7.4 & 5.6 & 12.2 & 26.9 & 4.8 & 4.7 & 2.8 & .4 & 9496 \\
\hline & & 2 & & & & 5.2 & 4. & 3. & 3. & 5.8 & 6 & & & 22 & & & & .3 & 9 \\
\hline & 2.5 & 2 & 2.0 & 2.5 & 2.2 & 4.1 & 4. & 2. & 2. & 5.1 & 7 & 8 & & 23. & & & & .4 & 9497 \\
\hline 2 & 40 & 11 & 1.6 & 1.8 & 19 & 2.1 & 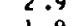 & $\because$ & 2. & 2.1 & 6.8 & 9.6 & 23.6 & 23.9 & 3.6 & 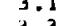 & & .4 & 9496 \\
\hline 24 & 1.7 & 1.3 & .7 & .9 & 1.1 & 1.7 & 1.8 & 1.8 & 2.1 & 4.3 & 0.5 & 11.2 & 26.9 & 24.0 & 8.0 & 3.6 & 2.7 & .4 & 9443 \\
\hline & & 3.1 & .2 & 2.6 & 2.4 & & & & & & 7.0 & & & 19.6 & & 5.5 & & & 7859 \\
\hline
\end{tabular}


TABLE 47. Monthly and Annual Percent Frequency of Hourly Wind Speed Class and Average Speed, 50-Foot Level, 1955 Through 1980

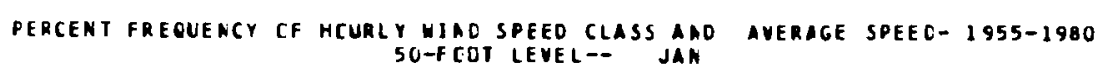

\begin{tabular}{|c|c|c|c|c|c|c|c|c|c|c|c|c|c|}
\hline & rUUR & c & $1-3$ & $4-7$ & $8-12$ & $13-1 \theta$ & $\begin{array}{c}\text { SPE } \\
19-24\end{array}$ & $\begin{array}{c}c \text { CLASS } \\
25-31\end{array}$ & $32-38$ & $39-46$ & 6T.46 & $\begin{array}{l}\text { TOTAL } \\
\text { SPEED }\end{array}$ & $\begin{array}{l}\text { AVE } \\
\text { SPEEE }\end{array}$ \\
\hline & 1 & 4.59 & 32.88 & 30.65 & 21.22 & 7.44 & 2.23 & .62 & .37 & .00 & .00 & 5046 & 0.3 \\
\hline & 2 & 5.46 & 29.78 & 34.86 & 19.60 & 7.32 & 1.49 & .02 & .37 & .25 & .00 & $\begin{array}{l}3046 \\
4958\end{array}$ & $\begin{array}{l}6.2 \\
0 . \bar{z}\end{array}$ \\
\hline & 3 & 6.20 & 31.27 & 33.50 & 19.73 & 6.32 & $\begin{array}{l}1.44 \\
1.36\end{array}$ & .99 & .02 & .00 & .00 & $\begin{array}{l}4958 \\
4857\end{array}$ & $\begin{array}{l}6.5 \\
6.0\end{array}$ \\
\hline & 4 & 6.20 & 32.26 & 32.80 & 19.73 & 5.58 & 1.86 & 1.12 & .37 & .00 & .00 & 4783 & 5.9 \\
\hline & 5 & 5.46 & 31.76 & 34.74 & 19.11 & 5.71 & 1.74 & 1.36 & .12 & .00 & .00 & 4768 & 5.9 \\
\hline & 6 & 6.58 & 30.89 & 34.49 & 17.99 & 6.33 & 2.36 & $\begin{array}{r}.99 \\
50\end{array}$ & .37 & .00 & .00 & 4831 & 6.0 \\
\hline & 7 & $\begin{array}{l}6.33 \\
5.96\end{array}$ & 34.99 & 29.28 & 19.85 & 5.96 & 2.61 & .50 & .50 & .00 & .00 & 4740 & 5.9 \\
\hline & $\begin{array}{l}8 \\
9\end{array}$ & $\begin{array}{l}5.96 \\
6.33\end{array}$ & $\begin{array}{l}32.51 \\
33.50\end{array}$ & $\begin{array}{l}34.622 \\
33.662\end{array}$ & $\begin{array}{l}17.37 \\
16.87\end{array}$ & $\begin{array}{l}6.33 \\
6.45\end{array}$ & 2.61 & .37 & .12 & .00 & .12 & 4689 & 5.8 \\
\hline & 10 & 0.70 & 35.73 & 29.16 & 17.87 & $\begin{array}{l}0.43 \\
6.20\end{array}$ & 2.98 & $\begin{array}{l}.74 \\
.99\end{array}$ & .25 & .00 & .12 & 4657 & 5.8 \\
\hline & 11 & 4.71 & 35.11 & 28.54 & 18.24 & 8.56 & 3.23 & $\begin{array}{r}.999 \\
1.24\end{array}$ & $\begin{array}{l}.25 \\
.25\end{array}$ & $\begin{array}{l}.00 \\
.00\end{array}$ & $\begin{array}{r}.12 \\
.12\end{array}$ & $\begin{array}{l}4737 \\
5123\end{array}$ & $\begin{array}{l}5.9 \\
6.4\end{array}$ \\
\hline & 12 & 3.47 & 35.61 & 28.78 & 17.49 & 8.44 & 3.47 & 2.11 & .50 & .12 & .00 & 5443 & 6.8 \\
\hline & 13 & 2.48 & 36.85 & 28.29 & 16.75 & 8.06 & 4.22 & 2.36 & .74 & .25 & .00 & 5641 & 7.0 \\
\hline & 14 & 3.10 & 35.61 & 27.92 & 17.74 & 8.93 & 4.09 & 1.99 & .25 & .37 & .00 & 5568 & 6.9 \\
\hline & is & 2.73 & 36.35 & 27.92 & 17.87 & 7.69 & 5.09 & 1.86 & .25 & .25 & .00 & 5497 & 6.8 \\
\hline & 16 & 4.71 & 35.24 & 29.03 & 16.75 & 8.56 & 3.85 & 1.49 & .37 & .00 & .00 & 5157 & 6.4 \\
\hline & +7 & 6.95 & 30.02 & 31.27 & 19.98 & 7.20 & 3.10 & 1.24 & .25 & .00 & .00 & 5064 & 0.4 \\
\hline & ie & 7.07 & 25.81 & 33.50 & 21.84 & 8.31 & 2.11 & .99 & .37 & .00 & .00 & 5205 & 6.5 \\
\hline & 19 & 5.83 & 24.94 & 31.89 & 24.57 & 8.06 & 3.47 & .99 & .25 & .00 & .00 & 5465 & 6.8 \\
\hline & $a$ & 5.33 & 25.31 & 33.62 & 22.46 & 8.56 & 2.61 & 1.74 & .12 & .25 & .00 & $\begin{array}{l}3403 \\
5572\end{array}$ & $\begin{array}{l}6.8 \\
6.5\end{array}$ \\
\hline & 21 & 5.58 & 26.92 & 32.26 & 22.33 & 8.44 & 2.98 & 1.24 & .12 & .12 & .00 & $\begin{array}{l}5312 \\
5417\end{array}$ & $\begin{array}{l}0.5 \\
6.7\end{array}$ \\
\hline & 22 & 5.46 & 29.90 & 30.77 & 22.46 & 7.07 & 3.23 & .74 & .37 & .00 & .00 & 5238 & 6.5 \\
\hline & 23 & t.cB & 30.40 & $3 C .27$ & 22.83 & 7.07 & 2.36 & .50 & .50 & .00 & .00 & 5052 & 6.3 \\
\hline & $<4$ & 5.63 & 30.89 & 32.38 & 20.22 & 7.57 & 1.99 & .74 & .37 & .00 & .00 & 4989 & $6 . \bar{c}$ \\
\hline & MTALL & 5.38 & 31.85 & 31.43 & 19.62 & 7.34 & 2.80 & 1.16 & .34 & .07 & .02 & 122497 & 6.3 \\
\hline
\end{tabular}

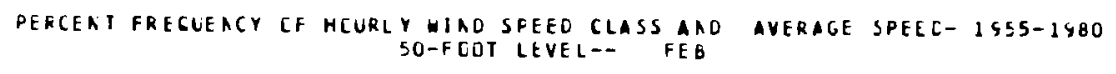

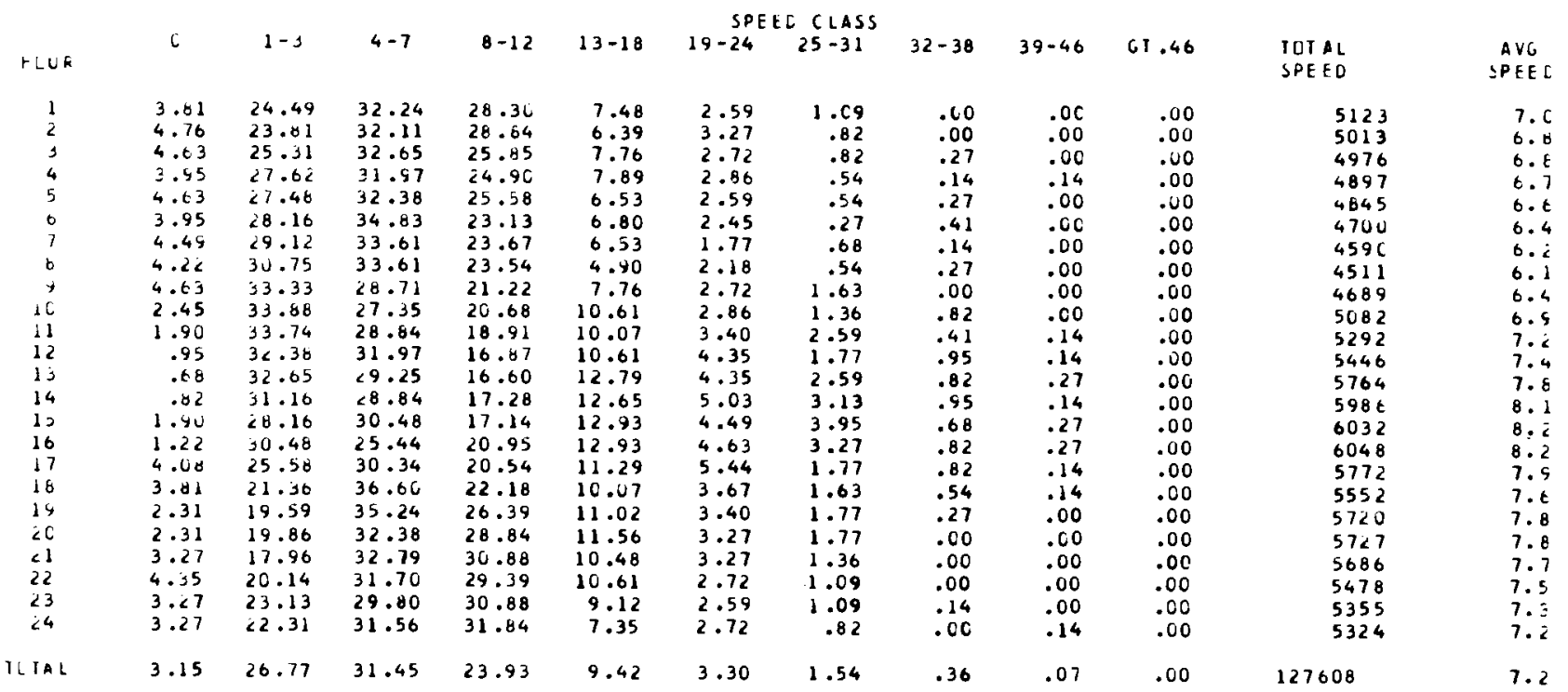


TABLE 47. Continued

PERCENT FREQUENCY CF HOURLY WIAD SPEED CLASS AMO AVERAGE SPEED-1955-1980

SPEED CLASS

\begin{tabular}{|c|c|c|c|c|c|c|c|c|c|c|c|c|}
\hline$r: L k$ & $c$ & $1-3$ & $4-7$ & $8-12$ & $13-18$ & $\begin{array}{c}\text { SPE } \\
19-24\end{array}$ & $\begin{array}{l}\text { CLASS } \\
25-31\end{array}$ & $32-38$ & $39-46$ & GT.46 & $\begin{array}{l}\text { TOTAL } \\
\text { SPEED }\end{array}$ & $\begin{array}{l}\text { AVG } \\
\text { SPEE C }\end{array}$ \\
\hline 1 & .62 & 14.52 & 33.13 & 37.34 & 10.79 & 2.61 & .50 & .37 & .00 & .12 & 6564 & 8.1 \\
\hline 2 & 1.49 & 16.38 & 34.00 & 33.13 & 11.54 & 2.48 & .50 & .50 & $.0 \mathrm{C}$ & .00 & 6424 & \\
\hline 3 & .07 & 17.87 & 34.24 & 33.25 & 9.93 & 2.48 & 1.24 & .12 & .00 & .0 & 6308 & 7.8 \\
\hline 4 & 1.24 & 20.72 & 33.13 & 32.63 & 9.31 & 2.11 & .74 & .12 & .00 & .00 & 5968 & 7.4 \\
\hline 5 & 1.06 & 21.96 & 32.26 & 31.14 & 9.68 & 2.61 & .25 & .25 & $.0 \mathrm{C}$ & .00 & 5861 & 7.3 \\
\hline t & $=48$ & 21.46 & 34.86 & 29.53 & 8.31 & 2.73 & .50 & .12 & .00 & .00 & 5751 & 7.1 \\
\hline 7 & 2.23 & 24.44 & 34.86 & 27.05 & 8.68 & 2.23 & .37 & .12 & .00 & .00 & 5555 & 6,3 \\
\hline 8 & 1.74 & 29.53 & 33.37 & 20.35 & 11.66 & 2.85 & .50 & .00 & .00 & .00 & 5491 & $\begin{array}{l}6.3 \\
6.8\end{array}$ \\
\hline 5 & 1.14 & 26.43 & 31.27 & 21.22 & 13.65 & 4.71 & 1.12 & .12 & .00 & .00 & 6163 & $\begin{array}{l}6.8 \\
7.6\end{array}$ \\
\hline 10 & 1.49 & 29.43 & 28.16 & 18.36 & 15.14 & 6.08 & 1.99 & .25 & .00 & .00 & 6564 & $\begin{array}{l}7 . t \\
8.1\end{array}$ \\
\hline 11 & $\begin{array}{l}.81 \\
.62\end{array}$ & 28.41 & $\begin{array}{l}80.160 \\
29.65\end{array}$ & 17.25 & 14.39 & 5.21 & 3.60 & .74 & .12 & .00 & 6839 & $\begin{array}{l}8.1 \\
8.5\end{array}$ \\
\hline 12 & .02 & 24.57 & 33.37 & 16.75 & 13.52 & 6.70 & 3.85 & .99 & .00 & .00 & 7148 & 8.9 \\
\hline 13 &.$C C$ & 19.60 & $3 t .1 \mathrm{C}$ & 17.62 & 13.65 & 8.31 & 3.35 & 1.12 & .25 & .00 & & 9.3 \\
\hline 14 & .12 & 17.12 & 36.48 & 17.37 & 14.89 & 8.56 & 4.34 & .87 & .12 & .12 & 7860 & 9.8 \\
\hline 15 & .60 & 15.01 & 34.00 & 20.97 & 14.14 & 10.05 & 4.84 & .87 & .12 & .00 & 8177 & 10.1 \\
\hline 10 & .25 & 16.75 & 30.89 & 20.72 & 13.90 & 11.66 & 5.21 & .62 & .00 & .00 & 8254 & $10 . \bar{z}$ \\
\hline 57 & .50 & 17.00 & 30.15 & 18.61 & 17.87 & 11.29 & 4.22 & .37 & .00 & .00 & 8241 & 10.2 \\
\hline 10 & 1.74 & 15.01 & 32.75 & 21.09 & 16.75 & 9.55 & 2.73 & .1 & .25 & .00 & 7763 & $9 . t$ \\
\hline ly & 1.74 & 11.91 & 30.40 & 28.16 & 19.11 & 6.82 & 1.74 & .10 & .12 & .0 & 7631 & 9.5 \\
\hline$<i$ & .62 & 8.56 & 31.39 & 32.51 & 19.60 & 6.08 & .99 & .2 &.$O C$ & .0 & 7741 & 9.6 \\
\hline ;1 & .18 & 9.68 & 28.91 & 38.34 & 16.38 & 5.83 & .50 & .25 & .00 & .0 & 7624 & 9.5 \\
\hline$<2$ & .87 & 10.43 & 33.13 & 32.51 & 17.99 & 4.47 & .99 & .00 & .00 & .0 & 7320 & 9.1 \\
\hline$\angle 3$ & .74 & 13.28 & 31.51 & 35.11 & 14.89 & 3.72 & .02 & .12 & $.0 \mathrm{C}$ & .0 & 6927 & $8 . t$ \\
\hline$<4$ & .74 & 11.41 & 35.61 & 36.10 & 12.03 & 3.23 & .62 & .12 & .12 & .00 & 6744 & 8.4 \\
\hline & I I & 18.37 & 32.65 & 26.55 & 13.66 & 5.52 & 1.89 & .35 & .05 & .01 & 166410 & 8.1 \\
\hline
\end{tabular}

PERCENT FRIOUEACY CF HOURLY HIMD SPEED CLASS AMO AVERAGE SPEED-1955-1980

\begin{tabular}{|c|c|c|c|c|c|c|c|c|c|c|c|c|}
\hline riuk & c & $1-3$ & $4-7$ & $8-12$ & $13-18$ & $19-24$ & $\begin{array}{c}\text { CLAss } \\
25-31\end{array}$ & $32-38$ & $39-46$ & GT.46 & $\begin{array}{l}\text { TUTAL } \\
\text { SPEED }\end{array}$ & $\begin{array}{l}\text { AVG } \\
\text { SPEEL }\end{array}$ \\
\hline 1 & .51 & 9.23 & 30.13 & 40.90 & 15.77 & 2.95 & .51 & .00 & .00 & .00 & 6946 & 8.5 \\
\hline 2 & .77 & 9.23 & 33.08 & 40.51 & 13.59 & 2.31 & .38 & .13 & .00 & .00 & 6707 & 8.6 \\
\hline 3 & 1.15 & 11.63 & 35.51 & 37.18 & 13.08 & 1.67 & .26 & .13 & .00 & .00 & 6405 & $8 \cdot \dot{z}$ \\
\hline 4 & 1.79 & 15.13 & 34.23 & 37.69 & 8.85 & 1.92 & .38 & .60 & .00 & .00 & 5968 & 7.7 \\
\hline 5 & 1.28 & 21.10 & 32.48 & 33.12 & 9.50 & 2.31 & .13 & .00 & .00 & .00 & 5685 & 7.2 \\
\hline e & 2.56 & 20.13 & 37.82 & 26.85 & 7.95 & 2.05 & .64 &. $\mathrm{CO}$ & .00 & .00 & 5479 & $7 . c$ \\
\hline$i$ & 2.36 & 26.59 & 33.72 & $\angle 2.82$ & 8.97 & 2.82 & .51 & .00 & .40 & .00 & 5212 & 0.7 \\
\hline o & 1.03 & 27.44 & 27.31 & 24.87 & 13.65 & 3.97 & 1.54 & .00 & .00 & .00 & 6034 & 7.7 \\
\hline 9 & .64 & 24.87 & 28.85 & 21.54 & 16.15 & 5.90 & 2.05 & .00 & .00 & .00 & 6532 & 8.4 \\
\hline IC & .13 & 26.54 & 31.15 & 18.46 & 16.15 & 6.03 & 1.54 & .00 & .00 & .00 & 6401 & 8.2 \\
\hline 11 & .00 & 21.92 & 37.56 & 16.67 & 16.15 & 5.26 & 2.18 & .26 & .00 & .00 & 6561 & 8.4 \\
\hline $\begin{array}{l}11 \\
12\end{array}$ & .13 & 17.31 & 41.41 & 17.56 & 14.49 & 6.54 & 2.18 & .38 & .00 & .00 & 6800 & 8.7 \\
\hline 13 & $.0 \mathrm{C}$ & 15.00 & 38.97 & 19.74 & 14.87 & 8.59 & 2.31 & .51 & .00 & .00 & $714 \mathrm{C}$ & 9.2 \\
\hline 14 & .13 & 12.62 & 38.21 & 21.54 & 15.51 & 8.59 & 2.82 & .38 & .00 & .00 & 7462 & 9.6 \\
\hline 15 & .00 & 11.79 & 37.44 & 21.03 & 14.74 & 11.15 & 2.95 & .77 & .13 & .00 & 7876 & 10.1 \\
\hline 16 & .13 & 11.41 & 37.56 & 18.72 & 15.51 & 11.28 & 5.00 & .38 & .00 & .00 & 8077 & 10.4 \\
\hline 17 & .60 & 12.95 & 30.90 & 20.00 & 17.05 & 12.69 & & .38 & .13 & .00 & 8609 & $11 . \mathrm{C}$ \\
\hline 16 & .38 & 12.44 & 26.92 & 21.79 & 19.87 & 13.08 & 5.38 & .13 & .00 & .00 & 8755 & 11.2 \\
\hline 19 & .77 & 10.77 & 24.87 & 27.69 & 20.77 & 11.67 & 3.21 & .26 & .00 & .00 & 8471 & 10.9 \\
\hline 20 & .90 & 8.46 & 24.23 & 29.87 & 22.95 & 11.03 & $2.3 i$ & .26 & .00 & .00 & 8564 & $11 . \mathrm{C}$ \\
\hline al & .26 & 6.15 & 23.59 & 33.97 & 23.33 & 10.51 & 1.92 & .26 & .00 & .00 & 8675 & 11.1 \\
\hline 22 & .38 & 5.90 & 25.13 & 35.90 & 22.44 & 8.97 & 1.28 & .00 & .00 & .00 & 8298 & $10 . t$ \\
\hline 23 & .26 & 6.79 & 25.77 & 38.33 & 22.44 & 5.38 & 1.03 & .00 & .00 & .00 & 7846 & 10.1 \\
\hline 24 & .90 & 8.33 & 29.74 & 37.56 & 18.59 & 3.97 & .90 & .00 & .00 & .00 & 7309 & 9.4 \\
\hline ILIAL & .69 & 14.81 & 31.94 & 27.76 & 15.94 & 6.69 & 1.97 & .18 & .01 & .00 & 171812 & 9.2 \\
\hline
\end{tabular}


TABLE 47. Continued

PERCENT FReQUENCY CF HGURLY HIAD SPEEO CLASS AMO AVERAGE SPEED-1955-1980

\begin{tabular}{|c|c|c|c|c|c|c|c|c|c|c|c|c|c|}
\hline & riuk & c & $1-3$ & $4-7$ & $8-12$ & $13-18$ & $\begin{array}{c}\text { SPE } \\
19-24\end{array}$ & $\begin{array}{l}c \text { class } \\
25-31\end{array}$ & $32-38$ & $39-46$ & GT.46 & $\begin{array}{l}\text { TOTAL } \\
\text { SPEED }\end{array}$ & $\begin{array}{l}\text { AVG } \\
\text { SHEE }\end{array}$ \\
\hline & 1 & .87 & 6.95 & 29.65 & 41.56 & 18.24 & 2.61 & .12 & .00 & .00 & .00 & 7334 & 9.1 \\
\hline & 2 & te $\bar{c}$ & 8.66 & 30.65 & 45.16 & 12.41 & 2.48 & .00 & .00 & .00 & .00 & 6937 & $8 . t$ \\
\hline & 3 & .62 & 11.64 & 31.14 & 45.29 & 10.42 & 1.24 & .25 & .00 & .00 & .00 & 6528 & 8.1 \\
\hline & 4 & .99 & 12.78 & 36.23 & 40.07 & 8.44 & 1.24 & .25 & .00 & .60 & .00 & 6185 & 7.7 \\
\hline & 5 & 1.49 & 15.51 & 37.47 & 34.37 & 9.80 & .99 & .37 & .00 & .00 & .00 & 5937 & 7.4 \\
\hline & 6 & 2.73 & 26.97 & 38.21 & 28.78 & 8.06 & .87 & .37 & .00 & .00 & .00 & 5456 & 6.8 \\
\hline & 7 & 2.23 & 28.78 & 24.32 & 30.27 & 11.79 & 2.61 & .00 &.$C 0$ & .00 & .00 & 5789 & 7.2 \\
\hline & 0 & .99 & 25.56 & 29.40 & 26.18 & 14.52 & 3.23 & .12 & .00 & .00 & .00 & 6074 & 7.5 \\
\hline & 9 & .37 & 29.40 & 32.51 & 2 2.08 & 12.16 & 3.10 & .37 & .00 & .00 & .00 & 5726 & 7.1 \\
\hline & li & .12 & 28.04 & 39.68 & 17.25 & 12.41 & 2.85 & .25 & .00 & $.0 \mathrm{C}$ & .00 & 5522 & 6.5 \\
\hline & 11 & .12 & 21.34 & 45.04 & 18.61 & 11.66 & 2.61 & .62 & .00 & $.0 \mathrm{C}$ & .00 & 5733 & 7.1 \\
\hline & 12 & .60 & 16.63 & 47.39 & 19.98 & 11.54 & 3.85 & .50 & .12 & .00 & .00 & 6106 & $7 . t$ \\
\hline & 13 & .25 & 12.16 & 47.27 & $22.4 t$ & 12.16 & 5.09 &.$t 2$ & .00 & .00 & .00 & 6438 & $8 . C$ \\
\hline & 14 & .25 & 10.17 & 45.91 & 22.46 & 15.26 & 4.84 & .99 & .12 & .00 & .00 & 6848 & 8.5 \\
\hline & 15 & .12 & 9.93 & 43.67 & 22.46 & 15.63 & 6.70 & 1.12 & .37 & .00 & .00 & 7276 & 9. C \\
\hline & $1 t$ &.$C C$ & 12.26 & 36.57 & $22.4 t$ & 17.25 & 8.44 & 2.48 & .12 & $.0 \mathrm{C}$ & .00 & 7757 & $9 . t$ \\
\hline & 17 & .25 & 11.91 & 31.39 & 24.07 & 18.11 & 10.55 & 3.47 & .25 & .00 & .00 & 8314 & 10.3 \\
\hline & io & .37 & 14.89 & 24.32 & $\leq 2.7 \mathrm{C}$ & 20.35 & 12.53 & 4.59 & .25 & $.0 \mathrm{C}$ & .00 & 8809 & 10.5 \\
\hline & 19 & 1.12 & 11.17 & 25.19 & 21.84 & 22.70 & 14.64 & 3.10 & .25 & .00 & .00 & 9064 & 11.2 \\
\hline & iv & .62 & 7.06 & 23.08 & 28.66 & 24.44 & 13.52 & 1.74 & .12 & .00 & .00 & $\$ 19 C$ & 11.4 \\
\hline & 21 & .62 & 6.45 & 22.33 & 29.03 & 24.81 & 14.04 & 1.49 & .12 & .00 & .00 & 9372 & $11 . t$ \\
\hline & 22 & ناל. & 5.09 & 23.33 & 29.05 & 27.17 & 12.78 & 1.49 & .00 & .00 & .00 & 9322 & 11.6 \\
\hline & 23 & .25 & 0.45 & 21.59 & 36.35 & 27.42 & 7.32 & .62 & .00 & .00 & .00 & 8081 & 10.8 \\
\hline & $<4$ & .62 & 5.33 & 24.57 & 43.55 & 20.47 & 5.09 & .37 & .00 & .00 & .00 & 8035 & $10 . c$ \\
\hline & $I L A A_{L}$ & .67 & 14.16 & 32.95 & 28.97 & 16.13 & 5.99 & 1.05 & .07 & $.0 \mathrm{C}$ & .00 & 172427 & 8.5 \\
\hline
\end{tabular}

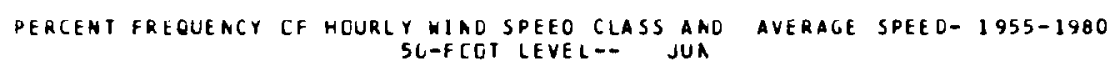

\begin{tabular}{|c|c|c|c|c|c|c|c|c|c|c|c|c|}
\hline riunn & $c$ & $1-3$ & $4-7$ & $8-12$ & $13-18$ & $19-24$ & $\begin{array}{c}\text { class } \\
25-31\end{array}$ & $32-38$ & $39-46$ & $6 J .46$ & $\begin{array}{l}\text { IUTAL } \\
\text { SPEED }\end{array}$ & $\begin{array}{l}\text { AVG } \\
\text { SPEE L }\end{array}$ \\
\hline 1 & .04 & 5.38 & 24.87 & 40.77 & 25.00 & 3.08 & .26 & .00 & .00 & .00 & $778 \mathrm{C}$ & $10 . c$ \\
\hline 2 & .38 & 6.28 & 29.36 & 43.97 & 18.33 & 1.67 & .00 & .00 & .00 & .00 & 7134 & 9.1 \\
\hline 3 & .04 & 7.18 & 33.72 & 45.26 & 12.56 & .04 & .00 &.$c 0$ & .00 & .60 & 6565 & 8.4 \\
\hline 4 & 1.28 & 11.28 & 35.51 & 43.08 & 7.95 & .77 & .13 & $.0 C$ & $.0 C$ & .00 & 6007 & 7.7 \\
\hline 5 & 1.67 & 12.10 & 38.85 & 38.72 & 7.31 & 1.28 & .00 & .00 & $.0 \mathrm{C}$ & .00 & 5758 & 7.4 \\
\hline c & 2.56 & 21.28 & 35.38 & 30.77 & 8.72 & 1.28 & .00 & .00 & .00 & .00 & 5323 & $6 . \mathrm{E}$ \\
\hline 7 & 1.42 & 20.77 & 27.95 & 31.92 & 15.77 & 1.54 & .13 & .00 & .00 & .00 & 6038 & 7.7 \\
\hline b & 1.43 & 24.10 & 31.28 & 25.51 & 15.77 & 2.18 & .13 & .00 & .00 & .00 & 3917 & 7.6 \\
\hline ; & .77 & 20.54 & 36.79 & 22.05 & 12.44 & 1.28 & .13 & .00 & .00 & .00 & 5371 & 6.5 \\
\hline 16 & .13 & 25.00 & 45.13 & 18.46 & 10.13 & 1.15 & $.0 \mathrm{C}$ & .60 & .60 & .00 & 5152 & $0 . t$ \\
\hline 11 & .00 & 14.02 & 52.95 & 21.54 & 8.72 & $\begin{array}{l}1.79 \\
1.79\end{array}$ & .38 & .00 & .00 & .00 & 5420 & 6.9 \\
\hline 12 & .13 & 10.77 & 52.18 & 25.00 & 9.62 & $\begin{array}{l}1.92 \\
\end{array}$ & .38 & .00 & .00 & .00 & 5761 & 7.4 \\
\hline 13 & .60 & 8.46 & 53.40 & $=3.59$ & 11.28 & $\begin{array}{l}2.72 \\
2.95\end{array}$ & .26 & .00 & $.0 \mathrm{C}$ & .00 & 6034 & 7.7 \\
\hline 14 & .60 & $\begin{array}{l}0.40 \\
7.31\end{array}$ & 50.00 & 26.15 & 10.38 & 5.13 & 1.03 & .00 & .00 & .00 & 6514 & 8.4 \\
\hline is &..$c$ & 6.92 & 47.95 & 24.62 & 12.31 & 6.54 & 1.67 & .00 & .00 & .00 & 6854 & 8.8 \\
\hline 16 & .13 & 8.46 & 40.51 & $24 . t 2$ & 15.64 & 8.33 & 1.79 & .51 & .00 & .00 & 7466 & $9 . i$ \\
\hline $\begin{array}{l}10 \\
17\end{array}$ & .00 & 7.82 & 36.67 & 23.08 & 16.67 & 11.15 & 4.23 & .38 & .00 & .00 & 8266 & $10 . t$ \\
\hline $\begin{array}{l}17 \\
18\end{array}$ & .00 & 7.82 & $\begin{array}{l}36.67 \\
27.18\end{array}$ & $\begin{array}{r}23.08 \\
23.72\end{array}$ & 20.51 & 14.49 & $\begin{array}{l}4.23 \\
6.41\end{array}$ & $\begin{array}{l}.30 \\
.13\end{array}$ & .00 & .00 & 9350 & $\begin{array}{l}12.6 \\
12 . \mathrm{c}\end{array}$ \\
\hline 18 & .06 & $\begin{array}{l}1.56 \\
0.41\end{array}$ & $\begin{array}{l}21.18 \\
21.92\end{array}$ & $\begin{array}{l}23.12 \\
23.08\end{array}$ & $\begin{array}{l}20.31 \\
22.31\end{array}$ & $\begin{array}{l}14.49 \\
20.90\end{array}$ & $\begin{array}{l}. .41 \\
5.00\end{array}$ & $\begin{array}{l}.13 \\
.13\end{array}$ & .00 & .00 & $\begin{array}{r}9330 \\
10032\end{array}$ & 12.9 \\
\hline 20 & .51 & $\begin{array}{l}0.41 \\
0.28\end{array}$ & 22.05 & 21.15 & 25.90 & 20.26 & 3.85 & .00 & .00 & .00 & 9969 & $\begin{array}{l}12 . \\
12 . \mathrm{t}\end{array}$ \\
\hline$<1$ & .51 & 4.87 & 20.64 & 22.56 & 30.26 & 18.46 & 2.69 & .00 & $.0 \mathrm{C}$ & .00 & 10000 & 12.8 \\
\hline 22 & .26 & 4.16 & 18.21 & 25.77 & 33.59 & 15.90 & 2.10 & .00 & .00 & .00 & 9936 & 12.7 \\
\hline 23 & .13 & 3.97 & 19.49 & 26.67 & 37.44 & 11.41 & .90 & .00 & .00 & .00 & 9495 & 12.2 \\
\hline$<4$ & .38 & 5.77 & 19.10 & 36.67 & 30.38 & 7.44 & .26 & .00 & .00 & .00 & 8566 & 11.0 \\
\hline ILIALL & .56 & 10.97 & 34.21 & 28.70 & 17.46 & 6.73 & 1.32 & .05 & .00 & .00 & 174708 & 9.2 \\
\hline
\end{tabular}


TABLE 47. Continued

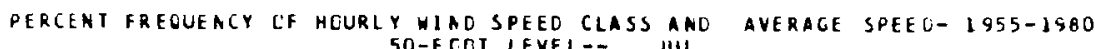

\begin{tabular}{|c|c|c|c|c|c|c|c|c|c|c|c|c|}
\hline rLUR & c & $1-3$ & $4-7$ & $8-12$ & $13-18$ & $19-24$ & $\begin{array}{c}\text { Class } \\
25-31\end{array}$ & $32-38$ & $39-46$ & CT.46 & $\begin{array}{l}\text { TCTALL } \\
\text { SPEED }\end{array}$ & $\begin{array}{l}\text { AVG } \\
\text { SPEEL }\end{array}$ \\
\hline 1 & .60 & 1.05 & 27.05 & 44.67 & 21.59 & 2.73 & .12 & .00 & .00 & .00 & 7917 & 9.8 \\
\hline 2 & .12 & 3.97 & $3 C .27$ & 49.88 & 14.64 & .87 & .25 & .00 & .00 & .00 & $730 \mathrm{C}$ & 9.1 \\
\hline 3 & .50 & 7.94 & 32.63 & 48.51 & 10.05 & .25 & .12 & .00 & .00 & .00 & 6627 & 8.: \\
\hline 4 & 1.24 & 9.80 & 37.34 & 44.42 & 0.82 & .37 & .00 & .60 &.$C C$ & .00 & 6170 & 7.7 \\
\hline 3 & 1.61 & 11.30 & 41.99 & 40.50 & 4.35 & .25 & .00 & .00 & .00 & .00 & 5731 & 7.1 \\
\hline$t$ & $1.1 i$ & 19.75 & 43.11 & 31.55 & 3.98 & .12 & .37 & .00 & .00 & .00 & 5223 & 6.5 \\
\hline 1 & 1.24 & 21.09 & 34.74 & 33.00 & 6.93 & .99 & .00 & .00 & .00 & .00 & 5701 & 7.1 \\
\hline 0 & .50 & 21.71 & 39.21 & 26.67 & 10.42 & 1.12 & .37 & .00 & .00 & .00 & 5680 & 7.0 \\
\hline$>$ &.$<5$ & 34.45 & 41.56 & 14.64 & 7.57 & 1.49 & .00 & .00 & .00 & .00 & 4704 & 5.8 \\
\hline ic & .25 & 35.36 & 44.79 & 13.63 & 5.46 & .99 & .12 & .00 & .00 & .00 & 4425 & 5.5 \\
\hline 11 & $.1<$ & 24.57 & 54.59 & 14.02 & 4.96 & 1.49 & .25 & .00 & .00 & .00 & 4701 & $5 . \varepsilon$ \\
\hline 16 & $.0 \mathrm{C}$ & 10.11 & 58.31 & 16.13 & 6.33 & .87 & .25 & .00 & .00 & .00 & 5003 & 6.0 \\
\hline 13 & $.2 c$ & 14.64 & 57.32 & 18.58 & 7.44 & 1.36 & .25 & .00 & .00 & .00 & 5435 & 6.5 \\
\hline 14 & .40 & 10.42 & 55.96 & 22.68 & 9.18 & 1.86 & .37 & & .00 & .00 & 5847 & 7.0 \\
\hline 4 & .00 & 9.68 & 53.23 & 22.45 & 9.68 & 3.47 & .99 & .00 & .00 & .60 & 6301 & 7.8 \\
\hline 26 & .12 & $\$ .66$ & 48.14 & 23.20 & 12.41 & 5.21 & 1.24 & .00 & .00 & .00 & 6727 & 8. \\
\hline i 7 & .60 & 11.54 & 41.32 & 22.21 & 15.51 & 6.82 & 2.48 & .12 & .00 & .00 & 7358 & 9.1 \\
\hline ic & . ik & 12.41 & 31.76 & 25.06 & 16.13 & 11.17 & 3.35 & .00 & .00 & .00 & 8260 & $10 . i$ \\
\hline 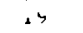 & .12 & 16.17 & at. 55 & 24.07 & 20.47 & 15.14 & 3.47 & .60 & .00 & .00 & 9167 & 11.4 \\
\hline \& & .62 & 7.32 & 26.41 & 18.86 & 24.81 & 17.25 & 2.61 & .12 & .00 & .00 & 5546 & $11 . t$ \\
\hline 61 & .56 & 0.43 & 19.48 & 22.33 & 30.52 & 18.36 & 2.36 & .00 & .00 & .00 & 10140 & 12.6 \\
\hline$<2$ & $\therefore=6$ & 4.04 & 18.24 & 23.95 & 31.02 & 19.11 & 2.11 & $.1 \tilde{z}$ & .12 & .00 & 10421 & 12.5 \\
\hline <3 & .25 & 3.05 & 18.98 & 30.15 & 33.00 & 12.41 & 1.36 & .00 & .00 & .00 & 9804 & 12.2 \\
\hline$<4$ & .56 & 4.47 & 21.46 & 38.83 & 28.78 & 5.83 & .12 & .00 & .00 & .00 & 8705 & 10.8 \\
\hline IIAL & .46 & 13.23 & $\$ 7.77$ & 27.90 & 14.34 & 5.40 & .94 & .02 & .01 & $.0 \mathrm{c}$ & 166503 & 8.6 \\
\hline
\end{tabular}

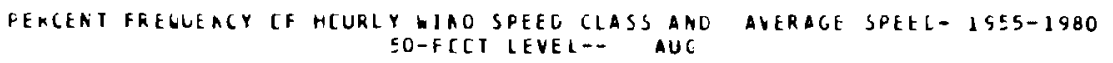

$$
\text { SPEEC CLASS }
$$

\begin{tabular}{|c|c|c|c|c|c|c|c|c|c|c|c|c|}
\hline \multicolumn{13}{|c|}{ SPEEL CLASS } \\
\hline rulk & $\iota$ & $1-1$ & $4-7$ & $8-12$ & $13-18$ & & $25-31$ & $32-38$ & $39=4 t$ & GT. $4 \mathrm{t}$ & $\begin{array}{l}\text { ICTAL } \\
\text { SPEEU }\end{array}$ & $\begin{array}{l}\text { AVE } \\
\text { SHEEE }\end{array}$ \\
\hline 1 & .97 & 5.33 & 30.15 & 44.79 & 17.87 & 1.49 &. $\mathrm{co}$ & .00 & .00 & .00 & 7432 & 9.2 \\
\hline 2 & .74 & 4.31 & 34.74 & 44.79 & 11.17 & .25 & .00 & .00 & .00 & .00 & 6674 & $8 .=$ \\
\hline 3 & .74 & 12.16 & 38.83 & $4 C .2 C$ & 7.44 & .62 & .60 & .60 & .00 & .00 & 0056 & 7.9 \\
\hline 4 & 1.24 & 15.06 & 40.94 & 36.10 & 5.34 & .50 & .00 & .00 & .00 & .00 & 5568 & 6.5 \\
\hline 2 & 2.11 & 16.36 & 42.80 & 34.49 & 3.35 & .37 & $.0 \mathrm{CO}$ & .00 & .00 & .00 & 5331 & $6 . t$ \\
\hline$\varepsilon$ & $2 .<3$ & 15.46 & $48.7 t$ & 25.56 & 3.72 & .25 & .00 & .00 & .00 & .00 & 4874 & $\begin{array}{ll}0.6 \\
6 . c\end{array}$ \\
\hline$i$ & 3.05 & 31.64 & 33.67 & 25.68 & 4.59 & .37 & .00 & .00 & .00 & .00 & $456 C$ & 5.7 \\
\hline 6 & 1.14 & 20.76 & 35.24 & 26.67 & 7.20 & .37 & .00 & .60 & .00 & .00 & $\begin{array}{l}4985 \\
4985\end{array}$ & $\begin{array}{l}3.1 \\
6.2\end{array}$ \\
\hline s &.$<5$ & 33.37 & 40.69 & 17.62 & 7.44 & .62 & .00 & .00 & .00 & .00 & 4668 & s.. \\
\hline iv & .36 & 40.69 & $39 .<1$ & 13.25 & 5.33 & .02 & .12 & .00 & .00 & .00 & $\begin{array}{l}4068 \\
429 \mathrm{C}\end{array}$ & $\begin{array}{l}3.6 \\
5.2\end{array}$ \\
\hline 11 & $.1 \mathrm{c}$ & 34.74 & 47.15 & 12.66 & 4.47 & .62 & .25 & .00 & .00 & .00 & $\begin{array}{l}4296 \\
4306\end{array}$ & 5.3 \\
\hline i2 & .00 & 24.07 & 55.58 & 13.65 & 5.83 & .74 & .12 & .60 & .00 & .00 & 4634 & $\begin{array}{l}5.3 \\
5.7\end{array}$ \\
\hline+3 & . vu & 16.06 & 57.94 & 14.09 & 7.07 & .99 & .25 & .00 & $.0 \mathrm{C}$ & .00 & 5047 & 5.7 \\
\hline .4 & .00 & 14.76 & 55.90 & $19 . \angle 3$ & 7.82 & 1.86 & .25 & .12 & .00 & .00 & 5494 & 6.2 \\
\hline 15 & $.1 c$ & 11.74 & 54.59 & 19.73 & 10.79 & 1.80 & 1.12 & .00 & .00 & .00 & 5887 & 6.6 \\
\hline ic & .60 & 13.40 & 47.39 & $21.4 t$ & 12.53 & 3.10 & 1.61 &. $\mathrm{CO}$ &. $\mathrm{OC}$ & .00 & 6378 & 7.3 \\
\hline .7 & .12 & 16.38 & 38.09 & 23.68 & 13.40 & 7.07 & 1.86 & .00 & .60 & .00 & 7005 & 7.9 \\
\hline 16 & .25 & 16.50 & 31.69 & 21.84 & 16.13 & 10.30 & 3.10 & .00 & .00 & .00 & 7813 & 8.7 \\
\hline 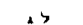 & 1.24 & 13.15 & $<8.78$ & 21.46 & 19.35 & 12.90 & $3.1 \mathrm{C}$ & .00 & .00 & 00 & $83 B$ & 9.7 \\
\hline 6 & 1.12 & 8.93 & 67.55 & 24.57 & 22.21 & 14.02 & 2 & 00 & OC & & 8300 & 10.4 \\
\hline t & . & 5.46 & 24.44 & 2519 & (26) & 14. & $\because 1$ & -60 & .0 & .00 & 8843 & 11.6 \\
\hline$\leqslant 4$ & 01 & 3.40 & 84.44 & 23.19 & 20.80 & 16.13 & 1.12 & .00 & .00 & .00 & 9452 & 11.7 \\
\hline 22 & .37 & 4.34 & 22.55 & cs. 28 & 27.30 & 14.85 & .87 & .00 & .00 & .00 & 9532 & 11.8 \\
\hline 23 & .00 & 5.04 & 22.83 & 34.49 & 29.40 & 7.82 & .37 & .00 & $.0 C$ & .00 & $884 \mathrm{C}$ & 11.6 \\
\hline$<4$ & .25 & 4.96 & 27.42 & 40.09 & 23.33 & 3.23 & .12 & .00 & .00 & .00 & 7947 & 9.5 \\
\hline$\| 1 A_{2}$ & .76 & 10.05 & 38.64 & 26.32 & 12.52 & 4.22 &.$t 8$ &.$C_{1}$ & .00 & .00 & $154 \mathrm{CO}$ & 8.6 \\
\hline
\end{tabular}


TABLE 47. Continued

PERCERI FREGLEACY CF HCURLY WIAD SPEED CLASS AAD AVERAGE SPEEL- 1555-1980
SO-FODT LEVEL SEP

\begin{tabular}{|c|c|c|c|c|c|c|c|c|c|c|c|c|}
\hline FLLKk & c & $1-3$ & $4-7$ & $8-12$ & $13-18$ & $\begin{array}{c}\text { SPE } \\
19-24\end{array}$ & $\begin{array}{c}0 \text { CLASS } \\
25-31\end{array}$ & $32-38$ & $39-46$ & GT.46 & $\begin{array}{l}\text { TOTAL } \\
\text { SPEED }\end{array}$ & $\begin{array}{l}\text { AVG } \\
\text { SPEE C }\end{array}$ \\
\hline 1 & 1.54 & 9.36 & 38.57 & 37.56 & 11.15 & 1.03 & .26 & .13 & $.0 C$ & .00 & 6182 & 7.9 \\
\hline 2 & 1.67 & 16.41 & 37.05 & 33.97 & 9.87 & .90 & .13 & .00 & .00 & .00 & 5711 & 7.3 \\
\hline 3 & 2.44 & 17.44 & 38.33 & 33.97 & 6.28 & 1.28 & .26 & .00 & .00 & .00 & 5478 & 7. $\mathrm{C}$ \\
\hline 4 & 2.55 & 20.64 & 36.54 & 31.41 & 7.18 & 1.15 & .13 & .00 & .00 & .00 & 5294 & $6 . \mathrm{E}$ \\
\hline 5 & 3.59 & 23.21 & 37.44 & 28.72 & 5.90 & .90 & .26 & .00 & .00 & .00 & 4988 & 6.4 \\
\hline 6 & 4.10 & 24.49 & 37.95 & 26.92 & 4.87 & 1.67 & .00 & .00 & .00 & .00 & 4829 & 6.2 \\
\hline 7 & 4.49 & 30.51 & 38.21 & 20.77 & 4.62 & 1.28 & .13 & .00 & .00 & .00 & 4388 & 5.6 \\
\hline 8 & 3.97 & 35.26 & 29.74 & 20.90 & 8.33 & 1.15 & .64 & .00 & .00 & .00 & $466 \mathrm{C}$ & $6 . c$ \\
\hline 9 & 1.03 & 34.87 & 33.33 & 17.95 & 10.00 & 2.18 & .64 & .00 & .00 & .00 & 4979 & 6.4 \\
\hline 20 & .38 & 36.28 & 33.21 & 17.95 & 8.85 & 2.82 & .51 & .00 & .00 & .00 & 4903 & 6.3 \\
\hline 11 & .38 & 34.74 & 36.03 & 17.44 & 8.59 & 2.18 & .51 & .13 & $.0 \mathrm{C}$ & .00 & 4915 & 0.3 \\
\hline 12 & .26 & 26.54 & 45.77 & 15.26 & 8.72 & 2.56 & .77 & .13 & .00 & .00 & 5098 & 6.5 \\
\hline 13 & .13 & 21.92 & 49.36 & 15.51 & 8.21 & 3.46 & 1.41 & .00 & .00 & $.0 \mathrm{C}$ & 5415 & 6.9 \\
\hline 14 & .13 & 22.56 & 45.90 & 17.56 & 8.97 & 3.33 & 1.41 & & $.0 C$ & .00 & 5530 & 7.1 \\
\hline 15 & .00 & 22.69 & 43.97 & 16.79 & 9.74 & 5.38 & 1.28 & .13 & .00 & .00 & 5871 & 7.5 \\
\hline & .00 & 22.69 & 38.33 & 18.59 & 11.92 & 0.92 & 1.41 & .13 & .00 & .00 & 6288 & 8.1 \\
\hline 17 & .64 & 22.95 & 33.59 & 18.59 & 14.10 & $\begin{array}{l}0.72 \\
8.33\end{array}$ & $\begin{array}{l}1.41 \\
1.67\end{array}$ & 013 & .00 & .00 & $\begin{array}{l}6080 \\
6647\end{array}$ & $\begin{array}{l}8.1 \\
8.5\end{array}$ \\
\hline le & 2.18 & 17.82 & 35.13 & 19.36 & 13.85 & 10.13 & 1.54 & .00 & .00 & .00 & 6857 & 8.6 \\
\hline 19 & 1.54 & 14.10 & 35.13 & $\begin{array}{r}830 \\
23.97\end{array}$ & $\begin{array}{l}15.77 \\
\end{array}$ & 8.46 & 1.03 & .00 & .00 & .00 & 7011 & $9 . i$ \\
\hline$\therefore 6$ & .26 & 8.85 & 34.23 & 28.85 & 19.36 & 7.69 & .77 & .00 & .00 & .00 & 7486 & $9 . t$ \\
\hline$\therefore 1$ & .04 & 7.05 & 33.46 & 33.72 & 18.72 & 5.51 & .90 & .00 &.$O C$ & .00 & $747 C$ & $9 . t$ \\
\hline 22 & .51 & 7.05 & 32.82 & 38.59 & 16.03 & 4.36 & .64 & .00 & .00 & .00 & 7205 & 9.8 \\
\hline$\angle 3$ & .13 & 9.87 & 34.74 & 57.95 & 14.10 & 3.08 & .13 & .00 & .00 & .00 & 6730 & $8 . t$ \\
\hline$<4$ & .64 & 8.59 & 38.72 & 37.31 & 12.95 & 1.79 & $.0 C$ & $.0 \mathrm{C}$ & $.0 C$ & .00 & 6373 & 8.6 \\
\hline TIIAL & 1.40 & 20.06 & 37.41 & 25.40 & 10.75 & 3.65 & .68 & .04 & .00 & .00 & 140308 & 7.5 \\
\hline
\end{tabular}

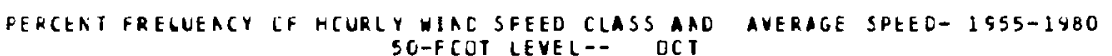

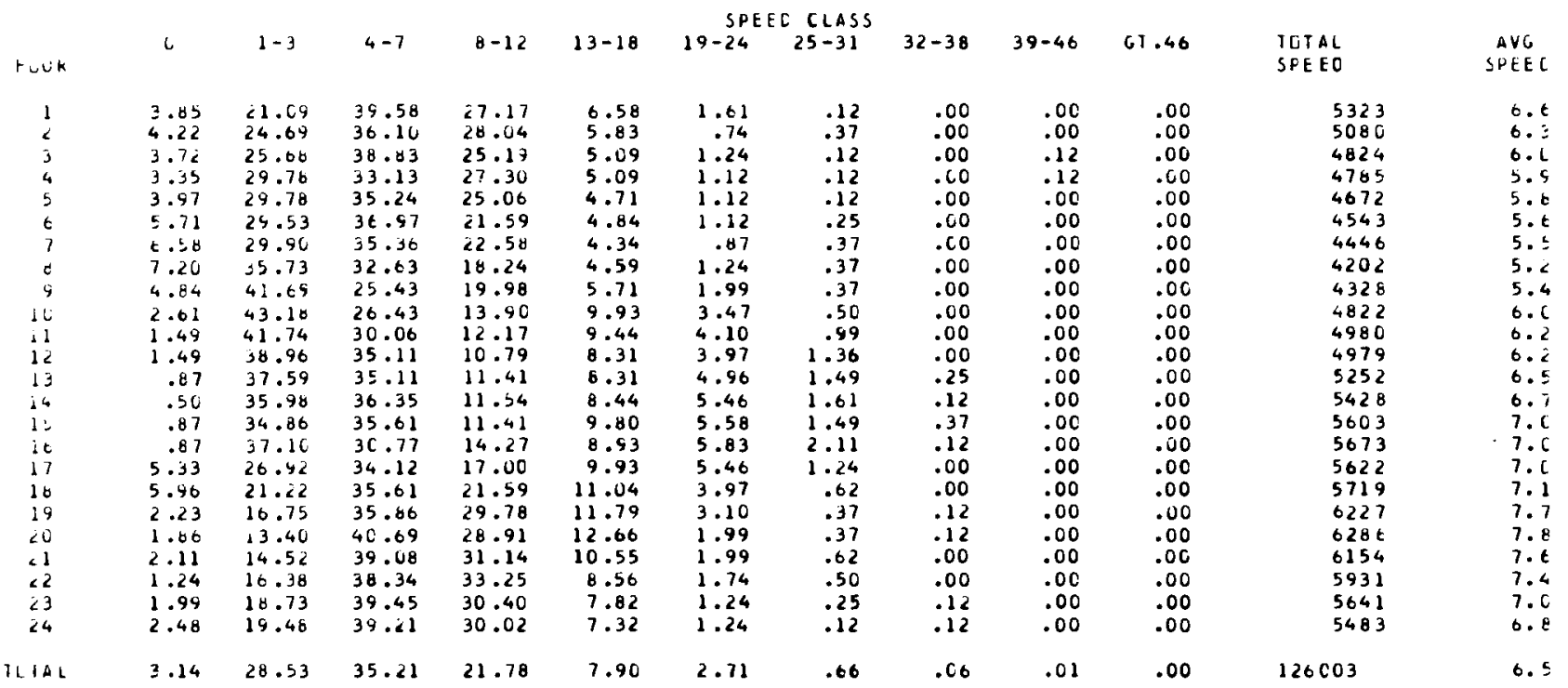


TABLE 47. Continued

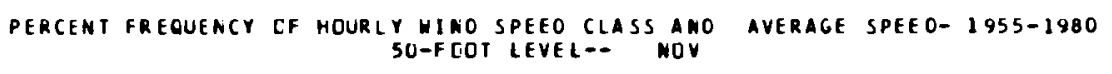

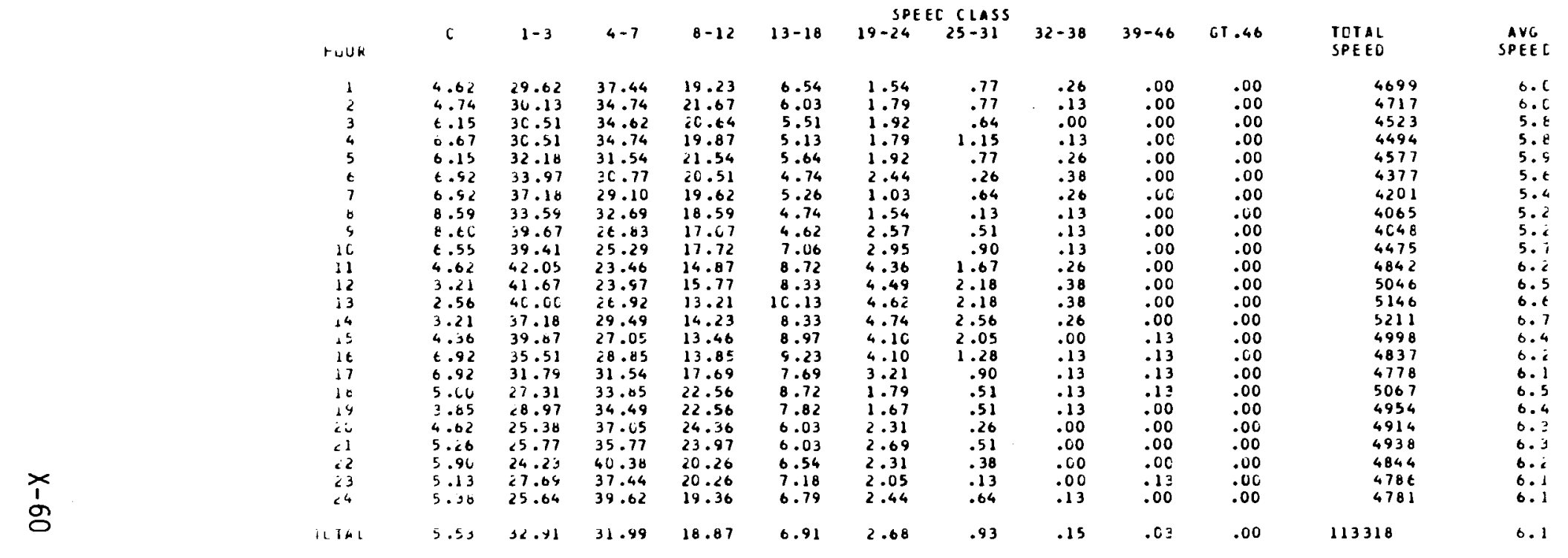

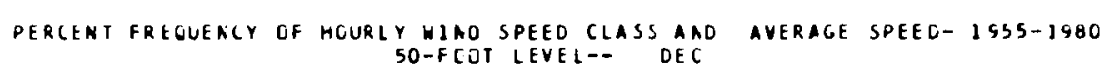

\begin{tabular}{|c|c|c|c|c|c|c|c|c|c|c|c|c|}
\hline rLLk & c & $1-3$ & $4-7$ & $\theta-1 i$ & $13-18$ & $\begin{array}{c}\text { SPE } \\
19-24\end{array}$ & $\begin{array}{l}\text { Class } \\
25-31\end{array}$ & $32-38$ & $39-46$ & GT.46 & $\begin{array}{l}\text { TCTAL } \\
\text { SPEEC }\end{array}$ & $\begin{array}{l}\text { AVG } \\
\text { SPEEL }\end{array}$ \\
\hline 1 & 7.67 & 30.15 & 31.51 & 20.47 & 7.57 & 1.86 & 1.24 & .12 & .00 & .00 & 4959 & 6.2 \\
\hline$i$ & 7.07 & 49.78 & 33.75 & 18.98 & 6.70 & 2.61 & .74 & .37 & $.0 \mathrm{C}$ & .60 & $487 t$ & 0.6 \\
\hline 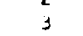 & 9.31 & 29.78 & 36.62 & 21.22 & 5.58 & 3.23 & .50 & .25 & .12 & .00 & $486 C$ & 6.6 \\
\hline 4 & 5.33 & 34.86 & 31.39 & $18.3 t$ & 6.70 & 2.23 & .74 & $.1 \%$ & .25 & .60 & 4781 & 5.5 \\
\hline 5 & 7.26 & 32.88 & 30.89 & 19.11 & 6.95 & 1.99 & .74 & .00 & .25 & .00 & 4774 & 5.5 \\
\hline ć & 7.69 & 32.38 & 32.26 & 18.49 & 5.46 & 2.73 & .74 & .25 & .00 & .00 & 4647 & 5.0 \\
\hline$y$ & 7.57 & 32.13 & 32.88 & 19.23 & 5.21 & 2.11 & .62 & .25 & .00 & .00 & $455 \mathrm{C}$ & $5 . t$ \\
\hline$t$ & 7.94 & 33.00 & 31.39 & 19.48 & 5.21 & 1.86 & .87 & .25 & .00 & .00 & 4520 & 5.6 \\
\hline y & t.38 & 35.01 & 31.51 & $16 .<5$ & 0.70 & 2.73 & .25 & .37 & .00 & .00 & 4555 & 5.7 \\
\hline ic & 7.57 & $4 c .57$ & 25.31 & $15 . \mathrm{ag}$ & 6.20 & 3.16 & 1.24 & .12 & .00 & .00 & 4517 & $5 . t$ \\
\hline 11 & $\begin{array}{l}5.46 \\
5.46\end{array}$ & 40.82 & 23.70 & 17.25 & 8.56 & 1.99 & 1.86 & .37 & .00 & .00 & 4804 & $\begin{array}{l}3.6 \\
6.6\end{array}$ \\
\hline 12 & 4.34 & 41.44 & 21.96 & 16.73 & 7.20 & 4.09 & 1.86 & .37 & .00 & .00 & 5126 & 6.4 \\
\hline 13 & 4.56 & 37.22 & 25.19 & 16.63 & 9.06 & 4.84 & 1.61 & .50 & .00 & .00 & 3345 & 0.4 \\
\hline 14 & 6.48 & 37.34 & 24.32 & 16.75 & 7.94 & 4.84 & 2.36 & .12 & .25 & .00 & 5374 & $\begin{array}{l}0.7 \\
6.7\end{array}$ \\
\hline 15 & 6.45 & 37.10 & 25.06 & 16.63 & 8.06 & 4.34 & 1.74 & .50 & .12 & .00 & 5143 & $\begin{array}{l}0.1 \\
6.4\end{array}$ \\
\hline 10 & 7.07 & 36.10 & 27.67 & 16.63 & 7.82 & 2.01 & 1.61 & 37 & .08 & 32 & 4943 & 0.4 \\
\hline 17 & 9.60 & $29.4 \mathrm{C}$ & 32.51 & 17.12 & 7.69 & 2.61 & 1.24 & .37 & 0 & .00 & 4915 & 0.1 \\
\hline 16 & 7.69 & $29.4 \mathrm{C}$ & 30.52 & 20.97 & 7.32 & 2.98 & .99 & .12 & .00 & .00 & 5062 & 6.1 \\
\hline iq & 6.76 & 27.79 & 33.13 & 21.34 & 6.45 & 3.23 & 1.12 & .25 & .00 & .00 & 5160 & $\begin{array}{l}0.2 \\
6.4\end{array}$ \\
\hline ¿i & 6.70 & 27.54 & 32.13 & 21.22 & 7.57 & 3.85 & .87 & .12 & $.0 \mathrm{C}$ & .00 & 5189 & 0.4 \\
\hline 21 & 7.69 & 25.03 & 33.75 & 21.46 & 7.44 & 3.10 & .74 & .00 & .00 & .00 & 5099 & 6.3 \\
\hline 22 & 6.58 & 28.54 & 32.38 & 21.09 & B. 19 & 1.99 & 1.24 & .00 & .00 & & 5034 & 6.2 \\
\hline 23 & $t . C B$ & 30.02 & 32.13 & 21.34 & 6.95 & 1.86 & 1.24 & .25 & .12 & .00 & 5002 & 6.2 \\
\hline 24 & 6.33 & 25.40 & 31.76 & 22.21 & 7.20 & 1.86 & 1.12 & .00 & .12 & .00 & 5004 & $6 . \overline{6}$ \\
\hline ILIAL & 6.65 & 32.88 & 29.88 & 19.03 & 7.07 & 2.86 & 1.14 & .23 & .05 & .01 & 118239 & 6.1 \\
\hline
\end{tabular}




\section{TABLE 47. Continued}

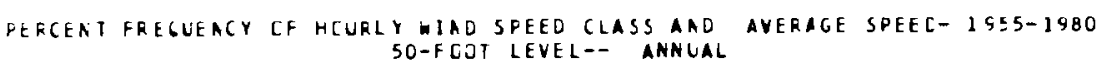

\begin{tabular}{|c|c|c|c|c|c|c|c|c|c|c|c|c|}
\hline rusk & $\iota$ & $1-j$ & $4-7$ & $8-12$ & $13-18$ & $\begin{array}{c}5 P E \\
19-24\end{array}$ & $\begin{array}{c}\text { CLASS } \\
25-31\end{array}$ & $32-38$ & $39-46$ & GT.46 & $\begin{array}{l}\text { TOA } \\
\text { TSEED }\end{array}$ & $\begin{array}{c}A V G \\
\text { SPEEC }\end{array}$ \\
\hline 1 & 2.37 & 16.04 & 32.10 & 33.69 & 13.03 & 2.19 & .46 & .11 & $.0 c$ & .01 & $\begin{array}{r}75305 \\
\end{array}$ & 7.5 \\
\hline & 2.06 & & $\begin{array}{l}33.40 \\
34.53\end{array}$ & 34.67 & 10.33 & $\begin{array}{l}1.73 \\
55\end{array}$ & .40 & .13 & $\begin{array}{r}.02 \\
.02\end{array}$ & .00 & $\begin{array}{l}71531 \\
68007\end{array}$ & 7.5 \\
\hline & & $\begin{array}{l}16.91 \\
21.75\end{array}$ & $\begin{array}{l}34.51 \\
34.85\end{array}$ & 31.06 & 7.01 & $\begin{array}{l}1.35 \\
1.48\end{array}$ & .44 & 0.07 & .04 & .00 & $\begin{array}{l}0 \\
t 490\end{array}$ & $\because . \varepsilon$ \\
\hline 5 & & 22.96 & 35.70 & 29.30 & 0.06 & 1.50 & .38 & .07 & .02 & .00 & 02927 & $\begin{array}{l}0 . t \\
\varepsilon . t\end{array}$ \\
\hline & 4.05 & 25.19 & 37.15 & 25.31 & 6.14 & 1.66 & .37 & .13 & $.0 c$ & .00 & 60027 & 6.3 \\
\hline 7 & 4.26 & 29.09 & 32.32 & 24.72 & 7.55 & 1.68 & .33 & .11 & .00 & .60 & 59776 & 6.3 \\
\hline$\circ$ & 3.74 & 29.82 & 32.56 & 22.35 & 8.97 & 2.02 & .46 & .06 & .00 & .01 & 66828 & 6.4 \\
\hline 16 & 2.01 & $\begin{array}{l}32.82 \\
34.53\end{array}$ & 32.63 & 19.02 & 9.44 & 3.02 & 89 & 3 & 0 & .01 & 00890 & $\begin{array}{l}0.4 \\
0.4\end{array}$ \\
\hline 11 & & & 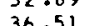 & 160 & 9.51 & 3.01 & & & & & & 6.7 \\
\hline 16 & I ly & 27.33 & 39.76 & 16.98 & 9.39 & 3.62 & 1.44 & .32 & .02 & .00 & 66590 & 7.6 \\
\hline 15 & i.lu & 24.56 & 40.50 & 17.28 & $10 . c^{2}$ & 4.48 & 1.55 & .36 & $.0 t$ & .00 & 70149 & 7.4 \\
\hline 14 & 1.20 & 22.67 & 39.68 & 18.06 & & $\begin{array}{l}4.85 \\
4.85\end{array}$ & & .28 & .01 & .01 & $\begin{array}{l}7312 i \\
73.525\end{array}$ & 7.7 \\
\hline $\begin{array}{l}13 \\
10 \\
10\end{array}$ & 106 & & 35.19 & 19.39 & 12.20 & & 2.37 & .29 & .03 & .01 & 77605 & \\
\hline & $\because 3$ & 3.33 & 33.52 & 2016 & 13.05 & 7.31 & 2.52 & .26 & .03 & 00 & 80591 & 8. \\
\hline 10 & 2.89 & 10.46 & 31.64 & 22.06 & 14.10 & 7.49 & 2.65 & .15 & .04 & .00 & 84212 & s \\
\hline 19 & 2.32 & 16.34 & 30.26 & 24.57 & 15.49 & 8.80 & 2.12 & .14 & .01 & .00 & 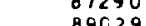 & \\
\hline 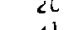 & 2013 & $\begin{array}{l}13.95 \\
13.712\end{array}$ & 法 & 27.03 & 17.85 & 0 & 101 & 07 & 4 & 100 & 50035 & 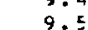 \\
\hline & 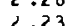 & 13.36 & 28.92 & 26.48 & 18.08 & 7.74 & 1.13 & .04 & .01 & .00 & 88559 & \\
\hline$<3$ & & 14.91 & 28.65 & 30.39 & 18.11 & 5.12 & .68 & .09 & .02 & .00 & 84159 & \\
\hline & $2 .<7$ & 14.09 & 36.92 & 32.67 & 15.27 & 3.40 & .48 & .66 & .63 & .00 & 79260 & \\
\hline & 2.46 & $i 1.8 \alpha$ & 33.81 & 24.57 & 11.62 & 4.38 & 1.16 & .15 & .02 & .00 & 1754237 & 7.7 \\
\hline
\end{tabular}


TABLE 48. Monthly and Annual Percent Frequency of Hourly Wind Speed Class and Average Speed, 200-Foot Level, 1955 Through 1980

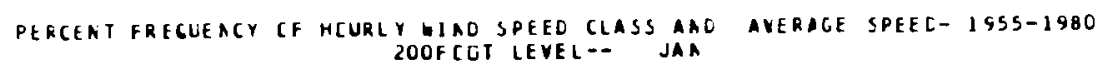

\begin{tabular}{|c|c|c|c|c|c|c|}
\hline $\begin{array}{c}\text { SPE } \\
19-24\end{array}$ & $\begin{array}{l}\text { CLASS } \\
25-31\end{array}$ & $32-38$ & $39-46$ & 61.46 & $\begin{array}{l}\text { TDTAL } \\
\text { SPEED }\end{array}$ & $\begin{array}{c}\text { AVG } \\
\text { SHEEL }\end{array}$ \\
\hline $\begin{array}{l}5.09 \\
4.47\end{array}$ & $\begin{array}{l}2.11 \\
1.74\end{array}$ & $\begin{array}{l}.87 \\
.99\end{array}$ & $\begin{array}{r}.37 \\
.25\end{array}$ & $\begin{array}{r}.25 \\
.37\end{array}$ & $\begin{array}{l}1844 \\
7085\end{array}$ & $\begin{array}{l}8.5 \\
8.6\end{array}$ \\
\hline 4.71 & 2.23 & .87 & .50 & .00 & 6984 & $\begin{array}{l}8 . E \\
8.7\end{array}$ \\
\hline 4.22 & 2.61 & 1.12 & .25 & .12 & 6923 & 8.6 \\
\hline 5.21 & 2.36 & 1.12 & .25 & .00 & 6994 & 8.7 \\
\hline 5.58 & 2.23 & .87 & .12 & .25 & 8923 & 8.6 \\
\hline 5.09 & 2.23 & .87 & .12 & .12 & 6849 & 8. 5 \\
\hline 4.96 & 2.36 & .62 & .25 & .12 & 6767 & 8.4 \\
\hline 4.22 & 2.45 & .99 & .37 & .12 & 6463 & B. C \\
\hline 4.34 & 2.98 & .74 & .37 & .12 & 0427 & 8.6 \\
\hline 5.83 & 2.98 & 1.24 & .62 & .12 & 6647 & 8.2 \\
\hline 5.22 & 3.11 & 1.74 & .62 & .37 & 6503 & 8.5 \\
\hline 5.96 & 3.98 & 1.12 & .62 & .25 & 6744 & 8.4 \\
\hline 5.71 & 4.34 & 1.24 & .37 & .25 & 6771 & 8.4 \\
\hline 5.46 & 3.85 & .99 & .62 & .00 & 6664 & B. \\
\hline 5.71 & 2.61 & 1.24 & .25 & .12 & 6916 & $8 . t$ \\
\hline 7.26 & $2.3 t$ & .50 & .50 & .12 & 7224 & 9.6 \\
\hline 5.36 & 3.35 & 1.36 & .12 & .25 & $757 \mathrm{C}$ & 9.4 \\
\hline 6.33 & 2.98 & 1.74 & .25 & .25 & 7761 & $9 . t$ \\
\hline$t .95$ & 3.10 & .87 & .62 & .12 & 7674 & 9.2 \\
\hline 5.46 & 3.60 & .99 & .37 & $.0 c$ & 7480 & 9.2 \\
\hline 5.21 & 2.98 & .62 & .25 & .12 & 7235 & 9.6 \\
\hline 5.76 & 1.99 & .74 & $.5 c$ & .00 & 7210 & 8.4 \\
\hline 5.47 & 2.79 & 1.02 & .38 & .14 & 168628 & ๑. \\
\hline
\end{tabular}

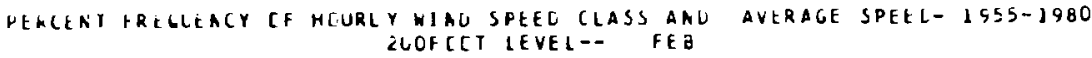

\begin{tabular}{|c|c|c|c|c|c|c|c|c|c|c|c|c|}
\hline I LUK & 6 & $1-3$ & $4-7$ & $0-12$ & $13-13$ & $19-24$ & $\begin{array}{c}\text { CLASS } \\
25-31\end{array}$ & $=2-38$ & $39-4 t$ & 61.46 & $\begin{array}{l}\text { ICTAL } \\
\text { SPEEC }\end{array}$ & $\begin{array}{l}\text { AVC } \\
\text { SHEEL }\end{array}$ \\
\hline 1 & c. .7c & 10.23 & 21.09 & 24.22 & 23.13 & 6.26 & 3.13 & 1.22 &. $\mathrm{CC}$ & .00 & 7353 & 10.6 \\
\hline 3 & c.to & 10.23 & $\angle C .55$ & 25.17 & 26.72 & 6.53 & 2.59 & .95 & $.0 \mathrm{C}$ & .00 & 7294 & 9.4 \\
\hline 3 & 3.46 & 19.45 & 21.09 & 21.50 & 23.95 & 6.53 & 3.27 & 1.69 & .14 & .00 & 7282 & 9.4 \\
\hline ; & 3.61 & 18.64 & $23.4 C$ & 22.59 & 19.73 & 7.35 & 3.54 & .68 & .14 & .14 & 7140 & $9 \cdot !$ \\
\hline c & 3.47 & $\begin{array}{l}14.58 \\
25.66\end{array}$ & $\begin{array}{l}22.72 \\
22.06\end{array}$ & $\begin{array}{r}2.012 \\
35.44\end{array}$ & $2 C .95$ & $\begin{array}{r}6.67 \\
7.35\end{array}$ & 3.13 & .41 & $\begin{array}{r}.41 \\
.54\end{array}$ & .14 & $\begin{array}{l}7005 \\
6868\end{array}$ & 9.5 \\
\hline 7 & 2.54 & 23.07 & C1.50 & $\begin{array}{l}<5.44 \\
23.01\end{array}$ & $\begin{array}{l}18.23 \\
18.76\end{array}$ & $\begin{array}{l}7.35 \\
7.48\end{array}$ & $\begin{array}{l}2.18 \\
1.63\end{array}$ & $\begin{array}{l}.14 \\
.54\end{array}$ & .14 & $\begin{array}{l}.00 \\
.00\end{array}$ & 0692 & 9.1 \\
\hline$b$ & $3 . t^{\prime}$ & $\therefore=4 c$ & $21 . t^{3}$ & 24.45 & 15.18 & 4.90 & 1.63 & .82 & .27 & .00 & 0561 & 8.5 \\
\hline 4 & 3.46 & <4. 35 & 25.44 & $\angle 1.9 c$ & 16.05 & 4.90 & 2.72 & 1.69 & .14 & .00 & 6357 & d.t \\
\hline ic & $<.06$ & 28.71 & 22.45 & 22.45 & 14.01 & 4.90 & 3.13 & .82 & .68 & & 6292 & $\theta \cdot c$ \\
\hline it & 1.77 & $<9.25$ & $\angle 5.17$ & 21.09 & 12.52 & 5.58 & 2.45 & 1.50 & .54 & .14 & 6296 & $\theta . t$ \\
\hline is & .02 & 20.57 & $3 C .2 C$ & 16.13 & 11.84 & 6.26 & 3.13 & 1.63 & .68 & .14 & 6403 & 6.7 \\
\hline $\begin{array}{l}13 \\
14\end{array}$ & . tet & $<7.76$ & $<9.52$ & $15.9 i$ & 13.66 & 6.67 & 3.95 & 1.50 & .82 & .14 & 6718 & 9.1 \\
\hline 14 & .60 & 27.76 & 27.21 & 16.46 & 14.01 & 6.80 & 3.95 & 2.18 & .95 & .00 & 7039 & $9 . t$ \\
\hline i" & $1 . i 7$ & $24.6=$ & 27.49 & 17.41 & 14.29 & 6.94 & 4.08 & 2.45 & .68 & .27 & 7137 & 9.7 \\
\hline 16 & .45 & $<5.71$ & 23.55 & 19.59 & 14.29 & $7.7 t$ & 4.35 & 2.31 & .68 & .41 & 7371 & $30 . c$ \\
\hline 1.7 & $\therefore .46$ & 22.64 & 23.81 & 20.54 & 15.24 & 8.30 & 4.49 & 1.90 & .54 & .27 & 7427 & $\begin{array}{l}10.1 \\
10.2\end{array}$ \\
\hline$\therefore$ & 3.13 & 17.14 & $t^{3} 3.61$ & 24.76 & 16.07 & $\begin{array}{r}8.71 \\
9.52\end{array}$ & $\begin{array}{l}3.54 \\
4.23\end{array}$ & 1.36 & .41 & .27 & $\begin{array}{l}7565 \\
7897\end{array}$ & 10.7 \\
\hline & 2.45 & 14.24 & 22.72 & 26.94 & $\begin{array}{l}18.23 \\
22.86\end{array}$ & $\begin{array}{l}9.52 \\
8.44\end{array}$ & $\begin{array}{l}4.22 \\
3.40\end{array}$ & $\begin{array}{l}1.36 \\
1.50\end{array}$ & .14 & $\begin{array}{r}.14 \\
00\end{array}$ & 7894 & 10.7 \\
\hline$\angle u$ & a. 64 & 15.51 & $<1.36$ & $\begin{array}{r}24.03 \\
23.99\end{array}$ & $\begin{array}{l}22.86 \\
24.90\end{array}$ & 9.39 & $\begin{array}{l}3.40 \\
2.99\end{array}$ & $\begin{array}{l}1.50 \\
1.63\end{array}$ & $\begin{array}{r}.27 \\
.60\end{array}$ & .00 & 7978 & 10.4 \\
\hline$<1$ & 2.59 & 10.33 & 17.82 & $\begin{array}{r}23.95 \\
23.25\end{array}$ & $\begin{array}{l}24.90 \\
24.63\end{array}$ & 8.84 & 3.67 & $\begin{array}{l}1.63 \\
1.22\end{array}$ & $\begin{array}{l}.00 \\
.00\end{array}$ & .00 & 7888 & $\begin{array}{l}10.9 \\
10.7\end{array}$ \\
\hline$\ll$ & 3.13 & 15.76 & 15.59 & 23.13 & 24.63 & 7.89 & 2.45 & & .14 & .00 & $\begin{array}{l}7888 \\
7629\end{array}$ & 10.4 \\
\hline $\begin{array}{l}<3 \\
<4\end{array}$ & $\begin{array}{l}2.00 \\
2.18\end{array}$ & $\begin{array}{l}17.1 .0 \\
19.05\end{array}$ & $\begin{array}{l}19.59 \\
18.64\end{array}$ & $\begin{array}{l}24.03 \\
23.01\end{array}$ & $\begin{array}{l}24.08 \\
25.58\end{array}$ & 7.07 & $\begin{array}{l}2.43 \\
2.59\end{array}$ & $\begin{array}{r}1.22 \\
.95\end{array}$ & .00 & .14 & 7522 & $\begin{array}{l}10.4 \\
10.2\end{array}$ \\
\hline isL & 2.51 & 21.45 & 23.10 & 22.22 & 18.71 & 7.13 & 3.17 & 1.27 & .35 & .09 & 171618 & 9.7 \\
\hline
\end{tabular}


TABLE 48. Continued

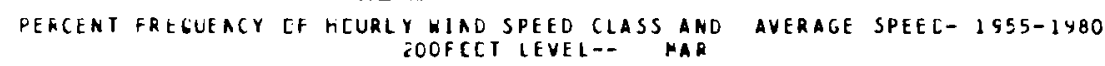

\begin{tabular}{|c|c|c|c|c|c|c|c|c|c|c|c|c|}
\hline riguk & $c$ & $1-3$ & $4-7$ & $8-12$ & $13-18$ & $19-24$ & {$\left[\begin{array}{c}c \text { CLASS } \\
25-31\end{array}\right.$} & $32-38$ & $39-4 t$ & GT .46 & $\begin{array}{l}\text { TOTAL } \\
\text { SPEED }\end{array}$ & $\begin{array}{l}\text { AVG } \\
\text { SPEEC }\end{array}$ \\
\hline 1 & .56 & 7.57 & $\angle 0.35$ & 29.16 & 30.15 & 8.68 & 2.61 & .50 & .37 & .12 & 9402 & 11.7 \\
\hline$\dot{a}$ & .74 & 16.42 & 17.99 & 29.65 & 26.67 & 10.17 & 2.73 & .62 & .37 & .12 & 9264 & 11.5 \\
\hline 3 & .02 & 12.66 & 19.48 & 28.54 & 27.17 & 7.57 & 2.58 & .62 & .37 & .00 & 8954 & 11.1 \\
\hline 4 & 1.12 & 13.90 & 20.72 & 27.05 & 27.42 & 6.70 & 2.23 & .062 & .25 & .00 & $862 \mathrm{C}$ & 10.7 \\
\hline 5 & 1.24 & 15.63 & 21.22 & 25.81 & 23.57 & 8.93 & 3.10 & .025 & .25 & .00 & 8415 & 10.4 \\
\hline 0 & 1.74 & 16.13 & 23.33 & 26.18 & 21.46 & 7.57 & $3.1 \mathrm{C}$ & .37 & .12 & .00 & 8111 & 10.1 \\
\hline 7 & 1.16 & 18.98 & $<2.21$ & 24.44 & 23.20 & 7.07 & 2.61 & .37 & .00 & .00 & 7956 & 9.5 \\
\hline 0 & .74 & $2 i .6 i$ & 24.94 & 34.24 & 18.06 & 7.57 & $\begin{array}{l}2.01 \\
2.48\end{array}$ & .50 & .00 & .00 & 7574 & 9.4 \\
\hline 9 & .49 & 22.21 & 27.79 & 22.13 & 15.14 & 7.69 & 2.98 & .74 & .12 & .00 & 7451 & $9 . \bar{c}$ \\
\hline ن j & .56 & 26.43 & 27.79 & 16.13 & 16.00 & 7.32 & 4.34 & 1.24 & .25 & .00 & 7547 & 9.4 \\
\hline 11 & (37 & 24.57 & 29.53 & 16.63 & $\begin{array}{l}16.00 \\
14.39\end{array}$ & $\begin{array}{l}1.32 \\
6.95\end{array}$ & $\begin{array}{l}4.34 \\
4.71\end{array}$ & $\begin{array}{l}1.24 \\
2.11\end{array}$ & .03 & $\begin{array}{l}.00 \\
.12\end{array}$ & $\begin{array}{l}1341 \\
7805\end{array}$ & $\begin{array}{l}9.4 \\
9.7\end{array}$ \\
\hline 12 & .05 & 22.46 & $3 C .52$ & 17.25 & 13.52 & 7.57 & 5.09 & 2.48 & .84 & .12 & 6165 & 10.1 \\
\hline 3 & $.1 z$ & 37.62 & 35.11 & 16.63 & 13.15 & 7.82 & 6.58 & 1.74 & .95 & .25 & 8507 & $10 . t$ \\
\hline 14 & .25 & 14.52 & 35.73 & $\begin{array}{l}0.03 \\
15.51\end{array}$ & 15.26 & 8.06 & $\begin{array}{l}0.30 \\
7.57\end{array}$ & 2.11 & .67 & .12 & 8932 & $\begin{array}{l}1.6 \\
11.1\end{array}$ \\
\hline 15 & $.6 u$ & $\begin{array}{l}14.52 \\
13.52\end{array}$ & 31.67 & $20 .<2$ & 13.90 & 9.43 & 8.44 & 2.48 & .62 & .12 & 9345 & 11.6 \\
\hline it & $.1 \mathrm{a}$ & 12.15 & 30.77 & 19.23 & 13.90 & 10.17 & 9.43 & 2.73 & .50 & .00 & 9611 & $\begin{array}{l}11.5 \\
11.5\end{array}$ \\
\hline 17 & .37 & 14.06 & 25.56 & $\angle 0.10$ & 15.76 & 11.91 & 9.31 & 2.48 & .50 & .00 & 9839 & $\begin{array}{l}12.3 \\
12.2\end{array}$ \\
\hline jo & .99 & $10.9 \overline{2}$ & $<4.32$ & 22.95 & 17.49 & 12.53 & 8.56 & 1.74 & .37 & .12 & 9963 & 12.4 \\
\hline 19 & 1.24 & 8.44 & 2C. 35 & $c^{3} .70$ & 22.93 & $1 t .00$ & 6.20 & 1.49 & .12 & .12 & 10368 & 12.9 \\
\hline$\therefore$ & .74 & 6.70 & 18.36 & 25.93 & 25.43 & 15.14 & 6.58 & .74 & .37 & .00 & 10526 & 13.1 \\
\hline .1. & .02 & 5.03 & 18.73 & 25.43 & 27.79 & 14.76 & 5.96 & .62 & .25 & .00 & 10535 & 13.1 \\
\hline$\angle 2$ &.$t z$ & 4.16 & $1 t=<5$ & 60.43 & 28.16 & $12 . t t$ & 5.58 & .87 & .25 & .00 & 10172 & $12 . t$ \\
\hline 23 & .97 & 10.30 & 16.87 & 28.91 & 25.93 & 12.41 & 4.47 & .50 & .25 & .00 & 9733 & 12.1 \\
\hline$<4$ & .56 & 0.31 & 20.16 & 29.53 & 28.54 & 8.44 & 3.47 & .87 & .12 & .12 & 9476 & ii. \\
\hline$\therefore M L$ & $.0 t$ & 14.16 & 24.14 & 23.42 & 21.05 & 9.71 & 5.05 & 1.20 & .36 & .06 & 216277 & 11.2 \\
\hline & & & RCENT FR & RE GUEACY & LF FCURL & $\begin{array}{l}Y W \operatorname{LACS} \\
2 C O F C G I\end{array}$ & $\begin{array}{l}\text { FEED CIASS } \\
\text { LEVELL-- }\end{array}$ & $\begin{array}{l}S A R D \\
A P R\end{array}$ & AVERAGE & SPEEL- 1 & $1455-1980$ & \\
\hline & & & & & & $S P E$ & $E[C L A S S$ & & & & & \\
\hline rudk & a & $1-3$ & $4-7$ & $0-12$ & $13-18$ & 19.24 & $25-31$ & $32-38$ & $39-4 t$ & GT.46 & $\begin{array}{l}\text { ICTAL } \\
\text { SPEEL }\end{array}$ & $\begin{array}{l}\text { AVG } \\
\text { SFEEL }\end{array}$ \\
\hline 1 & .19 & 4.87 & 17.56 & i 7.44 & 31.28 & 14.49 & 9.33 & .90 & .00 & .00 & 9977 & $12 . t$ \\
\hline 2 & $. i=$ & t.js & 17.31 & $\therefore 9 . t 2$ & 31.28 & 12.31 & 2.82 & .26 & .13 & .00 & 4639 & 12.2 \\
\hline 3 & 1. & 0.41 & 10.59 & 31.52 & 29.23 & 10.014 & 2.31 & .206 & .13 & .00 & 9265 & 11. \\
\hline 4 & .20 & 10.76 & 19.23 & 27.56 & 30.26 & $\begin{array}{r}16.04 \\
9.36\end{array}$ & 2.05 & .26 & .13 & .00 & $884 c$ & 11.3 \\
\hline$\vdots$ & 1.16 & 13.35 & 20.86 & 24.90 & 27.86 & $\begin{array}{l}9.36 \\
8.99\end{array}$ & 2.02 & .00 & .00 & .00 & 8400 & 10.6 \\
\hline t & 1.41 & 14.06 & 22.05 & 26.19 & 26.03 & $\begin{array}{l}8.99 \\
6.79\end{array}$ & $\begin{array}{l}2.82 \\
1.67\end{array}$ & .64 & .00 & .00 & 4005 & 10. \\
\hline 1 & 1.74 & 17.18 & 24.49 & $<0.21$ & $\begin{array}{l}26.03 \\
21.15\end{array}$ & $\begin{array}{l}0.17 \\
4.23\end{array}$ & $\begin{array}{l}1.67 \\
2.44\end{array}$ & .04 & .13 & .00 & 7350 & 9.2 \\
\hline$c$ & 1.43 & $<4 .<2$ & 22.45 & 22.56 & $\begin{array}{l}21.13 \\
19.49\end{array}$ & $\begin{array}{l}4.23 \\
6.28\end{array}$ & $\begin{array}{l}6.44 \\
2.44\end{array}$ & $\begin{array}{l}.38 \\
1.03\end{array}$ & $.4 c$ & .60 & 7244 & 9.4 \\
\hline , & .64 & 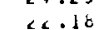 & $2 t . \bar{c} \theta$ & $\angle C D E$ & 17.44 & 8.08 & $\begin{array}{l}2.44 \\
3.85\end{array}$ & $\begin{array}{l}1.03 \\
1.03\end{array}$ & .00 & .00 & 7521 & 9.4 \\
\hline$i i$ & .19 & 24.44 & 28.33 & 16.93 & 15.51 & $7.8 \bar{z}$ & $\begin{array}{l}3.83 \\
4.62\end{array}$ & $\begin{array}{r}.03 \\
.77\end{array}$ &.$c c$ & .00 & 7302 & $\begin{array}{l}9 . t \\
9.4\end{array}$ \\
\hline $\begin{array}{lll}1 \\
.1\end{array}$ & $.0 \mathrm{C}$ & 26.64 & 33.33 & 18.08 & 15.26 & 7.18 & 4.10 & 1.77 & .06 & .00 & $\begin{array}{l}1302 \\
7423\end{array}$ & $\begin{array}{l}9.4 \\
9.5\end{array}$ \\
\hline .2 & $.6 \mathrm{C}$ & $1 \in .41$ & 37.21 & 17.56 & 14.87 & 8.46 & 3.85 & $\begin{array}{l}1.28 \\
1.15\end{array}$ & .13 & .00 & $\begin{array}{l}1423 \\
7641\end{array}$ & 9.5 \\
\hline 43 & .66 & 12.69 & 35.98 & 62.95 & 12.56 & 10.90 & 3.65 & $\begin{array}{l}1.15 \\
1.41\end{array}$ & $\begin{array}{r}.38 \\
.26\end{array}$ & $\begin{array}{l}.00 \\
.00\end{array}$ & $\begin{array}{l}1641 \\
8091\end{array}$ & $\begin{array}{l}9 . \mathrm{E} \\
10.5\end{array}$ \\
\hline$\therefore$ & 13 & 10.26 & 35.51 & 21.67 & 14.87 & 9.49 & 6.28 & 1.41 & $\begin{array}{r}.26 \\
.38\end{array}$ & .00 & 8543 & 10.4 \\
\hline : & $i u$ & 9.36 & 35.13 & 20.26 & 14.74 & 10.26 & $\begin{array}{l}7.60 \\
7.69\end{array}$ & 2.05 & $\begin{array}{r}.38 \\
.51\end{array}$ & .00 & 8503 & 10.9 \\
\hline 14 & .6 & 4.38 & 32.85 & ¿C. & 13.05 & 11.67 & 8.08 & 2.82 & .26 & .00 & $\begin{array}{l}8974 \\
9352\end{array}$ & 11.5 \\
\hline 14 & Lo & 9.08 & 28.33 & 16.85 & 17.05 & 12.05 & 10.26 & 3.59 & $\begin{array}{l}.20 \\
.13\end{array}$ & .00 & $\begin{array}{r}9352 \\
\end{array}$ & 12.6 \\
\hline 17 & .10 & $9.0 c$ & 62.69 & 19.02 & 18.85 & 14.49 & 11.67 & 3.21 & 38 & .13 & 10131 & 13.6 \\
\hline ic & .26 & 9.10 & 10.54 & $3=$ & 28.02 & 17.44 & 9.74 & 2.82 & $\begin{array}{r}-38 \\
.38\end{array}$ & $\begin{array}{l}.00 \\
.13\end{array}$ & $\begin{array}{l}107899 \\
11345\end{array}$ & \\
\hline 14 & .64 & 6.54 & 12.54 & $22+1$ & 2333 & 1974 & 11.79 & 2.31 & .38 & .13 & 11305 & 14.5 \\
\hline$c u$ & .77 & 5.00 & 14.49 & 22.11 & 23.33 & & 110.3 & & .26 & .00 & 11771 & \\
\hline$\therefore 1$ & .28 & 4.36 & 12.18 & 22.95 & 28.08 & 19.49 & 10.13 & 2.18 & $.2 t$ & .00 & 11921 & 15.3 \\
\hline 18 & ס ذد. & 4.74 & 14.10 & 21.67 & 29.36 & 18.72 & 9.74 & 1.28 & .00 & .00 & 11496 & 14.7 \\
\hline 23 & .13 & 4.62 & 15.77 & $21 \cdot 42$ & 32.82 & 17.69 & 5.51 & 1.54 & .60 & .010 & 10960 & 14.1 \\
\hline$i t$ & .64 & 5.30 & 17.69 & 22.95 & 31.79 & 15.77 & 4.74 & .90 & .13 & .00 & 10342 & $13 . j$ \\
\hline ILIAL & .44 & 11.35 & 23.75 & 22.48 & 22.49 & 11.76 & 5.66 & 1.40 & .17 & .01 & 222250 & 11.5 \\
\hline
\end{tabular}


TABLE 48. Continued

PERCENT frequency CF hourly HIAD SPEED CLASS aAd average SPEed-1955-1980

\begin{tabular}{|c|c|c|c|c|c|c|c|c|c|c|c|c|}
\hline r LUK & $i$ & $1-3$ & $4-7$ & $\theta-12$ & $13-18$ & $\begin{array}{c}\text { SPE } \\
19.24\end{array}$ & 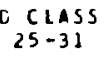 & $32-38$ & $39-46$ & GI.46 & $\begin{array}{l}\text { ICTAL } \\
\text { SPEEL }\end{array}$ & $\begin{array}{l}\text { AVG } \\
\text { SPEEC }\end{array}$ \\
\hline 1 &.$c c$ & 5.83 & 9.68 & 29.90 & 37.59 & 13.52 & 3.35 & .12 & .00 & .00 & 10694 & 13.3 \\
\hline 2 &.+2 & 4.59 & 12.43 & 29.40 & 40.32 & 10.67 & 2.36 & .00 & $.0 c$ & .00 & 10262 & 12.7 \\
\hline$j$ & $.5 c$ & $5.9 t$ & 13.77 & $\equiv 3.75$ & $3 t .35$ & 8.31 & 1.24 & .12 & .00 & .00 & 9669 & 12.6 \\
\hline 4 & .74 & 7.64 & 18.49 & 30.77 & 33.25 & 7.20 & 1.61 & .25 & .00 & .00 & 9201 & 11.4 \\
\hline 5 & 1.24 & 10.79 & 19.73 & 28.16 & 31.51 & 6.70 & 1.36 & .50 & $.0 \mathrm{C}$ & .00 & 8761 & 10.9 \\
\hline c & 1.49 & 12.40 & 22.68 & 30.27 & 27.05 & 5.09 & .87 & .25 & .00 & .00 & 8095 & $10 . c$ \\
\hline 7 & 1.06 & 19.48 & 21.56 & 30.15 & 20.10 & 5.46 & .99 & .00 & .00 & .00 & 7276 & 9.6 \\
\hline 0 & 1.04 & 21.96 & 27.05 & 24.69 & 17.74 & 5.21 & 1.99 & .12 & .00 & .00 & 6995 & 8.7 \\
\hline$y$ &.$<5$ & 25.93 & 30.15 & 22.08 & 14.89 & 4.71 & 1.99 & .00 & $.0 \mathrm{c}$ & .00 & 6521 & 8.1 \\
\hline 36 &.$<5$ & 25.01 & 35.24 & 19.00 & 12.90 & 4.59 & 1.61 & .00 & .00 & .00 & 6227 & 7.7 \\
\hline 11 & .12 & 20.35 & 40.32 & 19.98 & 13.03 & 4.96 & .99 & .25 & .00 & .00 & 6416 & 8.6 \\
\hline 12 & .00 & 14.52 & 44.67 & 20.22 & 13.03 & 5.58 & 1.86 & .12 & $.0 \mathrm{C}$ & .60 & 6795 & 8.4 \\
\hline 13 & .25 & 11.31 & 41.09 & 24.65 & 13.77 & 5.71 & 2.23 & .50 & .00 & .00 & 7206 & 8.5 \\
\hline$i-$ & $\begin{array}{l}.25 \\
.37\end{array}$ & 8.44 & 41.69 & $\begin{array}{l}23.08 \\
23.28\end{array}$ & 17.25 & 5.83 & 2.98 & .25 & .12 & .00 & 7683 & 9. \\
\hline 5 & .25 & 8.06 & 37.97 & 21.84 & 18.73 & 0.19 & 4.09 & .74 & .12 & .00 & 6309 & 10.3 \\
\hline $1 t$ &.$C C$ & 9.66 & 34.12 & 20.04 & 18.24 & 11.04 & 4.71 & 1.24 & .12 & .60 & 8913 & 11.1 \\
\hline 17 & .16 & 16.05 & 27.67 & 22.95 & 17.37 & 12.03 & 6.95 & 2.48 & .37 & .00 & 9728 & 12.1 \\
\hline 10 & .97 & 14.53 & 22.21 & $<1.34$ & 18.86 & 14.39 & 9.06 & 2.98 & .12 & .12 & 10582 & 13.1 \\
\hline 19 & .74 & 7.69 & 17.37 & 22.46 & 18.49 & 18.98 & 12.03 & 2.11 & .12 & .60 & 11507 & 14.1 \\
\hline <1 &.$<5$ & 4.71 & 14.27 & $<0.72$ & 21.24 & 22.83 & 13.40 & 1.74 & .25 & .00 & 12563 & $15 . \mathrm{t}$ \\
\hline$a$ & .10 & 4.22 & 12.10 & 18.24 & $25 .>3$ & 22.46 & 15.01 & 1.86 & .00 & .12 & 13054 & 16.6 \\
\hline$\therefore$ & .23 & 4.41 & 11.41 & 19.73 & 26.55 & 21.96 & 13.52 & 2.11 &.$C C$ & .00 & 12839 & 15.9 \\
\hline$<3$ & .27 & 3.05 & 12.06 & $C 6.10$ & 30.65 & 22.46 & 8.93 & .99 & $.0 C$ & .00 & 12129 & 15.6 \\
\hline$<4$ & .12 & 4.59 & 11.64 & 23.57 & 37.34 & 17.25 & 5.71 & .37 & .00 & .00 & $1139 \mathrm{C}$ & 14.1 \\
\hline$\| A_{2}$ & .40 & 16.47 & 24.14 & 24.11 & 23.45 & 11.05 & 4.95 & $.8 \mathrm{C}$ & .65 & .61 & 222815 & 11.5 \\
\hline
\end{tabular}

PEKCENT FREOUEACY CF HEURLY WIAC SFEEO CLASS AAD AVERAGE SPEEL- $1955-1980$

\begin{tabular}{|c|c|c|c|c|c|c|c|c|c|c|c|c|}
\hline \multirow[b]{2}{*}{ ネしい } & \multirow{2}{*}{6} & \multirow{2}{*}{$1-3$} & \multirow{2}{*}{$4-7$} & \multirow{2}{*}{$8-1 \tilde{z}$} & \multirow{2}{*}{$13-18$} & \multicolumn{2}{|c|}{ SPEEL CLASS } & \multirow{2}{*}{$32-38$} & \multirow{2}{*}{$39-46$} & \multirow{2}{*}{ GT.46 } & \multirow{2}{*}{$\begin{array}{l}\text { ICTAL } \\
\text { SPEEC }\end{array}$} & \multirow{2}{*}{$\begin{array}{l}\text { AVG } \\
\text { SPEEC }\end{array}$} \\
\hline & & & & & & $19-24$ & $25-31$ & & & & & \\
\hline 1 &. .3 & 3.31 & 11.28 & 20.77 & 38.08 & 21.28 & 4.49 & .00 & .00 & $.0 \mathrm{C}$ & 11209 & 14.4 \\
\hline$<$ & $.6 u$ & 3.06 & 12.05 & $28 .<1$ & 38.59 & 16.03 & 2.05 & .00 & .00 & .00 & 10472 & 13.4 \\
\hline ; & .60 & 4.74 & 12.56 & 31.54 & 38.85 & 11.28 & 1.63 & .00 & $.0 \mathrm{c}$ & .60 & 9752 & 12.5 \\
\hline 4 & .06 & 5.51 & 10.28 & $3 j .08$ & 36.67 & 7.05 & $.9 \mathrm{C}$ & .26 &. $\mathrm{CC}$ & .00 & $910<$ & 11.7 \\
\hline , & . Si & 7.69 & 10.08 & 33.33 & 32.44 & 0.54 & .90 & .13 & .00 & .00 & 8622 & 11.1 \\
\hline$\Rightarrow$ & 1.41 & 13.21 & 23.46 & 30.13 & 27.44 & 3.48 & 1.28 & .00 & .60 & .00 & 7590 & 9.7 \\
\hline 7 & 1.15 & 18.55 & 22.44 & 29.74 & 21.54 & 6.03 & .38 & .13 &. $\mathrm{CC}$ & $.0 \mathrm{C}$ & 7170 & 9.6 \\
\hline c & . 28 & $21 .<8$ & 28.21 & $\angle 5.00$ & 18.46 & 5.04 & .90 & .13 & .00 & $.0 \mathrm{c}$ & 6777 & 6.7 \\
\hline$y$ & .04 & 22.09 & 35.51 & 22.44 & 13.85 & 4.36 & .51 & .00 & .00 & .00 & 6071 & 7.6 \\
\hline$₫ i$ & .13 & 22.31 & 41.67 & 20.38 & 12.18 & 2.95 & .38 &. $\mathrm{CO}$ & .00 & .00 & 5745 & 7.4 \\
\hline 11 & .46 & 13.21 & 49.62 & $<0.77$ & 12.05 & & .90 & .00 & .00 & .00 & $002 t$ & 7.7 \\
\hline ic & .13 & 7.49 & 48.85 & 23.97 & 12.69 & 3.46 & 1.41 & .00 & .00 & .00 & 6393 & 8.6 \\
\hline 13 & .13 & 6.92 & 48.05 & 23.97 & 14.36 & 3.72 & 2.05 & .00 & .00 & .00 & $672 \mathrm{C}$ & $0 . \mathrm{e}$ \\
\hline 14 & .66 & 4.07 & 44.62 & 28.46 & 13.21 & 6.03 & 2.69 & .13 & $.0 \mathrm{C}$ & .60 & 7364 & 9.4 \\
\hline 13 & .13 & 7.05 & 42.18 & 23.59 & 15.90 & 6.92 & 3.46 & .77 & .00 & .00 & 7734 & 9.5 \\
\hline 16 &.$c c$ & 6.67 & 56.92 & 23.85 & 16.41 & 9.49 & 5.38 & 1.03 & .26 & .00 & 6511 & 10.5 \\
\hline$\$ 7$ & .60 & 7.05 & 31.03 & 23.08 & 17.05 & 10.77 & 8.33 & 2.31 & .38 & .00 & 9572 & $12 .=$ \\
\hline 18 & .13 & 5.64 & 24.36 & 22.44 & 15.64 & 16.28 & 11.79 & 3.59 & .13 & .00 & 11051 & 14.2 \\
\hline 14 &.$C O$ & 4.23 & 16.92 & 22.31 & 16.15 & 21.41 & 14.87 & 4.10 & .00 & .00 & 12363 & $15 . \mathrm{t}$ \\
\hline ¿l & .51 & 3.08 & 13.72 & 20.26 & 17.44 & 23.08 & 18.08 & 3.72 & .13 & .00 & 13099 & 16.8 \\
\hline$<1$ & .26 & $2.5 t$ & 10.77 & 17.44 & 20.38 & 25.51 & 20.13 & 2.82 & .13 & .00 & 13621 & 17.5 \\
\hline$\angle 2$ & .00 & 3.72 & 10.77 & 15.51 & 21.28 & 28.21 & 17.82 & 2.69 & $.0 \mathrm{C}$ & .00 & 13652 & 17.5 \\
\hline$<3$ & .13 & 4.23 & 8.72 & $15.2 t$ & 27.05 & 29.87 & 13.46 & 1.03 & .26 & .00 & 13134 & $16 . E$ \\
\hline 44 & .30 & 3.33 & 9.62 & 18.72 & 33.46 & 24.74 & 5.36 & .38 & .00 & .00 & 12128 & 15.5 \\
\hline ILIAL &.$<0$ & 8.55 & 25.77 & 23.93 & 22.13 & 12.38 & 5.94 & .97 & .05 & .00 & 223878 & $12 . c$ \\
\hline
\end{tabular}


TABLE 48. Continued

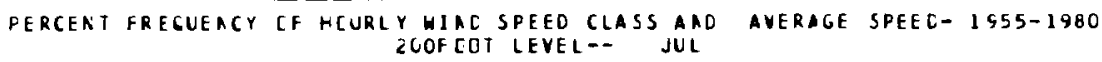

\begin{tabular}{|c|c|c|c|c|c|c|c|c|c|c|c|c|}
\hline \multirow{2}{*}{ ruUk } & \multirow{2}{*}{ c } & \multirow{2}{*}{$1-3$} & \multirow{2}{*}{$4-7$} & \multirow{2}{*}{$8-12$} & \multirow{2}{*}{$13-18$} & \multicolumn{2}{|c|}{ SPEEC CLASS } & \multirow{2}{*}{$32-38$} & \multirow{2}{*}{$39-46$} & \multirow{2}{*}{ GT. 46} & \multirow{2}{*}{$\begin{array}{l}\text { IOTAL } \\
\text { SPEEU }\end{array}$} & \multirow{2}{*}{$\begin{array}{c}\text { AVG } \\
\text { SPEE }\end{array}$} \\
\hline & & & & & & & & & & & & \\
\hline 1 & .12 & 3.10 & 8.19 & 23.33 & 42.80 & 18.98 & 3.23 & .25 & .00 & .00 & 11707 & 14.5 \\
\hline 2 & .06 & 2.11 & 10.05 & 26.67 & 45.91 & 13.52 & 1.49 & .25 &.$D C$ & .00 & 11104 & 13.6 \\
\hline 3 & .12 & 3.72 & 12.03 & 30.40 & 42.68 & 10.67 & .25 & .00 & .12 & .00 & 10230 & 12.7 \\
\hline 4 & .37 & 5.33 & 13.77 & 34.74 & 37.97 & 7.32 & .37 & .12 & .00 & .00 & 5566 & 11.5 \\
\hline 5 & .15 & 6.63 & 17.89 & 34.66 & 33.42 & $t .09$ & .37 & .00 & .00 & .00 & 8963 & 11.1 \\
\hline 6 & .12 & 10.31 & 23.23 & 34.41 & 28.32 & 3.11 & .12 & .37 & .00 & .00 & 8000 & 9.9 \\
\hline 7 & .62 & 14.52 & 29.53 & 34.24 & 17.74 & 2.61 & .74 & .60 & $.0 \mathrm{C}$ & .00 & $700 \mathrm{~d}$ & 8.7 \\
\hline 0 & .37 & 17.67 & $35.4 \theta$ & 28.54 & 13.65 & 3.10 & .99 & .00 & .00 & .00 & 6498 & 8. 1 \\
\hline 5 & .60 & 29.10 & 41.17 & 17.06 & 8.21 & 3.36 & $.5 \mathrm{C}$ & .60 & .00 & .00 & 5305 & $6 . t$ \\
\hline li & .25 & 31.06 & 46.09 & 12.92 & 7.20 & 1.74 & .75 & .00 & $.0 \mathrm{c}$ & .00 & 4956 & 6.2 \\
\hline i1 & .25 & 21.16 & 5.5 .51 & 15.02 & $t .71$ & 2.48 & .37 & .12 & .00 & .00 & 5175 & 6.4 \\
\hline 12 & .12 & 15.80 & 55.71 & 17.99 & 6.95 & 2.48 & .62 & .12 & .00 & .12 & 5554 & 6.5 \\
\hline 13 & .06 & 12.78 & 52.85 & 20.97 & 10.17 & 1.99 & .99 & .25 & .00 & .00 & 6018 & 7.5 \\
\hline 14 & .06 & 7.94 & 52.85 & 21.96 & 13.03 & 2.61 & 1.36 & .25 & .00 & .00 & 6531 & 8.1 \\
\hline is & .60 & 7.32 & 48.01 & 24.32 & 12.90 & 5.33 & 1.61 & .37 & .12 & .00 & $711 \%$ & B. \\
\hline & .06 & 6.44 & 43.18 & 23.70 & 14.64 & 5.71 & 3.60 & .62 & .12 & .00 & 7666 & 9.5 \\
\hline 17 & .0 & 9.55 & 35.36 & 23.45 & 17.00 & 8.19 & 5.33 & .99 & .12 & .00 & 8529 & $10 . \mathrm{t}$ \\
\hline iy & .12 & 8.93 & 28.16 & 25.21 & 15.63 & 11.54 & 8.68 & 1.61 & .00 &.$O C$ & 9752 & 12.1 \\
\hline 19 & .12 & 0.00 & 21.34 & 25.19 & 16.87 & 15.38 & 13.40 & 1.61 & .00 & .00 & 11290 & 14.0 \\
\hline ¿c & .37 & 3.35 & 15.76 & 24.69 & 15.26 & 20.97 & 17.12 & 2.36 & .12 & .00 & $1<770$ & 15.8 \\
\hline a & .50 & 3.47 & 11.41 & 18.24 & 16.87 & 25.93 & 21.09 & 2.48 & .00 & .00 & 13964 & 17.3 \\
\hline 22 & 32 & 3.65 & 10.67 & 15.76 & 18.98 & 26.05 & 21.34 & 2.98 & .12 & .12 & 14326 & 17.0 \\
\hline$<3$ & 32 & 3.47 & 10.30 & 15.41 & 25.43 & 29.28 & 15.01 & 1.36 & .00 & .00 & 13622 & 16.4 \\
\hline 24 & .05 & 3.16 & 8.19 & 19.48 & 34.49 & 27.17 & 7.20 & .12 & $.0 \mathrm{C}$ & .60 & 12582 & $15 . \mathrm{t}$ \\
\hline LAAL & ن 20 & 9.96 & 28.54 & 23.69 & 20.95 & 10.65 & 5.27 & .68 & .03 & .01 & $218<34$ & 11.3 \\
\hline
\end{tabular}

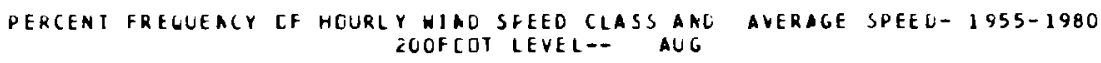

\begin{abstract}
SPEEC CLASS
\end{abstract}

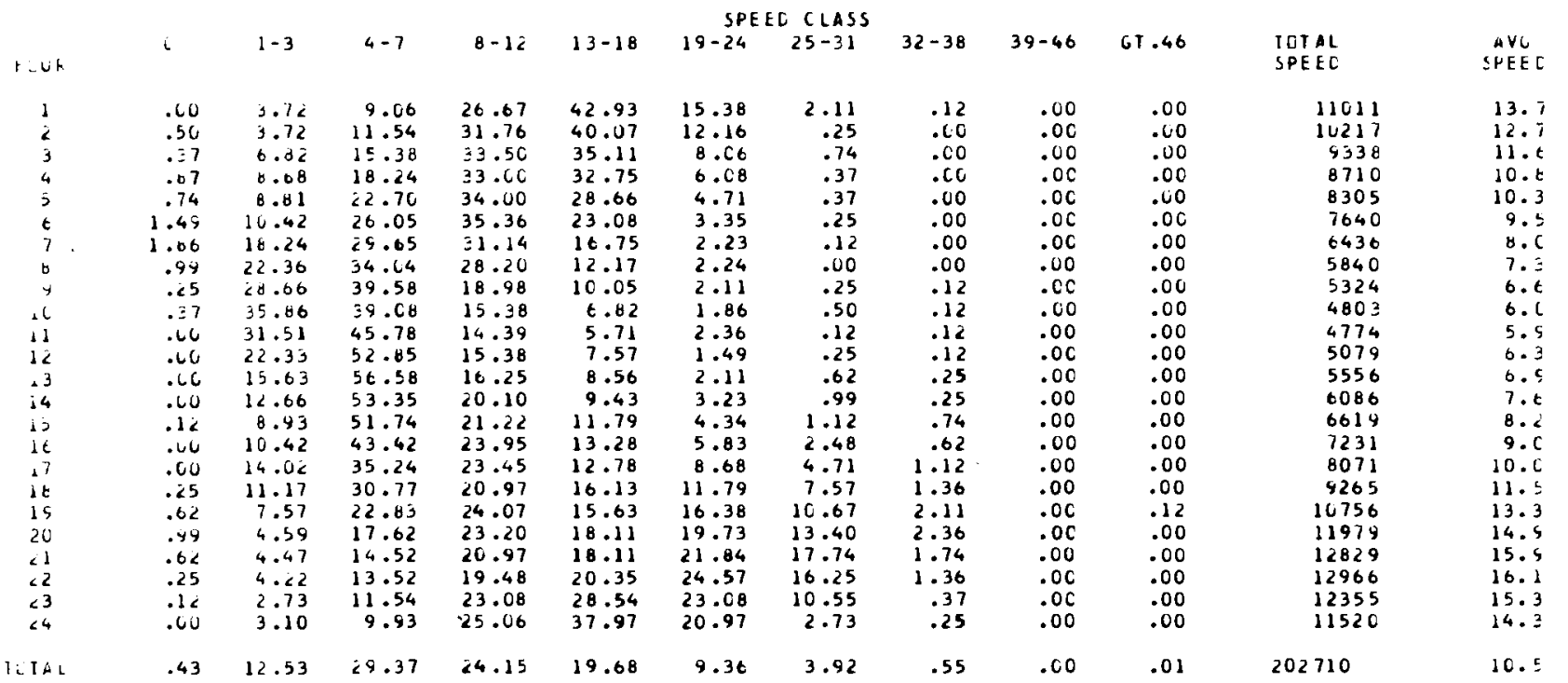


TABLE 48. Continued

PERCENi frequeACY CF hCURLY WIAD SPEED CLASS ARD aVERAGe SPEEL- $1555-1980$

\begin{tabular}{|c|c|c|c|c|c|c|c|c|c|c|c|c|}
\hline$r\left[c_{k}\right.$ & c & $1-3$ & $4-7$ & $8-12$ & $13-10$ & $\begin{array}{c}\text { SPE } \\
19-24\end{array}$ & $\begin{array}{c}\text { CLASS } \\
25-31\end{array}$ & $32-38$ & $39-46$ & GT.46 & $\begin{array}{l}\text { TOT AL } \\
\text { SPEED }\end{array}$ & $\begin{array}{l}\text { AVG } \\
\text { SPEEE }\end{array}$ \\
\hline 1 & .38 & 6.79 & 17.69 & 30.77 & 32.69 & 10.00 & 1.54 & .13 & $.0 \mathrm{C}$ & .00 & 9120 & 11.7 \\
\hline$\frac{1}{2}$ & 1.03 & 8.72 & 21.03 & 28.85 & 31.79 & 7.69 & $\begin{array}{l}1.34 \\
.90\end{array}$ & .00 & .00 & .00 & 8545 & 11.0 \\
\hline 3 & 1.15 & 11.67 & 21.54 & 27.95 & 29.23 & 0.79 & 1.41 & .26 & .00 & .00 & 8207 & 10.5 \\
\hline 4 & 2.31 & 12.95 & 23.59 & 25.13 & 28.33 & 0.15 & 1.41 & .13 & .00 & .00 & 7868 & 10.1 \\
\hline 5 & 3.21 & 17.31 & 20.13 & 27.82 & 25.26 & 5.26 & .90 & .13 & .00 & .00 & 7417 & 9.5 \\
\hline$t$ & 2.69 & 17.95 & 22.18 & 29.87 & 20.90 & 4.87 & 1.41 & .13 & .00 & .00 & 7072 & 9.1 \\
\hline 7 & $\begin{array}{l}2.07 \\
2.55\end{array}$ & 19.62 & $2 t .03$ & 28.97 & 18.33 & 3.08 & 1.03 & .00 & .00 & .00 & 6515 & 8.4 \\
\hline 8 & 2.69 & 27.82 & 27.18 & 25.38 & 12.18 & 3.59 & .64 & .51 & .00 & .00 & 5839 & 7.5 \\
\hline 9 & .51 & 30.38 & 32.18 & 20.26 & 9.87 & 5.26 & 1.28 & .26 & .00 & .00 & 5704 & 7.3 \\
\hline 10 & .13 & 33.08 & 31.54 & 18.72 & 10.38 & 3.85 & 2.05 & .26 & .00 & .00 & 5584 & 7.2 \\
\hline i1 & .36 & 30.90 & 35.64 & 18.08 & 9.36 & 3.59 & 1.79 & .26 & .00 & .00 & 5529 & 7.1 \\
\hline 12 & .13 & 23.46 & 43.85 & 16.28 & 10.64 & 3.21 & 2.05 & .26 & .13 & .00 & 5719 & $7 .=$ \\
\hline 13 & .13 & 21.03 & 45.51 & 10.67 & 9.36 & 4.23 & 2.31 & .77 & .00 & .00 & 6055 & 7.8 \\
\hline 14 & .00 & 20.51 & 43.46 & 18.08 & 10.00 & 4.62 & 2.82 & .51 & $.0 \mathrm{C}$ & .00 & 0226 & B.C \\
\hline 15 & .00 & 20.13 & 41.15 & 16.54 & 12.05 & 6.28 & 3.33 & .38 & .13 & .00 & 6669 & 0.5 \\
\hline 16 & .00 & 18.08 & 38.46 & 18.33 & 11.92 & 7.82 & 4.49 & .77 & .13 & .00 & 7262 & 9.3 \\
\hline 17 & .51 & 18.97 & 31.03 & 20.00 & 12.56 & 9.87 & 6.54 & .38 & .13 & .00 & 7865 & 10.1 \\
\hline 10 & 1.67 & 12.05 & 29.87 & 21.67 & 14.62 & 10.51 & 9.49 & .13 & .00 & .00 & 8730 & 11.2 \\
\hline i 9 & $1 .<0$ & 8.46 & 23.59 & 27.82 & 15.51 & 14.23 & 8.46 & .64 & .00 & .00 & 9451 & 12.1 \\
\hline < &.$t 4$ & 7.18 & 19.07 & ¿7.5t & 19.87 & 15.77 & 8.46 & .64 & .00 & .00 & $1007 \mathrm{C}$ & 12.5 \\
\hline$<1$ &.$<0$ & 6.67 & 18.45 & 27.56 & 23.59 & 16.54 & 5.51 & $\begin{array}{l}1.04 \\
1.03\end{array}$ & .00 & .00 & 10006 & 12.9 \\
\hline$\angle 2$ & .26 & 0.15 & 18.33 & 30.51 & 24.87 & 13.72 & 5.13 & 1.03 & .00 & .00 & 9809 & $12 . t$ \\
\hline 13 &.$<6$ & 5.51 & 17.69 & 32.05 & 28.97 & 11.92 & 3.46 & .13 & .00 & .00 & 9490 & 12.2 \\
\hline 24 & .34 & 0.41 & 15.38 & 35.11 & 30.64 & 10.13 & 1.67 & .26 & .00 & .00 & 9259 & 11.5 \\
\hline$L I A L$ & .46 & 10.32 & 27.74 & 24.58 & 18.87 & 7.87 & 3.25 & .37 & .02 & .00 & 184091 & 9. $\mathrm{e}$ \\
\hline
\end{tabular}

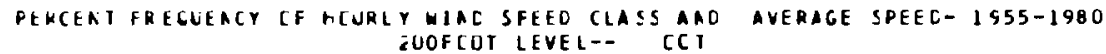

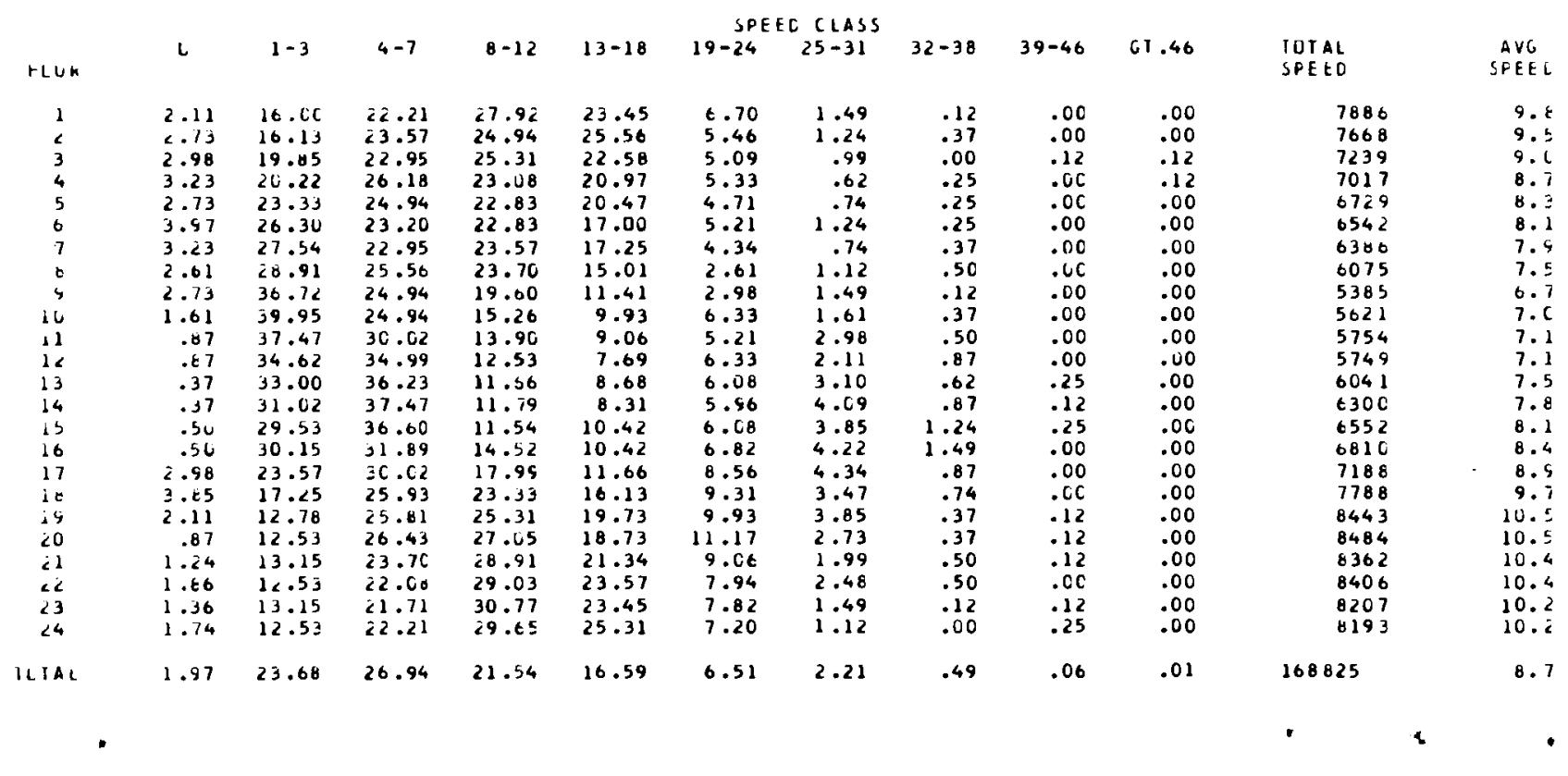


TABLE 48. Continued

PERCENT FREQUEACY CF HCURLY WIAD SPEED CLASS AMD AYERAGE SPEED-1955-1980 ZOOF COT LEVEL-- ROV

\begin{tabular}{|c|c|c|c|c|c|c|c|c|c|c|c|c|}
\hline rluk & C & $1-3$ & $4-7$ & $8-12$ & $13-18$ & $\begin{array}{c}\text { SPE } \\
19-24\end{array}$ & $\begin{array}{l}\text { CLASS } \\
25-31\end{array}$ & $32-38$ & $39-46$ & GT.46 & 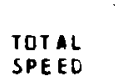 & $\begin{array}{l}\text { AVG } \\
\text { SPEEL }\end{array}$ \\
\hline$\frac{1}{2}$ & 4.14 & 19.10 & 27.05 & 25.51 & 16.67 & 4.62 & $\begin{array}{r}2.18 \\
1.54\end{array}$ & .38 & .38 & .00 & 6819 & 8.7 \\
\hline $\begin{array}{l}2 \\
3\end{array}$ & $\begin{array}{r}3.59 \\
3.46\end{array}$ & $\begin{array}{l}23.72 \\
24.02\end{array}$ & $\begin{array}{l}23.05 \\
25.38\end{array}$ & $\begin{array}{l}22.56 \\
21.7\end{array}$ & $\begin{array}{l}18.72 \\
16.92\end{array}$ & & $\begin{array}{l}1.54 \\
2.44\end{array}$ & $\begin{array}{l}.51 \\
.64\end{array}$ & $\begin{array}{l}.26 \\
.0 c\end{array}$ & .00 & $\begin{array}{l}6735 \\
6588\end{array}$ & $\begin{array}{l}8 . t \\
8.4\end{array}$ \\
\hline 4 & $\begin{array}{l}3.46 \\
4.36\end{array}$ & 25.77 & 22.95 & 23.21 & $\begin{array}{l}10.98 \\
16.15\end{array}$ & 4.23 & $\begin{array}{l}1.44 \\
1.92\end{array}$ & $\begin{array}{l}1.04 \\
1.28\end{array}$ & .13 & .00 & 6513 & 8.3 \\
\hline 5 & 4.74 & 23.97 & 25.00 & 20.64 & 17.95 & 4.49 & 2.05 & .90 & & .00 & 6597 & 8.5 \\
\hline 6 & 4.23 & 26.28 & 24.16 & 22.31 & 15.00 & 5.00 & 2.44 & .13 & .51 & .00 & 6425 & $8 . i$ \\
\hline & $\begin{array}{l}3.65 \\
3.3 .3\end{array}$ & $\begin{array}{l}27.31 \\
28.85\end{array}$ & $\begin{array}{l}25.13 \\
25.51\end{array}$ & $\begin{array}{l}22.02 \\
2.05\end{array}$ & $\begin{array}{l}13.05 \\
15.00\end{array}$ & $\begin{array}{l}4.87 \\
3.21\end{array}$ & $\begin{array}{l}1.28 \\
1.54\end{array}$ & $\begin{array}{r}.64 \\
.38\end{array}$ & $\begin{array}{r}.26 \\
.13\end{array}$ & .00 & $\begin{array}{l}6134 \\
5986\end{array}$ & 7.7 \\
\hline$\Rightarrow$ & & $\begin{array}{l}8.83 \\
28.63\end{array}$ & $\begin{array}{l}3.51 \\
25.89\end{array}$ & 22.85 & 12.58 & 3.34 & 1.80 & .51 & .13 & .00 & 5818 & 7.5 \\
\hline & 5.01 & 33.38 & 24.52 & 17.84 & 11.60 & 4.36 & 2.05 & .90 & .26 & .00 & 5675 & 7.3 \\
\hline 11 & 3.46 & 37.56 & 25.64 & 13.21 & 9.74 & 4.87 & 4.10 & 1.15 & .26 & .00 & 5820 & 7.5 \\
\hline 12 & 2.44 & 37.95 & 23.45 & 15.64 & $\begin{array}{r}8.59 \\
9.74\end{array}$ & 6.54 & 3.72 & $\begin{array}{r}.90 \\
1.28\end{array}$ & $\begin{array}{r}.38 \\
-38\end{array}$ & .00 & 5999 & 7.7 \\
\hline 14 & $\begin{array}{l}2.42 \\
2.04\end{array}$ & & & 15.13 & 9.74 & 5.64 & 3.46 & 1.92 & 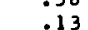 & .00 & 6182 & 7.9 \\
\hline is & $z .8 \bar{z}$ & 34.23 & 27.44 & 14.62 & 10.38 & 5.38 & 3.59 & 1.28 & .13 & & 6076 & $7 . \varepsilon$ \\
\hline it & 5.38 & 29.74 & 26.54 & 16.67 & 10.13 & 6.54 & 3.85 & .64 & .38 & .13 & 6203 & $8 . \mathrm{C}$ \\
\hline 17 & 6.03 & 23.72 & 27.95 & 18.59 & 13.59 & $\begin{array}{l}5.38 \\
7.56\end{array}$ & 3.59 & .64 & .38 & .13 & 6546 & 8.4 \\
\hline $\begin{array}{l}18 \\
19\end{array}$ & 3.78 & 19.62 & 87.95 & 10.54 & 18.08 & $\begin{array}{l}6.96 \\
6.92\end{array}$ & & .51 & 260 & & 6895 & \\
\hline & & 240.38 & 25.13 & 25.90 & 17.31 & 5.77 & & .26 & .00 & & & \\
\hline 1 & 2.95 & 21.28 & 23.72 & 25.77 & 17.56 & 5.90 & 2. & .64 & .13 & .00 & 7016 & 9.6 \\
\hline$\angle 2$ & 4.36 & 16.59 & 24.87 & 25.51 & 19.62 & 4.36 & 2.31 & .26 & .13 & .00 & $688 \mathrm{a}$ & .t \\
\hline $\begin{array}{l}23 \\
<4\end{array}$ & 3.72 & 26.13 & $\begin{array}{l}4.36 \\
6.23\end{array}$ & $\begin{array}{r}25.51 \\
23.85\end{array}$ & & 5.00 & & $\begin{array}{r}-38 \\
.38\end{array}$ & .00 & $\begin{array}{l}.13 \\
.00\end{array}$ & $\begin{array}{l}6911 \\
6896\end{array}$ & $\begin{array}{l}8.5 \\
8.9\end{array}$ \\
\hline 44 & 3.74 & 26.52 & 5.05 & 20.70 & 14.70 & 5.24 & 2.45 & 7 & .22 & .03 & 154611 & 8.2 \\
\hline
\end{tabular}

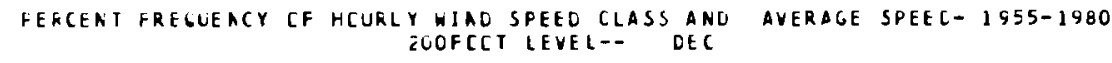

\begin{tabular}{|c|c|c|c|c|c|c|c|c|c|c|c|c|}
\hline \multirow[b]{2}{*}{$-1.6 k$} & \multicolumn{12}{|c|}{ SPEEC CLASS } \\
\hline & $i$ & $1-3$ & $4-7$ & $0-12$ & $13-18$ & $19-24$ & $25-31$ & $32-38$ & $39-4 t$ & GT .46 & $\begin{array}{l}\text { TUTAL } \\
\text { SPEEU }\end{array}$ & $\begin{array}{c}\text { AVG } \\
\text { SHEEC }\end{array}$ \\
\hline 1 & 4.34 & $<3.33$ & 23.68 & 21.34 & 18.36 & 6.00 & 2.11 & .74 & .62 & .00 & 7220 & 9.6 \\
\hline 2 & 4.04 & $<2.50$ & 24.94 & 21.59 & 16.13 & 5.83 & 2.73 & .74 & .50 & .12 & 7161 & 8.9 \\
\hline 3 & 5.96 & $\leq 3.95$ & $c 2.50$ & $21 \cdot 09$ & 17.12 & 4.84 & 2.98 & .99 & .25 & .25 & 7069 & 8.t \\
\hline 4 & 5.05 & 25.50 & 21.46 & 22.33 & 16.87 & 4.64 & 2.36 & 1.12 & .12 & .25 & 6953 & $8 . t$ \\
\hline 5 & 3.85 & $\angle 5.01$ & 21.64 & $23 \cdot 33$ & 16.25 & 5.21 & 2.11 & 1.36 & .00 & .25 & 7031 & 8.7 \\
\hline 6 & 4.54 & 25.15 & 22.63 & 24.32 & 14.89 & 4.09 & 2.98 & .87 & .25 & .00 & 6824 & 8. 5 \\
\hline 7 & 5.11 & 24.36 & 25.43 & 22.21 & 14.39 & 4.84 & 2.11 & .62 & .37 & .00 & 0599 & 8.2 \\
\hline 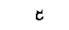 & 4.24 & 27.30 & $23.7 \mathrm{C}$ & $\overline{c u} \cdot \bar{c} 2$ & 16.50 & 4.22 & 2.23 & .50 & .50 & .00 & 6530 & 8.1 \\
\hline , & 4.84 & $<5.19$ & $2 t .43$ & 21.46 & 13.77 & 4.96 & 2.36 & .62 & .37 & .60 & 6565 & $8 . j$ \\
\hline Li & 4.55 & 29.90 & 25.31 & 19.85 & 12.03 & 4.09 & 2.85 & 1.24 & $.0 \mathrm{C}$ & .12 & 6254 & $7 . \varepsilon$ \\
\hline il & 3.60 & 34.24 & 23.95 & 17.62 & 12.28 & 4.34 & 1.99 & 1.36 & .50 & .12 & 6212 & 7.7 \\
\hline 12 & 3.47 & 32.75 & 22.62 & 19.11 & 11.29 & 3.97 & $3 . \in 0$ & 1.61 & .37 & .00 & 6419 & 8.6 \\
\hline 13 & 3.06 & 33.75 & 24.69 & 15.88 & 10.30 & 5.96 & 4.34 & .87 & $.5 \mathrm{C}$ & .12 & 6567 & 8.1 \\
\hline 14 & 4.59 & 34.12 & 21.56 & 16.50 & 10.05 & 6.45 & 3.97 & 1.74 & .37 & .25 & 6658 & 8.3 \\
\hline is & 4.34 & 32.75 & 23.95 & 17.37 & 10.05 & 5.71 & 3.60 & 1.61 & .50 & .12 & 6556 & 8.1 \\
\hline 16 & 4.22 & 29.65 & 24.19 & 19.73 & 11.79 & 5.96 & 2.48 & 1.64 & .62 & .12 & 6643 & $8 . i$ \\
\hline 17 & 5.58 & 24.44 & 25.81 & 19.35 & 14.52 & 5.71 & 2.85 & 1.36 & .25 & .12 & 6683 & 8.5 \\
\hline 14 & t.c. & 22.08 & 25.19 & 20.35 & 15.38 & 5.96 & 3.60 & 1.12 & .25 & .00 & 7061 & B.E \\
\hline 14 & 4.84 & 21.34 & $27.4 a$ & 19.11 & 17.49 & 4.71 & 3.47 & 1.36 & .12 & .12 & 7221 & 9.6 \\
\hline$<6$ & 4.59 & $=2.08$ & 24.19 & $<1.22$ & 16.87 & 5.96 & 3.72 & 1.12 & .25 & .00 & 7329 & 9.1 \\
\hline$a$ & 5.58 & 20.35 & 22.58 & 23.95 & 16.87 & 6.20 & 3.47 & .62 & .37 & .00 & 7370 & 9.1 \\
\hline 22 & 5.69 & 20.64 & $23.7 \mathrm{C}$ & 22.21 & 17.62 & 5.96 & 3.47 & .99 & .12 & .00 & 7339 & 9.1 \\
\hline$<\overline{3}$ & 4.22 & 23.95 & 22.46 & 21.46 & 17.87 & 6.20 & 2.48 & .74 & .50 & .12 & 7308 & 9.1 \\
\hline$<^{4}$ & 4.47 & 23.33 & 22.38 & 21.59 & 18.24 & 6.33 & 1.99 & 1.12 & .25 & .12 & 7173 & 8.9 \\
\hline ILIAL & 4.70 & 26.20 & 23.92 & 20.55 & 14.87 & 5.35 & 2.91 & 1.07 & .33 & .09 & 164950 & 8.5 \\
\hline
\end{tabular}


TABLE 48. Continued

PERCENT FRECUEACY CF HCURLY WIMD SPEED CLASS ANO AVERAGE SPEEC- $1955-1980$

\begin{tabular}{|c|c|c|c|c|c|c|c|c|c|c|c|c|}
\hline ruUk & $c$ & $1-3$ & $4-7$ & $8-12$ & $13-18$ & $19-24$ & $\begin{array}{c}\text { CLASS } \\
25-31\end{array}$ & $32-38$ & $39-4 t$ & 61.46 & $\begin{array}{l}\text { TOTAL } \\
\text { SPEED }\end{array}$ & $\begin{array}{l}\text { AVG } \\
\text { SPEEC }\end{array}$ \\
\hline 1 & 1.36 & 11.34 & 17.32 & $\begin{array}{l}25.76 \\
66.90\end{array}$ & 29.69 & 11.06 & 2.62 & .46 & .16 & .01 & 109722 & $11 . t$ \\
\hline s & 1.62 & $11 \cdot 23$ & 17.58 & 26.90 & 29.67 & 9.23 & 1.90 & .38 & .14 & .04 & 105545 & 11.1 \\
\hline $\begin{array}{l}3 \\
4\end{array}$ & 1.46 & 13.43 & 19.19 & 27.51 & 28.15 & 7.41 & 1.77 & .41 & .12 & .06 & 200672 & $10 . t$ \\
\hline $\begin{array}{l}4 \\
5\end{array}$ & 2.23 & 14.95 & $2 C .52$ & 27.25 & 26.44 & 6.35 & 1.62 & .48 & .11 & .04 & $\begin{array}{l}9652 C \\
\end{array}$ & 10.2 \\
\hline $\begin{array}{l}5 \\
6\end{array}$ & 2.35 & 16.27 & 21.03 & 26.66 & 24.59 & 6.03 & $1.7 c$ & .43 & .09 & .04 & 93172 & 9.8 \\
\hline $\begin{array}{l}6 \\
7\end{array}$ & 2.52 & 16.11 & 23.24 & 27.66 & 21.27 & 5.04 & 2.65 & - 36 & .14 & & 88166 & 9.3 \\
\hline ? & $2 . t 2$ & 21.30 & 24.46 & 26.68 & 18.34 & 4.80 & 1.36 & .33 & .08 & .02 & 82446 & 8.7 \\
\hline - & 2.13 & 24.17 & 26.70 & 24.34 & 16.15 & 4.47 & 1.52 & .44 & .08 & .01 & 78768 & 8.3 \\
\hline 9 & 1.95 & 26.64 & 30.06 & 21.28 & 13.01 & 4.72 & 1.83 & .42 & .08 & .01 & $7478 y$ & 7.5 \\
\hline 10 & 1.73 & 29.87 & 31.65 & 18.23 & 11.70 & 4.50 & 2.22 & .56 & .13 & .02 & 72474 & $7 . t$ \\
\hline 11 & 1.15 & 27.58 & 34.68 & 17.45 & 16.99 & 4.60 & 2.29 & .78 & .20 & .04 & 73657 & $7 . \varepsilon$ \\
\hline 12 & .91 & 24.10 & 37.79 & 17.56 & 10.81 & 5.09 & 2.55 & .87 & .27 & .04 & 76563 & 8.1 \\
\hline 13 & .75 & 21.71 & $38: 35$ & 18.07 & 11.26 & 5.50 & 3.06 & .91 & .32 & .07 & 80387 & 8.5 \\
\hline 14 & .96 & 19.76 & 37.47 & 18.69 & 12.23 & 5.88 & 3.68 & 1.05 & .29 & .05 & 84248 & 8.5 \\
\hline 15 & .57 & 18.88 & 35.85 & 18.93 & 12.93 & 6.71 & 4.10 & 1.27 & .28 & .07 & 87865 & 9.2 \\
\hline 16 & 1.25 & 18.47 & 32.69 & 19.87 & 13.40 & 7.84 & 4.74 & 1.37 & .31 & .05 & 92239 & 9.7 \\
\hline 17 & 2.00 & 16.77 & 20.89 & 20.76 & 14.94 & 8.93 & 5.77 & 1.61 & .25 & .06 & 58695 & 10.4 \\
\hline is & 2.13 & 13.94 & 25.98 & 21.81 & 16.65 & 10.86 & 6.82 & 1.57 & .29 & .06 & 106692 & 11.2 \\
\hline 19 & 1.82 & 11.58 & 22.21 & 23.44 & 18.37 & 13.08 & 7.66 & 1.65 & .12 & .07 & 115072 & 12.1 \\
\hline 26 & 1.55 & 20.45 & 19.61 & 23.68 & 19.69 & 14.60 & 8.67 & 1.57 & .17 & .02 & 121120 & 12.6 \\
\hline$<1$ & 1.59 & 10.28 & 17.54 & 22.95 & 21.54 & 15.36 & 9.14 & 1.41 & .16 & .02 & 124410 & 13.1 \\
\hline 22 & 1.61 & 10.65 & 17.29 & 22.05 & 22.77 & 14.90 & 8.78 & 1.36 & .08 & .01 & 123261 & $13 \cdot 6$ \\
\hline 23 & 1.44 & 11.16 & 16.90 & 23.38 & 25.14 & 15.02 & 6.05 & .75 & .23 & .03 & 128713 & 12.5 \\
\hline 24 & 1.58 & 10.96 & 17.07 & $24 .>8$ & 28.37 & 13.04 & 3.73 & .53 & .13 & .03 & 113691 & $12 . \mathrm{C}$ \\
\hline ILTAL & 1.69 & 17.26 & 25.62 & 22.75 & 19.09 & 8.54 & 3.97 & .87 & .27 & .04 & 2318887 & 10.2 \\
\hline
\end{tabular}


TABLE 49. Monthly and Annual Percent Frequency of Hourly Wind Speed Class and Average Speed, 400-Foot Leve1, 1955 Through 1980

percent freguency of hourly Himo speed class amo ayerage SPEeO-1955-1980 4OOF GOT LEVEL-- JAN

\begin{tabular}{|c|c|c|c|c|c|c|c|c|c|c|c|c|}
\hline rLLE & c & $1-3$ & $4-7$ & $8-12$ & $13-18$ & $\begin{array}{c}\text { SPE } \\
19-24\end{array}$ & $\begin{array}{c}0 \text { CLASS } \\
25-31\end{array}$ & $32-38$ & $39-46$ & GT.46 & $\begin{array}{l}\text { TOTAL } \\
\text { SPEED }\end{array}$ & $\begin{array}{l}\text { AVG } \\
\text { SPEEE }\end{array}$ \\
\hline 1 & 7.67 & 20.10 & 21.34 & 19.73 & 18.36 & 7.69 & 2.85 & 2.11 & .62 & .12 & 7831 & 9.7 \\
\hline 2 & 6.68 & 22.21 & 19.98 & 21.71 & 18.11 & 6.20 & 3.35 & 1.24 & .74 & .37 & 7705 & 9.6 \\
\hline 3 & 7.07 & 19.73 & 23.57 & 21.22 & 16.50 & 0.58 & 3.23 & .87 & .74 & .50 & 7563 & 9.4 \\
\hline 4 & 0.33 & 22.33 & 20.97 & 21.22 & 17.99 & 5.71 & 2.85 & 1.74 & .62 & .25 & 7523 & 9.2 \\
\hline 5 & 6.82 & 20.84 & 23.08 & 21.96 & 16.50 & 4.71 & 3.60 & 1.36 & .99 & .12 & 7447 & $9 . \bar{z}$ \\
\hline$t$ & 6.85 & 20.84 & 22.21 & 22.08 & 16.87 & 5.33 & 3.35 & 1.24 & .99 & .12 & 7482 & 9.3 \\
\hline 7 & 5.33 & 23.95 & 21.71 & 20.97 & 16.50 & 6.20 & 2.85 & 1.24 & .99 & .25 & 7449 & 9.2 \\
\hline$t$ & 4.84 & 22.58 & 23.70 & 20.97 & 16.25 & 6.33 & 2.73 & 1.86 & .50 & .25 & 7468 & 9.3 \\
\hline 9 & 5.50 & 23.45 & 21.46 & 21.22 & 17.49 & 6.20 & 1.86 & 1.86 & .50 & .37 & 7407 & 9.8 \\
\hline 16 & 6.70 & 23.57 & 21.96 & 23.20 & 14.52 & 4.22 & 3.60 & .99 & .99 & .25 & 7125 & 8.8 \\
\hline 11 & 5.71 & 26.18 & 24.19 & 20.84 & 12.41 & 5.21 & 2.85 & 1.49 & .74 & .37 & 6947 & $8 . t$ \\
\hline 12 & 3.72 & 29.90 & 25.06 & 18.24 & 10.79 & 5.83 & 2.98 & 2.11 & .87 & .50 & 7050 & 8.7 \\
\hline 13 & 3.45 & 31.39 & 23.70 & 16.75 & 11.41 & 5.46 & 4.09 & 1.74 & .87 & .74 & 7150 & 8.9 \\
\hline 14 & 4.59 & 32.63 & 22.83 & 15.01 & 11.29 & 6.20 & 3.72 & 2.23 & .99 & .50 & 7045 & 8.7 \\
\hline is & 4.34 & 29.65 & 24.94 & 17.49 & 9.93 & 5.46 & 4.84 & 2.11 & .87 & .37 & 7154 & 8.5 \\
\hline 16 & 6.82 & 28.78 & 22.70 & 16.25 & 12.53 & 5.71 & 4.22 & 1.74 & .99 & .25 & 7059 & 8.8 \\
\hline 17 & 7.94 & 25.43 & 20.84 & 19.73 & 13.65 & 4.96 & 4.47 & 1.86 & .87 & .25 & 7257 & $9 . \mathrm{C}$ \\
\hline 10 & 8.44 & 20.72 & 24.32 & 18.61 & 13.52 & 7.94 & 4.22 & 1.24 & .87 & .12 & 7528 & 9.3 \\
\hline 9 & $t . \angle \mathrm{C}$ & 22.70 & 20.22 & 19.23 & 16.87 & 7.32 & 4.71 & 1.61 & .87 & .25 & 7994 & 9.5 \\
\hline$<6$ & 5.58 & 20.84 & 22.33 & 17.74 & 17.99 & 7.20 & 4.71 & 1.99 & 1.24 & .37 & 8291 & 10.3 \\
\hline$<1$ & 5.83 & 20.47 & 21.96 & 19.00 & 17.12 & 7.69 & 3.97 & 2.23 & .74 & .37 & 8209 & $10 . \bar{z}$ \\
\hline$<2$ & 5.63 & 21.09 & 21.96 & 19.35 & 17.00 & 7.82 & 3.72 & 2.11 & .74 & .37 & 8047 & $10 . \mathrm{C}$ \\
\hline 23 & 6.33 & 21.46 & 19.73 & a1 $4 t$ & 17.00 & 7.69 & 3.72 & 1.86 & $.5 C$ & .25 & 7809 & 9.7 \\
\hline$<4$ & 6.70 & 20.16 & 22.58 & 19.35 & 17.99 & 7.69 & 3.47 & 1.12 & .87 & .12 & 7801 & 9.7 \\
\hline ICIAL & 6.03 & 23.79 & 22.39 & 19.75 & 15.36 & 6.31 & 3.58 & 1.66 & .82 & .31 & 180341 & 9.3 \\
\hline
\end{tabular}

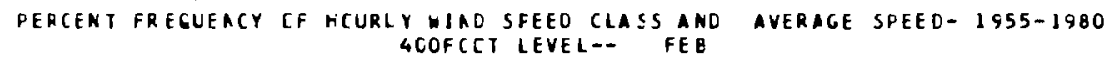

\begin{tabular}{|c|c|c|c|c|c|c|c|c|c|c|c|c|}
\hline riuk & $c$ & $1-1$ & $4-7$ & $8-12$ & $13-18$ & $\begin{array}{c}\text { SPE } \\
19-24\end{array}$ & $\begin{array}{l}\text { CLASS } \\
25-31\end{array}$ & $32-38$ & $39-46$ & GT.46 & $\begin{array}{l}\text { TOTAL } \\
\text { SPEEE }\end{array}$ & $\begin{array}{l}\text { AVG } \\
\text { SPEE }\end{array}$ \\
\hline 1 & 4.90 & 17.56 & 17.28 & 22.72 & 21.63 & 9.12 & 3.13 & 2.59 & .68 & .00 & 7862 & 10.7 \\
\hline$i$ & 4.63 & 17.14 & 18.04 & 23.13 & 22.18 & 7.21 & 4.76 & 2.04 & .27 & .00 & 7818 & $10 . t$ \\
\hline 3 & 4.90 & 17.01 & 18.91 & 23.81 & 19.86 & 7.89 & 4.49 & 2.18 & .82 & .14 & 7892 & 10.7 \\
\hline 4 & 5.17 & 17.28 & 20.95 & 22.99 & 17.41 & 8.71 & 4.49 & 2.45 & .41 & .14 & 7766 & 10.6 \\
\hline s & 4.63 & 17.69 & 21.22 & 23.27 & 20.00 & 6.67 & 4.08 & 1.77 & .41 & .27 & 7620 & 10.4 \\
\hline 0 & 4.50 & 17.01 & 22.86 & 21.50 & 21.22 & 5.85 & 4.90 & 1.09 & .41 & .27 & 7444 & 10.1 \\
\hline 7 & 5.17 & 18.64 & 22.99 & 21.63 & 18.10 & 8.16 & 4.08 & .68 & .54 & .00 & 7256 & 9.9 \\
\hline 8 & 5.31 & 20.41 & 21.09 & 20.41 & 20.95 & 6.94 & 3.40 & .82 & .68 & .00 & 7131 & 9.7 \\
\hline$s$ & 6.26 & 20.14 & 21.90 & 22.45 & 17.55 & 6.12 & 2.86 & 1.90 & .82 & .60 & 6991 & 9.5 \\
\hline 10 & 5.03 & 23.95 & 22.86 & 20.27 & 16.33 & 6.26 & 2.18 & 1.77 & 1.09 & .27 & 6842 & 9.3 \\
\hline 11 & 2.99 & 28.44 & c2.72 & 20.68 & 13.47 & 5.99 & 2.31 & 2.59 & .68 & .14 & 6592 & $9 . i$ \\
\hline 12 & 2.72 & 28.67 & 27.52 & 16.35 & 11.58 & 7.22 & 3.54 & 2.04 & .68 & .27 & 6634 & 9.6 \\
\hline 13 & 1.90 & 28.44 & 25.85 & 16.60 & 11.97 & 7.21 & 4.35 & 2.45 & .82 & .41 & 6992 & 9.5 \\
\hline 14 & 1.50 & $27.6 \bar{c}$ & 24.63 & 15.92 & 14.01 & 7.48 & 4.08 & 3.13 & 1.50 & .14 & 7344 & 10.6 \\
\hline 15 & 2.59 & 25.31 & 25.17 & 15.65 & 14.69 & 7.76 & 4.08 & 3.40 & .95 & .41 & 7463 & $10 . z$ \\
\hline 10 & 2.59 & 25.44 & 21.09 & 19.05 & 13.20 & 9.25 & 4.90 & 2.59 & 1.36 & .54 & 7756 & $10 . t$ \\
\hline 17 & 4.22 & 21.50 & 23.27 & 17.96 & 14.42 & 8.44 & 5.44 & 2.99 & 1.09 & .68 & 7939 & $10 . \varepsilon$ \\
\hline 16 & 4.35 & 17.14 & 22.31 & 21.50 & 15.24 & 9.80 & 5.71 & 2.31 & .95 & .68 & 8161 & 11.1 \\
\hline 14 & 3.54 & 15.65 & 20.95 & 21.63 & 18.64 & 9.66 & 5.71 & 3.27 & .68 & .27 & 8485 & 11.5 \\
\hline 20 & 3.40 & 16.73 & 19.46 & 20.41 & 20.00 & 11.43 & 4.63 & 2.86 & 1.09 & .00 & 8544 & $11 . t$ \\
\hline 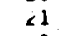 & 5.03 & 15.10 & 18.37 & 20.82 & 20.14 & 11.84 & 5.44 & 2.18 & 1.09 & .00 & $862 \mathrm{C}$ & 11.7 \\
\hline 22 & 4.76 & 16.33 & 15.51 & 21.22 & 23.27 & 11.29 & 4.22 & 2.45 & .95 & .00 & 8566 & 11.7 \\
\hline 23 & 3.81 & 17.55 & 19.46 & 18.78 & 23.95 & 9.25 & 4.35 & 2.31 & .41 & .14 & 8237 & 11.2 \\
\hline 24 & 5.17 & 14.97 & 21.22 & $2 C .68$ & 21.90 & 9.25 & 4.49 & 1.63 & .54 & .14 & 7997 & 10.5 \\
\hline$I C I A L$ & 4.14 & 20.23 & 21.51 & 20.39 & 17.99 & 8.28 & 4.23 & 2.23 & .79 & .20 & 183952 & 10.4 \\
\hline
\end{tabular}


TABLE 49. Continued

PERCEN FRECUEACY CF HCURLY HIMO SPEED CLASS AARD AVERAGE SPEED-1955-1980

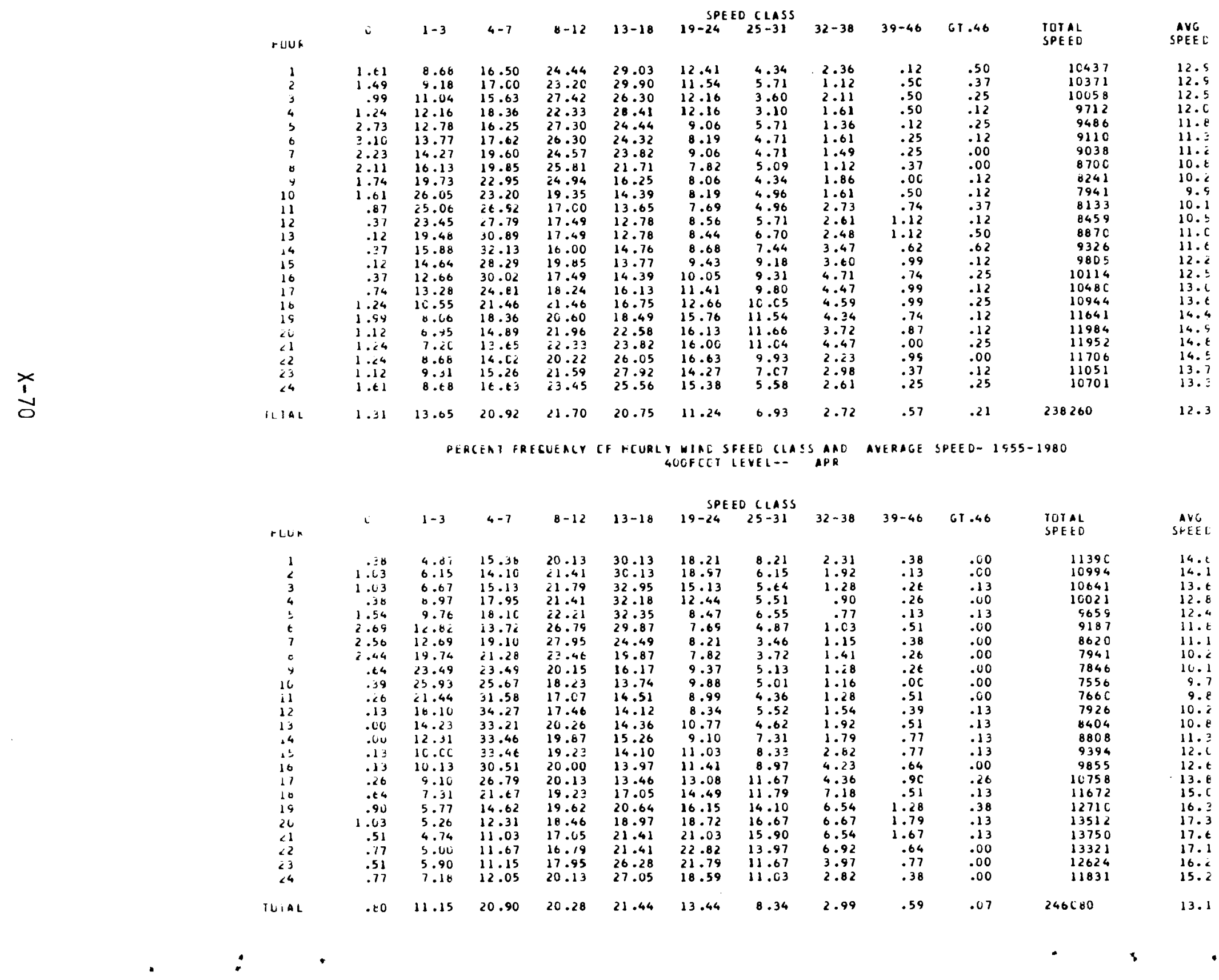


TABLE 49. Continued

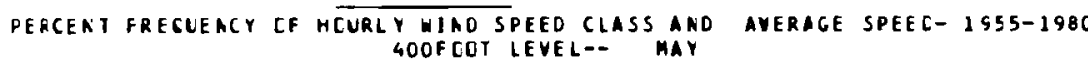

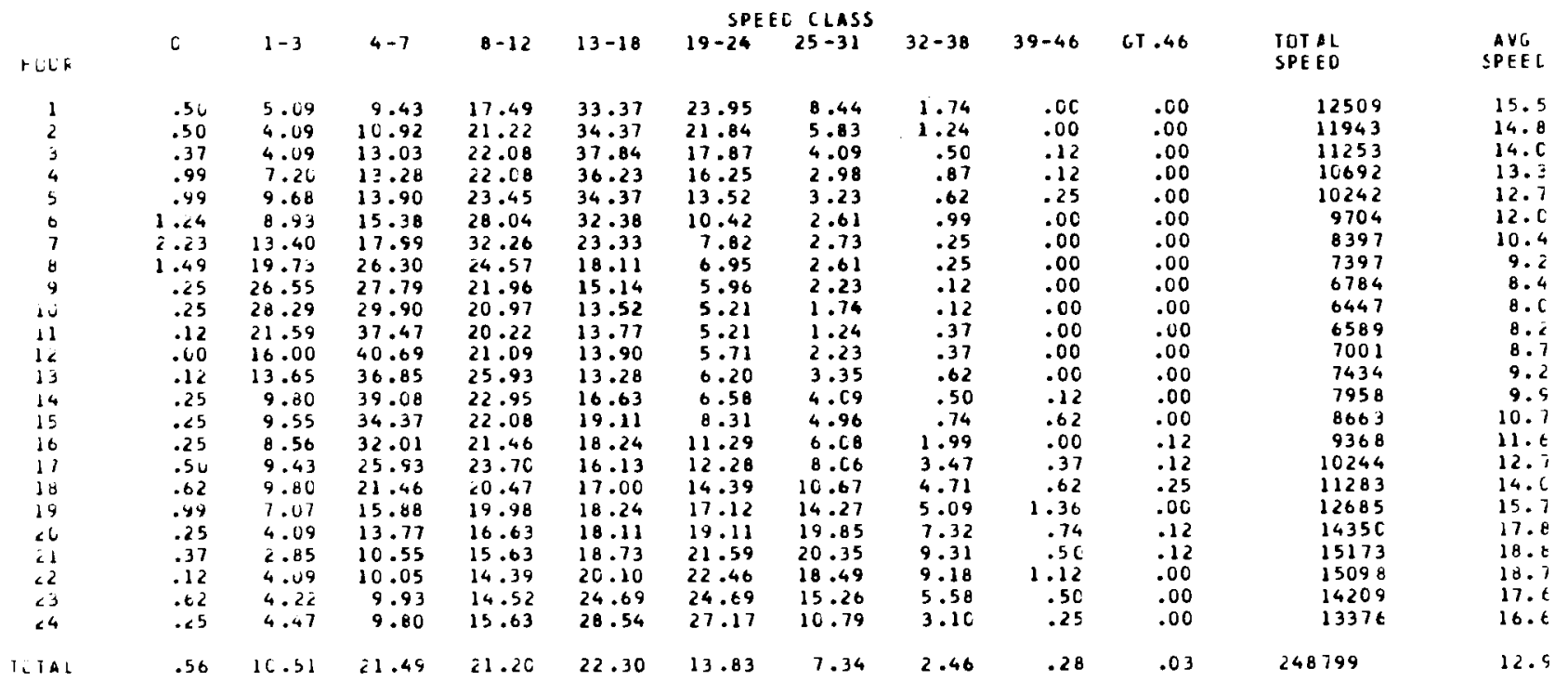

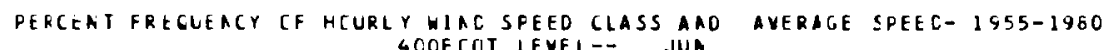

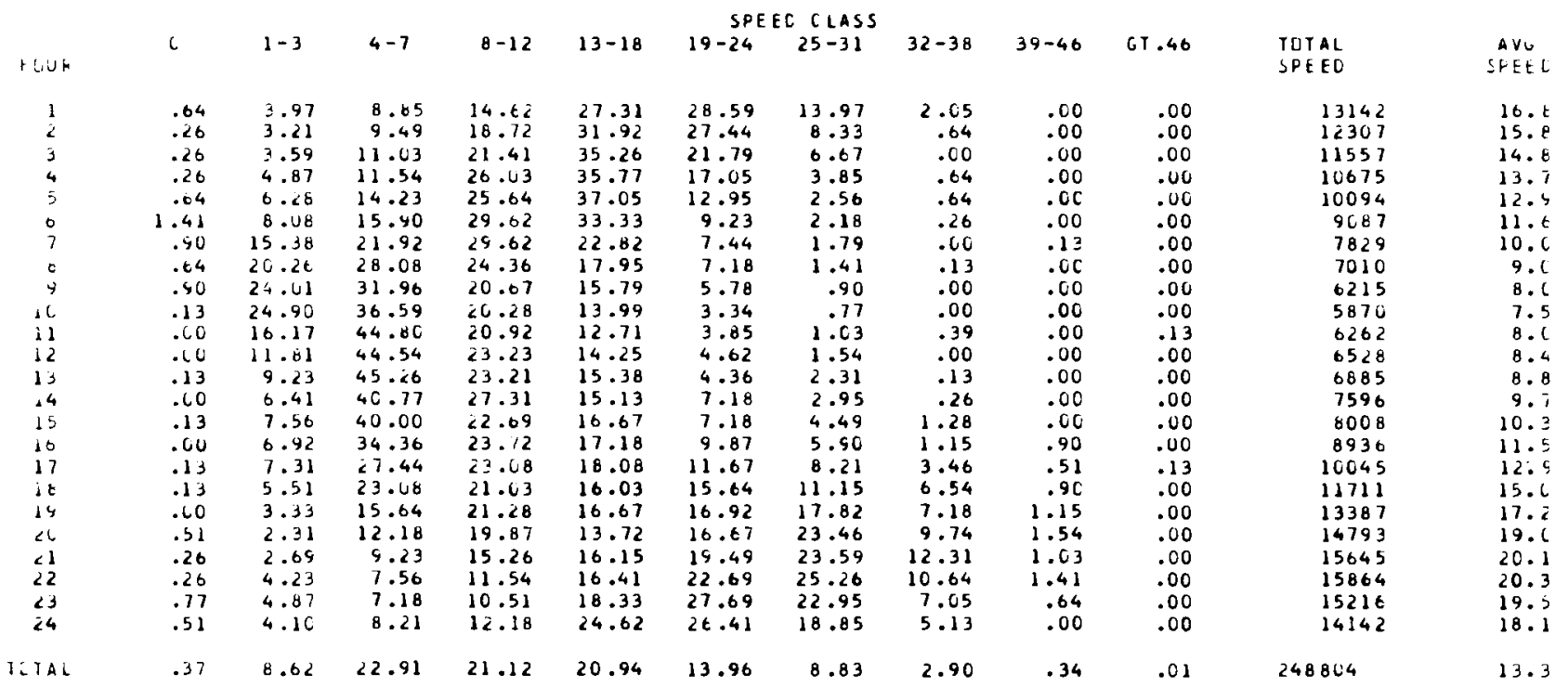


TABLE 49. Continued

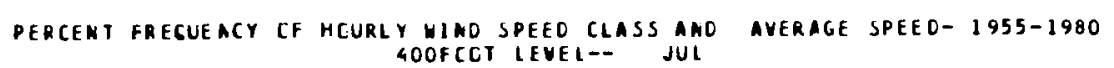

\begin{tabular}{|c|c|c|c|c|c|c|c|c|c|c|c|c|}
\hline rLUR & $c$ & $1-3$ & $4-7$ & $8-12$ & $13-18$ & $\begin{array}{c}\text { SPE } \\
19-24\end{array}$ & $\begin{array}{l}0 \text { CLASS } \\
25-31\end{array}$ & $32-38$ & $39-46$ & 61.46 & $\begin{array}{l}\text { TOTAL } \\
\text { SPEED }\end{array}$ & $\begin{array}{l}\text { AVG } \\
\text { SPEED }\end{array}$ \\
\hline 1 & .25 & 2.61 & 7.34 & 16.29 & 29.23 & 29.85 & 12.69 & 1.74 & .00 & .00 & 13739 & 17.1 \\
\hline 2 & .25 & 1.62 & 7.34 & 18.03 & 36.44 & 29.48 & 6.22 & .37 & .25 & .00 & 12952 & 16.1 \\
\hline 3 & $. i<$ & 3.23 & 8.71 & 20.90 & 40.67 & 23.51 & 2.61 & .12 & .12 & .00 & 11885 & 14.8 \\
\hline 4 & .62 & 3.23 & 10.20 & 24.00 & 41.67 & 18.16 & 1.87 & .25 & .00 & .00 & 11165 & 13.9 \\
\hline 5 & .75 & 3.46 & 13.33 & 26.28 & 41.22 & 12.83 & 1.74 & .00 & .00 & .00 & 10378 & 12.9 \\
\hline 0 & .02 & 0.72 & 13.33 & 32.88 & 36.86 & 8.34 & .87 & .27 & .00 & .00 & 9635 & $12 . \mathrm{C}$ \\
\hline 7 & 1.49 & 9.19 & 24.60 & 37.02 & 22.73 & 3.98 & .87 & .12 & .00 & .00 & 7881 & 9.8 \\
\hline 0 & .27 & 17.74 & 32.51 & 30.02 & 14.02 & 4.09 & .99 & .25 & .00 & .00 & 6699 & 8.2 \\
\hline 9 & .25 & 30.27 & $3 \theta .69$ & 1E.3E & 8.56 & 3.97 & .37 & .12 & $.0 \mathrm{C}$ & .00 & 5420 & 6.7 \\
\hline 10 & .12 & 33.13 & 42.62 & 13.52 & 7.20 & 2.61 & .74 & .00 & .00 & .00 & 4992 & 6.8 \\
\hline il & .12 & 23.45 & $5 C .12$ & 15.88 & 6.95 & 2.48 & .87 & .12 & .00 & .00 & 5238 & 6.5 \\
\hline 12 &.$\iota 0$ & 19.35 & $5 C .25$ & 17.99 & 8.44 & 3.10 & .62 & .12 & .12 & .00 & 5567 & 6.5 \\
\hline 13 &. .0 & 13.65 & 49.75 & 21.46 & 11.17 & 2.85 & .74 & .25 & .12 & .00 & $\in 119$ & 7.6 \\
\hline 14 & .60 & 16.42 & 49.50 & 21.46 & 13.52 & 2.98 & 1.61 & .37 & .12 & .00 & 6657 & 8.2 \\
\hline 13 & .60 & 6.36 & 45.16 & 24.69 & 13.52 & 5.09 & 2.23 & .50 & .25 & .00 & 7293 & 9.0 \\
\hline ic & .12 & 9.00 & 39.70 & 23.62 & 14.89 & 6.45 & 3.85 & 1.12 & .25 & .00 & 7952 & 9.9 \\
\hline 17 & .60 & 10.05 & 33.37 & 24.32 & 16.00 & 8.68 & 5.71 & 1.49 & .37 & .00 & 8860 & $11 . \mathrm{C}$ \\
\hline io & $.6 c$ & 9.66 & zE. $\$ 0$ & 24.81 & 15.88 & 11.04 & 9.55 & 2.23 & .62 & .00 & 10213 & 12.7 \\
\hline 19 & 11 & 5.46 & 19.85 & 25.06 & 15.76 & 13.52 & 14.64 & 5.33 & .25 & .00 & 12109 & 15.6 \\
\hline 20 & .25 & 2.85 & 13.28 & 22.33 & 15.01 & 15.38 & 20.97 & 8.93 & .87 & .12 & 16414 & $\begin{array}{l}17.9 \\
17.9\end{array}$ \\
\hline$\alpha$ & .07 & $3.1 \mathrm{C}$ & 9.31 & 17.62 & 13.03 & 15.51 & 27.54 & 11.66 & 1.36 & .00 & $1 \in 063$ & 19.5 \\
\hline & .14 & 2.96 & 11.29 & 11.66 & 13.77 & 19.23 & 26.05 & 12.90 & 1.36 & .00 & 16500 & 20.5 \\
\hline 23 & 67 & 5.09 & 7.95 & 12.30 & 14.53 & 24.97 & 26.09 & 7.45 & .75 & .00 & 15714 & $\begin{array}{l}19.5 \\
19.5\end{array}$ \\
\hline$<4$ & .060 & 3.23 & 7.58 & 13.29 & 22.73 & 29.44 & 19.13 & 4.10 & .60 & . & 14769 & 18.3 \\
\hline$i[1 / 4 b$ & .35 & 9.95 & 25.51 & 21.42 & 19.73 & 12.39 & 7.86 & 2.50 & .28 & .01 & 242214 & 12.5 \\
\hline
\end{tabular}

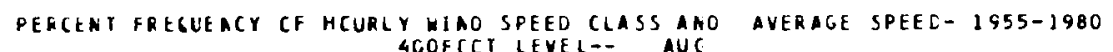

\begin{tabular}{|c|c|c|c|c|c|c|c|c|c|c|c|c|}
\hline ruluk & $i$ & $1-1$ & $4-7$ & $8-12$ & $13-18$ & $19-24$ & $\begin{array}{c}c \text { class } \\
25-31\end{array}$ & $32-38$ & $39-46$ & CT.46 & $\begin{array}{l}\text { IOTAL } \\
\text { SPEEL }\end{array}$ & $\begin{array}{l}\text { AVG } \\
\text { SPEEL }\end{array}$ \\
\hline 1 & .12 & 1.47 & 7.44 & 17.87 & 34.37 & 27.54 & 7.94 & 1.24 & .00 & .00 & 12935 & $16 . c$ \\
\hline 2 & .37 & 3.10 & 8.19 & 20.64 & 38.09 & 25.06 & 4.22 & & $.0 \mathrm{C}$ & & 12121 & 15.6 \\
\hline 3 & .50 & 4.22 & 10.30 & 24.94 & 40.07 & 17.12 & 2.48 & .37 & $.0 \mathrm{C}$ & .00 & 11034 & 13.7 \\
\hline 4 & $. b<$ & 4.71 & 15.14 & $26 \cdot 10$ & 37.59 & 13.28 & 2.23 & .12 & .00 & .00 & 10355 & 12.6 \\
\hline 3 & .87 & 5.58 & 15.76 & 29.28 & 36.23 & 11.17 & .74 & .37 & .00 & .00 & 9756 & 12.1 \\
\hline 6 & 1.49 & 6.26 & 17.00 & 34.24 & 32.01 & $8.0 t$ & .87 & .12 & .00 & .00 & 9153 & 11.4 \\
\hline 7 & 1.61 & 8.81 & 21.71 & 37.84 & 25.56 & 3.72 & .74 & .00 & .00 & .00 & 8023 & 10.0 \\
\hline$\varepsilon$ & 1.0 .1 & 18.61 & 32.26 & 30.40 & 13.40 & 3.47 & .25 & .00 & .00 & .00 & 6302 & 7.8 \\
\hline 4 &.$<5$ & 29.65 & $\lesssim 5.58$ & c1. $4 t$ & 9.18 & 2.96 & .50 & .00 & .00 & .00 & 5437 & 0.7 \\
\hline 10 & .62 & 37.84 & 35.24 & 16.15 & 6.45 & 2.11 & .87 & .12 & .00 & .00 & $484 C$ & 0.6 \\
\hline 11 & .00 & 33.00 & 42.68 & 15.76 & 5.96 & 2.23 & .12 & .25 & $.0 \mathrm{c}$ & .00 & 4797 & 6.1 \\
\hline $1 \bar{c}$ & .25 & 24.44 & 48.76 & 15.88 & 8.44 & 1.74 & .37 & .12 & .00 & .00 & 5125 & 6.4 \\
\hline 13 & .60 & 19.23 & 51.36 & 16.38 & 9.55 & 2.48 & .74 & .25 & .00 & .00 & 5635 & 7.6 \\
\hline 14 & .00 & 15.14 & 50.00 & 20.10 & 9.43 & 3.97 & 1.12 & .12 & .12 & .00 & 6191 & 7.7 \\
\hline is & .60 & 11.41 & 46.65 & 22.83 & 11.41 & 5.58 & 1.36 & .62 & .12 & .00 & $683 \mathrm{C}$ & 8.5 \\
\hline 16 & .60 & 12.78 & 39.33 & 24.19 & 13.03 & 7.32 & 2.36 & .87 & .12 & .00 & 7496 & 9.3 \\
\hline 17 & .12 & 13.77 & 34.99 & 21.96 & 11.79 & 10.42 & 5.21 & 1.74 & .00 & .00 & 8421 & 10.4 \\
\hline $1 \mathrm{~d}$ & .25 & 11.41 & 27.54 & 22.83 & 14.14 & 12.78 & 7.57 & 2.98 & .50 & .00 & 9835 & 12.2 \\
\hline is & .02 & 6.70 & 21.22 & 22.33 & 15.63 & 14.52 & 14.52 & 4.09 & .37 & .00 & 11811 & 14.7 \\
\hline 20 & 1.12 & 3.97 & 13.77 & 22.21 & 17.00 & 14.76 & 17.99 & 8.19 & .99 & .00 & 13708 & $17 . \mathrm{C}$ \\
\hline 21 & .87 & 4.49 & +3.40 & 18.61 & 13.90 & 17.49 & 19.35 & 11.79 & $.5 C$ & .00 & 14765 & 18.3 \\
\hline$<2$ & .67 & 5.58 & 11.17 & 14.89 & 15.76 & 19.60 & 20.97 & 10.92 & .25 & .00 & 14879 & 18.5 \\
\hline 23 & .56 & 3.23 & 12.66 & 13.77 & 21.34 & 24.57 & 18.49 & 5.46 & .00 & .00 & 14276 & 17.7 \\
\hline$<4$ & .60 & 3.83 & 9.18 & 14.64 & 28.29 & 30.02 & 13.03 & .87 & .12 & .00 & 13547 & 16.6 \\
\hline ILIAL & .53 & 12.12 & 25.90 & 21.93 & 19.53 & 11.75 & 6.00 & 2.11 & .13 & .00 & 227272 & 11.7 \\
\hline
\end{tabular}


TABLE 49. Continued

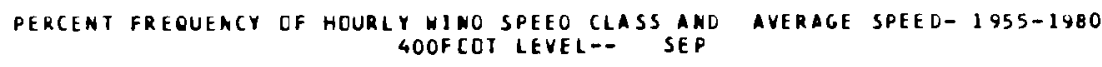

\begin{tabular}{|c|c|c|c|c|c|c|c|c|c|c|c|c|c|}
\hline & RUUR & c & $1-3$ & $4-7$ & $8-12$ & $13-18$ & $\begin{array}{r}\text { SP } \\
19-24\end{array}$ & $\begin{array}{l}\text { C CLASS } \\
25-311\end{array}$ & $32-38$ & $39-46$ & GT.46 & $\begin{array}{l}\text { TLTAL } \\
\text { SPEED }\end{array}$ & $\begin{array}{l}\text { AVG } \\
\text { SPEE C }\end{array}$ \\
\hline & 1 & .30 & $0 .<8$ & 14.62 & 24.87 & 32.31 & 15.51 & 5.38 & .51 & .13 & .00 & 10383 & 13.3 \\
\hline & 2 & 1.54 & 0.28 & 17.05 & 25.64 & 31.15 & 14.36 & 3.59 & .38 & .00 & .00 & 9882 & 12.7 \\
\hline & & 1.20 & 8.46 & 16.79 & 26.03 & 31.92 & 11.67 & 2.56 & 1.28 & .00 & .00 & $950 \mathrm{C}$ & 12.2 \\
\hline & 4 & 1.79 & 9.36 & 16.41 & 30.64 & 27.69 & 10.00 & 3.33 & .64 & .13 & .00 & 9145 & 11.7 \\
\hline & 5 & 2.44 & 10.51 & 17.18 & 30.26 & 28.08 & 8.08 & 2.95 & .38 & .13 & .00 & 8716 & 11.2 \\
\hline & 6 & 2.44 & 12.05 & 20.64 & 27.05 & 27.82 & 6.67 & 2.69 & .64 & $.0 \mathrm{C}$ & .00 & 8260 & $10 . t$ \\
\hline & 7 & 2.09 & 13.21 & 21.92 & 31.92 & 22.18 & 5.51 & 2.18 & .38 & .00 & .00 & 7763 & $10 . \mathrm{C}$ \\
\hline & 0 & 3.33 & 18.21 & 25.77 & 30.51 & 14.87 & 5.26 & 1.41 & .64 & .00 & .00 & 6836 & $8 . t$ \\
\hline & $s$ & 1.41 & 27.60 & 31.07 & 20.80 & 11.30 & 5.65 & 1.54 & .64 & .00 & .00 & 6052 & 7.8 \\
\hline & if & .90 & 32.35 & 30.55 & 17.46 & 11.94 & 3.85 & 2.57 & .26 & .13 & .00 & 3782 & 7.4 \\
\hline & 11 & .51 & 31.45 & 32.73 & 19.26 & 8.99 & 5.01 & 1.67 & .26 & .13 & .00 & 5716 & 7.3 \\
\hline & 12 & .64 & 25.26 & 40.51 & 16.41 & 10.64 & 3.72 & 2.44 & .26 & .13 & .00 & 5867 & 7.5 \\
\hline & 13 & .13 & 22.05 & 42.82 & 16.28 & 10.38 & 4.10 & 2.82 & 1.41 & $.0 \mathrm{C}$ & .00 & 6286 & 8.1 \\
\hline & $\begin{array}{l}12 \\
14\end{array}$ & .13 & 21.41 & 40.77 & 17.69 & 11.15 & 5.13 & 2.56 & 1.03 & .13 & .00 & 6448 & 8.3 \\
\hline & is & .60 & 21.03 & 36.92 & 18.21 & 12.05 & 6.79 & 3.97 & .90 & .13 & .00 & 6983 & 9. $\mathrm{C}$ \\
\hline & le & .60 & 17.95 & 36.15 & 18.72 & 11.92 & 8.72 & 5.26 & 1.15 & .13 & .00 & 7596 & 9.7 \\
\hline & 17 & .04 & 16.07 & 32.05 & 18.85 & 12.56 & 8.85 & 8.59 & 1.67 & .13 & .00 & 8360 & 10.7 \\
\hline & 18 & 1.54 & 11.94 & 27.21 & 22.21 & 12.32 & 10.27 & 11.42 & 3.08 & .00 & .00 & 9518 & 12.2 \\
\hline & 15 & l.63 & $\begin{array}{l}\text { B.C9 } \\
\text {. }\end{array}$ & 22.68 & 24.90 & 14.63 & 14.12 & 10.91 & 3.85 & .39 & .00 & 10637 & 13.7 \\
\hline & C & 2.16 & 7.31 & 16.92 & 23.21 & 17.44 & 14.49 & 13.97 & 4.23 & $.2 t$ & .00 & 11354 & $14 . t$ \\
\hline & $<1$ & 1.54 & 7.96 & 16.30 & 21.31 & 20.41 & 16.05 & 11.68 & 3.98 & .77 & .00 & 11393 & $14 . t$ \\
\hline & & 1.41 & 7.31 & 16.41 & $c 2.56$ & 22.44 & 10.54 & 9.36 & 3.46 & .51 & .00 & 11185 & 14.3 \\
\hline & 23 & .51 & 0.41 & 15.64 & 23.33 & 26.67 & 17.44 & 8.33 & 1.54 & .13 & .00 & 10906 & $14 . \mathrm{C}$ \\
\hline & 24 & .64 & 5.90 & 15.38 & 25.26 & 28.72 & 17.95 & 5.26 & .90 & .00 & .00 & 10508 & 13.5 \\
\hline & ILIAL & 1.21 & 14.79 & 25.16 & 23.06 & 19.15 & 9.82 & 5.27 & 1.39 & .14 & .00 & 205670 & 11.6 \\
\hline
\end{tabular}

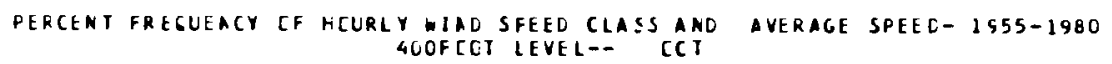

\begin{tabular}{|c|c|c|c|c|c|c|c|c|c|c|c|c|}
\hline riux & 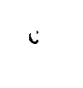 & $1-3$ & $4-7$ & $8-12$ & $13-18$ & $\underset{19-24}{\text { SPE }}$ & $=\begin{array}{c}\text { CLASS } \\
25-31\end{array}$ & $32-38$ & $39-46$ & GT.46 & $\begin{array}{l}\text { JUTAL } \\
\text { SPEED }\end{array}$ & $\begin{array}{l}\text { AVG } \\
\text { SPEEL }\end{array}$ \\
\hline$i$ & $\begin{array}{r}2.85 \\
3.97\end{array}$ & $\begin{array}{l}14.27 \\
13.90\end{array}$ & $\begin{array}{l}17.74 \\
19.11\end{array}$ & $\begin{array}{l}25.06 \\
22.95\end{array}$ & $\begin{array}{l}24.81 \\
26.80\end{array}$ & 10.67 & 2.85 & .62 & .12 & .00 & 8755 & 10.5 \\
\hline 2 & $\begin{array}{l}3.97 \\
4.34\end{array}$ & $\begin{array}{l}13.90 \\
13.15\end{array}$ & 19.11 & $\begin{array}{l}22.95 \\
26.57\end{array}$ & 26.80 & 9.93 & 2.48 & .74 & .12 & .00 & $868 \mathrm{E}$ & 10.8 \\
\hline $\begin{array}{l}3 \\
4\end{array}$ & $\begin{array}{l}4.34 \\
2.90\end{array}$ & $\begin{array}{l}13.15 \\
16.38\end{array}$ & $\begin{array}{l}19.11 \\
19.98\end{array}$ & 26.67 & 25.06 & 8.81 & 2.23 & .37 & .00 & .25 & 0369 & 10.4 \\
\hline $\begin{array}{l}4 \\
5\end{array}$ & $\begin{array}{l}2.90 \\
4.59\end{array}$ & $\begin{array}{l}16.38 \\
16.38\end{array}$ & $\begin{array}{l}19.98 \\
19.73\end{array}$ & $\begin{array}{r}27.17 \\
26.80\end{array}$ & 22.08 & 8.81 & 2.11 & .25 & .12 & .12 & 8215 & 10.2 \\
\hline $\begin{array}{l}5 \\
0\end{array}$ & $\begin{array}{l}4.39 \\
4.467\end{array}$ & 17.99 & $\begin{array}{l}19.73 \\
21.09\end{array}$ & $\begin{array}{l}26.80 \\
26.80\end{array}$ & 22.46 & 7.44 & 1.86 & .74 & .00 & .00 & 7881 & 9.8 \\
\hline 7 & 3.85 & 18.73 & 23.33 & $\begin{array}{l}26.80 \\
23.82\end{array}$ & $\begin{array}{l}20.35 \\
20.84\end{array}$ & 5.46 & 3.10 & .62 & .12 & .60 & 7639 & 9.5 \\
\hline 。 & 3.47 & 21.71 & 21.34 & 24.32 & $\begin{array}{l}20.84 \\
21.46\end{array}$ & $\begin{array}{r}6.33 \\
4.47\end{array}$ & $\begin{array}{r}2.23 \\
1.99\end{array}$ & $\begin{array}{l}.62 \\
.62\end{array}$ & $\begin{array}{r}.25 \\
.12\end{array}$ & $\begin{array}{l}.00 \\
.00\end{array}$ & $\begin{array}{l}7517 \\
7228\end{array}$ & 9.3 \\
\hline$y$ & 4.71 & 27.79 & 22.95 & 23.45 & 15.38 & 3.10 & 2.23 & .027 & $.0 C$ & .00 & $\begin{array}{l}1228 \\
6235\end{array}$ & $\begin{array}{l}9.6 \\
7.7\end{array}$ \\
\hline 10 & 3.23 & 36.48 & 23.82 & 16.13 & 10.55 & 6.58 & 2.85 & .37 & .00 & .00 & 5951 & 7.4 \\
\hline 11 & 1.86 & 38.21 & 25.53 & 14.64 & 8.81 & 5.96 & 3.35 & 1.12 & .12 & .00 & 5996 & 7.4 \\
\hline 12 & 1.86 & 35.11 & 31.64 & 13.28 & 7.44 & 7.07 & 2.48 & .99 & .12 & .00 & 5956 & 7.4 \\
\hline 13 & .74 & 33.75 & 33.62 & 12.16 & 8.44 & 5.71 & 4.09 & 1.24 & .25 & .00 & 6273 & 7.8 \\
\hline 14 &.+2 & 30.65 & 34.57 & 13.52 & 8.56 & 6.45 & 4.09 & 1.36 & .37 & .00 & 6571 & 6.6 \\
\hline is & .99 & 29.05 & 33.25 & 13.28 & 9.43 & 6.82 & 4.09 & 1.99 & .50 & .00 & 6895 & $8 . t$ \\
\hline 16 & .99 & 30.40 & 29.78 & 13.90 & 9.68 & 7.82 & 5.09 & 1.99 & .37 & .00 & 7223 & 9.6 \\
\hline 17 & 3.72 & 23.08 & 27.6 .7 & 17.25 & 11.91 & 8.56 & 4.71 & 2.61 & .50 & .00 & 7786 & 9.1 \\
\hline 10 & 5.09 & 17.62 & 23.57 & 19.98 & 14.14 & 11.04 & 6.20 & 2.23 & .12 & .00 & 8567 & $10 . t$ \\
\hline 19 & 4.09 & 14.52 & 22.33 & 20.47 & 17.37 & 12.03 & 7.07 & 1.99 & $.0 \mathrm{C}$ & .12 & 9240 & 11.5 \\
\hline 20 & 3.60 & 13.40 & 21.22 & 22.08 & 19.73 & 11.91 & 5.83 & 1.74 & .50 & .00 & 9323 & 11.0 \\
\hline 21 & 2.48 & $12.5 \mathrm{C}$ & 20.72 & 23.57 & 21.09 & 12.03 & 5.46 & .99 & .74 & .00 & 9393 & 11.7 \\
\hline$<2$ & 3.35 & 12.78 & $2 C .60$ & 19.98 & 24.81 & 12.41 & 4.47 & 1.36 & .25 & .00 & $929 \mathrm{C}$ & 110 \\
\hline 23 & 3.72 & 12.16 & 18.49 & 26.30 & 21.71 & 13.77 & 2.98 & .74 & .12 & .00 & 9096 & 11.3 \\
\hline 24 & 2.23 & 12.03 & 18.86 & 23.57 & 27.54 & 10.05 & 3.97 & .50 & .25 & .00 & 9110 & $11 . \equiv$ \\
\hline ILIAL & 3.18 & 21.38 & 23.76 & 20.71 & 17.52 & 8.47 & 3.66 & 1.04 & .21 & .02 & 187199 & 9.7 \\
\hline
\end{tabular}


TABLE 49. Continued

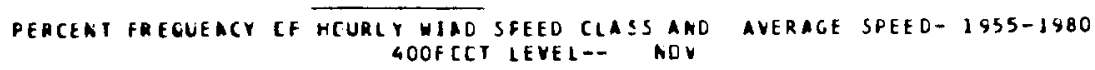

$\begin{array}{lllll}\text { SPEED CLASS } & & & \\ 19-24 & 25-31 & 32-38 & 39-46 & \text { GT .46 } \\ & & & & \\ 7.31 & 2.82 & 1.67 & .26 & .26 \\ 6.67 & 3.33 & 1.03 & .51 & .00 \\ 6.15 & 3.08 & 1.15 & .38 & .00 \\ 5.38 & 2.82 & 1.67 & .51 & .13 \\ 6.79 & 2.69 & 1.28 & .38 & .38 \\ 6.03 & 2.95 & 1.41 & .64 & .00 \\ 6.41 & 1.79 & .77 & .77 & .00 \\ 5.26 & 2.56 & .90 & .38 & .13 \\ 4.49 & 2.44 & 1.28 & .26 & .13 \\ 4.36 & 3.08 & 1.28 & .51 & .13 \\ 5.13 & 4.62 & 1.41 & .64 & .13 \\ 5.91 & 4.62 & 1.41 & .35 & .13 \\ 6.79 & 4.23 & 1.54 & .77 & .00 \\ 5.51 & 3.59 & 2.18 & .90 & .00 \\ 6.03 & 3.85 & 2.18 & .38 & .13 \\ 7.31 & 3.85 & 2.18 & .51 & .26 \\ 6.79 & 4.36 & 1.67 & .77 & .13 \\ 8.21 & 5.13 & 1.28 & .38 & .26 \\ 8.46 & 3.72 & 1.15 & .38 & .13 \\ 7.82 & 3.08 & 1.28 & .26 & .00 \\ 7.18 & 3.46 & 1.15 & .38 & .00 \\ 6.92 & 3.72 & .51 & .26 & .00 \\ 7.18 & 4.23 & .77 & .13 & .13 \\ 7.18 & 2.44 & 1.41 & .51 & .13 \\ 0.47 & 3.44 & 1.36 & .47 & .11\end{array}$

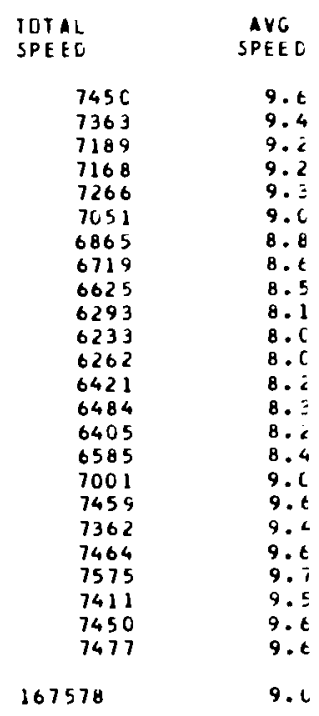

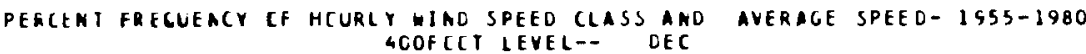

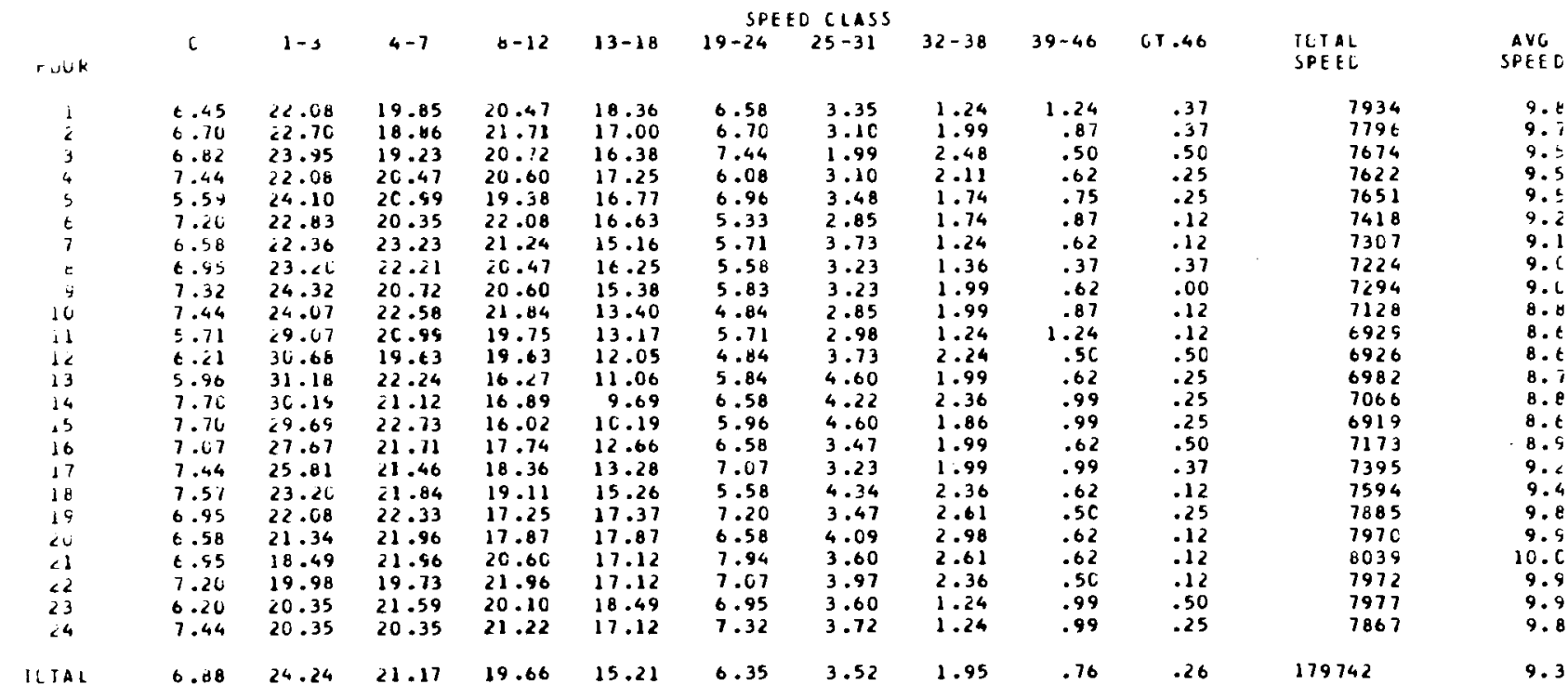

$\begin{array}{rr}8-12 & 13-18 \\ & \\ 21.79 & 17.18 \\ 23.46 & 17.82 \\ 20.77 & 18.33 \\ 22.56 & 17.44 \\ 22.18 & 17.18 \\ 23.33 & 14.62 \\ 21.92 & 15.38 \\ 21.28 & 15.90 \\ 18.87 & 17.07 \\ 17.97 & 13.61 \\ 11.42 & 11.42 \\ 14.89 & 9.11 \\ 13.59 & 9.10 \\ 13.46 & 10.51 \\ 13.33 & 16.38 \\ 15.38 & 9.10 \\ 16.28 & 12.95 \\ 17.44 & 14.49 \\ 18.08 & 16.92 \\ 20.38 & 19.23 \\ 21.79 & 15.62 \\ 24.10 & 19.10 \\ 22.95 & 18.46 \\ 19.87 & 20.00\end{array}$


TABLE 49. Continued

PERCENT FREQUEACY CF HOURLY WINO SPEEO CLASS AMO AVERAGE SPEED- $1955-1980$
4OOFECT LEVEL-- AMMUAL

\begin{tabular}{|c|c|c|c|c|c|c|c|c|c|c|c|c|}
\hline \multirow[b]{2}{*}{ ruUk } & \multicolumn{12}{|c|}{ SPEEC CLASS } \\
\hline & $c$ & $1-3$ & $4-7$ & $8-12$ & $13-18$ & $19-24$ & $25-31$ & $32-38$ & $39-46$ & GT.46 & $\begin{array}{l}\text { TLTAL } \\
\text { SPEED }\end{array}$ & $\begin{array}{c}\text { AVG } \\
\text { SPEED }\end{array}$ \\
\hline 1 & 2.03 & 10.60 & 14.99 & 20.44 & 26.37 & 16.49 & 6.34 & 1.67 & .29 & .11 & 124367 & 13.1 \\
\hline 2 & $\bar{c} .60$ & $10.8<$ & 15.13 & 21.82 & 27.87 & 15.49 & 4.75 & 1.06 & .28 & .09 & 119938 & $12 . t$ \\
\hline 3 & 2.76 & 11.34 & 16.21 & 23.15 & 28.48 & 13.04 & 3.54 & 1.05 & .28 & .15 & 114015 & 12.1 \\
\hline 4 & 2.77 & 12.71 & 27.06 & 23.94 & 27.71 & 11.18 & 3.17 & 1.10 & .27 & $.0 B$ & 110059 & $11 . t$ \\
\hline 5 & 3.11 & 13.33 & 17.85 & 24.84 & 27.25 & 9.07 & 3.26 & .92 & .26 & .12 & ICo196 & il. \\
\hline 6 & 3.50 & 14.17 & 18.53 & 26.76 & 25.54 & 7.23 & 2.98 & .93 & .32 & .05 & 101170 & 10.7 \\
\hline 7 & 3.38 & 15.93 & $22 . \mathrm{Cl}$ & 27.60 & 20.93 & 6.53 & 2.59 & .66 & .33 & .03 & 93945 & 9.5 \\
\hline d & 3.17 & 20.06 & 25.06 & 24.74 & 17.54 & 5.92 & 2.44 & .78 & .22 & .06 & 86655 & 9.1 \\
\hline ; & 2.80 & 25.34 & 26.91 & 21.25 & 14.58 & 5.61 & 2.30 & .95 & .20 & .05 & 80551 & 8.5 \\
\hline 10 & 2.81 & & 28.28 & 18.82 & 12.43 & 5.11 & 2.60 & .80 & .34 & .07 & 76767 & 8.1 \\
\hline 11 & 2.03 & 27.27 & 32.23 & 17.77 & 11.29 & 5.28 & 2.53 & 1.10 & .40 & .11 & 77092 & 8.1 \\
\hline 16 & 1.71 & 24.78 & 34.58 & 17.67 & 11.11 & 5.54 & 2.97 & 1.15 & .36 & .14 & 79301 & 8.4 \\
\hline 13 & 1.32 & 22.62 & 35.16 & 18.64 & 11.56 & 5.83 & 3.55 & 1.33 & .42 & .17 & 83451 & 8.8 \\
\hline 14 & 1.55 & 20.46 & 34.71 & 18.36 & 12.48 & 6.31 & 3.90 & 1.56 & .55 & .14 & 87494 & 9.2 \\
\hline 15 & 1.73 & 19.24 & 33.02 & 18.81 & 12.92 & 7.11 & 4.67 & 1.82 & .55 & .12 & 91812 & 9.7 \\
\hline 16 & 2.12 & 18.40 & 30.20 & 19.31 & 13.40 & 8.47 & 5.26 & 2.14 & .55 & .16 & 57113 & 10.2 \\
\hline 17 & 2.78 & 16.67 & 26.96 & 20.01 & 14.19 & 9.35 & 6.61 & 2.64 & .62 & .17 & 104546 & 11.0 \\
\hline 18 & 3.01 & 13.76 & 23.92 & 20.72 & 15.15 & 11.15 & 8.15 & 3.39 & .59 & .15 & 114485 & 12.1 \\
\hline 19 & 2.76 & 11.06 & 19.77 & 20.86 & 17.20 & 12.74 & 10.23 & 3.92 & .66 & .13 & 125946 & 13.3 \\
\hline 20 & 2.55 & 10.35 & 17.12 & 20.26 & 18.13 & 13.35 & 12.28 & 4.98 & .90 & .08 & 135707 & 14.3 \\
\hline$<$ & 2.52 & 10.04 & 15.61 & 19.51 & 18.52 & 14.49 & 12.66 & 5.79 & .78 & .08 & 140577 & 14.8 \\
\hline 22 & 2.73 & 10.68 & 14.90 & 18.20 & 19.74 & 15.47 & 12.06 & 5.44 & .75 & .04 & 199839 & 14.7 \\
\hline 23 & 2.05 & 10.73 & 14.95 & 18.63 & 21.59 & 16.72 & 10.76 & 3.42 & .44 & .09 & 134559 & 14.2 \\
\hline$<4$ & 2.70 & 10.38 & 15.35 & 19.09 & 24.18 & 17.26 & 8.50 & 2.12 & .35 & .07 & 129126 & 13.6 \\
\hline TLTAL & 2.57 & 16.26 & 22.94 & 20.46 & 18.76 & 10.20 & 5.75 & 2.11 & .45 & .10 & 2555311 & 11.2 \\
\hline
\end{tabular}




\section{WIND SPEED AND DIRECTION VERSUS STABILITY}

Tables 50, 51 and 52 show the joint percent frequency distribution between wind direction and six class intervals of wind speed.

These tables show the joint frequency distribution, in percent, between six class intervals of wind speed and eighteen class intervals of wind direction, with each grouping broken down into four stability categories as follows: VS (very stable), MS (moderately stable), $N$ (neutral) and $U$ (unstable). Table 50 relates $\Delta T_{1}$ to the 200 -foot wind and Table 51 relates $\Delta T_{2}$ to the same wind. Table 52 relates $\Delta T_{6}$ to the 400-foot wind.

The $\Delta T s$, together with the stability category determination for each, are explained below, where $T$ is temperature in ${ }^{\circ} \mathrm{F}$, and the subscripts denote height above ground surface in feet.

$$
\begin{aligned}
& \Delta T_{1}=T_{200}-T_{3} \\
& \Delta T_{2}=T_{250}-T_{50} \\
& \Delta T_{6}=T_{400}-T_{250} \\
& \geq 3.5 \\
& \geq 2.5 \\
& 3.4 \text { to }-0.4 \\
& 3.4 \text { to }-0.4 \\
& 2.4 \text { to }-0.3 \\
& N \quad-0.5 \text { to }-1.4 \\
& -0.5 \text { to }-1.4 \\
& -0.4 \text { to }-1.1 \\
& \leq-1.5 \\
& \leq-1.5 \\
& \leq-1.2
\end{aligned}
$$

VS

MS$$
\text { U }
$$

Monthly and annual hourly average temperatures measured on the Hanford Meteorology Tower are summarized in Tables 53 through 60 . The temperatures are recorded hourly on the half-hour. Temperature data used in Figures 26 through 28 and Tables 50 through 52 are taken from these summaries. 
TABLE 50. Seasonal and Annual Percent Frequency Distribution of Wind Speed and Direction Versus Stability (1955 Through 1980) at 200-Foot Level, Using $\Delta T_{1}$

\section{WINTER}

\begin{tabular}{|c|c|c|c|c|c|c|c|c|c|c|c|c|c|c|c|c|c|c|c|c|}
\hline $\begin{array}{l}\text { SPEE } \\
\text { CLA }\end{array}$ & & NNE & NE & ENE & E & ESE & $\mathrm{SE}$ & SSE & s & Ssw & sw & WSW & $w$ & WNW & NW & NNW & $\mathbf{N}$ & CALM & VAR & TOTAL \\
\hline 0.3 & $u$ & 0.41 & 0.33 & 0.25 & 0.20 & 0.17 & 0.14 & 0.07 & 0.07 & 0.05 & 0.05 & 0.05 & 0.07 & 0.11 & 0.18 & 0.30 & 0.36 & 0.22 & 0.09 & 3.12 \\
\hline $0-3$ & $\mathbf{N}$ & 0.58 & 0.53 & 0.45 & 0.56 & 0.58 & 0.76 & 0.50 & 0.30 & 0.21 & 0.17 & 0.21 & 0.37 & 0.39 & 0.59 & 0.73 & 0.79 & 1.46 & 0.25 & 9.42 \\
\hline 0.3 & MS & 0.37 & 0.33 & 0.31 & 0.40 & 0.58 & 0.72 & 0.45 & 0.38 & 0.25 & 0.22 & 0.23 & 0.40 & 0.45 & 0.57 & 0.58 & 0.59 & 1.34 & 0.31 & 8.47 \\
\hline 0.3 & vs & 0.33 & 0.32 & 0.22 & 0.29 & 0.36 & 0.57 & 0.36 & 0.37 & 0.25 & 0.28 & 0.30 & 0.45 & 0.38 & 0.51 & 0.52 & 0.54 & 0.73 & 0.41 & 7.18 \\
\hline 4-7 & $u$ & 0.32 & 0.27 & 0.20 & 0.16 & 0.13 & 0.14 & 0.06 & 0.05 & 0.05 & 0.04 & 0.04 & 0.06 & 0.19 & 0.70 & 0.63 & 0.50 & 0.00 & 0.00 & 3.55 \\
\hline $4-7$ & $\mathbf{N}$ & 0.18 & 0.20 & 0.18 & 0.17 & 0.18 & 0.24 & 0.20 & 0.10 & 0.07 & 0.12 & 0.15 & 0.26 & 0.50 & 1.11 & 0.64 & 0.37 & 0.00 & 0.01 & 4.68 \\
\hline 4-7 & MS & 0.33 & 0.27 & 0.19 & 0.23 & 0.26 & 0.47 & 0.33 & 0.24 & 0.20 & 0.25 & 0.25 & 0.56 & 0.88 & 1.35 & 1.06 & 0.70 & 0.00 & 0.04 & 7.62 \\
\hline 4-7 & vs & 0.28 & 0.21 & 0.16 & 0.21 & 0.22 & 0.32 & 0.36 & 0.38 & 0.29 & 0.41 & 0.49 & 0.93 & 1.03 & 1.05 & 0.91 & 0.58 & 0.00 & 0.07 & 7.89 \\
\hline $8-12$ & $\mathbf{u}$ & 0.12 & 0.07 & 0.03 & 0.02 & 0.01 & 0.02 & 0.02 & 0.03 & 0.07 & 0.06 & 0.11 & 0.07 & 0.29 & 1.14 & 0.35 & 0.15 & 0.00 & 0.00 & 2.54 \\
\hline $8-12$ & $\mathbf{N}$ & 0.06 & 0.05 & 0.02 & 0.01 & 0.02 & 0.07 & 0.06 & 0.03 & 0.06 & 0.06 & 0.09 & 0.12 & 0.88 & 1.73 & 0.32 & 0.13 & 0.00 & 0.00 & 3.69 \\
\hline 8-12 & MS & 0.14 & 0.07 & 0.03 & 0.06 & 0.10 & 0.28 & 0.20 & 0.15 & 0.23 & 0.36 & 0.42 & 0.69 & 1.65 & 2.88 & 0.81 & 0.24 & 0.00 & 0.00 & 8.31 \\
\hline $8-12$ & vs & 0.09 & 0.06 & 0.04 & 0.04 & 0.04 & 0.11 & 0.14 & 0.13 & 0.12 & 0.30 & 0.55 & 1.00 & 1.43 & 1.73 & 0.74 & 0.20 & 0.00 & 0.00 & 6.73 \\
\hline 13.18 & $u$ & 0.11 & 0.02 & 0.00 & 0.00 & 0.00 & 0.00 & 0.01 & 0.02 & 0.07 & 0.12 & 0.19 & 0.11 & 0.25 & 0.44 & 0.08 & 0.10 & 0.00 & 0.00 & 1.52 \\
\hline $13-18$ & $\mathbf{N}$ & 0.07 & 0.01 & 0.00 & 0.01 & 0.00 & 0.01 & 0.02 & 0.03 & 0.07 & 0.12 & 0.12 & 0.07 & 0.67 & 1.06 & 0.09 & 0.10 & 0.00 & 0.00 & 2.44 \\
\hline 13-18 & MS & 0.15 & 0.04 & 0.00 & 0.01 & 0.04 & 0.08 & 0.13 & 0.23 & 0.33 & 0.72 & 0.90 & 0.81 & 1.97 & 2.79 & 0.35 & 0.16 & 0.00 & 0.00 & 8.71 \\
\hline 13.18 & vs & 0.04 & 0.02 & 0.01 & 0.00 & 0.00 & 0.03 & 0.04 & 0.05 & 0.10 & 0.19 & 0.31 & 0.54 & 0.87 & 1.24 & 0.16 & 0.04 & 0.00 & 0.00 & 3.63 \\
\hline 19.24 & $u$ & 0.04 & 0.02 & 0.01 & 0.00 & 0.00 & 0.00 & 0.00 & 0.01 & 0.04 & 0.15 & 0.13 & 0.06 & 0.07 & 0.10 & 0.01 & 0.03 & 0.00 & 0.00 & 0.68 \\
\hline $19-24$ & $\mathbf{N}$ & 0.05 & 0.01 & 0.00 & 0.00 & 0.00 & 0.00 & 0.01 & 0.04 & 0.08 & 0.16 & 0.11 & 0.03 & 0.10 & 0.16 & 0.00 & 0.06 & 0.00 & 0.00 & 0.81 \\
\hline 19.24 & MS & 0.06 & 0.04 & 0.00 & 0.00 & 0.00 & 0.02 & 0.09 & 0.19 & 0.41 & 0.93 & 0.64 & 0.39 & 0.51 & 0.61 & 0.04 & 0.03 & 0.00 & 0.00 & 3.96 \\
\hline $19-24$ & vs & 0.00 & 0.00 & 0.00 & 0.00 & 0.00 & 0.01 & 0.02 & 0.01 & 0.03 & 0.07 & 0.07 & 0.07 & 0.11 & 0.11 & 0.00 & 0.00 & 0.00 & 0.00 & 0.49 \\
\hline GT. 24 & $u$ & 0.03 & 0.01 & 0.01 & 0.00 & 0.00 & 0.00 & 0.00 & 0.00 & 0.07 & 0.22 & 0.20 & 0.06 & 0.03 & 0.05 & 0.00 & 0.02 & 0.00 & 0.00 & 0.70 \\
\hline GT.24 & $\mathbf{N}$ & 0.02 & 0.01 & 0.00 & 0.00 & 0.00 & 0.00 & 0.01 & 0.02 & 0.12 & 0.26 & 0.09 & 0.03 & 0.02 & 0.02 & 0.00 & 0.02 & 0.00 & 0.00 & 0.64 \\
\hline GT. 24 & MS & 0.02 & 0.04 & 0.01 & 0.00 & 0.00 & 0.01 & 0.06 & 0.18 & 0.75 & 1.10 & 0.51 & 0.15 & 0.14 & 0.11 & 0.01 & 0.01 & 0.00 & 0.00 & 3.09 \\
\hline GT.24 & vs & 0.00 & 0.00 & 0.00 & 0.00 & 0.00 & 0.00 & 0.01 & 0.01 & 0.04 & 0.03 & 0.01 & 0.01 & 0.00 & 0.00 & 0.00 & 0.00 & 0.00 & 0.00 & 0.10 \\
\hline TOTALS & $u$ & 1.03 & 0.73 & 0.50 & 0.38 & 0.31 & 0.31 & 0.15 & 0.18 & 0.33 & 0.64 & 0.72 & 0.43 & 0.94 & 2.61 & 1.37 & 1.17 & 0.22 & 0.09 & 12.12 \\
\hline TOTALS & $\mathbf{N}$ & 0.96 & 0.81 & 0.65 & 0.73 & 0.78 & 1.08 & 0.79 & 0.52 & 0.60 & 0.90 & 0.77 & 0.89 & 2.55 & 4.68 & 1.79 & 1.46 & 1.46 & 0.26 & 21.69 \\
\hline TOTALS & MS & 1.06 & 0.78 & 0.54 & 0.70 & 0.99 & 1.58 & 1.27 & 1.37 & 2.17 & 3.58 & 2.95 & 3.00 & 5.60 & 8.30 & 2.85 & 1.73 & 1.34 & 0.35 & 40.16 \\
\hline TOTALS & VS & 0.74 & 0.61 & 0.42 & 0.53 & 0.62 & 1.04 & 0.93 & 0.95 & 0.82 & 1.28 & 1.73 & 3.00 & 3.81 & 4.64 & 2.34 & 1.36 & 0.73 & 0.48 & 26.03 \\
\hline
\end{tabular}




\section{TABLE 50. Continued}

\section{SPRING}

SPEED CLASS

NNE NE ENE E ESE SE SSE S SSW SW WSW W WNW NW NNW N CALM VAR TOTAL

\begin{tabular}{|c|c|c|c|c|c|c|c|c|c|c|c|c|c|c|c|c|c|c|c|c|}
\hline 0-3 & u & 0.55 & 0.66 & 0.36 & 0.42 & 0.30 & 0.32 & 0.15 & 0.18 & 0.16 & 0.16 & 0.12 & 0.18 & 0.17 & 0.30 & 0.38 & 0.65 & 0.06 & 0.51 & 5.64 \\
\hline 0.3 & $\mathbf{N}$ & 0.09 & 0.15 & 0.10 & 0.13 & 0.14 & 0.16 & 0.07 & 0.07 & 0.04 & 0.05 & 0.04 & 0.09 & 0.05 & 0.11 & 0.14 & 0.18 & 0.09 & 0.11 & 1.80 \\
\hline $0-3$ & MS & 0.08 & 0.10 & 0.07 & 0.11 & 0.15 & 0.17 & 0.08 & 0.09 & 0.06 & 0.07 & 0.08 & 0.13 & 0.11 & 0.11 & 0.11 & 0.14 & 0.13 & 0.09 & 1.87 \\
\hline $0-3$ & VS & 0.13 & 0.12 & 0.11 & 0.16 & 0.20 & 0.23 & 0.17 & 0.13 & 0.15 & 0.19 & 0.14 & 0.34 & 0.23 & 0.27 & 0.25 & 0.21 & 0.26 & .18 & 3.47 \\
\hline 4.7 & $\mathbf{U}$ & 1.02 & 1.00 & 0.72 & 0.68 & 0.57 & 0.76 & 0.48 & 0.60 & 0.55 & 0.67 & 0.48 & 0.48 & 0.62 & 1.18 & 1.25 & 1.36 & 0.00 & 0.29 & 12.70 \\
\hline 4.7 & $\mathbf{N}$ & 0.07 & 0.09 & 0.07 & 0.09 & 0.12 & 0.21 & 0.12 & 0.08 & 0.06 & 0.06 & 0.08 & 0.11 & 0.16 & 0.18 & 0.14 & 0.10 & 0.00 & 0.02 & 1.76 \\
\hline 4-7 & MS & 0.09 & 0.12 & 0.11 & 0.16 & 0.19 & 0.33 & 0.15 & 0.18 & 0.14 & 0.18 & 0.27 & 0.41 & 0.36 & 0.36 & 0.24 & 0.22 & 0.00 & 0.02 & 3.53 \\
\hline 4-7 & vs & 0.14 & 0.13 & 0.12 & 0.15 & 0.20 & 0.28 & 0.22 & 0.24 & 0.21 & 0.32 & 0.47 & 0.93 & 0.93 & 0.80 & 0.50 & 0.37 & 0.00 & 0.01 & 6.01 \\
\hline 12 & u & 0.59 & 0.40 & 0.17 & 0.14 & 0.11 & 0.24 & 0.21 & 0.28 & 0.50 & 0.72 & 0.70 & 0.49 & 0.80 & 1.55 & 0.63 & 0.59 & 0.00 & 0.01 & 8.14 \\
\hline 8-12 & $\mathbf{N}$ & 0.06 & 0.03 & 0.03 & 0.04 & 0.05 & 0.08 & 0.08 & 0.05 & 0.07 & 0.12 & 0.15 & 0.19 & 0.29 & 0.33 & 0.11 & 0.06 & 0.00 & 0.00 & 1.75 \\
\hline 8-12 & MS & 0.11 & 0.08 & 0.04 & 0.06 & 0.07 & 0.20 & 0.19 & 0.17 & 0.26 & 0.32 & 0.60 & 1.26 & 1.38 & 0.91 & 0.32 & 0.15 & 0.00 & 0.00 & 6.10 \\
\hline 8-12 & VS & 0.11 & 0.13 & 0.12 & 0.10 & 0.07 & 0.13 & 0.22 & 0.16 & 0.13 & 0.24 & 0.56 & 1.46 & 1.87 & 1.49 & 0.51 & 0.21 & 0.00 & 0.00 & 7.52 \\
\hline 13-18 & U & 0.38 & 0.19 & 0.07 & 0.02 & 0.01 & 0.03 & 0.08 & 0.12 & 0.36 & 0.78 & 1.07 & 0.53 & 0.95 & 1.20 & 0.16 & 0.22 & 0.00 & 0.00 & 6.15 \\
\hline 13-18 & $\mathbf{N}$ & 0.07 & 0.02 & 0.02 & 0.01 & 0.01 & 0.04 & 0.05 & 0.08 & 0.09 & 0.18 & 0.30 & 0.19 & 0.40 & 0.36 & 0.04 & 0.04 & 0.00 & 0.00 & 1.90 \\
\hline 13-18 & MS & 0.08 & 0.06 & 0.03 & 0.03 & 0.02 & 0.08 & 0.18 & 0.14 & 0.25 & 0.51 & 1.12 & 2.02 & 3.41 & 1.93 & 0.18 & 0.11 & 0.00 & 0.00 & 10.14 \\
\hline $13-18$ & VS & 0.05 & 0.04 & 0.04 & 0.03 & 0.01 & 0.05 & 0.14 & 0.03 & 0.02 & 0.06 & 0.32 & 0.55 & 1.18 & 1.36 & 0.19 & 0.08 & 0.00 & 0.00 & 4.16 \\
\hline 19-24 & $\mathbf{u}$ & 0.12 & 0.07 & 0.02 & 0.00 & 0.00 & 0.00 & 0.01 & 0.05 & 0.21 & 0.56 & 0.68 & 0.24 & 0.60 & 0.73 & 0.04 & 0.0 & 0.00 & 0.00 & 3.36 \\
\hline $19-24$ & $\mathbf{N}$ & 0.02 & 0.02 & 0.01 & 0.00 & 0.00 & 0.01 & 0.02 & 0.06 & 0.11 & 0.19 & 0.22 & 0.09 & 0.32 & 0.33 & 0.02 & 0.01 & 0.00 & 0.00 & 1.41 \\
\hline $19 \cdot 24$ & MS & 0.04 & 0.03 & 0.02 & 0.01 & 0.00 & 0.03 & 0.07 & 0.07 & 0.16 & 0.48 & 0.72 & 0.50 & 2.07 & 1.43 & 0.04 & 0.01 & 0.00 & 0.00 & 5.68 \\
\hline $19-24$ & VS & 0.00 & 0.00 & 0.00 & 0.01 & 0.00 & 0.00 & 0.01 & 0.00 & 0.00 & 0.00 & 0.03 & 0.02 & 0.07 & 0.19 & 0.01 & 0.00 & 0.00 & 0.00 & 0.36 \\
\hline GT.24 & $\mathbf{u}$ & 0.03 & 0.03 & .02 & 0.01 & 0.00 & 0.00 & 0.00 & 0.02 & 0.15 & 0.78 & 0.60 & 0.18 & 0.41 & 0.61 & 0.0 & 0.02 & 0.00 & 0.00 & 2.88 \\
\hline GT.24 & $\mathbf{N}$ & 0.01 & 0.00 & 0.01 & 0.00 & 0.00 & 0.00 & 0.00 & 0.02 & 0.06 & 0.23 & 0.12 & 0.05 & 0.25 & 0.28 & 0.00 & 0.00 & 0.00 & 0.00 & 1.03 \\
\hline GT.24 & MS & 0.01 & 0.01 & 0.01 & 0.00 & 0.00 & 0.00 & 0.01 & 0.05 & 0.17 & 0.40 & 0.22 & 0.06 & 0.78 & 0.92 & 0.00 & 0.01 & 0.00 & 0.00 & 2.64 \\
\hline GT.24 & vs & 0.00 & 0.00 & 0.00 & 0.00 & 0.00 & 0.00 & 0.00 & 0.00 & 0.00 & 0.00 & 0.01 & 0.00 & 0.00 & 0.00 & 0.00 & 0.00 & 0.00 & 0.00 & 0.01 \\
\hline TOTALS & $\mathbf{U}$ & 2.69 & 2.35 & 1.36 & 1.28 & 0.98 & 1.34 & 0.94 & 1.25 & 1.93 & 3.67 & 3.65 & 2.09 & 3.5 & 5.58 & 2.47 & 2.88 & & & 38.87 \\
\hline TOTALS & $\mathbf{N}$ & 0.31 & 0.32 & 0.23 & 0.28 & 0.32 & 0.50 & 0.34 & 0.36 & 0.43 & 0.82 & 0.91 & 0.72 & 1.46 & 1.60 & 0.44 & 0.40 & 0.09 & 0.13 & 9.64 \\
\hline TOTALS & MS & 0.40 & 0.39 & 0.27 & 0.38 & 0.44 & 0.80 & 0.68 & 0.69 & 1.04 & 1.96 & 3.00 & 4.39 & 8.11 & 5.65 & 0.89 & 0.64 & 0.13 & 0.11 & 29.96 \\
\hline TOTALS & vS & 0.43 & 0.43 & 0.40 & 0.45 & 0.48 & 0.69 & 0.76 & 0.57 & 0.52 & 0.82 & 1.52 & 3.30 & 4.27 & 4.11 & 1.46 & 0.87 & 0.26 & 0.19 & 21.52 \\
\hline
\end{tabular}




\section{TABLE 50. Continued}

\section{SUMMER}

SPEED NNE NE ENE E ESE SE SSE S SSW SW WSW W WNW NW NNW N CALM VAR TOTAL

\begin{tabular}{|c|c|c|c|c|c|c|c|c|c|c|c|c|c|c|c|c|c|c|c|c|}
\hline & & & & & & & & & & & & & & & & & & & & \\
\hline $0-3$ & $\mathbf{U}$ & 0.50 & 0.61 & 0.32 & & 0.37 & 0.35 & 0.20 & & & 0.31 & & & 0.20 & 0.31 & 0.34 & 0.58 & 0.05 & 1.02 & 6.50 \\
\hline $0-3$ & $\mathbf{N}$ & .08 & 0.07 & 0.07 & 0.09 & 0.08 & 0.11 & 0.06 & 0.05 & 0.05 & 0.04 & 0.06 & 0.07 & 0.06 & 0.09 & 0.08 & 0.10 & 0.06 & 0.08 & 1.30 \\
\hline $0-3$ & MS & .05 & 0.03 & 0.04 & 0.04 & 0.07 & 0.10 & 0.04 & 0.07 & 0.03 & 0.04 & 0.06 & 0.10 & & & & 0.07 & 0.06 & 0.06 & 1.10 \\
\hline $0-3$ & VS & .08 & 0.06 & 0.05 & 0.05 & 0.06 & 0.10 & 0.06 & 0.08 & 0.07 & 0.10 & 0.13 & 0.20 & 0.17 & .15 & 0.10 & .12 & 0.13 & 0.05 & 1.76 \\
\hline & $\mathbf{u}$ & & & & & & & .80 & .99 & 38 & 1.01 & 0.85 & .86 & & & .59 & .86 & 00 & 83 & \\
\hline 4-7 & $\mathbf{N}$ & 08 & 07 & .06 & 07 & 15 & 18 & .07 & .07 & 6 & 0.08 & .08 & .16 & & 17 & .11 & .10 & & .02 & 1.66 \\
\hline 4-7 & MS & & & .07 & 09 & & 19 & 0.08 & 12 & 0.08 & 17 & 0.20 & 38 & & .20 & .13 & .07 & & 01 & 2.38 \\
\hline 4-7 & VS & 0.12 & .11 & 0.09 & 0.12 & 0.14 & 0.19 & 0.14 & .12 & 0.12 & 0.20 & 0.37 & .80 & 0.7 & .50 & .32 & 0.23 & .00 & 0.01 & 4.35 \\
\hline & $\mathbf{U}$ & & & 24 & & & & & 27 & & 11 & & 72 & & 90 & & & & 01 & 10.75 \\
\hline & $n$ & 04 & & 05 & 05 & 06 & 05 & 05 & 03 & & .08 & & 18 & & 27 & & & & & 1.42 \\
\hline 8-1 & N & & & .05 & 10 & 12 & 11 & 10 & 07 & 08 & .20 & & .29 & & & & & & & 5.13 \\
\hline 8-12 & vS & & 11 & .09 & 0.10 & 0.09 & 0.07 & 0.14 & 10 & 07 & .14 & & .25 & & & & 0.18 & & 00 & 6.64 \\
\hline & $\mathrm{c}$ & & & & & & & & & & 84 & & & & & & & & & 6.22 \\
\hline $13-$ & N & & & 01 & & & & & & & .08 & & 25 & & 38 & 04 & .02 & & & 1.61 \\
\hline 13. & MS & 06 & 04 & .04 & 0.03 & & 0.02 & 0.07 & 0.05 & & 0.17 & & .49 & & 2.06 & & .06 & & .00 & 9.55 \\
\hline $13-18$ & VS & 0.03 & 0.03 & 0.02 & 0.02 & 0.00 & 0.02 & 0.08 & 0.01 & 0.01 & 003 & & 28 & 1.3 & 1.38 & & 0.03 & & 00 & 3.50 \\
\hline & $\mathbf{u}$ & & & & & & & & & & 28 & & & & & & & & & 2.81 \\
\hline 19-24 & $\Lambda$ & & & & & & & & 0.00 & & 0.07 & & 0.08 & & & 01 & & 00 & & 1.42 \\
\hline $19-24$ & MS & & & 1.02 & .00 & & .00 & & 0.01 & 0.02 & 0.09 & .17 & 0.31 & 2.79 & 2.75 & 0.05 & 0.01 & .00 & 0.00 & 6.28 \\
\hline $19-24$ & vs & .00 & .00 & 0.00 & 0.00 & 0.00 & 0.00 & 0.00 & 0.00 & 0.00 & 0.00 & 0.01 & 0.00 & 0.04 & 0.21 & 0.00 & 0.00 & 0.00 & 0.00 & 0.28 \\
\hline & $u$ & & & & & & & & & & & & & & & & & & & 1.79 \\
\hline GT.24 & $\mathbf{N}$ & & & & 0.00 & 0.00 & & 0.00 & & & 0.03 & & & & & & & & & 1.30 \\
\hline & & & & & & & & & & & & & & & & & & & & 2.74 \\
\hline GT.24 & vs & 0.00 & 0.00 & 0.00 & 0.00 & 0.00 & 0.00 & 0.00 & 0.00 & 0.00 & 0.00 & 0.00 & 0.00 & 0.00 & 0.00 & 0.00 & 0.00 & 0.00 & 0.00 & 0.01 \\
\hline TOTALS & U & & & & & & & & & & & & & & & & & & & 47.58 \\
\hline & $\mathbf{N}$ & & 0.21 & 0.20 & 0.22 & & & & & & & & & 1.60 & 2.24 & 0.30 & 0.27 & 0.06 & & 8.71 \\
\hline TOTALS & MS & & 0.26 & 0.21 & 0.27 & 0.35 & 0.43 & 0.30 & 0.33 & 0.28 & 0.69 & 1.58 & 3.61 & 10.30 & 7.31 & 0.54 & 0.34 & 0.06 & 0.07 & 27.18 \\
\hline & VS & 0.35 & & 0.26 & 0.31 & 0.29 & 0.39 & 0.43 & 0.32 & 0.27 & 0.46 & 1.04 & 2.52 & 4. & 3.51 & 1.00 & 0.56 & 0.13 & & \\
\hline
\end{tabular}


TABLE 50. Continued

\section{AUTUMN}

SPEED

NNE NE ENE $\underline{E}$ ESE SE SSE S SSW SW WSW W WNW NW NNW N CALM VAR TOTAL

$\begin{array}{llllllllllllll}\text { u } & 0.87 & 0.97 & 0.62 & 0.67 & 0.52 & 0.40 & 0.17 & 0.12 & 0.08 & 0.10 & 0.10 & 0.14 & 0.18 \\ \text { N } & 0.32 & 0.33 & 0.28 & 0.35 & 0.39 & 0.47 & 0.20 & 0.18 & 0.11 & 0.08 & 0.08 & 0.12 & 0.14 \\ \text { MS } & 0.20 & 0.19 & 0.18 & 0.27 & 0.33 & 0.49 & 0.22 & 0.20 & 0.12 & 0.13 & 0.18 & 0.16 & 0.22 \\ \text { VS } & 0.34 & 0.29 & 0.24 & 0.35 & 0.42 & 0.56 & 0.38 & 0.39 & 0.33 & 0.29 & 0.34 & 0.54 & 0.52\end{array}$

$\begin{array}{lllll}0.31 & 0.53 & 0.79 & 0.23 & 0.41\end{array}$ $\begin{array}{llllll}0.28 & 0.37 & 0.35 & 0.51 & 0.15 & 4.71\end{array}$ $0-3$

$0-3$

$\begin{array}{llllll}0.33 & 0.28 & 0.37 & 0.61 & 0.17 & 4.66\end{array}$

$\begin{array}{lllllllllllllllllllll}4-7 & U & 1.02 & 0.73 & 0.50 & 0.59 & 0.63 & 0.53 & 0.23 & 0.20 & 0.24 & 0.25 & 0.21 & 0.23 & 0.35 & 0.89 & 1.25 & 1.42 & 0.00 & 0.09 & 9.35 \\ 4-7 & N & 0.13 & 0.11 & 0.08 & 0.11 & 0.23 & 0.28 & 0.13 & 0.08 & 0.07 & 0.07 & 0.09 & 0.13 & 0.19 & 0.48 & 0.35 & 0.16 & 0.00 & 0.01 & 2.71\end{array}$

$\begin{array}{lllllllllllllllllllll}4-7 & \text { MS } & 0.19 & 0.12 & 0.15 & 0.19 & 0.28 & 0.45 & 0.30 & 0.22 & 0.16 & 0.21 & 0.20 & 0.36 & 0.51 & 0.73 & 0.52 & 0.37 & 0.00 & 0.01 & 4.98\end{array}$

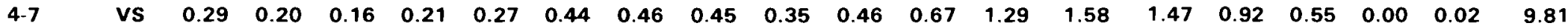

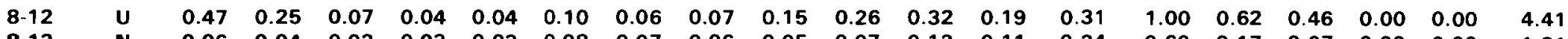

$\begin{array}{llllllllllllllllllllll}8-12 & N & 0.06 & 0.04 & 0.02 & 0.03 & 0.03 & 0.08 & 0.07 & 0.06 & 0.05 & 0.07 & 0.12 & 0.11 & 0.24 & 0.60 & 0.17 & 0.07 & 0.00 & 0.00 & 1.81 \\ 8-12 & N S & 0.10 & 0.06 & 0.03 & 0.05 & 0.10 & 0.23 & 0.27 & 0.18 & 0.24 & 0.35 & 0.43 & 0.85 & 1.28 & 1.46 & 0.50 & 0.19 & 0.00 & 0.00 & 6.33\end{array}$

$\begin{array}{lllllllllllllllllllll}8-12 & M S & 0.10 & 0.06 & 0.03 & 0.05 & 0.10 & 0.23 & 0.27 & 0.18 & 0.24 & 0.35 & 0.43 & 0.85 & 1.28 & 1.46 & 0.50 & 0.19 & 0.00 & 0.00 & 6.33\end{array}$

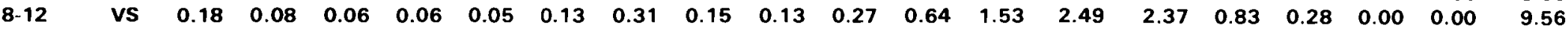

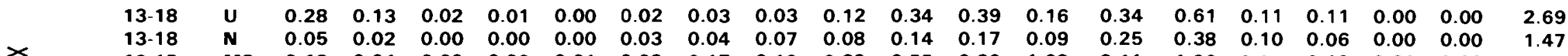

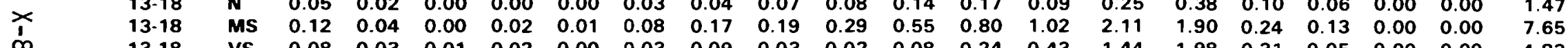

$\begin{array}{lllllllllllllllllllllll}\infty & 0 & 13-18 & \text { vS } & 0.08 & 0.03 & 0.01 & 0.02 & 0.00 & 0.03 & 0.09 & 0.03 & 0.02 & 0.08 & 0.24 & 0.43 & 1.44 & 1.98 & 0.31 & 0.05 & 0.00 & 0.00 & 4.83\end{array}$

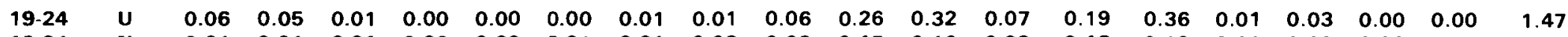

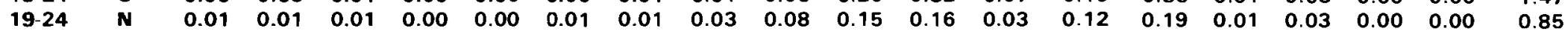

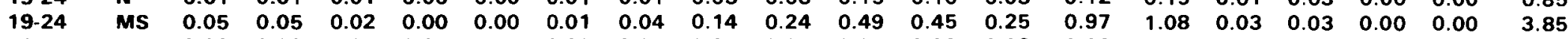

$\begin{array}{lllllllllllllllllllllll}19-24 & \text { VS } & 0.00 & 0.00 & 0.01 & 0.00 & 0.00 & 0.00 & 0.01 & 0.01 & 0.01 & 0.01 & 0.03 & 0.02 & 0.08 & 0.21 & 0.00 & 0.00 & 0.00 & 0.00 & 0.38\end{array}$

$\begin{array}{llllllllllllllllllll}\text { GT.24 U U } & 0.01 & 0.05 & 0.01 & 0.00 & 0.00 & 0.00 & 0.00 & 0.01 & 0.07 & 0.32 & 0.21 & 0.06 & 0.10 & 0.21 & 0.01 & 0.01 & 0.00 & 0.00 & 1.09\end{array}$

$\begin{array}{llllllllllllllllllllll}\text { GT.24 } & N & 0.01 & 0.01 & 0.00 & 0.00 & 0.00 & 0.00 & 0.00 & 0.02 & 0.07 & 0.16 & 0.07 & 0.03 & 0.07 & 0.12 & 0.00 & 0.00 & 0.00 & 0.00 & 0.55\end{array}$

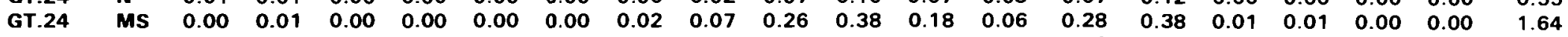

$\begin{array}{lllllllllllllllllllllllll}\text { GT.24 VS } & 0.00 & 0.00 & 0.00 & 0.00 & 0.00 & 0.00 & 0.00 & 0.00 & 0.00 & 0.00 & 0.00 & 0.00 & 0.00 & 0.00 & 0.00 & 0.00 & 0.00 & 0.00 & 0.01\end{array}$

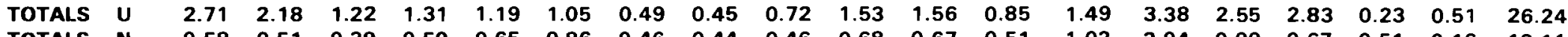

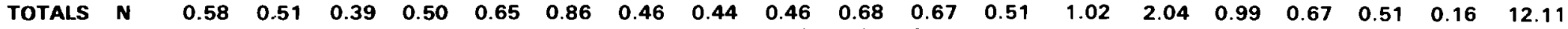

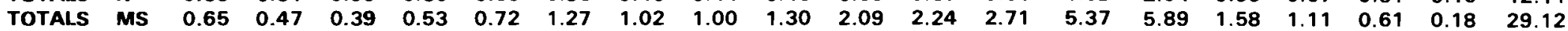

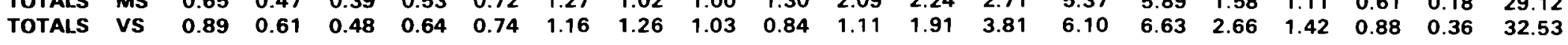


TABLE 50. Continued

ANNUAL

SPEED

NNE NE ENE E ESE SE SSE S SSW SW WSW W WNW NW NNW N CALM VAR TOTAL CLASS

$\begin{array}{lllll}\text { U } & 0.58 & 0.64 & 0.39\end{array}$

\begin{tabular}{|c|c|c|c|c|c|c|c|c|c|c|c|c|c|c|c|c|c|c|c|c|}
\hline $0-3$ & U & 0.58 & 0.64 & 0.39 & 0.42 & 0.34 & 0.30 & 0.14 & 0.17 & 0.12 & 0.16 & 0.12 & 0.16 & 0.17 & 0.27 & 0.39 & 0.60 & 0.14 & 0.51 & 5.62 \\
\hline $0-3$ & $\mathbf{N}$ & 0.26 & 0.27 & 0.22 & 0.28 & 0.30 & 0.37 & 0.21 & 0.15 & 0.10 & 0.09 & 0.10 & 0.16 & 0.16 & 0.27 & 0.33 & 0.36 & 0.53 & 0.15 & 4.29 \\
\hline 0.3 & MS & 0.17 & 0.16 & 0.15 & 0.20 & 0.28 & 0.37 & 0.20 & 0.18 & 0.12 & 0.11 & 0.14 & 0.20 & 0.22 & 0.27 & 0.25 & 0.29 & 0.53 & 0.16 & 4.01 \\
\hline 0.3 & VS & 0.22 & 0.20 & 0.15 & 0.21 & 0.26 & 0.36 & 0.25 & 0.24 & 0.20 & 0.21 & 0.23 & 0.38 & 0.32 & 0.38 & 0.37 & 0.35 & 0.49 & 0.24 & 5.07 \\
\hline-7 & $\mathbf{U}$ & 1.01 & 0.88 & 0.59 & 0.64 & 0.58 & 0.66 & 0.39 & 0.46 & 0.43 & 0.49 & 0.40 & 0.41 & 0.51 & 1.08 & 1.18 & 1.29 & 0.00 & 0.30 & 11.30 \\
\hline 4.7 & $\mathbf{N}$ & 0.11 & 0.12 & 0.10 & 0.11 & 0.17 & 0.23 & 0.13 & 0.09 & 0.07 & 0.08 & 0.10 & 0.16 & 0.24 & 0.48 & 0.31 & 0.18 & 0.00 & 0.01 & .2 .70 \\
\hline 4.7 & MS & 0.17 & 0.14 & 0.13 & 0.17 & 0.22 & 0.36 & 0.22 & 0.19 & 0.14 & 0.20 & 0.23 & 0.43 & 0.51 & 0.66 & 0.49 & 0.34 & 0.00 & 0.02 & 4.62 \\
\hline $4-7$ & VS & 0.21 & 0.16 & 0.13 & 0.17 & 0.21 & 0.31 & 0.29 & 0.30 & 0.24 & 0.35 & 0.50 & 0.99 & 1.07 & 0.95 & 0.66 & 0.43 & 0.00 & 0.03 & 7.00 \\
\hline 12 & $\mathbf{U}$ & 0.49 & 0.31 & 0.13 & 0.12 & 0.10 & 0.15 & 0.12 & 0.16 & 0.31 & 0.54 & 0.56 & 0.37 & 0.60 & 1.40 & 0.62 & 0.49 & 0.00 & 0.00 & 6.48 \\
\hline 8.12 & $\mathbf{N}$ & 0.05 & 0.04 & 0.03 & 0.03 & 0.04 & 0.07 & 0.06 & 0.04 & 0.06 & 0.08 & 0.13 & 0.15 & 0.41 & 0.73 & 0.16 & 0.07 & 0.00 & 0.00 & 2.17 \\
\hline 12 & MS & 0.11 & 0.07 & 0.04 & 0.07 & 0.10 & 0.20 & 0.19 & 0.14 & 0.20 & 0.31 & 0.48 & 1.02 & 1.45 & 1.47 & 0.44 & 0.18 & 0.00 & 0.00 & 6.47 \\
\hline 12 & VS & 0.12 & 0.10 & 0.08 & 0.07 & 0.07 & 0.11 & 0.20 & 0.13 & 0.11 & 0.24 & 0.54 & 1.31 & 1.95 & 1.71 & 0.63 & 0.22 & 0.00 & 0.00 & 7.60 \\
\hline $13-18$ & $\mathrm{U}$ & 0.25 & 0.13 & 0.04 & 0.02 & 0.01 & 0.02 & 0.04 & 0.06 & 0.19 & 0.52 & 0.68 & 0.3 & 0.62 & 0.98 & 0.13 & 0.14 & 0.00 & 0.00 & 4.16 \\
\hline 13.18 & $\mathbf{N}$ & 0.06 & 0.02 & 0.01 & 0.01 & 0.01 & 0.02 & 0.04 & 0.05 & 0.07 & 0.13 & 0.21 & 0.15 & 0.43 & 0.54 & 0.07 & 0.05 & 0.00 & 0.00 & 1.86 \\
\hline 13-18 & MS & 0.10 & 0.05 & 0.02 & 0.02 & 0.02 & 0.06 & 0.13 & 0.15 & 0.23 & 0.49 & 0.86 & 1.34 & 3.03 & 2.17 & 0.23 & 0.11 & 0.00 & 0.00 & 9.02 \\
\hline $13-18$ & VS & 0.05 & 0.03 & 0.02 & 0.02 & 0.00 & 0.03 & 0.09 & 0.03 & 0.04 & 0.09 & 0.24 & 0.45 & 1.20 & 1.49 & 0.20 & 0.05 & 0.00 & 0.00 & 4.03 \\
\hline $19 \cdot 24$ & $\mathbf{U}$ & 0.07 & 0.05 & 0.01 & 0.00 & 0.00 & 0.00 & 0.01 & 0.02 & 0.10 & 0.31 & 0.40 & 0.13 & 0.33 & 0.60 & 0.03 & 0.03 & 0.00 & 0.00 & 2.09 \\
\hline 19-24 & $\mathbf{N}$ & 0.02 & 0.01 & 0.00 & 0.00 & 0.00 & 0.00 & 0.01 & 0.03 & 0.07 & 0.14 & 0.16 & 0.06 & 0.25 & 0.32 & 0.01 & 0.03 & 0.00 & 0.00 & 1.12 \\
\hline $19 \cdot 24$ & MS & 0.04 & 0.04 & 0.01 & 0.00 & 0.00 & 0.02 & 0.05 & 0.10 & 0.21 & 0.50 & 0.50 & 0.36 & 1.59 & 1.47 & 0.04 & 0.02 & 0.00 & 0.00 & 4.95 \\
\hline $19 \cdot 24$ & VS & 0.00 & 0.00 & 0.00 & 0.00 & 0.00 & 0.00 & 0.01 & 0.01 & 0.01 & 0.02 & 0.03 & 0.03 & 0.07 & 0.18 & 0.00 & 0.00 & 0.00 & 0.00 & 0.38 \\
\hline GT.24 & $\mathbf{U}$ & 0.02 & 0.03 & 0.01 & 0.00 & 0.00 & 0.00 & 0.00 & 0.01 & 0.08 & 0.37 & 0.32 & 0.09 & 0.20 & 0.46 & 0.01 & 0.01 & 0.00 & 0.00 & 1.62 \\
\hline GT. 24 & $\mathbf{N}$ & 0.01 & 0.01 & 0.00 & 0.00 & 0.00 & 000 & 0.00 & 0.02 & 0.06 & 0.17 & 0.09 & 0.03 & 0.18 & 0.29 & 0.00 & 0.01 & 0.00 & 0.00 & 0.88 \\
\hline GT. 24 & MS & 0.01 & 0.01 & 0.00 & 0.00 & 0.00 & 0.01 & 0.02 & 0.07 & 0.30 & 0.48 & 0.23 & 0.07 & 0.56 & 0.75 & 0.00 & 0.01 & 0.00 & 0.00 & 2.53 \\
\hline GT. 24 & VS & 0.00 & 0.00 & 0.00 & 0.00 & 0.00 & 0.00 & 0.00 & 0.00 & 0.01 & 0.01 & 0.01 & 0.00 & 0.00 & 0.00 & 0.00 & 0.00 & 0.00 & 0.00 & 0.03 \\
\hline TOTALS & $\mathbf{U}$ & 2.42 & 2.04 & 1.17 & 1.21 & 1.03 & 1.13 & 0.71 & 0.88 & 1.23 & 2.40 & 2.47 & 1.49 & 2.42 & 4.79 & 2.36 & 2.56 & 0.14 & 0.82 & 31.27 \\
\hline TOTALS & $\mathbf{N}$ & 0.52 & 0.46 & 0.37 & 0.43 & 0.51 & 0.70 & 0.45 & 0.37 & 0.42 & 0.69 & 0.79 & 0.72 & 1.68 & 2.63 & 0.88 & 0.70 & 0.53 & 0.16 & 13.02 \\
\hline TOTALS & MS & 0.60 & 0.47 & 0.35 & 0.47 & 0.62 & 1.02 & 0.81 & 0.84 & 1.20 & 2.08 & 2.44 & 3.43 & 7.36 & 6.79 & 1.46 & 0.95 & 0.53 & 0.18 & 31.60 \\
\hline TOTALS & VS & 60 & 0.49 & 0.39 & 0.48 & 0.53 & 0.82 & 0.84 & 0.71 & 0.61 & 0.92 & 1.55 & 3.16 & 4.62 & 4.71 & 1.86 & 1.05 & 0.49 & 0.27 & 24.11 \\
\hline
\end{tabular}


TABLE 51. Seasonal and Annual Percent Frequency Distribution of Wind Speed and Direction Versus Stability (1955 Through 1980) at 200-Foot Level Using $\Delta T_{2}$

\section{SPRING}

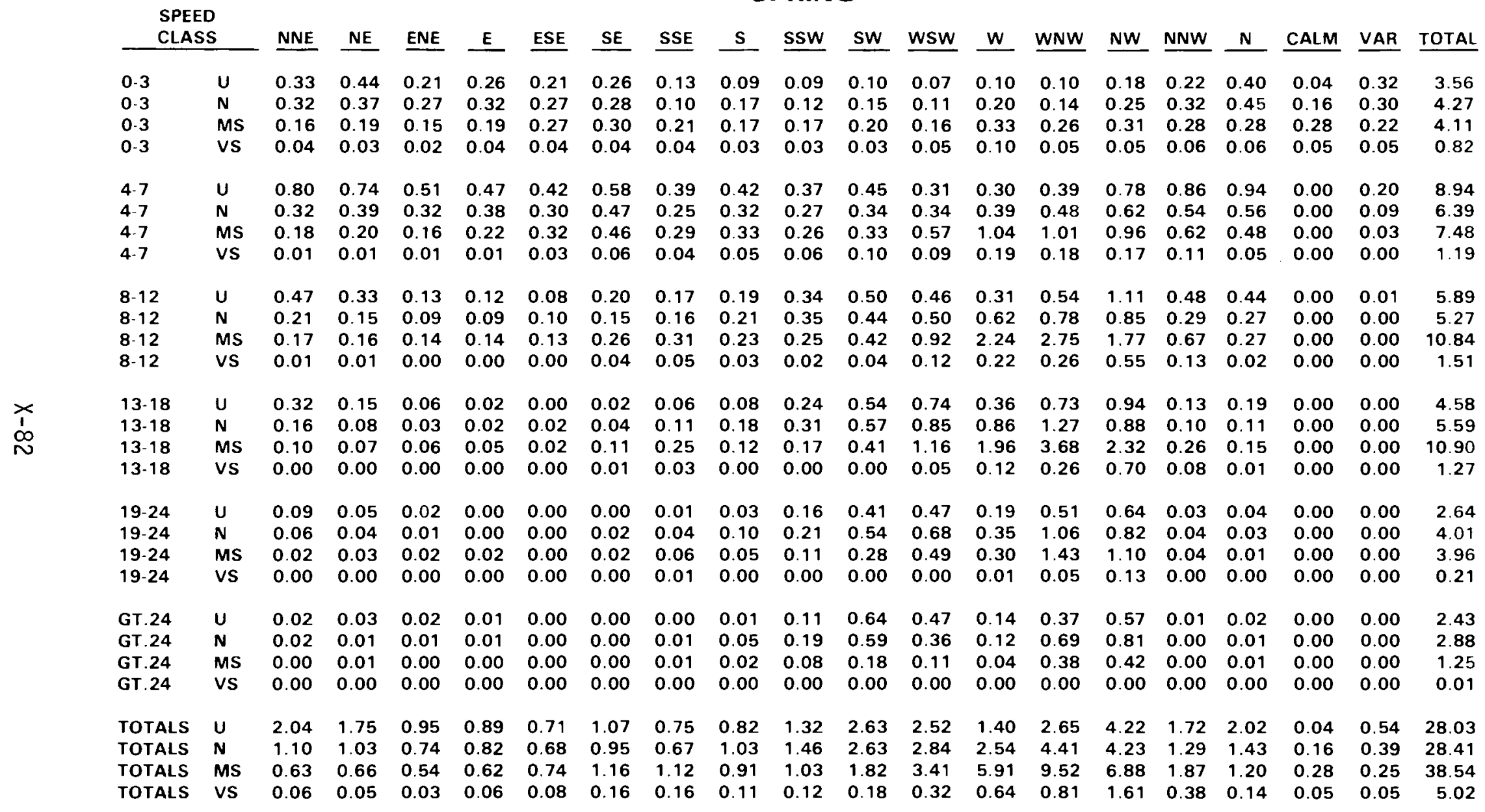




\section{TABLE 51. Continued}

\section{SUMMER}

SPEED

CLASS

NNE NE ENE E ESE SE SSE S SSW SW WSW

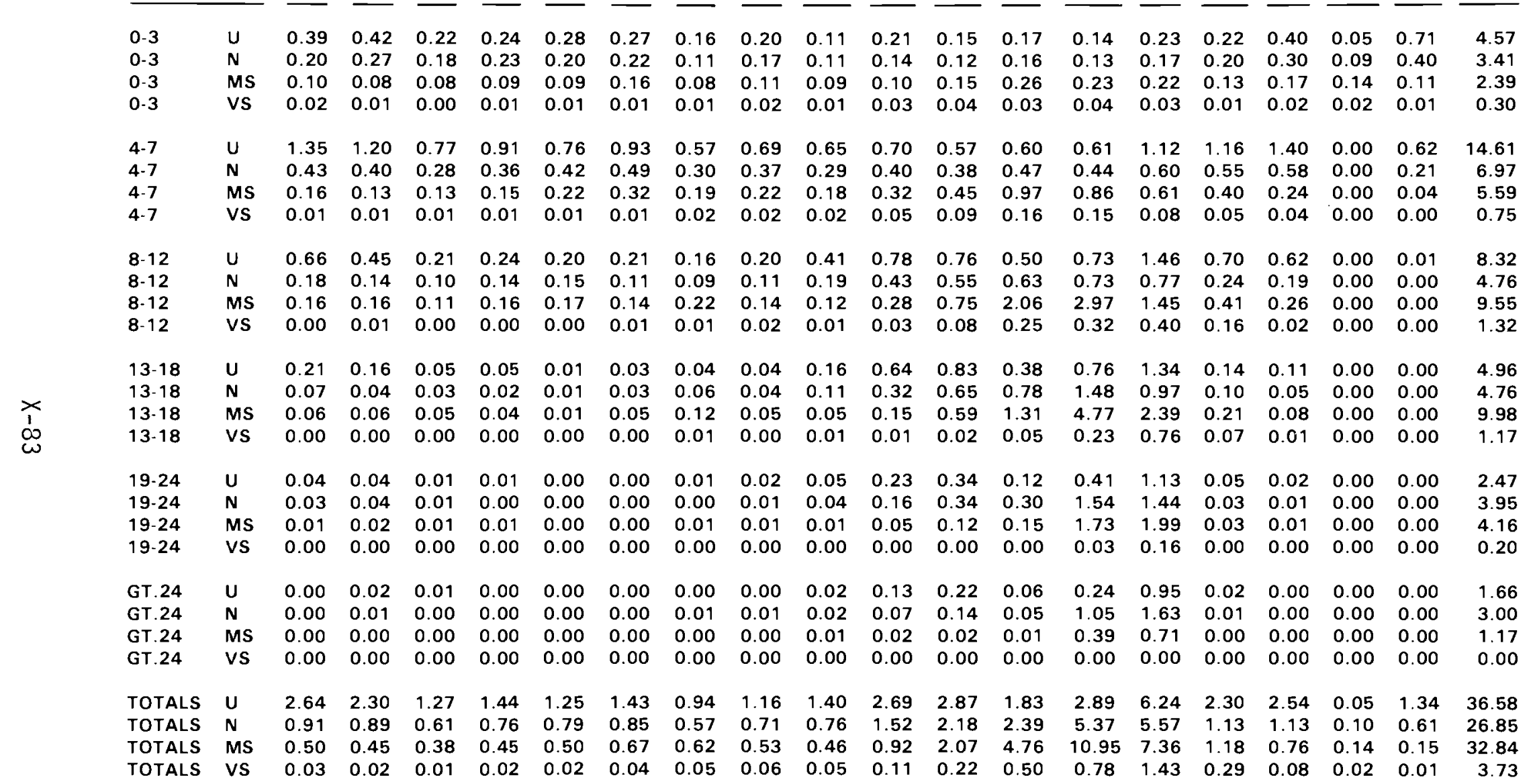


TABLE 51. Continued

\section{AUTUMN}

SPEED CLASS

NNE NE ENE. E ESE SE SSE S SSW SW WSW W WNW NW NNW N CALM VAR TOTAL

$\begin{array}{lllllllllllllllllllll}0-3 & U & 0.54 & 0.58 & 0.35 & 0.44 & 0.33 & 0.33 & 0.12 & 0.07 & 0.07 & 0.07 & 0.07 & 0.06 & 0.08 & 0.18 & 0.26 & 0.43 & 0.09 & 0.26 & 4.34\end{array}$ $\begin{array}{llllllllllllllllllllll}0-3 & N & 0.65 & 0.77 & 0.56 & 0.66 & 0.69 & 0.65 & 0.30 & 0.26 & 0.15 & 0.15 & 0.16 & 0.24 & 0.29 & 0.51 & 0.68 & 0.77 & 0.85 & 0.31 & 8.64 \\ 0.3 & N S & 0.46 & 0.38 & 0.34 & 0.45 & 0.52 & 0.75 & 0.40 & 0.43 & 0.32 & 0.33 & 0.38 & 0.52 & 0.55 & 0.68 & 0.67 & 0.68 & 1.09 & 0.39 & 9.35\end{array}$

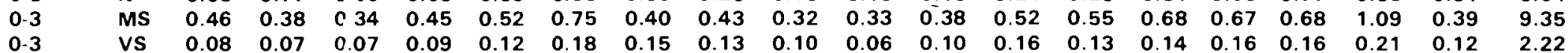

$\begin{array}{lllllllllllllllllllll}4.7 & U & 0.78 & 0.52 & 0.36 & 0.41 & 0.49 & 0.45 & 0.17 & 0.14 & 0.16 & 0.16 & 0.12 & 0.14 & 0.23 & 0.55 & 0.83 & 0.97 & 0.00 & 0.06 & 6.55\end{array}$

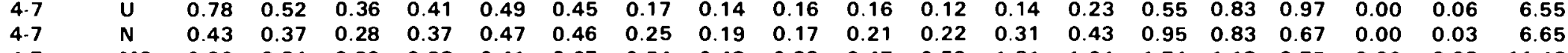

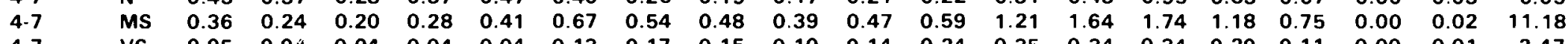

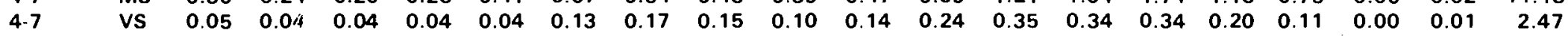

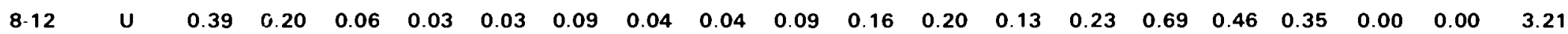
$\begin{array}{llllllllllllllllllllll}8.12 & N & 0.19 & 0.10 & 0.04 & 0.06 & 0.06 & 0.11 & 0.12 & 0.14 & 0.18 & 0.31 & 0.34 & 0.36 & 0.54 & 1.01 & 0.37 & 0.23 & 0.00 & 0.00 & 4.17\end{array}$ $\begin{array}{lllllllllllllllllllll}8-12 & \text { MS } & 0.24 & 0.12 & 0.07 & 0.08 & 0.13 & 0.30 & 0.45 & 0.26 & 0.26 & 0.43 & 0.79 & 1.75 & 3.03 & 2.99 & 1.04 & 0.40 & 0.00 & 0.00 & 12.35\end{array}$

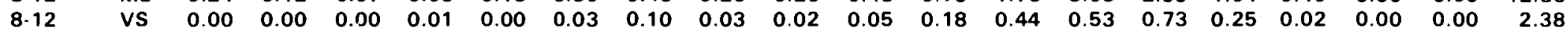

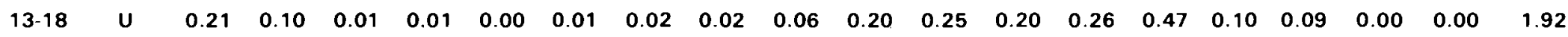
$\begin{array}{lllllllllllllllllllll}13.18 & N & 0.15 & 0.07 & 0.01 & 0.01 & 0.01 & 0.04 & 0.06 & 0.12 & 0.23 & 0.52 & 0.51 & 0.37 & 0.65 & 0.74 & 0.15 & 0.13 & 0.00 & 0.00 & 3.77\end{array}$

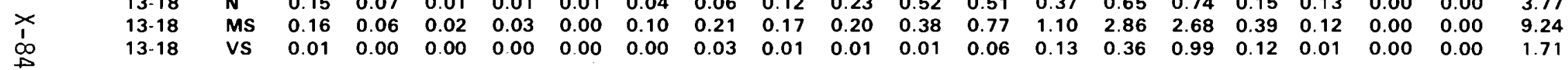

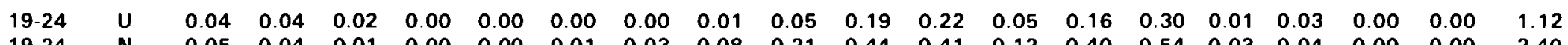
$\begin{array}{lllllllllllllllllllll}19-24 & N & 0.05 & 0.04 & 0.01 & 0.00 & 0.00 & 0.01 & 0.03 & 0.08 & 0.21 & 0.44 & 0.41 & 0.12 & 0.40 & 0.54 & 0.03 & 0.04 & 0.00 & 0.00 & 2.40\end{array}$

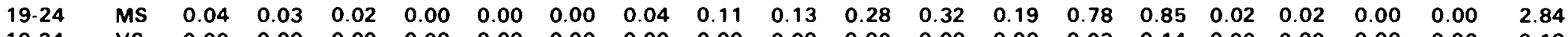
$\begin{array}{llllllllllllllllllllll}19-24 & V S & 0.00 & 0.00 & 0.00 & 0.00 & 0.00 & 0.00 & 0.00 & 0.00 & 0.00 & 0.00 & 0.00 & 0.00 & 0.03 & 0.14 & 0.00 & 0.00 & 0.00 & 0.00 & 0.19\end{array}$

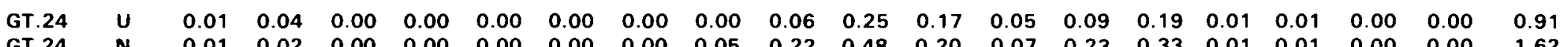
$\begin{array}{lllllllllllllllllllllll}\text { GT.24 N } & N & 0.01 & 0.02 & 0.00 & 0.00 & 0.00 & 0.00 & 0.00 & 0.05 & 0.22 & 0.48 & 0.20 & 0.07 & 0.23 & 0.33 & 0.01 & 0.01 & 0.00 & 0.00 & 1.62\end{array}$ $\begin{array}{lllllllllllllllllllll}\text { GT.24 } & \text { MS } & 0.00 & 0.01 & 0.00 & 0.00 & 0.00 & 0.00 & 0.02 & 0.04 & 0.12 & 0.13 & 0.09 & 0.03 & 0.13 & 0.19 & 0.00 & 0.01 & 0.00 & 0.00 & 0.76 \\ \text { GT.24 } & \text { VS } & 0.00 & 0.00 & 0.00 & 0.00 & 0.00 & 0.00 & 0.00 & 0.00 & 0.00 & 0.00 & 0.00 & 0.00 & 0.00 & 0.00 & 0.00 & 0.00 & 0.00 & 0.00 & 0.00\end{array}$

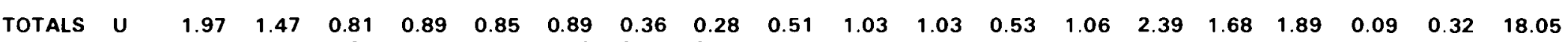

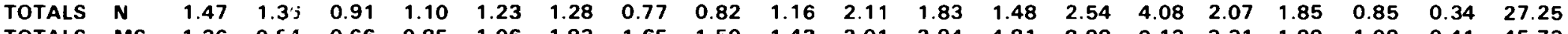

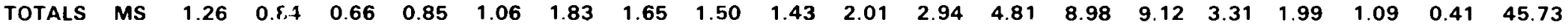

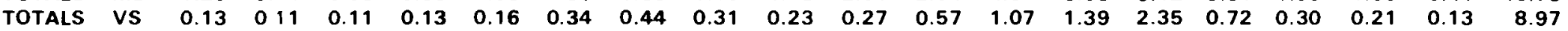


TABLE 51. Continued

\section{WINTER}

SPEED

CLASS NNE NE ENE E ESE SE SSE S SSW SW WSW W WNW NW NNW N CALM VAR TOTAL

\begin{tabular}{|c|c|c|c|c|c|c|c|c|c|c|c|c|c|c|c|c|c|c|c|c|}
\hline $0-3$ & U & 0.24 & 0.25 & 0.17 & 0.13 & 0.16 & 0.15 & 0.10 & 0.04 & 0.03 & 0.03 & 0.03 & 0.05 & 0.08 & 0.10 & 0.17 & 0.22 & 0.15 & 0.07 & 2.17 \\
\hline $0-3$ & $\mathbf{N}$ & 0.78 & 0.65 & 0.58 & 0.69 & 0.77 & 0.86 & 0.53 & 0.40 & 0.27 & 0.26 & 0.26 & 0.48 & 0.55 & 0.79 & 0.96 & 1.01 & 1.95 & 0.30 & 12.11 \\
\hline $0-3$ & MS & 0.55 & 0.49 & 0.40 & 0.54 & 0.66 & 0.98 & 0.64 & 0.55 & 0.36 & 0.34 & 0.41 & 0.65 & 0.63 & 0.84 & 0.82 & 0.90 & 1.51 & 0.49 & 11.76 \\
\hline 0.3 & vs & 0.11 & 0.11 & 0.07 & 0.09 & 0.10 & 0.20 & 0.10 & 0.12 & 0.09 & 0.09 & 0.09 & 0.12 & 0.08 & 0.12 & 0.18 & 0.14 & 0.14 & 0.21 & 2.16 \\
\hline 4-7 & $\mathbf{N}$ & 0.34 & 0.33 & 0.28 & 0.27 & 0.22 & 0.31 & 0.26 & 0.16 & 0.12 & 0.21 & 0.20 & 0.44 & 0.78 & 1.62 & 0.95 & 0.67 & 0.00 & 0.02 & 7. 18 \\
\hline $4-7$ & MS & 0.43 & 0.33 & 0.26 & 0.31 & 0.36 & 0.57 & 0.51 & 0.44 & 0.34 & 0.44 & 0.55 & 1.06 & 1.48 & 1.93 & 1.57 & 0.95 & 0.00 & 0.06 & 11.61 \\
\hline 4.7 & vs & 0.11 & 0.10 & 0.06 & 0.07 & 0.08 & 0.15 & 0.15 & 0.13 & 0.11 & 0.13 & 0.15 & 0.29 & 0.21 & 0.25 & 0.31 & 0.23 & 0.00 & 0.04 & 2.56 \\
\hline 8-12 & U & 0.09 & .06 & .03 & 0.01 & 0.01 & 0.03 & 0.01 & 0.02 & 0.05 & 0.04 & 0.08 & 0.05 & 0.22 & 0.70 & 0.22 & 0.11 & 0.00 & .00 & 1.72 \\
\hline $8-12$ & $\mathbf{N}$ & 0.16 & 0.07 & 0.04 & 0.03 & 0.06 & 0.10 & 0.10 & 0.08 & 0.15 & 0.23 & 0.22 & 0.29 & 1.26 & 2.42 & 0.53 & 0.23 & 0.00 & .00 & 5.96 \\
\hline 8-12 & MS & 0.15 & 0.10 & 0.05 & 0.07 & 0.10 & 0.31 & 0.25 & 0.20 & 0.23 & 0.43 & 0.74 & 1.33 & 2.49 & 3.83 & 1.17 & 0.34 & 0.00 & 0.01 & 11.80 \\
\hline $8 \cdot 12$ & vs & 0.01 & 0.01 & 0.01 & 0.01 & 0.01 & 0.04 & 0.06 & 0.04 & 0.05 & 0.08 & 0.12 & 0.22 & 0.27 & 0.53 & 0.30 & 0.04 & 0.00 & 0.00 & 1.81 \\
\hline 13-18 & $u$ & .09 & .01 & 0.00 & 0.00 & 0.00 & 0.01 & 0.00 & 0.02 & 0.05 & 0.08 & 0.13 & 0.06 & 0.16 & 0.30 & 0.06 & 0.08 & 0.00 & .00 & 1.05 \\
\hline 13.18 & $N$ & 0.17 & 0.04 & 0.00 & 0.01 & 0.01 & 0.02 & 0.05 & 0.13 & 0.22 & 0.39 & 0.41 & 0.26 & 0.94 & 1.38 & 0.17 & 0.20 & 0.00 & 0.00 & 4.39 \\
\hline 13.18 & MS & 0.10 & 0.04 & 0.01 & 0.01 & 0.03 & 0.09 & 0.13 & 0.17 & 0.26 & 0.65 & 0.94 & 1.09 & 2.44 & 3.26 & 0.39 & 0.11 & 0.00 & 0.00 & 9.73 \\
\hline $13-18$ & vs & 0.01 & 0.80 & 0.00 & 0.00 & 0.00 & 0.01 & 0.01 & 0.01 & 0.03 & 0.02 & 0.05 & 0.12 & 0.22 & 0.59 & 0.07 & 0.00 & 0.00 & 0.00 & 1.14 \\
\hline $19-24$ & $u$ & 05 & .03 & .0 & 0 & .00 & 0.00 & 0.00 & .01 & 0.02 & & 0.11 & 0.0 & 0.04 & & & 0. & 0.00 & .00 & 0.55 \\
\hline 19-24 & vs & 0.00 & 0.00 & 0.00 & 0.00 & 0.00 & 0.00 & 0.01 & 0.00 & 0.01 & 0.01 & 0.01 & 0.02 & 0.04 & 0.06 & 0.00 & 0.00 & 0.00 & 0.00 & 0.17 \\
\hline GT. 24 & U & .02 & .01 & 0.01 & 0.00 & 0.00 & 0.00 & 0.00 & 0.01 & 0.06 & 0.18 & 0.15 & 0.04 & 0.02 & 0.04 & 0.00 & 0.01 & 0.00 & 0.00 & 0.56 \\
\hline GT 24 & $\mathbf{N}$ & 0.04 & 0.03 & 0.01 & 0.00 & 0.00 & 0.01 & 0.01 & 0.09 & 0.47 & 0.79 & 0.35 & 0.09 & 0.06 & 0.06 & 0.0 & $0 . C$ & 0.00 & 0.00 & 2.04 \\
\hline GT.24 & MS & 0.01 & 0.02 & 0.00 & 0.00 & 0.00 & 0.01 & 0.05 & 0.12 & 0.45 & 0.65 & 0.31 & 0.11 & 0.10 & 0.08 & 0.00 & 0.00 & 0.00 & 0.00 & 1.92 \\
\hline GT. 24 & vs & 0.00 & 0.00 & 0.00 & 0.00 & 0.00 & 0.00 & 0.00 & 0.00 & 0.00 & 0.00 & 0.00 & 0.00 & 0.00 & 0.00 & 0.00 & 0.00 & 0.00 & 0.00 & 0.01 \\
\hline TOTALS & U & 0.73 & 0.55 & 0.33 & 0.25 & 0.29 & 0.32 & 0.16 & 0.13 & 0.25 & 0.47 & 0.54 & 0.29 & 0.64 & 1.64 & 0.87 & 0.76 & 0.15 & 0.07 & 8.43 \\
\hline TOTALS & $\mathbf{N}$ & 1.57 & 1.16 & 0.91 & 1.00 & 1.07 & 1.30 & 0.98 & 0.97 & 1.49 & 2.42 & 1.73 & 1.68 & 3.77 & 6.49 & 2.63 & 2.23 & 1.95 & 0.31 & 33.66 \\
\hline TOTALS & MS & 1.27 & 1.00 & 0.73 & 0.93 & 1.16 & 1.98 & 1.65 & 1.60 & 1.91 & 3.18 & 3.48 & 4.58 & 7.67 & 10.55 & 3.99 & 2.32 & 1.51 & 0.56 & 50.07 \\
\hline TOTALS & VS & 0.23 & 0.22 & 0.15 & 0.16 & 0.18 & 0.40 & 0.34 & 0.32 & 0.28 & 0.33 & 0.42 & 0.77 & 0.82 & 1.54 & 0.86 & 0.42 & 0.14 & 0.24 & 7.84 \\
\hline
\end{tabular}


TABLE 51. Continued

\section{ANNUAL}

SPEED

CLASS NNE NE ENE E ESE SE SSE S SSW SW WSW W WNW NW NNW N CALM VAR TOTAL

\begin{tabular}{|c|c|c|c|c|c|c|c|c|c|c|c|c|c|c|c|c|c|c|c|c|}
\hline $0-3$ & $u$ & 0.37 & 0.42 & 0.24 & 0.27 & 0.25 & 0.25 & 0.13 & 0.10 & 0.08 & 0.10 & 0.08 & 0.10 & 0.10 & 0.17 & 0.22 & 0.36 & 0.08 & 0.34 & 3.66 \\
\hline 0.3 & $\mathbf{N}$ & 0.48 & 0.51 & 0.40 & 0.47 & 0.48 & 0.50 & 0.26 & 0.25 & 0.16 & 0.18 & 0.16 & 0.27 & 0.27 & 0.43 & 0.54 & 0.63 & 0.76 & 0.33 & 7.09 \\
\hline 0.3 & MS & 0.32 & 0.28 & 0.24 & 0.32 & 0.38 & 0.54 & 0.33 & 0.31 & 0.24 & 0.24 & 0.27 & 0.44 & 0.41 & 0.51 & 0.47 & 0.51 & 0.75 & 0.30 & 6.88 \\
\hline $0-3$ & vs & 0.06 & 0.05 & 0.04 & 0.06 & 0.07 & 0.11 & 0.07 & 0.08 & 0.06 & 0.05 & 0.07 & 0.10 & 0.08 & 0.08 & 0.10 & 0.09 & 0.10 & 0.09 & 1.37 \\
\hline $4-7$ & $\mathrm{u}$ & 0.79 & 0.66 & 0.44 & 0.47 & 0.45 & 0.53 & 0.29 & 0.32 & 0.30 & 0.33 & 0.26 & 0.27 & 0.34 & 0.72 & 0.82 & 0.91 & 0.00 & 0.22 & 8.14 \\
\hline $4-7$ & $\mathbf{N}$ & 0.38 & 0.37 & 0.29 & 0.35 & 0.35 & 0.43 & 0.27 & 0.26 & 0.21 & 0.29 & 0.29 & 0.40 & 0.53 & 0.94 & 0.72 & 0.62 & 0.00 & 0.09 & 6.80 \\
\hline 4-7 & MS & 0.28 & 0.23 & 0.19 & 0.24 & 0.33 & 0.50 & 0.38 & 0.37 & 0.29 & 0.39 & 0.54 & 1.07 & 1.25 & 1.31 & 0.94 & 0.61 & 0.00 & 0.04 & 8.95 \\
\hline $4-7$ & vs & 0.04 & 0.04 & 0.03 & 0.03 & 0.04 & 0.09 & 0.10 & 0.09 & 0.07 & 0.10 & 0.14 & 0.25 & 0.22 & 0.21 & 0.16 & 0.11 & 0.00 & 0.01 & 1.73 \\
\hline 8-12 & $\mathbf{u}$ & 0.40 & 0.26 & 0.11 & 0.10 & 0.08 & 0.13 & 0.10 & 0.11 & 0.23 & 0.37 & 0.38 & 0.25 & 0.43 & 0.99 & 0.46 & 0.38 & 0.00 & 0.00 & 4.80 \\
\hline $8-12$ & $\mathbf{N}$ & 0.19 & 0.11 & 0.07 & 0.08 & 0.09 & 0.12 & 0.12 & 0.13 & 0.22 & 0.35 & 0.41 & 0.48 & 0.83 & 1.26 & 0.36 & 0.23 & 0.00 & 0.00 & 5.04 \\
\hline 8-12 & MS & 0.18 & 0.13 & 0.09 & 0.11 & 0.13 & 0.25 & 0.31 & 0.21 & 0.21 & 0.39 & 0.80 & 1.85 & 2.81 & 2.50 & 0.82 & 0.32 & 0.00 & 0.00 & 11.13 \\
\hline 8.12 & vS & 0.01 & 0.01 & 0.00 & 0.00 & 0.00 & 0.03 & 0.05 & 0.03 & 0.03 & 0.05 & 0.12 & 0.28 & 0.35 & 0.55 & 0.21 & 0.03 & 0.00 & 0.00 & 1.75 \\
\hline 13-18 & $\mathbf{u}$ & 0.21 & 0.11 & 0.03 & 0.02 & 0.00 & 0.02 & 0.03 & 0.04 & 0.13 & 0.37 & 0.49 & 0.23 & 0.48 & 0.76 & 0.11 & 0.12 & 0.00 & 0.00 & 3.14 \\
\hline 13-18 & $\mathbf{N}$ & 0.14 & 0.06 & 0.02 & 0.02 & 0.01 & 0.03 & 0.07 & 0.12 & 0.22 & 0.45 & 0.61 & 0.57 & 1.09 & 0.99 & 0.13 & 0.12 & 0.00 & 0.00 & 4.63 \\
\hline 13-18 & MS & 0.10 & 0.06 & 0.04 & 0.04 & 0.02 & 0.09 & 0.18 & 0.13 & 0.17 & 0.39 & 0.86 & 1.37 & 3.44 & 2.66 & 0.31 & 0.12 & 0.00 & 0.00 & 9.97 \\
\hline 13-18 & VS & 0.00 & 0.00 & 0.00 & 0.00 & 0.00 & 0.01 & 0.02 & 0.01 & 0.01 & 0.01 & 0.04 & 0.10 & 0.27 & 0.76 & 0.08 & 0.01 & 0.00 & 0.00 & 1.32 \\
\hline $19-24$ & $\mathbf{U}$ & 0.05 & 0.04 & 0.01 & 0.00 & 0.00 & 0.00 & 0.01 & 0.02 & 0.07 & 0.23 & 0.29 & 0.10 & 0.28 & 0.54 & 0.02 & 0.03 & 0.00 & 0.00 & 1.70 \\
\hline $19-24$ & $\mathbf{N}$ & 0.05 & 0.04 & 0.01 & 0.00 & 0.00 & 0.01 & 0.03 & 0.07 & 0.18 & 0.42 & 0.43 & 0.23 & 0.80 & 0.76 & 0.03 & 0.04 & 0.00 & 0.00 & 3.09 \\
\hline $19-24$ & MS & 0.02 & 0.02 & 0.01 & 0.01 & 0.00 & 0.01 & 0.04 & 0.07 & 0.13 & 0.32 & 0.37 & 0.25 & 1,12 & 1.14 & 0.03 & 0.01 & 0.00 & 0.00 & 3.56 \\
\hline $19-24$ & VS & 0.00 & 0.00 & 0.00 & 0.00 & 0.00 & 0.00 & 0.01 & 0.00 & 0.00 & 0.00 & 0.01 & 0.01 & 0.04 & 0.12 & 0.00 & 0.00 & 0.00 & 0.00 & 0.19 \\
\hline GT. 24 & $\mathbf{U}$ & 0.01 & 0.02 & 0.01 & 0.00 & 0.00 & 0.00 & 0.00 & 0.00 & 0.06 & 0.30 & 0.26 & 0.07 & 0.18 & 0.44 & 0.01 & 0.01 & 0.00 & 0.00 & 1.39 \\
\hline GT. 24 & $\mathbf{N}$ & 0.02 & 0.02 & 0.01 & 0.00 & 0.00 & 0.00 & 0.01 & 0.05 & 0.22 & 0.48 & 0.26 & 0.08 & 0.51 & 0.71 & 0.01 & 0.01 & 0.00 & 0.00 & 2.39 \\
\hline GT. 24 & MS & 0.00 & 0.01 & 0.00 & 0.00 & 0.00 & 0.00 & 0.02 & 0.05 & 0.16 & 0.24 & 0.13 & 0.05 & 0.25 & 0.35 & 0.00 & 0.00 & 0.00 & 0.00 & 1.28 \\
\hline GT 24 & VS & 0.00 & 0.00 & 0.00 & 0.00 & 0.00 & 0.00 & 0.00 & 0.00 & 0.00 & 0.00 & 0.00 & 0.00 & 0.00 & 0.00 & 0.00 & 0.00 & 0.00 & 0.00 & 0.01 \\
\hline TOTALS & $\mathbf{U}$ & 1.85 & 1.52 & 0.84 & 0.87 & 0.78 & 0.93 & 0.5 & 0.6 & 0.87 & 1.71 & 1.75 & 1.0 & 1.82 & 3.63 & 1.64 & 1.80 & 0.08 & 0.57 & 22.83 \\
\hline TOTALS & $\mathbf{N}$ & 1.26 & 1.11 & 0.79 & 0.92 & 0.94 & 1.10 & 0.75 & 0.88 & 1.22 & 2.17 & 2.15 & 2.03 & 4.03 & 5.10 & 1.77 & 1.66 & 0.76 & 0.41 & 29.04 \\
\hline TOTALS & MS & 0.91 & 0.73 & 0.58 & 0.71 & 0.86 & 1.41 & 1.26 & 1.13 & 1.20 & 1.98 & 2.98 & 5.02 & 9.28 & 8.47 & 2.58 & 1.56 & 0.75 & 0.34 & 41.76 \\
\hline TOTALS & VS & 0.11 & 0.10 & 0.07 & 0.09 & 0.11 & 0.24 & 0.25 & 0.20 & 0.17 & 0.22 & 0.38 & 0.74 & 0.95 & 1.73 & 0.56 & 0.23 & 0.10 & 0.11 & 6.38 \\
\hline
\end{tabular}

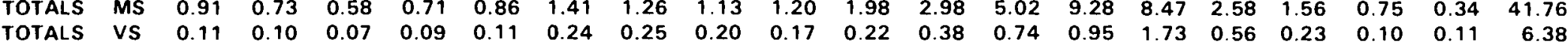


TABLE 52. Seasonal and Annual Percent Frequency Distribution of Wind Speed and Direction Versus Stability (1955 Through 1980) at 400-Foot Level, Using $\Delta_{6}$

\section{WINTER}

SPEED NNE NE ENE E ESE SE SSE S SSW SW WSW W WNW NW NNW N CALM VAR TOTAL CLASS

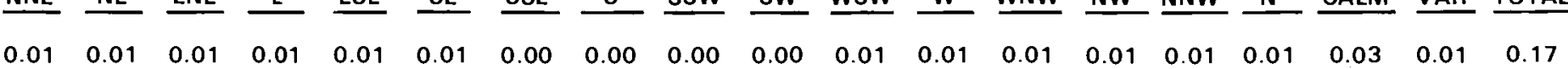

\begin{tabular}{|c|c|c|c|c|c|c|c|c|c|c|c|c|c|c|c|c|c|c|c|c|}
\hline $0-3$ & U & 0.01 & 0.01 & 0.01 & 0.01 & 0.01 & 0.01 & 0.00 & 0.00 & 0.00 & 0.00 & 0.01 & 0.01 & 0.01 & 0.01 & 0.01 & 0.01 & 0.03 & 0.01 & 0.17 \\
\hline $0-3$ & $\mathbf{N}$ & 0.45 & 0.40 & 0.34 & 0.41 & 0.33 & 0.47 & 0.28 & 0.20 & 0.11 & 0.12 & 0.13 & 0.25 & 0.36 & 0.60 & 0.57 & 0.69 & 1.64 & 0.16 & 7.51 \\
\hline $0-3$ & MS & 0.94 & 0.86 & 0.77 & 1.15 & 1.10 & 1.38 & 0.78 & 0.62 & 0.39 & 0.44 & 0.46 & 0.82 & 0.99 & 1.33 & 1.40 & 1.50 & 3.94 & 0.72 & 19.60 \\
\hline $0-3$ & VS & 0.05 & 0.06 & 0.03 & 0.07 & 0.07 & 0.10 & 0.08 & 0.07 & 0.05 & 0.04 & 0.06 & 0.07 & 0.07 & 0.06 & 0.06 & 0.09 & 0.13 & 0.12 & 1.28 \\
\hline 4-7 & $\mathbf{u}$ & 0.01 & 0.01 & 0.00 & 0.00 & 0.01 & 0.00 & 0.01 & 0.01 & 0.00 & 0.00 & 0.00 & 0.01 & 0.01 & 0.04 & 0.02 & 0.02 & 0.00 & 0.00 & 0.14 \\
\hline $4-7$ & $\mathbf{N}$ & 0.30 & 0.20 & 0.19 & 0.18 & 0.15 & 0.23 & 0.13 & 0.13 & 0.07 & 0.09 & 0.15 & 0.26 & 0.48 & 1.09 & 0.96 & 0.60 & 0.00 & 0.01 & 5.22 \\
\hline 4.7 & MS & 0.59 & 0.44 & 0.38 & 0.45 & 0.50 & 0.82 & 0.51 & 0.47 & 0.35 & 0.48 & 0.58 & 1.18 & 1.71 & 2.82 & 2.37 & 1.49 & 0.00 & 0.04 & 15.18 \\
\hline 4.7 & VS & 0.04 & 0.03 & 0.03 & 0.04 & 0.03 & 0.06 & 0.05 & 0.07 & 0.06 & 0.10 & 0.09 & 0.14 & 0.10 & 0.12 & 0.13 & 0.06 & 0.00 & 0.01 & 1.16 \\
\hline 8-12 & $\mathbf{U}$ & .00 & 0.00 & 0.00 & 0.00 & 0.00 & 0.00 & 0.00 & 0.00 & 0.00 & 0.01 & 0.00 & 0.01 & 0.01 & 0.03 & 0.02 & 0.01 & 0.00 & 0.00 & 0.10 \\
\hline $8-12$ & $\mathbf{N}$ & 0.16 & 0.05 & 0.03 & 0.02 & 0.03 & 0.07 & 0.06 & 0.06 & 0.09 & 0.13 & 0.14 & 0.26 & 0.49 & 1.37 & 0.76 & 0.31 & 0.00 & 0.00 & 4.03 \\
\hline 8.12 & MS & 0.28 & 0.14 & 0.07 & 0.07 & 0.10 & 0.30 & 0.25 & 0.20 & 0.32 & 0.52 & 0.76 & 1.26 & 2.45 & 5.76 & 2.04 & 0.59 & 0.00 & 0.00 & 15.10 \\
\hline 8-12 & VS & 0.01 & 0.00 & 0.00 & 0.01 & 0.01 & 0.02 & 0.02 & 0.04 & 0.02 & 0.06 & 0.07 & 0.12 & 0.09 & 0.15 & 0.05 & 0.01 & 0.00 & 0.00 & 0.68 \\
\hline 13-18 & U & 0.00 & 0.00 & 0.00 & 0.00 & 0.00 & 0.00 & 0.00 & 0.00 & 0.00 & 0.01 & 0.01 & 0.00 & 0.01 & 0.02 & 0.01 & 0.00 & 0.00 & 0.00 & 0.06 \\
\hline 13-18 & $\mathbf{N}$ & 0.18 & 0.04 & 0.01 & 0.00 & 0.01 & 0.04 & 0.03 & 0.09 & 0.15 & 0.33 & 0.30 & 0.30 & 0.32 & 0.64 & 0.31 & 0.24 & 0.00 & 0.00 & 2.99 \\
\hline 13-18 & MS & 0.25 & 0.07 & 0.01 & 0.01 & 0.01 & 0.14 & 0.21 & 0.21 & 0.38 & 0.65 & 1.08 & 1.20 & 2.40 & 5.12 & 0.71 & 0.25 & 0.00 & 0.00 & 12.70 \\
\hline $13-18$ & VS & 0.00 & 0.00 & 0.00 & 0.00 & 0.00 & 0.01 & 0.02 & 0.01 & 0.02 & 0.03 & 0.04 & 0.04 & 0.06 & 0.13 & 0.01 & 0.00 & 0.00 & 0.00 & 0.38 \\
\hline $19 \cdot 24$ & u & 0.00 & 0.00 & 0.00 & 0.00 & 0.00 & 0.00 & 0.00 & 0.00 & 0.00 & 0.00 & 0.01 & 0.00 & 0.00 & 0.00 & 0.00 & 0.00 & 0.00 & 0.00 & 0.03 \\
\hline $19-24$ & $\mathbf{N}$ & 0.12 & 0.05 & 0.00 & 0.00 & 0.00 & 0.01 & 0.03 & 0.10 & 0.18 & 0.37 & 0.27 & 0.15 & 0.12 & 0.16 & 0.05 & 0.09 & 0.00 & 0.00 & 1.68 \\
\hline 19-24 & MS & 0.10 & 0.04 & 0.01 & 0.00 & 0.01 & 0.03 & 0.10 & 0.15 & 0.38 & 0.83 & 0.91 & 0.59 & 0.75 & 1.12 & 0.06 & 0.06 & 0.00 & 0.00 & 5.14 \\
\hline $19-24$ & VS & 0.00 & 0.00 & 0.00 & 0.00 & 0.00 & 0.00 & 0.00 & 0.01 & 0.01 & 0.01 & 0.01 & 0.01 & 0.01 & 0.02 & 0.00 & 0.00 & 0.00 & 0.00 & 0.08 \\
\hline GT. 24 & $\mathrm{U}$ & 0.00 & 0.00 & 0.00 & 0.00 & 0.00 & 0.00 & 0.01 & 0.00 & 0.00 & 0.02 & 0.01 & 0.00 & 0.00 & 0.01 & 0.00 & 0.00 & 0.00 & 0.00 & 0.05 \\
\hline GT. 24 & $\mathbf{N}$ & 0.07 & 0.05 & 0.00 & 0.00 & 0.00 & 0.01 & 0.02 & 0.09 & 0.33 & 0.69 & 0.28 & 0.09 & 0.09 & 0.10 & 0.01 & 0.04 & 0.00 & 0.00 & 1.85 \\
\hline GT. 24 & MS & 0.04 & 0.04 & 0.00 & 0.00 & 0.00 & 0.02 & 0.09 & 0.18 & 0.82 & 1.67 & 1.00 & 0.34 & 0.33 & 0.29 & 0.01 & 0.02 & 0.00 & 0.00 & 4.84 \\
\hline GT. 24 & VS & 0.00 & 0.00 & 0.00 & 0.00 & 0.00 & 0.00 & 0.00 & 0.00 & 0.01 & 0.00 & 0.00 & 0.01 & 0.00 & 0.00 & 0.00 & 0.00 & 0.00 & 0.00 & 0.02 \\
\hline TOTALS & u & 0.02 & 0.02 & 0.01 & 0.02 & 0.02 & 0.02 & 0.02 & 0.01 & 0.01 & 0.04 & 0.03 & 0.02 & 0.05 & 0.10 & 0.07 & 0.04 & 0.03 & 0.01 & 0.55 \\
\hline TOTALS & $\mathbf{N}$ & 1.28 & 0.79 & 0.57 & 0.61 & 0.52 & 0.82 & 0.55 & 0.68 & 0.94 & 1.73 & 1.26 & 1.30 & 1.86 & 3.96 & 2.65 & 1.97 & 1.64 & 0.17 & 23.29 \\
\hline TOTALS & MS & 2.20 & 1.59 & 1.25 & 1.68 & 1.73 & 2.70 & 1.94 & 1.83 & 2.65 & 4.59 & 4.78 & 5.39 & 8.62 & 16.44 & 6.58 & 3.91 & 3.94 & 0.76 & 72.56 \\
\hline TOTALS & VS & 0.10 & 0.09 & 0.07 & 0.11 & 0.12 & 0.20 & 0.18 & 0.19 & 0.16 & 0.23 & 0.27 & 0.38 & 0.33 & 0.49 & 0.25 & 0.17 & 0.13 & 0.12 & 3.60 \\
\hline
\end{tabular}


TABLE 52. Continued

\section{SPRING}

SPEED

NNE NE ENE E ESE SE SSE S SSW SW WSW W WNW NW NNW N CALM VAR TOTAL

\begin{tabular}{|c|c|c|c|c|c|c|c|c|c|c|c|c|c|c|c|c|c|c|c|c|}
\hline 0.3 & u & 0.02 & 0.02 & 0.02 & 0.02 & 0.01 & 0.02 & 0.01 & 0.01 & 0.01 & 0.01 & 0.01 & 0.01 & 0.01 & 0.01 & 0.03 & 0.04 & 0.01 & 0.03 & 0.29 \\
\hline 0.3 & $\mathbf{N}$ & 0.32 & 0.32 & 0.27 & 0.30 & 0.21 & 0.27 & 0.15 & 0.17 & 0.11 & 0.10 & 0.09 & 0.18 & 0.14 & 0.23 & 0.31 & 0.40 & 0.23 & 0.31 & 4.12 \\
\hline $0-3$ & MS & 0.45 & 0.53 & 0.36 & 0.48 & 0.45 & 0.55 & 0.34 & 0.31 & 0.22 & 0.28 & 0.25 & 0.47 & 0.46 & 0.56 & 0.52 & 0.61 & 0.61 & 0.55 & 7.98 \\
\hline 0.3 & Vs & 0.00 & 0.02 & 0.01 & 0.01 & 0.01 & 0.02 & 0.01 & 0.01 & 0.01 & 0.01 & 0.00 & 0.02 & 0.01 & 0.02 & 0.03 & 0.02 & 0.04 & 0.02 & 0.27 \\
\hline .7 & $\mathbf{u}$ & 0.02 & 0.03 & 0.02 & 0.04 & 0.02 & 0.02 & 0.02 & 0.02 & 0.02 & 0.03 & 0.02 & 0.03 & 0.02 & 0.04 & 0.05 & 0.06 & 0.00 & 0.01 & 0.49 \\
\hline 4.7 & $\mathbf{N}$ & 0.47 & 0.42 & 0.38 & 0.43 & 0.34 & 0.45 & 0.31 & 0.38 & 0.34 & 0.43 & 0.40 & 0.41 & 0.48 & 0.67 & 0.78 & 0.78 & 0.00 & 0.08 & 7.56 \\
\hline $4-7$ & MS & 0.69 & 0.61 & 0.51 & 0.58 & 0.60 & 0.90 & 0.52 & 0.58 & 0.49 & 0.56 & 0.55 & 1.06 & 1.16 & 1.55 & 1.31 & 1.01 & 0.00 & 0.10 & 12.77 \\
\hline 1.8 & VS & 0.01 & 0.01 & 0.01 & 0.00 & 0.01 & 0.01 & 0.01 & 0.01 & 0.01 & 0.00 & 0.01 & 0.03 & 0.06 & 0.08 & 0.03 & 0.01 & 0.00 & 0.00 & 0.29 \\
\hline $3 \cdot 12$ & U & 0.02 & 0.01 & 0.01 & 0.00 & 0.00 & 0.00 & 0.01 & 0.01 & 0.01 & 0.02 & 0.02 & 0.01 & 0.03 & 0.05 & 0.02 & 0.02 & 0.00 & 0.00 & 0.24 \\
\hline 3-12 & $\mathbf{N}$ & 0.37 & 0.21 & 0.15 & 0.15 & 0.11 & 0.22 & 0.23 & 0.28 & 0.35 & 0.49 & 0.53 & 0.68 & 0.82 & 1.05 & 0.58 & 0.52 & 0.00 & 0.00 & 6.75 \\
\hline -12 & MS & 0.51 & 0.39 & 0.26 & 0.20 & 0.16 & 0.44 & 0.44 & 0.36 & 0.52 & 0.74 & 0.97 & 1.52 & 2.40 & 2.93 & 1.29 & 0.65 & 0.00 & 0.00 & 13.80 \\
\hline-12 & VS & 0.00 & 0.00 & 0.00 & 0.00 & 0.00 & 0.01 & 0.01 & 0.01 & 0.00 & 0.01 & 0.00 & 0.01 & 0.06 & 0.13 & 0.03 & 0.00 & 0.00 & 0.00 & 0.28 \\
\hline 13-18 & U & 0.01 & 0.00 & 0.00 & 0.00 & 0.00 & 0.00 & 0.01 & 0.01 & 0.01 & 0.04 & 0.03 & 0.03 & 0.03 & 0.06 & 0.01 & 0.01 & 0.00 & 0.00 & 0.24 \\
\hline 13-18 & $N$ & 0.31 & 0.16 & 0.08 & 0.05 & 0.03 & 0.06 & 0.16 & 0.18 & 0.34 & 0.63 & 0.84 & 0.96 & 1.28 & 0.87 & 0.30 & 0.27 & 0.00 & 0.00 & 6.51 \\
\hline 13-18 & MS & 0.34 & 0.23 & 0.09 & 0.09 & 0.03 & 0.20 & 0.27 & 0.18 & 0.38 & 0.78 & 1.36 & 2.21 & 3.82 & 3.52 & 0.67 & 0.38 & 0.00 & 0.00 & 14.53 \\
\hline 13.18 & VS & 0.00 & 0.00 & 0.00 & 0.00 & 0.00 & 0.00 & 0.01 & 0.00 & 0.00 & 0.01 & 0.01 & 0.01 & 0.05 & 0.13 & 0.01 & 0.00 & 0.00 & 0.00 & 0.24 \\
\hline |9-24 & U & 0.00 & 0.01 & 0.00 & 0.00 & 0.00 & 0.00 & 0.00 & 0.00 & 0.01 & 0.03 & 0.04 & 0.01 & 0.04 & 0.06 & 0.00 & 0.01 & 0.00 & 0.00 & 0.22 \\
\hline 19-24 & $\mathbf{N}$ & 0.10 & 0.08 & 0.02 & 0.00 & 0.00 & 0.01 & 0.04 & 0.08 & 0.27 & 0.59 & 0.72 & 0.53 & 1.02 & 0.78 & 0.06 & 0.06 & 0.00 & 0.00 & 4.38 \\
\hline 19-24 & MS & 0.12 & 0.07 & 0.05 & 0.02 & 0.00 & 0.06 & 0.09 & 0.10 & 0.21 & 0.63 & 1.08 & 0.92 & 2.77 & 1.88 & 0.09 & 0.05 & 0.00 & 0.00 & 8.13 \\
\hline $19-24$ & VS & 0.00 & 0.00 & 0.00 & 0.00 & 0.00 & 0.00 & 0.00 & 0.00 & 0.00 & 0.00 & 0.00 & 0.00 & 0.04 & 0.04 & 0.00 & 0.00 & 0.00 & 0.00 & 0.09 \\
\hline GT. 24 & u & 0.00 & 0.00 & 0.00 & 0.00 & 0.00 & 0.00 & 0.00 & 0.00 & 0.02 & 0.06 & 0.06 & 0.02 & 0.03 & 0.07 & 0.00 & 0.00 & 0.00 & 0.00 & 0.27 \\
\hline GT.24 & $\mathbf{N}$ & 0.04 & 0.04 & 0.03 & 0.00 & 0.00 & 0.00 & 0.00 & 0.05 & 0.24 & 0.88 & 0.74 & 0.26 & 0.93 & 0.97 & 0.02 & 0.03 & 0.00 & 0.00 & 4.22 \\
\hline GT.24 & MS & 0.03 & 0.05 & 0.03 & 0.00 & 0.00 & 0.01 & 0.04 & 0.07 & 0.22 & 0.87 & 0.72 & 0.29 & 2.27 & 1.66 & 0.03 & 0.03 & 0.00 & 0.00 & 6.31 \\
\hline GT.24 & VS & 0.00 & 0.00 & 0.00 & 0.00 & 0.00 & 0.00 & 0.00 & 0.00 & 0.00 & 0.00 & 0.00 & .00 & 0.01 & 0.01 & 0.00 & 0.00 & 0.00 & 0.00 & 0.03 \\
\hline OTALS & U & .07 & 0.07 & 0.06 & 0.07 & 0.04 & 0.04 & 0.04 & 0.05 & 0.07 & 0.19 & 0.18 & 0.11 & 0.16 & 0.30 & 0.11 & 0.14 & 0.01 & 0.04 & 1.74 \\
\hline SOTALS & $\mathbf{N}$ & 1.61 & 1.23 & 0.92 & 0.93 & 0.69 & 1.03 & 0.89 & 1.15 & 1.66 & 3.11 & 3.32 & 3.02 & 4.68 & 4.57 & 2.05 & 2.06 & 0.23 & 0.39 & 33.54 \\
\hline OTALS & MS & 2.14 & 1.88 & 1.30 & 1.37 & 1.24 & 2.16 & 1.70 & 1.60 & 2.04 & 3.86 & 4.92 & 6.47 & 12.87 & 2.09 & 3.90 & 2.73 & 0.61 & 0.65 & 63.53 \\
\hline$T$ & VS & 0.01 & .03 & 0.02 & 0.01 & 0.01 & 0.04 & 0.05 & 0.03 & 0.02 & 0.04 & 0.02 & 0.07 & 0.23 & 0.41 & 0.10 & 0.03 & 0.04 & 0.02 & 1.20 \\
\hline
\end{tabular}


TABLE 52. Continued

\section{SUMMER}

SPEED

NNE NE ENE $\quad$ E ESE SE SSE $S \quad$ SSW SW WSW W WNW NW NNW N CALM VAR TOTAL

\section{0}

\begin{tabular}{|c|c|c|c|c|c|c|c|c|c|c|c|c|c|c|c|c|c|c|c|c|}
\hline $0-3$ & u & .01 & 0.02 & 0.01 & 0.01 & 0.02 & 0.01 & 0.01 & 0.01 & 0.01 & 0.01 & 0.02 & 0.01 & 0.01 & 0.01 & 0.02 & 0.04 & 0.00 & 0.03 & 0.29 \\
\hline 0.3 & $\mathbf{N}$ & .26 & 0.28 & 0.20 & 0.26 & 0.22 & 0.24 & 0.11 & 0.18 & 0.10 & 0.15 & 0.08 & 0.19 & 0.15 & 0.22 & 0.20 & 0.34 & 0.10 & 0.49 & 3.77 \\
\hline $0-3$ & MS & 40 & 0.47 & 0.27 & 0.35 & 0.33 & .44 & 0.24 & .28 & 0.21 & .28 & 0.24 & .37 & 0.33 & 0.40 & 0.37 & 0.49 & 0.30 & 0.74 & 6.52 \\
\hline 0.3 & VS & .00 & .00 & .00 & .00 & 0.01 & .00 & 0.00 & .00 & 0.00 & 1.00 & 0.00 & .01 & 0.01 & 0.01 & .01 & 0.01 & 0.00 & 0.00 & 0.06 \\
\hline $4-7$ & U & .05 & 0.06 & 0.04 & 0.02 & 0.02 & 0.04 & 0.03 & 0.05 & 0.03 & 0.03 & 0.02 & 0.03 & 0.03 & 0.05 & .06 & 0.05 & 0.00 & 0.02 & 0.65 \\
\hline 4-7 & $n$ & 6 & 0 & 8 & 0.53 & 0.5 & 0.59 & & 0.43 & & & 0.39 & & 0.5 & .67 & 0.76 & 0.88 & 0.00 & 0.22 & 8.90 \\
\hline 4-7 & 1S & 1.02 & .94 & .62 & 0.74 & .75 & .96 & 0.58 & 0.68 & 0.60 & .79 & 0.71 & 1.20 & 1.32 & 1.46 & 1.21 & 1.25 & 0.00 & 0.34 & 15.17 \\
\hline 4-7 & vS & .00 & .00 & 0.00 & 0.00 & 0.00 & 0.00 & 0.01 & 0.00 & 0.00 & 0.01 & 0.00 & 0.01 & 0.02 & 0.02 & 0.02 & 0.01 & 0.00 & 0.00 & 0.10 \\
\hline 1 & & 03 & 01 & .00 & .01 & .00 & .01 & .01 & 0.02 & .01 & 0.04 & 0.03 & 0.02 & 0.03 & 0.06 & 0.02 & 0.03 & 0.00 & 0.00 & 0.34 \\
\hline 8-12 & I & 1.36 & .27 & 0.18 & 0.28 & 0.18 & 0.18 & 0.17 & 0.18 & 0.29 & 0.57 & 0.65 & 0.67 & 0.8 & 0.96 & 0.58 & 0.49 & .00 & 0.00 & 6.81 \\
\hline 8-12 & AS & 64 & 0.48 & 0.28 & 0.30 & 0.28 & 0.33 & 0.28 & 0.26 & 0.41 & 0.74 & 1.07 & 1.81 & 2.70 & 2.72 & .14 & 0.75 & 0.00 & 0.00 & 14.18 \\
\hline $8-12$ & VS & .00 & .00 & .00 & .00 & 0 & 0.00 & 0.0 & 0.00 & 0 & 0.00 & .01 & 0.0 & 0.0 & 0.10 & .02 & 0.01 & .00 & 0.00 & 0.19 \\
\hline 13-1 & 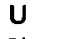 & 0 & 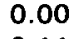 & .0 & .00 & & .00 & & 0 & & 0. & & 0.0 & & 0.03 & .01 & 0.00 & & 0.0 & 0.19 \\
\hline 13-1 & & 16 & .11 & 0.07 & 0.05 & .02 & 0.05 & 09 & 0.04 & 0.14 & 0. & 0.79 & 0.8 & & 0.92 & 0.15 & 0.10 & & $0 . C$ & 5.25 \\
\hline 13-18 & IS & .25 & 0.21 & 0.09 & 0.08 & 0.04 & 0.10 & 0. & 0.08 & 0.19 & 0.6 & 1.11 & 1.89 & 4.8 & 3.78 & 0.44 & 0.21 & & 0.00 & 14.09 \\
\hline $13-18$ & VS & .00 & 0.00 & .00 & 0.00 & .00 & 0.00 & 0.00 & 0.00 & 0.00 & 0.00 & 0.00 & 0.01 & 0.09 & 0.37 & 0.01 & 0.00 & 0.00 & 0.00 & 0.49 \\
\hline $19-24$ & & & & & .00 & & & & & & & & & & 0. & 0. & & & & 0.13 \\
\hline 19.24 & 1 & & 05 & 0.01 & 0.01 & .00 & $0 . c$ & 0.02 & 0.01 & 0.06 & & 0. & & & & & 0.02 & & 0.1 & 3.49 \\
\hline $19-24$ & MS & 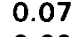 & 0.08 & 0.04 & 0.02 & 0.00 & 0.01 & 0.04 & 0.02 & 0.05 & 0. & 0. & 0.2 & & 2.83 & 0.08 & 0.04 & & 0.0 & 8.70 \\
\hline $19-24$ & VS & 0.00 & 0.00 & 0.00 & 0.00 & 0.00 & 0.00 & 0.00 & 0.00 & 0.00 & 0.00 & 0.00 & 0.00 & 0.12 & 0.22 & 0.00 & 0.00 & 0.00 & 0.00 & 0.35 \\
\hline GT.24 & & & & & .0 & & & & & & & & & & & & & & & 0.14 \\
\hline GT.24 & $N$ & .01 & .03 & 0.01 & 0.00 & .00 & 0.00 & 0.00 & 0.00 & 0.02 & 0.19 & 0.33 & 0.1 & 0 & 1.61 & $0 . C$ & 0.00 & 0.00 & 0.0 & 3.45 \\
\hline GT.24 & MS & 0.01 & 0.01 & 0.01 & 0.01 & 0.00 & 0.01 & 0.01 & 0.0 & 0.04 & 0.1 & 0.20 & 0.0 & 2.99 & 3.14 & 0.01 & 0.00 & & 0.00 & 6.65 \\
\hline GT. 24 & VS & 0.00 & 0.00 & 0.00 & 0.00 & 0.00 & 0.00 & 0.00 & 0.00 & 0.00 & 0.00 & 0.00 & 0.00 & 0.02 & 0.06 & 0.00 & 0.00 & 0.00 & 0.00 & 0.09 \\
\hline TOTALS & U & & & ( & & & & & & & & & & & & & & & & 1.74 \\
\hline & $\mathbf{N}$ & & & 0.95 & & & 1.07 & & 0.84 & 0.98 & & 2.68 & & & 5.37 & 1.7 & & & 0.71 & 31.67 \\
\hline TOTALS & MS & 2.40 & 2.20 & 1.31 & 1.48 & 1.41 & 1.84 & 1.32 & 1.33 & 1.50 & 2.83 & 3.97 & 5.92 & 16.11 & 14.33 & 3.25 & 2.74 & 0.30 & 1.08 & 65.31 \\
\hline TOTALS & VS & 0.00 & 0.01 & 0.00 & 0.00 & 0.01 & 0.01 & 0.01 & 0.00 & 0.01 & 0.01 & 0.02 & 0.04 & 0.30 & 0.78 & 0.06 & 0.02 & 0.00 & 0.00 & 1.28 \\
\hline
\end{tabular}


TABLE 52. Continued

\section{AUTUMN}

SPEED

CLASS NNE NE ENE E ESE SE SSE $S$ SSW SW WSW W WNW NW NNW N CALM VAR TOTAL

$\begin{array}{llllllllllllllllllllll}0-3 & U & 0.02 & 0.02 & 0.01 & 0.02 & 0.01 & 0.02 & 0.01 & 0.00 & 0.00 & 0.00 & 0.00 & 0.01 & 0.01 & 0.02 & 0.03 & 0.03 & 0.02 & 0.01 & 0.24\end{array}$

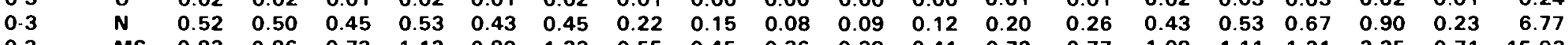

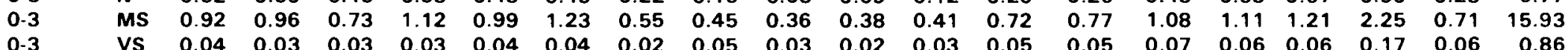

$\begin{array}{llllllllllllllllllllll}4-7 & U & 0.02 & 0.01 & 0.00 & 0.01 & 0.01 & 0.02 & 0.00 & 0.01 & 0.01 & 0.01 & 0.00 & 0.02 & 0.01 & 0.02 & 0.05 & 0.03 & 0.00 & 0.00 & 0.23\end{array}$

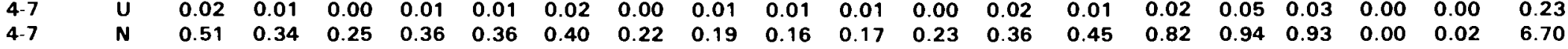

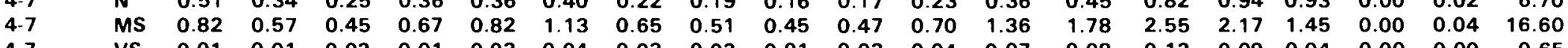

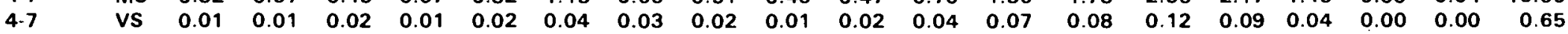

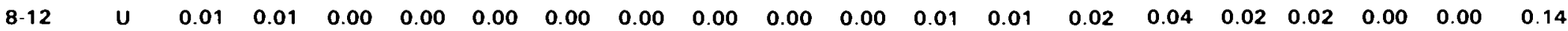

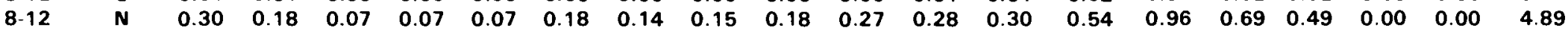

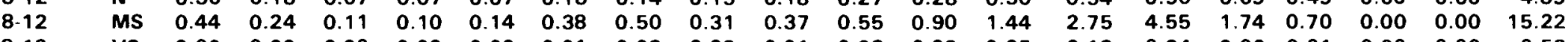

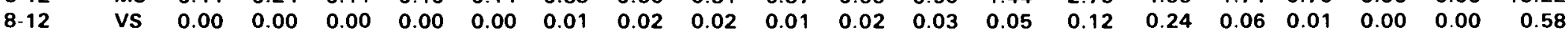

\begin{tabular}{|c|c|c|c|c|c|c|c|c|c|c|c|c|c|c|c|c|c|c|c|c|}
\hline $13-18$ & $\mathbf{u}$ & 0.01 & 0.00 & 0.00 & 0.00 & 0.00 & 0.00 & 0.00 & 0.00 & 0.01 & 0.02 & 0.02 & 0.01 & 0.02 & 0.02 & 0.01 & 0.01 & 0.00 & 0.00 & 0.11 \\
\hline 13.18 & $\mathbf{N}$ & 0.22 & 0.09 & 0.02 & 0.02 & 0.00 & 0.05 & 0.07 & 0.13 & 0.22 & 0.41 & 0.48 & 0.45 & 0.61 & 0.70 & 0.30 & 0.19 & 0.00 & 0.00 & 3.97 \\
\hline $13-18$ & MS & 0.37 & 0.15 & 0.03 & 0.03 & 0.01 & 0.19 & 0.24 & 0.21 & 0.25 & 0.61 & 1.03 & 1.37 & 2.90 & 4.23 & 0.68 & 0.33 & 0.00 & 0.00 & 12.62 \\
\hline $13-18$ & vs & 0.00 & 0.00 & 0.00 & 0.00 & 0.00 & 0.00 & 0.01 & 0.00 & 0.00 & 0.02 & 0.01 & 0.02 & 0.09 & 0.34 & 0.02 & 0.00 & 0.00 & 0.00 & 0.51 \\
\hline $19-24$ & $\mathbf{U}$ & 0.00 & 0.00 & 0.00 & 0.00 & 0.00 & 0.00 & 0.00 & 0.01 & 0.01 & 0.02 & 0.01 & 0.00 & 0.01 & 0.02 & 0.00 & 0.01 & 0.00 & 0.00 & 0.08 \\
\hline $19-24$ & $\mathbf{N}$ & 0.11 & 0.07 & 0.02 & 0.00 & 0.00 & 0.01 & 0.02 & 0.08 & 0.19 & 0.44 & 0.37 & 0.20 & 0.46 & 0.39 & 0.03 & 0.08 & 0.00 & 0.00 & 2.46 \\
\hline 19.24 & MS & 0.11 & 0.06 & 0.02 & 0.01 & 0.00 & 0.02 & 0.09 & 0.12 & 0.26 & 0.52 & 0.77 & 0.45 & 1.51 & 1.46 & 0.08 & 0.08 & 0.00 & 0.00 & 5.56 \\
\hline $19-24$ & vs & 0.00 & 0.00 & 0.00 & 0.00 & 0.00 & 0.00 & 0.00 & 0.00 & 0.01 & 0.00 & 0.00 & 0.00 & 0.03 & 0.08 & 0.00 & 0.00 & 0.00 & 0.00 & 0.12 \\
\hline GT. 24 & u & 0.00 & 0.00 & 0.00 & 0.00 & 0.00 & 0.00 & 0.00 & 0.00 & 0.01 & 0.00 & 0.00 & 0.00 & 0.01 & 0.01 & 0.00 & 0.00 & 0.00 & 0.00 & 0.04 \\
\hline GT. 24 & $\mathbf{N}$ & 0.03 & 0.06 & 0.00 & 0.00 & 0.00 & 0.00 & 0.01 & 0.06 & 0.22 & 0.52 & 0.33 & 0.11 & 0.34 & 0.41 & 0.02 & 0.02 & 0.00 & 0.00 & 2.12 \\
\hline GT.24 & MS & 0.03 & 0.04 & 0.02 & 0.00 & 0.00 & 0.00 & 0.03 & 0.09 & 0.34 & 0.64 & 0.44 & 0.17 & 0.90 & 0.83 & 0.01 & 0.02 & 0.00 & 0.00 & 3.57 \\
\hline GT. 24 & vs & 0.00 & 0.00 & 0.00 & 0.00 & 0.00 & 0.00 & 0.00 & 0.00 & 0.00 & 0.00 & 0.00 & 0.00 & 0.00 & 0.01 & 0.00 & 0.00 & 0.00 & 0.00 & 0.01 \\
\hline TOTALS & u & 0.06 & 0.04 & 0.01 & 0.03 & 0.02 & 0.04 & 0.01 & 0.03 & 0.03 & 0.06 & 0.05 & 0.05 & 0.07 & 0.13 & 0.10 & 0.09 & 0.02 & 0.01 & 0.84 \\
\hline TOTALS & $\mathbf{N}$ & 1.69 & 1.24 & 0.81 & 0.99 & 0.86 & 1.09 & 0.68 & 0.76 & 1.05 & 1.90 & 1.82 & 1.63 & 2.66 & 3.70 & 2.51 & 2.38 & 0.90 & 0.25 & 26.92 \\
\hline TOTALS & MS & 2.69 & 2.03 & 1.35 & 1.93 & 1.95 & 2.96 & 2.06 & 1.70 & 2.02 & 3.17 & 4.25 & 5.51 & 10.62 & 14.70 & 5.78 & 3.78 & 2.25 & 0.75 & 69.50 \\
\hline TOTALS & Vs & 0.06 & 0.04 & 0.04 & 0.04 & 0.06 & 0.09 & 0.08 & 0.09 & 0.06 & 0.08 & 0.11 & 0.19 & 0.37 & 0.85 & 0.23 & 0.11 & 0.17 & 0.06 & 2.73 \\
\hline
\end{tabular}


TABLE 52. Continued

\section{ANNUAL}

SPEED CLASS

NNE NE ENE E ESE SE SSE S SSW SW WSW W WNW NW NNW N CALM VAR TOTAL

\begin{tabular}{|c|c|c|c|c|c|c|c|c|c|c|c|c|c|c|c|c|c|c|c|c|}
\hline $0-3$ & $\mathbf{U}$ & 0.01 & 0.02 & 0.01 & 0.02 & 0.01 & 0.02 & 0.01 & 0.01 & 0.01 & 0.01 & 0.01 & 0.01 & 0.01 & 0.01 & 0.02 & 0.03 & 0.02 & 0.02 & 0.25 \\
\hline 0.3 & $\mathbf{N}$ & 0.39 & 0.37 & 0.32 & 0.38 & 0.30 & 0.36 & 0.19 & 0.18 & 0.10 & 0.11 & 0.11 & 0.21 & 0.23 & 0.37 & 0.40 & 0.52 & 0.71 & 0.30 & 5.53 \\
\hline 0.3 & MS & 0.67 & 0.70 & 0.53 & 0.77 & 0.71 & 0.90 & 0.48 & 0.42 & 0.30 & 0.35 & 0.34 & 0.59 & 0.64 & 0.84 & 0.85 & 0.95 & 1.77 & 0.68 & 12.47 \\
\hline 0.3 & vs & 0.02 & 0.03 & 0.02 & 0.03 & 0.03 & 0.04 & 0.03 & 0.03 & 0.02 & 0.02 & 0.02 & 0.04 & 0.03 & 0.04 & 0.04 & 0.04 & 0.08 & 0.05 & 0.62 \\
\hline 4.7 & U & 0.03 & 0.03 & 0.02 & 0.02 & 0.01 & 0.02 & 0.02 & 0.02 & 0.01 & 0.02 & 0.01 & 0.02 & 0.02 & 0.04 & 0.04 & 0.04 & 0.00 & 0.01 & 0.38 \\
\hline $4-7$ & $\mathbf{N}$ & 0.49 & 0.39 & 0.33 & 0.37 & 0.34 & 0.42 & 0.27 & 0.28 & 0.23 & 0.28 & 0.29 & 0.37 & 0.48 & 0.81 & 0.86 & 0.80 & 0.00 & 0.08 & 7.10 \\
\hline 4.7 & MS & 0.78 & 0.64 & 0.49 & 0.61 & 0.67 & 0.95 & 0.57 & 0.56 & 0.47 & 0.58 & 0.64 & 1.20 & 1.49 & 2.09 & 1.76 & 1.30 & 0.00 & 0.13 & 14.92 \\
\hline 4-7 & vs & 0.02 & 0.01 & 0.01 & 0.01 & 0.02 & 0.03 & 0.03 & 0.02 & 0.02 & 0.03 & 0.04 & 0.06 & 0.06 & 0.08 & 0.07 & 0.03 & 0.00 & 0.00 & 0.55 \\
\hline 8-12 & u & .01 & 0.01 & 0.00 & 0.00 & 1.00 & 0.00 & 0.01 & 0.01 & 0.01 & 0.02 & 0.02 & 0.01 & 0.02 & 0.04 & 0.02 & 0.02 & 0.00 & 0.00 & 0.20 \\
\hline $8-12$ & $\mathbf{N}$ & 0.30 & 0.18 & 0.11 & 0.13 & 0.10 & 0.16 & 0.15 & 0.17 & 0.23 & 0.37 & 0.40 & 0.48 & 0.67 & 1.09 & 0.65 & 0.45 & 0.00 & 0.00 & 5.63 \\
\hline 8.12 & MS & 0.47 & 0.31 & 0.18 & 0.16 & 0.17 & 0.37 & 0.37 & 0.28 & 0.41 & 0.64 & 0.93 & 1.51 & 2.57 & 3.98 & 1.55 & 0.67 & 0.00 & 0.00 & 14.57 \\
\hline $8-12$ & VS & 0.00 & 0.00 & 0.00 & 0.00 & 0.00 & 0.01 & 0.01 & 0.01 & 0.01 & 0.02 & 0.03 & 0.05 & 0.08 & 0.16 & 0.04 & 0.01 & 0.00 & 0.00 & 0.43 \\
\hline $13-18$ & U & 0.00 & .00 & 0.00 & 0.00 & 0.00 & 0.00 & 0.00 & 0.00 & 0.01 & 0.02 & 0.02 & 0.01 & 0.03 & 0.03 & 0.01 & 0.00 & 0.00 & 0.00 & 0.15 \\
\hline $13-18$ & $\mathbf{N}$ & 0.22 & 0.10 & 0.04 & 0.03 & 0.02 & 0.05 & 0.09 & 0.11 & 0.21 & 0.46 & 0.60 & 0.64 & 0.87 & 0.78 & 0.27 & 0.20 & 0.00 & 0.00 & 4.69 \\
\hline $13-18$ & MS & 0.30 & 0.16 & 0.06 & 0.05 & 0.02 & 0.16 & 0.22 & 0.17 & 0.30 & 0.67 & 1.14 & 1.67 & 3.48 & 4.16 & 0.62 & 0.29 & 0.00 & 0.00 & 13.49 \\
\hline $13-18$ & vs & 0.00 & 0.00 & 0.00 & 0.00 & 0.00 & 0.00 & 0.01 & 0.00 & 0.01 & 0.01 & 0.01 & 0.02 & 0.07 & 0.24 & 0.01 & 0.00 & 0.00 & 0.00 & 0.40 \\
\hline $19-24$ & $\mathrm{~L}$ & .00 & .00 & 0.00 & 0.00 & 0.00 & 0.00 & .00 & 0.00 & 0.0 & 0.02 & 0.0 & 0.01 & 0.02 & 0.03 & 0.00 & 0.00 & 0.00 & & 0.12 \\
\hline $19-24$ & $\mathbf{N}$ & 0.09 & 0.06 & 0.01 & 0.00 & 0.00 & 0.01 & 0.03 & 0.07 & 0.17 & 0.41 & 0.45 & 0.30 & 0.71 & 0.58 & 0.05 & 0.06 & 0.00 & 0.00 & 3.01 \\
\hline $19-24$ & MS & 0.10 & 0.06 & 0.03 & 0.01 & 0.01 & 0.03 & 0.08 & 0.10 & 0.22 & 0.56 & 0.85 & 0.63 & 2.26 & 1.83 & 0.07 & 0.06 & 0.00 & 0.00 & 6.90 \\
\hline $19-24$ & vs & 0.00 & 0.00 & 0.00 & 0.00 & 0.00 & 0.00 & 0.00 & 0.00 & 0.00 & 0.00 & 0.00 & 0.00 & 0.05 & 0.09 & 0.00 & 0.00 & 0.00 & 0.00 & 0.16 \\
\hline T.24 & $\mathrm{L}$ & 00 & 0.0 & 1.00 & 0 & 0 & 0.00 & & 0.0 & & 0.02 & 0.0 & 0.8 & 02 & & 0. & 00 & 0.00 & & 0.13 \\
\hline GT. 24 & $\mathbf{N}$ & 0.03 & 0.05 & 0.01 & 0.00 & 0.00 & 0.00 & 0.01 & 0.05 & 0.20 & 0.57 & 0.42 & 0.15 & 0.62 & 0.77 & 0.01 & 0.02 & 0.00 & 0.00 & 2.92 \\
\hline GT.24 & MS & 0.03 & 0.04 & 0.02 & 0.00 & 0.00 & 0.01 & 0.04 & 0.09 & 0.36 & 0.82 & 0.59 & 0.22 & 1.63 & 1.48 & 0.01 & 0.02 & 0.00 & 0.00 & 5.35 \\
\hline GT. 24 & VS & 0.00 & 0.00 & 0.00 & 0.00 & 0.00 & 0.00 & 0.00 & 0.00 & 0.00 & 0.00 & 0.00 & 0.00 & 0.01 & 0.02 & 0.00 & 0.00 & 0.00 & 0.00 & 0.04 \\
\hline TOTALS & $\mathbf{u}$ & 0.06 & 0.06 & 0.03 & 0.0 & 0.03 & 0.04 & 0.03 & 0.04 & 0.0 & 0.10 & 0. & 0.07 & 0.12 & 0.21 & 0.10 & 0.10 & 0.02 & 0.03 & 1.22 \\
\hline TOTALS & $\mathbf{N}$ & 1.52 & 1.15 & 0.82 & 0.92 & 0.75 & 1.00 & 0. & 0.86 & 1. & 2.20 & & 2.14 & 3.58 & 4.41 & 2.24 & 2.06 & 0.71 & 0.38 & 28.88 \\
\hline TOTALS & MS & 2.35 & 1.92 & 1.30 & 1.61 & 1.58 & 2.41 & & 1.61 & & 3.61 & & 5.83 & 12.07 & 14.38 & 4.87 & 3.28 & 1.77 & 0.81 & 67.70 \\
\hline TOTALS & vs & 0.05 & 0.04 & 0.03 & 0.04 & 0.05 & 0.08 & 0.08 & 0.08 & 0.06 & 0.09 & 0.11 & 0.17 & 0.31 & 0.63 & 0.16 & 0.08 & 0.08 & 0.05 & 2.20 \\
\hline
\end{tabular}


TABLE 53. Monthly and Annual Hourly Average Tower Temperature at 3 Feet (1955 Through 1980)

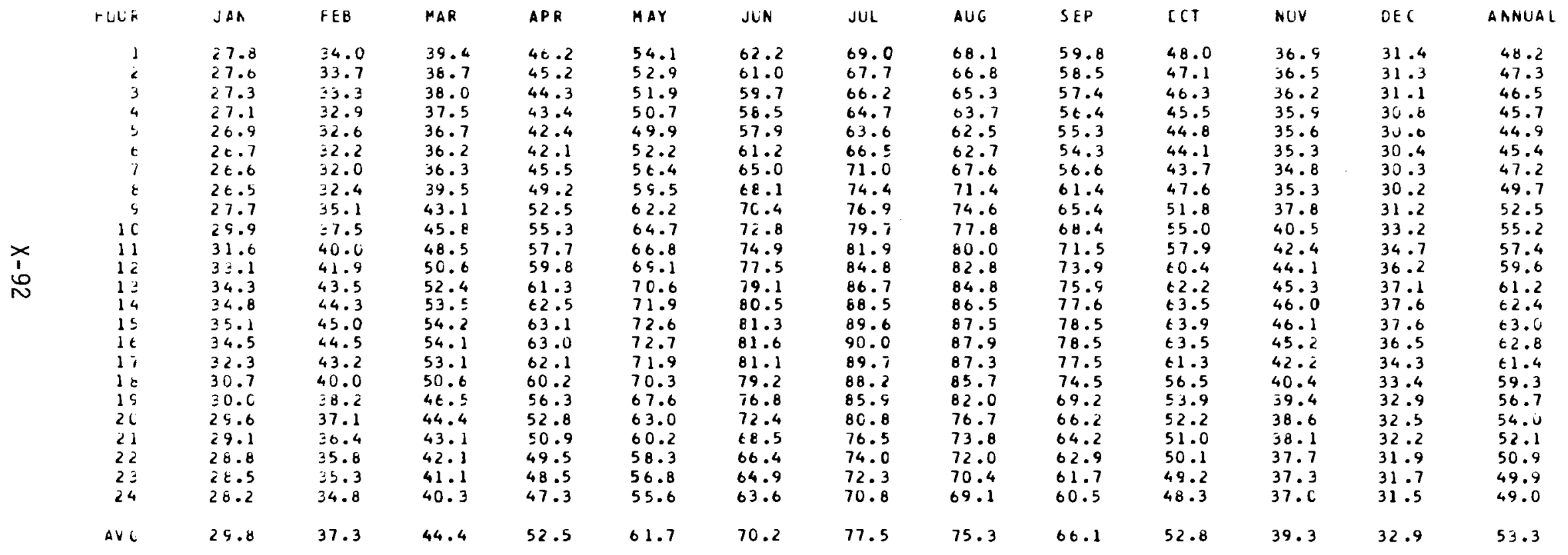


TABLE 54. Monthly and Annual Hourly Average Tower Temperature at 20 Feet (1955 Through 1980)

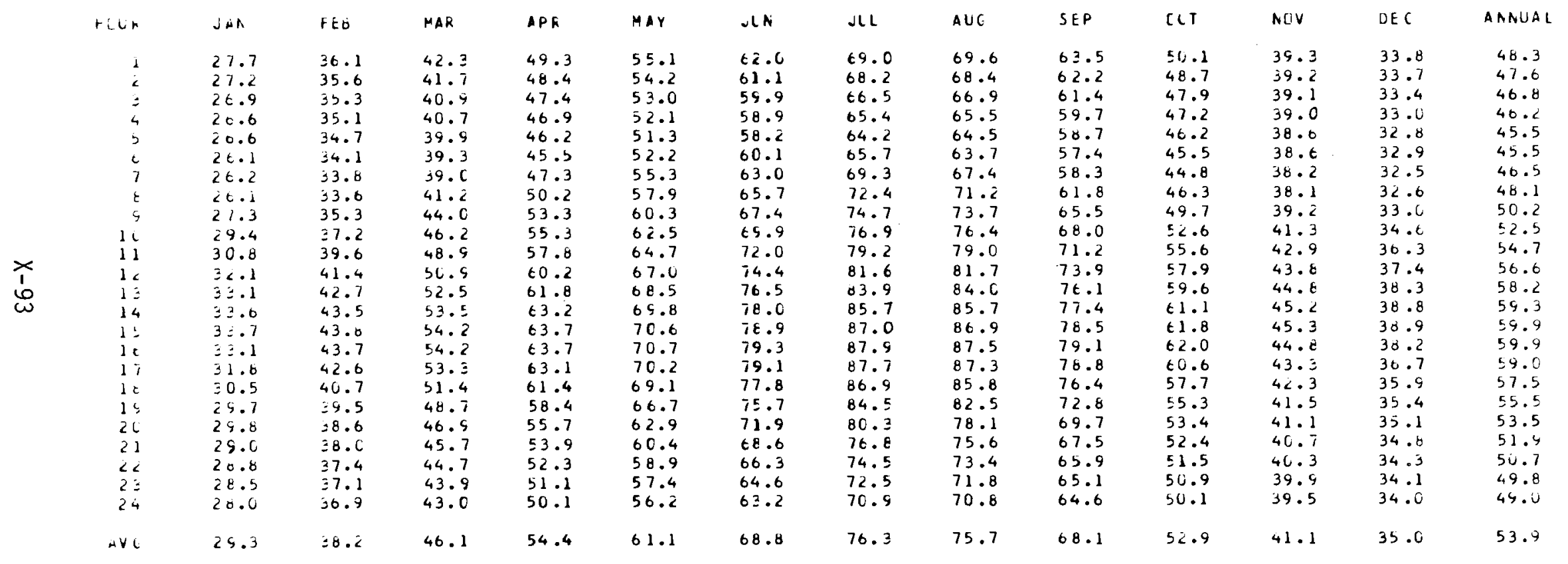


TABLE 55. Monthly and Annual Hourly Average Tower Temperature at 50 Feet (1955 Through 1980)

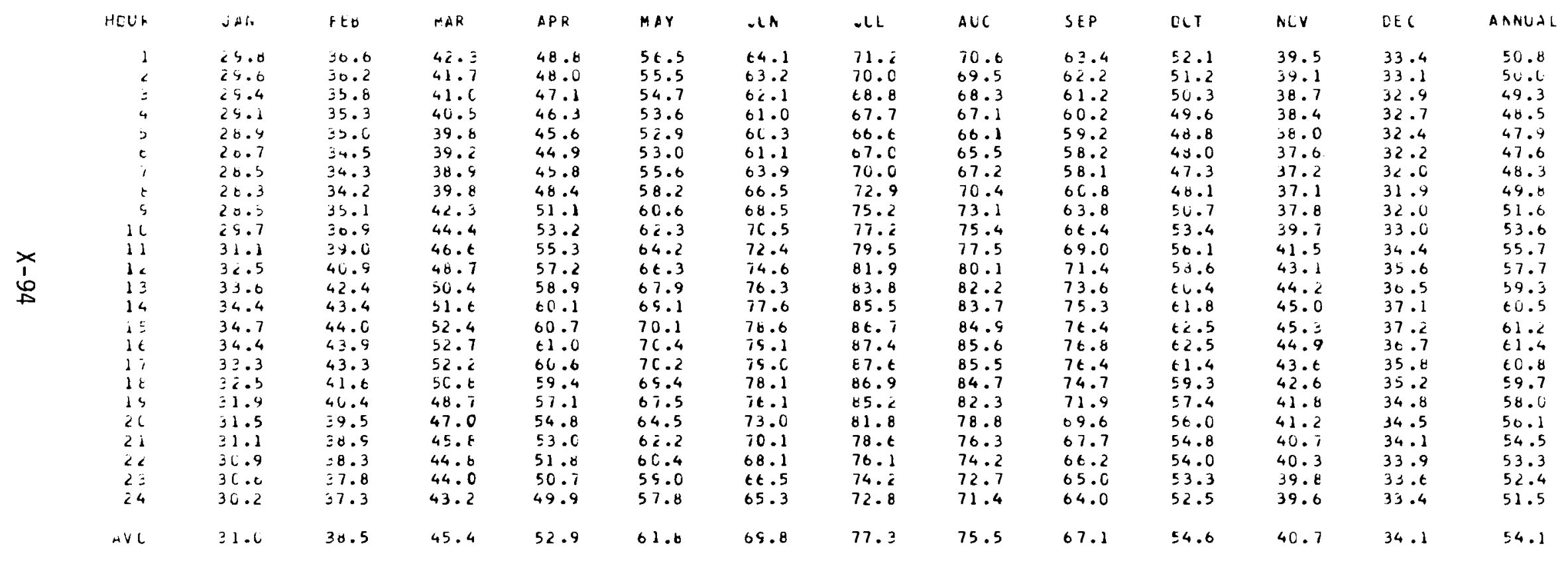


TABLE 56. Monthly and Annual Hourly Average Tower Temperature at 100 Feet (1955 Through 1980)

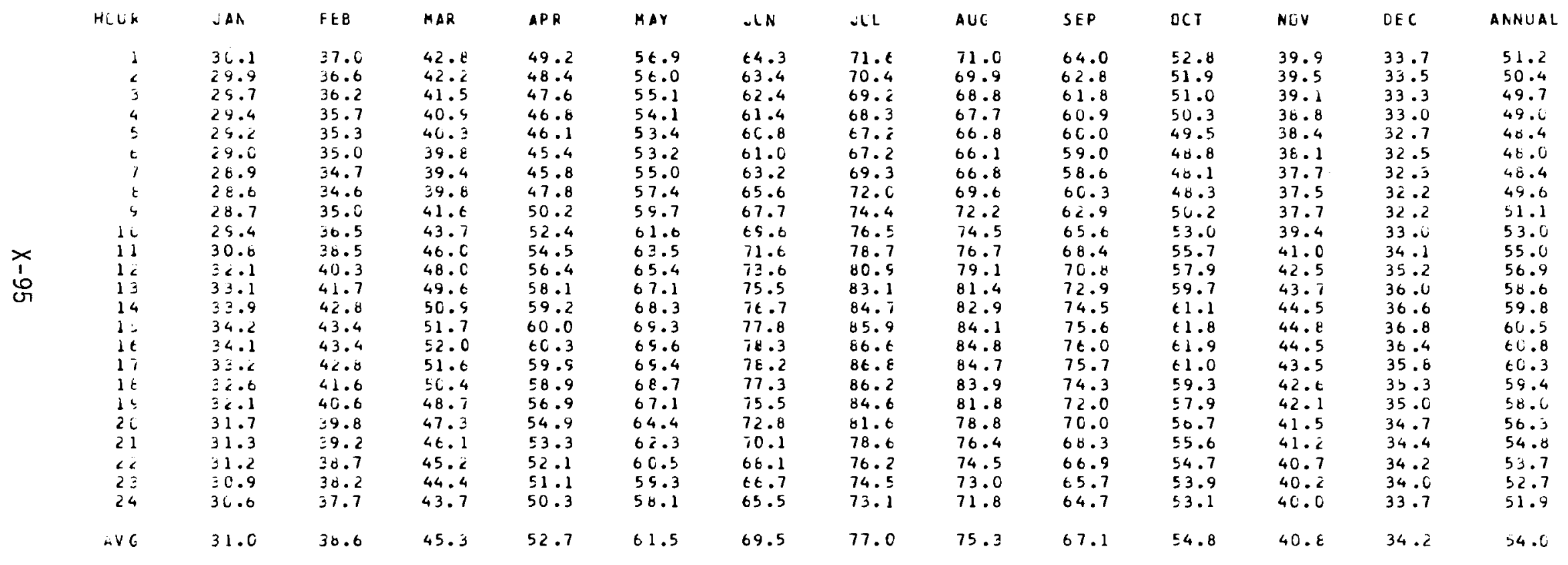


TABLE 57. Monthly and Annual Hourly Average Tower Temperature at 200 Feet (1955 Through 1980)

\begin{tabular}{|c|c|c|c|c|c|c|c|c|c|c|c|c|c|}
\hline HiLK & $\sim A \Lambda$ & FEt & MAR & APR & MAY & N & $\because L L$ & $A \cup C$ & SEP & [IT & MEV & DEC & ANNUAL \\
\hline 1 & 30.9 & $=8.0$ & 43.7 & 50.0 & 57.6 & 64.5 & 72.3 & 71.7 & 65.0 & 53.9 & 40.7 & 34.4 & 52.0 \\
\hline$\vdots$ & 36.7 & 37.5 & 43.5 & 49.3 & 56.8 & 64.1 & 71.1 & 70.7 & 63.8 & 53.1 & 40.3 & 34.2 & 51.3 \\
\hline$\dot{4}$ & 36.6 & 37.2 & 42.5 & 48.5 & 55.9 & 63.1 & $7 \mathrm{C} .1$ & 69.6 & 62.9 & $52 \cdot 3$ & $4 C .0$ & 34.1 & 50.6 \\
\hline $\begin{array}{l}4 \\
5\end{array}$ & 30.3 & 36.7 & 41.9 & 47.7 & 55.1 & 62.3 & 69.2 & 68.7 & 62.1 & 51.5 & 39.6 & 33.6 & 50.0 \\
\hline $\begin{array}{l}5 \\
c\end{array}$ & 36.0 & 36.4 & 41.3 & 47.0 & 54.4 & 61.6 & $68 \cdot 3$ & 67.8 & 61.1 & 50.7 & 39.3 & 33.5 & 49.4 \\
\hline c & 29.9 & 36.1 & 40.7 & $46 \cdot 3$ & 54.0 & 61.5 & 68.0 & 67.1 & 60.3 & 50.0 & 38.9 & 33.4 & 48.9 \\
\hline$\hat{\varepsilon}$ & 29.7 & 35.7 & 40.4 & 46.4 & 54.9 & 63.0 & 69.2 & 67.2 & 59.8 & 49.3 & 38.5 & 33.1 & 49.0 \\
\hline $\begin{array}{l}\varepsilon \\
\dot{y}\end{array}$ & 29.4 & $=5.6$ & 40.4 & 47.7 & 57.0 & 65.2 & 71.6 & 69.3 & $6 C .4$ & 49.3 & 38.3 & 33.0 & 49.9 \\
\hline $1 c^{y}$ & 29.5 & 35.6 & $41 \cdot t$ & 50.0 & 59.3 & 67.3 & 74.0 & 71.9 & 62.7 & $5 \mathrm{C} .2$ & 38.4 & 33.0 & 51.2 \\
\hline $\begin{array}{l}16 \\
11\end{array}$ & 25.5 & 36.7 & 43.5 & 52.1 & 61.2 & E9.2 & 76.2 & 74.3 & 65.4 & 52.6 & 39.4 & 33.4 & 52.9 \\
\hline $\begin{array}{l}11 \\
1 .\end{array}$ & 30.9 & 38.4 & 45.6 & 54.1 & 63.1 & 71.2 & $78 \cdot 3$ & 76.4 & 67.9 & 55.2 & 40.8 & 34.2 & 54.8 \\
\hline $\begin{array}{l}15 \\
13\end{array}$ & $\begin{array}{l}2<.1 \\
33.6\end{array}$ & $\begin{array}{l}40.1 \\
41.5\end{array}$ & $\begin{array}{l}47 . t \\
49.2\end{array}$ & $\begin{array}{l}55.9 \\
57.6\end{array}$ & $\begin{array}{l}64.9 \\
66.5\end{array}$ & $\begin{array}{l}72.2 \\
75.0\end{array}$ & $\begin{array}{l}8 C .5 \\
82.5\end{array}$ & $\begin{array}{l}78.7 \\
80.9\end{array}$ & $\begin{array}{l}70.2 \\
72.3\end{array}$ & $\begin{array}{l}57.5 \\
59.3\end{array}$ & $\begin{array}{l}42.2 \\
43.4\end{array}$ & $\begin{array}{l}35.1 \\
35.9\end{array}$ & 56.6 \\
\hline 14 & $3=.8$ & 42.5 & $5 C .4$ & 58.7 & 67.7 & 76.2 & 84.1 & 82.4 & 74.0 & $\begin{array}{r}29.3 \\
+6.7\end{array}$ & $\begin{array}{l}43.4 \\
44.2\end{array}$ & $\begin{array}{l}35.7 \\
36.5\end{array}$ & $\begin{array}{l}58.2 \\
59.3\end{array}$ \\
\hline 15 & 34.2 & 43.1 & 51.2 & 59.4 & 68.7 & $7 i .2$ & 85.3 & 83.5 & 75.1 & t 1.4 & 44.6 & 30.8 & $\begin{array}{l}29.3 \\
60.1\end{array}$ \\
\hline $1 t$ & 34.1 & 43.2 & $51 . t$ & 59.8 & 69.1 & 77.7 & 86.0 & 84.2 & 75.6 & $t 1.6$ & 44.4 & 36.6 & 60.4 \\
\hline 17 & 32.4 & 42.8 & 51.3 & 59.5 & 65.0 & $7 \pi .7$ & 86.2 & 84.3 & 75.4 & t6.9 & 43.6 & 36.1 & $t 0.1$ \\
\hline Ic & 32.0 & 41.8 & 50.4 & 58.6 & 68.4 & 76.9 & 85.8 & 83.6 & 74.1 & 59.6 & 43.1 & 35.9 & 59.4 \\
\hline 15 & $3 z \cdot 6$ & 41.1 & 49.0 & 57.0 & $6 t .9$ & 75.2 & 84.4 & 81.7 & 72.2 & 58.5 & 42.6 & 35.6 & 58.2 \\
\hline $2 c$ & 32.3 & 40.4 & 47.8 & 55.2 & 64.7 & 72.8 & 81.6 & 79.0 & 70.5 & 57.5 & 42.2 & 35.3 & 56.7 \\
\hline 21 & $\equiv 2.0$ & 39.9 & $4 t . \varepsilon$ & 53.8 & $6 \overline{8.7}$ & 70.3 & 78.8 & 76.9 & 69.1 & 56.6 & 41.9 & 35.1 & 55.4 \\
\hline $2 c$ & 31.8 & 39.5 & 45.9 & 52.7 & 61.1 & 68.6 & 76.7 & 75.1 & 67.8 & 55.8 & 41.4 & 34.9 & 54.4 \\
\hline $2 \vdots$ & $31 . t$ & $\Xi 9 . C$ & 45.2 & 51.8 & 59.9 & t 7.1 & 75.0 & 73.7 & 66.7 & 55.0 & 41.1 & 34.7 & 53.5 \\
\hline 24 & 31.3 & 38.6 & 44.6 & 51.0 & 58.8 & 66.0 & 73.7 & 72.5 & 65.6 & 54.2 & 40.8 & 34.5 & 52.7 \\
\hline$\dot{\Delta V C}$ & 31.5 & 35.1 & 45.7 & 52.4 & 61.6 & 69.5 & 77.0 & 75.5 & 67.5 & 55.3 & 41.2 & 34.7 & 54.3 \\
\hline
\end{tabular}


TABLE 58. Monthly and Annual Hourly Average Tower Temperature at 250 Feet (1955 Through 1980)

\begin{tabular}{|c|c|c|c|c|c|c|c|c|c|c|c|c|c|}
\hline HLLK & $J A R$ & FEG & MAR & $A P R$ & MAY & JUN & JUL & $A \cup G$ & SEP & DCT & NCV & DEC & ANNUAL \\
\hline 1 & 20.9 & $\equiv 7.9$ & 43.7 & 49.9 & 57.5 & 64.8 & 72.2 & 71.7 & 65.1 & 54.0 & $4 \mathrm{C} .7$ & 34.4 & 52.0 \\
\hline c & 36.7 & 37.6 & 43.2 & 49.2 & $5 t .7$ & 64.0 & 71.1 & 70.6 & 63.9 & 53.2 & 40.3 & 34.2 & 51.3 \\
\hline$\Xi$ & $3 c \cdot t$ & 37.2 & 42.6 & 48.4 & 55.9 & 63.1 & 70.1 & 69.6 & 63.0 & 52.3 & 40.0 & 34.6 & 50.6 \\
\hline 4 & $3 c .3$ & 36.8 & 41.9 & 47.7 & 55.1 & 62.2 & 69.2 & 68.7 & 62.1 & 51.6 & 39.6 & 33.7 & 56.0 \\
\hline$\underline{E}$ & 36.0 & 36.4 & 41.3 & 46.9 & 54.3 & 61.6 & 68.4 & 67.8 & 61.3 & 56.8 & 39.2 & 33.5 & 49.4 \\
\hline$t$ & 29.9 & 36.1 & 40.7 & 46.3 & 53.9 & 61.3 & 67.8 & 67.1 & $6 \mathrm{C} .3$ & 50.1 & 38.9 & 33.4 & 40.9 \\
\hline$i$ & 29.7 & 35.8 & 40.4 & 46.2 & 54.5 & 62.5 & 68.7 & 66.5 & 59.8 & 49.4 & 38.5 & 33.1 & 48.9 \\
\hline$t$ & 25.4 & 35.7 & 40.3 & 47.3 & 56.5 & 64.7 & 71.0 & 68.8 & 60.1 & 49.3 & 38.3 & 33.0 & 49.6 \\
\hline$\varsigma$ & 28.5 & 35.7 & 41.2 & 49.5 & 58.7 & 66.8 & 73.5 & 71.3 & 62.2 & 49.9 & 38.3 & 32.9 & 50.9 \\
\hline $1 \mathrm{C}$ & 29.8 & 36.5 & 43.0 & 51.5 & 60.7 & 68.7 & 75.5 & 73.7 & 64.8 & 52.2 & 39.1 & 33.3 & 52.5 \\
\hline 11 & $3 c .0$ & 26.1 & 45.1 & 53.6 & 62.6 & 70.7 & 77.7 & 75.8 & 67.4 & 54.7 & 40.4 & 34.0 & 54.3 \\
\hline 12 & 31.7 & 39.6 & 47.0 & 55.4 & 64.3 & 72.6 & 79.9 & 78.1 & 65.7 & 50.9 & 41.8 & 34.0 & 50.1 \\
\hline 13 & 32.0 & 41.0 & 48.6 & 57.0 & 65.9 & 74.4 & 81.9 & 80.2 & 71.7 & 58.7 & 42.9 & 35.5 & 57.6 \\
\hline 14 & \pm 3.4 & 42.0 & 49.8 & 58.1 & 67.2 & 75.5 & 83.4 & 81.8 & 73.4 & 60.1 & 43.7 & 36.1 & 58.8 \\
\hline 15 & 33.8 & 42.7 & 50.7 & 58.9 & 68.1 & 76.6 & 84.6 & 82.9 & 74.5 & $\in C .9$ & 44.1 & 36.4 & 59.0 \\
\hline $1 t$ & 33.7 & $4<.8$ & 51.0 & 59.2 & $6 t .5$ & 77.1 & 85.4 & 83.6 & 75.0 & $t 1.1$ & $44 . C$ & 36.2 & 59.9 \\
\hline 17 & $\vdots \equiv .1$ & 42.4 & $50 . \varepsilon$ & 58.9 & 68.4 & 77.1 & 85.6 & 83.6 & 74.8 & $t C .4$ & 43.4 & 35.9 & 59.6 \\
\hline $1 \varepsilon$ & 32.6 & 41.6 & $5 \mathrm{C} .0$ & 58.1 & 67.8 & $i t .3$ & 85.1 & 83.0 & 73.7 & 59.2 & 42.9 & 35.7 & 59.0 \\
\hline 15 & 32.4 & 40.9 & 48.7 & 56.6 & $6 t .4$ & 74.7 & $B 3 . E$ & 81.2 & 71.9 & 58.3 & 42.5 & 35.5 & 57.8 \\
\hline 20 & 32.2 & 40.3 & $47 . t$ & 55.0 & 64.2 & 72.4 & 81.2 & 78.7 & 70.4 & 57.4 & 42.1 & 35.2 & 56.5 \\
\hline 21 & $\equiv 1.9$ & 39.9 & $46 . t$ & 53.6 & 62.4 & ic. 1 & 78.5 & 76.7 & 69.0 & 56.5 & 41.8 & 35.0 & 55.3 \\
\hline 22 & 31.7 & 39.4 & 45.8 & 52.6 & 60.9 & 68.4 & 76.5 & 75.0 & 67.8 & 55.8 & 41.4 & 34.8 & 54.2 \\
\hline 23 & 21.5 & $=9.0$ & $45 . i$ & 51.7 & 59.7 & $t \in .9$ & 74.5 & 73.6 & be. .7 & 55.0 & $41 . C$ & 34.7 & 53.4 \\
\hline 24 & 31.3 & 38.6 & 44.5 & 50.9 & 58.7 & 65.9 & $73 . t$ & 72.4 & 65.7 & 54.3 & 40.7 & 34.4 & 52.7 \\
\hline AVC & 31.4 & 30.9 & 45.4 & $52 . t$ & 61.2 & 69.1 & $7 t .7$ & 75.1 & 67.3 & 55.1 & 41.1 & $34 . t$ & 54.0 \\
\hline
\end{tabular}


TABLE 59. Monthly and Annual Hourly Average Tower Temperature at 300 Feet (1955 Through 1980)

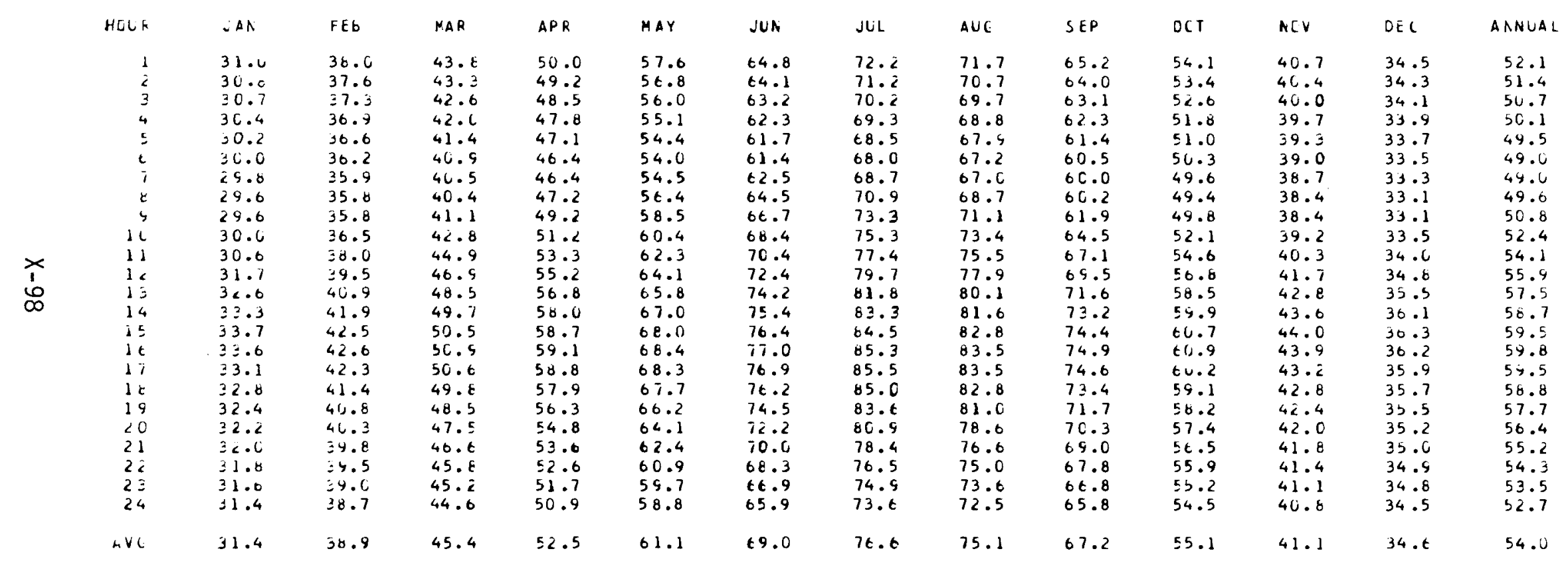


TABLE 60. Monthly and Annual Hourly Average Tower Temperature at 400 Feet (1955 Through 1980)

\begin{tabular}{|c|c|c|c|c|c|c|c|c|c|c|c|c|c|}
\hline HuLk & $J A N$ & $F E B$ & MAR & APR & MAY & JUN & JUL & $A \cup C$ & SEP & $0<1$ & neV & DEC & AANUAL \\
\hline 1 & 31.2 & 38.2 & 43.5 & 50.1 & 57.7 & 65.0 & 72.5 & 72.2 & 65.5 & 54.4 & 40.9 & 34.7 & 52.2 \\
\hline$c$ & 31.1 & 37.9 & 43.4 & 49.4 & 56.9 & 64.2 & 71.5 & 71.2 & 64.4 & 53.7 & 40.6 & 34.5 & 51.5 \\
\hline$\vdots$ & 30.9 & $\Xi 7.6$ & 42.6 & 48.6 & 56.2 & 63.3 & 70.5 & 70.2 & 63.5 & 52.9 & 40.2 & 34.3 & 50.9 \\
\hline 4 & 35.6 & 37.1 & $42 . \overline{3}$ & 47.9 & 55.3 & 62.5 & 69.6 & 69.3 & 62.7 & 52.1 & 39.9 & 34.1 & 50.3 \\
\hline$\underline{5}$ & $3 C .4$ & 36.8 & 41.6 & 47.2 & 54.6 & 61.9 & 68.8 & 68.4 & 61.8 & 51.4 & 39.6 & 33.9 & 49.7 \\
\hline t & 30.2 & 36.5 & 41.1 & 46.6 & 54.2 & 61.6 & 68.3 & 67.7 & 60.9 & 50.6 & 39.2 & 33.8 & 49.2 \\
\hline 7 & $3 c .0$ & 30.2 & 40.8 & 46.5 & 54.5 & 62.4 & 68.7 & 67.5 & $6 C .5$ & 50.0 & 38.9 & 33.5 & 49.1 \\
\hline b & 29.9 & 36.1 & $40 . t$ & 47.1 & 56.2 & 64.3 & 70.7 & 68.7 & 60.4 & 49.8 & 38.7 & 33.4 & 49.7 \\
\hline s & 29.9 & 30.1 & 41.0 & 48.9 & 58.3 & 66.6 & 73.1 & 70.9 & 61.7 & 49.9 & 38.7 & 33.3 & 50.7 \\
\hline $1 C$ & $3 c .2$ & 36.6 & $42 . t$ & 50.9 & 60.2 & 68.4 & 75.2 & 73.3 & 64.2 & 51.9 & 39.2 & 33.7 & 52.2 \\
\hline 11 & 36.7 & $\equiv 8.0$ & 44.7 & 53.1 & 62.0 & $7 \mathrm{c} .1$ & 77.1 & 75.4 & 67.1 & 54.3 & 40.3 & 34.2 & 53.9 \\
\hline 16 & 31.7 & 39.5 & 46.7 & 55.0 & 63.8 & 72.1 & 79.3 & 77.8 & 69.4 & 56.5 & 41.5 & 34.8 & 55.6 \\
\hline 13 & 32.6 & 40.8 & 48.2 & 56.6 & 65.5 & 74.0 & 81.5 & 80.1 & 71.4 & 58.3 & 42.7 & 35.5 & 57.2 \\
\hline 14 & 33.2 & 41.7 & 49.4 & 57.7 & $6 t .7$ & 75.2 & 83.1 & 81.6 & 73.1 & 59.6 & 43.4 & 36.0 & 58.4 \\
\hline 15 & 33.0 & 42.4 & 50.2 & 58.5 & 67.7 & 76.2 & 84.3 & 82.8 & 74.2 & 60.4 & 43.8 & 36.2 & 59.2 \\
\hline $1 t$ & 32.5 & 42.4 & 50.6 & 58.0 & $6 E .1$ & 76.8 & 65.1 & 83.5 & 74.6 & 80.6 & 43.7 & 36.1 & 59.5 \\
\hline 17 & 32.0 & 42.1 & 50.3 & 58.5 & 60.0 & 76.7 & 05.3 & 83.5 & 74.4 & 59.9 & 43.1 & 3).9 & 59.2 \\
\hline it & $3<.7$ & 41.3 & 49.5 & 57.6 & 67.4 & 75.9 & 84.8 & 82.8 & 73.2 & 50.9 & 42.7 & 35.7 & 58.5 \\
\hline 15 & 32.4 & 40.8 & 48.4 & 56.1 & 65.9 & 74.2 & 83.2 & 80.9 & 71.6 & 58.0 & 42.4 & 35.5 & 57.4 \\
\hline 20 & $3 c .3$ & 40.3 & 47.4 & 54.6 & $6 \equiv .9$ & 71.9 & 80.7 & 78.6 & 70.3 & 57.3 & 42.1 & 35.4 & 56.2 \\
\hline 21 & 32.1 & $\Xi 9.9$ & 46.6 & 53.5 & 62.3 & $\in 5.9$ & 78.4 & 76.9 & 65.1 & 56.6 & 41.4 & 35.2 & 55.2 \\
\hline$<<$ & 31.9 & $\Xi 9 . t$ & 45.9 & 52.6 & 60.9 & 68.4 & 76.7 & 75.3 & 68.0 & 56.0 & 41.5 & 35.6 & 54.3 \\
\hline 23 & 31.7 & $29 . \tilde{c}$ & 45.3 & 51.8 & 55.8 & 67.1 & 75.1 & 74.0 & 67.1 & 55.4 & 41.2 & 34.9 & 53.5 \\
\hline 24 & 31.5 & 28.9 & 44.7 & 51.0 & 58.9 & 66.0 & 73.9 & 73.0 & 66.1 & 54.7 & 41.0 & 34.7 & 52.6 \\
\hline$A V E$ & 31.6 & 35.0 & 45.2 & 52.4 & 61.0 & $t 8.9$ & 76.6 & 75.2 & 67.3 & 55.1 & 41.1 & 34.8 & 54.0 \\
\hline
\end{tabular}


XI. PERSISTENCE AND EXTREME VALUES 


\section{PERSISTENCE AND EXTREME VALUES}

PROBABILITY THAT A WINTER MINIMUM WILL FALL BELOW OR A SUMMER MAXIMUM WILL EXCEED A GIVEN TEMPERATURE

The low temperature for each winter (1912-1913 through 1979-1980) is plotted on arithmetic probability paper (Figure 31 ). Another plot for the high temperature for each summer (1912 through 1980) is shown in Figure 32. A straight line fitted to each plot shows a greater slope during the winter. This is due to the greater range in winter low temperatures.

PROBABILITY THAT A WINTER MINIMUM SUBSOIL TEMPERATURE WILL FALL BELOW OR SUMMER MAXIMUM WILL EXCEED A GIVEN TEMPERATURE

Figures 33 and 34 show plots of annual subsoil temperature extremes for the period 1955 to 1980. Only in 1957 has the temperature at the $36-$ inch depth fallen to $32^{\circ} \mathrm{F}$.

\section{EXTREME VALUE ANALYSIS OF PEAK GUSTS}

The annual peak wind gusts for the period of record 1945 through 1980 for three tower levels are plotted on arithmetic probability paper and a straight line fitted to the plots (Figure 35$)$. Equations for the three lines are as follows:

$$
\begin{aligned}
50 \text {-foot level } & x_{50}=58.45+5.90 y \\
200 \text {-foot leve } 1 & x_{200}=65.46+6.43 y \\
400 \text {-foot leve1 } & x_{400}=69.43+7.79 y
\end{aligned}
$$

RAINFALL INTENS ITY DURATION AND FREQUENCY

Design criteria sometimes require a knowledge of the expected frequency of intensity and short-period rainfall duration (24 hours or less). Figure 36 and Table 53 (based on data 1947 through 1969) show this information for the HMS (Stone, Jenne and Thorp 1972). 


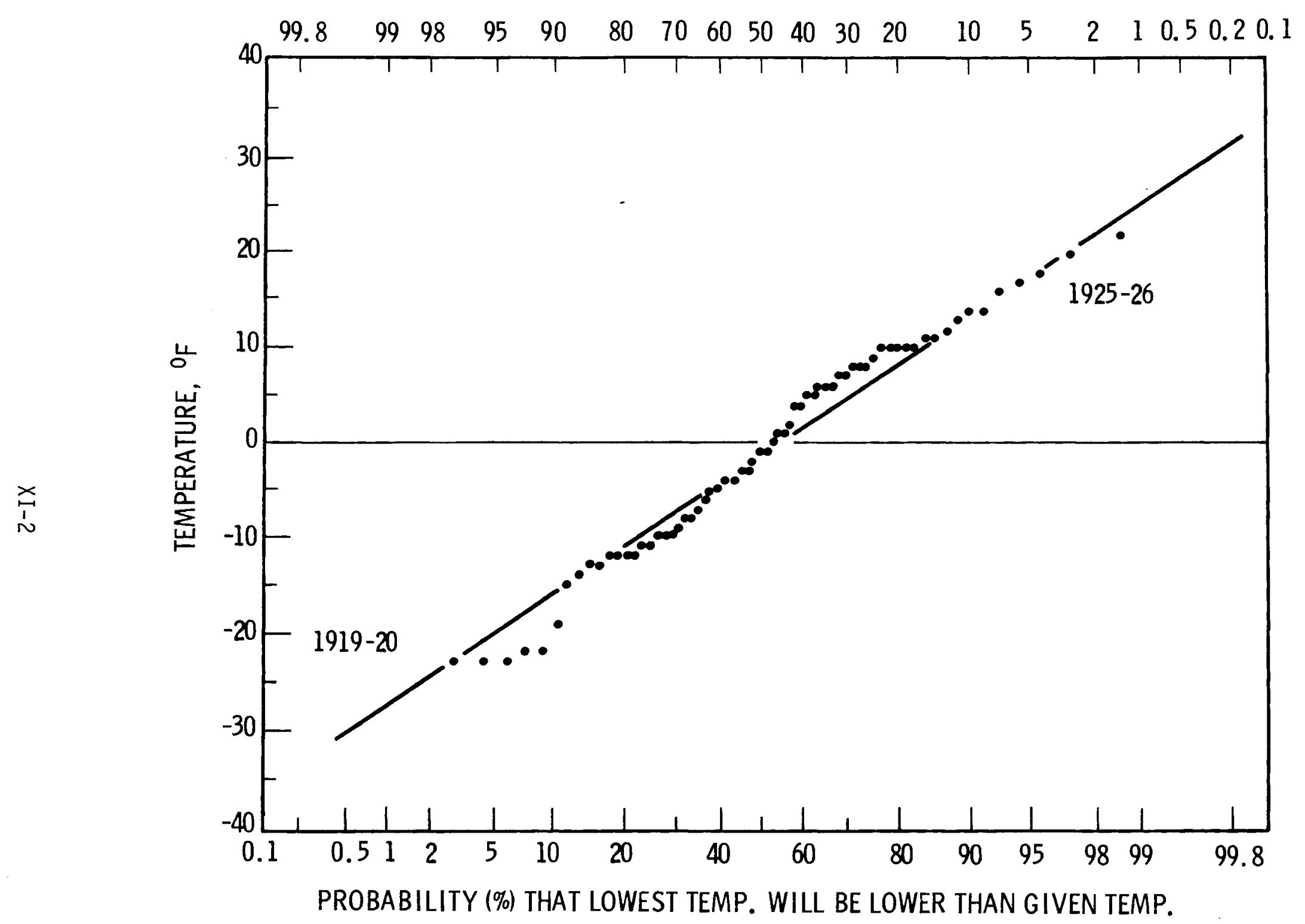

FIGURE 31. Lowest Temperature During Each of 68 Winters at Hanford: 1912-13 to 1979-80-Probability $(\%)$ That Lowest Temperature Will be Higher Than Given Temperature 
PROBABILITY (\%) THAT HIGHEST TEN.P. WILL EXCEED GIVEN TEM.P

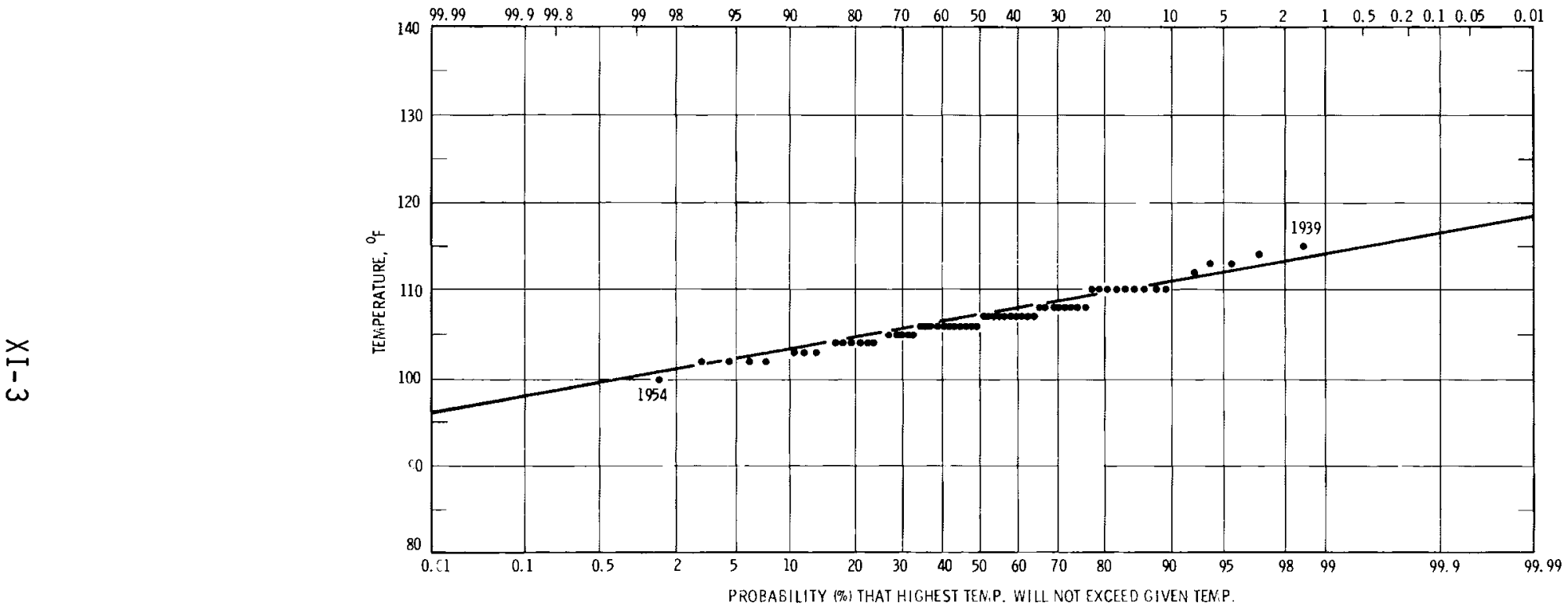

FIGURE 32. Highest Temperature During Each of 66 Summers of Record at Hanford: 1912 Through 1980 (1943-44 Missing) 


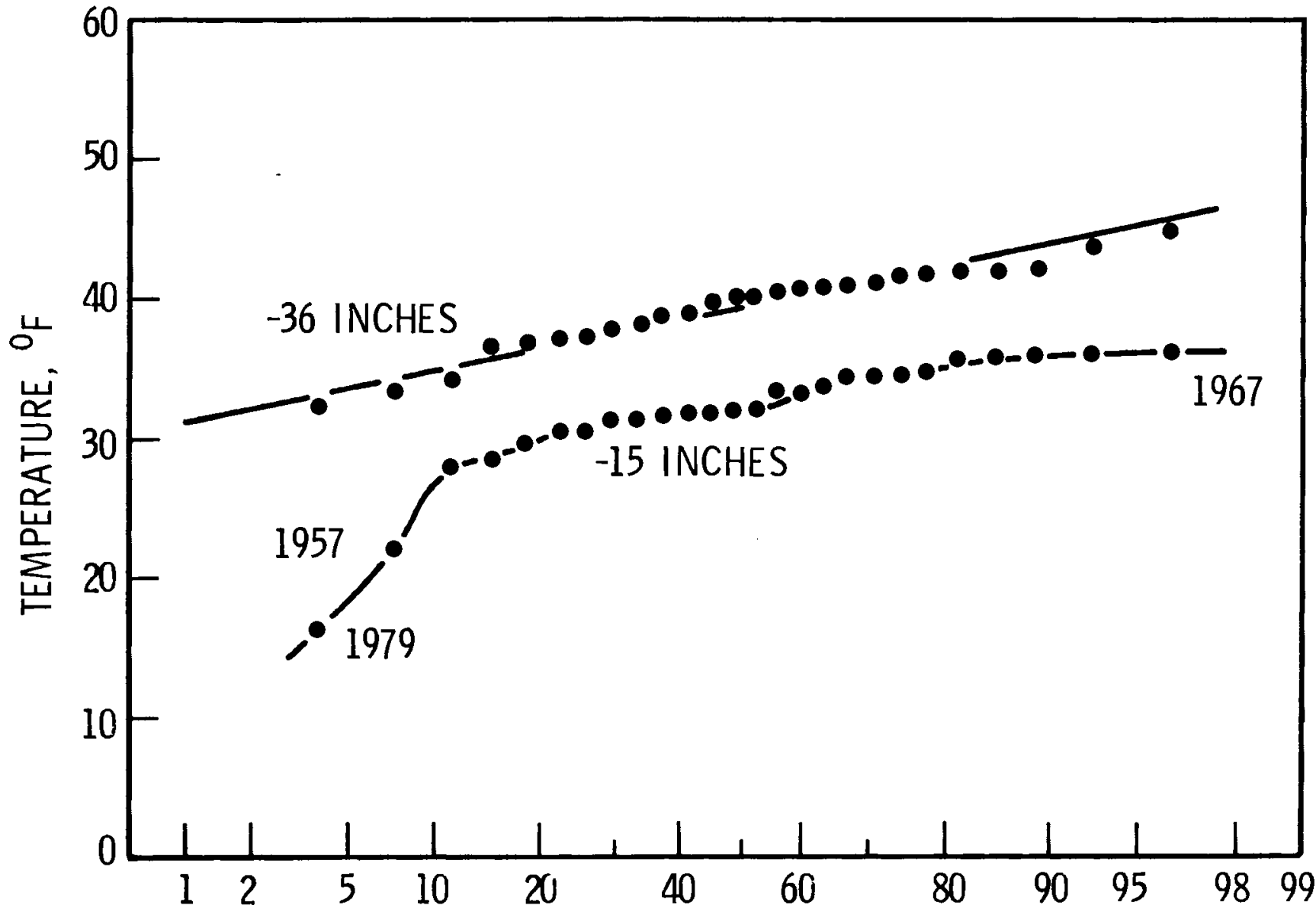

PROBABILITY (\%) THAT MINIMUM SUBSOIL TEMPERATURE WILL BE LOWER THAN GIVEN TEMPERATURE

FIGURE 33. Annual Lowest Subsoil Temperatures, 1955 Through 1980 


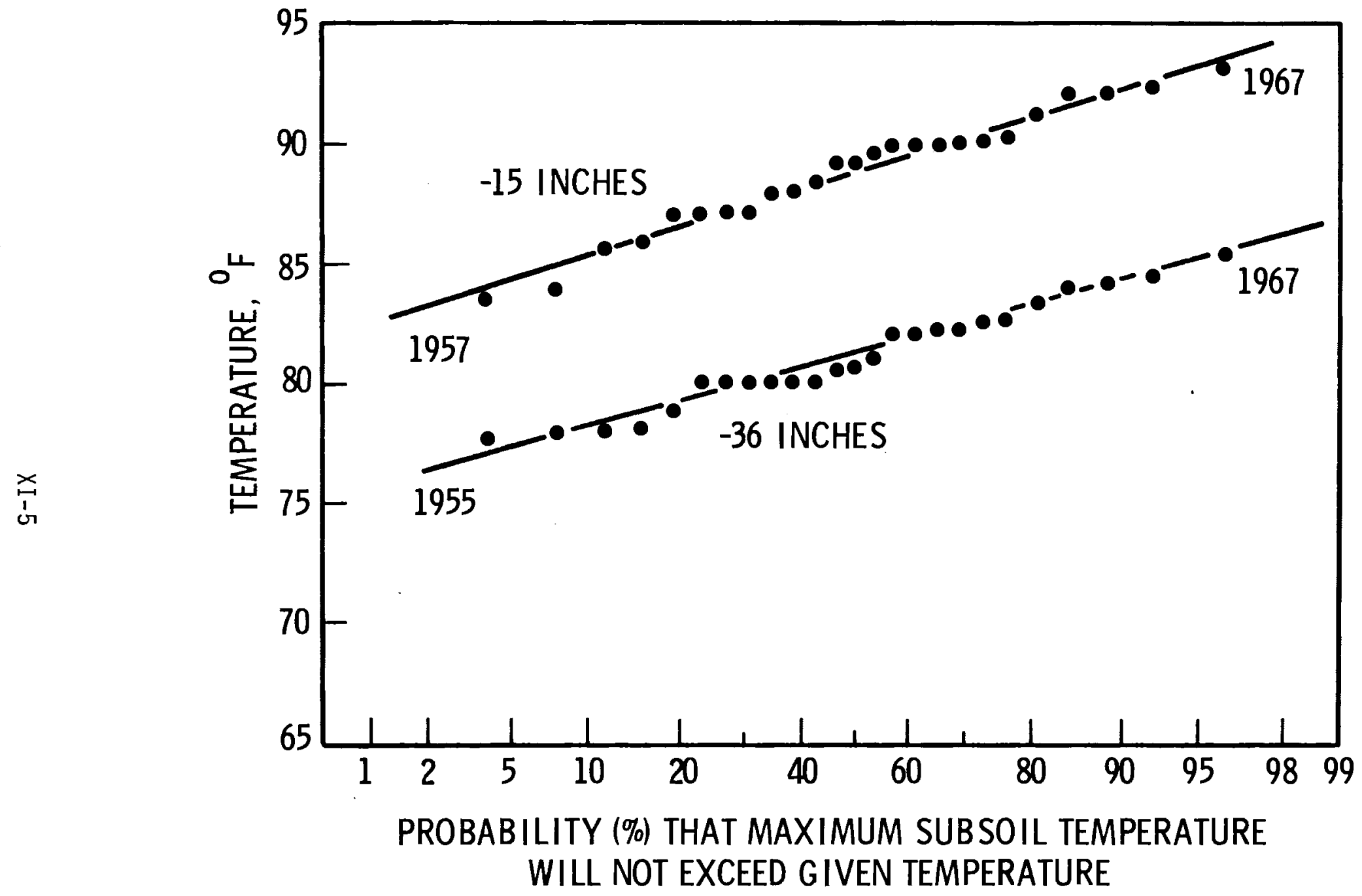

FIGURE 34. Annual Highest Subsoil Temperatures, 1955 Through 1979 


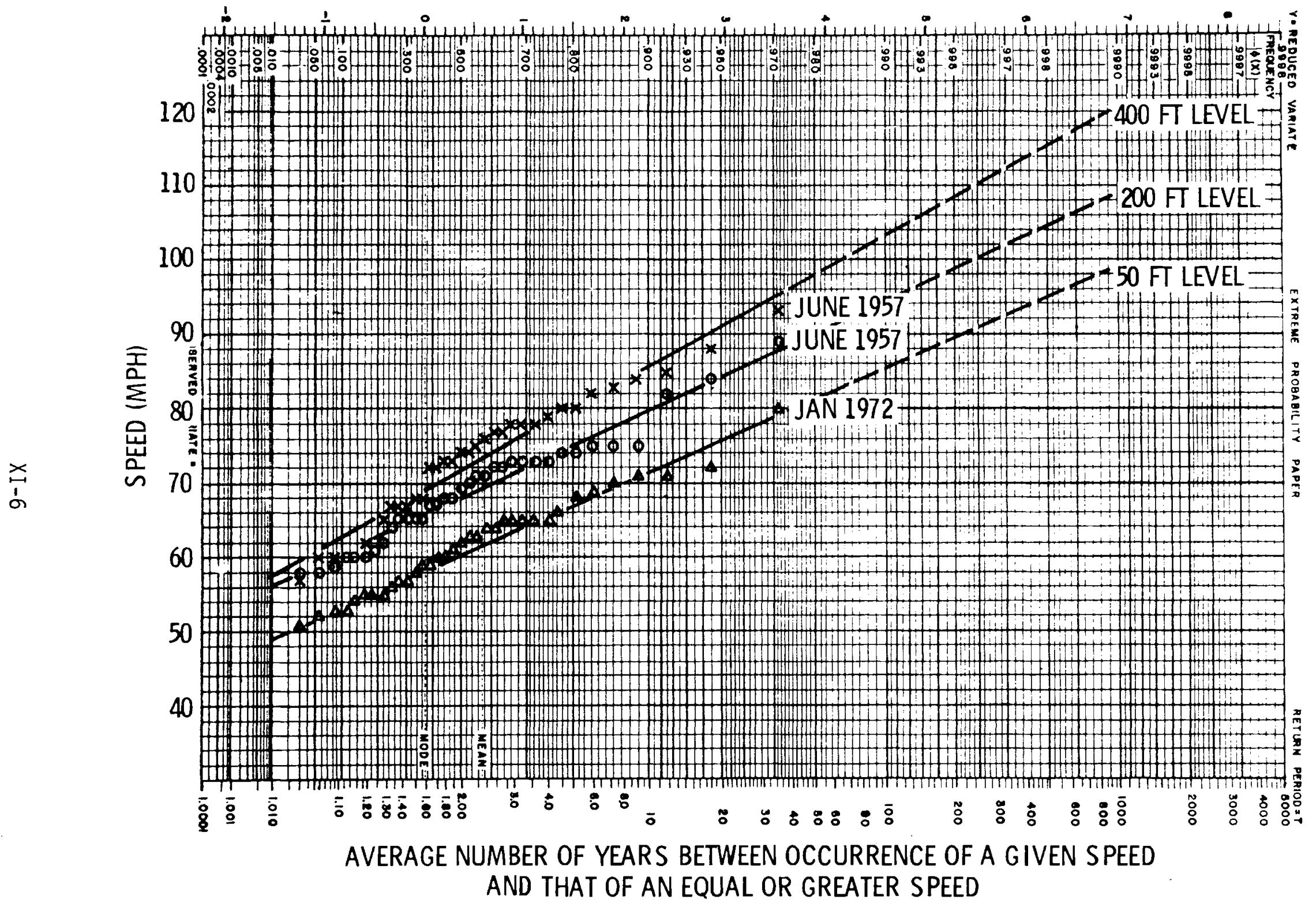

FIGURE 35. Peak Wind Gust Return Period Probability Diagram, Based on Records 1945 Through 1980 


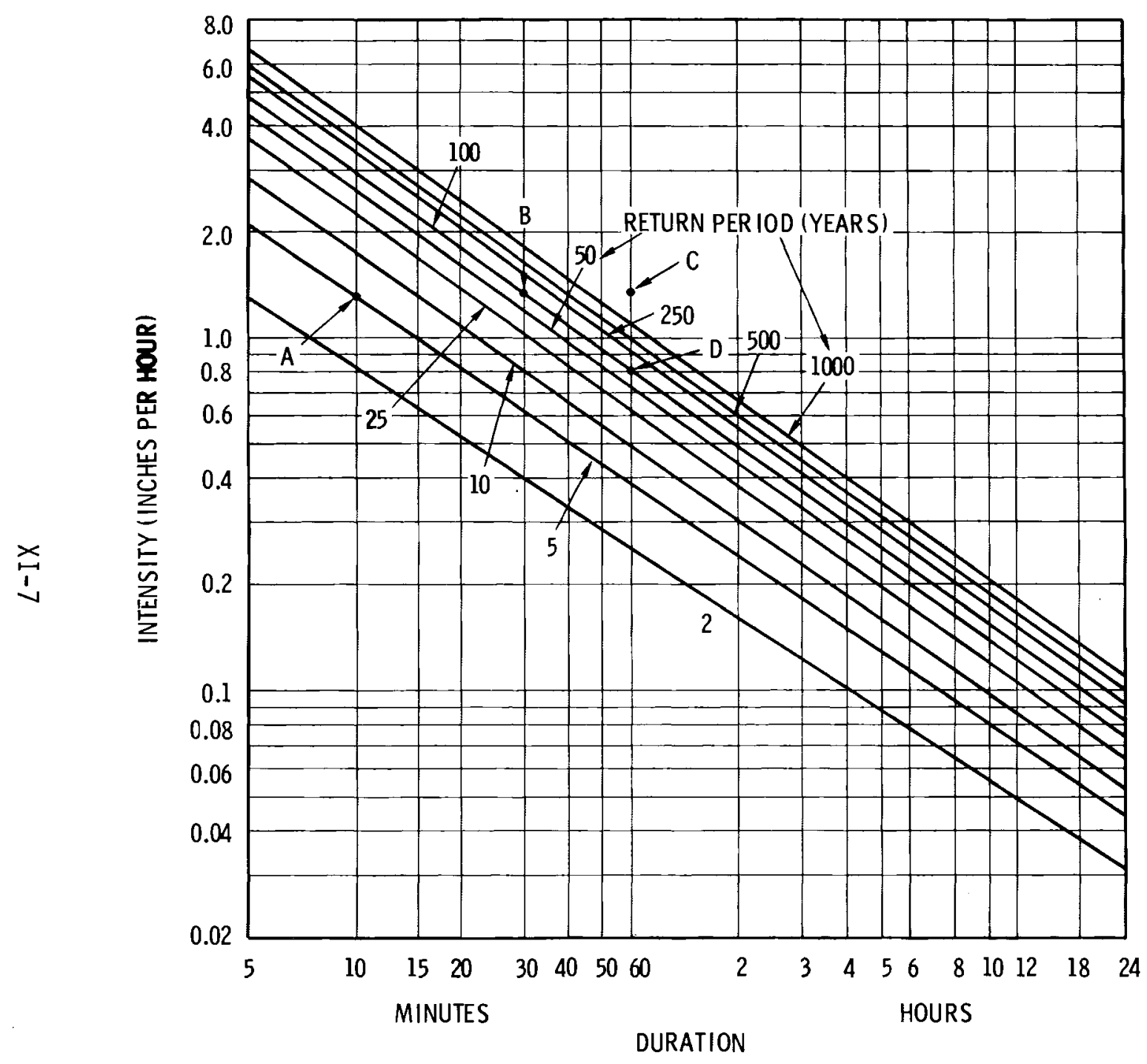

TO USE THIS CHART, SELECT ANY DESIRED RAINFALL INTENSITY AND DURATION AND READ FROM THE DIAGONAL LINES THE EXPEC TED FREQUENCY OF SUCH INTENSITY AND DURATION. FOR EXAMPLE, RAINFALL INTENSITY OF 1.3 INCHES PER HOUR FOR 10 MINUTES CAN BE EXPECTED TO OCCUR, ON AVERAGE, ONCE EVERY 5 YEARS (POINT A). HOWEVER, SUCH INTENSITY CAN BE EXPECTED FOR 30 MINUTES DURATION ONLY ABOUT ONCE IN 100 YEARS (POINT B). THE RETURN PER IOD FOR THIS INTENSITY FOR 60 MINUTES DURATION IS GREATER THAN 1000 YEARS (POINT C).

THERE ARE, OF COURSE, VARIATIONS IN USE OF THE CHART. SUPPOSE, FOR EXAMPLE, IT IS DESIRED TO FIND THE "100-YEAR STORM" FOR 60 MINUTES. THIS IS 0.8 INCH (POINT D).

FIGURE 36. Rainfall Intensity, Duration and Frequency Based on the Period 1947 to 1969 at Hanford 
TABLE 61. Average Return Period (R) and Existing Record (ER) for Various Precipitation Amounts and Intensity During Specified Time Periods at Hanford (Based on Extreme Value Analys is of 1947 Through 1969 Records)

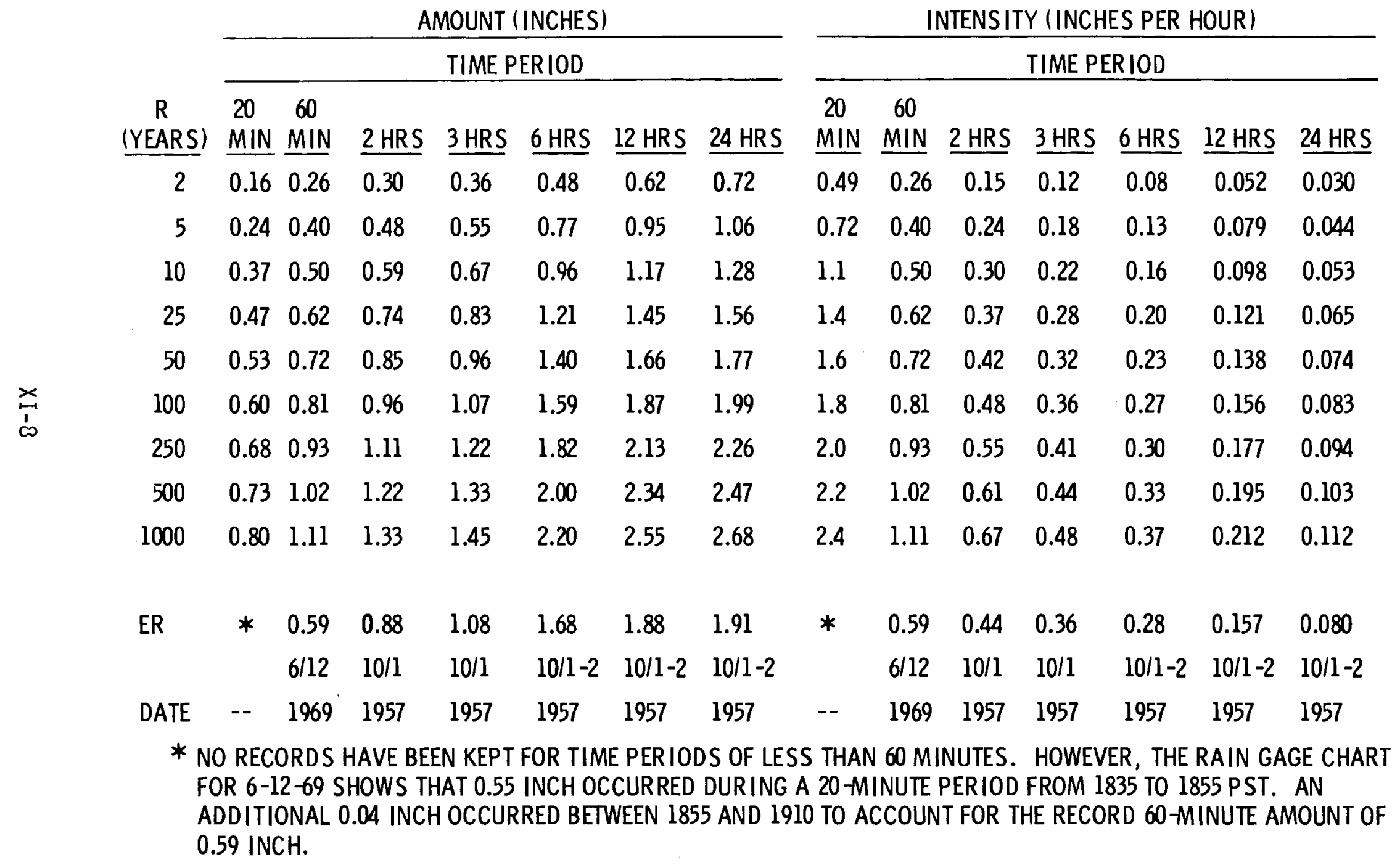


PROBABILITY THAT THE GREATEST DEPTH OF SNOW ON THE GROUND WILL EXCEED A GIVEN AMOUNT

$$
\text { Refer to Section IV, page } 14 .
$$

PROBABILITY THAT TOTAL ANNUAL PRECIPITATION WILL EXCEED A GIVEN AMOUNT

Figure 37 shows total annual precipitation for the years 1912 through 1980 plotted on arithmetic probability paper, and a straight line fitted to these data. 
PROBABILITY (क) THAT tOTAL ANNUAL PRECIPITATION WI LL EXCEED A GIVEN AMOUNT

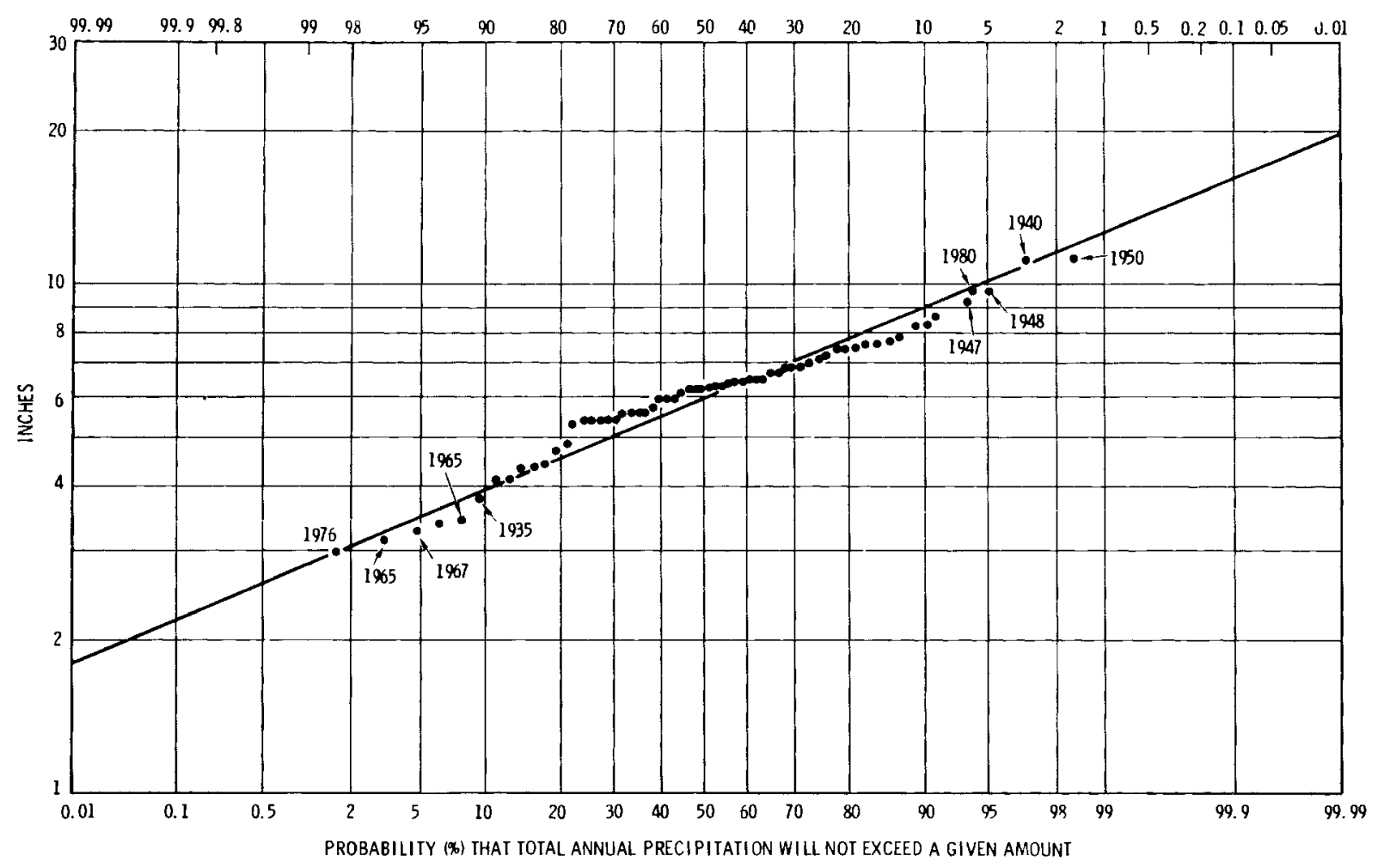

FIGURE 37. Hanford Meteorology Station Total Annual Precipitation 1913 Through 1980 (1943 Through 1946 Missing) 
XII. METEOROLOGICAL INSTRUMENTATION 


\section{METEOROLOGICAL INSTRUMENTATION}

The locations and types of meteorological sensors used at the HMS and on the Hanford Meteorology Tower (HMT), are shown below:

\section{Instrument Height Locations}

\begin{tabular}{|c|c|c|c|c|c|c|c|c|c|c|}
\hline & $\begin{array}{l}\text { Surface } \\
\text { (Feet) }\end{array}$ & & & & Tower & evels & (Feet) & & & \\
\hline Instruments & 3 & 20 & 50 & 100 & 150 & 200 & 250 & 300 & 350 & 400 \\
\hline Thermohms & $x$ & $x$ & $x$ & $x$ & & $x$ & $x$ & $x$ & & $x$ \\
\hline Aerovanes & $\gamma$ & & $x$ & $x$ & & $x$ & & $x$ & & $x$ \\
\hline Dewce 1 & $x$ & & & & & & & & & \\
\hline
\end{tabular}

\section{TEMPERATURE}

The temperature sensors for the HMT and subsoil are Leeds \& Northrup (a) copper thermohms. Temperatures are recorded on Leeds \& Northrup Speedomax, Type $G$ recorders. The accuracies of the thermohms and recorders are about $\pm 0.2^{\circ} \mathrm{F}$. The Quality Assurance Program specifies calibration on an annual basis except for the subsoil thermohms which are calibrated only when the data are questionable. A standard instrument shelter houses the Taylor maximum and minimum thermometers.

SOLAR RADIATION

Solar radiation is measured with an Eppley ${ }^{(b)}$ Model PSP Pyranometer. The sensor is calibrated by the Solar Radiation Calibration Facility at Boulder, Colorado. The data are recorded on a Leeds \& Northrup Type H, Model $S$ Speedomax. The Quality Assurance Program specifies an annual calibration.

WIND

Wind speed and direction are measured by Bendix-Friez (c) Aerovane, Model 120 sensors, and recorded on Aerovane, Model 141-7

(a) Leeds \& Northrup Company, North Wales, Pennsylvania

(b) Eppley Laboratories, Inc., Newport, Rhode Is land

(c) Bendix Aviation Corporation, Friez Instrument Division, Baltimore, Maryland 
recorders. The low speed threshold of the sensors is about $2.5 \mathrm{mph}$. The Quality Assurance Program specifies an annual calibration of the sensors and recorders. On rare occasions, during low wind speeds and icing conditions the sensors have become inoperative.

\section{ATMOSPHERIC PRESSURE}

A Fortin-type mercurial barometer and a Bendix Friez ${ }^{(a)}$ Model 790 Microbarograph are used to measure atmospheric pressure. The mercurial barometer is calibrated by the National Weather Service at their convenience. The microbarograph is calibrated every 6 hours by comparison with the reading taken from the mercurial barometer.

\section{PRECIPITATION}

Precipitation is measured with a Bendix-Friez, Model 405 tipping bucket automatic rain gage and a standard 8 -inch rain gage. A Casella (b) No. 3032 recorder is used with the automatic gage. The standard 8-inch gage is used to check the accuracy of the automatic gage, especially during periods of snow.

\section{TEMPERATURE OF THE DEW POINT}

Measurements are made with a Foxboro ${ }^{(c)}$ Dew Point Measuring System consisting of a Dewcel (humidity-sensing cel1), a power unit, and a Leeds \& Northrup (d) Speedomax, Type G recorder. The Dewcel is not accurate when the temperature is high and the humidity is below $11 \%$, or when the humidity is below $30 \%$ and the temperature is low. (See next page.)

(a) Bendix Aviation Corporation, Friez Instrument Division, Baltimore, Maryland

(b) Casella

(c) Foxboro Company, Foxboro, Massachusetts

(d) Leeds \& Northrup Company, North Wales, Pennsylvania 
Dew points cannot be measured when relative humidity is below:

\begin{tabular}{ccc}
$\begin{array}{c}\text { Ambient } \\
\text { Temperature }\end{array}$ & $\begin{array}{c}\text { by International } \\
\text { Critical Tables }\end{array}$ & by B1ue Hi \\
\cline { 1 - 2 }$\left({ }^{\circ} \mathrm{F}\right)$ & $(\%)$ & $(\%)$ \\
120 & 10 & 10 \\
100 & 11 & 11 \\
80 & 11 & 11 \\
60 & 11 & 8 \\
40 & 14 & 9 \\
20 & 21 & 10 \\
0 & 26 & $13(\mathrm{a})$ \\
-20 & 41 & $20(\mathrm{a})$ \\
-40 & 100 & $30^{(\mathrm{a})}$
\end{tabular}

(a) Calibration curve extrapolated

Whenever the dew point values are questionable, the Dewcel readings are checked with a sling psychrometer.

The Dewcel response time varies as the dew point rises or falls. With a rise of $20^{\circ} \mathrm{F}$ at an air temperature of $65^{\circ} \mathrm{F}$, the response time is about 1.5 minutes to reach $98 \%$ of the new value. With an equal amount of fall, the time lag was about 3.5 minutes at $80 \%$ relative humidity and the lag increases as the relative humidity decreases. 
XIII. ACKNOWLEDGMENTS 


\section{ACKNOWLEDGEMENTS}

The authors would like to express their appreciation to past and present members of the Hanford Meteorology Station Forecast Staff for their assistance in collecting and summarizing the data for this document. We wish to thank William E. Davis and J. Van Ramsdell, Jr. for reviewing the manuscript. Thanks are due to Gloria Guajardo and Debbie Atkin for their assistance in typing the document. 


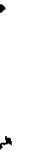


XIV. REFERENCES 


\section{REFERENCES}

Daubek, H. G. 1970. Tornado History and a Discussion of the Tornado Warning System to the Jersey Nuclear Company, BNW/JN 19-20, Battelle, Pacific Northwest Laboratories, Richland, Washington.

Federal Meteorological Handbook No. 1. Surface Observations. January 1970.

Federal Meteorological Handbook No. 2. Surface Synoptic Code. January 1982.

Jenne, D. E. 1963. Frequency Analys is of Some Climatological Extremes at Hanford, HW-75445, General Electric Co., Richland, Washington.

Jenne, D. E. and R. E. Kerns. 1959. A Climatological Study of the Hanford Area, HW-57722, General Electric Co., Richland, Washington.

Singer, I. A. and M. E. Smith. 1963. "Relation of Gustiness to 0ther Meteorological Parameters." Journal of Meteorology, 10(2):121-126.

Stone, W. A. 1964. Meteorological Instrumentation of the Hanford Area, HW-62455, General Electric Co., Richland, Washington.

Stone, W. A., D. E. Jenne and J. M. Thorp. 1972. Climatography of the Hanford Area, BNWL-1605, Pacific Northwest Laboratory, Richland, Washington. 
APPENDIX I

NOTABLE COLD PERIODS 


\section{APPENDIX I}

\section{NOTABLE COLD PERIODS}

Table A.1-1 presents periods of 5 or more consecutive winter days (with the average period temperature less than $20^{\circ} \mathrm{F}$ ) when the mean daily temperature was $10^{\circ} \mathrm{F}$ or more below normal.

TABLE A.I-1. Notable Cold Periods

\begin{tabular}{|c|c|c|c|c|c|}
\hline \multirow{2}{*}{$\frac{\text { Season }}{1944-1945}$} & Date & $\begin{array}{l}\text { Mean } \\
\left.\text { Temp. ( }{ }^{\circ} \mathrm{F}\right) \\
\end{array}$ & Season & Date & $\begin{array}{c}\text { Mean } \\
\text { Temp. }\left({ }^{\circ} \mathrm{F}\right) \\
\end{array}$ \\
\hline & \multicolumn{2}{|l|}{ None } & \multirow{2}{*}{$\begin{array}{l}1948-1949 \\
\text { Cont'd }\end{array}$} & \multirow{2}{*}{$\begin{array}{l}30 \\
31\end{array}$} & \multirow{2}{*}{$\begin{array}{l}15 \\
18\end{array}$} \\
\hline $1945-1946$ & \multicolumn{2}{|l|}{ None } & & & \\
\hline \multirow{6}{*}{$1946-1947$} & 1 - & \multirow{2}{*}{20} & & \multirow{3}{*}{$\begin{array}{r}2-1 \\
2 \\
3\end{array}$} & 18 \\
\hline & $1-$ & & & & 14 \\
\hline & & 10 & & & 20 \\
\hline & 5 & 12 & & $\overline{16}$ days & $\overline{13}$ \\
\hline & 6 & 16 & $1949-1950$ & $1-2$ & 12 \\
\hline & 5 days & $\overline{15}$ & & 3 & 7 \\
\hline $1947-1948$ & None & & & $\begin{array}{l}4 \\
5\end{array}$ & 5 \\
\hline \multirow{26}{*}{$1948-1949$} & \multirow{7}{*}{$\begin{array}{r}12-23 \\
24 \\
25 \\
26 \\
27 \\
28 \\
6\end{array}$} & 18 & & $\begin{array}{r}5 \\
6 \\
\end{array}$ & $\begin{array}{r}2 \\
14\end{array}$ \\
\hline & & 14 & & 5 days & $\frac{1}{8}$ \\
\hline & & 17 & & $1-13$ & 4 \\
\hline & & 10 & & & $\begin{array}{r}4 \\
-\quad ?\end{array}$ \\
\hline & & 8 & & & $\begin{array}{r}-2 \\
0\end{array}$ \\
\hline & & 14 & & 10 & 0 \\
\hline & & $\overline{14}$ & & 17 & -3 \\
\hline & $1-9$ & 15 & & 18 & 6 \\
\hline & 10 & 8 & & 19 & 10 \\
\hline & & 5 & & & $\underline{11}$ \\
\hline & & 6 & & 8 days & $\overline{3}$ \\
\hline & & $\begin{array}{r}7 \\
10\end{array}$ & & $1-24$ & 12 \\
\hline & $\begin{array}{l}14 \\
15\end{array}$ & $\begin{array}{l}10 \\
17\end{array}$ & & 25 & 2 \\
\hline & 16 & 12 & & 26 & 6 \\
\hline & 8 days & $\frac{1 L}{9}$ & & 27 & 6 \\
\hline & $1-19$ & 18 & & 29 & -8 \\
\hline & 20 & 7 & & 30 & 0 \\
\hline & 21 & 16 & & 31 & -12 \\
\hline & 22 & 18 & & $2-1$ & -13 \\
\hline & 23 & 12 & & 2 & -10 \\
\hline & 24 & 4 & & 3 & -11 \\
\hline & 25 & 0 & & 4 & 8 \\
\hline & 26 & 10 & & 5 & 21 \\
\hline & 27 & $\begin{array}{r}14 \\
7\end{array}$ & & $\overline{13 \text { days }}$ & $\overline{0}$ \\
\hline & $\begin{array}{l}28 \\
29\end{array}$ & $\begin{array}{r}7 \\
10\end{array}$ & & & \\
\hline & & 10 & & & \\
\hline
\end{tabular}

A. I-1 


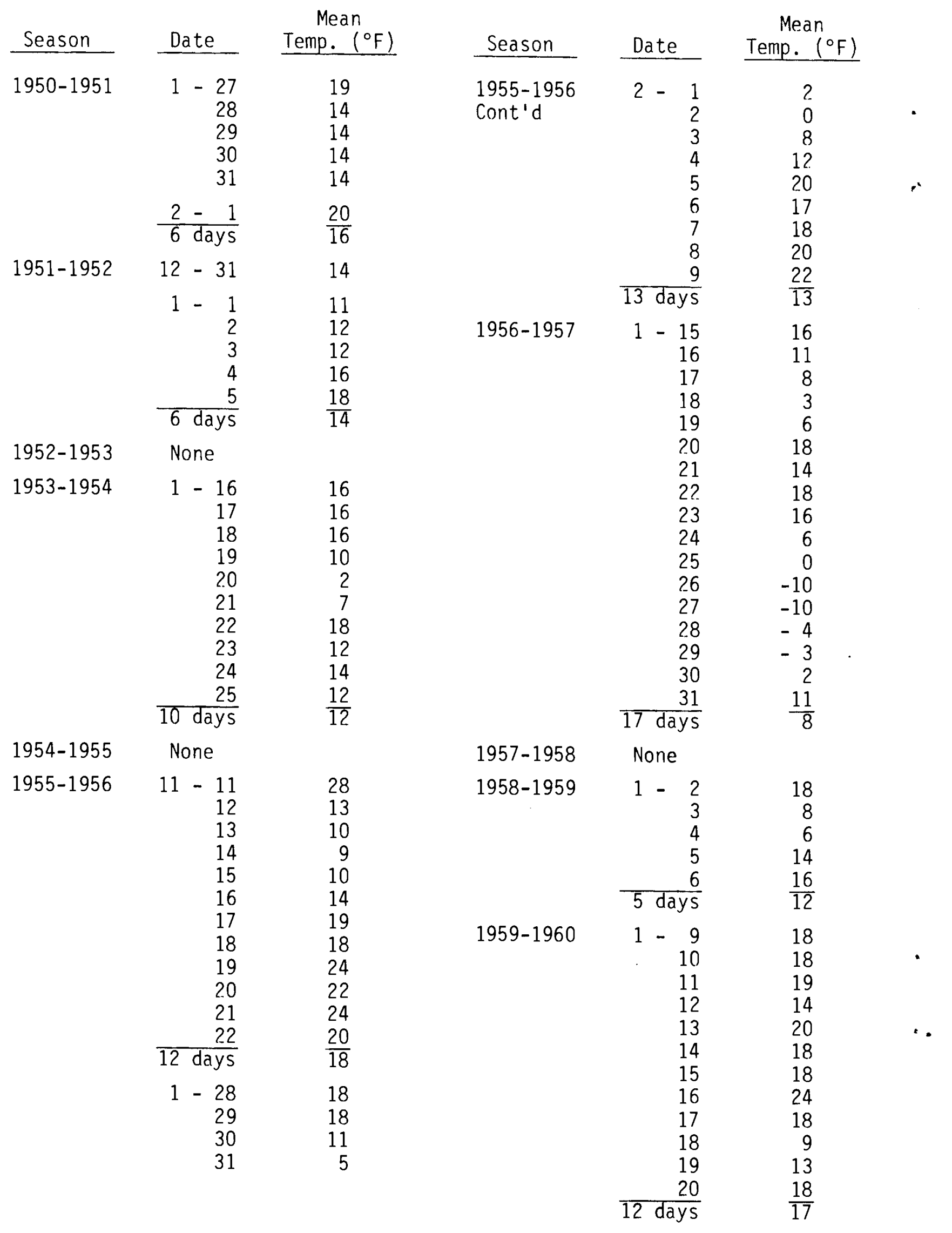




\begin{tabular}{|c|c|c|c|c|c|}
\hline Season & Date & $\begin{array}{c}\text { Mean } \\
\text { Temp. }\left({ }^{\circ} \mathrm{F}\right) \\
\end{array}$ & Season & Date & $\begin{array}{l}\text { Mean } \\
\text { Temp. }\left({ }^{\circ} \mathrm{F}\right) \\
\end{array}$ \\
\hline $1960-1961$ & None & & $1968-1969$ & $1-21$ & 15 \\
\hline \multirow[t]{2}{*}{$1961-1962$} & $\begin{array}{rr}1- & 18 \\
19 \\
\\
20 \\
\\
21 \\
22\end{array}$ & $\begin{array}{r}18 \\
10 \\
12 \\
14 \\
9\end{array}$ & Cont'd & $\begin{array}{r}22 \\
23 \\
24 \\
25 \\
5 \text { days }\end{array}$ & $\begin{array}{r}9 \\
1 \\
10 \\
10 \\
9\end{array}$ \\
\hline & $\frac{23}{6 \text { days }}$ & $\frac{14}{13}$ & & & $\begin{array}{r}12 \\
2\end{array}$ \\
\hline \multirow[t]{5}{*}{$1962-1963$} & $\begin{array}{rr}1- & 10 \\
& 11 \\
& 12\end{array}$ & $\begin{array}{r}14 \\
5 \\
6\end{array}$ & & $\begin{array}{l}29 \\
30 \\
31\end{array}$ & $\begin{array}{l}2 \\
6 \\
7\end{array}$ \\
\hline & $\begin{array}{l}13 \\
14 \\
\end{array}$ & $\begin{array}{l}14 \\
20(-9)\end{array}$ & & $\frac{2-1}{6 \text { days }}$ & $\frac{16}{8}$ \\
\hline & 5 days & $\overline{12}$ & $1969-1970$ & None & \\
\hline & $\begin{array}{r}1-29 \\
30 \\
31\end{array}$ & $\begin{array}{l}16 \\
12 \\
19\end{array}$ & $1970-1971$ & $\begin{array}{r}12-21 \\
22 \\
23\end{array}$ & $\begin{array}{l}23 \\
19 \\
18\end{array}$ \\
\hline & $\begin{array}{r}2-\quad 1 \\
2 \\
5 \text { days }\end{array}$ & $\begin{array}{l}19 \\
\frac{18}{17}\end{array}$ & & $\begin{array}{r}24 \\
25 \\
5 \text { days }\end{array}$ & $\begin{array}{l}14 \\
\frac{18}{18}\end{array}$ \\
\hline $1963-1964$ & None & & $1971-1972$ & $1-25$ & 16 \\
\hline $1964-1965$ & $\begin{array}{r}12-15 \\
16 \\
17 \\
18 \\
19 \\
20 \\
\end{array}$ & $\begin{array}{r}20 \\
-4 \\
-4 \\
8 \\
15 \\
19 \\
\end{array}$ & & $\begin{array}{l}26 \\
27 \\
28 \\
29 \\
30 \\
31\end{array}$ & $\begin{array}{r}6 \\
8 \\
10 \\
12 \\
11 \\
18\end{array}$ \\
\hline & 6 days & 9 & & $2-1$ & 14 \\
\hline $1965-1966$ & None & & & $\begin{array}{l}2 \\
3\end{array}$ & $\begin{array}{l}9 \\
7\end{array}$ \\
\hline $1966-1967$ & None & & & 4 & 12 \\
\hline $1967-1968$ & $\begin{array}{r}12-13 \\
14\end{array}$ & $\begin{array}{l}23 \\
22\end{array}$ & & $\frac{5}{12 \text { days }}$ & $\frac{22}{12}$ \\
\hline & $\begin{array}{r}15 \\
16 \\
17 \\
5 \text { days }\end{array}$ & $\begin{array}{l}18 \\
16 \\
18 \\
19\end{array}$ & $1972-1973$ & $\begin{array}{r}12-3 \\
4 \\
5 \\
6\end{array}$ & $\begin{array}{l}24 \\
12 \\
14 \\
18\end{array}$ \\
\hline $1968-1969$ & $\begin{array}{r}12-28 \\
29 \\
30 \\
31\end{array}$ & $\begin{array}{r}6 \\
-6 \\
-8 \\
0\end{array}$ & & $\begin{array}{r}7 \\
8 \\
9 \\
10 \\
11\end{array}$ & $\begin{array}{r}11 \\
6 \\
4 \\
2 \\
4\end{array}$ \\
\hline & $\begin{array}{r}1-\quad 1 \\
2 \\
3 \\
3 \\
4 \text { days }\end{array}$ & $\begin{array}{r}6 \\
10 \\
16 \\
20 \\
6\end{array}$ & & $\begin{array}{r}12 \\
13 \\
14 \\
15 \\
16 \\
14 \text { days }\end{array}$ & $\begin{array}{r}8 \\
4 \\
6 \\
9 \\
21 \\
10\end{array}$ \\
\hline
\end{tabular}

A. I-3 


\begin{tabular}{|c|c|c|c|c|c|}
\hline Season & Date & $\begin{array}{l}\text { Mean } \\
\text { Temp. }\left({ }^{\circ} \mathrm{F}\right) \\
\end{array}$ & Season & Date & $\begin{array}{c}\text { Mean } \\
\text { Temp. }\left({ }^{\circ} \mathrm{F}\right) \\
\end{array}$ \\
\hline $\begin{array}{l}1972-1973 \\
\text { Cont'd }\end{array}$ & $\begin{array}{rr}1-\quad 4 \\
& 5 \\
& 6 \\
& 7 \\
& \\
& 8 \\
& 9 \\
& 9 \\
10 & 10 \\
7 \text { days }\end{array}$ & $\begin{array}{l}18 \\
16 \\
10 \\
12 \\
10 \\
15 \\
\frac{16}{14}\end{array}$ & $\begin{array}{l}1978-1979 \\
\text { Cont'd }\end{array}$ & $\begin{array}{rr}1-\quad 1 \\
& 2 \\
& 3 \\
& \\
& 4 \\
& \\
& \\
& \\
& \\
& 6 \\
& \\
& 7 \\
& 8\end{array}$ & $\begin{array}{r}-1 \\
12 \\
12 \\
15 \\
8 \\
2 \\
1 \\
6\end{array}$ \\
\hline $1973-1974$ & $\begin{array}{r}1-\quad 1 \\
2 \\
3 \\
4 \\
5 \\
6 \\
7 \\
8 \\
9 \\
10 \\
11 \\
12 \\
12 \text { days }\end{array}$ & $\begin{array}{r}15 \\
17 \\
14 \\
7 \\
7 \\
1 \\
2 \\
-\quad 2 \\
-4 \\
2 \\
6 \\
12 \\
6\end{array}$ & & $\begin{array}{r}9 \\
10 \\
14 \text { days } \\
1-22 \\
23 \\
24 \\
25 \\
25 \\
26 \\
27 \\
28 \\
29 \\
30 \\
31\end{array}$ & $\begin{array}{r}16 \\
\frac{18}{8} \\
17 \\
12 \\
20 \\
14 \\
10 \\
9 \\
10 \\
10 \\
10 \\
3\end{array}$ \\
\hline $1974-1975$ & None & & & $2-1$ & 0 \\
\hline $1975-1976$ & None & & & $\begin{array}{l}2 \\
3\end{array}$ & $\begin{array}{l}0 \\
9\end{array}$ \\
\hline $1976-1977$ & $\begin{array}{r}1-\quad 5 \\
6\end{array}$ & $\begin{array}{l}17 \\
12\end{array}$ & & $\frac{4}{14 \text { days }}$ & $\frac{12}{8}$ \\
\hline & $\begin{array}{r}7 \\
8 \\
9 \\
10 \\
11 \\
7 \text { days }\end{array}$ & $\begin{array}{l}13 \\
14 \\
14 \\
14 \\
18 \\
15\end{array}$ & $1979-1980$ & 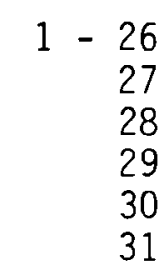 & $\begin{array}{l}18 \\
11 \\
12 \\
12 \\
12 \\
20\end{array}$ \\
\hline $1977-1978$ & None & & & 6 days & $\frac{c 0}{14}$ \\
\hline $1978-1979$ & $\begin{array}{r}12-28 \\
29 \\
30 \\
31\end{array}$ & $\begin{array}{r}14 \\
10 \\
0 \\
0\end{array}$ & & & \\
\hline
\end{tabular}

( ) Exceptions to the $10^{\circ} \mathrm{F}$ or more below normal criteria. 
APPENDIX II

THUNDERSTORM STATISTICS 


\section{APPENDIX II}

\section{HANFORD CLIMATOLOGICAL DATA PERTAINING TO THUNDERSTORMS}

Thunderstorm Days: $1945-1980$

$\begin{array}{lrrrrrrrrrrrrr} & \underline{J} & \underline{F} & \underline{M} & \underline{A} & \underline{M} & \underline{J} & \underline{J} & \underline{A} & \underline{S} & \underline{0} & \underline{N} & \underline{D} & \underline{\text { Sum }} \\ \text { Tota1 } & 0 & 2 & 7 & 25 & 64 & 91 & 73 & 79 & 31 & 8 & 0 & 1 & 381 \\ \text { Average } & 0 & + & + & 1 & 2 & 2 & 2 & 2 & 1 & + & 0 & + & 10 \\ \% \text { of Total } & 0 & \# & 2 & 7 & 17 & 24 & 19 & 21 & 8 & 2 & 0 & \# & 100\end{array}$

$\#=$ less than $0.5 \%$

$+=$ less than $0.5 /$ day

Precipitation measurements were not taken during 1945 and 1946 , however 26 thunderstorm days were recorded. For the period 1947-1980, 355 thunderstorm days were recorded and the daily precipitation distribution for these days are tabulated below:

\begin{tabular}{crc} 
Amount - Inches & Number of Cases & $\%$ of Total \\
\cline { 2 - 3 } None or trace & 158 & 44 \\
$0.01-0.10$ & 129 & 36 \\
$0.11-0.25$ & 42 & 12 \\
$0.26-0.50$ & 20 & 6 \\
$>0.50$ & 6 & 2 \\
& 355 & 100
\end{tabular}

The Federal Meteorological Handbook No. 1, Surface Observations, dated January 1, 1970, defines rainfall intensities as follows:

Very Light: surface not wet

Light: trace to 0.10 inch/hour

Moderate: 0.11 to $0.30 \mathrm{inch} /$ hour

Heavy: $\quad$ more than 0.30 inch/hour, or 0.03 inch

in 6 minutes. 
The HMS record for rainfall intensity during a thunderstorm is 0.55 inch in 20 minutes (1.65 inches per hour) on June 2, 1969. Hailstones of 1/4-inch diameter were observed during this storm.

Hail was observed on $16(5 \%)$ of the thunderstorm days. The distribution of hail by month is as follows:

$$
\text { J } \quad \underline{F} \quad \underline{M} \quad \underline{A} \quad \underline{M} \quad \underline{J} \quad \underline{J} \quad \underline{A} \quad \underline{S} \quad \underline{0} \quad \underline{N} \quad \underline{D} \quad \underline{S u m}
$$

$\begin{array}{llllllllllllll}\text { Number } & 0 & 1 & 1 & 5 & 3 & 1 & 2 & 2 & 1 & 0 & 0 & 0 & 16\end{array}$ $\begin{array}{llllllllllllll}\% \text { of Total } & 0 & 6 & 6 & 31 & 19 & 6 & 13 & 13 & 6 & 0 & 0 & 0 & 100\end{array}$

When size was reported, all except two occurrences were in the 0.2-0.3-inch range. The exception occurred on May 26, 1954 and July 1, 1955 when the size recorded was 0.4 inch.

Peak wind gust records for the 50-, 200- and 400-foot tower levels began in 1952. Speed categories of peak gusts for the 294 thunderstorm days recorded from 1952-1980 are tabulated below:

\begin{tabular}{|c|c|c|c|c|c|c|}
\hline \multirow[b]{2}{*}{$\mathrm{MPH}$} & \multicolumn{3}{|c|}{ Number of Cases } & \multicolumn{3}{|c|}{$\%$ of Total } \\
\hline & $50 \mathrm{ft}$ & $200 \mathrm{ft}$ & $400 \mathrm{ft}$ & $50 \mathrm{ft}$ & $200 \mathrm{ft}$ & $400 \mathrm{ft}$ \\
\hline$<21$ & 33 & 16 & 12 & 11 & 6 & 4 \\
\hline $21-30$ & 120 & 81 & 69 & 41 & 28 & 23 \\
\hline $31-40$ & 98 & 127 & 124 & 33 & 43 & 42 \\
\hline $41-50$ & 33 & 48 & 61 & 11 & 16 & 21 \\
\hline $51-60$ & 6 & 14 & 19 & 2 & 5 & 7 \\
\hline $61-70$ & 2 & 4 & 5 & 1 & 1 & 2 \\
\hline$>70$ & 2 & 4 & 4 & 1 & 1 & 1 \\
\hline & 294 & 294 & 294 & 100 & 100 & 100 \\
\hline
\end{tabular}


SUNRISE AND SUNSET TABLE FOR THE HMS 


\section{APPENDIX III}

\section{SUNRISE AND SUNSET AT THE HANFORD METEOROLOGY STATION}

\section{TABLE A.III-1. Sunrise and Sunset at the Hanford Meteorology Station}

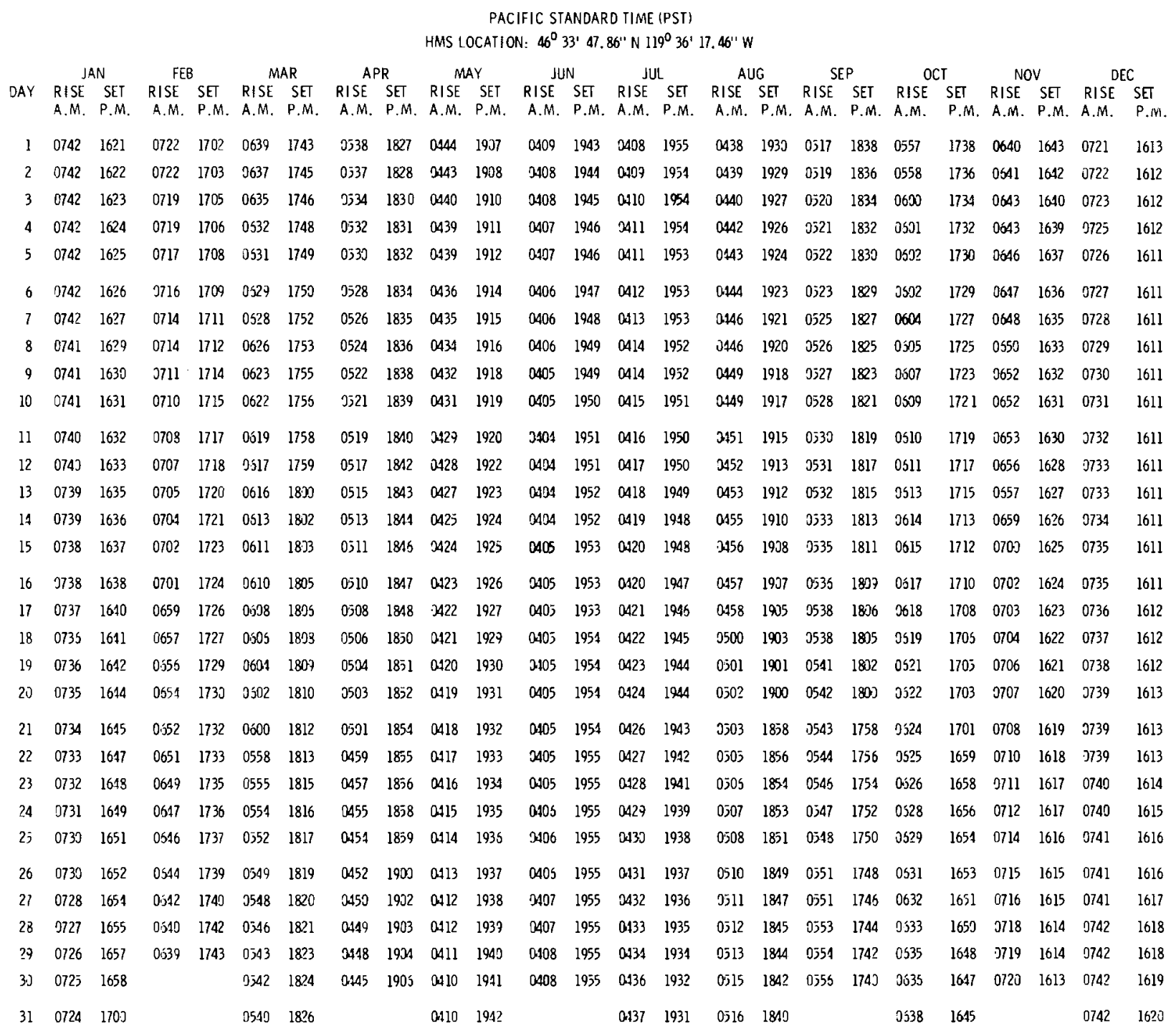

\section{A. III-1}


HANFORD WIND TELEMETRY NETWORK 


\section{HANFORD WIND TELEMETRY NETWORK}

\section{DESCRIPTION}

At the present time the Hanford Wind Telemetry Network consists of 20 wind stations. The stations are located in and around the Hanford Area at locations where, because of the terrain, the wind flow may be unique. Figure A.IV-1 shows station locations and wind roses for 13 of the stations. The wind sensors are mounted 30 feet $(9.14 \mathrm{~m})$ above the ground on triangular steel towers. A computerized central station at the HMS interrogates each station in sequence every 5 minutes. At the end of each hour, the average wind direction and wind speed as well as the maximum and minimum 5-minute average wind speed are recorded by a Teletype 43 Teleprinter on paper and also archived on magnetic tape. While only wind speed and direction are presently measured, the units can be modified to measure other meteorological parameters, such as atmospheric pressure, temperature and psychrometric data.

\section{PURPOSE}

The Wind Telemetry Network was designed to provide real-time air flow patterns across the Hanford Area and its environs. Telemetry wind information combined with wind forecasts are utilized by the MESOI Diffusion Model (Athey et a1., Ramsdell and Athey 1981) to provide transport trajectories of contaminants. This information is essential to the Hanford Area emergency response programs in the event of a release of radioactive material to the atmosphere.

\section{COMPUTER DATA ANALYSIS}

Tables A.IV-1 shows wind speed classes versus wind direction for each station. Figure A.IV-1 presents wind roses for the same locations. Note that there are differences in the periods of record. 


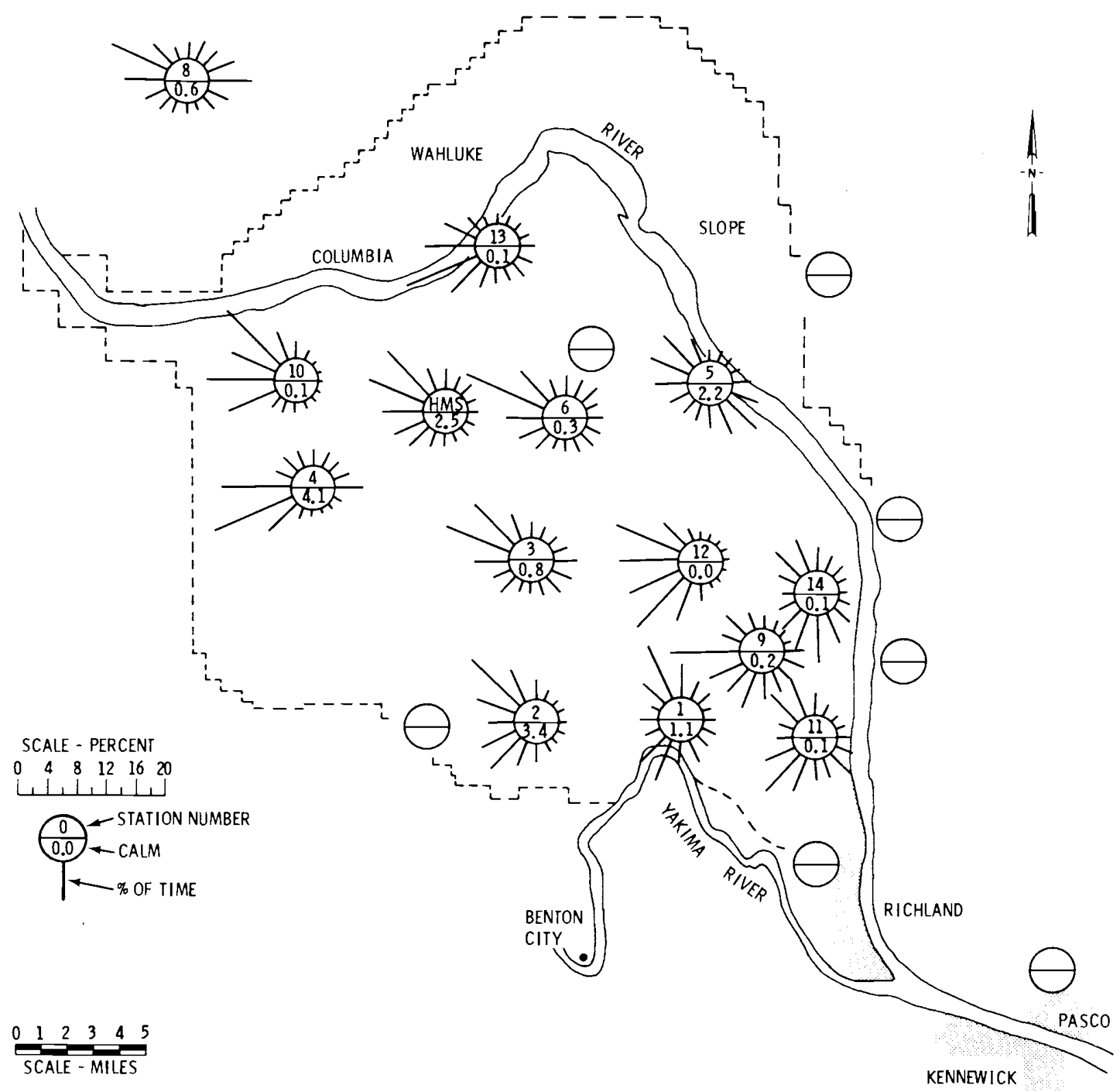

FIGURE A.IV-1. Wind Roses for the Hanford Telemetry Network 
TABLE A.IV-1. Percent Frequency Distribution of Wind Direction and Average Wind Speeds (mph) for the Hanford Telemetry Network

STATION 1 (PROSSER BARRICADE) ELEV, $480 \mathrm{FT}, 146 \mathrm{M}$, MSL PERIOD OF RECORD: FEB. 27, 1979 TO APR. 15, 1982

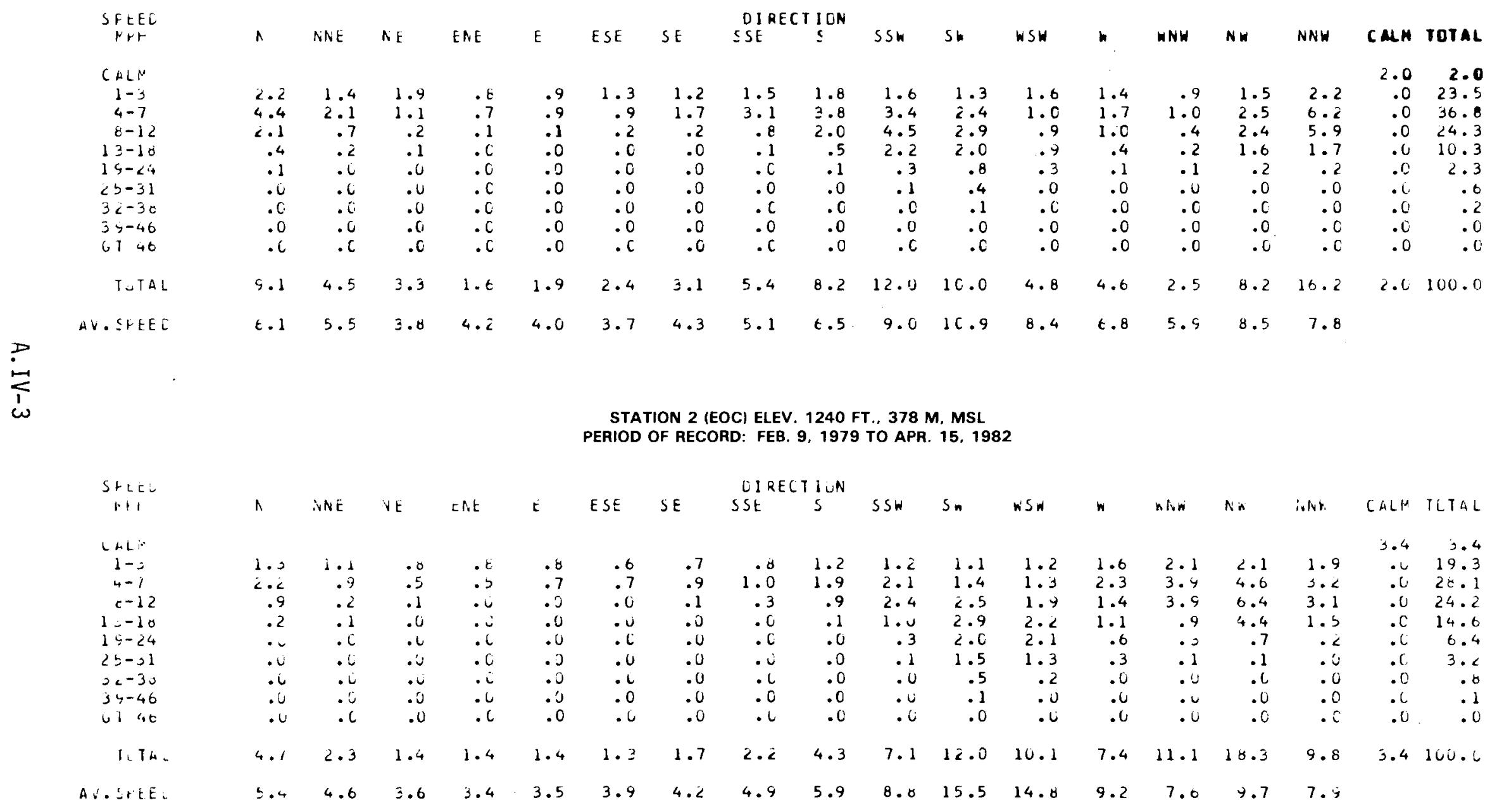


TABLE A.IV-1. Continued

STATION 3 (ARMY LOOP ROAD) ELEV. 565 FT., 172 M, MSL

PERIOD OF RECORD: FEB. 3, 1979 TO APR. 15, 1982

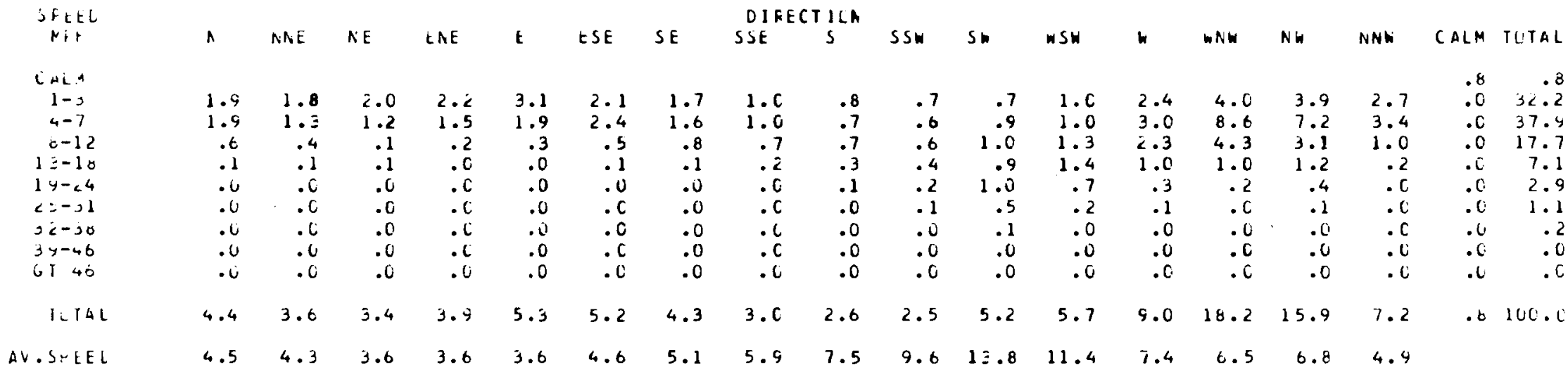

$\underset{⿱}{\stackrel{D}{0}}$

STATION 4 (RATTLESNAKE SPRINGS) ELEV. 680 FT., 207 M, MSL

PERIOD OF RECORD: MAR. 12, 1979 TO DEC. 31, 1981

\begin{tabular}{|c|c|c|c|c|c|c|c|c|c|c|c|c|c|c|c|c|c|c|}
\hline $\begin{array}{c}S F \in E L \\
F r r\end{array}$ & $\kappa$ & WIVE & NE & ENE & $E$ & ESE & SE & $\operatorname{SSE}_{S E}^{D I R E}$ & $\operatorname{lin}_{\leq}$ & SSW & Sh & W SW & h & WNW & $\mathrm{Nw}$ & NNG & $C \Delta L M$ & IUIAL \\
\hline$C A L$ & & & & & & & & & & & & & & & & & 4.1 & 4.1 \\
\hline $1-1$ & 1.6 & 2.8 & 2.5 & 3.4 & 2.2 & 1.9 & .9 & .6 & .7 & 1.1 & 2.7 & 4.2 & 3.5 & .8 & 1.0 & 1.4 & .0 & 30.8 \\
\hline $4-7$ & c.s & 1.3 & 1.0 & .7 & 1.3 & $1 . c$ & .4 & .3 & .5 & .7 & 3.7 & 9.3 & 7.4 & 2.1 & 2.2 & 2.3 & . C & 36.3 \\
\hline$t-12$ & .2 & .2 & .0 & . C & .1 & .1 & .0 & .0 & .3 & .0 & 2.9 & 8.4 & 5.2 & 1.4 & 1.2 & .7 & .0 & 21.3 \\
\hline $13-13$ & .0 & .0 & .0 & . C & .0 & .0 & .0 & .0 & .1 & .4 & 1.0 & .9 & 2.1 & .5 & .6 & .1 & .0 & 5.8 \\
\hline $15-24$ &.$u$ & . $C$ & .0 & .8 & .0 & . $C$ & .0 & . C & .1 & .3 & .6 & .2 & .2 & . C & .1 &.$c$ & .0 & 1.5 \\
\hline $25-31$ & .0 & .0 &.$c$ & . $\mathrm{C}$ & .0 &.$c$ & .0 & . $C$ & .0 & .1 & .1 & .0 & .0 & . C &.$c$ & . C & .0 & .3 \\
\hline $3 c-30$ &.$u$ & . $C$ & . $C$ & . $c$ & .0 & . C & .0 & . $C$ & .0 & .0 & .0 & .0 & .0 & .0 & .0 & . $\mathrm{C}$ & . & . $\mathrm{C}$ \\
\hline $39-46$ & .0 &.$c$ & .0 & .0 & .0 & .0 & .0 & . $C$ & .0 &.$v$ & .0 & .0 &.$c$ &.$c$ & .0 &.$c$ & . C &.$c$ \\
\hline 6146 & .6 & . $\mathrm{C}$ & .0 & . C & .0 & . C & .0 &. $\mathrm{c}$ & .0 & .0 & .0 & .0 & .0 &.$C$ & .0 & . c & .0 & . C \\
\hline T:TAL & 3.9 & 3.6 & 3.5 & 4.2 & 3.6 & 2.9 & 1.4 & .9 & 1.7 & 3.2 & $1 C .9$ & 23.0 & 16.5 & 4.8 & 5.1 & 4.6 & 4.1 & 100.0 \\
\hline . $\triangle F t E L$ & $\Xi .9$ & 3.5 & 2.9 & 2.6 & 3.5 & 3.1 & 2.8 & 3.2 & $t .0$ & 8.6 & 7.5 & 6.8 & 7.2 & 7.2 & 7.2 & 5.? & & \\
\hline
\end{tabular}


TABLE A.IV-1. Continued

STATION 5 (EDNA) ELEV, $400 \mathrm{FT}, 122 \mathrm{M}$ MSL

PERIOD OF RECORD: FEB. 3, 1979 TO APR. 15, 1982

\begin{tabular}{|c|c|c|c|c|c|c|c|c|c|c|c|c|c|c|c|c|c|c|}
\hline S r LEU & & & & & & & & UI KE & ILN & & & & & & & & & \\
\hline$r+H$ & N & NNE & $N E$ & ENE & $\mathrm{E}$ & ESE & SE & SSE & $s$ & SSH & Sh & W SW & $w$ & WNW & $N W$ & NNW & CALM & TUTAL \\
\hline CAL: & & & & & & & & & & & & & & & & & 2.2 & $\begin{array}{r}2.2 \\
35.4\end{array}$ \\
\hline $4-7$ & 1.0 & .6 & .5 & .6 & 1.5 & 2.1 & 4.0 & 3.5 & 2.8 & 2.0 & C. 0 & 2.3 & 3.5 & $\begin{array}{l}3.8 \\
3.7\end{array}$ & 3.2 & 1.7 & .0 & $\begin{array}{l}35.4 \\
37.5\end{array}$ \\
\hline$\varepsilon-12$ & .3 & .3 & .2 & . j & .6 & 1.2 & 1.0 & 1.6 & 1.1 & .7 & .9 & 1.0 & 1.6 & 1.7 & 1.8 & 1.4 & .0 & 15.1 \\
\hline $1 \equiv-1 \theta$ & .2 & .2 & .2 & .1 & .0 & .1 & .2 & .4 & .6 & .5 & .7 &.$\&$ & .9 & 1.6 &.$t$ & .1 & .0 & 7.2 \\
\hline $1 \leq-24$ &.$c$ &.$c$ & .1 &.$c$ & .0 &.$c$ & .0 &.$c$ & .1 & .1 & .3 & .3 & .2 & .7 & .2 & - $C$ & .0 & $2 \cdot c$ \\
\hline$i=-21$ & .6 &.$c$ & .6 & .6 & .0 & - $C$ & .0 & - $c$ & . $\mathrm{C}$ & - $C$ & .1 & .1 & .1 & .3 & .0 & . $\mathrm{C}$ & . $\mathrm{c}$ & $\cdot 5$ \\
\hline $3<-30$ &.$u$ & . & .0 & . 0 & .0 & .0 & .0 &.$c$ & .0 & .0 & .0 & .0 & .0 & . C & .0 & - $c$ & . C & .0 \\
\hline $3 c-46$ &. & . $\mathrm{C}$ & . $c$ & . $C$ & .0 & . $\mathrm{C}$ & .0 &.$c$ &.$c$ &.$u$ & .0 &.$i$ & .0 & . $C$ & .0 & - $C$ & - 6 & - $\mathrm{C}$ \\
\hline 6140 & .0 & .0 & .0 &. $\mathrm{C}$ & .0 & .0 & .0 & - $c$ & .0 & .6 & .0 & .0 & . C & .0 & .0 & .0 & - $C$ & .0 \\
\hline IETAL & 2.5 & 1.5 & $1 . t$ & $1 . \equiv$ & 4.4 & 7.7 & 11.4 & $8 \cdot \overline{2}$ & t.1 & 4.1 & 4.7 & 5.4 & 8.5 & 11.7 & 11.8 & 6.7 & $c .2$ & $100 . c$ \\
\hline - SrEEL & 5.0 & $t .3$ & $t .6$ & 5.3 & 4.8 & $5 .<$ & 4.6 & 4.7 & 5.8 & 6.3 & 7.2 & 7.3 & $t .3$ & 7.0 & 5.9 & 5.7 & & \\
\hline
\end{tabular}

$\underset{\text { í }}{\stackrel{P}{*}}$

STATION 6 (200-E AREA) ELEV. 670 FT., 204 M, MSL

PERIOD OF RECORD: FEB. 3, 1979 TO APR. 15, 1982

\begin{tabular}{|c|c|c|c|c|c|c|c|c|c|c|c|c|c|c|c|c|c|c|}
\hline $\begin{array}{c}\text { Sreti } \\
\text { Art }\end{array}$ & $N$ & VIVE & $V_{c}$ & ENE & t & ESE & $S E$ & $\begin{array}{l}\text { DI KE } \\
\text { SSE }\end{array}$ & $\int_{S}^{L L N}$ & SSW & $5 \mathrm{~m}$ & nsh & $w$ & $n N w$ & Nr & NNn & $\sim A L M$ & TLTAL \\
\hline CAL": & & & & & & & & & & & & & & & & & .3 & . \\
\hline $1-=$ & $<\cdot c$ & $c \cdot t$ & 2.7 & c. $\ddot{v}$ & 1.7 & 1.7 & 1.7 & 1.4 & 1.1 & .7 & .8 & 1.1 & 1.5 & 2.3 & 2.5 & 2.2 & . c & $\angle .9$ \\
\hline $4-1$ & 1.5 & 1.1 & .6 &.$\delta$ & 1.3 & $1 . \partial$ & 2.2 & $2 . C$ & 1.1 & 1.0 & 1.5 & 2.4 & 4.3 & B. 6 & 3.3 & $\angle 0$ & . C & 37.4 \\
\hline$c-12$ & .7 & .3 & .2 & .1 & .2 & .3 & .4 & .9 & .6 &.$c$ & 1.0 & 1.8 & 3.3 & 8.1 & $<.1$ & .5 & .6 & 21.3 \\
\hline $1 \equiv-10$ & .2 & .2 & .1 & . $C$ & .0 &.$c$ & .0 & .2 & .2 & .4 & 1.0 & 1.5 & .9 & $3 . i$ & 1.0 & .1 &.$c$ & 8.9 \\
\hline $1 y-<4$ &.$v$ & .1 & .0 & . C & .0 & . C & .0 & .0 & . & .1 & .6 & .5 & .1 & .8 & .3 & .0 & .6 & 2.7 \\
\hline $2:-31$ &.$c$ & . C & .0 & . $c$ & .3 & . C & .0 & .0 & .0 & .1 & .2 & .1 & .1 & .1 & .1 & . C & .0 & .t \\
\hline $3<-3 x$ & .0 & .6 & .6 & .0 & .0 & . C &.$v$ & . C & .0 & .0 & .0 & . & .0 & .0 &.$i$ & .0 & .6 & .0 \\
\hline$\approx>-40$ & . C & .0 & .0 & . C & .0 & .0 & .0 & . C & .0 &.$u$ & .0 & .0 & .0 & . C & . C & . C & .0 & .0 \\
\hline$\therefore 145$ & .0 &.$u$ & U & . L & .0 & .0 & .0 & .0 & .0 &.$c$ & .0 & .0 & .0 & .0 &.$u$ &. $\mathrm{C}$ & .6 & .0 \\
\hline ILTAL & 4.4 & 4.5 & 4.5 & 2.0 & 3.2 & 3.8 & 4.4 & 4.5 & 3.1 & $<.8$ & 5.1 & 7.5 & 10.2 & $<2.9$ & 11.3 & 4.7 & .3 & lut. . C \\
\hline$\therefore$ OCK & 5.2 & 4.3 & 2.4 & 3.0 & 3.8 & 4.1 & 4.5 & 5.7 & 5.9 & 7.9 & 10.5 & 9.6 & 7.4 & 8.6 & 0.9 & 4.4 & & \\
\hline
\end{tabular}


TABLE A.IV-1. Continued

STATION 8 (NW WAHLUKE SLOPE) ELEV. 845 FT., 258 M. MSL

PERIOD OF RECORD: MAR. 12, 1979 TO APR. 15, 1982

\begin{tabular}{|c|c|c|c|c|c|c|c|c|c|c|c|c|c|c|c|c|c|c|}
\hline $\begin{array}{l}\text { SFEE } \\
\text { RHF }\end{array}$ & $n$ & INNE & $N E$ & ENE & $E$ & ESE & SE & $\begin{array}{c}\text { DIR } \\
\text { SSE }\end{array}$ & $\operatorname{lil}_{S}$ & SSH & SH & HSW & h & In N & $\mathrm{Nin}$ & NNW & CALM & TDTAL \\
\hline CALM & & & & & & & & & & & & & & & & & .6 & \\
\hline $1-3$ & 1.3 & 1.4 & 1.7 & 2.2 & 2.4 & 1.9 & 1.6 & 1.2 & 1.1 & 1.0 & 1.2 & 1.5 & 1.9 & 2.2 & 1.9 & 1.6 &. $\mathrm{C}$ & 26.1 \\
\hline $4-7$ & 1.3 & 1.9 & 2.0 & $4 . C$ & t. 2 & 3.3 & 2.1 & 1.1 & 1.0 & 1.2 & 1.4 & 1.7 & 4.0 & 5.3 & 2.6 & 1.5 & .0 & 40.6 \\
\hline$t-12$ & .6 & 1.6 & .8 & 1.0 & 1.7 & .3 & .3 & .2 & .3 & .6 & .8 & 1.8 & 2.5 & 4.0 & 1.5 & .5 & .0 & 18.6 \\
\hline $12-10$ & .5 & .8 & .3 & .2 & .1 & .0 & .1 & .1 & .1 & .3 & .8 & .7 & 1.3 & 3.4 & 1.2 & .1 & .0 & 9.9 \\
\hline $14-24$ & .1 & .1 & .1 & .0 & .0 & . $\mathrm{C}$ & .0 & .0 & .0 & .1 & .4 & .3 & .4 & 1.2 & .4 & .0 & .0 & 3.1 \\
\hline $2 b-31$ & .0 & .0 & .0 & .0 & .0 & .0 & .0 &. $\mathrm{C}$ & .0 & .0 & .2 & .2 & .1 & .3 & .2 & .0 & .0 & .9 \\
\hline $2<-30$ & .0 & .0 & .0 & .0 & .0 & .0 & .0 & .0 & .0 & .0 & .0 & .0 & .0 & .0 & .0 &. $\mathrm{C}$ & .0 & .1 \\
\hline $34-40$ & .0 & .0 & .0 & . $\mathrm{C}$ & .0 & .0 & .0 & .0 & .0 & .0 & .0 & .0 & .0 & .0 & .0 & . $\mathrm{C}$ & .0 & .0 \\
\hline 6140 & .0 & .6 & .6 & .0 & .0 & .0 & .0 & .0 & .0 & .0 & .0 & .0 & .0 & .0 & . $\mathrm{C}$ & . C & .0 & .0 \\
\hline TUIAL & 4.0 & 5.0 & 4.9 & 7.4 & 10.4 & 5.6 & 4.0 & 2.6 & 6.6 & 3.2 & 4.7 & 6.1 & 10.2 & 16.4 & 7.8 & 3.8 & .6 & 100.0 \\
\hline - Sretei & 7.4 & 7.4 & 5.6 & 5.1 & 5.4 & 4.4 & 4.4 & 4.3 & 5.3 & 6.5 & 9.4 & 8.4 & 7.8 & 9.6 & 0.3 & $5 . C$ & & \\
\hline
\end{tabular}

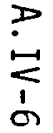

STATION 9 (FFTF) ELEV. 550 FT., $168 \mathrm{M}$, MSL

PERIOD OF RECORD: APR. 5, 1979 TO APR. 15, 1982

\begin{tabular}{|c|c|c|c|c|c|c|c|c|c|c|c|c|c|c|c|c|c|c|}
\hline $\begin{array}{c}\text { SPEEU } \\
M H r\end{array}$ & $A$ & NIVE & $N \bar{E}$ & ENE & E & ESE & $S E$ & $\begin{array}{l}\text { DIRE } \\
\text { SSE }\end{array}$ & ${ }_{S}^{I}$ & SSW & SW & WSW & in & NH & NW & NNh & $C A L M$ & TUTAL \\
\hline CAL:A & & & & & & & & & & & & & & & & &.$\dot{a}$ & $\cdot 2$ \\
\hline $1-3$ & .9 & .7 & .7 & .8 & 2.6 & 4.4 & 2.2 & 1.7 & 1.7 & 2.4 & 3.3 & 7.3 & 3.6 & 1.4 & 1.2 & 1.0 &.$C$ & 35.7 \\
\hline $4-7$ & 1.3 & .7 & .4 &.$\Xi$ & 1.7 & .7 & .8 & 2.3 & 2.4 & 2.5 & 1.8 & 2.0 & 9.0 & 2.3 & 2.9 & 2.0 & .0 & 32.9 \\
\hline$\varepsilon-12$ & .4 & .2 & .1 & .1 & .4 & .1 & .1 & 1.7 & 2.2 & 3.0 & 1.4 & .7 & 4.4 & 2.0 & 2.6 & 1.1 & .0 & 20.5 \\
\hline $1 \equiv-18$ & .2 & .1 & .0 & .0 & .1 & .0 & .0 & .2 & .6 & 1.8 & 1.3 & .3 & $1 . t$ & .7 & .5 & .3 & .0 & 7.9 \\
\hline $19-24$ & .0 & .0 & .0 & .0 & .0 & .0 & .0 & .0 & .1 & .5 & .6 & .2 & .3 & .2 & .1 & .0 & .0 & 2.1 \\
\hline $2 b-31$ & ن & .0 & .0 & .0 & .0 & .0 & .0 & .0 & .0 & .1 & .3 & .0 & .0 & .0 & .1 & .0 & .0 & .6 \\
\hline $3<-35$ & .6 & .0 & .0 & .0 & .0 & .0 & .0 & .0 & .0 & .0 & .1 & .0 & .0 & .0 &. $\mathrm{C}$ & .0 & .0 & .1 \\
\hline $3 y-46$ & .0 & .0 & .0 &.$c$ & .0 & .0 & .0 & .0 & .0 & .0 & .0 & .0 & .0 & .0 & .0 & .0 & .0 & .0 \\
\hline 0745 & .0 &.$u$ & .0 & .0 & .0 & .0 & .0 & .0 & .0 & .0 & .0 & .0 & .0 & .0 & .6 & .0 & .0 & .0 \\
\hline TLTAL & 2.6 & 1.8 & 1.2 & 1.1 & 4.7 & 5.2 & 3.2 & 5.9 & 6.9 & 10.4 & 8.8 & 10.5 & 18.9 & 6.6 & 7.4 & 4.4 & .2 & 100.0 \\
\hline - SHCEU & 5.4 & 5.5 & 4.5 & 3.2 & 4.0 & 2.5 & 3.0 & 5.9 & 6.9 & 8.7 & 8.3 & 4.0 & 6.8 & 7.6 & 7.6 & 6.4 & & \\
\hline
\end{tabular}


TABLE A.IV-1. Continued

STATION 10 (YAKIMA BARRICADE) ELEV. 795 FT., 242 M, MSL

PERIOD OF RECORD: DEC. 29, 1980 TO APR. 15, 1982

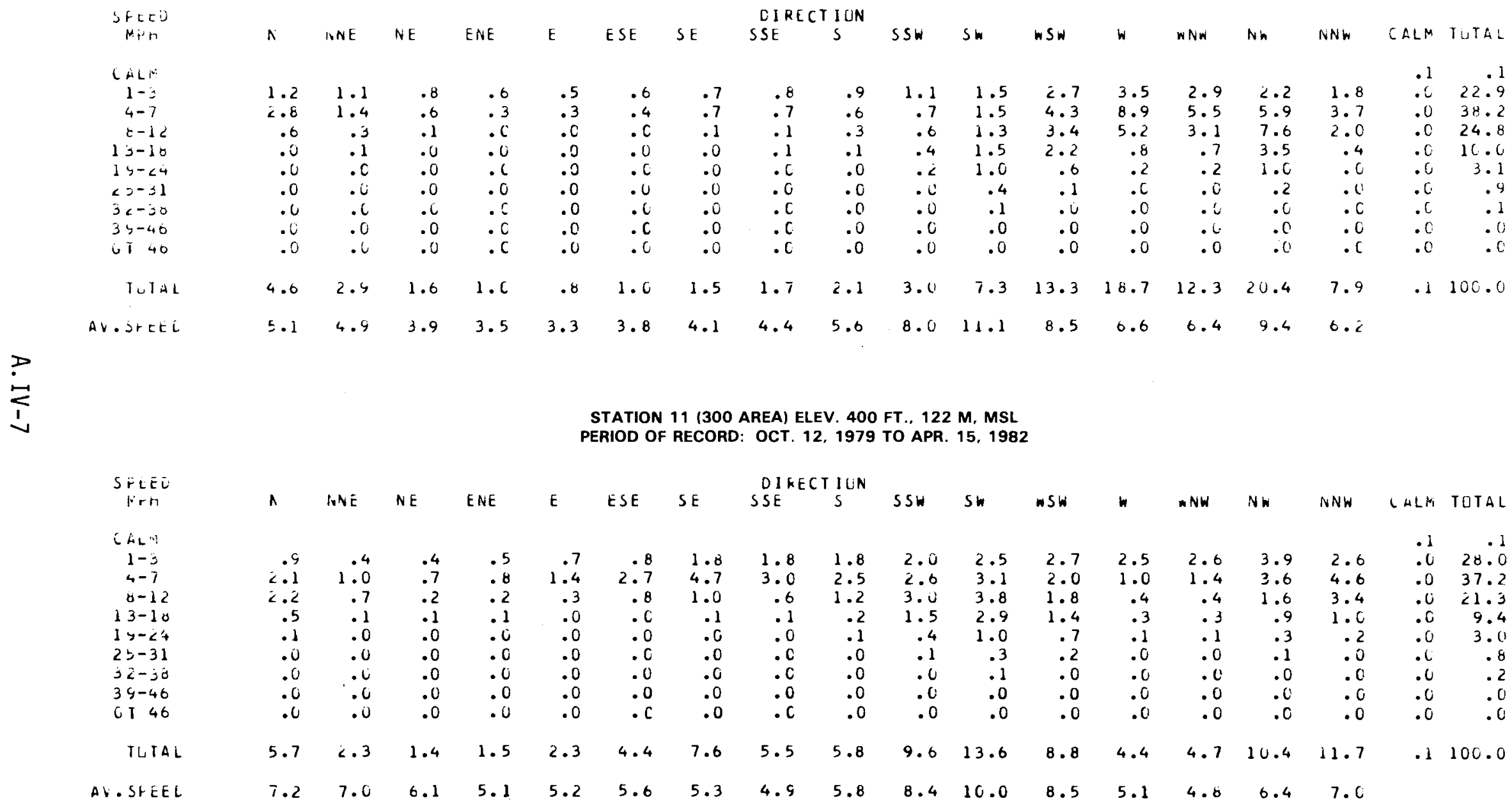




\section{TABLE A.IV-1. Continued}

STATION 12 (WYE BARAICADE) ELEV. 550 FT., 168 M, MSL

PERIOD OF RECORD: OCT. 19, 1979 TO APR. 15, 1982

SHEE
$M+F$

$$
\begin{aligned}
C A L \\
1-3 \\
4-3
\end{aligned}
$$$$
\begin{aligned}
& 1-3 \\
& 4-7 \\
& 8-12 \\
& 13-18
\end{aligned}
$$$$
\begin{array}{r}
0-12 \\
1 j-18 \\
15-24
\end{array}
$$$$
15-24
$$$$
<5-31
$$$$
3<-35
$$$$
39-45
$$$$
\text { GT } 46
$$

ILIAL

AV.STEEL

$\underset{\substack{P \\:}}{\stackrel{P}{K}}$
STATION $13(100-N$ AREA $)$ ELEV. 480 FT. 146 M, MSL
PERIOD OF RECORD: NOV. 17,1979 TO APR. 15,1982

\begin{tabular}{|c|c|c|c|c|c|c|c|c|c|c|c|c|c|c|c|c|c|c|}
\hline $\begin{array}{l}\text { SHEEL } \\
\text { PRH }\end{array}$ & N & INAE & NE & EISE & $t$ & ESE & $S E$ & $\begin{array}{l}\text { UIRE } \\
\text { SSE }\end{array}$ & $\int_{S}^{1 U N}$ & SSW & Sw & WSW & h & WNW & $\mathrm{Nin}$ & inNh & LALM & TUTAL \\
\hline CALH & & & & & & & & & & & & & & & & & .1 & \\
\hline $1-3$ & 1.1 & .9 & 1.3 & 1.3 & 1.9 & 2.2 & 2.4 & 2.2 & 2.0 & 2.7 & 5.3 & 9.5 & 4.2 & 3.0 & $\angle .5$ & 1.7 & .0 & 44.0 \\
\hline $4-7$ & 1.1 & .9 & .8 & 1.0 & 1.5 & 1.6 & 2.1 & 1.2 & 1.1 & 1.3 & 3.0 & 6.3 & 4.7 & 3.6 & 2.0 & 1.2 & . C & 32.7 \\
\hline$t-12$ &.$<$ & .5 & .3 & .0 & .1 & .3 & .7 & .5 & .4 & .7 & 1.6 & 3.2 & 3.4 & 1.7 & .3 & .3 & .0 & 14.3 \\
\hline $13-16$ & .1 & .3 & .2 & .0 & .0 & . $\mathrm{C}$ & .1 & .1 & .2 & .4 & 1.2 & 1.1 & 1.4 & 1.1 & .3 & .1 & . C & 6.5 \\
\hline $15-24$ & .0 & .0 & .0 & .0 & .0 & .0 & .0 & .0 & .0 & .2 & .5 & .4 & .2 & .5 & .1 & . 6 & .0 & 1.9 \\
\hline $2 s-31$ & .0 &.$C$ & .0 & . $C$ & .0 & .0 & .0 & . C & .0 & .1 & .1 & .0 & .0 & .2 & .0 &.$i$ & .0 & .4 \\
\hline $32-30$ & . C & .0 & .0 & .0 & .0 & .0 & .0 & . C & . C & . C & .0 & .0 & .0 & .0 &.$c$ & .0 & .0 & .0 \\
\hline $39-46$ & . C & . C & .0 & . C & .0 & .0 & .0 & .0 & .0 & .0 & .0 & .0 & .0 & .0 & .0 & .0 & .0 & .0 \\
\hline 6145 & .0 & .0 & .0 & .0 & .0 & .0 & .0 & .0 & .0 & .0 & .0 & .0 & .0 & .0 & .0 & .0 & .0 & .0 \\
\hline TUIAL & 2.6 & 2.0 & 2.5 & 2.3 & 3.5 & 4.1 & 5.3 & 4.0 & 3.8 & 5.3 & 11.7 & 20.3 & 13.9 & 9.5 & 5.3 & $3 \cdot 3$ & .1 & 100.0 \\
\hline$S P E E Z$ & 5.2 & 6.0 & 4.9 & 3.7 & 3.7 & 4.0 & 4.6 & 4.2 & 4.6 & 5.7 & 0.1 & 5.1 & 6.7 & 7.5 & 5.0 & 4.2 & & \\
\hline
\end{tabular}




\section{TABLE A.IV-1. Continued}

STATION 14 (WPPSS) ELEV. 450 FT., 137 M, MSL

PEAIOD OF RECORD: OCT. 24, 1979 TO APR. 15, 1982

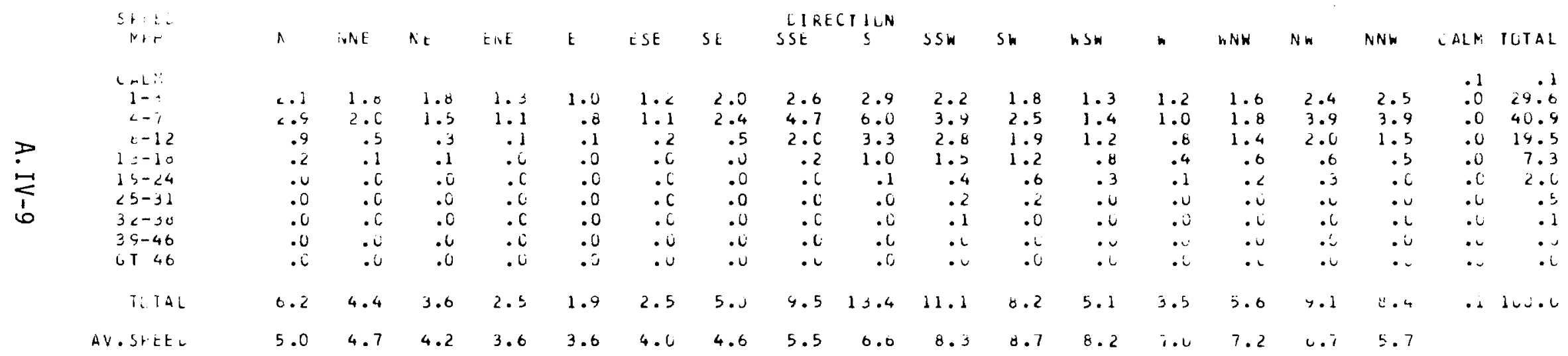




\section{REFERENCES}

Athey, G. F., K. J. Allwine and J. V. Ramsde11. 1981. User's Guide to the MESOI Diffusion Model and to the Utility Programs UPDATE and LOGRVU. PNL-3999, Pacific Northwest Laboratory, Richland, Washington.

Ramsde11, J. V. and G. F. Athey. 1981. MESOI: An Interactive Lagrangian Trajectory Puff Diffusion Model. PNL-3998, Pacific Northwest Laboratory, Richland, Washington. 
APPENDIX $V$

ARID LANDS ECOLOGY RESERVE PRECIPITATION 


\section{APPENDIX V}

\section{PRECIPITATION CLIMATOLOGY OF THE ARID LANDS ECOLOGY RESERVE}

The southwestern portion of the Hanford Reservation was set aside in 1968 as the Arid Lands Ecology (ALE) Reserve (Figure A.V-1). This ecological study area contains the most diverse topography of the Hanford region. Elevations range from $\sim 3500 \mathrm{ft} \mathrm{MSL}$ in the southern part of the ALE Reserve, which includes the crest and northeast face of Rattlesnake Mountain, to about $450 \mathrm{ft}$ MSL at the northern boundary near the Cold Creek valley (Figure A.V-2).

To provide microclimatological data for research projects conducted on the ALE Reserve a network of 26 temperature and precipitation measuring stations was established in 1968-1969 (Thorp and Hinds 1977) at points along existing roads on the Reserve (Figure A.V-2).

Precipitation amounts and extreme temperatures were measured monthly at the 26 sites from autumn 1968 to the end of 1981 . The monthly and annual average precipitation amounts for each of the sites, and the HMS annual average for the same period, are shown in inches (Table A.V-1) and centimeters (Table A.V-2) of water. The annual average distribution of precipitation (in $\mathrm{cm}$ of water) for the ALE Reserve is shown in Figure A.V-3. This figure shows a precipitation maximum greater than $25 \mathrm{~cm}$ (9.8 in.) just north of the Rattlesnake Mountain crest, and an apparent rapid reduction in annual amount of precipitation on and south of the crest. This gradient on the south is partially explained by the probability that precipitation borne by strong southwest winds over the mountain crest never enters the collection gage. The nearest precipitation recording stations south of the crest are 4 miles northeast of Prosser and at Sunnyside (respectively about $15 \mathrm{mi}$ south and southwest at $900 \mathrm{ft} \mathrm{MSL}$ and $745 \mathrm{ft}$ MSL). Normally, Prosser receives $20.0 \mathrm{~cm}$ (7.9 in.) annual precipitation and Sunnyside $17.3 \mathrm{~cm}(6.8 \mathrm{in}$.$) . These values indicate$ that the variation in annual average precipitation on the gentle southwest slope of Rattlesnake Mountain away from the crest is less than that on the northeast slope. 


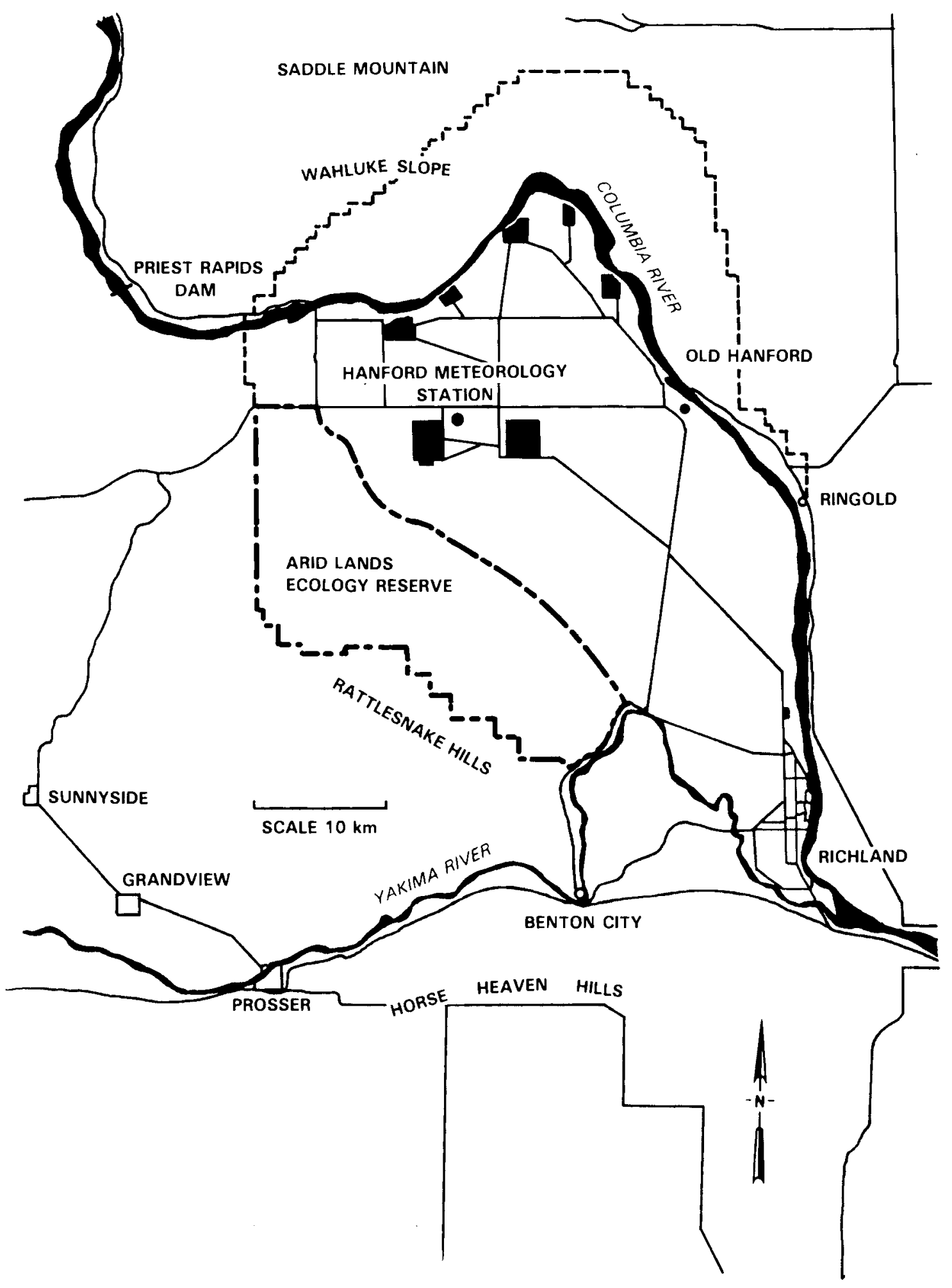

FIGURE A.V-1. Location of the Arid Lands Ecology Reserve 


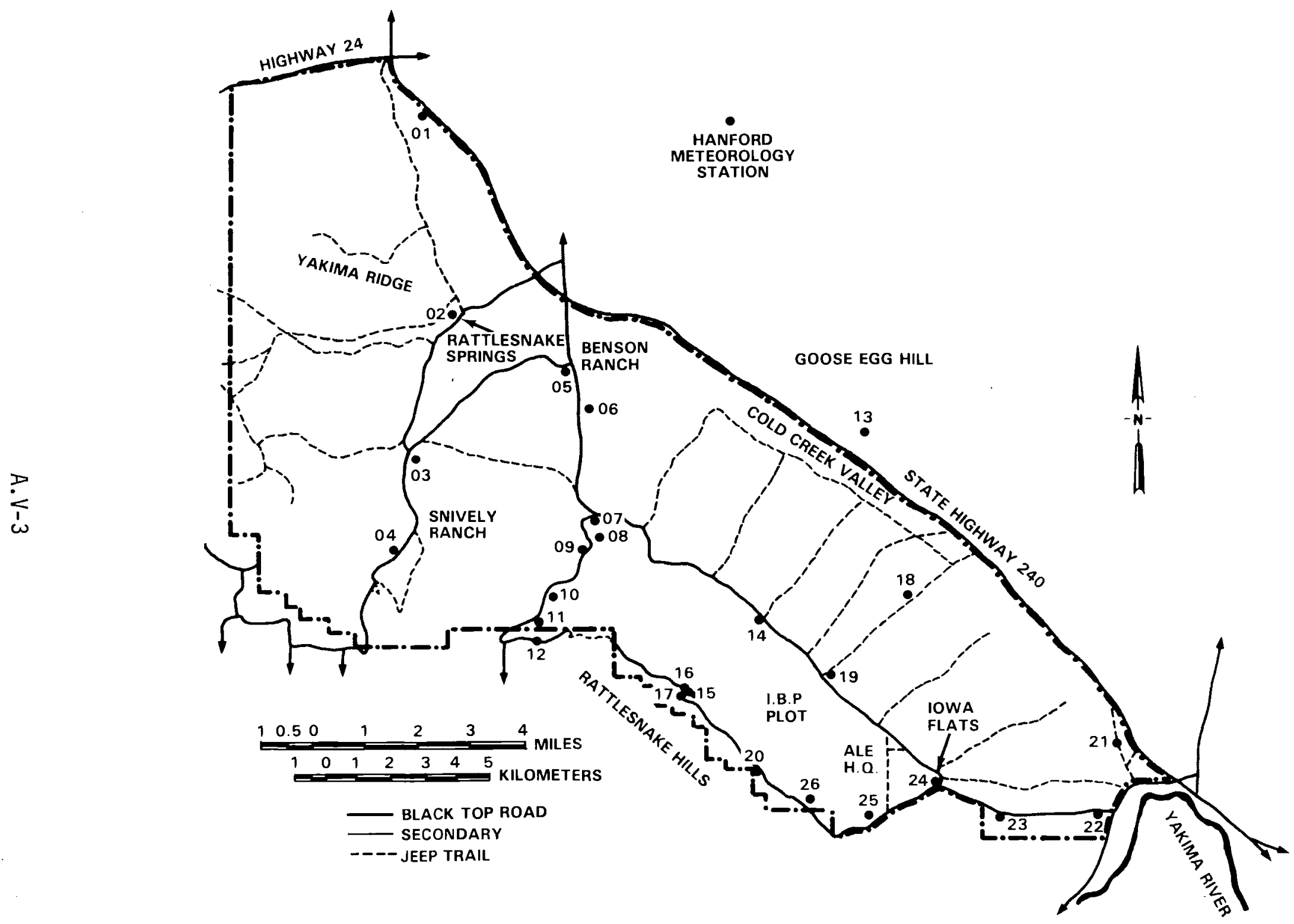

FIGURE A.V-2. Locations of Temperature and Precipitation Measuring Stations in the Arid Lands Ecology Reserve 
TABLE A.V-1. Arid Lands Ecology Reserve--Average Monthly Precipitation (in.) for Years 1969 Through 1980

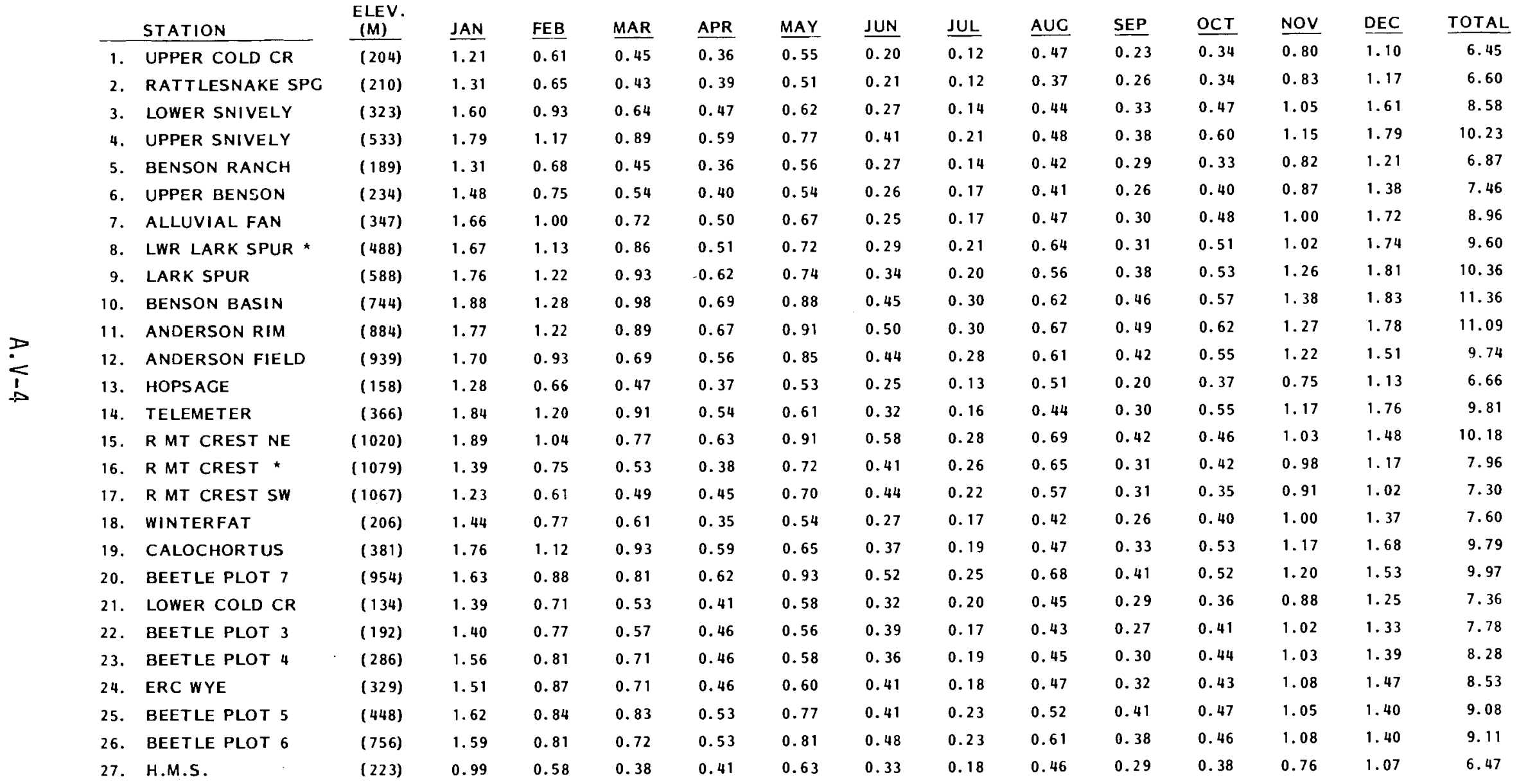


TABLE A.V-2. Arid Lands Ecology Reserve--Average Monthly Precipitation (cm) for Years 1969 Through 1980

\begin{tabular}{|c|c|c|c|c|c|c|c|c|c|c|c|c|c|c|c|}
\hline & STATION & $\begin{array}{l}\text { ELEV. } \\
\text { (M) }\end{array}$ & JAN & FEB & MAR & APR & MAY & $\underline{\text { JUN }}$ & JUL & $\underline{\mathrm{A} \cup \mathrm{C}}$ & $\underline{\text { SEP }}$ & $\underline{O C T}$ & Nov & $\underline{D E C}$ & TOTAL \\
\hline 1. & UPPER COLD CR & $(204)$ & 3.09 & 1.55 & 1.14 & 0.90 & 1.40 & 0.51 & 0.31 & 1.20 & 0.60 & 0.87 & 2.04 & 2.79 & 16.40 \\
\hline 2. & RATTLESNAKE SPG & $(210)$ & 3.34 & 1.64 & 1.09 & 0.99 & 1.30 & 0.54 & 0.31 & 0.94 & 0.65 & 0.86 & 2.12 & 2.97 & 16.77 \\
\hline 3. & LOWER SNIVELY & $(323)$ & 4.06 & 2.37 & 1.62 & 1.19 & 1.58 & 0.70 & 0.36 & 1.12 & 0.83 & 1.19 & 2.67 & 4.09 & 21.78 \\
\hline 4. & UPPER SNIVELY & (533) & 4.55 & 2.98 & 2.27 & 1.50 & 1.96 & 1.04 & 0.52 & 1.22 & 0.96 & 1.53 & 2.93 & 4.54 & 25.98 \\
\hline 5. & BENSON RANCH & (189) & 3.34 & 1.72 & 1.14 & 0.93 & 1.42 & 0.69 & 0.37 & 1.08 & 0.73 & 0.85 & 2.09 & 3.08 & 17.44 \\
\hline 6. & UPPER BENSON & $(234)$ & 3.77 & 1.90 & 1.37 & 1.01 & 1.36 & 0.67 & 0.42 & 1.05 & 0.67 & 1.01 & 2.20 & 3.52 & 18.96 \\
\hline 7. & ALLUVIAL FAN & (347) & 4.22 & 2.54 & 1.84 & 1.28 & 1.71 & 0.65 & 0.42 & 1.19 & 0.77 & 1.23 & 2.55 & 4.38 & 22.77 \\
\hline 8. & LWR LARK SPUR * & (488) & 4.25 & 2.87 & 2.18 & 1.29 & 1.83 & 0.75 & 0.52 & 1.63 & 0.78 & 1.29 & 2.58 & 4.42 & 24.38 \\
\hline 9. & LARK SPUR & $(588)$ & 4.47 & 3.11 & 2.37 & 1.58 & 1.87 & 0.86 & 0.51 & 1.43 & 0.97 & 1.34 & 3.21 & 4.61 & 26.32 \\
\hline 10. & BENSON BASIN & $(744)$ & 4.79 & 3.26 & 2.49 & 1.77 & 2.25 & 1.16 & 0.76 & 1.59 & 1.17 & 1.45 & 3.52 & 4.66 & 28.85 \\
\hline 11. & ANDERSON RIM & $(884)$ & 4.49 & 3.09 & 2.26 & 1.69 & 2.32 & 1.27 & 0.77 & 1.71 & 1.24 & 1.57 & 3.23 & 4.52 & 28.17 \\
\hline 12. & ANDERSON FIELD & (939) & 4.33 & 2.35 & 1.75 & 1.41 & 2.15 & 1.13 & 0.70 & 1.54 & 1.07 & 1.39 & 3.09 & 3.83 & 24.75 \\
\hline 13. & HOPSAGE & (158) & 3.26 & 1.68 & 1.21 & 0.94 & 1.34 & 0.65 & 0.34 & 1.29 & 0.51 & 0.93 & 1.91 & 2.88 & 16.92 \\
\hline 14. & TE LEME TER & $(366)$ & 4.68 & 3.04 & 2.30 & 1.38 & 1.56 & 0.81 & 0.42 & 1.13 & 0.77 & 1.40 & 2.96 & 4.46 & 24.92 \\
\hline 15. & R MT CREST NE & $(1020)$ & 4.80 & 2.65 & 1.95 & 1.59 & 2.32 & 1.47 & 0.72 & 1.77 & 1.06 & 1.16 & 2.61 & 3.77 & 25.87 \\
\hline 16. & R MT CREST * & (1079) & 3.53 & 1.91 & 1.35 & 0.97 & 1.82 & 1.04 & 0.65 & 1.64 & 0.79 & 1.07 & 2.48 & 2.97 & 20.22 \\
\hline 17. & R MT CREST SW & $(1067)$ & 3.12 & 1.55 & 1.26 & 1.16 & 1.77 & 1.12 & 0.55 & 1.44 & 0.78 & 0.89 & 2.32 & 2.59 & 18.55 \\
\hline 18. & WINTERFAT & $(206)$ & 3.65 & 1.96 & 1.56 & 0.88 & 1.36 & 0.68 & 0.43 & 1.07 & 0.66 & 1.01 & 2.55 & 3.49 & 19.31 \\
\hline 19. & CALOCHORTUS & (381) & 4.47 & 2.83 & 2.36 & 1.49 & 1.66 & 0.93 & 0.50 & 1.19 & 0.84 & 1.36 & 2.97 & 4.27 & 24.88 \\
\hline 20. & BEETLE PLOT 7 & $(954)$ & 4.13 & 2.25 & 2.05 & 1.58 & 2.35 & 1.31 & 0.64 & 1.72 & 1.04 & 1.33 & 3.05 & 3.89 & 25.33 \\
\hline 21. & LOWER COLD CR & $(134)$ & 3.52 & 1.81 & 1.34 & 1.05 & 1.48 & 0.81 & 0.52 & 1.13 & 0.73 & 0.91 & 2.23 & 3.18 & 18.70 \\
\hline 22. & BEETLE PLOT 3 & $(192)$ & 3.55 & 1.95 & 1.44 & 1.18 & 1.42 & 0.98 & 0.43 & 1.09 & 0.69 & 1.05 & 2.60 & 3.39 & 19.75 \\
\hline 23. & BEETLE PLOT 4 & $(286)$ & 3.96 & 2.07 & 1.80 & 1.17 & 1.47 & 0.92 & 0.47 & 1.15 & 0.76 & 1.11 & 2.62 & 3.53 & 21.04 \\
\hline 24. & ERC WYE & (329) & 3.84 & 2.22 & 1.81 & 1.18 & 1.54 & 1.04 & 0.46 & 1.18 & 0.81 & 1.10 & 2.74 & 3.74 & 21.66 \\
\hline 25. & BEETLE PLOT 5 & $(448)$ & 4.11 & 2.12 & 2.10 & 1.36 & 1.95 & 1.05 & 0.57 & 1.33 & 1.05 & 1.20 & 2.67 & 3.55 & 23.07 \\
\hline 26. & BEET LE PLOT 6 & $(756)$ & 4.04 & 2.05 & 1.83 & 1.35 & 2.06 & 1.23 & 0.59 & 1.56 & 0.96 & 1.18 & 2.74 & 3.56 & 23.14 \\
\hline 27. & H.M.S. & $(223)$ & 2.51 & 1.47 & 0.97 & 1.05 & 1.60 & 0.83 & 0.45 & 1.17 & 0.75 & 0.96 & 1.94 & 2.73 & 16.43 \\
\hline
\end{tabular}




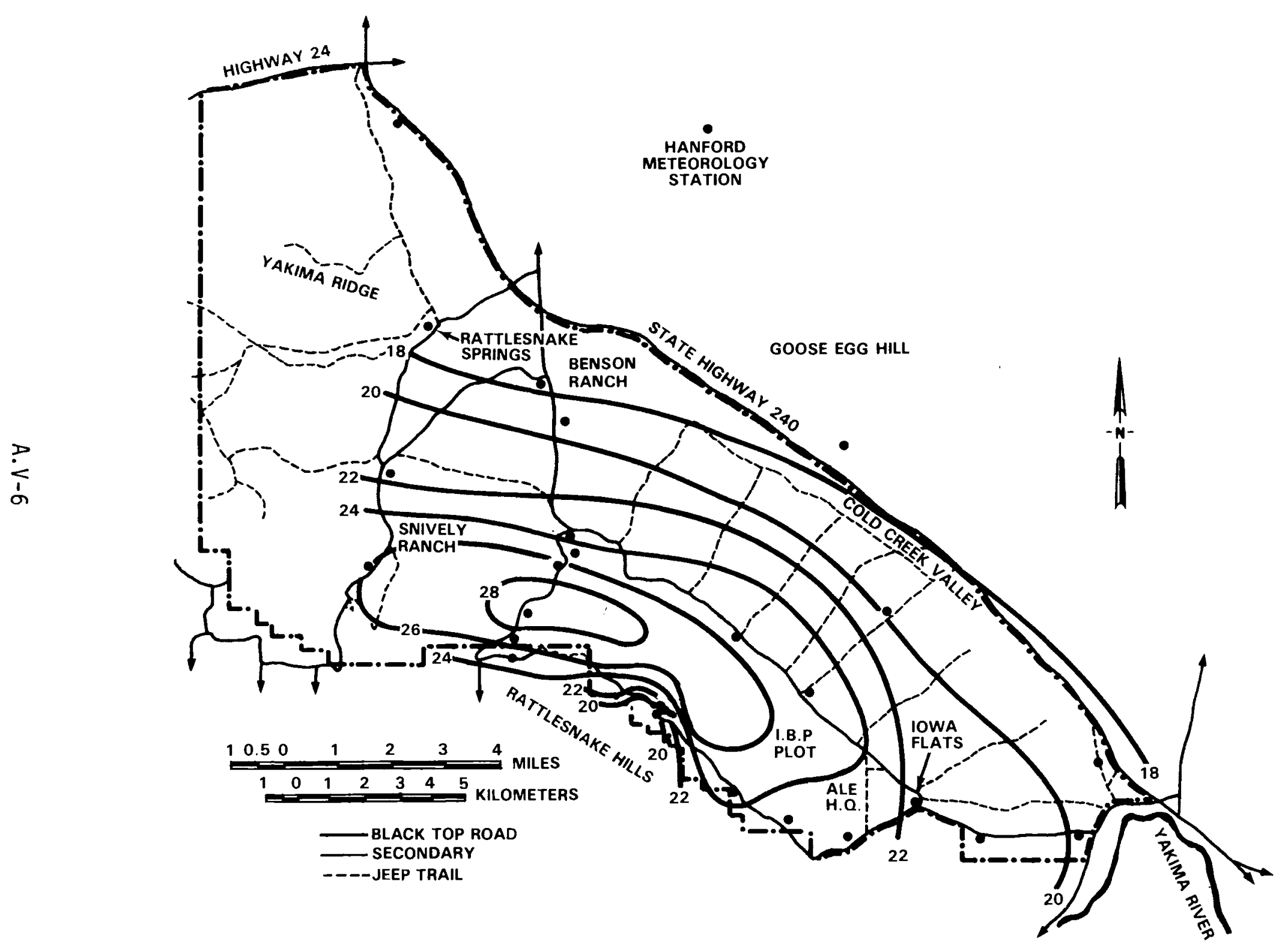

FIGURE A.V-3. Annual Average Distribution of Precipitation for the ALE Reserve 
Annual and annual average precipitation (inches and centimeters of water) for the ALE sites and the HMS are given in Tables A.V-3 and A.V-4.

A frequently useful datum for ecological studies is the amount of precipitation which falls during the so-called bioyear (the period of greatest soil moisture accumulation). For the Lower Columbia Basin, which includes the Hanford area, we have defined the bioyear as October through May (see Figure 14, Section IV). Precipitation amounts for each bioyear from 1969 through 1980, and the bioyear average, for each of the stations are shown in Tables A.V-5 and A.V-6. Bioyear 1969 is defined as the period October 1968 through May 1969, etc.

\section{REFERENCES}

Thorp, J. M. and W. T. Hinds. 1977. "Microclimates of the Arid Lands Ecology Reserve 1968-1975." BNWL-SA-6231, Pacific Northwest Laboratory, Richland, WA 99352. 
TABLE A.V-3. Arid Lands Ecology Reserve--Calendar Year Precipitation (in.) for Years 1969 Through 1980

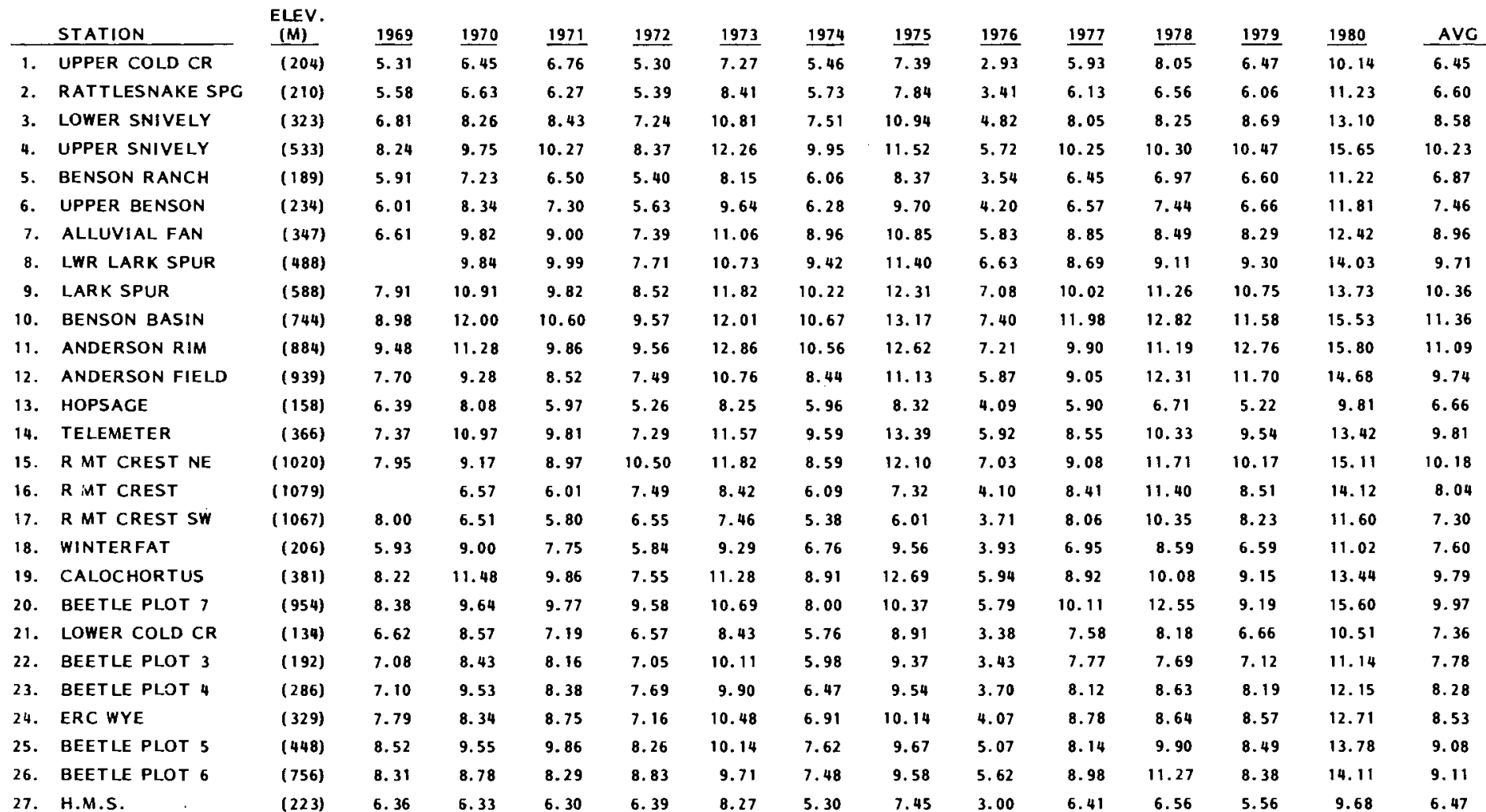


TABLE A.V-4. Arid Lands Ecology Reserve--Calendar Year Precipitation (cm) for Years 1969 Through 1980

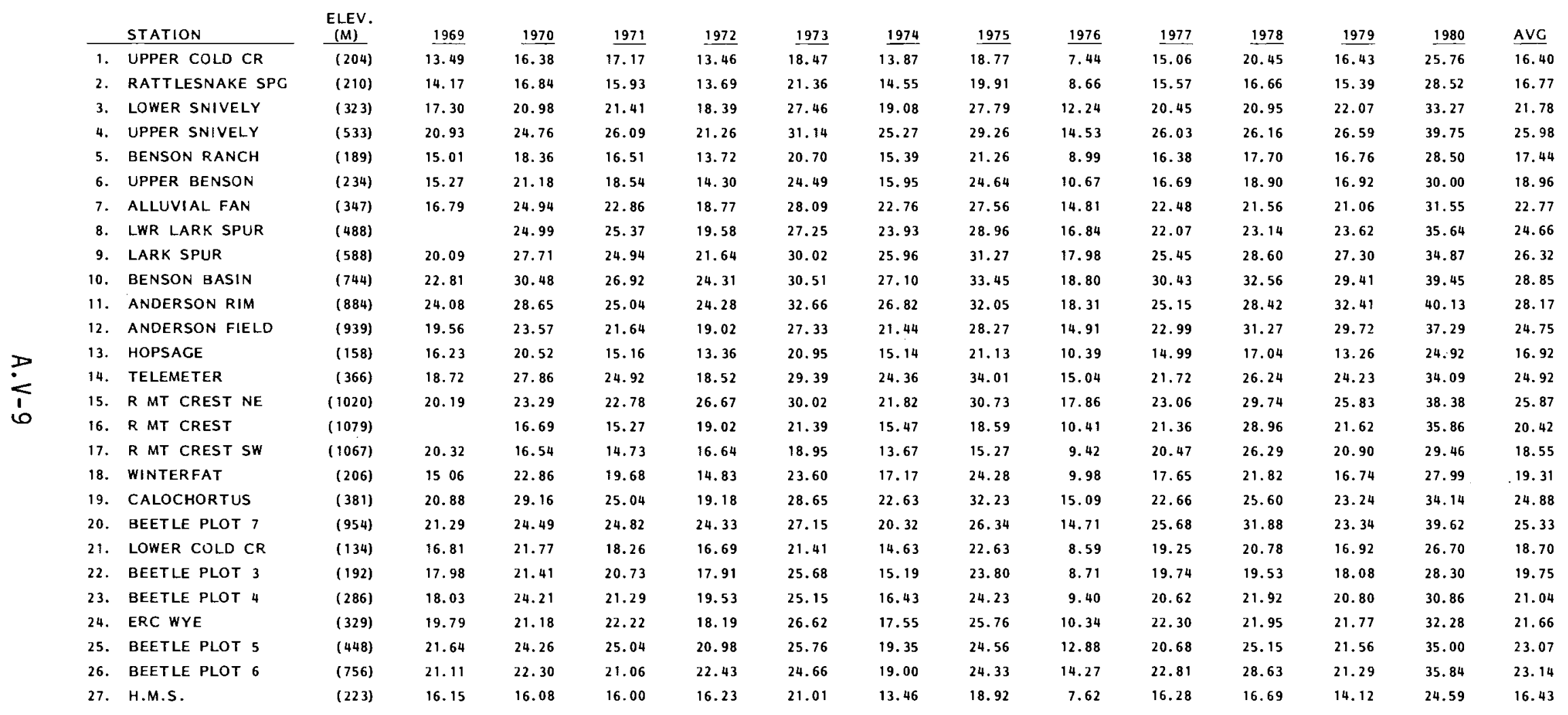


IABLE A.V-5. Arid Lands Ecology Reserve--Bioyear Precipitation (in.) for Years 1969 Through 1980

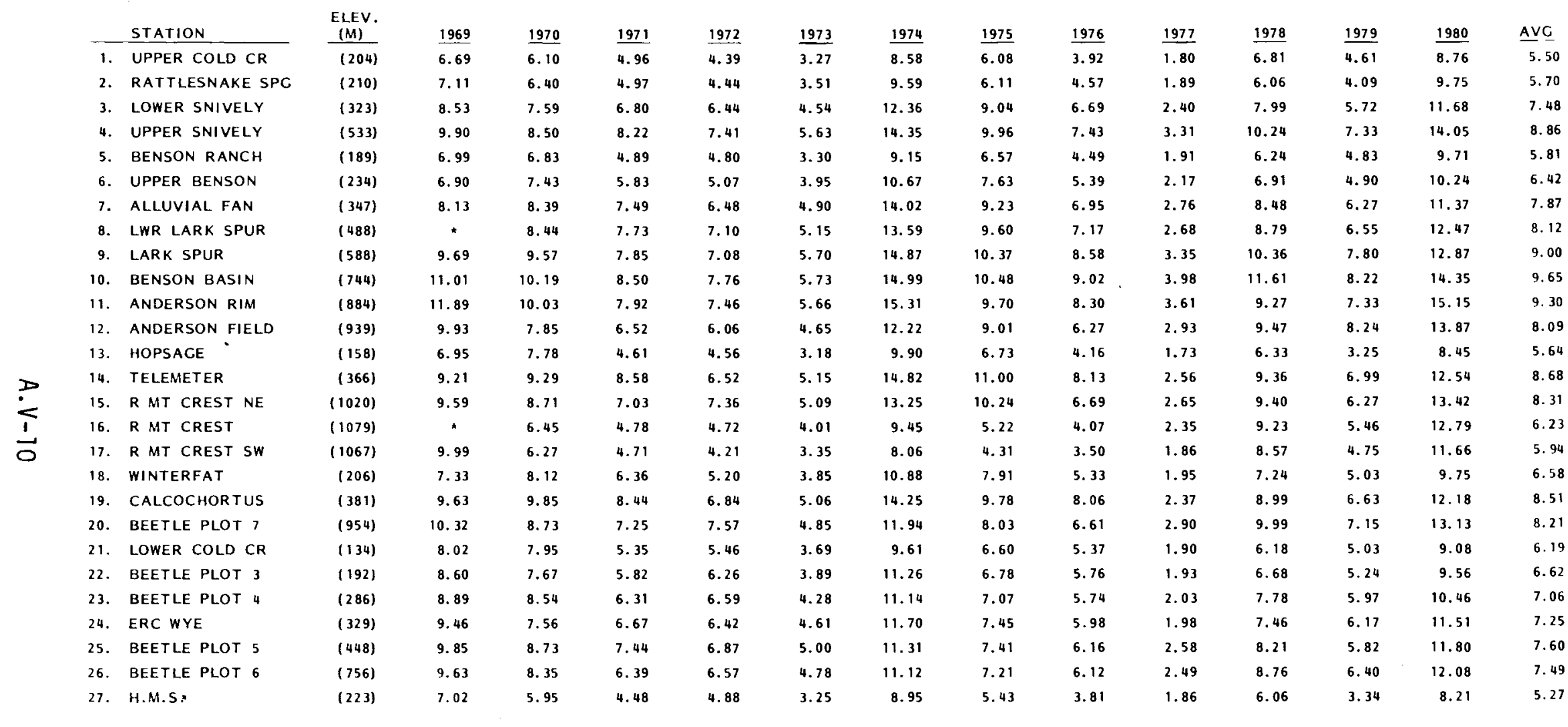

*NO MEASUREMENT IN BIOYEAR 1969 
TABLE A.V-6. Arid Lands Ecology Reserve--Bioyear Precipitation (cm) for Years 1969 Through 1980

\begin{tabular}{|c|c|c|c|c|c|c|c|c|c|c|c|c|c|c|c|}
\hline & STATION & $\begin{array}{l}\text { ELEV. } \\
(M)\end{array}$ & 1969 & 1970 & 1971 & 1972 & 1973 & 1974 & 1975 & $\underline{1976}$ & 1977 & 1978 & 1979 & 1980 & $\underline{A V G}$ \\
\hline 1. & UPPER COLD CR & (204) & 16.99 & 15.49 & 12.60 & 11.15 & 8.31 & 21.79 & 15.44 & 9.96 & 4.57 & 17.30 & 11.71 & 22.25 & 13.96 \\
\hline 2. & RATTLESNAKE SPG & $(210)$ & 18.06 & 16.26 & 12.62 & 11.28 & 8.92 & 24.36 & 15.52 & 11.61 & 4.80 & 15.39 & 10.39 & 24.76 & 14.49 \\
\hline 3. & LOWER SNIVELY & (323) & 21.67 & 19.28 & 17.27 & 16.36 & 11.53 & 31.39 & 22.96 & 16.99 & 6.10 & 20.29 & 14.53 & 29.67 & 18.99 \\
\hline 4. & UPPER SNIVELY & (533) & 25.15 & 21.59 & 20.88 & 18.82 & 14.30 & 36.45 & 25.30 & 18.87 & 8.41 & 26.01 & 18.62 & 35.69 & 22.50 \\
\hline 5. & BENSON RANCH & (189) & 17.75 & 17.35 & 12.42 & 12.19 & 8.38 & 23.24 & 16.69 & 11.40 & 4.85 & 15.85 & 12.27 & 24.66 & 14.75 \\
\hline 6. & UPPER BENSON & (234) & 17.53 & 18.87 & 14.81 & 12.88 & 10.03 & 27.10 & 19.38 & 13.69 & 5.51 & 17.55 & 12.45 & 26.01 & 16.32 \\
\hline 7. & ALLUVIAL FAN & (347) & 20.65 & 21.31 & 19.02 & 16.46 & 12.45 & 35.61 & 23.44 & 17.65 & 7.01 & 21.54 & 15.93 & 28.88 & 19.99 \\
\hline 8. & LWR LARK SPUR & (488) & * & 21.44 & 19.63 & 18.03 & 13.08 & 34.52 & 24.38 & 18.21 & 6.81 & 22.33 & 16.64 & 31.67 & 20.62 \\
\hline 9. & LARK SPUR & (588) & 24.61 & 24.31 & 19.94 & 17.98 & 14.48 & 37.77 & 26.34 & 21.79 & 8.51 & 26.31 & 19.81 & 32.69 & 22.87 \\
\hline 10. & BENSON BASIN & $(744)$ & 27.97 & 25.88 & 21.59 & 19.71 & 14.55 & 38.07 & 26.62 & 22.91 & 10.11 & 29.49 & 20.88 & 36.45 & 24.52 \\
\hline 11. & ANDERSON RIM & (884) & 30.20 & 25.48 & 20.12 & 18.95 & 14.38 & 38.89 & 24.64 & 21.08 & 9.17 & 23.55 & 18.62 & 38.48 & 23.63 \\
\hline 12. & ANDERSON FIELD & (939) & 25.22 & 19.94 & 16.56 & 15.39 & 11.81 & 31.04 & 22.89 & 15.93 & 7.44 & 24.05 & 20.93 & 35.23 & 20.54 \\
\hline 13. & HOPSACE & (158) & 17.65 & 19.76 & 11.71 & 11.58 & 8.08 & 25.15 & 17.09 & 10.57 & 4.39 & 16.08 & 8.25 & 21.46 & 14.33 \\
\hline 14. & TELEMETER & $(366)$ & 23.39 & 23.60 & 21.79 & 16.56 & 13.08 & 37.64 & 27.94 & 20.65 & 6.50 & 23.77 & 17.75 & 31.85 & 22.06 \\
\hline 15. & R MT CREST NE & $\{1020\}$ & 24.36 & 22.12 & 17.86 & 18.69 & 12.93 & 33.65 & 26.01 & 16.99 & 6.73 & 23.88 & 15.93 & 34.09 & 21.11 \\
\hline 16. & R MT CREST & $(1079)$ & * & 16.38 & 12.14 & 11.99 & 10.19 & 24.00 & 13.26 & 10.34 & 5.97 & 23.44 & 13.87 & 32.49 & 15.82 \\
\hline & R MT CREST SW & $\{1067\}$ & 25.37 & 15.93 & 11.96 & 10.69 & 8.51 & 20.47 & 10.95 & 8.89 & 4.72 & 21.77 & 12.06 & 29.62 & 15.09 \\
\hline 18. & WINTERFAT & $(206)$ & 18.62 & 20.62 & 16.15 & 13.21 & 9.78 & 27.64 & 20.09 & 13.54 & 4.95 & 18.39 & 12.78 & 24.76 & 16.71 \\
\hline 19. & CALOCHORTUS & (381) & 24.46 & 25.02 & 21.44 & 17.37 & 12.85 & 36.19 & 24.84 & 20.47 & 6.02 & 22.83 & 16.84 & 30.94 & 21.61 \\
\hline 20. & BEETLE PLOT 7 & (954) & 26.21 & 22.17 & 18.41 & 19.23 & 12.32 & 30.33 & 20.40 & 16.79 & 7.37 & 25.37 & 18.16 & 33.35 & 20.85 \\
\hline 21. & LOWER COLD CR & (134) & 20.37 & 20.19 & 13.59 & 13.87 & 9.37 & 24.41 & 16.76 & 13.64 & 4.83 & 15.70 & 12.78 & 23.06 & 15.72 \\
\hline 22. & BEETLE PLOT 3 & (192) & 21.84 & 19.48 & 14.78 & 15.90 & 9.88 & 28.60 & 17.22 & 14.63 & 4.90 & 16.97 & 13.31 & 24.28 & 16.82 \\
\hline 23. & BEETLE PLOT 4 & (286) & 22.58 & 21.69 & 16.03 & 16.74 & 10.87 & 28.30 & 17.96 & 14.58 & 5.16 & 19.76 & 15.16 & 26.57 & 17.94 \\
\hline 24. & ERC WYE & (329) & 24.03 & 19.20 & 16.94 & 16.31 & 11.71 & 29.72 & 18.92 & 15.19 & 5.03 & 18.95 & 15.67 & 29.24 & 18.41 \\
\hline 25. & BEETLE PLOT 5 & (448) & 25.02 & 22.17 & 18.90 & 17.45 & 12.70 & 28.73 & 18.82 & 15.65 & 6.55 & 20.85 & 14.78 & 29.97 & 19.30 \\
\hline 26. & BEETLE PLOT 6 & (756) & 24.46 & 21.21 & 16.23 & 16.69 & 12.14 & 28.24 & 18.31 & 15.54 & 6.32 & 22.25 & 16.26 & 30.68 & 19.02 \\
\hline 27. & H.M.S. & (223) & 17.83 & 15.11 & 11.38 & 12.40 & 8.25 & 22.73 & 13.79 & 9.68 & 4.72 & 15.39 & 8.48 & 20.85 & 13.39 \\
\hline
\end{tabular}

*NO MEASUREMENT IN BIOYEAR 1969 


\section{DISTRIBUTION}

No. of

Copies

OFFSITE
No. of

Copies

\section{DOE Technical Information Center}

Ronald A. Chitwood

Washington Public Power Supply System

301 Fifth Avenue

P.0. Box 968

Richland, WA 99352

City of Richland/Energy

Services Department

Attn: Administration Division

P.0. Box 190

Richland, WA 99352

City of Richland/Energy

Services Department

Attn: Conservation Division

P.0. Box 190

Richland, WA 99352

Columbia National Wildlife Refuge

U.S. Fish \& Wildlife Service

U.S. Department of the Interior

P.0. Box $F$

0the110, WA 99344

J. Phillip Cooke

Benton-Franklin-Walla Walla

Air Quality Control Office

650 George Washington Way

Richland, WA 99352

Dr. Howard Critchfield

Washington State Climatologist Western Washington University

Bellingham, WA 98225
D. E. Jenne

Tri-County Air Pollution Control Authority

650 George Washington Way

Richland, WA 99352

Eldon Johns

Bureau of Reclamation

P.0. Box 25007-Code 752

Denver Federal Center

Denver, CO 80225

George R. Miller

Meteorologist in Charge

National Weather Service

5420 NE Marine Drive

Portland, OR 97218

Thomas Moak

Reference Librarian

Mid-Columbia Regional Library

405 South Dayton

Kennewick, WA 99336

National Weather Records Center

Climatic Information Section

Federal Building

Asheville, NC 28801

NOAA National Weather Service OA/WSFO SEA

7600 Sand Point Way NE

BIN CI5700

Seattle, WA 98115

J. T. Raese

U.S. Department of Agriculture 11104 N. Western Avenue

Wenatchee, WA 98801 
No. of

Copies

Leslie Ratchye

Bonneville Power

Administration

P.0. Box 1518

Walla Walla, WA 99362

Richland Public Library

Reference Department

Swift \& Northgate

Richland, WA 99352

Jim Sanders

Benton County PUD

P.0. Box 6270

Kennewick, WA 99336

U.S. Army Corps of Engineers

Attn: Water Control Section

Building 602 City-County

Airport

Walla Walla, WA 99362

Weather Records Section

Washington State University

Irrigated Agriculture Research

\& Extension Center

P.0. Box 30

Prosser, WA 99350

Weather Service Office

P.0. Box 1355

Walla Walla, WA 99362

Weather Service Office

2406 W. Washington Avenue

Yakima, WA 98902

Darre11 Weaver

Department of Ecology

Meteorologist

P.0. Box 829

01ympia, WA 98504

Jack Wright

Customer Service Office

PUD Building

P.0. Box 6270

Kennewick, WA 99336
No. of

Copies

ONSITE

6 DOE Richland Operations Office

CD Compton

DR Elle

RE Gerton

EC Norman

HE Ransom

SC Whitfield

BCS Richland

PE Lemargie

13 Hanford Engineering Development Laboratory

DS Beesley

PFX Dunigan

JF Erben

D Gray

JA Guinn

$\mathrm{RB} \mathrm{Hall}$

CA Hinman

JD McCormack

LJ Nitteberg

NF Panayotou

RW Reed

RB Richman

ME Roosa

$3 \mathrm{~J}$. A. Jones

PG Beaudet

BT Burt

GR Meek

Joint Center for Graduate Studies

BB Valett

2 Kaiser Engineers

CR McCarter

LH Smith 
No. of

Copies

28 Rockwe11 Hanford Operations

WB Barton
ML Bell
JA Caggiano
PJ Certa
HA Clark
GR Cox
RJ Cragin
JP Cunningham
RC Edwards
RG Geier
MA Helle
JJ Hogan
JH Hummer
LA Johnson
AG Law
M Malarchick
GE Martin
RM Mitchell
LR Pierce
IE Reep
DD Rountry
DF Shepard
CM Walker
DJ Washenfelder
JL Watkins
WJ Waugh
TM Wintczak
H Zbyszewski

3 UNC Nuclear Industries

DR Haffner

RS Peterson

SA Slinn

78 Pacific Northwest Laboratory

AJ Alkezweeny

LL Ames

GE Backman

DA Baker

JC Barnard

PJ Blumer

DA Cataldo
No. of

Copies
DA Cochran
RL Conley
JR Connel1
JP Corley
CE Cushing
JM Davidson
JR Divine
JC Doran
DW Dragnich
CE Elderkin
DL Elliott
MH Engelhard
JF Fletcher
JJ Fuquay
OP Gifford
FO Gladfelder
EN Greenwe 11
PJ Gutknecht
DL Hadley
RK Hadlock
DJ Hoitink
TW Horst
LE Jenkins
ND Jenkins
ER Job
TL Jones
RE Kerns
RR Kirkham
LV Kimmel
DC Klopfer
NS Laulainen
RN Lee
CA Lopresti
WE Lusty
OM Lyso
RP Mazzucchi
BJ Merril1
MC Miller
DW Murphy
RE Nightingale
MM Orgill
TL Page
PM Potter
DC Powe 11
JV Ramsde 11
DS Renne
CA Rohrmann 
No. of

Copies

RH Sauer

DD Scott

GA Sehme 1

RE Shippert

CL Simpson

GM Stokes

WA Stone

CW Thomas

MT Thomas

JM Thorp
No. of

Copies

RJ Traub

EC Watson

HL Wegley

LL Wendel1

CD Whiteman

GL Wilfert

Technical Information

Files (5)

Publishing Coordination (2)

2400 Stevens Library 